\title{
FÁBIA CRISTINA SEGATTO MARCONDES
}

\section{SISTEMAS LOGÍSTICOS REVERSOS NA INDÚSTRIA DA CONSTRUÇÃO CIVIL - ESTUDO DA CADEIA PRODUTIVA DE CHAPAS DE GESSO ACARTONADO.}

Dissertação apresentada à Escola Politécnica da Universidade de São Paulo para obtenção do Título de Mestre em Engenharia. 


\section{FÁBIA CRISTINA SEGATTO MARCONDES}

\section{SISTEMAS LOGÍSTICOS REVERSOS NA INDÚSTRIA DA CONSTRUÇÃO CIVIL - ESTUDO DA CADEIA PRODUTIVA DE CHAPAS DE GESSO ACARTONADO.}

Dissertação apresentada à Escola Politécnica da Universidade de São Paulo para obtenção do Título de Mestre em Engenharia.

Área de Concentração: Engenharia de Construção Civil e Urbana.

Orientador:

Prof. Livre-Docente

Francisco Ferreira Cardoso 
Este exemplar foi revisado e alterado em relação à versão original, sob responsabilidade única do autor e com a anuência de seu orientador.

São Paulo, 17 de setembro de 2007.

Assinatura do autor:

Assinatura do orientador:

FICHA CATALOGRÁFICA

Marcondes, Fábia Cristina Segatto

Sistemas logísticos reversos na indústria da construção civil - estudo da cadeia produtiva de chapas de gesso acartonado / F.C.S. Marcondes. -- ed.rev. -- São Paulo, 2007. $364 p$.

Dissertação (Mestrado) - Escola Politécnica da Universidade de São Paulo. Departamento de Engenharia de Construção Civil.

1.Logística reversa 2.Cadeia de suprimentos 3.Gerenciamento de resíduos 4.Resíduos de construção e demolição 5.Gesso acartonado I.Universidade de São Paulo. Escola Politécnica. Departamento de Engenharia de Construção Civil II.t. 


\section{DEDICATÓRIA}

Aos meus pais, Zoraide e José Antonio, à minha irmã Ana Paula, à Mel e à Dot, pelo amor, compreensão e apoio inesgotável e incondicional que me concedem todos os dias. Esta obra não seria possível sem vocês. 
Ninguém há que, depois de ter acendido uma candeia, a cubra com um vaso, ou a ponha debaixo da cama; põe-na sobre o candeeiro, a fim de que os que entrem vejam a luz; - pois nada há secreto que não haja de ser descoberto, nem nada oculto que não haja de ser conhecido e de aparecer publicamente.

Lucas, capítulo 8, versículo 16 e 17

Bíblia - Novo Testamento 


\section{AGRADECIMENTOS}

A lista de agradecimentos desta dissertação é, com certeza, menor do que a gratidão que expressa. Mas, é grande o suficiente para mostrar que o trabalho de três anos é resultado de inúmeras interações pessoais que estruturam e formam o pesquisador, seja no âmbito acadêmico, profissional, pessoal ou espiritual.

Esta é uma das poucas, talvez a única, oportunidade de expressar publicamente e, se não pela vida inteira, por um longo tempo, a gratidão pela participação de todos.

$$
\text { Agradeço... }
$$

Aos meus avós maternos e paternos (todos in memorian) com quem pouco convivi mas, muito prezo em minhas lembranças. Em especial à minha avó materna Floripes, exemplo de fé e resignação, que me ajuda aonde quer que esteja.

Aos meus pais, Zoraide e José Antonio, por me ensinarem e demonstrarem que a família é a base de todos os homens, que sem amor nada se tem e sem fé e crença não se vai adiante. Amo vocês.

À minha mãe, Zoraide por demonstrar que ser feliz é simples e ajudar a aceitar-me como sou.

Ao meu pai por ser meu 'porto seguro' dar-me segurança para alçar vôos cada vez mais altos, mesmo nas horas mais difíceis.

À minha irmã, Ana Paula, por ser meu exemplo de garra, otimismo e perseverança, além de companheira e amiga em qualquer situação. Amo você.

Ao meu tio Diógenes por ser meu exemplo de superação e sempre me estimular a vencer.

A minha tia (de coração) Djalba Gabriela, pelo exemplo de superação, atitude e dignidade. Obrigada pela paciência, por toda psicologia, e por aturar as minhas 'fossas'. Eu adoro você.

Aos meus tios, Araide e Nina, sempre prontos a me ajudar, que me tratam como verdadeira filha na ausência dos meus pais.

Aos meus tios, Zuma e Isaías, pelo carinho que me concedem e pelas lindas roupas que titia me faz.

As minhas primas, Magnólia e Magali, parabéns pelas lindas famílias que constituíram - Emerson, Najla e Natasha; Carlos, Bruno e Danilo, respectivamente.

Obrigada pelo alto astral e pela compreensão quando eu precisava ser escutada. 
À Najla e Natasha, que sempre serão minhas “menininhas". Saibam que as amo muito, que as tenho como minhas meio-filhas e que agradeço a Deus por vê-las crescer sempre perto a mim.

A minha super prima (pima) Cláudia, sempre pronta a me escutar, com quem descobri que com serenidade se vai longe e que têm sido pra mim um exemplo de reforma íntima nos últimos anos.

Ás minhas irmãs 'emprestadas' de alma e coração Adelaide e Vanessa, por todas as experiências compartilhadas e apoio em todas as horas.

Ao meu futuro cunhado, Fernando L. Santos, que me mostrou o quanto um ser humano pode aprender com a vida, mudar em sua essência e se tornar muito melhor. Sem dúvida, um guerreiro. Ahh... obrigada também pela ajuda na apropriação dos custos presentes na análise de viabilidade econômica.

A toda minha família (não seria possível agradecer nominalmente, afinal são mais de trezentas pessoas...), por compreenderem minha ausência em alguns momentos e me ajudarem, cada um a sua maneira, a ter equilíbrio e harmonia durante a execução deste trabalho.

Ao meu grande amigo e orientador, em todas as horas, Francisco Ferreira Cardoso, pelo incansável apoio e por inspirar-me cada vez mais para a vida acadêmica. Não tenho como expressar a gratidão à sua cumplicidade e compreensão, tanto dos meus motivos e inseguranças pessoais, quanto dos conhecimentos, entendendo mesmo aqueles que eu mal conseguia falar, quanto mais escrever.

Aos grandes sábios e conhecedores, meus professores de pós-graduação, Fernando Henrique Sabbatini, Mércia M. S. B.de Barros, Silvio B. Melhado, e Ubiraci E. L. de Souza, meu muito obrigado por todos os ensinamentos, técnicos e não-técnicos.

Aos grandes professores que passaram por minha vida escolar e acadêmica, pois a formação é algo construído ao longo de muitos anos. Aos inesquecíveis:

Ensino fundamental - Colégio Padre Giordano: Profa. Sandra (jardim e $1^{\mathrm{a}}$ série ); Profa. Cristina (pré-escola); Profa. Sandra ( $3^{\mathrm{a}}$ série); Prof. Márcio (História $-5^{\mathrm{a}}$ a $8^{\mathrm{a}}$ série); Prof. Rivail (Português e Literatura $-5^{\mathrm{a}}$ a $8^{\mathrm{a}}$ série); Prof. Carlão (Educação Física $-6^{\mathrm{a}}$ a $8^{\mathrm{a}}$ série); Prof. Kalozdi (Treinador Voleibol - 1993-1995); Prof. Silvio (Matemática $-5^{\mathrm{a}}$ a $8^{\mathrm{a}}$ série);

Ensino médio - Do $1^{\circ}$ ao $4^{\circ}$ ano colegial, na Escola Técnica Estadual Guaracy Silveira: Profa. Marisa Demitri (Português e Literatura); Profa. Marisa (Desenho Técnico e Arquitetônico); Profa. Cidinha (Desenho Técnico e Arquitetônico); Prof. Odmir Machado (Construção de Edifícios); Prof. Samuel C. da Mata (Construção de Edifícios e Orçamentos); Prof. Ailton Dias (Materiais de Construção Civil); Prof.

Marcos Tanaka (Educação Física); Profa. Sônia (Coordenadora Pedagógica); e Ensino superior - Faculdade de Tecnologia de São Paulo: Prof. Celso (Materiais de Construção Civil); Prof. Viégas (Prática de Construção Civil); Prof. Luiz (Ciências Ambientais); Prof. Regina (Ciências Ambientais); Prof. Fernanda (Planejamento em 
Construção Civil), Prof. Célio Zattoni (Hidráulica), Prof. Ariovaldo Nuvolari (Hidráulica). À Isabel Ap. por tão carinhosamente me ensinar seu profissionalismo.

Aos meus colegas do $1^{\circ}$ grau: Priscila, Damiana, Everton, Rodrigo Gimenes e Angela.

Aos meus colegas de colégio: Regina, Karen, Juliana (Xica), Luciano (Da Praia), Pedro, Anderson, Fernando, Thiago, Fabiane e Wagner.

Aos meus colegas de faculdade: Flávio, Eliane, Viviane, Marcelo (Piu), Kize, Vânia, Wilson, Alexandre, Willian, Wagner, Giva, Ricardo, Jefferson, Ronaldo e Válber.

Aos colegas de pós-graduação pelas ricas discussões, amizade e companheirismo compartilhados - Juliana Araújo (apesar de breve), Heitor, Fabiana Cleto, Auriciane, Ana Luiza, Frederico, Juan, Fernanda, Antônio Acácio, Juarez, Abla, Odair, Jamil, Rodrigo, Elisabeth (Betinha), pela grande ajuda na análise de viabilidade econômica, Marcelo Barbosa, Marcelo Matsusato, Maurício Grochowski, as mais próximas e confidentes, Rosiany e Luciana Peixoto, aos de amizade e farra, Luciana Oliveira e

Flávio Maranhão, aos mais recentes, mas não menos queridos, Cristina, Patrícia, Viviane, Ricardo Oviedo e Jamil, aos nem tão próximos Ana Chalita, Ricardo, Rosa,

Carlos Borges, Maurício Bernardes, Daniel Ohnuma, Maria Cristiana e as que encontrei a pouco e já tenho tanto afeto, Cristine e Laura.

Ao meu colega de pós-graduação e ex-namorado Alexandre A. Britez, por me dedicar amor e apoio durante grande parte deste período, e a sua família, que tão gentilmente me acolheu nestes anos.

Aos amigos de infância, da minha vizinhança, Denise, Marcelo, Sidnei (Du), Simone e Viviane, pelas brincadeiras, 'artes' e amizade. Ao meu amigo Roberto Bonafé, desligado, brincalhão e cativante. Você é terrível.

Aos colegas que encontrei pela vida, em razão dos amigos(a) dos amigos (a):

Cristiane Campos, Josiane e Daniel, Liliam e Fábio, Daniela e Rogério.

Aos meus irmãos espirituais do DEA - Desenvolvimento Espiritual do Amor, incluindo minhas professoras Sandra e Laís, que me despertaram para o Espiritismo; aos meus alunos que muito têm me ensinado e estimulado, Henrique, Tida, Rose, Helena, João, Viviane, Juliana, Angela, Adail, (alunos do primeiro ano); pela firme direção de Déa e Yara; aos meus colegas de trabalho Dulce, Marcos, Lígia, Neusa, Carlos, Letícia, Alfredo, Maia, Paulo e Leco. Vocês fizeram do DEA minha segunda casa e me mostram exemplos de como proceder todas as semanas.

Saibam que nutro um profundo afeto por todos.

Ao pessoal dos departamentos da Poli: Patrícia, Edson e Rogério, pelo apoio nas panes de informática; Denise, Alcione e Fátima da secretaria, por serem tão atenciosas quando das minhas solicitações, sempre sorridentes; e Sara, da biblioteca pela revisão da referência bibliográfica. 
Aos professores Vanderley Moacir John e Orlando Fontes Lima Júnior pelas contribuições quando da qualificação. Aos professores Vanderley Moacir John e Eliane Zamith Brito por aceitarem participar de minha banca examinadora para a defesa deste trabalho.

Aos meus colegas de trabalho, de experiências profissionais anteriores, grandes profissionais: Flávio, Felipe Masetti, Cristiane Masetti, George Beato, Cláudio

Kanashiro, Gabriela Jordão, Rogério Jordão, Leandro, Fabíola Rago, Betuel Macfadem, Rosana e Rosano. Todos os funcionários do laboratório de Construção Civil da L. A. Falcão Bauer com quem tive a honra de trabalhar.

Aos profissionais David Antonio Nono (Sinco Construtora), Roberto Pastor Júnior (Cyrela Construtora), Joelson de Oliveira Santos (Tecnisa Construtora) que me apoiaram na realização de pesquisas para as disciplinas de pós-graduação.

Aos profissionais e empresas que contribuíram diretamente para o resultado desta dissertação:

Günter Leitner, Marcelo Hansen Einsfeld e Omair Zorzi - Knauf do Brasil Ltda. Alvaro Villagrán, Carlos E. dos Santos e Nilton L. Antonialli - Placo do Brasil Ltda. Amedeo Salvatore - Lafarge Com. Ind. e Imp. Ltda Paulo Salomão - Grupo Lafarge Brasil

Carlos Roberto de Luca - Associação Brasileira dos Fabricantes de Chapas para Drywall Rodrigo Muller e Ênio Castro - Gafisa S.A. Julio Fernandes da Silva e Wanderley - Schahin Engenharia S.A. Manuel R. Rodriguez - Lucio Engenharia e Construções Ltda. Cláudio Augusto Fernandes - Rossi Residencial S.A. Cristina Bonini - Brasfor Comercial Ltda.

Everardo Ruiz Cláudio - Wall Tech Engenharia e Construção Ltda.

Luiz Antonio L. de Toledo - Maxi Papel Comércio de Aparas e Sucatas Ltda. Vagner Maringolo - Associação Brasileira de Cimento Portland - ABCP. Os especialistas:

Prof. Me. Paulo Roberto Leite - Universidade Presbiteriana Mackenzie;

Prof. Dr. Orlando Fontes Lima Júnior e Profa. Dra. Emília Wanda Rutkowski Universidade Estadual de Campinas - UNICAMP; e

Prof. Dr. Edson Martins de Aguiar, Universidade de São Paulo - USP - São Carlos.

A todos que participaram direta ou indiretamente deste trabalho e que porventura eu tenha esquecido de citar, perdão e muito obrigado.

Agradece-se a CAPES pelo apoio financeiro através da concessão de bolsa de estudo. 


\section{RESUMO}

Atualmente, as legislações ambientais e os consumidores estão cada vez mais exigentes e restritivos em relação ao adequado tratamento dado aos resíduos industriais. Neste contexto, a logística reversa tem por objetivo gerenciar os fluxos reversos, fazendo com que bens e produtos com pouco uso após a venda, com ciclo de vida útil ampliado ou após extinta a sua vida útil, retornem ao ciclo produtivo, readquirindo valor em outros mercados. Baseado em uma revisão bibliográfica, um estudo exploratório e um trabalho de campo, composto por entrevistas, analisa-se as possibilidades de aplicação do conceito de logística reversa na cadeia produtiva da Construção Civil, particularmente em relação aos fluxos de Resíduos de Construção e Demolição - RCD, como forma de contribuir para a sustentabilidade do ambiente construído. Expõe-se de forma ampla, os fatores intervenientes no processo de implantação dos sistemas logísticos reversos para RCD e os condicionantes e benefícios decorrentes desta aplicação, considerando os aspectos técnicos, econômicos e ambientas do reaproveitamento de RCD. A partir do estudo das práticas atuais de gerenciamento de RCD em empresas construtoras e de algumas experiências estrangeiras, conclui-se sobre as necessidades de avanço das práticas e legislações brasileiras relacionadas ao gerenciamento de RCD, e sobre o papel dos fornecedores no estabelecimento e consolidação de sistemas logísticos reversos SLR. A aplicação do conceito é realizada na cadeia produtiva de Chapas de Gesso Acartonado - CGA, para a qual é proposto um sistema logístico reverso - SLR-CGA, englobando-se a caracterização dos agentes, as tecnologias de aproveitamento para resíduos de CGA e os mercados disponíveis para a sua reinserção, dentre outros pontos. São realizadas simulações de viabilidade econômica de possíveis cadeias reversas de CGA. A partir das alternativas viáveis, conclui-se sobre o efeito da implantação destas sobre a cadeia produtiva de CGA. Conclui-se que a implantação de um sistema logístico reverso consiste em uma ferramenta organizacional que pode ajudar companhias a resolver impactos econômicos e ambientais e criar novos negócios na cadeia produtiva da Construção Civil.

Palavras-chave: Logística reversa. Cadeia de suprimentos. Resíduo de construção e demolição. Construção sustentável. Gesso acartonado. 


\begin{abstract}
$\underline{\text { ABSTRACT }}$
Currently, environmental legislation and pressure of consumer awareness are getting more stringent and restrictive in relation of the proper treatment gave to the industrial wastes. In this context, reverse logistics systems aims to manage the reverse flow, making with that facilities and products with little use after sales, useful life cycle extended or extinct, return to the productive cycle, to regain value still incorporated in them. Based on a bibliographical research and a survey, the possibilities of application of reverse logistics concept in Civil Construction productive chain is analyzed with focus on construction and demolition wastes (CDW).This analyze contribute for the sustainability in Civil Construction. The intervenient factors in the reverse logistics systems implementation is discussed, such as the benefits from the application, taking into account technical, economical e environmental aspects of recycling. The analyze of current CWD management system, mainly in building sites, avoids to conclude about Brazilian necessities and the important role that producers can have in this systems. The application of the concept is done in the drywall gypsum board supply chain. For this chain, a reverse logistics system for gypsum board wastes (GBW) is proposed approaching the stakeholders, technologies of GBW and markets for recycled product, among another aspects. Economic liability simulations of possible GBW reverse chains are conduced and for that liable, the impact of its implementation is discussed. The implementation of reverse logistics systems is considered like an organizational tool that can help the companies to solve environmental and costs impacts on production and problems surroundings this issues.
\end{abstract}

Key-words: Reverse logistics. Supply chain. Construction and demolition wastes (CDW). Sustainable construction. Drywall. Gypsum Board. 


\section{SUMÁRIO}

\section{LISTA DE FIGURAS}

LISTA DE TABELAS

\section{LISTA DE SIGLAS}

1 - INTRODUÇÃO..................................................................................................................... 1

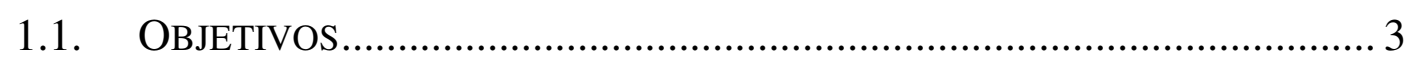

1.2. IMPORTÂNCIA E JUSTIFICATIVA DO TEMA …................................... 3

1.3. DELIMITAÇÃO DA PESQUISA ......................................................... 6

1.4. METOdOLOGIA DA PESQUISA.................................................... 10

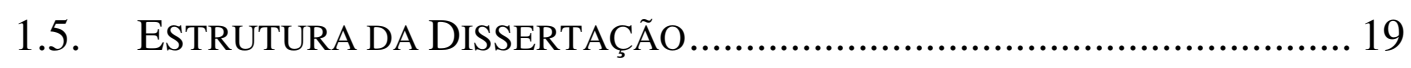

2 - Cadeia Produtiva da Construção Civil e Sustentabilidade

2.1. A CADEIA PRODUTIVA DA INDÚSTRIA DA CONSTRUÇÃO CIVIL ......... 22

2.2. SUSTENTABILIDADE - ATUAL DESAFIO DO SETOR ............................ 28

2.3. Sustentabilidade No AMBIENTE CONSTRUÍdo ............................. 33

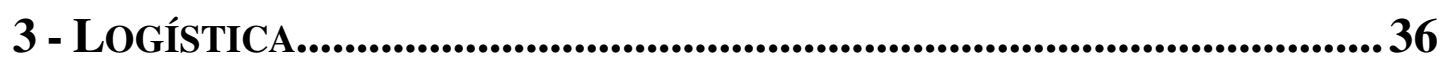

3.1. LOGÍSTICA NA INDÚSTRIA DA CONSTRUÇÃO CIVIL: A SISTEMATIZAÇÃO DOS FLUXOS ............................................... 36

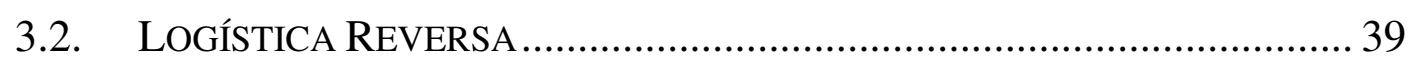

3.3. LOGÍSTICA REVERSA NA INDÚSTRIA DA CONSTRUÇÃO CIVIL ........... 49

3.3.1. FATORES INTERVENIENTES NA CONSOLIDAÇÃO DOS CDR DE RECICLAGEM NA ICC .............................................................................51

3.3.2. LOGíSTICA REVERSA E SEU PAPEL NO DESENVOLVIMENTO SUSTENTÁVEL DO AMBIENTE CONSTRUÍDO ..............................................60

\section{4 - LOGÍSTICA REVERSA APLICADA AO GERENCIAMENTO DE RESÍDUOS} DE CONSTRUÇÃO E DEMOLIÇÃO .............................................64

4.1. O MODELO PRECONIZADO PELA RESOLUÇÃO N. ${ }^{\circ} 307$ DO CONAMA 65

4.1.1. GRANDES GERADORES.........................................................................68

4.1.2. ÁREAS DE DESTINAÇÃo DOS RCD ....................................................... 74

4.1.3. PEQUENOS GERAdORES ....................................................................8 80

4.2. GESTÃO DE RESÍDUOS DA CONSTRUÇÃO CIVIL EM EMPRESAS CONSTRUTORAS PAULISTAS..

4.3. PROPOSIÇÃO DE MODELO DE SISTEMA DE GERENCIAMENTO DE RESÍDUOS DA CONSTRUÇÃO CIVIL EM EMPRESAS CONSTRUTORAS.. 83 
4.4. CONSIDERAÇÕES EM RELAÇÃO À RESOLUÇÃO N. ${ }^{\circ} 307$ DO CONAMA 88

4.5. CONSIDERAÇÕES EM RELAÇÃO AO SISTEMA DE GERENCIAMENTO DE RESÍDUOS DA CONSTRUÇÃO CIVIL EM EMPRESAS CONSTRUTORAS.. 89

4.6. CONSIDERAÇÕES EM RELAÇÃO AO SISTEMA LOGÍSTICO REVERSO DE RESÍDUOS DA CONSTRUÇÃO CIVIL PARA GRANDES GERADORES. .... 92

5.1. RESULTADOS DO ESTUDO EXPLORATÓRIO 100

5.2. Resultados do TrabalHO de CAMPO: APLICAÇÃO DO CONCEITO DE LOGÍSTICA REVERSA À CADEIA PRODUTIVA DE CHAPAS DE GESSO

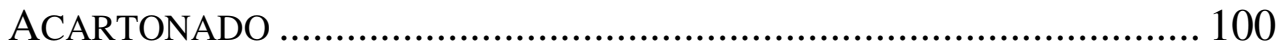

5.2.1. Cadeia Direta de CGA............................................................ 102

5.2.1.1. FLUXOS DE MATÉRIAS-PRIMAS................................................... 102

5.2.1.2. Produção de Chapas de Gesso ACARTONAdo no Brasil...... 106

5.2.1.3. MERCAdo de Chapas de Gesso ACARtonado no Brasil ....... 109

5.2.1.4. Composição Química dos Resíduos de Chapas de Gesso

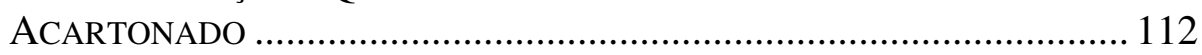

5.2.1.5. GeraÇÃo de Resíduos de CHAPAS de GESSO ACARTONADO .... 113

5.2.1.6. GERENCIAMENTO dos Resíduos À bASE DE GESSO EM CANTEIROS DE OBRAS DE GRANDES GERADORES …......................................... 119

5.2.1.6.1. Triagem das Classes de Resíduos...................................... 119

5.2.1.6.2. Destinação dos Resíduos de CGA ....................................... 125

5.2.2. CAdEIA REVERSA DE CGA .................................................................. 129

5.2.2.1. RECICLAGEM DE RESÍDUOS À BASE DE GESSO ............................ 129

5.2.2.2.NECESSIDADE DE TRIAGEM DENTRE OS RESÍDUOS À BASE DE GESSO 130

5.2.2.3. CANAIS REVERSOS DE RESÍDUOS DE CGA.................................. 131

5.2.2.3.1. Reciclagem de resíduos de CGA ........................................ 132

5.2.2.3.2..... Possíveis mercados para a utilização de resíduos de CGA

5.2.2.3.2.a. Alternativa de consumo: Indústria de cimento ............. 134

5.2.2.3.2.b. Alternativa de consumo: Correção de solos ................. 150

5.2.2.3.2.c. Alternativa de consumo para papel cartão presente nos resíduos de CGA por indústria de papel............................................. 155

5.3. FATORES INTERVENIENTES NA CONSOLIDAÇÃO DOS SISTEMAS LOGÍSTICOS REVERSOS DE RECICLAGEM DE RESÍDUOS DE CGA -

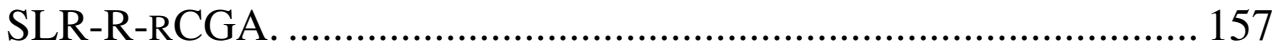

5.3.1. FATORES INTERVENIENTES NA CONSOLIDAÇÃO DOS CDR DE RECICLAGEM DE CGA VISANDO À PRODUÇÃO DE NOVA CGA COM CONTEÚDO RECICLADO 
5.3.2. FATORES INTERVENIENTES PARA A CONSOLIDAÇÃo dOS CDR DE RECICLAGEM DE CGA VISANDO À PRODUÇÃo DE GESSO (GIPISTA) RECICLADO.

6 - ANÁlise de ViabILIDAde ECONÔMICA DE POSSÍvEIS SistemaS LOGÍSTICOS REVERSOS PARA RESÍDUOS DE CHAPAS DE GESSO ACARTONADO - CGA ........................................................172

6.1. MÉTODO UTILIZADO PARA ANÁLISE DE VIABILIDADE ECONÔMICA 173

6.1.1. EXPECTATIVA DE RETORNO DO INVESTIMENTO ................................. 176

6.1.1.1. AVALIAÇÃO DA ATRATIVIDADE DO INVESTIMENTO....................... 176

6.1.1.2. ANÁLISE DE RISCO................................................................ 178

6.1.1.3. VAlOR DE VENDA do Gesso (GIPSITA) RECIClado DE RESÍDUO DE

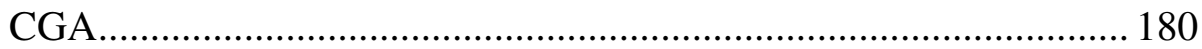

6.1.2. Custos da Central de Reciclagem ........................................... 184

6.1.2.1. CUSTOS DE IMPLANTAÇÃO........................................................... 184

6.1.2.2. CUSTOS DE OPERAÇÃO ......................................................... 187

6.1.2.3. CUSTOS DE MANUTENÇÃO........................................................... 189

6.1.2.4. CUSTO DO FRETE DE DISTRIBUIÇÃO ............................................ 192

6.1.2.5. Custo de DesPesas Administrativas .................................... 192

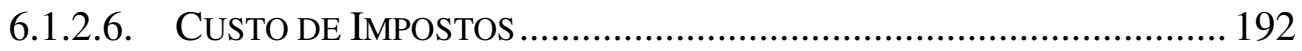

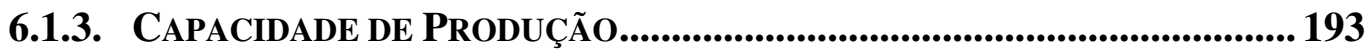

6.1.4. FINANCIAMENTO ............................................................................................. 194

6.1.5. DEMONSTRATIVO DE RESULTADOS .................................................. 197

6.1.6. FLUXO DE CAIXA................................................................................. 197

6.2. SiMULAÇÕES DE ANÁLISE DE VIABILIDADE ECONÔMICA................ 198

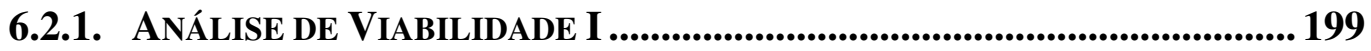

6.2.2. ANÁliSE DE VIABILIDADE II......................................................... 201

6.2.3. ANÁlISE DE VIABILIDADE III ...........................................................203

6.2.4. ANÁlISE DE VIABILIDADE IV ....................................................... 205

6.2.5. ANÁLISE DE VIABILIDADE V ...................................................................... 207

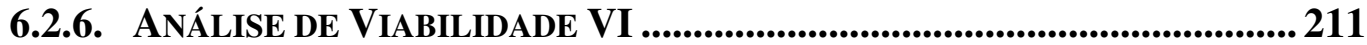

6.2.7. ANÁliSE dE VIABILIDAdE VII...................................................... 212

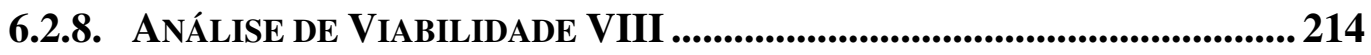

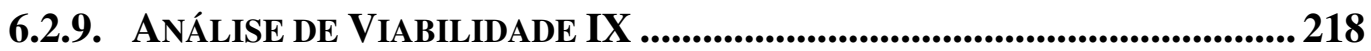

6.2.10. ANÁLISE DE VIABILIDAdE X............................................................ 222

6.3. CONCLUSÕES SOBRE AS ANÁLISES DE VIABILIDADE ECONÔMICA .. 225

6.3.1. IMPACTO do CUSTO de DEPOSiÇão nO CuSTO da ObRa, PARA

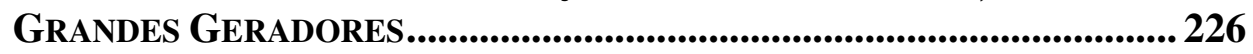

6.3.2. ECONOMIA de MATÉria-Prima PARA O FABriCANTE de CGA ........ 228

6.3.3. A POSSIBILIDAdE do CICLO FECHADO .................................................. 230 


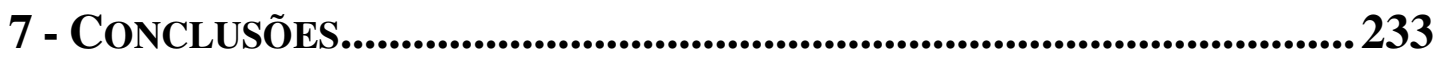

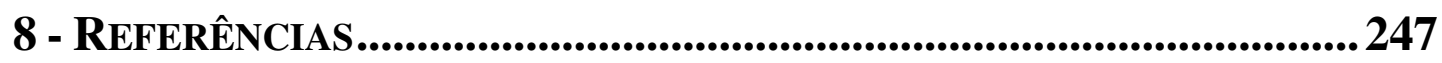

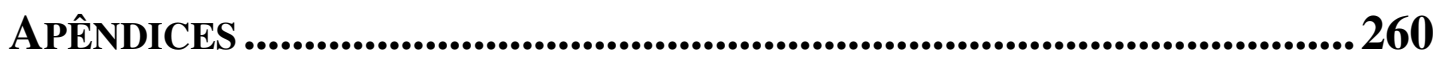

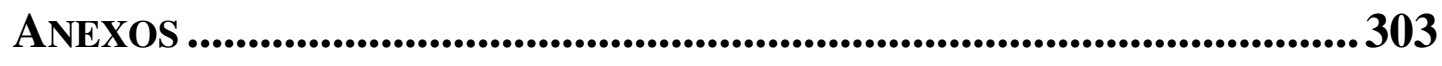




\section{LISTA DE FIGURAS}

Figura 1.1 - Etapas de pesquisa da metodologia adotada (autora, 2007). .............. 12

Figura 1.2 - Agentes integrantes da cadeia direta de CGA (autora, 2007).............. 16

Figura 1.3 - Agentes integrantes da cadeia reversa de CGA (autora, 2007). .......... 17

Figura 2.1 - Ilustração da cadeia construtiva para o sub-segmento residencial

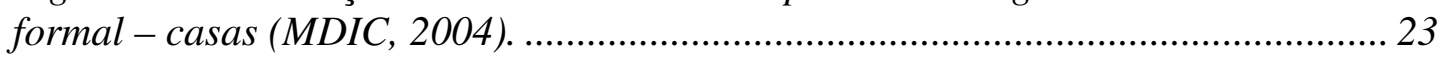

Figura 2.2 - Ilustração da cadeia construtiva para o sub-segmento residencial formal-edifícios e condomínios horizontais (MDIC, 2004). ................................. 23

Figura 2.3 - Participação do setor da Construção Civil no PIB brasileiro (MDIC,

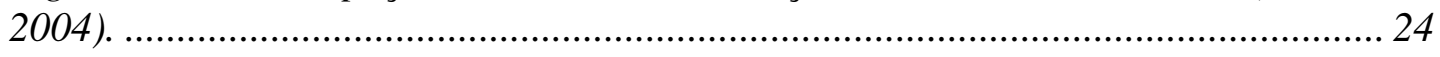

Figura 2.4 - Representação do Construbusiness, com dados de 2003 (adaptado de CONSTRUBUSINESS, 2005).

Figura 2.5 - Participação da construção formal no mercado de edificações residenciais, de acordo com a classe social (ESTEBAN, 2004).

Figura 2.6 - Diagrama de Venn (Parkin et al., 2003).

Figura 2.7 - Mudança na cultura do consumo e suas conseqüências (LEITE, 2003).

Figura 3.1 - Ilustração sobre a abrangência e complementaridade das definições adotadas (autora, 2007).

Figura 3.2 - Fluxos e agentes que compõem os canais de distribuição de pósconsumo (CDR-PC) de ciclo aberto(FLEISCHMANN, 2001).

Figura 3.3 - Fluxos e agentes que compõem os canais de distribuição de pósconsumo (CDR-PC) de ciclo fechado (FLEISCHMANN, 2001). ...

Figura 3.4 - Papel da logística reversa na cadeia produtiva da ICC, sob o ponto de vista da sustentabilidade (MARCONDES; CARDOSO, 2005).

Figura 4.1 - Estrutura do Plano Integrado, prevista na Resolução $n .^{\circ} 307$ do CONAMA (2002).

Figura 4.2 - Composição média dos entulhos depositados no aterro de Itatinga, São Paulo (BRITO FILHO, 1999).

Figura 4.3 - Tipos de caçambas comumente utilizadas para o acondicionamento e coleta de RCD (autora, 2007).

Figura 4.4 - Modelo de fluxos de RCD estabelecido pela Resolução $n .^{\circ} 307$ do CONAMA (SINDUSCON-SP, 2006).

Figura 4.5 - Etapas e atividades do gerenciamento de RCD inserido na cadeia produtiva da ICC (baseado em MARCONDES; CARDOSO, 2005)..

Figura 4.6 - Formas de atuação do Sistema de Gerenciamento de Resíduos para grandes geradores (baseado em OHNUMA; ROZENDO; GONÇALVES, 2005)..... 86 
Figura 5.1 - Distribuição da Produção de Gipsita no Brasil (a partir dos dados de LYRA SOBRINHO; AMARAL; DANTAS, 2005).

Figura 5.2 - Processo de produção das CGA (autora, 2007). 107

Figura 5.3 - Consumo de CGA em alguns países (ASSOCIAÇÃO DRYWALL, 2006).

Figura 5.4 - Representação do mercado brasileiro de chapas de gesso acartonado. (ASSOCIAÇÃO DRYWALL, 2005).

Figura 5.5 - Participação das construtoras, distribuidores e instaladores no mercado de chapas de gesso acartonado da RMSP (ASSOCIAÇÃO DRYWALL, 2005).

Figura 5.6 - Exemplo de caçamba contendo resíduos de obra de CGA (SABATINNI).

Figura 5.7 - Síntese da geração de resíduos de CGA na RMSP (autora, 2007).... 117

Figura 5.8 - Fontes de resíduos de gesso da fase de construção na RMSP. (JOHN;

SILVA; AGOPYAN, 2005 partir de dados do SINDUSGESSO e da ABRAGESSO).

Figura 5.9 - Resíduos de CGA, antes e depois da triagem, na ATT do Pari (autora, 2007).

Figura 5.10 - Gerenciamento dos resíduos à base de gesso em canteiros de obra na RMSP e fluxos de resíduos de CGA (autora, 2007).....

Figura 5.11 - Gesso reciclado a partir de resíduos de CGA (GYSPUM RECYCLING, 2006).

Figura 5.12 - Identificação e localização das fábricas de cimento instaladas no Brasil (SNIC, 2006).

Figura 5.13 - Processo de fabricação de cimento (ABCP, 2006). 138

Figura 5.14 - Esquema simplificado de produção de fertilizantes (FOSFÉRTIL, 2006).

Figura 5.15 - Distribuição relativa de raízes no perfil do solo com e sem o uso de fosfogesso (EMBRAPA, 2006).

Figura 5.16 - Transporte e identificação de aparas (resíduos) de papel utilizados na fábrica 'P' (autora, 2007).

Figura 5.17 - Ilustração da mesa formadora e dos cilindros de secagem e conformação do papel na indústria 'P' (autora, 2007).

Figura 5.18 - Equipamento de reciclagem de resíduos de CGA (ANDELA, 2006).159

Figura 6.1 - Variáveis consideradas para as análises de viabilidade econômica da implantação de Central de Reciclagem de resíduos de CGA (autora, 2007).

Figura 6.2 - Localização das indústrias de cimento no estado de São Paulo e das situadas num raio de até $130 \mathrm{~km}$ da capital (baseado em SNIC, 2006). 183 
Figura 6.3 - Esquema de formação de custo limite para formação de preço de gesso reciclado de resíduo de CGA, em São Paulo, modalidade CIF até 130km (autora, 2007).

Figura 6.4 - Layout da central de reciclagem de CGA (autora, 2007)

Figura 6.5 - Análises de Viabilidade Econômica e suas respectivas variáveis contempladas (autora, 2007).

Figura 6.6 - Variáveis contempladas na Análise de Viabilidade Econômica I (autora, 2007).

Figura 6.7 - Variáveis contempladas na Análise de Viabilidade Econômica II (autora, 2007).

Figura 6.8 - Variáveis contempladas na Análise de Viabilidade Econômica III (autora, 2007).

Figura 6.9 - Variáveis contempladas na Análise de Viabilidade Econômica IV (autora, 2007).

Figura 6.10 - Variáveis contempladas na Análise de Viabilidade Econômica V (autora, 2007).

Figura 6.11 - Variáveis contempladas na Análise de Viabilidade Econômica VI (autora, 2007).

Figura 6.12 - Variáveis contempladas na Análise de Viabilidade Econômica VII (autora, 2007).

Figura 6.13 - Variáveis contempladas na Análise de Viabilidade Econômica VIII (autora, 2007).

Figura 6.14 - Variáveis contempladas na Análise de Viabilidade Econômica IX (autora, 2007).

Figura 6.15 - Variáveis contempladas na Análise de Viabilidade Econômica X (autora, 2007).

Figura 6.16 - Ciclo fechado da cadeia produtiva de CGA (autora, 2007).

Figura 7.1 - Fluxos do Sistema Logístico Reverso de resíduos de Chapas de Gesso Acartonado, considerado ideal (autora, 2007).

Figura 7.2 - Cadeia de suprimentos reversa de resíduos de CGA (autora, 2007). 245 


\section{LISTA DE TABELAS}

Tabela 1.1 - Representatividade e amostragem das entrevistas (autora, 2007)...... 19

Tabela 3.1 - Resumo dos fatores intervenientes na consolidação dos CDR de reciclagem na ICC (autora, 2007) .......................................................................... 52

Tabela 4.1 - Classificação dos Resíduos de Construção e Demolição segundo a Resolução n. ${ }^{\circ} 307$ do CONAMA (2002).

Tabela 4.2 - Levantamento das quantidades de RCD geradas e caçambas utilizadas em nove obras na cidade de São Paulo, entre jul/2003 e out/2004 (GIMENES, 2007).

Tabela 4.3 - Destinação dos RCD, segundo a Resolução n. ${ }^{\circ} 307$ do CONAMA (2002).

Tabela 5.1 - Composição química incluindo a presença de metais pesados em gesso acartonado norte-americano (CARR; MUNN, 1997).

Tabela 5.2 - Geração de resíduos de obra de CGA na RMSP no canteiro (autora, 2007).

Tabela 5.3 - Produção e consumo de cimento na região Sudeste, em 2005. (SNIC, 2006).

Tabela 5.4 - Distância do município de São Paulo até as fábricas de cimento localizadas na região Sudeste e no estado do Paraná (baseado em SNIC, 2006). . 144

Tabela 5.5 - Produção e consumo de fosfogesso no Brasil (AQUINO, 2005)........ 148

Tabela 5.6 - Síntese dos fatores intervenientes na consolidação de sistemas logísticos reversos de reciclagem de resíduos de chapas de gesso acartonadoSLR-R-rCGA (autora, 2007).

Tabela 5.7 - Fatores intervenientes na consolidação dos CDR-R-rCGA, visando a produção de nova CGA com conteúdo reciclado (autora, 2007).

Tabela 5.8 - Fatores intervenientes na consolidação dos CDR-R-rCGA, visando a produção de gesso (gipsita) reciclado para a indústria de cimento e a agricultura (autora, 2007).

Tabela 6.1 - Ranking dos melhores fundos de investimento de renda fixa (VALOR ECONÔMICO, 2006).

Tabela 6.2 - Localização das indústrias de cimento no estado de São Paulo e suas respectivas distâncias até o município de São Paulo (SNIC, 2006).

Tabela 6.3 - Custo do frete de distribuição de gesso reciclado de rCGA para indústrias de cimento no estado de São Paulo (autora, 2007).

Tabela 6.4 - Custo de mão-de-obra de operação da central de reciclagem (autora, 2007).

Tabela 6.5 - Custos de manutenção dos equipamentos previstos para a central de reciclagem (autora, 2007)..... 
Tabela 6.6 - Parâmetros para o cálculo dos custos de depreciação dos equipamentos e das obras civis da central de reciclagem, de acordo com a Receita Federal (BRASIL, 1998).

Tabela 6.7 - Custos de depreciação dos equipamentos da central de reciclagem (autora, 2007).

Tabela 6.8 - Custos de depreciação de obras civis da central de reciclagem (autora, 2007).

Tabela 6.9 - Custos de implantação da central de reciclagem (autora, 2007)......

Tabela 6.10 - Composição do financiamento de $75 \%$ do valor do investimento necessário à implantação da central de reciclagem (autora, 2007).

Tabela 6.11 - Balanço de operação da Central de Reciclagem segundo as variáveis da Análise de Viabilidade I (autora, 2007).....

Tabela 6.12 - Balanço de operação da Central de Reciclagem segundo as variáveis da Análise de Viabilidade II (autora, 2007).

Tabela 6.13 - Balanço de operação da Central de Reciclagem segundo as variáveis da Análise de Viabilidade III (autora, 2007).

Tabela 6.14 - Fluxo de caixa da análise de viabilidade econômica III (autora, 2007).

Tabela 6.15 - Balanço de operação da Central de Reciclagem segundo as variáveis da Análise de Viabilidade IV (autora, 2007).

Tabela 6.16 - Balanço de operação da Central de Reciclagem segundo as variáveis da Análise de Viabilidade V (autora, 2007).

Tabela 6.17 - Fluxo de caixa da análise de viabilidade econômica V (autora, 2007).

Tabela 6.18 - Balanço de operação da Central de Reciclagem segundo as variáveis da Análise de Viabilidade VI (autora, 2007).

Tabela 6.19 - Balanço de operação da Central de Reciclagem segundo as variáveis da Análise de Viabilidade VII (autora, 2007).

Tabela 6.20 - Balanço de operação da Central de Reciclagem segundo as variáveis da Análise de Viabilidade VIII (autora, 2007).

Tabela 6.21 - Custos de Implantação da central de reciclagem, considerando as variáveis da análise VIII (autora, 2007).

Tabela 6.22 - Composição do financiamento de $50 \%$ do valor do investimento necessário à atualização (upgrade) da central de reciclagem de um fabricante de CGA (autora, 2007).

Tabela 6.23 - Fluxo de caixa da análise de viabilidade econômica VIII (autora, 2007).

Tabela 6.24 - Balanço de operação da Central de Reciclagem segundo as variáveis da Análise de Viabilidade IX (autora, 2007). 
Tabela 6.25 - Fluxo de caixa da análise de viabilidade econômica IX (autora, 2007).

Tabela 6.26 - Balanço de operação da Central de Reciclagem segundo as variáveis da Análise de Viabilidade X (autora, 2007).

Tabela 6.27 - Custos de Implantação da central de reciclagem, considerando as variáveis da análise $X$ (autora, 2007).

Tabela 6.28 - Composição do financiamento de 74,45\% do valor do investimento necessário à atualização (upgrade) da central de reciclagem de um fabricante de CGA (autora, 2007).

Tabela 6.29 - Fluxo de caixa da análise de viabilidade econômica X (autora, 2007).

Tabela 6.30 - Impacto do custo de disposição de resíduos de CGA em obras de grandes geradores (autora, 2007).

Tabela 6.31 - Consumo de CGA, geração e capacidade de absorção de resíduos de CGA, na RMSP (autora, 2007). 


\section{LISTA DE SIGLAS}

\begin{tabular}{|c|c|}
\hline $\mathrm{ABCP}$ & Associação Brasileira de Cimento Portland \\
\hline ABRAMAT & Associação Brasileira da Indústria de Materiais de Construção \\
\hline ATT & Área de Triagem e Transbordo \\
\hline CETESB & Companhia de Tecnologia de Saneamento Ambiental \\
\hline CGA & Chapa de Gesso Acartonado \\
\hline CIWMB & Califórnia Integrated Waste Management Board. \\
\hline CONAMA & Conselho Nacional do Meio-Ambiente \\
\hline CSCMP & Council of Supply Chain Management Professionals \\
\hline DNPM & Departamento Nacional de Produção Mineral \\
\hline EMBRAPA & Empresa Brasileira de Pesquisa Agropecuária \\
\hline $\mathrm{ICC}$ & Indústria da Construção Civil \\
\hline LIMPURB & Departamento de Limpeza Urbana; \\
\hline MCT & Ministério da Ciência e Tecnologia \\
\hline MDIC & Ministério do Desenvolvimento, Indústria e Comércio. \\
\hline PBQP-H & Programa Brasileiro de Qualidade e Produtividade no Habitat \\
\hline PGRCC & Projeto de Gerenciamento de Resíduos da Construção Civil \\
\hline PIGRCC & Plano Integrado de Gerenciamento de Resíduos da Construção Civil \\
\hline $\mathrm{RCD}$ & Resíduos de Construção e Demolição \\
\hline Revlog & Reverse Logistics \\
\hline RLEC & Reverse Logistics Executive Council \\
\hline RMSP & Região Metropolitana de São Paulo \\
\hline SINDUSCON - SP & Sindicato da Indústria da Construção Civil do Estado de São Paulo \\
\hline SLR & Sistema Logístico Reverso \\
\hline SNIC & Sindicato Nacional da Indústria de Cimento \\
\hline TIR & Taxa Interna de Retorno \\
\hline USEPA & United States Environment Protection Agency \\
\hline
\end{tabular}




\section{1 - Introdução}

A alta competição entre as empresas e a busca constante de aumento na eficiência nos processos de gestão da produção e da produção em si têm caracterizado o ambiente empresarial atual.

Dentre os inúmeros processos presentes em uma empresa, destaca-se a logística empresarial, a qual está orientada para assegurar a entrega do produto fabricado ${ }^{1}$ de maneira correta, no lugar certo, no instante desejado e ao menor custo possível. Em muitos setores, a logística tem recebido maior atenção principalmente em virtude da globalização dos mercados consumidores e da pressão por redução dos custos de distribuição.

O cliente, por sua vez, está inserido na cultura do consumo, na qual é orientado pelo ciclo 'compre-use-disponha'. Esta cultura demonstra-se insustentável, perecível e inadequada para a perpetuação das condições atuais de sobrevivência da sociedade contemporânea, ou seja, para um desenvolvimento sustentável, uma vez que estimula a crescente fabricação de novos produtos, em detrimento da reutilização e do reaproveitamento de subprodutos ou de resíduos. Assim, observa-se que as ações de incentivo ao consumo não são planejadas com visão sistêmica, uma vez que produtos

${ }^{1}$ Entende-se por produto um bem ou serviço 
inservíveis não têm suas opções de reaproveitamento ${ }^{2}$ estruturadas, restando, por vezes, apenas a disposição em aterros como solução para o descarte dos mesmos.

Neste cenário, a logística reversa, ou mais precisamente a implantação de sistemas de logística reversa ganha importância, na medida em que trata do retorno de bens - aos produtores ou a outro agente da cadeia produtiva - que foram usados até o fim de vida útil ou se tornaram obsoletos ao cliente e que, no modelo atual de consumo, seriam descartados. A estruturação dos canais reversos é um caminho para se dar novo uso a estes produtos, por meio de um novo emprego ou de uma transformação, por beneficiamento industrial, em outros produtos úteis.

Sendo assim, a logística reversa possui uma grande interface com o desenvolvimento sustentável, uma vez que a viabilização das cadeias reversas permite o reaproveitamento de produtos obsoletos, subprodutos e resíduos, diminuindo os volumes descartados no ambiente e a extração de novos recursos naturais. Ela apresenta, ainda, outra característica favorável, já que o surgimento de novos negócios promove também o desenvolvimento social, além de permitir retornos financeiros para as empresas envolvidas nas cadeias reversas.

Particularmente na Indústria da Construção Civil (ICC), os sistemas de logística reversa têm por objetivo desenvolver cadeias reversas para o reaproveitamento dos produtos e resíduos originados nos processos produtivos e estabelecer nos agentes que nela atuam o censo de responsabilidade por todo o ciclo de vida do produto.

Esta postura deve ser compartilhada não somente pelas construtoras, mas principalmente pelas empresas fornecedoras de materiais, por estarem estas em um ambiente industrial, onde há menores variabilidades de processo. Assim, podem estas empresas tornarem-se as propulsoras da implantação deste conceito em toda a cadeia produtiva da Construção Civil.

\footnotetext{
2 Considera-se nesta pesquisa o reaproveitamento como o termo que designa um conjunto de possibilidades de uso de resíduos - materiais ou energia - incluindo os processos de reuso, remanufatura, reciclagem e incineração com recuperação de energia. Não estão inclusos no termo "reaproveitamento" os processos de deposição em aterros e de incineração sem recuperação de energia.
} 


\subsection{Objetivos}

A dissertação tem por objetivo principal analisar as possibilidades de aplicação do conceito de logística reversa na cadeia produtiva da Construção Civil. Pretende-se expor de forma ampla os fatores intervenientes, peculiares deste setor, no processo de implantação da logística reversa, com intuito de mostrar os condicionantes, adaptações e benefícios decorrentes desta aplicação.

Em decorrência disto, perfaz o segundo objetivo desta dissertação demonstrar a aplicação deste conceito como elemento essencial à correta gestão da fração de resíduos de chapas de gesso acartonado (CGA) presentes nos resíduos de construção e demolição (RCD) e sua importância para a melhoria da sustentabilidade da construção. Esta escolha tem sua justificativa apresentada no item 1.3.

\subsection{IMPORTÂNCIA E JUSTIFICATIVA DO TEMA}

Na presente pesquisa pressupõe-se que os fluxos reversos de produtos, ou seja, os provenientes do ponto de consumo, não têm recebido a devida atenção por parte das empresas atuantes na Construção Civil, assim como não o têm as iniciativas brasileiras de reaproveitamento de resíduos industriais.

Desta forma, o estudo da logística reversa revela-se uma das condições iniciais para implantar o correto gerenciamento destes fluxos. Considera-se a logística reversa como o processo de planejamento, implementação e controle eficiente, de fluxos de matérias-primas, de inventários em processo, estoques, bens finalizados - incluindo subprodutos e resíduos -, custos e informações relativas a eles, do ponto de consumo para o ponto de origem ou ainda para um outro ponto de reaproveitamento, que se mostre mais viável, levando em consideração os requisitos técnico-sócioeconômicos, sem significar necessariamente a transferência de responsabilidade pelos produtos. A discussão sobre as definições de "logística reversa" é apresentada no capítulo 3 -, item 3.2.

Segundo Leite (2003), o seu estudo justifica-se e torna-se importante, em qualquer segmento produtivo, devido aos seguintes principais fatores: 
- o aumento da velocidade de lançamento de produtos e a diminuição do tempo de vida útil destes, devido principalmente a freqüentes atualizações tecnológicas e de desenho industrial (design), causam um desequilíbrio entre o montante produzido, o montante consumido e aquele que efetivamente consegue ser 'absorvido' pelo meio ambiente;

- o oferecimento de um melhor nível de serviço ao cliente, seja ele usuário final ou empresa, pode proporcionar maior capacidade competitiva às empresas; este nível de serviço pode ser aumentado ao se oferecer soluções de disposição de resíduos para os clientes;

- a maior conscientização ambiental dos clientes em relação ao consumo de produtos e serviços denominados 'ambientalmente corretos' exerce pressões sobre as empresas, graças à preferência de compra de produtos com estes atributos;

- as legislações estão se tornando mais severas em relação aos impactos ambientais de produtos e resíduos e ao consumo de recursos naturais, tanto renováveis quanto não-renováveis;

- a crescente preocupação das empresas com a imagem corporativa, que se beneficiam ao incorporarem os princípios da sustentabilidade às suas práticas;

- a reutilização de máquinas e componentes em diversos 'ciclos' de produção e entrega, como pallets, bags, gaiolas metálicas, maquinários alugados por tempo determinado, etc., exige que atividades logísticas sejam planejadas para que os retorno dos produtos proporcione eficiência na operação e diminuição dos custos de distribuição.

Reproduzindo-se estas diretrizes para a Construção Civil, reitera-se a relevância do estudo em virtude:

- da geração de resíduos; embora não tenha sido verificada uma diminuição no tempo de vida útil dos componentes utilizados na construção civil, nem dos edifícios, os processos industriais da cadeia produtiva da Construção 
Civil geram resíduos industriais de características diversas e em grande volume e massa, os quais causam expressivos impactos ambientais;

- de, por outro lado, já se observar o aumento da velocidade de lançamento de certos produtos e a diminuição do tempo de vida útil destes quanto a aspectos como o desenho industrial, na Construção Civil; este é o caso, por exemplo, de produtos de acabamento, principalmente de áreas frias, como banheiros e cozinhas, sujeitas a reformas antes que os produtos e sistemas implantados tenham atingido o limite de sua vida útil;

- das constantes adaptações que os edifícios sofrem devido à necessidade de flexibilidade no uso dos espaços, principalmente em edifícios comerciais (escritórios e shopping centers, por exemplo), mas também em habitacionais;

- das atividades de logística reversa já existentes na cadeia configurarem-se por meio de iniciativas isoladas, e não possuírem o grau de organização necessário para serem reproduzidas e ampliadas;

- do desenvolvimento sustentável do ambiente construído ser condição primordial para a sustentabilidade do planeta;

- de começarem a existir legislações mais severas em relação aos impactos ambientais causados pela indústria da Construção Civil;

- da possibilidade de se aumentar o nível de serviço ao cliente;

- da crescente preocupação das empresas com a imagem corporativa, como, por exemplo, a possibilidade de atender a requisitos para a certificação segundo a NBR ISO 14001;

- do fato da retirada/devolução de equipamentos de transporte como gruas e elevadores requerer atividades de logísticas reversa, assim como o retorno de pallets geralmente utilizados no transporte de blocos de vedação e outros componentes. 
Portanto, faz-se necessária uma abordagem sistêmica dos fatores que influenciam estes fluxos reversos de produtos, identificando-se os obstáculos e dificuldades a serem transpostos para a consecução de um sistema logístico reverso aplicado às obras civis.

\subsection{Delimitação da Pesquisa}

A cadeia produtiva da Indústria da Construção Civil (ICC) brasileira possui uma grande importância sócio-econômica. De acordo com os dados do Ministério do Desenvolvimento, Indústria e Comércio Exterior - MDIC (2004), o encadeamento setorial anual da Construção Civil corresponde a aproximadamente $\mathrm{R} \$ 81,8$ bilhões ( $\mathrm{R} \$ 74,98$ bilhões para trás e $\mathrm{R} \$ 7,81$ bilhões para frente).

Neste contexto, é perceptível que a cadeia de suprimentos da ICC gera grande valor econômico. Entende-se a logística reversa como uma área da logística empresarial, e esta como um campo de estudo inserido na gestão da cadeia de suprimentos. A logística empresarial revela-se como fator essencialmente influenciador das relações comerciais entre as empresas da cadeia sendo, portanto, determinante de sua competitividade como um todo e de cada agente em particular.

Freqüentemente, verificam-se estudos de logística focados em uma empresa e sua cadeia de suprimentos. No entanto, nesta pesquisa não se foca em uma empresa em especial, mas sim em um grupo de empresas, - por vezes concorrentes no mercado, como, por exemplo, o grupo 'construtoras' - que, pelo fato de possuírem o mesmo 'negócio', têm interesses comuns.

Não se está também abordando somente a cadeia de suprimentos de uma empresa, na qual os elos entre os agentes se dão essencialmente pelas relações comerciais, com maior ou menor grau de interação com o cliente final. Entende-se que a cadeia produtiva inclui, além da cadeia de suprimentos, os agentes institucionais como a academia, os sindicatos, órgãos de classe e governamentais, dentre outros. Estes demais agentes não possuem relações comerciais diretamente com uma empresa, mas influenciam e são influenciados pelas decisões e mudanças que ocorrem na cadeia produtiva em que eles estão inseridos. 
No caso da aplicação apresentada no capítulo 5, item 5.2, analisa-se a logística reversa da cadeia produtiva de Chapas de Gesso Acartonado - CGA, sobre o ponto de vista dos fabricantes, levando em consideração todos estes demais agentes envolvidos.

O escopo desta dissertação abrange os diferentes tipos de agentes, que atuam na cadeia produtiva da Construção Civil e suas atividades logísticas. Tem-se, portanto, um escopo amplo, não limitado a um agente especial. Este estudo preocupa-se com as inter-relações entre agentes, os quais devem ter uma visão conjunta e holística do ambiente em que estão inseridos e da cadeia onde atuam e devem estar alinhados estrategicamente. Acredita-se que é com este enfoque que se conseguirá desenvolver uma proposta para uma ação estruturada de implantação de um sistema logístico reverso, que envolva todos os agentes, como única forma de obter sucesso em sua aplicação.

Segundo esta perspectiva, neste estudo, a aplicação do conceito de logística reversa está restrita à ICC brasileira, especificamente ao setor formal e seu sub-setor de edificações comerciais e habitacionais. Apesar do setor formal - constituído por empresas fornecedoras de materiais, componentes e sistemas, empresas construtoras e fornecedoras de outros serviços - representar parcela menos significativa na produção de edificações, é ele que será abordado, visto haver neste setor uma estruturação mínima necessária para sistematizar a atuação dos agentes envolvidos na cadeia produtiva.

A logística reversa é um conceito relativamente novo e em evolução. Os autores estudados (CHRISTOPHER, 1997; STOCK, 1998; ROGERS; TIBBEN-LEMBKE, 1999) afirmam que a logística reversa constitui-se em uma área ampla de estudo, englobada pela Logística Empresarial. Embora esta área esteja sendo explorada pela indústria seriada desde 1975 em países desenvolvidos, como Inglaterra e EUA (CARTER; ELLRAM, 1998), somente recentemente, na última década, começou a ser estudada no Brasil.

Há duas grandes abordagens da logística reversa em uma cadeia de suprimentos. A primeira refere-se ao retorno de determinados componentes para o ciclo de distribuição, sem requerer qualquer beneficiamento, somente reutilizando-os. Aliás, 
esta é a abordagem que deu origem ao termo. Ela refere-se, por exemplo, ao retorno de pallets, bags, gaiolas metálicas e outros recipientes de distribuição ao cliente.

A segunda abordagem aplica-se ao retorno de produtos ao ciclo de produção, ao reaproveitamento de determinados componentes na fabricação de outros de função semelhante ou não. Esta abordagem refere-se ao aproveitamento de resíduos industriais e comerciais (tanto pós-venda quando pós-consumo) e possui um forte apelo ambiental. Nesta abordagem, o tema de reciclagem é muito significativo.

A aplicação do conceito de logística reversa à ICC, em qualquer uma destas duas abordagens, é um assunto até o momento pouquíssimo explorado. Por outro lado, a análise de trabalhos acadêmicos já concluídos, voltados a outros setores, permite afirmar que são enormes as possibilidades de sua aplicação, desde que respeitadas as características específicas do setor.

No entanto, o sub-setor de edificações comerciais e habitacionais é bastante complexo, envolvendo diversas sub-cadeias, em função dos diferentes subsistemas que compõem os edifícios e das alternativas tecnológicas que cada um oferece. Por isso, achou-se conveniente restringir o estudo de campo a um subsistema e a uma tecnologia.

Assim, e com o intuito de ilustrar as possibilidades de sua implementação, realizouse um estudo sobre a aplicação do conceito de logística reversa a uma fração dos Resíduos de Construção e Demolição - RCD gerados nas obras. Dentre as frações presentes nos RCD optou-se pela dos resíduos de gesso, particularmente aqueles advindos de chapas de gesso acartonado - CGA, uma alternativa tecnológica cada vez mais em uso na produção de vedações verticais internas.

Esta escolha pela fração de CGA baseia-se, igualmente, na disponibilidade de dados consistentes sobre esta fração do RCD, como por exemplo, quantificação, composição e caracterização; na existência de tecnologias de reciclagem e reaproveitamento desenvolvidas; no fato do gesso ser um material determinante da contaminação das demais frações de RCD; dele apresentar toxidade e ausência de tratamento específico para disposição; na existência de experiências internacionais e de uma experiência inicial de reciclagem no Brasil; no fato deste ser um setor organizado, em que os agentes podem ser mais facilmente identificados (seus 
fabricantes estão organizados em uma associação) e; no interesse demonstrado pelas indústrias produtoras e pelas empresas consumidoras em colaborar com este estudo, vislumbrando soluções possíveis para contribuir com a mitigação dos impactos ambientais provenientes de seu produto.

No âmbito desta aplicação são contempladas, como experiências mais relevantes para o estudo, as realizadas no Brasil, restringindo-se o alcance geográfico de mercado ao da Região Metropolitana de São $\mathrm{Paulo}^{3}$ (RMSP), por ser esta a região em que se concentra o maior consumo de chapas de gesso acartonado do país. Segundo a Associação Brasileira dos Fabricantes de Chapas para Drywall ${ }^{4}$ (ASSOCIAÇÃO DRYWALL, 2006), o consumo desta região corresponde de 38 a $40 \%$ de todo o mercado brasileiro. Além disto, na RMSP as experiências demonstraram-se mais ricas e com disponibilidade de dados e informações.

Serão considerados os três fabricantes de CGA, os quais possuem plantas industriais em Mogi das Cruzes, a cerca de 60km da capital paulista; em Queimados, região sul do estado do Rio de Janeiro, a 380km da capital paulista; e em Petrolina, PE, a aproximadamente $2.000 \mathrm{~km}$ da capital paulista.

Acredita-se que os princípios da logística empresarial e da cadeia de suprimentos são de grande valia para a elaboração de um sistema logístico reverso de resíduos de construção de chapas de gesso acartonado - SLR-CGA.

A elaboração deste sistema e a demonstração de sua utilidade, um dos objetivos desta pesquisa, dá-se por meio da identificação, quantificação, organização e consolidação dos agentes envolvidos, suas atividades e fluxos reversos - incluindo os fluxos físicos e de informação - de forma a configurar-se um SLR-CGA viável técnica e economicamente para a zona geográfica delimitada, e capaz de contribuir para tornar a Construção Civil mais sustentável.

\footnotetext{
${ }^{3}$ A Região Metropolitana de São Paulo - RMSP está localizada no entorno do município de São Paulo. Reúne 39 municípios ocupando uma área de $8.051 \mathrm{~km}^{2}$. Possui uma população de 17,879 milhões de habitantes (PREFEITURA DO MUNICÍPIO DE SÃO PAULO, 2006a, a partir de dados do Censo Demográfico, IBGE, 2002).

${ }^{4}$ Fundada em 2000 pela BPB Placo, Knauf do Brasil e Lafarge Gypsum, a Associação Brasileira dos Fabricantes de Chapas para Drywall tem como objetivo difundir a tecnologia do drywall em toda a cadeia de negócios da construção civil do país. Esta associação é conhecida no mercado como Associação Drywall e este será o termo utilizado, deste ponto em diante no texto, para referenciá-la. (ASSOCIAÇÃO DRYWALL, 2006).
} 


\subsection{Metodologia da Pesquisa}

Todo e qualquer estudo, técnico ou científico, deve ser conduzido de uma forma préestabelecida, sob pena de se perder o foco da questão, não obter conclusões ou até mesmo não se conseguir terminar o referido estudo. A forma como o estudo é conduzido, abordado e solucionado consiste então na metodologia de pesquisa.

Segundo Sabbatini (1989), "o objetivo de uma metodologia é o de estabelecer uma orientação efetiva ao pesquisador que dela se utilizar em um certo processo investigativo, possibilitando-lhe tomar decisões oportunas e selecionar as hipóteses, técnicas e dados mais adequados. E não simplesmente estabelecer um roteiro a ser seguido, como é próprio do método. O domínio da metodologia introduz a visão de conjunto".

Em concordância com esta citação, como se está utilizando uma metodologia para um processo investigativo, existem questões a serem respondidas. Na presente pesquisa, as questões centrais que a motivaram foram:

I. O que caracteriza o conceito de logística reversa e como aplicá-lo à ICC?

II. Como a logística reversa pode auxiliar a obtenção de uma construção mais sustentável?

III. Quais fatores podem inviabilizar um sistema logístico reverso na ICC?

IV. Como estruturar um sistema logístico reverso para a ICC?

V. Como demonstrar sua aplicabilidade, ainda que parcialmente, voltada a uma cadeia específica a ICC, como a de CGA?

Em decorrência destas, surgiram outras adicionais:

VI. Quais as atividades de logística reversa existentes, no caso da cadeia de CGA? Como elas ocorrem e de que forma podem ser organizadas?

VII. Onde estão localizados os agentes participantes das cadeias de suprimentos de uma empresa, no caso das três indústrias de CGA existentes no país?

VIII. Quais são os fluxos nelas gerados, para a zona geográfica delimitada? 
IX. Quais as tecnologias utilizadas na entrega, armazenamento, transporte, segregação e reaproveitamento dos resíduos da cadeia de CGA?

X. Qual a demanda das tecnologias de reaproveitamento na cadeia de CGA?

XI. É viável física, técnica e economicamente estabelecerem-se sistemas logísticos reversos para RCDs de CGA (para a zona geográfica delimitada)?

Isto posto, ao se estabelecer a metodologia da presente pesquisa, percebeu-se que apenas uma estratégia de pesquisa não permitiria responder a todas estas questões. De forma similar, Yin (2005) afirma que "muito embora cada estratégia (de pesquisa) tenha suas características distintas, há grandes áreas de sobreposições entre elas" e ainda que uma estratégia pode estar inserida em um estudo mais amplo, que utilize uma outra estratégia, ou complementar a principal.

Assim, para atingir os objetivos definidos e responder às questões de pesquisa, optou-se por três estratégias: a pesquisa bibliográfica, o levantamento de dados exploratórios e o estudo de caso.

A pesquisa bibliográfica foi utilizada em dois momentos, sempre concomitantemente com as outras duas estratégias de pesquisa. Desta forma, para a consecução deste trabalho, a metodologia de pesquisa constitui-se de duas etapas, a saber:

- Etapa 1: Estudo genérico:

- Pesquisa bibliográfica 1: levantamento e análise das bibliografias disponíveis específicas e correlatas aos assuntos: Cadeia produtiva da ICC; Sustentabilidade; Construção Sustentável; Logística empresarial; Logística Reversa; e Gerenciamento de RCD.

- Estudo exploratório: constituído por entrevistas com especialistas, acadêmicos, agentes da indústria e outras partes interessadas.

- Etapa 2: Estudo do Exemplo Escolhido:

- Pesquisa bibliográfica 2: levantamento e análise das bibliografias disponíveis específicas e correlatas aos assuntos: Gesso Acartonado; Tecnologias de Reciclagem, Armazenamento e Disposição. 
- Trabalho de campo: levantamento de dados quantitativos na indústria de CGA.

A Figura 1.1 ilustra as etapas da pesquisa e o detalhamento destas encontra-se nos itens que seguem.

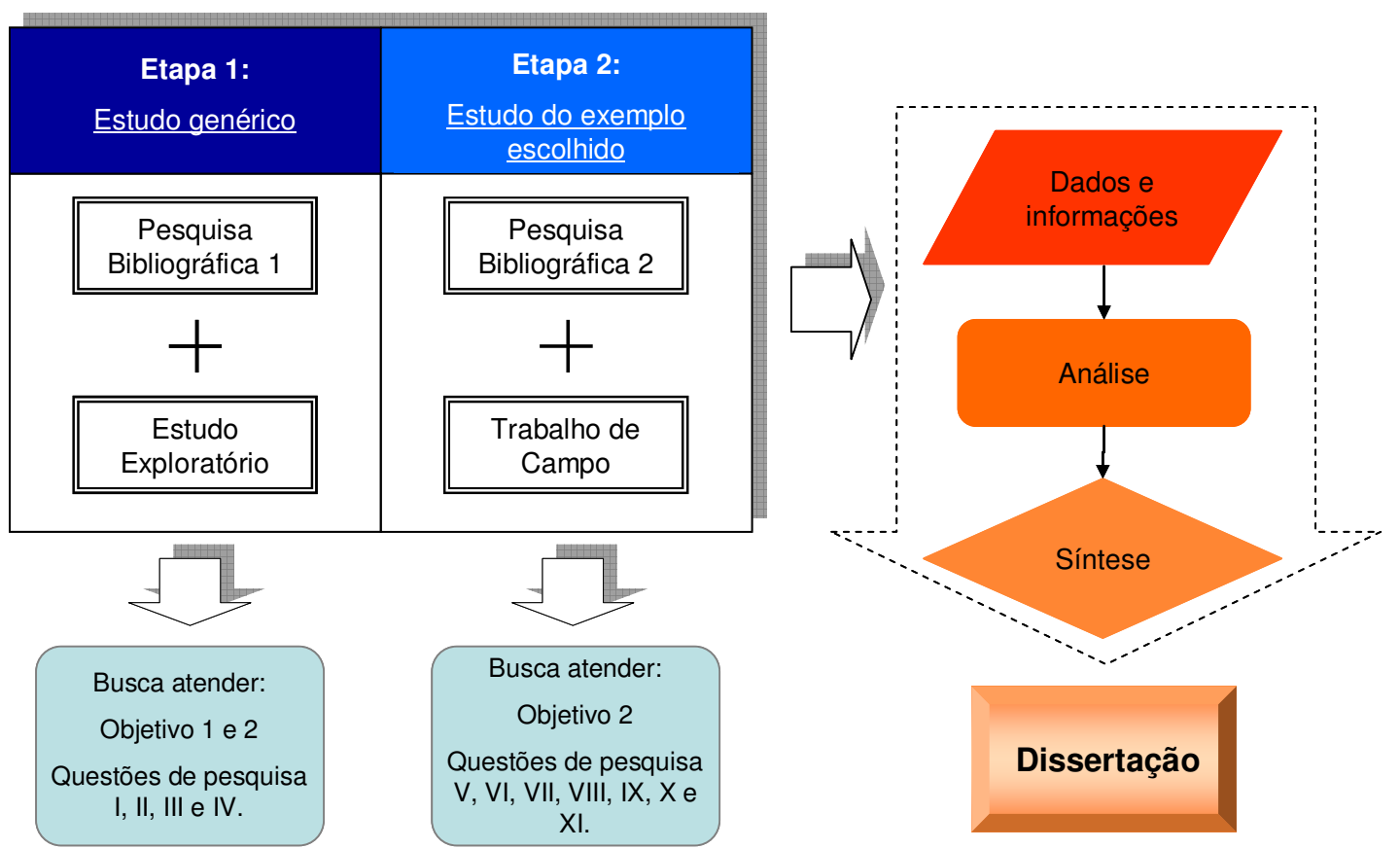

Figura 1.1 - Etapas de pesquisa da metodologia adotada (autora, 2007).

\section{Pesquisa bibliográfica 1 e 2}

As pesquisas bibliográficas envolveram a consulta a livros, dissertações, teses, boletins técnicos, revistas científicas de interesse, jornais, artigos de congressos e estudos de núcleos de pesquisa de universidades, tanto nacionais como estrangeiras, todos de reconhecida importância e idoneidade.

Os documentos foram obtidos por meio de bancos de dados, como o Infohab, Dedalus e Capes, nas bibliotecas de Engenharia Civil e de Engenharia de Produção da Universidade de São Paulo e na internet. Foram utilizadas também informações referentes a organizações estrangeiras de profissionais da área de logística, como as norte-americanas CSCMP - Council of Supply Chain Management Professionals e RLEC - Reverse Logistics Executive Council e a holandesa Reverse Logistics Revlog. 
Mostraram-se como principais fontes de consulta internacional os artigos publicados no International Journal of Logistics: Research and Applications, no Journal of Business Logistics e no Building and Environment.

Com base na análise do material levantado definiu-se os conceitos básicos envolvidos no tema da pesquisa, assim como desenvolveu-se o raciocínio de como consolidar e otimizar um canal de logística reversa em uma estrutura de cadeia produtiva tão diferenciada, como a da Construção Civil.

As palavras-chaves usadas em buscas de bibliografia de apoio disseram, portanto, respeito sobretudo aos temas logística, logística reversa e chapa de gesso, tanto em língua portuguesa quanto inglesa.

\section{Estudo exploratório}

O objetivo do estudo exploratório foi diagnosticar como os especialistas da área de logística reversa vislumbram a sua aplicabilidade no setor da Construção Civil, a partir de suas experiências em outros setores. Foram realizadas quatro (4) entrevistas, orientadas por um questionário semi-estruturado elaborado pela pesquisadora, que se encontra no Apêndice A. As perguntas presentes neste questionário são de caráter geral e concentram-se em questões amplas, sem especificidade.

Os especialistas entrevistados foram:

- Paulo Roberto Leite, mestre pela Universidade Presbiteriana Mackenzie, pós-graduado pela Fundação Getúlio Vargas - FGV, professor de graduação e pós-graduação da Universidade Presbiteriana Mackenzie, responsável pelos cursos de pós-graduação em logística empresarial, consultor, autor do livro "Logística Reversa - Meio Ambiente e Competitividade".

- Orlando Fontes Lima Júnior, engenheiro, mestre e doutor pela Universidade de São Paulo - USP, professor de graduação e pós-graduação da Universidade Estadual de Campinas - UNICAMP, e especialista na área de logística. 
- Edson Martins de Aguiar, mestre e doutor pela Universidade de São Paulo, professor de graduação e pós-graduação da Universidade de São Paulo USP (campus São Carlos), e especialista na área de logística.

- Emília Wanda Rutkowski, mestre pela University of Stirling, doutora pela Universidade de São Paulo - USP, professora de graduação e pósgraduação da Universidade Estadual de Campinas - UNICAMP, e especialista na área de saneamento.

\section{Trabalho de Campo}

O trabalho de campo utilizou o estudo de caso somente como estratégia de pesquisa. O 'estudo de caso’ não foi realizado, uma vez que não foi possível estudar o caso "cadeia reversa de CGA", pois esta cadeia ainda não existe.

A estratégia de estudo de caso aplica-se quando se faz uma questão do tipo "como" ou "por que" sobre um conjunto contemporâneo de acontecimentos, sobre o qual o pesquisador tem pouco ou nenhum controle. Julga-se ser esta a condição em que esta pesquisa se insere, uma vez que tanto o conceito quanto as atividades de logística reversa são recentes e não há ainda consenso sobre os mesmos. Além disso, as questões centrais fixam-se sobre "como" e "por que" ocorrem ou deveriam ocorrer determinadas atividades.

Considera-se como um estudo de caso único, pelo fato de se analisar apenas uma cadeia produtiva, a de CGA, e suas unidades múltiplas correspondem aos diversos agentes que a formam e que são abordados.

As questões centrais de "como" e "por que" poderiam ser respondidas apenas qualitativamente. No entanto, o imperativo de responder também às questões adicionais sobre a viabilização dos canais de distribuição da cadeia de suprimentos de CGA levou à necessidade de se realizar um levantamento de dados quantitativos, como parte das evidências deste caso.

Assim o trabalho de campo teve por objetivo, a partir de levantamento de dados em entidades e na indústria, detalhar os fluxos e canais reversos da cadeia de CGA hoje 
existentes na região metropolitana de São Paulo, identificando tanto os pontos problemáticos vigentes quanto os pontos positivos.

A obtenção das informações necessárias nesta etapa - tanto qualitativos quanto quantitativos - foi efetuada por meio entrevistas, as quais, segundo Yin (2005), são "uma das fontes mais importantes de informações para um estudo de caso". Os questionários de entrevista utilizados foram semi-estruturados, sempre que possível aplicados pessoalmente e acompanhados de visitas técnicas às instalações industriais, se existentes.

As entrevistas foram apoiadas em questionários específicos para cada grupo de agentes, uma vez que tiveram a intenção de identificar visões e interesses distintos no gerenciamento dos fluxos reversos, assim como a influência que cada um exerce sobre a viabilização ou não dos sistemas de logística reversa.

Foram realizadas, em alguns casos duas entrevistas. A entrevista inicial teve por objetivo o levantamento de dados primordiais para o entendimento dos mecanismos logísticos e das inter-relações no âmbito da empresa, e foi preferencialmente presencial. Utilizou-se eventualmente a segunda para dirimir possíveis dúvidas ou abordar pontos não esclarecidos anteriormente, aprofundando-os.

De acordo com este raciocínio e tomando-se por base a empresa fabricante das chapas de gesso acartonado, identificou-se inicialmente quais são os agentes que integram os canais de distribuição diretos de chapas de gesso acartonado, ilustrados na Figura 1.2.

Nestes canais relacionou-se três grandes grupos: fornecedores, fabricantes e consumidores. Os consumidores subdividem-se em três agentes: construtoras, distribuidores (atacadistas e varejistas) e instaladores. Por vezes, ocorre de os distribuidores também fornecerem serviços de instalação. Neste caso, os dados referentes a este grupo foram considerados no item "distribuidores", uma vez que interessava aqui, precisamente, quem era o agente comprador do material, independentemente de ter sido ele próprio o instalador ou não. 


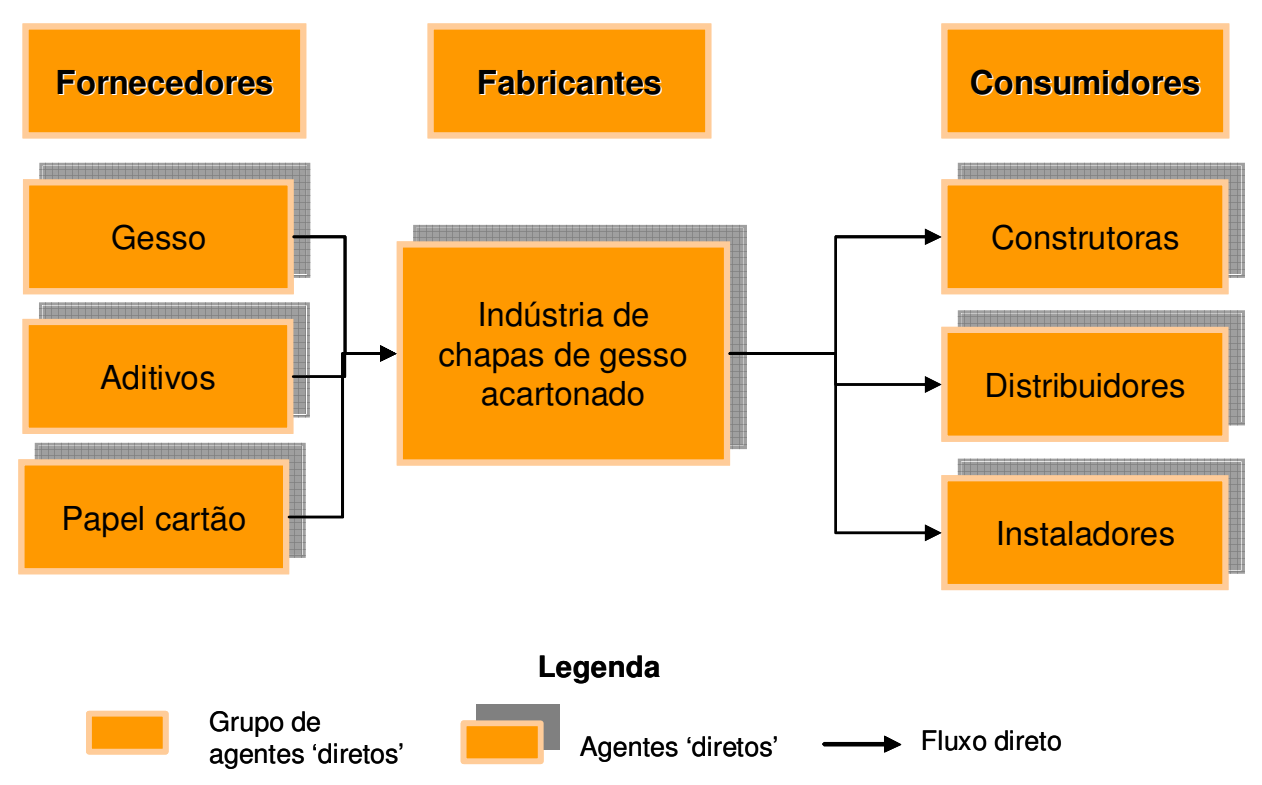

Figura 1.2 - Agentes integrantes da cadeia direta de CGA (autora, 2007).

Em seguida, foram listados os agentes dos canais de distribuição reversos, indicados em verde, os quais incluem os já citados agentes dos canais diretos e ainda os seguintes três grupos: coletores e transportadores de RCD; indústrias e; aterros. Considerou-se, em relação ao grupo 'indústrias', aquelas que podem absorver os resíduos de CGA como matéria-prima de seus processos produtivos, desde que estes resíduos atendam a certos padrões de qualidade e especificações exigidas, de acordo com as tecnologias de reciclagem disponíveis no Brasil durante a elaboração desta pesquisa. Sendo assim, o grupo 'indústrias' abrange a própria indústria de chapas de gesso acartonado, as indústrias de cimento e de papel e a agroindústria (Figura 1.3).

$\mathrm{Na}$ pesquisa, não foram abordados os três únicos tipos de fornecedores de insumos da indústria de CGA devido a três fatores. Em primeiro lugar, todas as três empresas de fabricação de CGA estudadas possuem atividades próprias de extração de gipsita, matéria-prima do gesso utilizado; portanto, não há uma transação comercial, somente uma transferência de material entre as unidades da mesma empresa. Depois, pelo fato dos aditivos acrescentados nos processos industriais corresponderem à parcela insignificante na composição da CGA. E, finalmente, porque o papel cartão utilizado é importado. 

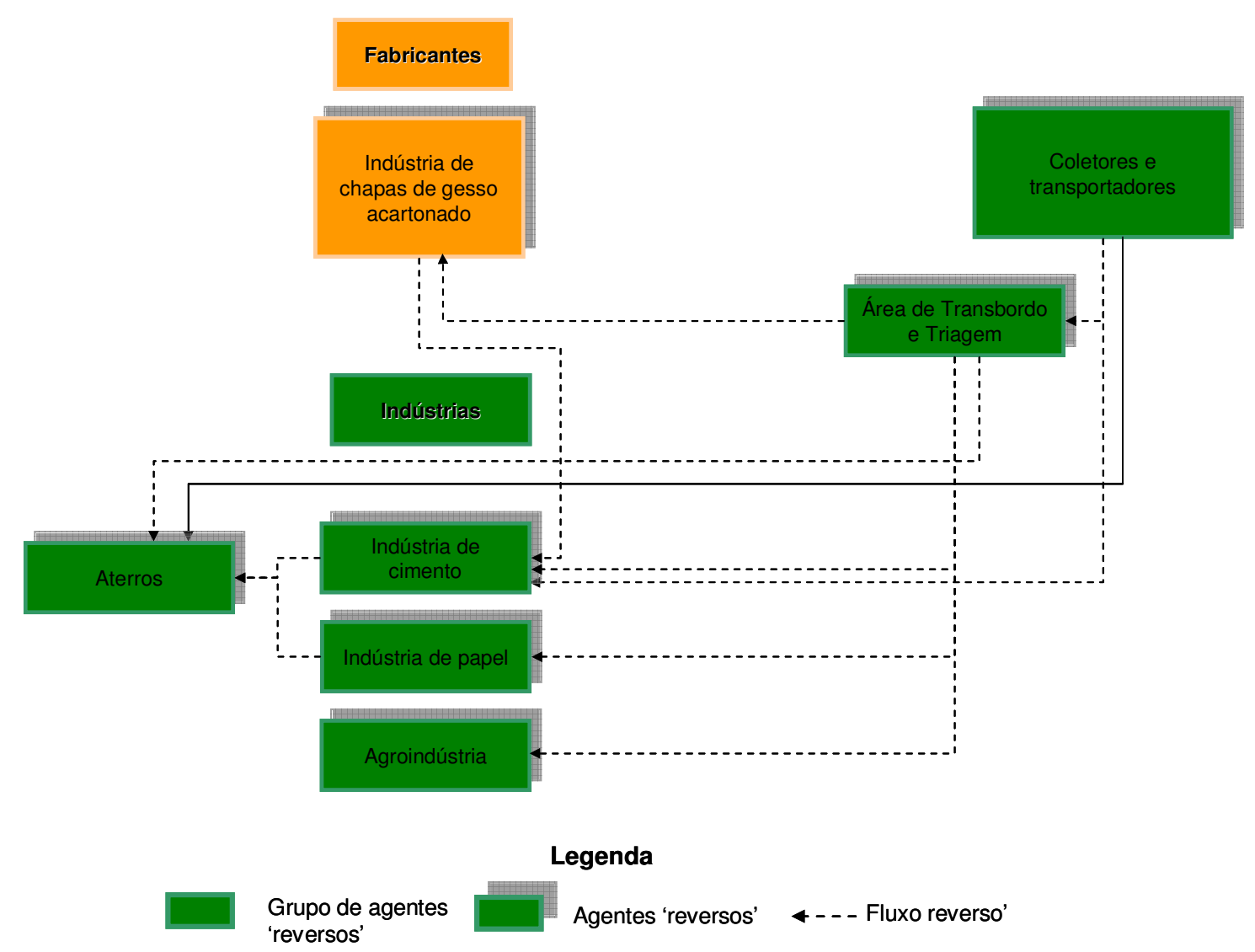

Figura 1.3 - Agentes integrantes da cadeia reversa de CGA (autora, 2007).

No caso dos fabricantes da CGA, tem-se três empresas atuantes no mercado brasileiro, as quais possuem unidades fabris no sudeste (RJ e SP) e no nordeste do país (PE). Para estes, elaborou-se três diferentes tipos de questionários. O primeiro tipo teve por objetivo analisar as relações comerciais entre fabricantes, construtoras e distribuidoras, definindo os fluxos de informações, além de obter dados acerca dos volumes vendidos, locais principais de distribuição e custos. O segundo tipo relaciona-se à área industrial e teve por intuito caracterizar o processo de produção, de modo a investigar as possibilidades de reaproveitamento dos materiais e quantificar os volumes de resíduos de produção; no caso de uma das indústrias, que já realiza reciclagem na sua planta, o tema também foi aqui coberto. Já o terceiro buscou identificar as motivações empresarias para a logística reversa e qual seu impacto na estratégia empresarial dos fabricantes. 
Em relação ao grupo 'consumidores', devido ao seu elevado número de atores, optou-se, para o caso dos distribuidores e instaladores, pelo envio do questionário por correio.

Quanto às construtoras, também devido ao seu elevado número, optou-se por perguntar aos fabricantes quais eram seus maiores clientes no caso da venda direta; foram assim identificadas as quatro maiores compradoras da RMSP.

De cada grupo de agentes contemplou-se uma amostragem mínima de 33\% em relação ao mercado da RMSP. Isto significa, por exemplo, que dos 3 fabricantes de CGA existentes, 3 foram entrevistados quanto ao perfil comercial, tendo portanto uma representatividade no mercado, em relação à produção, de $100 \%$. Já em relação aos distribuidores de CGA, 16 foram contemplados, os quais representam, em consumo de CGA, $80 \%$ do mercado.

O início da cadeia reversa é contemplado por meio da entrevista à Área de Transbordo e Triagem da empresa Maxi Papel Comércio de Aparas e Sucatas Ltda; conhecida por ATT do Pari. Na época da realização do estudo exploratório, em julho de 2006, havia somente esta Área de Transbordo e Triagem operando com resíduos de CGA. Em janeiro de 2007 já havia mais uma ATT operando com estes resíduos.

Na medida em que o estudo foi sendo realizado, fez-se necessária a consulta a outros agentes. São eles: a Associação Brasileira de Cimento Portland - ABCP, a indústria de cimento do Grupo Lafarge, e uma indústria de papel, localizada no estado do Paraná e denominada por indústria ' $\mathrm{P}$ '.

Consultou-se a ABCP por meio de mensagens eletrônicas com o Dr. Vagner Maringolo, sem o uso questionário estruturado. Por meio da $\mathrm{ABCP}$ estabeleceu-se contato com a Lafarge. No caso da Lafarge, as informações foram obtidas por meio de questionário respondido através de mensagens eletrônicas. Este questionário procurou identificar as vantagens e desvantagens, assim como os empecilhos, do uso de resíduos de CGA por esta indústria.

De forma similar, a visita realizada e o questionário aplicado à indústria de papel 'P' possibilitaram verificar os empecilhos ao uso dos resíduos de papel cartão de CGA por esta indústria. 
Em síntese, de acordo com o perfil requerido do entrevistado, atribuiu-se a aplicação dos questionários conforme Tabela 1.1 .

Tabela 1.1 - Representatividade e amostragem das entrevistas (autora, 2007).

\begin{tabular}{|c|c|c|c|c|c|}
\hline & Agentes & Perfil & $\begin{array}{l}\text { Amostra- } \\
\text { gem (Un.) }\end{array}$ & $\begin{array}{c}\text { Representatividade } \\
\text { no mercado da } \\
\text { RMSP (\%) }\end{array}$ & $\begin{array}{l}\text { Tipos de } \\
\text { entrevista }\end{array}$ \\
\hline \multirow{6}{*}{ 蛋 } & \multirow{3}{*}{$\begin{array}{l}\text { Fabricantes de } \\
\text { CGA }\end{array}$} & Estratégico & 1 & 33 & A \\
\hline & & Comercial & 3 & 100 & $\mathrm{~B}$ \\
\hline & & Produção e reciclagem & 1 & 33 & $\mathrm{C}$ \\
\hline & Construtoras & Usuário & 4 & 80 & $\mathrm{D}$ \\
\hline & $\begin{array}{l}\text { Áreas de } \\
\text { Transbordo e } \\
\text { Triagem }\end{array}$ & Reciclagem & 1 & $100\left(^{*}\right)$ & G \\
\hline & $\begin{array}{l}\text { Indústria de } \\
\text { papel }\end{array}$ & Reciclagem & 1 & - & 1 \\
\hline 它 을 을 & Distribuidores & Comercial; Usuário & 16 & 80 & $E$ \\
\hline 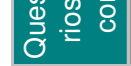 & Instaladores & Usuário & 18 & 80 & $\mathrm{~F}$ \\
\hline 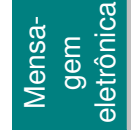 & $\begin{array}{l}\text { Indústria de } \\
\text { cimento }\end{array}$ & Reciclagem & 1 & - & $\mathrm{H}$ \\
\hline & & Total: & 46 & $\begin{array}{l}\text { Total de tipos de } \\
\text { questionários: }\end{array}$ & 9 \\
\hline
\end{tabular}

(*) Na época da realização do estudo exploratório, em julho de 2006, havia somente uma Área de Transbordo e Triagem operando com resíduos de CGA. Em janeiro de 2007 já haviam duas ATT operando com estes resíduos.

Os nove tipos de questionários de entrevista utilizados no trabalho de campo encontram-se nos Apêndices B a J.

Os questionários que foram aplicados em entrevistas retornaram aos entrevistados para a confirmação e ou correção das informações obtidas. Com exceção dos agentes Indústria de papel e Indústria de cimento, de todos os outros agentes foram utilizadas somente informações que se confirmaram em mais de uma amostra.

\subsection{ESTRUTURa Da DisSERTAÇão}

Esta dissertação é composta por sete capítulos, incluindo-se este, além dos apêndices e anexos. Neste primeiro capítulo são apresentados os objetivos, as justificativas para o tema, a delimitação e a metodologia da pesquisa, a estrutura da dissertação e as 
definições dos principais conceitos envolvidos, de forma a transmitir ao leitor a visão segundo a qual o estudo se desenvolve, o que exatamente ele abrange e de que forma ele foi concebido e desenvolvido.

No capítulo seguinte apresenta-se o cenário em que o estudo está inserido - a cadeia produtiva da Indústria da Construção Civil, considerando-se o conceito de sustentabilidade, inclusive aplicado ao ambiente construído. Conclui-se acerca da influência que o mesmo exerce sobre a possibilidade de implantação de sistemas logísticos reversos.

A base teórica sobre a logística na Construção Civil é abordada no Capítulo 3, onde se expôs o estágio atual de seu desenvolvimento. Abordou-se ainda a teoria sobre a logística reversa, suas classificações, como ela se relaciona com os conceitos de cadeia de suprimentos e desenvolvimento sustentável. As conclusões apontam as condicionantes à aplicação do conceito de logística reversa aos fluxos de RCD.

O capítulo 4 aborda o Sistema de Gerenciamento de Resíduos de Construção Civil brasileiro. Através da comparação deste sistema com as experiências americanas e européias, guardadas as características locais, é possível concluir sobre as necessidades de avanço das práticas, normas técnicas e legislações brasileiras.

A aplicação do conhecimento até então alcançado é demonstrada no Capítulo 5. Neste, é exposto o exemplo da cadeia de chapas de gesso acartonado, para a qual é proposto um sistema logístico reverso - SLR-CGA, englobando-se a caracterização dos agentes, a gestão dos Resíduos de Construção e Demolição, as tecnologias de aproveitamento dos resíduos de CGA, a análise quantitativa de volumes gerados e demandados e os fluxos de informações, dentre outros pontos.

A partir disto, no capítulo seguinte, são realizadas simulações, de acordo com cinco variáveis, de viabilidade econômica de cadeias reversas, com o objetivo de apontar algumas oportunidades de negócios. A partir das alternativas viáveis, conclui-se sobre o efeito da implantação destas sobre a cadeia de CGA.

Por fim, o Capítulo 7, fundamentado nos capítulos antecedentes, apresenta as conclusões finais sobre os objetivos inicialmente expostos nesta pesquisa. 
Relacionam-se então as referências bibliográficas utilizadas, seguidas pela apresentação dos apêndices elaborados e anexos referenciados. 


\section{2 - Cadeia Produtiva da Construção Civil e Sustentabilidade}

\subsection{A CAdeia Produtiva da Indústria da CONSTRuÇão Civil}

A Indústria da Construção Civil possui características bastante peculiares se comparada às demais indústrias. Apresenta-se como um setor muito heterogêneo em relação aos segmentos de mercado que cobre, ou sub-setores, com uma grande diversidade de especialidades e, por vezes, com uma imensa disparidade em relação ao porte das empresas que a constituem.

Assim, o levantamento do MDIC (2004) comprova a existência de cerca de 115.939 empresas do sub-setor de Edificações, 10.811 do de Construção Pesada, 1.660 do de Montagem Industrial e 76.445 do de Empreiteiros e Locadores de Mão-de-Obra. Tais empresas são as chamadas transformadoras, ou seja, responsáveis pela produção ou construção do bem final, a obra civil ou a edificação. Estas empresas, de características distintas, formam parte dos agentes da chamada cadeia produtiva da Construção Civil, que inclui ainda empresas da área de serviços, como projeto e gerenciamento, e as indústrias de materiais e componentes, dentre outros. Segundo o 
MDIC (2000), a cadeia produtiva de um dado segmento "consiste em um conjunto de atividades que se articulam progressivamente desde os insumos básicos até o produto final, incluindo distribuição e comercialização, constituindo-se em elos de uma corrente”.

A estrutura da cadeia e seus agentes participantes variam de acordo com o sub-setor e a tipologia do empreendimento. As figuras 2.1 e 2.2 ilustram, respectivamente, exemplos de cadeias que podem ser chamadas de construtivas para os sub-segmentos residencial formal de casas e de edifícios e condomínios horizontais, do sub-setor de Edificações.

- Cadeia Construtiva para o Sub-Segmento Residencial Formal - Casas

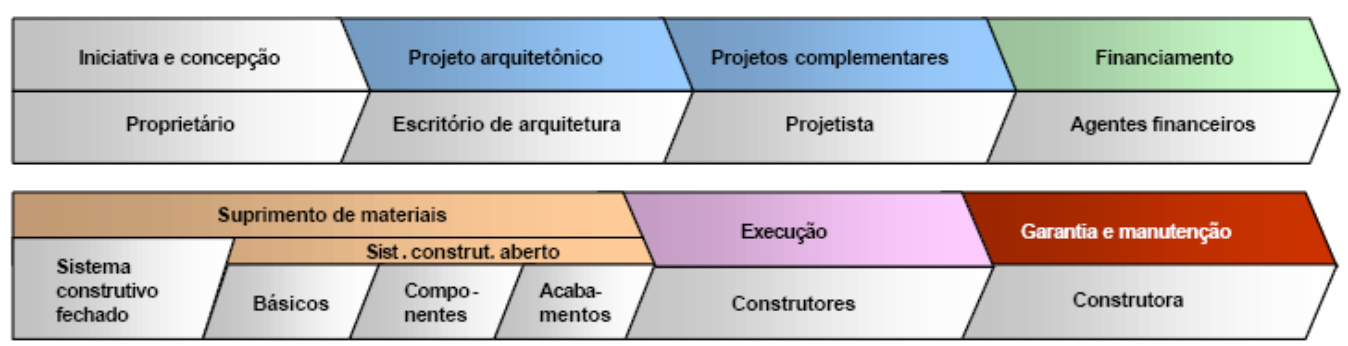

\section{Legenda}
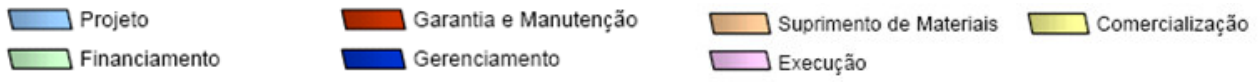

Figura 2.1 - Ilustração da cadeia construtiva para o sub-segmento residencial formal - casas (MDIC, 2004).

\section{- Cadeia Construtiva para o Sub-Segmento Residencial Formal ${ }^{\star \star}$ - Edifícios e Condomínios Horizontais}

\begin{tabular}{|c|l|l|l|l|l|}
\hline $\begin{array}{l}\text { Iniciativa e } \\
\text { concepção do } \\
\text { empreendimento }\end{array}$ & $\begin{array}{l}\text { Projeto } \\
\text { arquitetônico }\end{array}$ & Gerenciamento & $\begin{array}{l}\text { Orçamento e } \\
\text { avaliaçäo de } \\
\text { viabilidade }\end{array}$ & Financiamento & $\begin{array}{l}\text { Projetos } \\
\text { complementares }\end{array}$ \\
\hline Incorporador & $\begin{array}{l}\text { Escritório de } \\
\text { arquitetura }\end{array}$ & Gerenciadora & Incorporadora & $\begin{array}{l}\text { Agente } \\
\text { financeiro }\end{array}$ & Projetista \\
\hline
\end{tabular}

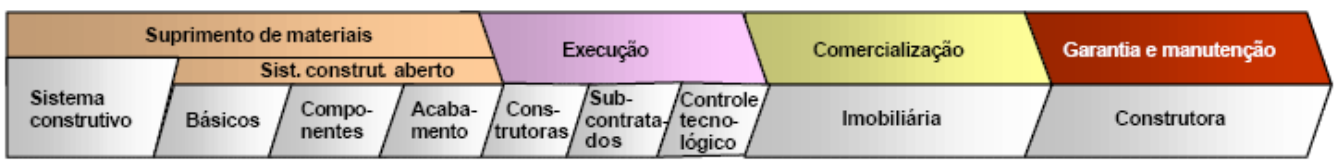

${ }^{* *}$ Exclui auto construção

\section{Legenda}
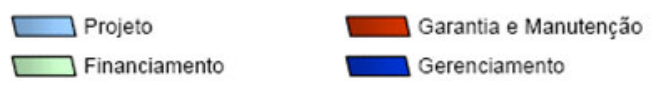

$\square$ Suprimento de Materiais $\square$ Comercialização

Figura 2.2 - Ilustração da cadeia construtiva para o sub-segmento residencial formal-edifícios e condomínios horizontais (MDIC, 2004). 
Segundo dados do MDIC (2004), a economia da Construção Civil, considerando-se apenas as empresas transformadoras, na última década e na atual, tem apresentado queda de participação no Produto Interno Bruto - PIB, conforme ilustrado na Figura 2.3 .

\begin{tabular}{|c|c|}
\hline \multicolumn{2}{|c|}{$\begin{array}{l}\text { PARTIC. (\%) DO SETOR NO PIB } \\
\text { (VALOR ADICIONADO) }\end{array}$} \\
\hline Ano & Construção \\
\hline 1993 & 8,3 \\
\hline 1994 & 9,2 \\
\hline 1995 & 9,2 \\
\hline 1996 & 9,5 \\
\hline 1997 & 9,9 \\
\hline 1998 & 10,1 \\
\hline 1999 & 9,4 \\
\hline 2000 & 9,1 \\
\hline 2001 & 8,5 \\
\hline 2002 & 8,0 \\
\hline
\end{tabular}

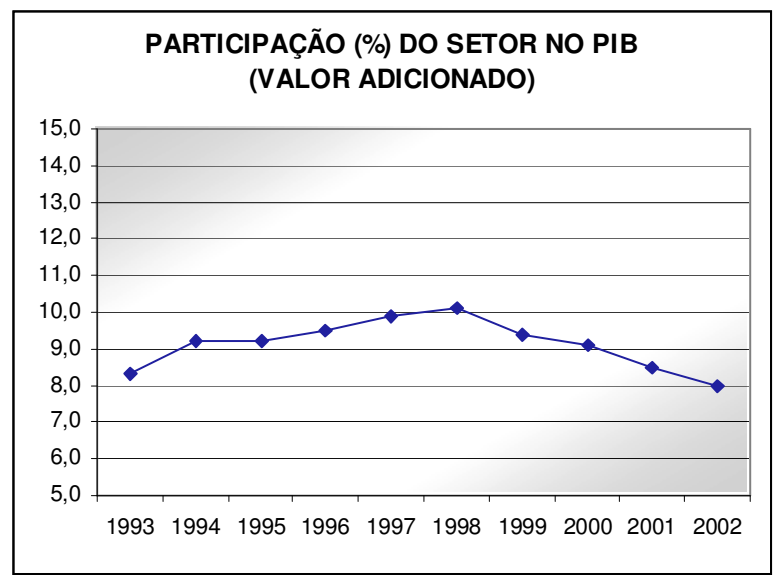

Figura 2.3 - Participação do setor da Construção Civil no PIB brasileiro (MDIC, 2004).

Ainda assim, e considerando que os dados econômicos atuais indicam uma reversão desta tendência de queda existente desde 1998, a ICC representa uma parcela significativa da economia. Por exemplo, em 2003, foi responsável por 7,8\% do PIB (CONSTRUBUSINESS, 2005).

Mais ainda, ao se abordar, de forma mais ampla, a cadeia produtiva da Construção Civil, e como ela é tratada nas estimativas do Instituto Brasileiro de Geografia e Estatística - IBGE, incluindo os setores de materiais de construção, máquinas e equipamentos e serviços, incluindo-se o de pós-entrega - assistência técnica, garantia, atividades imobiliárias, etc. - obtém-se os dados do que vem sendo denominado Construbusiness (Figura 2.4). A importância econômica do setor passa a ser da ordem de 14 a 16\% (CONSTRUBUSINESS, 2005).

Vale ressaltar que, conforme Gondim et. al. (2004), que se basearam nos dados do Construbusiness, "o poder de alavancagem da ICC pode ser representado pela sua elevada participação na formação de investimento: a construção civil é responsável por aproximadamente $70 \%$ da formação de capital da economia brasileira”. Os mesmos autores afirmam também que a construção civil "não requer grande 
demanda de importações, o que não pressiona a balança comercial com o aumento da atividade. Ou seja, a ICC funciona como um grande incentivador dos outros setores da economia, sendo por meio de sua alta taxa de geração de emprego, renda, impostos ou pela sua variada demanda industrial".

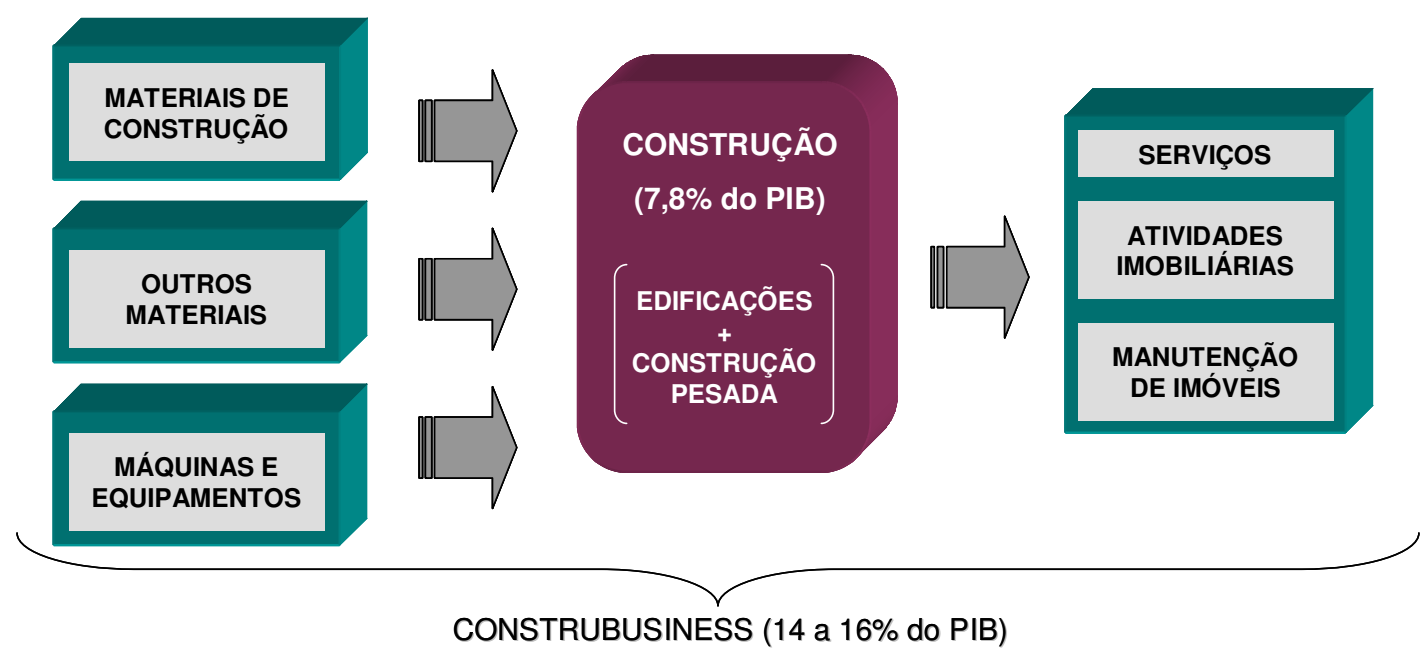

Figura 2.4 - Representação do Construbusiness, com dados de 2003 (adaptado de CONSTRUBUSINESS, 2005).

Além da sua expressiva participação econômica, destaca-se a grande importância social da cadeia produtiva da Construção Civil, a qual pode ser expressa por meio do déficit habitacional que ela tem que atender, da taxa de geração de empregos (diretos, indiretos e induzidos) que permite e da necessidade de infra-estrutura, também a ser superada.

Segundo os dados do MDIC (2004), a taxa de geração de empregos da ICC é relevante. Para cada 100 empregos diretos do setor são gerados 285 indiretos e induzidos, perfazendo, no ano de 2000, um total de 14,01 milhões de empregos. Acrescentam Gondim et. al. (2004) que, em termos econômicos, "calcula-se que para cada 1,0 bilhão de reais a mais da demanda da construção, sejam criados 177.000 novos empregos (Mello, 1997), somando os diretos $e$ indiretos ou induzidos".

Em relação ao déficit habitacional, segundo a Fundação João Pinheiro o mesmo encontrava-se próximo de 6,65 milhões de moradias em 2000. No entanto, uma 
estimativa mais recente da mesma instituição, contabiliza um déficit de 7,2 milhões de moradias, referente ao ano de 2002 (FUNDAÇÃO JOÃO PINHEIRO, 2004).

A ICC caracteriza-se também por uma cultura tradicional, onde a maioria das tecnologias foi incorporada ao longo do tempo de forma empírica, inclusive com características regionais dos locais de criação. De acordo com Sabbatini (1989) "estas tecnologias (tradicionais) caracterizam-se por terem condições de produção amplamente insatisfatórias (...) as quais se traduzem normalmente por uma baixa produtividade (de todos os recursos envolvidos), baixo nível de produção e exigência de um grande volume de mão-de-obra especializada”.

A existência desta cultura baseada em conhecimentos empíricos, que ainda não conseguiu ser superada por trabalhos técnicos e pesquisa de desenvolvimento tecnológico, aliada a fatores de natureza sócio-econômica, como baixa capacitação dos recursos humanos e alta tributação sobre as atividades produtivas, promoveu um quadro bastante intrínseco desta indústria - a informalidade.

Em pesquisa recente, elaborada pela GVconsult para o Sindicato da Indústria da Construção Civil do Estado de São Paulo - SINDUSCON-SP, com base em dados do IBGE, Zaidan (2005) afirma que o valor adicionado da construção civil, em 2004, somou $\mathrm{R} \$ 115,1$ bilhões. Destes, $45 \%$ foi adicionado pelo segmento formal, enquanto que a informalidade contribui com os restantes 55\%. No entanto, a mesma pesquisa demonstra que as atividades formais possuem uma produtividade $34 \%$ maior que a do setor informal.

A constatação de Zaidan (2005) revela-se também no sub-setor de edificações habitacionais. Os estudos da Associação Brasileira da Indústria de Materiais de Construção - ABRAMAT (ESTEBAN, 2004), conforme Figura 2.5, mostram que o mercado habitacional do setor da Construção Civil é formado, na sua maioria, pelas construções auto-geridas. A tarefa de melhorar as condições de construção e o desempenho das moradias auto-geridas tem se demonstrado como um grande desafio dos agentes desta cadeia. 

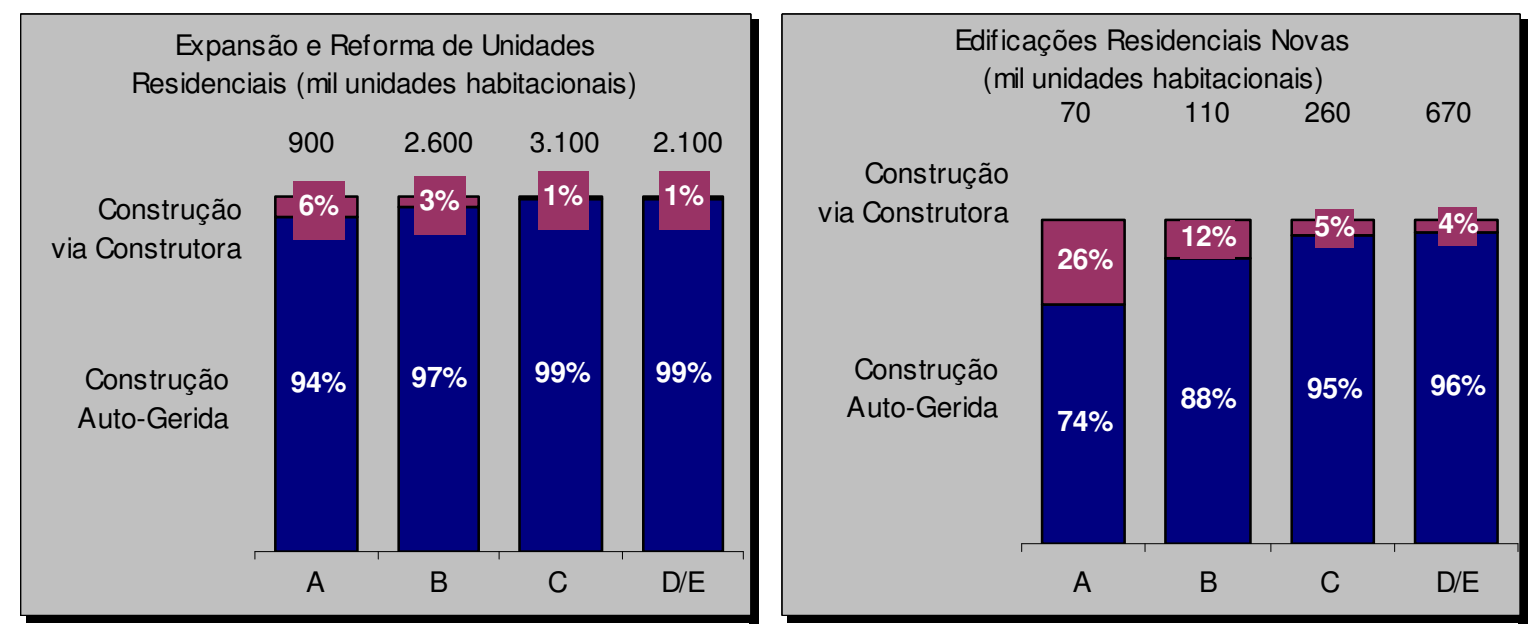

Figura 2.5 - Participação da construção formal no mercado de edificações residenciais, de acordo com a classe social (ESTEBAN, 2004).

Assim como os aspectos econômico e social, a cadeia produtiva da ICC também envolve aspectos ambientais expressivos. Isto deve-se ao fato da atividade construtiva ser responsável por grandes impactos ambientais, decorrentes tanto dos processos de produção quanto do próprio produto final em uso, dentre eles, a poluição do ar, água e solo, o elevado consumo de energia e o esgotamento dos recursos naturais (DEGANI, 2003).

A importância ambiental desta cadeia advém basicamente de dois fatores: o uso de recursos naturais e a geração de resíduos. De acordo com John (2004), a Construção Civil é responsável por entre 15 a 50\% do volume de recursos naturais consumidos e contribui com 40 a 70\% da massa total de resíduos sólidos urbanos (PINTO, 1999). São valores muito significativos, não compartilhados por nenhum outro setor industrial.

Portanto, concordando-se com John; Silva e Agopyan (2001), “fica patente que não há desenvolvimento sustentável sem construção sustentável. Conseqüentemente, qualquer sociedade que procure atingir um desenvolvimento mais sustentável precisa necessariamente passar pelo estabelecimento de políticas ambientais específicas para a construção civil”. 


\subsection{SUSTENTABILIDADE - ATUAL DESAFIO DO SETOR}

Os aspectos sociais, econômicos e ambientais que caracterizam a ICC, citados anteriormente, dizem respeito a um conceito sobre o qual muito há de se explorar: o da sustentabilidade.

Sustentabilidade, segundo a definição da Agenda 21 on Sustainable Construction publicada pelo CIB (International Council for Research and Innovation in Building and Construction) em 1999, "é a condição ou estado que permite a existência continuada do homo sapiens, e provê uma segura, saudável e produtiva vida por todas as gerações em harmonia com os valores culturais e espirituais locais. Tratase de objetivo que gostaríamos de alcançar". Desta forma, para se atingir a sustentabilidade é necessário que a humanidade pratique um desenvolvimento sustentável.

Embora o conceito de desenvolvimento sustentável tenha sido elaborado há quase 20 anos, considerando o Relatório Brundtland ${ }^{5}$ de 1987, atualmente a discussão sobre este tem se tornado, cada vez mais, uma constante no âmbito governamental, empresarial ou social. Segundo Parkin et al. (2003), há mais de 200 definições de desenvolvimento sustentável. Neste trabalho adota-se a definição encontrada na Agenda 21 on Sustainable Construction, segundo a qual desenvolvimento sustentável é aquele que satisfaz as necessidades do presente sem comprometer a capacidade das gerações futuras de satisfazer as próprias necessidades (Relatório "Our Commom Future" - United Nations Brundtland Comission, WCED $\left.{ }^{6}, 1987\right)$.

Embora a definição acima destaque a questão ambiental, verificam-se três grandes dimensões do desenvolvimento sustentável: a econômica, a social e a ambiental, as quais são indissociáveis nas análises de viabilidade e custo-benefício.

A interdependência entre estas dimensões pode ser verificada nas afirmações da Comissão Européia ${ }^{7}(2005)$, segundo a qual o desenvolvimento sustentável abrange:

- o desenvolvimento econômico balanceado e igualitário;

\footnotetext{
${ }^{5} \mathrm{O}$ relatório conhecido como Relatório Brundtland, é intitulado "Our Common Future" (Nosso Futuro Comum) foi elaborado pela United Nations Brundtland Commission, órgão do WCED.

${ }^{6}$ World Commission on Environmental Initiatives [Conselho Internacional para Iniciativas Ambientais Locais].

${ }^{7}$ A Comissão Européia é um órgão colegiado da União Européia que foi criado para representar o interesse europeu comum a todos os Estados-Membros da União Européia e que tem por objetivo tornar a legislação européia mais efetiva, transparente e clara. Maiores informações podem ser obtidas em http://europa.eu.int/comm/index_pt.htm
} 
- $\quad$ altos níveis de emprego, coesão e inclusão social;

- $\quad$ alto nível de proteção ambiental e responsabilidade no uso dos recursos naturais;

- política coerente de abertura e sistema político responsável e transparente;

- cooperação internacional eficiente para a promoção do desenvolvimento sustentável globalmente.

Como forma de tornar mais claro este conceito, a comunidade acadêmica desenvolveu vários modelos para analisar as questões inerentes ao desenvolvimento sustentável. Comumente utiliza-se o modelo do diagrama de Venn (Figura 2.6), havendo, no entanto, outros modelos como o Triple-Bottom Line, o Five Capitals Model, o Twelve Features of a Sustainable Society e o Natural Step Framework (FORUM FOR THE FUTURE, 2005).

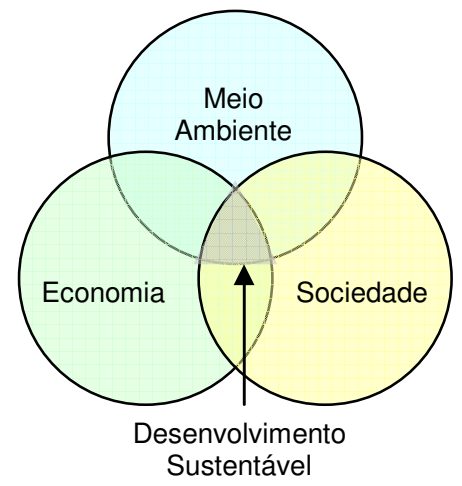

Figura 2.6 - Diagrama de Venn (Parkin et al., 2003).

Segundo o Forum for the Future (2005), o triple-bottom line é o modelo mais popular de entendimento do conceito de sustentabilidade, mas esta instituição considera este modelo limitado porque atribui pesos iguais a cada um dos três "bottom lines", ou seja, a cada um dos três aspectos destacados pelo Diagrama de Venn. Para o Forum for the Future, a sustentabilidade ambiental é uma pré-condição porque sem ela as outras dimensões não podem existir. Portanto, o Forum for the Future utiliza o Five Capitals Model ou Modelo dos Cinco Recursos, para caracterizar o conceito do desenvolvimento sustentável. 
Independentemente do modelo utilizado, acredita-se que uma perspectiva de desenvolvimento sustentável deve atentar para assuntos de longo prazo e para as interligações entre suas diferentes dimensões, sendo de fundamental importância o uso de indicadores (COMUNIDADE EUROPÉIA, 2002).

Reproduzindo o conceito de desenvolvimento sustentável para o âmbito empresarial, Kraemer (2005) identifica que "estamos diante de um novo modelo estratégico, um modelo que tende a se fortificar nas próximas décadas. Nesse novo ambiente, os interesses dos acionistas dividem espaços com as demandas da comunidade e dos clientes, funcionários e fornecedores. É para esse grupo, os chamados 'stakeholders', que a empresa do futuro terá de gerar valor'.

Além das novas exigências da sociedade demonstrarem-se cada vez mais severas, as empresas devem vislumbrar que a prática do desenvolvimento sustentável pode ser origem de diferencial competitivo. Mais do que um simples conceito elaborado pela academia e por ambientalistas, o desenvolvimento sustentável constitui-se em um novo modelo de desenvolvimento da humanidade.

Neste sentido, corroboram John; Silva e Agopyan (2001) quando mencionam que “certamente a construção de uma sociedade realmente sustentável passa por uma radical transformação nos padrões de consumo e processos de produção. Os conceitos culturais de desenvolvimento, bem estar etc. deverão ser radicalmente transformados. Isto vai requerer soluções baseadas em outros paradigmas que não os que embasaram a sociedade industrial”.

Em vista disso, com tudo o que é novo, a implantação deste modelo também exige o rompimento de antigos paradigmas da sociedade, como, por exemplo, a mudança do modelo de consumo atual, também conhecido por 'cultura do consumo'.

De acordo com Leite (2003) "a cultura do consumo é caracterizada pela idéia do ciclo 'compre-use-disponha' e adotada como padrão pela sociedade até recentemente sem questionamentos, privilegiando inovações e altas taxas de lançamento de produtos, gerando forças de mercado que criam necessidades adicionais de consumo e tornam comum a posse de bens de mesma natureza em grandes quantidades, privilegiando a moda e o status em relação à utilidade do bem”. 
De forma similar, uma pesquisa canadense, do PRI - Policy Research Initiative (SLAYEN, 2003), constata que “as pressões da classe média emergente de países em desenvolvimento, sobre os recursos globais estão aumentando, pois esta aspira a um estilo de vida consumista” (MYERS, 2000 apud SLAYEN 2003).

Muitos sociólogos afirmam que "as escolhas dos consumidores não são ações isoladas provenientes de um processo de decisão racional" (PRINCEN; MANIATES; CONCA, 2002 apud SLAYEN 2003), e estas escolhas "estão inseridas em idéias individuais sobre status e identidade, influenciadas por forças sociais contextuais, tais como a mídia e a publicidade, e pelas características estruturais maiores da economia, do ambiente, e da política. As políticas, sejam econômicas, ambientais, ou sociais, afetam escolhas do consumidor e, dentre os muitos instrumentos da política disponíveis, a persuasão moral é um usado freqüentemente para motivar a mudança social”.

Não obstante, segundo Mackoy; Calantone e Dröge (1995 apud LEITE, 2003) "diversas correntes criticam a cultura do consumo por não privilegiar principalmente os aspectos de melhor utilização dos recursos naturais, de responsabilidade das empresas para com a sociedade, dos custos relacionados ao descarte dos bens, da preservação do sistema ambiental para as gerações futuras, entre outros".

No entanto, há autores que identificam um quadro de mudança desse comportamento. Por exemplo, Leite (2003) diz que "mais recentemente tem se observado o aparecimento de uma nova cultura, que pode ser sintetizada pelo ciclo 'reduz-reuse-recicle', caracterizada pelo que se convencionou denominar cultura ambientalista, que privilegia uma maior responsabilidade da sociedade e das organizações empresariais ao observar os impactos dos processos e produtos no meio ambiente". A tendência de mudança no modelo de consumo é ilustrada na Figura 2.7.

Além do modelo de consumo, outro paradigma tende a ser quebrado: o que afirma ser inviável atingir-se forte desempenho econômico sem o extensivo uso de recursos naturais. Para a Comissão Européia (2002), “a relação entre crescimento econômico, consumo de recursos naturais e a geração de resíduos deve mudar. Desempenho 
econômico forte deve andar lado a lado com uso sustentável de recursos naturais e níveis de resíduos, manutenção da biodiversidade, preservação de ecossistemas e evitação da desertificação”.

\section{MUDANÇA NA CULTURA DO CONSUMO E SUAS CONSEQÜÊNCIAS}

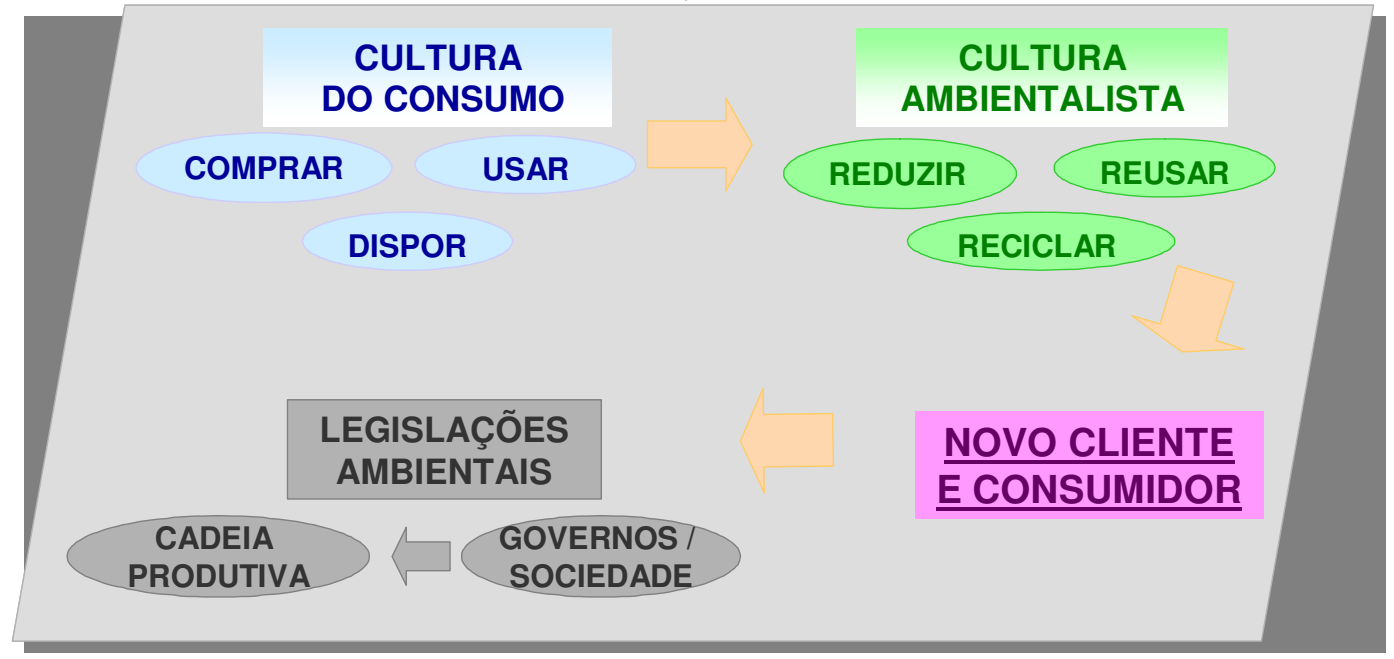

Figura 2.7 - Mudança na cultura do consumo e suas conseqüências (LEITE, 2003).

No entanto, a Comissão Européia é formada por países desenvolvidos. Percebe-se por esta afirmação que os aspectos sociais do desempenho econômico não são abordados. Isto se deve ao fato de, nos países da Comunidade Européia, estes aspectos não serem tão relevantes como o são os dois outros, principalmente o ambiental.

Acredita-se, assim, que o amplo conceito de desenvolvimento sustentável pode ter diferentes abordagens de acordo com a realidade existente em cada país ou mesmo localidade.

Segundo Schiller et al. (2003) "enquanto a sustentabilidade em países centrais está principalmente ligada à eficiência energética para reduzir o aquecimento, nos países em desenvolvimento da América Latina, a sustentabilidade está relacionada à preocupação social para sobrevivência e à provisão de condições de vida básicas, levando em consideração o crescimento da lacuna existente entre ricos e pobres". 
De acordo com John; Silva e Agopyan (2001), as propostas da Agenda 21 têm sua aplicabilidade especialmente direcionada aos países desenvolvidos. As profundas diferenças sócio-econômico-culturais entre estes países e os em desenvolvimento, dentre eles o Brasil, motivou a discussão de uma proposta adaptada e específica para a cadeia produtiva da construção civil brasileira. Isto se justifica porque, segundo os autores, o "desenvolvimento sustentável também implica em equidade social e este item certamente é muito mais importante em países como o Brasil, marcados por concentração de renda. A transposição deste conceito para o campo da construção sustentável inclui, portanto, a melhoria de qualidade de vida para toda a população”.

Ainda de acordo com Schiller et al. (2003) "a sustentabilidade do ambiente construído não é fácil de ser atingida, com os mesmos valores e prioridades que vêm sendo adotados no mundo desenvolvido. $O$ variado contexto geográfico $e$ demográfico da região, a vasta extensão, também têm um forte impacto nos requisitos e no potencial para construção sustentável”.

A complexidade das análises de sustentabilidade, devido às suas indissolúveis interações, permite afirmar que o desenvolvimento sustentável de uma cadeia produtiva só pode ser alcançado por meio do esforço integrado de seus diversos agentes, com o objetivo maior de perpetuar as condições de existência humana atuais.

\subsection{Sustentabiliddade no Ambiente Construído}

Tornam-se evidentes, em todo o meio acadêmico, as afirmações de que a cadeia produtiva da Construção Civil - assim como outras cadeias industriais - deve promover o desenvolvimento sustentável, ou seja, deve desenvolver-se de forma a não comprometer a capacidade das gerações futuras em fazê-lo também.

Segundo a Agenda 21 (2000), o entendimento ou a interpretação da sustentabilidade na edificação e na construção civil sofreu mudanças ao longo dos anos. Se antes o problema era técnico, focado na limitação de recursos e no impacto na natureza, hoje 
esta análise considera também os aspectos culturais e as implicações no patrimônio cultural do ambiente construído.

Segundo a Agenda 21 on Sustainable Construction for Developing Countries (1999), “construção sustentável significa que os princípios do desenvolvimento sustentável são aplicados a todo o ciclo de construção, da extração e beneficiamento dos materiais, passando pelo planejamento, projeto e construção de edifícios e obras de infra-estrutura, até a sua demolição e gestão dos resíduos dela resultantes. Trata-se de processo holístico que leva à recomposição e à manutenção da harmonia entre os ambientes naturais e construídos, assegurando a criação de assentamentos que afirmem a dignidade humana e encorajam a equidade econômica”.

John; Silva e Agopyan (2001) afirmam que "é importante observar que, como o impacto ambiental de uma construção é função do impacto ambiental de cada um de seus componentes, o efeito de qualquer medida ambiental de um determinado agente é multiplicada quando a sua ação é coordenada com ações de outros agente. $O$ estabelecimento de redes de trabalho sinérgicas, a partir de interesses ambientais econômicos comuns, torna-se, portanto, uma estratégia das mais eficientes”.

Dentre os inúmeros aspectos presentes nas políticas de desenvolvimento sustentável da cadeia produtiva da Construção Civil, encontram-se a responsabilidade para com o uso de recursos naturais e a destinação dos resíduos das atividades industriais. " $A$ indústria da construção e seus produtos consomem aproximadamente $40 \%$ da energia e dos recursos naturais e gera $40 \%$ dos resíduos produzidos por todo o conjunto de atividades humanas (SJOSTROM, 2000), mas podem atingir até 75\%, como no caso dos EUA” (JOHN; SILVA; AGOPYAN, 2000).

De acordo com Schiller et al. (2003), "as dimensões ambiental, econômica, cultural e social da construção sustentável se estendem para além do uso de materiais 'verdes' e renováveis, eficiência energética e baixo impacto da construção, reciclagem e demolição residual. Outros fatores como adequação ao uso, durabilidade adaptabilidadelflexibilidade constante, condição da qualidade do ar interno e externo, independência de recursos importados e capacidade de promover a produção local e o emprego são altamente relevantes para países emergentes da 
América Latina, como o Brasil, e são essenciais uma vez que os edifícios projetados hoje são para satisfazer as necessidades da atual e das futuras gerações”.

Concluindo, sintetiza-se aqui alguns aspectos de sustentabilidade relacionados à construção civil, sem a pretensão de exaurir todos, mas de destacar aqueles que serão foco do presente trabalho, como:

- impacto ambiental das atividades da cadeia produtiva da Construção Civil;

- consumo de recursos naturais e energéticos;

- déficit habitacional;

- destinação de resíduos;

- responsabilidade social.

A implantação de um sistema logístico reverso é uma ação que se alinha perfeitamente a esses cinco aspectos. No entanto, como toda ação interorganizacional, a sua implantação depende não somente dos próprios agentes diretamente envolvidos, como também das forças existentes no macro-ambiente em que ela se insere.

No caso da ICC, analisando-se as informações econômicas expostas, percebe-se que todas as empresas que compõem o Construbusiness têm aumentado sua participação no PIB, demonstrando assim um crescimento econômico. Dentre estes 'demais' tipos de empresas, acredita-se que os fabricantes de materiais e componentes de construção possuam uma participação expressiva e que, em vista disto, podem atuar como agentes impulsionadores de ações interempresariais estruturadas e integradas, como devem ser as de implantação dos sistemas logísticos reversos. 


\section{3 - Logística}

Neste capítulo analisa-se como os conceitos da área logística têm sido aplicados à Indústria da Construção Civil e como eles podem auxiliar no entendimento sobre a dinâmica de movimentações do fluxo reverso nesta indústria.

Discorre-se brevemente sobre a logística empresarial, sobre os conceitos - por vezes complementares, por vezes conflitantes - de logística reversa e cadeia de suprimentos, sendo por último demonstrado o papel da logística reversa na sustentabilidade.

Com base na análise do material levantado desenvolve-se o raciocínio de como consolidar e otimizar um canal de logística reversa em uma estrutura de cadeia produtiva tão diferenciada, como a da Construção Civil, com destaque para a identificação e análise dos fatores intervenientes que podem dificultar, ou mesmo impedir, tal consolidação.

\subsection{Logística Na Indústria da Construção Civil: A SISTEMATIZAÇÃO DOS FLUXOS}

O estudo da Logística Empresarial adquiriu maior interesse a partir da década de 50, quando a expansão dos mercados consumidores promoveu maior preocupação com a distribuição física de bens. Antes deste período, as atividades inerentes à logística 
estavam fragmentadas sob a responsabilidade de diversos departamentos dentro de uma organização (BALLOU, 1993).

De acordo com Ballou (1993), a partir da década de 80, a logística empresarial consolidou-se como um campo de estudo mais amplo, com ênfase não somente na distribuição física como também na administração de materiais, ou seja, para entregar produtos da maneira correta, no lugar certo e no instante desejado, era preciso - para obter maior eficiência - receber matérias-primas com estes mesmos atributos, além de coordenar os fluxos dentro dos processos inerentes à produção para assegurar que tais atributos não se degradassem.

Conceitualmente, segundo o mesmo autor, a Logística Empresarial "trata de todas as atividades de movimentação e armazenagem que facilitam o fluxo de produtos $e$ informações desde o ponto de aquisição da matéria-prima até o ponto de consumo final, assim como dos fluxos de informação que colocam os produtos em movimento, com o propósito de providenciar níveis de serviço adequados aos clientes a um custo razoável”. Esta definição chama a atenção para três aspectos muito importantes da logística, que vão além do fluxo de produtos: (1) o fluxo de informações; (2) o nível de serviço; (3) e o custo. Estes aspectos são interdependentes e a ineficiência em qualquer um dos processos deles decorrentes pode determinar um desempenho inferior de toda a cadeia logística.

É importante ressaltar, ainda, que o fluxo de produtos diz respeito a todas as atividades presentes no processo de produção da empresa, incluindo tanto a administração de materiais - responsável pelas 'entradas' do processo de produção, quanto os fluxos da produção propriamente dita - dentro da 'fábrica' -, como também a distribuição física de bens/produtos - 'saídas' do processo de produção.

A importância econômica e mercadológica, devido respectivamente aos custos envolvidos e às estratégias competitivas praticadas, determinou, por alguns anos, o foco da logística empresarial na melhoria da eficiência dos canais de distribuição, também chamados de 'canais de distribuição diretos' (desde o ponto de aquisição de matéria-prima até o ponto de consumo final) (BALLOU, 1993). Estes canais são constituídos pelas diversas etapas pelas quais os bens produzidos são 
comercializados até chegar ao consumidor final, seja uma empresa ou uma pessoa física (KOTLER, 2000).

Para a abordagem logística na indústria da Construção Civil, assim como em qualquer outro setor, deve-se considerar os aspectos inerentes a ele, de forma a subsidiar uma implementação adequada de suas ferramentas e constituir-se assim um sistema logístico.

Segundo Silva e Cardoso (1997), a logística nas empresas de Construção Civil consiste no "conjunto das atividades de planejamento e gestão dos fluxos físicos de produção através dos fluxos de informação e as atividades de transporte $e$ suprimento dos recursos de diversos tipos (humanos, materiais, equipamentos, etc.)”. E ainda que “o conjunto de operações organizadas e relacionadas entre si, para um determinado empreendimento ou empresa, de gestão dos fluxos físicos e de informação no âmbito do canteiro, de atividades de transporte e de suprimento de recursos materiais ou humanos, denomina-se por sistemas logísticos” na Construção Civil.

Cardoso (1996) apresenta uma subdivisão para a logística aplicável às empresas construtoras, classificando-a quanto a sua função, em logística de suprimentos e logística de canteiro.

Segundo esta subdivisão da indústria, a logística pode ser aplicada em dois momentos distintos. O primeiro, antes de chegar ao ambiente de produção - o canteiro de obras - trata-se da logística de suprimentos da obra, equivalente às atividades de administração de materiais da indústria. Em um segundo momento, temos a logística "interna" isto é, a que ocorre dentro do ambiente de produção, denominada no meio técnico e acadêmico de logística do canteiro de obras. Esta visa gerenciar as atividades de movimentação dentro do canteiro de obras.

De acordo com Silva (2000), “a logística de suprimentos é aquela relacionada com 'o transporte e suprimento dos recursos de todos os tipos susceptíveis de serem deslocados (mão-de-obra, materiais, equipamentos, etc.)' necessários à produção dos edifícios. As tarefas mais importantes dessa função compreendem: emissão e transmissão de pedidos de compra; transporte dos recursos até a obra; manutenção dos suprimentos previstos no planejamento". 
O mesmo autor define que, "a logística de canteiro é aquela relacionada com o planejamento e gestão dos fluxos físicos e dos fluxos de informações associados à execução de atividades no canteiro de obra. As principais tarefas da logística de canteiro são: gestão dos fluxos físicos ligados à execução, ou seja, o conhecimento das datas de início e término de serviços, os detalhes dos fluxos que serão feitos durante a execução dos serviços, os mecanismos de controles dos serviços; a gestão da interface entre agentes que interagem no processo de produção de uma edificação, as informações que são necessárias para que estes exerçam suas atividades dentro de padrões pré-estabelecidos, a resolução de interferências entre os serviços; a gestão física da praça de trabalho, incluindo a implantação do canteiro, os sistemas de transportes, zonas de estocagem e pré-fabricação e os requisitos de segurança no canteiro”. A estes, é necessário acrescentar-se o sistema de gerenciamento de RCD.

A respeito dos fluxos físicos do canteiro de obras têm-se os trabalhos de Cardoso (1996); Silva e Cardoso (2000); Zegarra (2000); Caldas e Soibelman, (2001); e Cruz (2002); entre outros, sendo, portanto, uma área que já é objeto de estudo há algum tempo e que não será abordada especificamente neste trabalho.

O foco das análises aqui pretendidas está sobre um ponto de vista mais amplo, o da cadeia produtiva. Abordar-se aqui a cadeia produtiva como um todo e não um ou outro papel dos agentes. Acredita-se que o gerenciamento da cadeia de suprimentos conceito que engloba a logística empresarial e, por consequiência a logística reversa só pode ser alcançado de forma eficiente se houver uma ação conjunta e integrada entre todos os agentes da cadeia produtiva da Construção Civil.

Apenas no capítulo 5, onde demonstra-se uma aplicação, o foco se fixa sobre um agente em especial: os fornecedores de materiais.

\subsection{LOGÍSTICA REVERSA}

Até pouco tempo atrás, o foco da logística empresarial fixava-se nos canais de distribuição diretos. Os fluxos de bens e informações decorrentes do ponto de consumo para o ponto de aquisição de matérias-primas (ou ponto de origem) - 
chamados fluxos reversos -, não recebiam a devida atenção, pois se tratava de um volume que representava apenas uma fração do volume de distribuição direta (LEITE, 2003). No entanto, recentemente, a logística reversa tem sido vista como uma potencial fonte de diferencial competitivo para as empresas.

De acordo com Stock (2001), "atributos como qualidade do produto, preços competitivos, ciclos de produção consistentes, entregas em tempo correto e baixa taxa de erros são e irão continuar sendo no futuro, muito importantes para a cadeia de suprimentos. No entanto, atualmente estes atributos têm se traduzido em uma oferta padrão para os clientes [passaram de características 'ganhadoras de pedido' para 'qualificadoras de produtos'] $]^{8}$. Quando uma empresa atinge um padrão aceitável nestes atributos, outros fatores tornam-se diferenciadores para a decisão de aquisição do cliente. Um deles é a logística reversa. Algumas companhias oferecem programas de logística reversa, mas poucas oferecem soluções otimizadas".

Cabe ressaltar que a logística reversa constitui-se em uma área de estudo da logística empresarial pouco abordada até o presente momento.

Segundo o CSCMP - Council of Supply Chain Management Professionals (antigo Council of Logistics Management - CLM) (2004), a logística reversa é uma das partes presentes na logística empresarial, que por sua vez faz parte do gerenciamento da cadeia de suprimentos, também chamado de supply chain management. Esta instituição afirma que a logística "é uma parte do processo de gestão da cadeia de suprimentos que planeja, implementa e controla o fluxo direto e reverso e a armazenagem eficiente e eficaz de bens, serviços e informações relacionadas, do seu ponto de origem até o seu ponto de consumo, de maneira a satisfazer as necessidades dos clientes".

Kopicki (1993) define que a "logística reversa é um termo amplo que se refere ao gerenciamento logístico e à disposição de resíduos perigosos e não perigosos de embalagens e produtos. Ela compreende habilidades gerenciais e atividades relacionadas a redução, gerenciamento e descarte de resíduos”.

${ }^{8}$ [ ] Acrescentado pela autora. 
Para o Revlog (1999), a logística reversa é “o processo de planejamento, implementação e controle dos fluxos de matérias-primas, de inventário em processo, e bens acabados, do ponto de uso para o ponto de recuperação ou ponto de disposição adequado". (Note-se que 'ponto de recuperação' inclui todos os processos relacionados para a recuperação.)

Rogers e Tibben-Lembke (1999) definem a logística reversa como "o processo de planejamento, implementação e controle eficiente, inclusive de custos, dos fluxos de matérias-primas, de inventário em processo (estoques), bens finalizados, e informações relativas a eles, do ponto de consumo para o ponto de origem com o propósito de recapturar ou criar valor ou ainda dar disposição adequada”.

Encontra-se também definições ligadas a questões ambientais, tal como a de Stock (1998), para quem logística reversa é um "termo utilizado para referir-se à logística na reciclagem, descarte e gerenciamento de materiais contaminantes que, numa perspectiva mais ampla, inclui atividades logísticas de redução de emissão, reciclagem, substituição, reutilização de materiais e descarte”.

Já outro autor, Fleischmann (2001), ressalta a necessidade de se recuperar o valor dos bens, produtos ou resíduos, visto ser esta a motivação para a comercialização dos mesmos. Ele define a logística reversa como "o processo de planejamento, implementação, e controle eficiente e eficaz do fluxo de entradas e armazenagem de materiais secundários e informações relacionadas, opostas ao sentido tradicional da cadeia de suprimentos, com o propósito de recuperar valor ou descartar corretamente materiais".

Idéia semelhante é compartilhada por Leite (2003). Apesar de ser um conceito recente e ainda em evolução, Leite (2003) define a logística reversa como uma "área da logística empresarial que planeja, opera e controla o fluxo e as informações logísticas correspondentes, do retorno dos bens de pós-venda e de pós-consumo ao ciclo de negócios ou ao ciclo produtivo, por meio dos canais de distribuição reversos, agregando-lhes valor de diversas naturezas: econômico, ecológico, legal, logístico, de imagem corporativa, entre outros”.

Em todas as definições apresentadas percebe-se certa unanimidade na afirmação de que a logística, seja ela direta ou reversa, consiste em um processo de planejamento, 
implantação/operação e controle, de bens e informações relacionadas a um fluxo. No entanto, as definições internacionais comumente mencionam que o fluxo reverso consiste no retorno de materiais do ponto de consumo para o ponto de origem. Isto ocorre porque em outros países, principalmente os europeus, a responsabilidade sobre os resíduos de produtos recai sobre o fabricante deste e estende-se por toda a sua vida, incluindo sua destinação final. Assim, nestes países, em geral, os resíduos de um produto - que consistem em um tipo de fluxo reverso - retornam até a fábrica onde foi produzido o produto, para então serem corretamente reaproveitados ou destinados.

No entanto, existem situações em que o fluxo de produtos não necessariamente precisa retornar ao ponto de origem, ou seja, de fabricação, para ser reaproveitado. Muito pelo contrário. Por vezes, este retorno ao ponto de origem gera altos custos logísticos, suficientes, na maioria dos casos, para inviabilizar economicamente os programas de logística reversa. Em outras vezes, o reaproveitamento se mostra mais vantajoso se o fluxo for direcionado para outra cadeia produtiva, antes de chegar ao ponto de origem. Portanto, apesar de concordar-se que este fluxo ocorre no sentido oposto ao da logística direta (também chamada de 'tradicional), ele possivelmente terá a viabilidade de seu reaproveitamento potencializada se não voltar à origem.

Por fim, acredita-se que o grande objetivo da logística reversa, como conceito é recapturar ou agregar novo valor aos produtos descartados, tendo como última opção a disposição adequada.

Conclui-se como melhor definição de logística reversa para os propósitos desta pesquisa a de processo de planejamento, implementação e controle eficiente, de fluxos de matéria-prima, de inventário em processo, estoques, bens finalizados, custos e informações relativas a eles, do ponto de consumo para o ponto de origem, ou ainda para um outro ponto de reaproveitamento, que se mostre mais viável, com o propósito de recapturar valor, criar valor ou ainda dar disposição adequada, levando-se em consideração os requisitos técnicos, sociais e econômicos, sem significar necessariamente a transferência de responsabilidade pelos fluxos. 
Entende-se, ainda, que a logística reversa é uma das partes que compõem a logística empresarial, assim como o são a administração de materiais e a distribuição física. Ela está inserida na logística empresarial, uma vez que planeja, opera e gerencia o fluxo reverso de produtos produzidos por uma determinada empresa.

Quando a preocupação com o fluxo reverso de uma determinada empresa/indústria é estendida para seus fornecedores primários e secundários, para seus distribuidores e clientes, até o consumidor final, é constituída uma cadeia de suprimentos reversa. Conjuntamente com a cadeia de suprimentos direta, forma-se a Cadeia de Suprimentos, conforme ilustrado na Figura 3.1.

O sistema logístico reverso, analogamente ao direto, se dá por meio do conjunto de três elementos: os fluxos reversos, os canais de distribuição reversos e as relações comerciais e econômicas entre os agentes das cadeias produtivas.

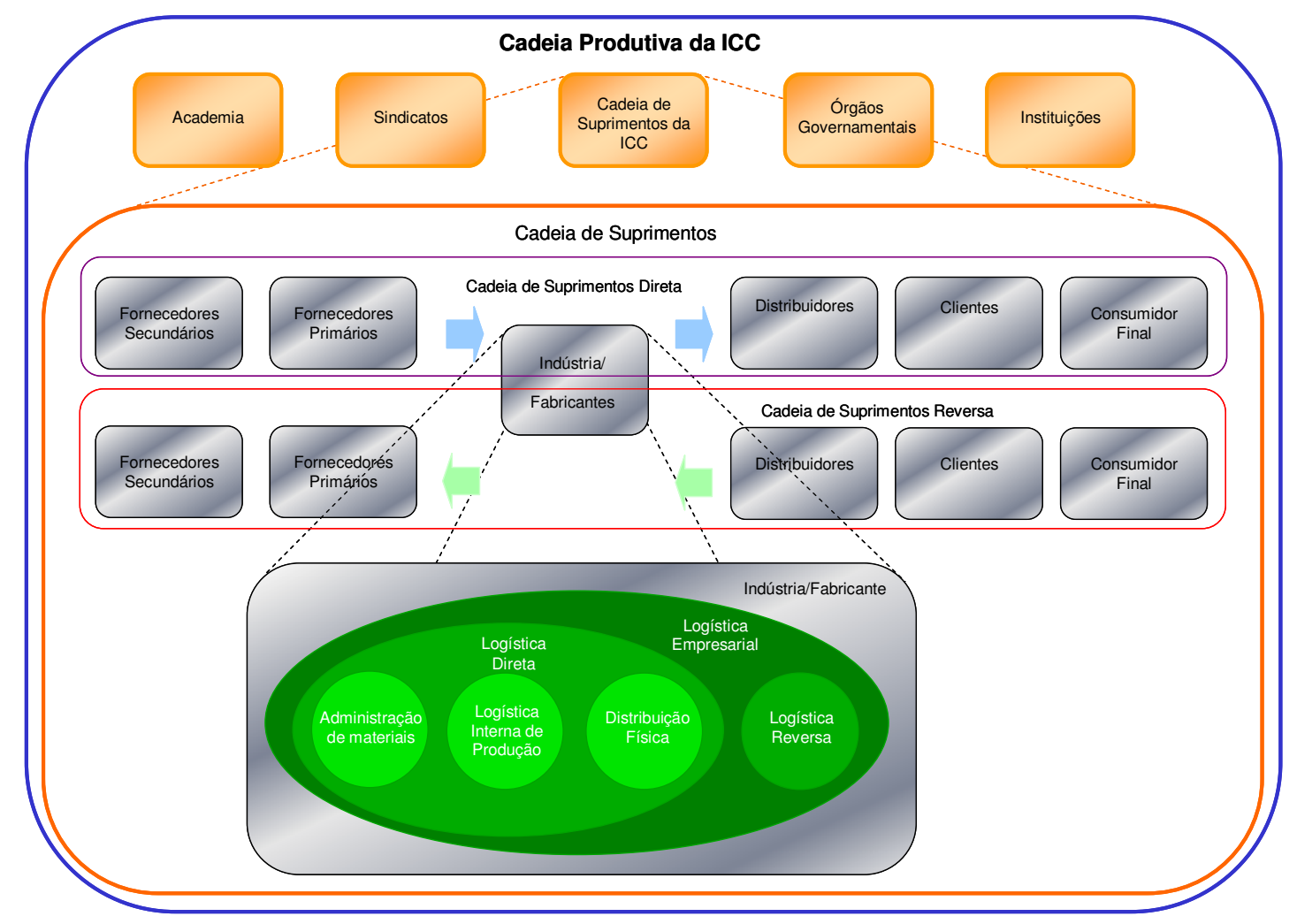

Figura 3.1 - Ilustração sobre a abrangência e complementaridade das definições adotadas (autora, 2007). 
Os fluxos reversos podem ter diversas origens: obsolescência tecnológica, defeitos, fim de vida útil e consignação, entre outros. Para sistematizar seu estudo, classificaram-se os fluxos em dois grupos: os fluxos reversos de pós-venda e de pósconsumo. Assim, cada tipo de fluxo tem seus próprios e característicos meios de retorno ao ciclo produtivo, possuindo, portanto, específicos canais de distribuição reversos $(\mathrm{CDR})$.

Segundo Leite (2003), "os CDR têm por objetivo retornar uma parcela dos produtos ao ciclo produtivo elou de negócios, revalorizando o produto para mercados secundários, seja através do reuso ou da reciclagem, de forma a prolongar a vida útil ou mesmo iniciar um novo ciclo de vida útil" (quando parte de um novo produto - reciclagem de parte). Para uma abordagem holística, optou-se por definir dois canais reversos distintos, de acordo com sua origem na cadeia reversa. Portanto, os CDR podem ser de pós-venda - CDR-PV ou de pós-consumo - CDR-PC.

Lembra Leite (2003) que “os canais de distribuição reversos de pós-venda CDR-PV são constituídos pelas diferentes formas e possibilidades de retorno de uma parcela de produtos, com pouco ou nenhum uso, que fluem no sentido inverso, do consumidor ao varejista ou ao fabricante, do varejista ao fabricante, entre as empresas, motivados por problemas relacionados à qualidade em geral ou a processos comerciais entre empresas, retornando ao ciclo de negócios de alguma maneira". Consequientemente, a logística reversa de pós-venda "é a específica área de atuação que se ocupa do equacionamento e operacionalização do fluxo físico e das informações logísticas correspondentes de bens de pós-venda, que se movimentam através dos CDR-PV. Seu objetivo estratégico é agregar valor a um produto logístico que é devolvido por razões comerciais, erros de processamento de pedidos, (...) avarias no transporte, entre outros motivos (...), os quais são agrupados nas classificações: garantia/qualidade; comerciais; substituição de componentes” (LEITE, 2003). Esta pesquisa não se interessa pelos canais de distribuição reversos de pós-venda.

Já os canais de distribuição reversos de pós-consumo - CDR-PC - constituem “as diferentes formas de processamento e de comercialização dos produtos de pós- 
consumo ou de seus materiais constituintes, desde sua coleta até sua reintegração ao ciclo produtivo como matéria-prima secundária” (LEITE, 2003).

A logística reversa de pós-consumo é, segundo Leite (2003), "a específica área de atuação que equaciona e operacionaliza igualmente o fluxo físico e das informações correspondentes de bens de pós-consumo descartados pela sociedade em geral, que retornam ao ciclo de negócios ou ao ciclo produtivo por meio de canais de distribuição reversos específicos. Seu objetivo estratégico é agregar valor a um produto logístico constituído por bens inservíveis ao proprietário original, (...) classificados, em função de seu estado de vida e origem, em: em condições de uso; fim de vida útil; resíduos industriais. Esses produtos de pós-consumo poderão se originar de bens duráveis ou descartáveis e fluir por canais reversos de reuso, desmanche, reciclagem até a destinação final". O referido autor explica também que os CDR-PC podem ainda ser sub-classificados em duas categorias: os CDR-PC de Ciclo Aberto e de Ciclo Fechado.

Os CDR-PC de Ciclo Aberto referem-se às diversas etapas de retorno dos materiais constituintes dos produtos de pós-consumo, extraídos de diferentes produtos de pósconsumo, visando substituir matérias-primas novas na fabricação de diferentes tipos de produtos (por exemplo, os produtos de pós-consumo em ferro e aço).

Neste tipo de CDR-PC observa-se o desenvolvimento de uma nova cadeia, chamada de 'alternativa' ou 'complementar', uma vez que ela constitui-se em uma alternativa de reaproveitamento e complementa a cadeia original na sua função de coresponsabilidade pelos resíduos gerados na atividade industrial original.

A Figura 3.2 ilustra os fluxos e agentes dos canais de distribuição de pós-consumo de ciclo aberto. 


\section{Cadeia Original}

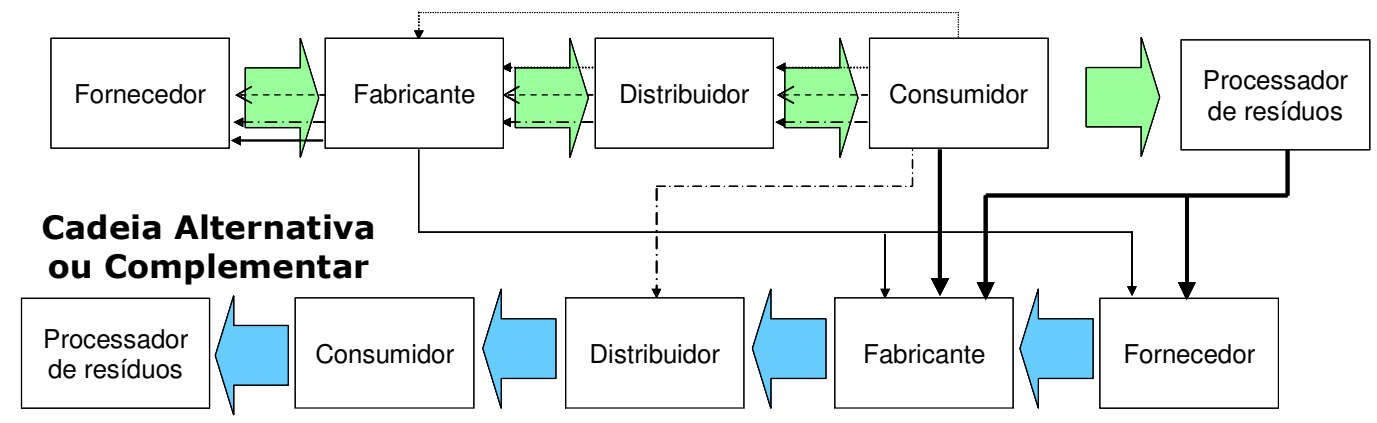

Ciclo Aberto: retornos utilizados na fabricação do outros novos produtos sem função similar.

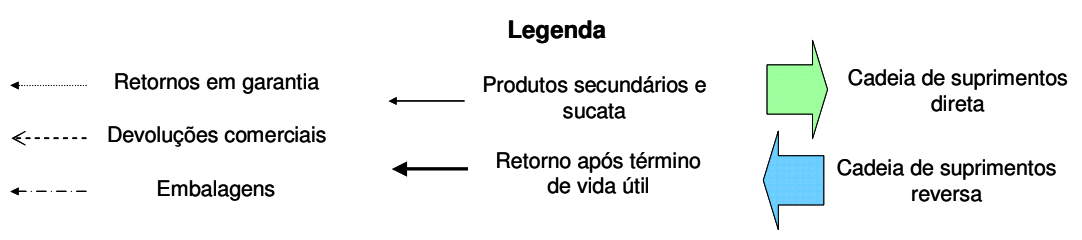

Figura 3.2 - Fluxos e agentes que compõem os canais de distribuição de pósconsumo (CDR-PC) de ciclo aberto(FLEISCHMANN, 2001).

Já os CDR-PC de Ciclo Fechado referem-se ao retorno de produtos de pós-consumo, advindo de uma extração seletiva dos materiais deste produto, com o objetivo de empregá-los na fabricação de produtos similares ao de origem (por exemplo, os produtos de pós-consumo de latas de alumínio). A Figura 3.3 ilustra os fluxos e agentes dos canais de distribuição de pós-consumo de ciclo fechado.

\section{Cadeia Original}

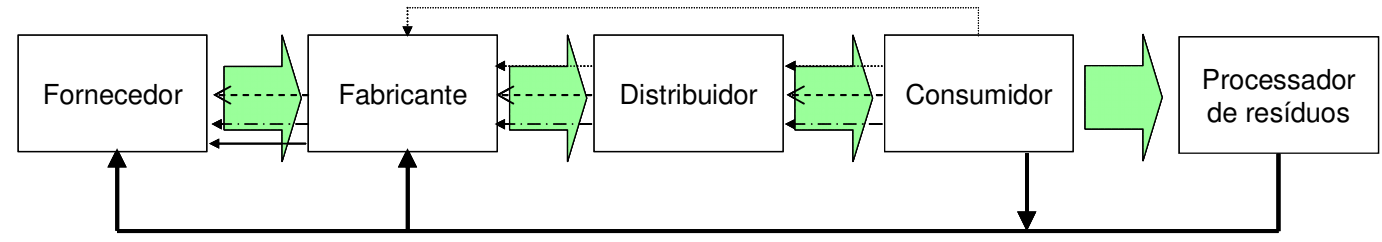

Ciclo Fechado: retornos utilizados na fabricação do mesmo produto que o originou ou de um novo produto com função similar.

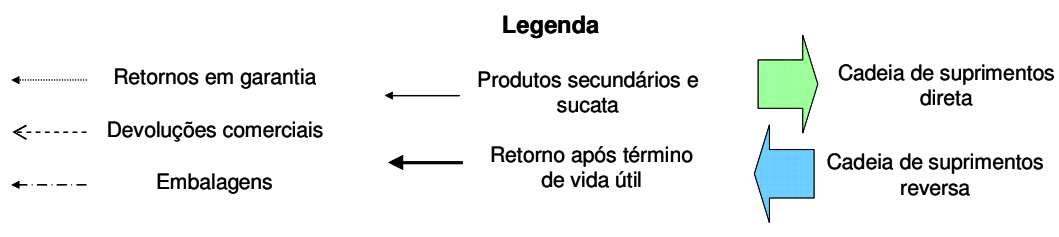

Figura 3.3 - Fluxos e agentes que compõem os canais de distribuição de pósconsumo (CDR-PC) de ciclo fechado (FLEISCHMANN, 2001). 
O REVLOG (2005) subclassifica ainda os CDR-PC de Ciclo Fechado em: Físico e Funcional. Segundo este grupo, o Ciclo Fechado (Closed Loop), é a "seqüência de atividades logísticas do ponto de uso para o ponto de reuso, no qual o usuário [do resíduo] é o [fabricante] original (ciclo fechado físico) ou alguém que usa o produto com sua funcionalidade original (ciclo fechado funcional)”.

Nesta pesquisa abordar-se os dois tipos - aberto e fechado - de CDR-PC.

Os produtos de pós-consumo ou pós-venda, denominados genericamente por 'resíduos', podem ter diferentes destinações e, de acordo com elas, estabelecerem, ou não, diferentes tipos de CDR.

As opções de destinação de resíduos podem ser classificadas em duas categorias:

- destinação com reaproveitamento de materiais/componentes;

- destinação sem reaproveitamento de materiais/componentes.

O termo reaproveitamento designa um conjunto de possibilidades de uso de resíduos, sejam eles materiais, componentes ou energia.

Os processos de aproveitamento de resíduos dão origem à CDR específicos. Se a redução da geração do resíduo não é possível, estes processos, de acordo com Steven (2004), podem ser hierarquizados na seguinte ordem: reuso; remanufatura; reciclagem; disposição com recuperação de energia; disposição em aterro.

Esta hierarquia vem sendo aceita pelas principais legislações relativas a resíduos, mas John (2000) afirma que "esta hierarquia é questionável, uma vez que a melhor alternativa é, por definição, aquela de menor impacto ambiental e é perfeitamente possível imaginar que existam situações onde a redução do volume de resíduos pode resultar em um impacto ambiental maior do que o benefício obtido”. De acordo com o autor, a escolha por uma destinação adequada precisa ser balizada pelo melhor desempenho ambiental obtido através de, por exemplo, uma análise de ciclo de vida.

A destinação com reaproveitamento de materiais/componentes permite determinar diferentes tipos de CDR de acordo com o processo de reaproveitamento, a saber:

- CDR - Reuso: utilização de um resíduo para um mesmo ou diferente propósito, sem a necessidade de sofrer beneficiamento industrial. Inclui as 
opções de canibalização da demanda ${ }^{9}$, canibalização de componentes $^{10}$, e upgrading $^{l 1}$ (ROGERS; TIBBEN-LEMBKE, 1998; STEVEN, 2004

- CDR - Remanufatura: processo industrial no qual um resíduo, geralmente um componente danificado, é recuperado para estado de 'como novo' (REVLOG 1999). Inclui os processos de reforma $^{12}$ e remanufatura ${ }^{13}$ propriamente dita.

- CDR - Reciclagem: utilização de um resíduo por meio de beneficiamento industrial, responsável por retirar algo de valor intrínseco ao produto e tornar os resíduos em matéria-prima ou produtos para a mesma aplicação que o originou ou para uma nova aplicação.

- CDR - Incineração com recuperação de energia: "Processo no qual um produto ou componente é queimado (incinerado) para recapturar sua energia” (REVLOG, 2005). Como conseqüência, a incineração reduz o volume do resíduo e ocupa menor capacidade no aterro (STEVEN, 2004).

Segundo Steven (2004), os processos de reaproveitamento podem ainda ser classificados de acordo com o nível de recuperação que desenvolvem. São três níveis de recuperação, a saber nível de produto, nível de componente e nível de material.

Deve-se, portanto considerar os diferentes tipos de CDR como uma gama de opções não hierarquizadas e não excludentes. John (2000) lembra que "como um resíduos é algo bastante heterogêneo em função tanto de sua origem, quanto em função das contaminações no processo de geração e manuseio, é muitas vezes muito mais lógico adotar, para diferentes frações, diferentes objetivos”. Portanto, os CDR podem ainda congregar diferentes processos de reaproveitamento, ou seja, constituírem-se, por exemplo, do reuso de uma fração e da reciclagem de outra fração de um mesmo resíduo.

\footnotetext{
9 Canibalização da demanda: “Redução de vendas em um canal 'A' para venda em mercados secundários” (ROGERS; TIBBEN-LEMBKE, 1998), mesmo que o produto não apresente defeito.

${ }^{10}$ Canibalização de componentes: Processo no qual "partes ou componentes são retirados de um item e usados para reparar ou reconstruir outra unidade do mesmo produto" (ROGERS; TIBBEN-LEMBKE, 1998).

11 Upgrading: "Processo no qual um produto ou componente é atualizado com novos padrões de tecnologia" (REVLOG, 2005).

${ }^{12}$ Reforma: "Processo no qual um produto é limpo e reparado para retorná-lo pra um estado "como novo"” (ROGERS; TIBBEN LEMBKE, 1998).

${ }^{13}$ Remanufatura: Processo industrial no qual um produto/componente danificado é recuperado para uma condição 'como novo', passando por uma série de processos industriais, como desmontagem, substituição de partes antigas por partes novas e montagem (REVLOG, 2005).
} 
A destinação sem reaproveitamento de materiais/componentes não estabelece um CDR, e inclui os processos de deposição em aterros e de incineração sem recuperação de energia.

Quando da realização do estudo exploratório, os especialistas concordaram em haver um campo de estudo ainda inexplorado sobre a aplicação do conceito de logística reversa na ICC, particularmente em relação ao estabelecimento de CDR para os fluxos reversos de resíduos de construção e demolição (RCD). Desta forma, prosseguiu-se com o estudo, conforme o item 3.3.

\subsection{Logística Reversa na Indústria da CONSTRUÇão CiviL}

Recentemente, devido à crescente competição presente tanto nos mercados internos quanto nos externos, fruto da globalização, as organizações têm demonstrado maior preocupação em relação à manutenção das vantagens competitivas que embasaram suas estratégias, à criação de oportunidades que lhes permitam atingir mercados cada vez maiores e à adição de valor aos negócios existentes. A adição de valores pode ser atingida pelo oferecimento ao cliente de um nível de serviço diferenciado.

De acordo com Leite (2003), a logística reversa "adiciona valor ao nível de serviço de pós-transação oferecido ao cliente, na medida em que estabelece uma política de disposição final, reutilização, reciclagem, reforma, reparo (reaproveitamento) para um determinado produto. Desta forma, tem a visão ampla de sua responsabilidade sobre toda o ciclo de vida do produto, e não somente durante sua vida útil, atentando para os impactos ambientais, para as possibilidades de desenvolvimento de atividades econômicas e pelo comprometimento para com a sociedade”.

Particularmente no setor da Construção Civil pressupõe-se que este interesse ainda seja incipiente e demonstrado por poucas indústrias, assim como o são as iniciativas brasileiras de reaproveitamento de resíduos industriais.

A aplicação do conceito de logística reversa na ICC pode ocorrer de diversas formas. Pode constituir-se em ferramenta organizacional para os fluxos de produtos de pósvenda, de pós-consumo, de resíduos do processo de produção, de mobilização e desmobilização de equipamentos utilizados durante a construção do 
empreendimento, e configurar-se como uma iniciativa inédita ou como um aprimoramento de um canal reverso já existente.

Especificamente no que se refere aos fluxos, a quantidade e variabilidade de composição dos resíduos da ICC geram fluxos de características bastante distintas. Na ICC os fluxos de pós-consumo e de processo de produção (resíduos) são dificilmente distinguidos, porque ocorrem simultaneamente, exceto quando da demolição de uma edificação - notoriamente um fluxo de produto de pós-consumo. $\mathrm{O}$ resíduo gerado durante a fase de produção do edifício é um resíduo industrial ou de processo, mas é também de pós-consumo em relação aos fabricantes de materiais e equipamentos. Ressalta-se que o resíduo proveniente da fase de uso do edifício não é contemplado neste estudo.

Os fluxos de produtos de pós-venda constituem-se essencialmente por devoluções por erro de processamento de pedidos e geralmente são destinados ao mercado secundário, sendo, por exemplo, liquidados em 'saldões' ou doados para entidades beneficentes. Há ainda os provenientes de equipamentos e transporte como os de devolução de pallets e retirada de elevadores e gruas.

No presente trabalho não será dada ênfase aos fluxos de produtos de pós-venda, pois, a preocupação maior recai atualmente sobre os produtos de pós-consumos ou de processo, denominados genericamente por resíduos da construção civil - RCD.

A aplicação do conceito de logística reversa na ICC pode ainda ter abrangência de uma empresa isoladamente, desta e de sua cadeia de suprimentos, como também de entidades setoriais, ou ainda de toda a cadeia produtiva (cadeia de suprimentos reversa). Quando os sistemas logísticos reversos da ICC são compartilhados por todos os agentes da cadeia e estes possuem objetivos estratégicos alinhados quanto ao reaproveitamento dos fluxos reversos, consolida-se o gerenciamento da cadeia de suprimentos reversa (reverse supply chain management).

Os sistemas logísticos reversos são formados por fluxos, canais de distribuição reversa, ou simplesmente canais reversos e relações comerciais. No presente estudo, os sistemas logísticos reversos da ICC correspondem aos fluxos de RCD, seus canais reversos, ou seja, os meios que percorrem e utilizam objetivando o reaproveitamento, e às relações comerciais entre fornecedores de matérias-primas, fabricantes de 
materiais e componentes; fornecedores de serviços; distribuidores; consumidores representados pelas construtoras; receptores/processadores de resíduos; e agentes governamentais.

Em relação aos canais reversos, o reaproveitamento dos RCD se dá em grande parte por processos de reciclagem, em virtude deles terem sua maior parcela constituída por materiais, onde nem a forma nem a funcionalidade do produto original são mantidas (STEVEN, 2004).

De acordo com Steven (2004), “os processos de reciclagem são a principal peça dos sistemas logísticos reversos". Para John (2000) "sob o ponto de vista da cadeia produtiva da construção civil, a reciclagem de resíduos é uma das formas de redução do seu impacto ambiental, um dos maiores na sociedade”. Assim abordarse-á com detalhe os sistemas logísticos reversos de reciclagem de RCD, embora muitos dos fatores a serem apresentados possam também ser estendidos aos outros processos de reaproveitamento.

\subsubsection{Fatores intervenientes na consolidação dos CDR de Reciclagem na ICC}

John (2000) lista como fatores que facilitam a reciclagem na cadeia produtiva da ICC os seguintes:

- ICC é a maior consumidora de materiais na economia;

- possui diferentes ramos da cadeia produtiva instalados em todas as regiões, o que permite uma reciclagem local;

- consome uma enorme variedade de materiais;

- consome componentes que em grande parte têm produção simples;

- pode consumir materiais alternativos para uma mesma função.

No entanto, fatores como os a seguir relacionados, sintetizados na Tabela 3.1, podem dificultar a consolidação destes canais, influenciando a viabilidade 
técnica, econômica, ambiental e social de um CDR (JOHN, 2000; JOHN; CINCOTTO, 2003; LEITE, 2003; STEVEN, 2004).

Tabela 3.1 - Resumo dos fatores intervenientes na consolidação dos CDR de reciclagem na ICC (autora, 2007)

- Inexistência, ineficiência ou inviabilidade econômica de tecnologia de reciclagem

- Dificuldade de identificação e separação dos resíduos, sua capacidade de degradação e reciclabilidade

- Onerosidade do transporte de coleta dos resíduos

- Baixa disponibilidade do resíduo

- Incerteza quanto à oferta de resíduos no mercado: existência, quantidade, qualidade e prazo

- Preço da matéria-prima original

- $\quad$ Necessidade de estoques para proteger a produção

- $\quad$ Necessidade de gatekeeping e políticas de devolução

- Decisão pela verticalização ou terceirização das atividades

- Mercado insuficiente ou não-desenvolvido para o produto originado no ciclo reverso

- Incerteza quanto à demanda por produtos reciclados ou com conteúdo reciclado: quantidade, qualidade e prazo

- Existência de oligarquias

- Característica monopsônica ou oligopsônica do mercado

- Análise das componentes do custo para determinar a viabilidade

- Custos das opções de destinação

- Impacto ambiental do processo de reciclagem

- Ausência de políticas de longo prazo para a gestão dos resíduos

- Baixo grau de educação/escolaridade da população

- Dificuldade de introdução de novas tecnologias

- Ausência de informações sobre os resíduos

- Existência de interesses conflitantes entre os agentes envolvidos

- Falta de interesse dos produtores do resíduos na reciclagem

Cada um destes fatores é discutido a seguir: 
- Inexistência, ineficiência ou inviabilidade econômica de tecnologia de reciclagem. A inexistência de tecnologia de reciclagem ou de sua indisponibilidade em certo local determina, por muitas vezes, a inexistência do próprio CDR. Em relação à inexistência, Leite (2003) afirma que a "viabilidade técnica e econômica do processo de reciclagem é um dos aspectos mais importantes na estruturação dos canais reversos de pós-consumo, sendo em alguns casos, o motivo principal da sua dificuldade de organização”. A tecnologia de reciclagem possui também uma limitação quanto a sua eficiência. Em muitos casos não é possível reciclar 100\% dos produtos/materiais. Além disso, a qualidade do material/produto reciclado frequentemente é menor do que o produto original, a menos que o material reciclado seja adicionado ao material original como conteúdo reciclado (STEVEN, 2004). Se a tecnologia for inviável economicamente ela não será utilizada.

- Dificuldade de identificação e separação dos resíduos, sua capacidade de degradação das propriedades originais e a reciclabilidade, ou seja, o número de vezes em que é possível reciclá-lo, são características técnicas muito importantes que podem inviabilizar o canal reverso de reciclagem.

- Onerosidade do transporte de coleta dos resíduos, os quais possuem baixo valor agregado e, geralmente, são leves e volumosos. A forma do RCD e de como ele é acondicionado influencia o maior ou menor aproveitamento do volume do recipiente de coleta, sendo desejável a maior taxa de compactação possível.

- Baixa disponibilidade do resíduo. A baixa disponibilidade do resíduo pode inviabilizar economicamente a reciclagem em função da capacidade dos equipamentos de processamento não ser atingida, ocasionando ociosidade e paradas de produção. Significa também um alto risco de falta de suprimento para o agente reciclador. Pode ser ocasionada por uma dificuldade de captação/coleta dos resíduos.

- Incerteza quanto à oferta de resíduos no mercado: existência, quantidade, qualidade e prazo. Os materiais/produtos provenientes de sobras de 
processos industriais, denominados resíduos industriais, apresentam-se melhor organizados, com composição constante e quantidade estimada com certa precisão. Fazendo-se uma analogia entre o canteiro de obras e a indústria, tem-se que os RCD podem ser considerados resíduos industriais. No entanto, os RCD apresentam grande variabilidade de composição, seja devido à tecnologia de produção empregada na sua geração, seja pelo manuseio despendido a ele no canteiro de obras, seja pela fase de execução em que se encontra o empreendimento, etc. Esta incerteza em relação à qualidade pode ser minimizada pela triagem dos RCD e pelo estabelecimento de limites de contaminação. A quantidade de resíduo disponível também é difícil de ser estimada, pois cada empreendimento possui produtividades e índices de perda diferentes, os quais variam enormemente. No entanto, segundo John (2000), "se o reciclador não tiver confiança na estabilidade do fornecimento de resíduo, por período suficientemente longo para amortizar o investimento, a reciclagem dificilmente se concretizará”. A incerteza em relação ao prazo deve-se ao ritmo de produção, geralmente inconstante, das obras.

- Preço da matéria-prima original. A formação do preço de produtos reciclados deve considerar diversos custos, dentre eles, o de produção, operação da instalação, logísticos, indiretos, ambientais e de capital. Se o preço da matéria-prima original for menor que o do produto reciclado, o produto não será competitivo em preço no mercado.

- Necessidade de estoques para proteger a produção. Em virtude da baixa confiabilidade de suprimento, os agentes recicladores precisam ter estoques que lhes permitam trabalhar com a incerteza na quantidade, qualidade e prazo do suprimento. Estes estoques representam capital imobilizado e podem dificultar a viabilização econômica da reciclagem.

- Necessidade de políticas de devolução e gatekeeping. As políticas de devolução, elaboradas geralmente pelos fabricantes, definem os requisitos que os produtos devem atender e os procedimentos para a devolução. Elas não servem apenas para produtos de pós-venda mas, 
também para a devolução de resíduos aos fabricantes. Já o gatekeeping é o processo de seleção dos produtos retornados que ocorre no ponto de entrada do sistema logístico reverso. Trata-se do primeiro fator crítico para o gerenciamento do fluxo reverso inteiro e de sua lucratividade. É este processo que permite (ou não) que produtos entrem no sistema logístico reverso (ROGERS; TIBBEN-LEMBKE, 1999). Cabe a este processo inspecionar a qualidade dos produtos retornados, decidir sobre sua disposição do resíduo e barrar, por exemplo, resíduos de produtos que foram vendidos por outras companhias (RAVI; SHANKAR, 2005). No caso dos RCD a existência destes mecanismos é muito importante. Primeiro, para definir com transparência os parâmetros/requisitos de aceitação de resíduos pelos recicladores, sejam eles terceirizados ou os próprios fabricantes. Segundo, para assegurar a qualidade dos RCD, principalmente em relação à triagem e à contaminação, e evitar uma destinação incorreta destes.

- Decisão pela verticalização ou terceirização das atividades. As atividades de logística reversa podem ser desempenhadas pelo próprio fabricante, situação em que este possui maior controle sobre a composição, qualidade e quantidade do resíduo. Em alguns países desenvolvidos, como Alemanha e Holanda, os fabricantes de determinados produtos são os responsáveis por sua destinação e obrigados a estabelecer sistemas logísticos reversos, em geral, verticalizados. Estes países adotaram legislações que instituem a política do take-back para certos resíduos. Segundo Rogers; Tibben-Lembke (1998) a política do take-back consiste em "exigir dos fabricantes que eles coletem os produtos ao fim da vida útil para recuperar materiais ou dispô-los adequadamente”. Outra opção é a contratação de empresas especializadas no gerenciamento dos sistemas logísticos reversos. Embora não se tenha conhecimento, até o presente momento, deste tipo de empresa atuando no Brasil, os operadores logísticos reversos são comuns em outros países, principalmente nos ditos desenvolvidos. Consiste na terceirização do sistema logístico reverso. Há ainda a possibilidade de parceria no 
tratamento dos fluxos reversos entre empresas que sejam, até mesmo, concorrentes na logística de distribuição direta. Por exemplo, se a identificação da origem do resíduo é difícil - como em geral o é para os RCD - é possível que retornos de outros fabricantes 'entrem' ou 'estejam' no canal reverso de outra empresa. Assim, graças a uma parceria, é possível estabelecer um único sistema logístico reverso para operacionalizar o reaproveitamento dos retornos de um conjunto de fabricantes.

- Mercado insuficiente ou não-desenvolvido para o produto originado no ciclo reverso. A constatação dos possíveis mercados para os produtos reciclados ou com conteúdo reciclado abrange a identificação dos requisitos de qualidade e desempenho que estes devem apresentar para serem aceitos pelos clientes. $\mathrm{O}$ fornecimento de produto reciclado ou com conteúdo reciclado depende da curva de demanda por estes produtos no mercado, geralmente o secundário, das atividades de promoção de marketing, geralmente baseadas no marketing ambiental, e nas previsões de produção e distribuição destes produtos para o mercado (BALLOU, 1993). Ilustra-se melhor por meio de um exemplo: uma empresa que transforma garrafas de PET em fio para tecelagem terá sua gestão de materiais condicionada aos seguintes aspectos, dentre outros: (1) mercado para o consumo de fios de PET: dependendo da participação de mercado (market share) desta empresa, haverá maior ou menor demanda pela sua produção e conseqüentemente por garrafas de PET; (2) ações de marketing: as ações de marketing têm por objetivo aumentar o market share das empresas, ou ainda, desenvolver o mercado, demonstrando as potencialidades do produto; (3) os planos de produção e distribuição definem de que forma as garrafas devem chegar à empresa, supondo prensadas, lavadas, separadas por cor, em lotes de tamanhos determinados e iguais, em quais localizações estarão as plantas industriais de transformação e onde estão os mercados consumidores. No caso dos RCD os mercados existem mas, não estão desenvolvidos. $\mathrm{O}$ fornecimento de produtos reciclados esbarra na visão do cliente que é um 
produto de má qualidade, na ausência de mecanismos que comprovem o seu desempenho etc. De acordo com Dekker; Barros e Scholten (1998), na Holanda, 70\% dos RCD já são reciclados e, para aumentar esta porcentagem para 90\%, novas leis têm sido criadas para restringir a deposição de RCD em aterros e encorajar o controle de qualidade de materiais reciclados.

- Incerteza quanto à demanda por produtos reciclados ou com conteúdo reciclado: quantidade, qualidade e prazo. Os produtos reciclados frequentemente enfrentam obstáculos mentais na opinião de seus usuários potenciais. Eles supõem que produtos reciclados possuem menor qualidade do que produtos feitos de recursos primários e não estão dispostos a comprá-los, pelo menos não pelo mesmo preço (STEVEN, 2004).

- Existência de oligarquias; que dificultam a entrada de novos produtos no mercado.

- Característica monopsônica ou oligopsônica do mercado, isto é, a situação em que há somente um ou bem poucos compradores para o produto reciclado ou com conteúdo reciclado. Neste caso, o poder de negociação do agente reciclador é pequeno.

- Análise das componentes do custo para determinar a viabilidade. De acordo com Steven (2004), a reciclagem só começa a ser lucrativa se os custos dos processos adicionais de logística reversa não forem maiores que as economias obtidas pela redução de materiais e energia no lado da entrada e de resíduos no lado da saída. Já os custos ambientais e sociais, apesar de difícil valoração em função de seus caracteres intangíveis, devem ser considerados com base em estudos de análise de ciclo de vida.

- Custos das opções de destinação. Exceto por força de legislações rígidas, os geradores de RCD que possuem diferentes opções de destinação geralmente têm suas decisões baseadas somente no critério de custo. No entanto, nem sempre este custo considera todos os componentes que deveria, como, por exemplo, os custos ambientais. No caso dos RCD a 
taxação de descargas em aterros é um dos principais mecanismos que pode auxiliar na viabilidade dos processos de reciclagem.

- Impacto ambiental do processo de reciclagem. A reciclagem pode não ser viável do ponto de vista ambiental se os processos logísticos e de processamento de reciclagem causarem grandes impactos ambientais negativos. Por exemplo, se o processo de reciclagem necessita muito mais energia, ou ainda, muito mais atividades de transporte, ele pode incorrer em maiores impactos ambientais do que a simples deposição do material (STEVEN, 2004).

- Ausência de políticas de longo prazo para a gestão dos resíduos. A descontinuidade das políticas relativas à gestão de resíduos atrasa o estabelecimento de legislações, regulamentações, procedimentos e normas técnicas tão necessárias. Além disso, ações implementadas não recebem credibilidade por logo serem relegadas. Segundo John (2000), esta condição pode ser alterada por um grande envolvimento da sociedade, organizada em associações, exercendo pressão sob os órgãos governamentais.

- Baixo grau de educação/escolaridade da população (JOHN, 2000). O baixo grau de educação e a ausência de educação ambiental desde o ensino básico forma cidadãos, e por conseqüência, profissionais, com baixa consciência ecológica, pouco comprometidos com a questão ambiental e inconscientes de sua responsabilidades perante, por exemplo, o consumo de recursos naturais e a geração de resíduos. A cooperação e o comprometimento dos geradores de RCD é vital para o estabelecimento dos canais reversos. Segundo John e Agopyan (2000), campanhas educativas poderiam atingir também a construção informal.

- Dificuldade de introdução de novas tecnologias. Produtos de características similares por vezes requerem tecnologias de produção diferentes. No caso dos produtos reciclados ou com conteúdo reciclado na ICC novas tecnologias de produção podem ser necessárias. John (2000) aponta como causas desta dificuldade o baixo impacto da inovação nos custos do empreendimento, a existência de normas 
prescritivas e o histórico brasileiro recente de novas tecnologias que resultaram em desempenhos insatisfatórios. Para os produtos reciclados ou com conteúdo reciclado, acredita-se haver um alto potencial de redução de custos do empreendimento com o uso destes. Já as normas prescritivas, que determinam soluções pré-estabelecidas em detrimento aos parâmetros de desempenho, representam grande obstáculo para os produtos reciclados. Sem normas de desempenho, os produtos reciclados dificilmente vencerão a desconfiança do cliente quanto à sua qualidade e desempenho (JOHN; ZORDAN, 2000).

- Ausência de informações sobre os resíduos. Segundo John (2000), os inventários de resíduos são as fontes mais fáceis de obtenção de informações sobre os resíduos disponíveis e suas quantidades geradas. Porém, eles são raros e, no Brasil, não abrangem os resíduos inertes, somente os industriais e perigosos. Apesar de ser possível a realização de levantamentos indiretos, a ausência destes inventários no Brasil dificulta a quantificação dos fluxos e, consequentemente, o estudo de viabilidade técnica-econômica dos canais reversos de reaproveitamento.

- Existência de interesses conflitantes entre os agentes envolvidos no canal reverso.

- Falta de interesse dos produtores dos resíduos na reciclagem. Segundo o BCSD-GM (1999, apud JOHN, 2000), “se não houver a firme disposição da direção da empresa, seguida da definição dos objetivos que a empresa tem com relação aos resíduos e o envolvimento da equipe da empresa, a reciclagem do resíduo dificilmente será concretizada”. Dentre outros fatores, para estabelecer a reciclagem são necessárias informações sobre processos internos à empresa que definem as características dos resíduos. Além disso, “a reciclagem vai exigir uma mudança na cultura da empresa geradora. Embora dificilmente o resíduo venha a ser o negócio principal, ele terá que ser tratado de maneira dual: como resíduo, por imposição legal; e como produto, pois ele passará a contar com consumidor(es), interessados em prazos, manutenção da qualidade e etc.” (JOHN, 2000). Caso não exista este 
interesse imediato, o resíduo poderá ser objeto de política pública visando criar condições para a reciclagem, inclusive por meio de dispositivos fiscais (HARTLÉN, 1995 apud JOHN, 2000).

A análise e discussão detalhada dos fatores apresentados, assim como seu embasamento em estudos específicos a cada cadeia, são necessárias para a tomada de decisão em relação à implantação e consolidação de CDR-PC de reciclagem de RCD.

A identificação e discussão destes fatores serviram de estruturação para a análise do caso estudado. No capítulo 5 discutem-se como tais fatores se apresentam no caso da cadeia de CGA.

\subsubsection{Logística Reversa e seu papel no desenvolvimento sustentável do ambiente construído}

Verifica-se na ICC uma grande preocupação com a sustentabilidade porque esta é vista como um diferencial competitivo, perante os clientes, e como fonte de vantagem competitiva para uma estratégia empresarial, já que a crescente sensibilização ambiental e social das sociedades modernas configura novas exigências dos consumidores.

Além disso, neste setor, tanto os processos de produção nos canteiros de obras, quanto o produto que dele deriva são potencialmente impactantes no ambiente. Destaca-se, ainda, que este setor possui interfaces com muitas cadeias produtivas, das mais variadas composições e níveis de organização, desde, por exemplo, a cadeia produtiva de madeiras, passando pela de PVC, até a de cimento.

Mais recentemente, as empresas perceberam que a ausência de sistemas de logística reversa e políticas definidas de retornos influenciam negativamente na logística direta, causando problemas de grandes dimensões. Perceberam igualmente, a sua importância para a questão ambiental. 
Analisando-se as três dimensões do desenvolvimento sustentável - a econômica, a ambiental e a social -, verifica-se uma importante contribuição da logística reversa para a sistematização deste desenvolvimento.

Quanto à dimensão econômica, esta contribuição se dá na medida em que, segundo Leite (2003), "o objetivo econômico da implementação da logística reversa de pós-consumo pode ser entendido como a motivação para a obtenção de resultados financeiros por meio de economias obtidas nas operações industriais, principalmente pelo aproveitamento de matérias-primas secundárias, provenientes dos canais reversos de reciclagem, ou de revalorizações mercadológicas nos canais reversos de reuso e de remanufatura". Identificam-se ainda os benefícios de economia de energia para a produção e o menor investimento em fábricas.

Na interface entre a dimensão econômica e ambiental observa-se que, segundo Carter e Ellram (1998), o expressivo gasto da indústria com as regulamentações ambientais tem destacado a relevância da logística reversa. Estes autores estimam que nos Estados Unidos este valor ultrapassa US\$124 bilhões por ano. Além disso, o mercado de produtos denominados "ambientalmente amigáveis", o que no Brasil corresponderia aos “ecologicamente corretos”, cresce aproximadamente US\$200 bilhões por ano, confirmando pesquisas que afirmam que os consumidores estão dispostos a pagar preços maiores na compra destes produtos (KOPICKI, 1993).

Tornam-se evidentes, em todo o meio acadêmico, as afirmações de que a ICC assim como outras cadeias industriais - deve promover o desenvolvimento sustentável, ou seja, deve desenvolver-se de forma a não comprometer a capacidade das gerações futuras em fazê-lo também. Dentre os inúmeros aspectos presentes nas políticas de desenvolvimento sustentável da cadeia produtiva da ICC, em relação às dimensões ambiental e social, encontram-se a responsabilidade para com o uso de recursos naturais e a destinação dos resíduos das atividades industriais.

Assim, a implantação da logística reversa, além dos benefícios econômicos que proporciona, revela-se também como uma grande oportunidade de se 
desenvolver a sistematização dos fluxos de resíduos, bens e produtos descartados - seja pelo fim de sua vida útil, seja por obsolescência tecnológica ou outro motivo - e o seu reaproveitamento, dentro ou fora da cadeia produtiva que o originou, contribuindo para a redução do uso de recursos naturais e dos demais impactos ambientais. O sistema logístico reverso consiste em uma ferramenta organizacional com o intuito de viabilizar técnica $\mathrm{e}$ economicamente as cadeias reversas, de forma a contribuir para a promoção da sustentabilidade de uma cadeia produtiva.

Desta forma a disposição da empresa para a aplicação de um sistema estruturado de logística reversa revela uma visão ampliada de sua responsabilidade sobre todo o ciclo de vida do produto (e não somente durante a vida útil), atentando para os impactos ambientais, para as possibilidades de desenvolvimento de atividades econômicas e pelo comprometimento para com o futuro da sociedade.

Destacam-se ainda os seguintes benefícios (LEITE, 2003): (1) consolidação da imagem corporativa; (2) responsabilidade social: geração de novas atividades econômicas, empregos e renda; incentivo à pesquisa de desenvolvimento de tecnologias de materiais, de reuso e reciclagem; (3) responsabilidade ambiental: diminuição do volume de deposição final de produtos que possam ser revalorizados; redução do consumo de matérias-primas virgens; (4) retornos financeiros apreciáveis; (5) melhoria da competitividade devido ao nível de serviço diferenciado.

Percebe-se, portanto, que a logística reversa pode constituir-se em uma ferramenta para subsidiar ações relacionadas a todas as dimensões do desenvolvimento sustentável.

A Figura 3.4 ilustra o inter-relacionamento destas ações e de seus respectivos benefícios na cadeia produtiva da ICC. 


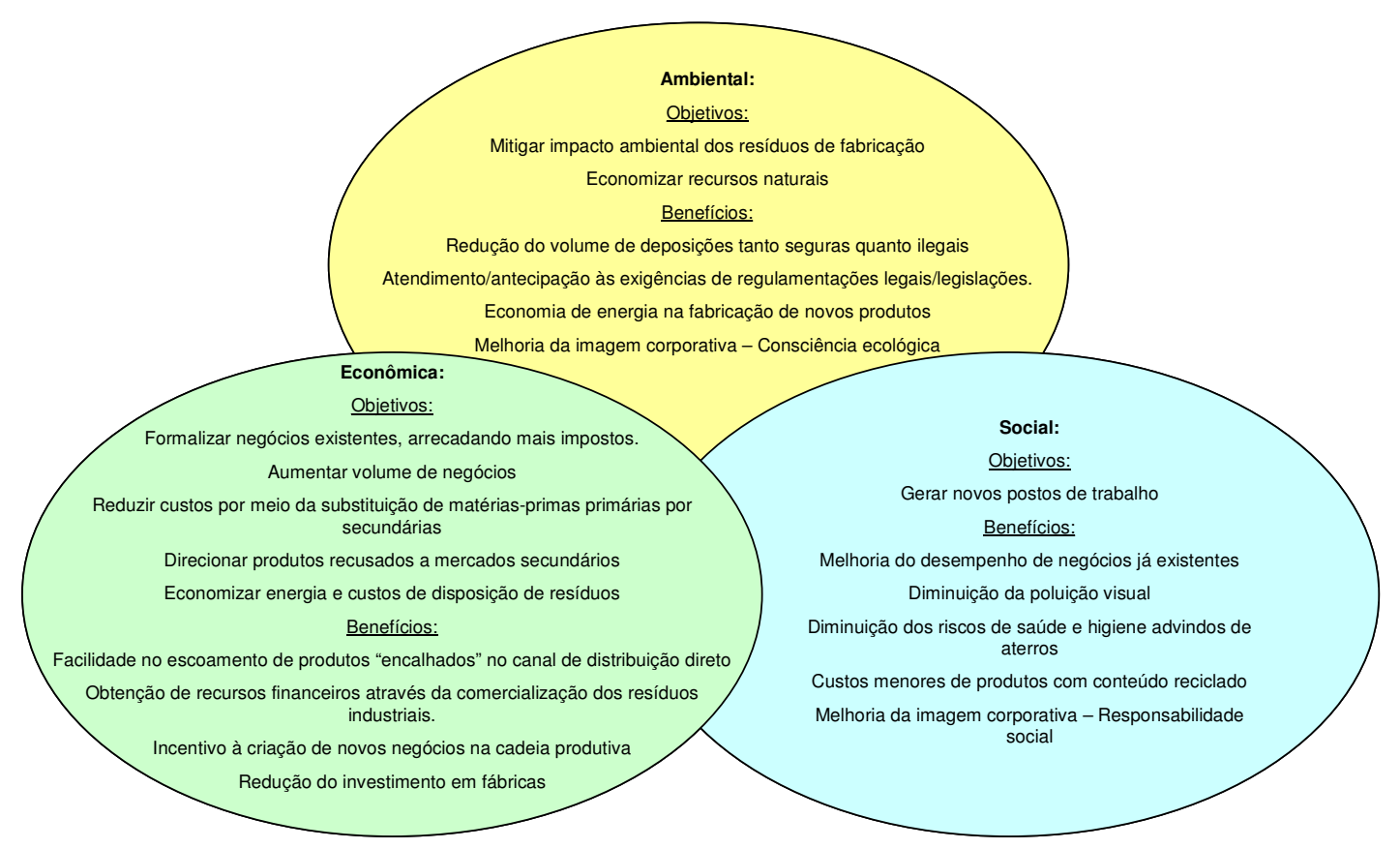

Figura 3.4 - Papel da logística reversa na cadeia produtiva da ICC, sob o ponto de vista da sustentabilidade (MARCONDES; CARDOSO, 2005).

Finalmente, devido a certas características das empresas que atuam na ICC, relacionadas à pulverização existente, ao seu porte, à capacidade de aporte de recursos e à sua capacidade de articulação na cadeia produtiva, pode-se questionar a eficácia de sistemas de logística reversa estruturados por empresas. Para determinadas cadeias, que dependam de empresas de pequeno porte, como construtoras, subcontratadas e projetistas como elo principal, pode-se vislumbrar sistemas articulados por entidades setoriais. 


\section{4 - Logística Reversa aplicada ao} Gerenciamento de Resíduos de
Construção e
Demolição

Os fluxos de produtos de pós-consumo da ICC - os RCD - têm sua origem no canteiro de obras. Neste ambiente desenvolveram-se recentemente algumas iniciativas de gerenciamento dos RCD. Neste capítulo apresentam-se as exigências impostas pelas legislações federal (incluindo as normas técnicas), estadual e municipal e como elas foram interpretadas e implantadas no município de São Paulo. 
Particularmente neste município abordam-se os equipamentos públicos disponíveis para o gerenciamento de RCD, a atuação das empresas construtoras e um modelo para o gerenciamento de RCD por estas empresas.

A análise das exigências de legislações versus as necessidades das construtoras, permite concluir acerca das ações necessárias para o estabelecimento de um sistema logístico reverso para os RCD.

\subsection{O Modelo Preconizado Pela Resolução N. . $^{\circ} 07$ DO CONAMA}

Conforme citado no capítulo 3, item 3.3.2, a Indústria da Construção Civil é um setor responsável por grandes impactos ambientais, decorrentes tanto dos processos de produção quanto do próprio produto, dentre eles, a poluição do ar, água e solo, o elevado consumo de energia e o esgotamento dos recursos naturais (DEGANI, 2003). Dentre os aspectos apontados como prioritários na agenda 21 para o Construbusiness brasileiro, segundo John; Silva e Agopyan (2001), dois estão intimamente ligados aos processos de logística reversa: o consumo de recursos e o reaproveitamento dos resíduos gerados pela ICC.

Em relação ao consumo de recursos, ele se localiza nas entradas (inputs) do processo de transformação e, portanto, o foco de atuação para seu combate está em evitar o 'consumo'. Neste caso, as ferramentas de controle da produção e da produtividade, tanto de materiais quanto de mão-de-obra e equipamento, podem auxiliar no controle deste aspecto. Já no outro extremo do processo de transformação - as saídas (outputs), quando o resíduo já foi gerado, o foco da atuação está no correto tratamento destes resíduos e são necessárias ações que mitiguem o impacto ambiental negativo dos mesmos. Neste ponto, a logística reversa de pós-consumo revela-se uma importante ferramenta para que os fluxos de resíduos, e consequentemente os possíveis impactos ambientais negativos relacionados a eles, sejam corretamente tratados, seja pela redução da quantidade, ocasionada pelo seu reaproveitamento, seja pela correta destinação dada a eles. 
Segundo Pinto (1999) e Schneider (2003), no Brasil, o gerenciamento de resíduos sólidos urbanos tornou-se particularmente crítico nas últimas décadas devido ao crescimento desordenado e desenvolvimento acelerado dos pólos urbanos. A discussão sobre o gerenciamento de resíduos sólidos urbanos tem sido uma constante nos grupos de pesquisa que têm por objetivo debater a sustentabilidade e mais especificamente a gestão ambiental. Segundo o CONAMA - Conselho Nacional do Meio Ambiente (apud BLUMENSCHEIN, 2001), cerca de 50\% do peso total dos resíduos sólidos urbanos produzidos diariamente em grandes cidades brasileiras, com mais de 500 mil habitantes, correspondem aos resíduos das atividades da Indústria da Construção Civil.

A ausência, ou até mesmo a ineficiência, de políticas públicas que contemplem os resíduos sólidos urbanos tem contribuído para o agravamento dos problemas urbanos. Particularmente os RCD, não estavam subordinados a nenhuma legislação, até a elaboração da Resolução n. 307 do CONAMA, em 2002, em vigor desde janeiro de 2003 (ver Anexo B). Portanto, esta resolução destaca-se como a primeira ação consolidada para a regulamentação do Gerenciamento de Resíduos Sólidos de Construção e Demolição. Ela é de extrema importância porque estabelece diretrizes e procedimentos para o gerenciamento dos $\mathrm{RCD}$, além de definir termos correlatos ao assunto (MARCONDES; CARDOSO, 2005).

Segundo esta resolução, os resíduos da construção civil "são os provenientes de construções, reformas, reparos e demolições de obras de construção civil, e os resultantes da preparação e da escavação de terrenos (...), comumente chamados de entulhos de obras, caliça ou metralha". E ainda, "o sistema de gestão que visa reduzir, reutilizar ou reciclar resíduos, incluindo planejamento, responsabilidades, práticas, procedimentos e recursos para desenvolver e implementar as ações necessárias ao cumprimento das etapas previstas em programas e planos, é então denominado de Gerenciamento de Resíduos” (CONAMA, 2002).

A escassez de dados precisos sobre os processos de demolição determinou a ênfase deste estudo na gestão de RCD decorrentes da fase de construção de novos empreendimentos. Apesar disto, é necessário citar que os agentes de serviços de 
demolição desenvolveram um nicho de mercado valorizado para seus sub-produtos ou resíduos como componentes, por exemplo, portas e janelas 'de demolição'.

\section{Exigências da Resolucão n. ${ }^{\circ} 307$ quanto aos Sistemas de Gerenciamento de RCD}

Para possibilitar o gerenciamento de RCD, a Resolução n. 307 (CONAMA, 2002) também determina a criação por parte de cada município e do Distrito Federal de um Plano Integrado de Gerenciamento de Resíduos da Construção Civil - PIGRCC.

Em relação à atribuição de responsabilidades, esta Resolução determina apenas dois grupos de agentes: os geradores e os transportadores, sendo que os geradores são pessoas "físicas ou jurídicas, públicas ou privadas, responsáveis por atividades ou empreendimentos que gerem os RCD”.

A Resolução prevê ainda dois grupos de geradores de resíduos: os de grande porte, representado principalmente por empresas construtoras, e os de pequeno porte, que inclui os provenientes de pequenas reformas ou reparos. Tanto os pequenos quanto os grandes geradores de resíduos devem ser contemplados no PIGRCC, por meio do estabelecimento de procedimento para cada um destes grupos. A estrutura do PIGRCC é apresentada na Figura 4.1.

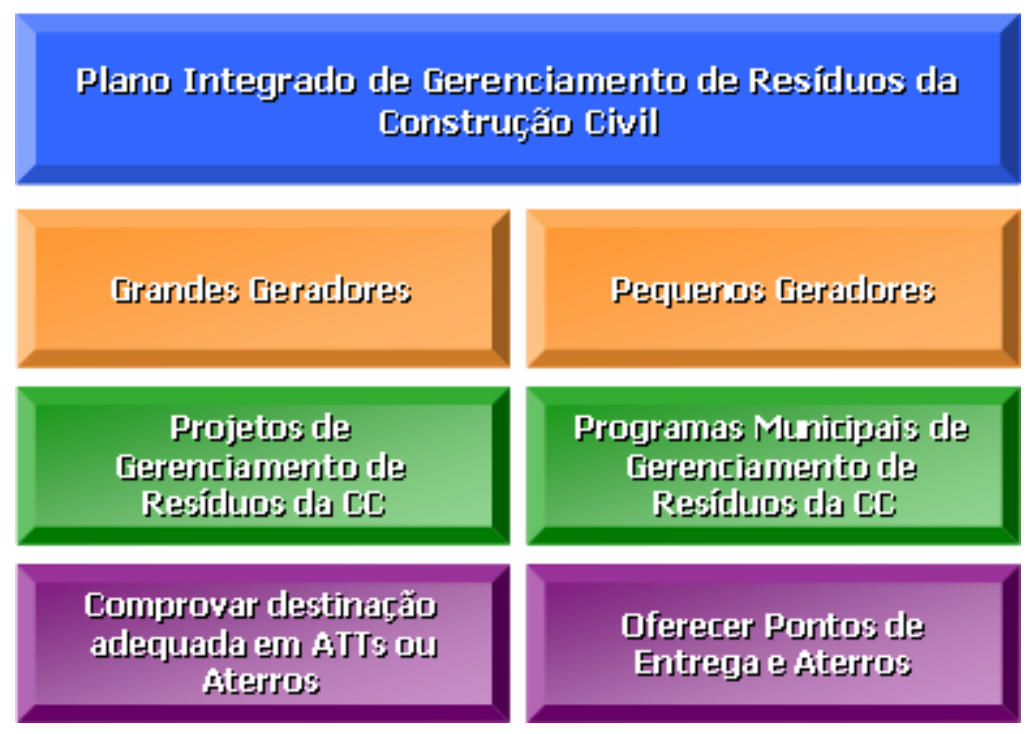

Figura 4.1 - Estrutura do Plano Integrado, prevista na Resolução $n .^{\circ} 307$ do CONAMA (2002). 
Embora a resolução vigore desde janeiro de 2003, muitos municípios demoraram a elaborar seus Planos Integrados de Gerenciamento de RCC, e poucos o implementaram. No caso da Prefeitura do Município de São Paulo, o Plano de Gestão Sustentável do Entulho na Cidade - um pacote de medidas para incentivar a iniciativa privada a investir e gerir o ramo de atividades e melhorar a gestão do entulho - foi lançado somente em outubro de 2005 (PMSP, 2006b).

\subsubsection{Grandes Geradores}

Os geradores de grande porte têm que elaborar os Projetos de Gerenciamento de Resíduos de Construção Civil, referenciados aqui pela sigla PGRCC. Para as empresas construtoras, a elaboração dos PGRCC é fundamental, porque cada projeto será analisado pelo órgão ambiental local, para a aprovação do empreendimento na prefeitura do município.

Estes projetos devem estabelecer os procedimentos necessários ao manejo e à destinação ambientalmente adequados dos resíduos, instituindo intervenções e planos específicos para cada empreendimento. Devem, ainda, contemplar as etapas de caracterização, triagem, acondicionamento, transporte e destinação (PINTO, 2005). Estabelecido e aprovado o PGRCC irá se proceder à implantação do mesmo.

As etapas de caracterização, triagem, acondicionamento, transporte e destinação previstas no PGRCC serão abordadas uma a uma nos itens que se seguem.

\section{Composicão e caracterizacão dos $R C D$}

De acordo com John (2000), o RCD tem constituição variável, depende da fonte geradora - construção ou reforma/demolição, fase da obra, tecnologia construtiva, natureza da obra, etc. O estudo de Brito Filho (1999) no aterro de Itatinga, na cidade de São Paulo, indica os valores apresentados na Figura 4.2. 


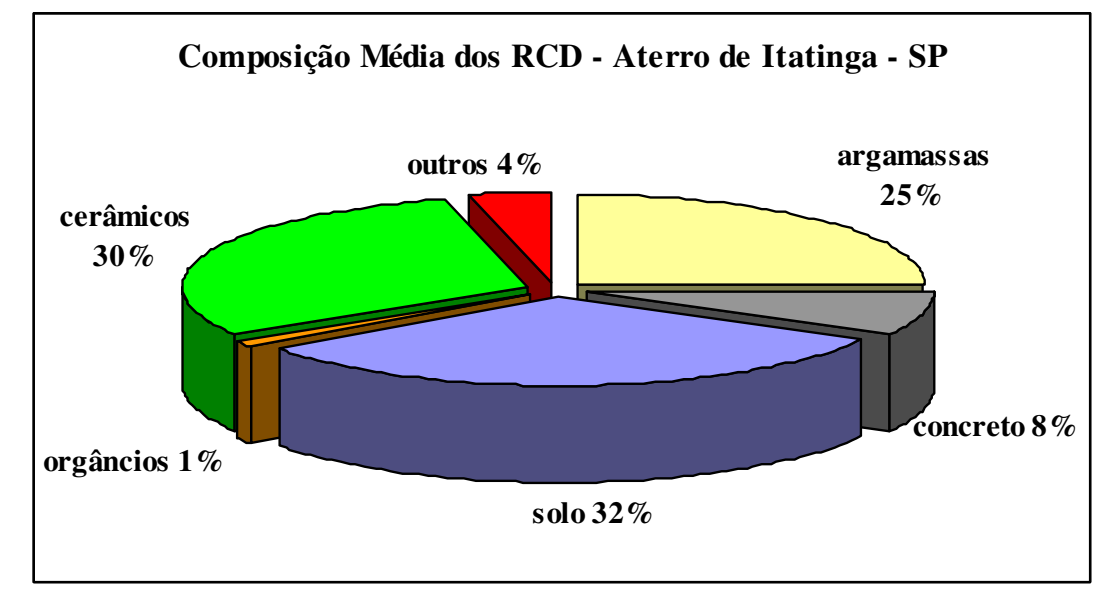

Figura 4.2 - Composição média dos entulhos depositados no aterro de Itatinga, São Paulo (BRITO FILHO, 1999).

A etapa de caracterização constitui-se na identificação e quantificação dos resíduos gerados no canteiro de obras (PINTO, 2005). Ela pressupõe o treinamento da mão-de-obra para realizar a identificação visual dos resíduos e proceder em seguida a triagem, de acordo com a classificação da Resolução n. ${ }^{\circ}$ 307 (CONAMA, 2002), apresentada na Tabela 4.1.

Tabela 4.1 - Classificação dos Resíduos de Construção e Demolição segundo a Resolução $n .^{\circ} 307$ do CONAMA (2002).

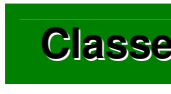

A

B

D

\section{Definjição}

Resíduos reutilizáveis ou recicláveis como agregados

Resíduos recicláveis para outras destinações

Resíduos para os quais não foram desenvolvidas tecnologias ou aplicações economicamente viáveis que permitam a sua reciclagem/recuperação

Resíduos perigosos ou aqueles contaminados oriundos de demolições, reformas e reparos de clínicas radiológicas, instalações industriais e outros

\section{Exemplos}

Componentes cerâmicos, argamassas, concretos, solos etc.

Plástico, papel e papelão, metais, vidros, madeiras e outros

Gesso e outros sem tecnologia de recuperação (lixas, manta asfáltica etc.)

Tintas, solventes, óleos e outros resíduos contaminados. 
A quantificação da geração de RCD é complexa porque envolve a coleta de dados em campo, uma vez que não há dados precisos, nem indicadores divulgados; a geração depende muito do projeto do empreendimento e das tecnologias utilizadas; da organização do canteiro, dos recipientes utilizados para acondicionamento, dos diferentes 'empolamentos' dos resíduos; além de variar conforme a etapa da obra.

O levantamento realizado por Gimenes (2007) mostra como estes números podem variar, tomando-se por base empreendimentos de uma mesma empresa construtora, executados em 2004 (Tabela 4.2).

Tabela 4.2 - Levantamento das quantidades de RCD geradas e caçambas utilizadas em nove obras na cidade de São Paulo, entre jul/2003 e out/2004

(GIMENES, 2007).

\begin{tabular}{|c|c|c|c|c|c|c|}
\hline OBRAS & $\begin{array}{c}\text { Área } \\
\text { Construída } \\
\left(\mathbf{m}^{2}\right)\end{array}$ & $\begin{array}{c}\text { Início da } \\
\text { Obra }\end{array}$ & $\begin{array}{c}\text { Término } \\
\text { da Obra }\end{array}$ & $\begin{array}{c}\text { Prazo de } \\
\text { execução da } \\
\text { obra (meses) }\end{array}$ & $\begin{array}{c}\text { Quantidade de } \\
\text { Caçambas } \\
\text { Utilizadas no } \\
\text { Período (Un) }\end{array}$ & $\begin{array}{c}\text { Quantidade } \\
\left.\text { de RCD (m }{ }^{3}\right)\end{array}$ \\
\hline A & $15.880,00$ & jul-03 & ago-04 & 13 & 110 & 440,00 \\
\hline B & $35.000,00$ & abr-02 & jan-05 & 28 & 527 & $2.108,00$ \\
\hline C & $12.280,00$ & fev-03 & set-04 & 18 & 179 & 716,00 \\
\hline D & $10.300,00$ & mar-02 & set-03 & 18 & 238 & 952,00 \\
\hline E & $8.500,00$ & abr-00 & out-01 & 19 & 298 & $1.192,00$ \\
\hline F & $9.500,00$ & mar-01 & ago-02 & 18 & 259 & $1.036,00$ \\
\hline G & $15.100,00$ & mar-00 & ago-01 & 18 & 553 & $2.212,00$ \\
\hline H & $63.000,00$ & mai-00 & out-02 & 30 & 1.636 & $6.544,00$ \\
\hline I & $9.500,00$ & set-99 & dez-01 & 28 & 288 & $1.152,00$ \\
\hline
\end{tabular}

\begin{tabular}{|c|c|c|c|c|c|}
\hline OBRAS & $\begin{array}{c}\text { Índice de } \\
\text { Caçambas por } \\
\text { Área Construída } \\
\left(\text { Caçambas } / \mathrm{m}^{2}\right)\end{array}$ & $\begin{array}{l}\text { Taxa de geração de } \\
\text { RCD por Ârea } \\
\text { Construída }\left(\mathrm{m}^{3} / \mathrm{m}^{2}\right)\end{array}$ & $\begin{array}{c}\text { Quantidade de } \\
\text { Caçambas Utilizadas } \\
\text { por Mês } \\
\text { (Caçamba/mês) }\end{array}$ & $\begin{array}{c}\text { Taxa de Geração } \\
\text { de RCD Prevista } \\
\left(\mathrm{m}^{3} / \mathrm{m}^{2}\right)\end{array}$ & $\begin{array}{l}\text { Variação da Taxa de } \\
\text { Geração de RCD } \\
\text { Obtida com a Prevista } \\
(\%)\end{array}$ \\
\hline A & 0,0069 & 0,0277 & 8,5 & 0,0600 & $-53,82 \%$ (ABAIXO) \\
\hline $\mathrm{B}$ & 0,0151 & 0,0602 & 18,8 & 0,0600 & $0,38 \%$ (ACIMA) \\
\hline $\mathrm{C}$ & 0,0146 & 0,0583 & 9,9 & 0,0600 & $-2,82 \%($ ABAIXO) \\
\hline $\mathrm{D}$ & 0,0231 & 0,0924 & 13,2 & 0,0600 & $54,05 \%$ (ACIMA) \\
\hline$E$ & 0,0351 & 0,1402 & 15,7 & 0,0600 & $133,73 \%$ (ACIMA) \\
\hline $\mathrm{F}$ & 0,0273 & 0,1091 & 14,4 & 0,0600 & $81,75 \%$ (ACIMA) \\
\hline $\mathrm{G}$ & 0,0366 & 0,1465 & 30,7 & 0,0600 & $144,15 \%$ (ACIMA) \\
\hline $\mathrm{H}$ & 0,0260 & 0,1039 & 54,5 & 0,0600 & $73,12 \%$ (ACIMA) \\
\hline 1 & 0,0303 & 0,1213 & 10,3 & 0,0600 & $102,11 \%$ (ACIMA) \\
\hline $\begin{array}{l}\text { ÍNDICE } \\
\text { HISTÓRICO } \\
\text { MÉDIO }\end{array}$ & 0,0282 & 0,1129 & 25,0 & 0,0600 & $88,21 \%$ (ACIMA) \\
\hline
\end{tabular}


Em Marcondes e Cardoso (2006) os autores demonstram por meio de um método de planejamento, uma forma de estimar a quantidade de RCD gerado em um empreendimento.

\section{$\underline{\text { Triagem dos } R C D}$}

O processo de triagem consiste na separação e classificação dos resíduos e pode acontecer na origem, ou seja, dentro do canteiro de obras, ou fora do canteiro, em uma Área de Transbordo e Triagem - ATT. As Áreas de Transbordo e Triagem, segundo da NBR 15112 (ABNT, 2004), são “áreas destinadas ao recebimento de resíduos da construção civil e resíduos volumosos, para triagem, armazenamento temporário dos materiais segregados, eventual transformação e posterior remoção para destinação adequada, sem causar danos à saúde pública e ao meio ambiente”.

No caso da triagem ser realizada fora, na ATT, o processo será descrito no item "áreas de destinação".

Dentro do canteiro de obras a triagem pode ocorrer de forma descentralizada, por exemplo, por andares, ou centralizada, sendo o transporte feito com os RCD misturados e a separação feita em uma central localizada dentro do canteiro de obras, por exemplo, no pavimento térreo do edifício.

Segundo a Resolução n. 307 (CONAMA, 2002) a etapa de triagem "deverá ser realizada, preferencialmente, pelo gerador na origem, ou ser realizada nas áreas de destinação licenciadas para essa finalidade, respeitadas as classes de resíduos estabelecidas no art. $3^{\circ}$ desta Resolução”.

A recomendação da Resolução em realizar-se a triagem preferencialmente na origem deve-se a preocupação em se evitar a contaminação da fração mineral (resíduos de argamassa, concreto, blocos cerâmicos e de concreto, entre outros) dos RCD. O principal agente desta contaminação é o gesso. Seu efeito será discutido no capítulo 5, item 5.2.1.6. 


\section{$\underline{\text { Acondicionamento dos } R C D}$}

O acondicionamento diz respeito à forma com que o resíduo será "estocado" antes de ser corretamente destinado. Para o acondicionamento são utilizadas baias, caçambas, de capacidade de 4,5 ou $16 \mathrm{~m}^{3}$, bombonas, tambores e bags $^{14}$ desde que garantam segurança, não-vazamento, ergonomia no manuseio e possuam tamanho adequado ao volume de RCD (Figura 4.3).

Esta atividade pode ocorrer em dois momentos, havendo um acondicionamento inicial, por exemplo, em bombonas no andar e, posteriormente, um acondicionamento final em caçambas no térreo, ou não, ocorrendo direto o acondicionamento final.

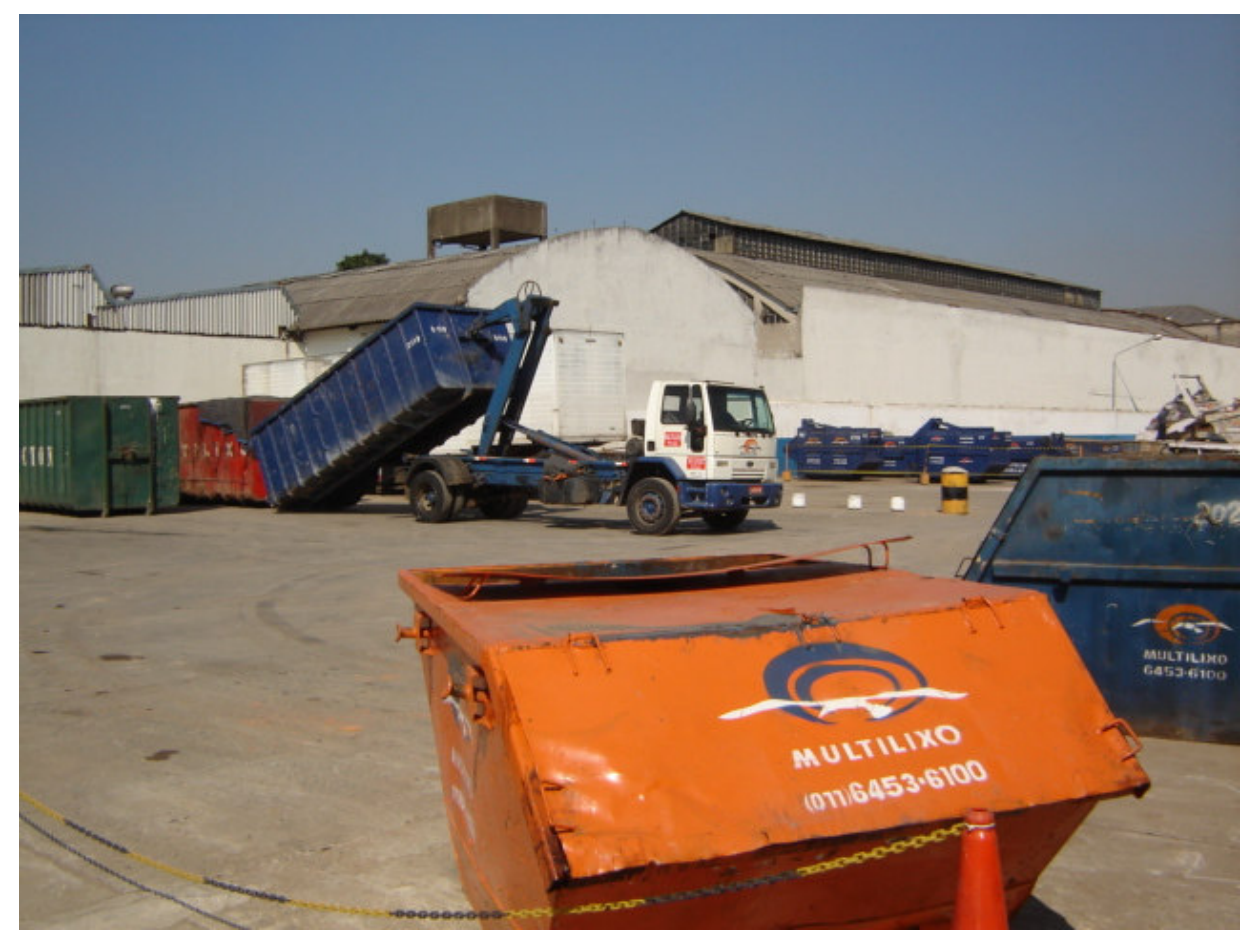

Figura 4.3 - Tipos de caçambas comumente utilizadas para o acondicionamento e coleta de RCD (autora, 2007).

As características do resíduo, o espaço disponível dentro do canteiro de obras e a periodicidade de retirada/coleta dos RCD influenciam a escolha do tipo de

\footnotetext{
${ }^{14}$ Bags são sacos de polietileno com capacidade para $1 \mathrm{~m}^{3}$. Para maiores informações sobre os recipientes de acondicionamento, ver PINTO (2005).
} 
recipiente a ser utilizado. A escolha do recipiente determina o meio de transporte - tipo de caminhão - a ser utilizado na coleta dos RCD.

\section{$\underline{\text { Transporte dos } R C D}$}

A etapa de transporte compreende a retirada/coleta do RCD no canteiro de obras e sua movimentação até a destinação designada na Resolução n. ${ }^{\circ} 307$ (CONAMA, 2002). Este transporte é terceirizado para empresas que devem ser credenciadas, no caso do município de São Paulo, no LIMPURB Departamento de Limpeza Pública, Secretaria de Serviços da Prefeitura de São Paulo. Como afirmado no item anterior, o tipo de veículo a ser utilizado depende do recipiente utilizado para o acondicionamento, mas, geralmente o transporte é realizado em caminhões poliguindastes que carregam caçambas metálicas de 4 ou $5 \mathrm{~m}^{3}$ de capacidade.

Segundo John e Agopyan (2000) pode-se estimar grosseiramente que o negócio de coleta do entulho para cidades maiores que 600 mil habitantes no Brasil, como por exemplo a de São Paulo, pode atingir mais que $\mathrm{R} \$ 400$ milhões por ano.

O transporte de RCD dispõe de legislação própria, a qual deve ser obedecida regularmente. De acordo com o LIMPURB (PMSP, 2006c) existem 41 empresas de transporte de resíduos sólidos cadastradas para atender aos grandes geradores e outras quase 700 empresas cadastradas para o transporte de resíduos inertes.

Comumente o custo de transporte do RCD é um ônus da construtora. No entanto, algumas construtoras relatam terem firmado parcerias com empresas de reciclagem - principalmente cooperativas - próximas aos canteiros de obras, onde os RCD são doados, desde que sejam retirados pelas cooperativas no canteiro de obras. Assim, a construtora economiza o custo de transporte e possibilita uma economia em 'matéria-prima' para a cooperativa de reciclagem. 
O custo de transporte é bastante relevante na determinação da viabilidade econômica dos processos de reaproveitamento, sejam eles reuso ou reciclagem. Este custo é influenciado essencialmente pela distância e pelo volume de RCD.

\subsection{2. Áreas de Destinação dos RCD}

A Resolução n. 307 (CONAMA, 2002) estabelece qual deve ser o destino dado para cada classe de resíduos que ela classifica, conforme apresentado na Tabela 4.3.

Tabela 4.3 - Destinação dos RCD, segundo a Resolução $n .^{\circ} 307$ do CONAMA (2002).

\section{Classe}

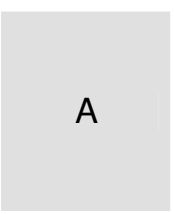

B

C

D

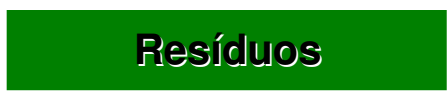

Componentes cerâmicos, argamassas, concretos, solos etc.

Plástico, papel e papelão, metais, vidros, madeiras e outros

Gesso e outros sem tecnologia de recuperação (lixas, manta asfáltica etc.)

Tintas, solventes, óleos e outros resíduos contaminados

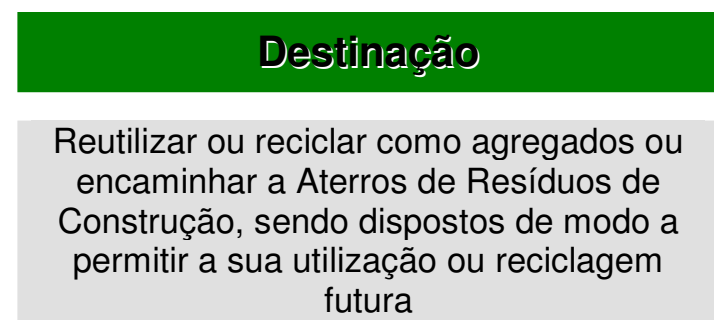

Reutilizar, reciclar ou encaminhar a áreas de armazenamento temporário, sendo dispostos de modo a permitir a sua utilização ou reciclagem futura

\section{Armazenar, transportar e destinar} conforme normas técnicas

Armazenar, transportar, reutilizar e destinar conforme normas técnicas

O sistema de gestão de resíduos compõe-se das atividades de caracterização, transporte, triagem ou segregação, reuso, reciclagem ou reservação e disposição (deposição em aterro). Cada uma destas atividades deve ter seu responsável claramente identificado. Se uma empresa se responsabilizar pela execução de alguma destas atividades individualmente, precisa tê-la devidamente remunerada. 


\section{Áreas de Transbordo e Triagem de Resíduos da Construcão Civil - ATT}

A Resolução n. 307 (CONAMA, 2002) não define, nem faz referência, ao termo ATT - Área de Transbordo e Triagem. Apesar disto, esta é uma opção de destinação para os RCD.

A operação das ATT no município de São Paulo está estabelecida pela legislação do Decreto n. ${ }^{\circ} 42.417$, de 24 de julho de 2002, o qual regulamenta o uso de áreas destinadas ao transbordo e triagem de resíduos de construção civil e resíduos volumosos (PMSP, 2002). O texto na íntegra deste decreto encontrase no Anexo C.

O decreto n. ${ }^{\circ} 42.217$ (PMSP, 2002) explicita em seu item IV do artigo 2 que as ATT são "estabelecimentos privados destinados ao recebimento de resíduos da construção civil e resíduos volumosos gerados e coletados por agentes privados, e que deverão ser usadas para a triagem dos resíduos recebidos, eventual transformação e posterior remoção para adequada disposição”. Já a NBR 15112 (ABNT, 2004), publicada dois anos depois do decreto, não faz referência aos agentes privados e restringe-se a definir a ATT como "áreas destinadas ao recebimento de resíduos da construção civil e resíduos volumosos, para triagem, armazenamento temporário dos materiais segregados, eventual transformação e posterior remoção para destinação adequada, sem causar danos à saúde pública e ao meio ambiente”.

As primeiras licenças provisórias de funcionamento de ATT no município de São Paulo foram aprovadas em novembro de 2005. As ATT, localizadas nos bairros de Belém, Guaianases, Jardim Aricanduva, Jardim Campo Grande e Vila Andrade, obtiveram suas licenças possíveis somente "após a criação de portaria intersecretarial, publicada em setembro, feita para agilizar a autorização e reduzir o prazo de espera, que chegava a demorar três anos" (PMSP, 2006b).

Na visão da Prefeitura do Município de São Paulo (2006b) "as ATT são destinadas à recepção de grandes volumes que, através de triagem, redução de percursos e reciclagem do resíduo, podem tornar-se um negócio rentável às empresas. Nestas áreas, o material recebido é separado, o resíduo de origem 
mineral (concreto, argamassa, alvenaria e outros) é encaminhado para aterros de inertes, o rejeito é levado para aterros sanitários e o resíduo reaproveitável é comercializado".

A PMSP reconhece que um dos problemas detectados é a falta de área para disposição do entulho, já que hoje a cidade tem poucos locais para receber o resíduo. São sete Ecopontos, um aterro de inertes em Itaquera (que será desativado) e duas ATT particulares (Pari e Jaçanã), além de quatro aterros privados licenciados pela Companhia de Tecnologia de Saneamento Ambiental - CETESB. "Por isso, estamos estimulando as empresas a investirem em áreas de deposição de entulho e na reciclagem dos resíduos, o que gera uma grande economia” (PMSP, 2006b).

A ATT possui como única restrição o recebimento de cargas predominantemente constituídas por resíduos classe D (PINTO, 2005).

Segundo o decreto n. ${ }^{\circ} 42.217$ (PMSP, 2002) as ATT:

- devem ser implantadas e operadas por particulares interessados;

- devem controlar os resíduos recebidos quanto à procedência, quantidade e qualidade, por meio do Controle de Transporte de Resíduos, o qual deverá acompanhar sua respectiva carga; a emissão do Controle de Transporte de Resíduos será de responsabilidade do transportador;

- devem receber apenas resíduos de construção civil e resíduos volumosos;

- não devem permitir o recebimento de cargas de resíduos de construção civil constituídas predominantemente por resíduos da construção civil perigosos e não-inertes (tintas, solventes, óleos, resíduos provenientes de instalações industriais e outros), enquadrados na Classe I da NBR 10004 (ABNT, 2004);

- só podem aceitar descargas e expedições de veículos com a devida cobertura dos resíduos neles acondicionados; 
- $\quad$ podem realizar a transformação dos materiais triados desde que possuam licenciamento específico para essa atividade, a critério do órgão ambiental municipal;

- têm que emitir Controle de Transporte de Resíduos, emitido em 3 (três) vias, a cada carga, sempre que houver a remoção de resíduos da ATT para outros destinos.

De acordo com a LIMPURB, atualmente (levantamento realizado em 15/01/07) existem sete ATT 'em funcionamento', isto é, que possuem licença de funcionamento. A lista com os nomes e respectivos endereços encontra-se no Anexo G.

\section{Aterros de Resíduos da Construcão Civil}

As definições de Aterros de Resíduos da Construção Civil apresentadas na Resolução n. ${ }^{\circ} 307$ (CONAMA, 2002), no Decreto n. ${ }^{\circ} 42.217$ (PMSP, 2002) e na NBR 15113 (ABNT, 2004) são concordantes e muito similares e, segundo esta última, o Aterro de resíduos da construção civil consiste na "área onde são empregadas técnicas de disposição de resíduos da Construção Civil, classe A, conforme classificação da Resolução CONAMA $n .^{\circ} 307$, e resíduos inertes no solo, visando a reservação de materiais segregados, de forma a possibilitar o uso futuro dos materiais elou futura utilização da área, conforme princípios de engenharia para confiná-los ao menor volume possível, sem causar danos à saúde pública e ao meio ambiente” (ABNT, 2004).

Segundo a NBR 15112 (ABNT, 2004), reservação de resíduos é o "processo de disposição segregada de resíduos triados para reutilização ou reciclagem futura".

No Município de São Paulo as principais exigências referentes aos Aterros de Resíduos da Construção Civil constam no Decreto n. ${ }^{\circ} 42.217$ (PMSP, 2002) e compreendem:

- os resíduos da construção civil de origem mineral (concreto, argamassas, produtos cerâmicos e outros), excluídos os produtos à base de gesso e 
amianto, devem ser reutilizados, reciclados na forma de agregados ou encaminhados aos Aterros de Resíduos da Construção Civil, para reservação segregada ou constituição de espaços para futura utilização;

- os demais tipos de resíduos da construção civil devem ser encaminhados à reutilização, reciclagem, armazenagem ou a aterros adequados, obedecidas as normas técnicas específicas;

- os resíduos de construção civil oriundos de eventos de grande porte (demolições, calamidades, escavações e outros) podem ser encaminhados diretamente para Aterros de Resíduos da Construção Civil, visando sua reutilização, reciclagem ou reservação segregada, após consulta ao órgão ambiental responsável.

Tanto as ATT quanto os Aterros de RCC podem ter Áreas de Reciclagem de resíduos Classe $\mathrm{A}$ anexas às suas instalações. Estas áreas compreendem instalações para a realização das etapas de moagem e peneiramento do resíduo classe A e devem ser objeto de licenciamento no órgão ambiental responsável. A Resolução n. 307 (CONAMA, 2002) não define as Áreas de Reciclagem, apenas menciona o termo Áreas de destinação de resíduos, como "áreas destinadas ao beneficiamento ou à disposição final de resíduos" (artigo 2, item X, CONAMA, 2002).

Em novembro de 2005, a PMSP publicou o decreto n. ${ }^{\circ} 46.594$ (PMSP, 2005) (ver anexo F) que regulamenta a coleta, o transporte, o tratamento e a disposição final de resíduos inertes no Município de São Paulo. O decreto determina as obrigações dos geradores, dos autorizatários de coleta e transporte e a fiscalização.

A principal exigência deste decreto, em relação aos geradores, refere-se ao cadastramento dos geradores de RCD. Este cadastramento exige alguns documentos, dentre eles, uma "declaração indicando as características e a quantidade média diária de resíduos inertes produzidos pelo grande gerador" e o "extrato de contrato firmado com empresa autorizatária para a prestação em regime privado dos serviços de coleta, transporte, tratamento e disposição final de seus resíduos inertes, que deverá conter nome do responsável pelo 
contrato, nome da autorizatária, prazo de vigência, quantidade de resíduos, freqüência e horário de coleta, locais coletados e de disposição final” (PMSP, 2006d).

Já os autorizatários, comumente chamados de 'caçambeiros', têm por obrigações principais:

- identificar todos os locais utilizados para tratamento ou disposição final dos resíduos, dentro do Município ou fora dele, os quais deverão ser licenciados pelos órgãos competentes;

- fornecer todos os dados necessários ao controle e à fiscalização de sua atividade pela Autoridade Municipal de Limpeza Urbana - AMLURB ${ }^{15}$, na forma por ela estabelecida;

- fornecer aos geradores usuários dos serviços de coleta em regime privado, em até 15 (quinze) dias após a data da descarga, cópia (segunda via) dos comprovantes de cada coleta e destinação final realizada.

Um dos pontos mais relevantes desta legislação estabelece a coresponsabilidade entre as construtoras e os caçambeiros quanto à destinação final dos resíduos. $\mathrm{O}$ artigo 37 determina:

Art. 37. Os proprietários, possuidores ou titulares de estabelecimentos grandes geradores de resíduos inertes, bem como as empresas ou prestadores de serviços de coleta, transporte, tratamento elou disposição final de resíduos sólidos inertes serão solidariamente responsáveis pelo cumprimento dos dispositivos estatuídos na Lei $n^{\circ} 13.478$, de 2002, com as alterações subseqüentes, a eles aplicáveis, e também por quaisquer danos que vierem a causar a bens públicos e particulares na execução dos serviços de limpeza urbana prestados em regime privado, não cabendo à Autoridade Municipal de Limpeza Urbana - AMLURB qualquer tipo de responsabilidade (DECRETO n. 46.594 - PMSP, 2005).

\footnotetext{
15 A Autoridade Municipal de Limpeza Urbana - AMLURB foi criada por meio da Lei $\mathrm{n}^{\circ}$ 13.478/2002 - Livro V, Título I, Artigo 193. No entanto, o Decreto $n^{\circ} 46.594 / 2005$ determina em seu artigo 42 que "enquanto não instalada a Autoridade Municipal de Limpeza Urbana - AMLURB, atribuições a ela conferida por este decreto serão exercidas pelo Departamento de Limpeza Urbana - LIMPURB, da Secretaria Municipal de Serviços - SES”. Até a elaboração final deste trabalho, em agosto de 2007, a AMLURB não constava no organograma da SES e suas atribuições estavam sendo desenvolvidas pela Secretaria de Limpeza Pública - LIMPURB, no Município de São Paulo.
} 
O decreto n. ${ }^{\circ} 46.594$ (PMSP, 2005), no entanto, peca quando determina os grandes geradores como "aqueles que produzem resíduos sólidos inertes, tais como entulhos, terra e materiais de construção, com massa superior a 50 (cinqüenta) quilogramas diários, de produção contínua e não sujeita a prazo”, um critério de difícil mensuração e baixa precisão.

De acordo com a Santana (2007), em consulta a CETESB, existem 10 aterros de resíduos sólidos inertes licenciados no município de São Paulo. " $O$ município, por meio de contratação, utiliza três aterros particulares para fazer o depósito dos resíduos que recebe diariamente, cerca de 3,8 mil toneladas de entulho. Para 2007, está programada a abertura de um edital de contratação de cinco aterros" (PMSP, 2007).

No edital para a contratação destes cinco aterros de inertes "está previsto que cada aterro mantenha uma máquina recicladora para o reaproveitamento do inerte. Com isto, as subprefeituras poderão utilizar o material sem custos para a Prefeitura. Atualmente, são gastos cerca de $R \$ 3$ milhões mensalmente para recolher, transportar, transbordar e destinar os resíduos inertes" (PMSP, 2007).

\subsubsection{Pequenos Geradores}

Os geradores de pequeno porte representam de 70 a $80 \%$ do volume de geração de RCD (PINTO, 1999). Os estabelecimentos destinados a receber os resíduos dos pequenos geradores, denominados no município de São Paulo de Ecopontos, são apresentados neste capítulo como parte do PIGRCC. Apesar disto, os pequenos geradores não são abordados no estudo da Cadeia de CGA, apresentado no capítulo 5.

Os Ecopontos estão autorizados a receber, além de resíduos da construção civil, resíduos volumosos, como móveis e podas de árvores, e resíduos recicláveis, como papel, metal e plástico. O limite de recebimento, em São Paulo, é de um metro cúbico de resíduos por habitante $\left(1 \mathrm{~m}^{3} / \mathrm{hab}\right)$. É um serviço gratuito, gerenciado pela LIMPURB, que possui sete unidades em operação: 
Bresser, Pinheiros, Imperador, Padre Nogueira Lopes (Pirituba), Santo Amaro, Tatuapé e Cupecê. Está prevista a construção de mais 48 unidades na RMSP (PMSP, 2007).

Apesar de o serviço ser gratuito, em Minas Gerais, a prefeitura adotou uma solução para a inclusão dos transportadores autônomos que trabalham utilizando carroças e até carrinhos de mão, chamados carrinheiros ou ainda, carroceiros. Nesta cidade, estes transportadores ficam no ponto de entrega de pequenos volumes. Quando um pequeno gerador precisa enviar uma carga de resíduo, liga para o ponto de entrega e 'contrata' um carroceiro para retirar o resíduo no local da obra. Assim o carroceiro é remunerado pelo serviço de transporte que realiza, e deposita o resíduo no ponto de entrega, evitando a deposição em bota-foras inadequados.

Sendo assim, a Resolução n. 307 (CONAMA, 2002) permite determinar um modelo de fluxos de RCD após a saída dos mesmos do canteiro de obras, conforme a Figura 4.4.

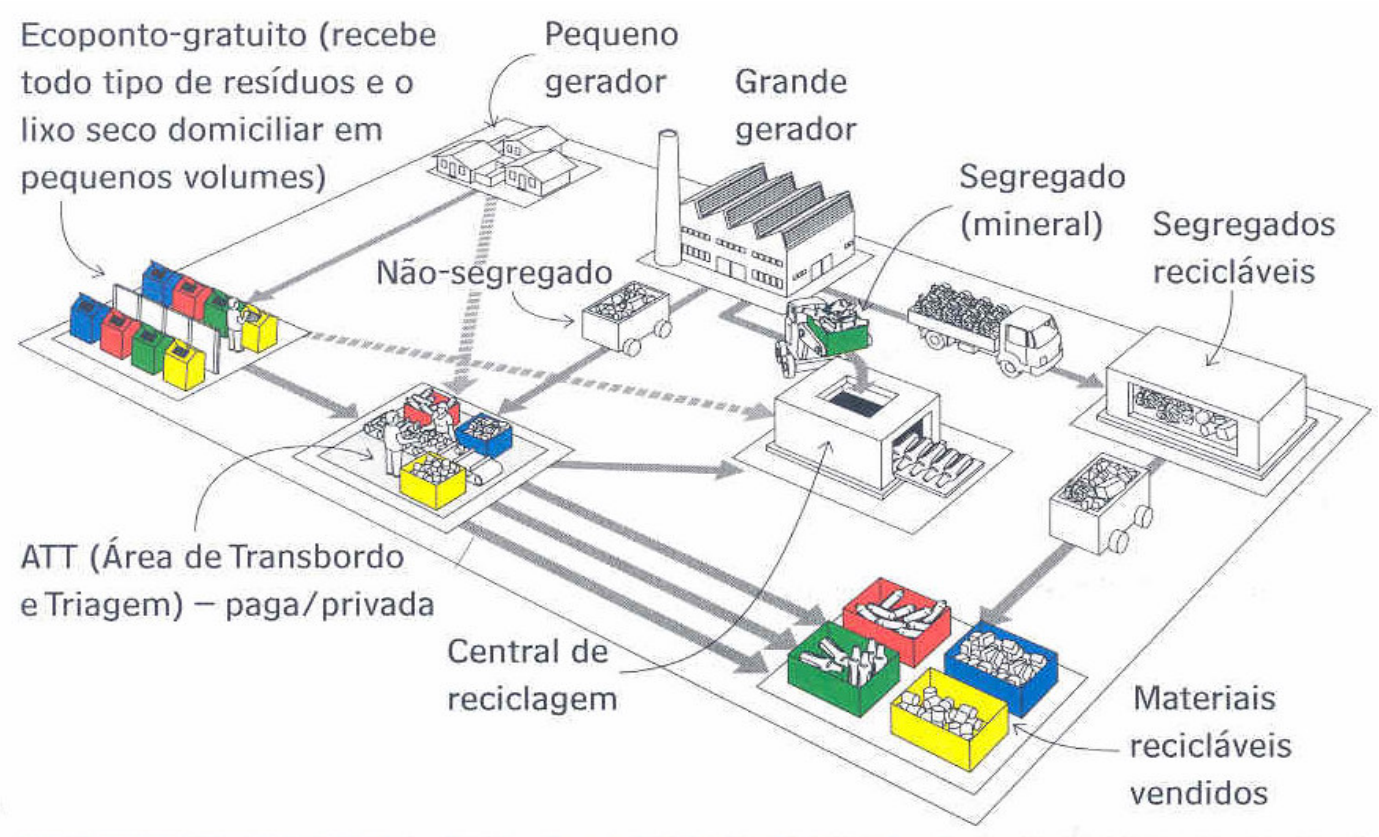

Figura 4.4 - Modelo de fluxos de RCD estabelecido pela Resolução $n .^{\circ} 307$ do CONAMA (SINDUSCON-SP, 2006). 


\subsection{Gestão de Resíduos da Construção Civil em empresas Construtoras Paulistas}

Segundo Marcondes e Cardoso (2005), “a obrigatoriedade imposta às empresas construtoras em atender a Resolução $n^{\circ} 307$ (CONAMA, 2002) estimulou a adoção de sistemas de gestão destes resíduos".

A primeira experiência significativa e documentada em gestão de RCD no município de São Paulo foi denominada Programa Obra Limpa. Preocupado em orientar as empresas construtoras no atendimento à Resolução n. 307 do CONAMA (2002), em vigor desde janeiro de 2003, o Comitê de Meio Ambiente, Segurança e Produtividade - COMASP, do SINDUSCON-SP, instituiu o Programa de Gestão Ambiental de Resíduos de Obra. Em parceria com a empresa Obra Limpa Comércio e Serviços Ltda. e contando com a assessoria técnica da I\&T - Informações e Tecnologia em Construção Civil, o COMASP elaborou uma metodologia e a aplicou em um Grupo Piloto de Construtoras, formado por 11 empresas.

O programa, batizado de "Obra Limpa", tinha por objetivo a implantação de um sistema de gestão de resíduos no canteiro, em obras já em andamento. Não abordava portanto, os PGRCC (Projetos de Gerenciamento de Resíduos de Construção Civil).

Segundo Pinto (2005) e Marcondes e Cardoso (2005), os principais resultados, obtidos na época de implantação do programa (março de 2004) foram, em maior grau:

- redução de custos, principalmente em relação ao transporte de resíduos;

- redução das perdas de material;

- comprometimento dos operários com a limpeza e organização;

- melhor acondicionamento dos resíduos em caçambas estacionárias; e

- melhor aproveitamento de sua capacidade devido à diminuição do “empolamento" dos resíduos.

E em menor grau:

- diferencial de imagem perante o cliente; 
- possibilidade em atender aos requisitos ambientais de programas de certificação, como o Programa Brasileiro de Qualidade e Produtividade no Habitat - PBQP-H e a NBR ISO 14001;

- descontos oferecidos por empresas de transporte, caso o resíduo estivesse segregado, pois tinha-se por objetivo a comercialização dos resíduos.

As principais dificuldades encontradas durante a implantação do sistema de gerenciamento desenvolvido foram (MARCONDES; CARDOSO, 2005):

- baixo comprometimento da direção de algumas obras (mestres, engenheiros, etc.);

- dificuldade na articulação com produtores e aplicadores de insumos para a atividade construtiva, principalmente quando permanecem por um curto prazo na obra;

- presença de empresas de transporte não credenciadas no LIMPURB Departamento de Limpeza Urbana da Prefeitura de São Paulo;

- carência de Áreas de Reciclagem e ATT, em virtude da escassez de áreas disponíveis e a necessidade de licenciamento ambiental municipal e/ou estadual;

- ausência de legislação sobre o mecanismo de fiscalização e sobre a penalidade pelo não cumprimento das exigências da Resolução n. ${ }^{\circ} 307$ do CONAMA (2002).

\subsection{Proposição de modelo de Sistema de Gerenciamento de RESíduOS da CONSTRUÇÃo CIVIL EM EMPRESAS CONSTRUTORAS}

A partir da experiência do Programa Obra Limpa, Marcondes e Cardoso (2006) elaboraram a proposição de um modelo de gerenciamento de resíduos da construção civil para grandes geradores. Segundo estes autores, "a concepção de metodologias/sistemas para a implantação, consolidação e manutenção do gerenciamento de RCD envolve questões complexas. Aborda fatores como a disponibilidade de dados, a atribuição de responsabilidades aos diversos agentes, a 
quantificação e a avaliação de aspectos tangíveis e intangíveis, como retorno econômico e custos sociais”.

A proposição de uma metodologia de gerenciamento de RCD tem por principais objetivos:

- viabilizar o manejo dos resíduos, ou seja, a diferenciação dos mesmos;

- proporcionar espaços adequados à deposição dos resíduos e;

- estimular a adoção da reciclagem como alternativa economicamente atrativa e de preservação dos recursos não-renováveis (PINTO, 1999).

Já sua adoção é motivada pelo atendimento às legislações, à redução dos custos de disposição e a melhoria da imagem corporativa, dentre outros (MARCONDES; CARDOSO, 2005).

Analisando-se a cadeia produtiva da Construção Civil, os autores propõem a abordagem do sistema de gerenciamento de RCD dividida em 3 etapas distintas (Figura 4.5):

1) o desenvolvimento dos fornecedores;

2) o processo produtivo propriamente dito e;

3) o reaproveitamento e destinação.

De acordo com Marcondes e Cardoso (2005) "na etapa de desenvolvimento de fornecedores, que inclui os de projeto, o foco está, primeiramente, na utilização racional dos recursos e na minimização das perdas existentes nos processos de extração de recursos e entrega em obra. Contemplam-se também os aspectos ligados à preferência pela utilização de materiais e componentes obtidos de processos produtivos menos impactantes ao meio ambiente e no desenvolvimento de projetos e especificações que favoreçam a utilização de materiais reciclados e desmontáveis, de forma a viabilizar o processo de reutilização”. 


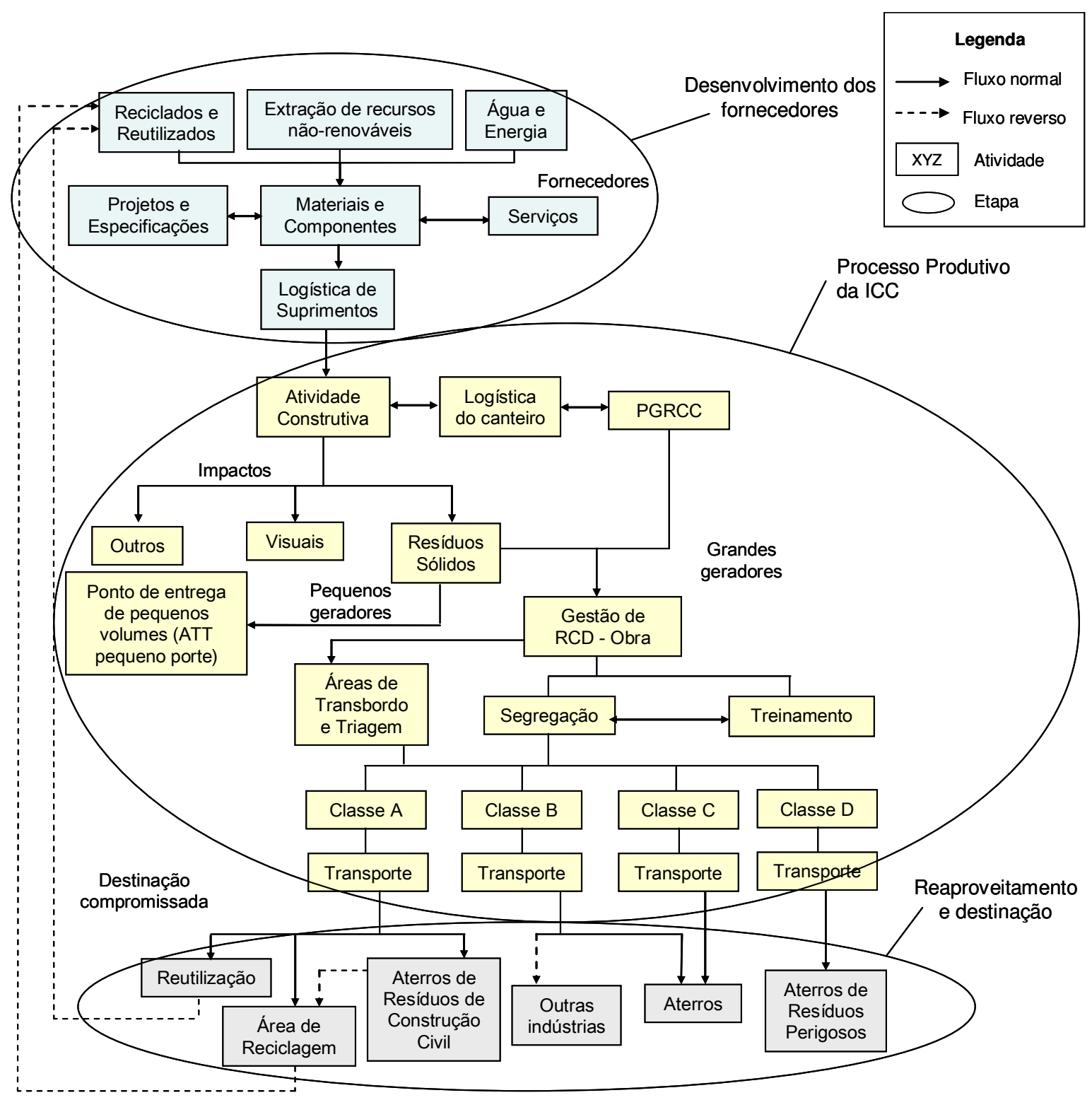

Figura 4.5 - Etapas e atividades do gerenciamento de RCD inserido na cadeia produtiva da ICC (baseado em MARCONDES; CARDOSO, 2005).

Todos os recursos consumidos durante a produção de um empreendimento de Construção Civil, os quais se agrupam aqui genericamente como Projetos, Materiais, Mão-de-obra e Equipamentos, e os agentes a eles associados, influenciam a composição e, principalmente, a quantidade de resíduo gerado (Figura 4.6).

Os projetos exercem esta influência porque incorporadores e projetista determinam as tecnologias que serão utilizadas - sendo que as mais racionalizadas devem produzir menos resíduo -, determinam a construtibilidade, além de serem responsáveis pela especificação de materiais e produtos, os quais terão maior ou 
menor impacto ambiental. Os fabricantes de materiais devem assegurar a produção "limpa" dos mesmos, a qualidade em conformidade com as normas técnicas vigentes e a possibilidade de adequada disposição, indicando a melhor forma de fazê-la.

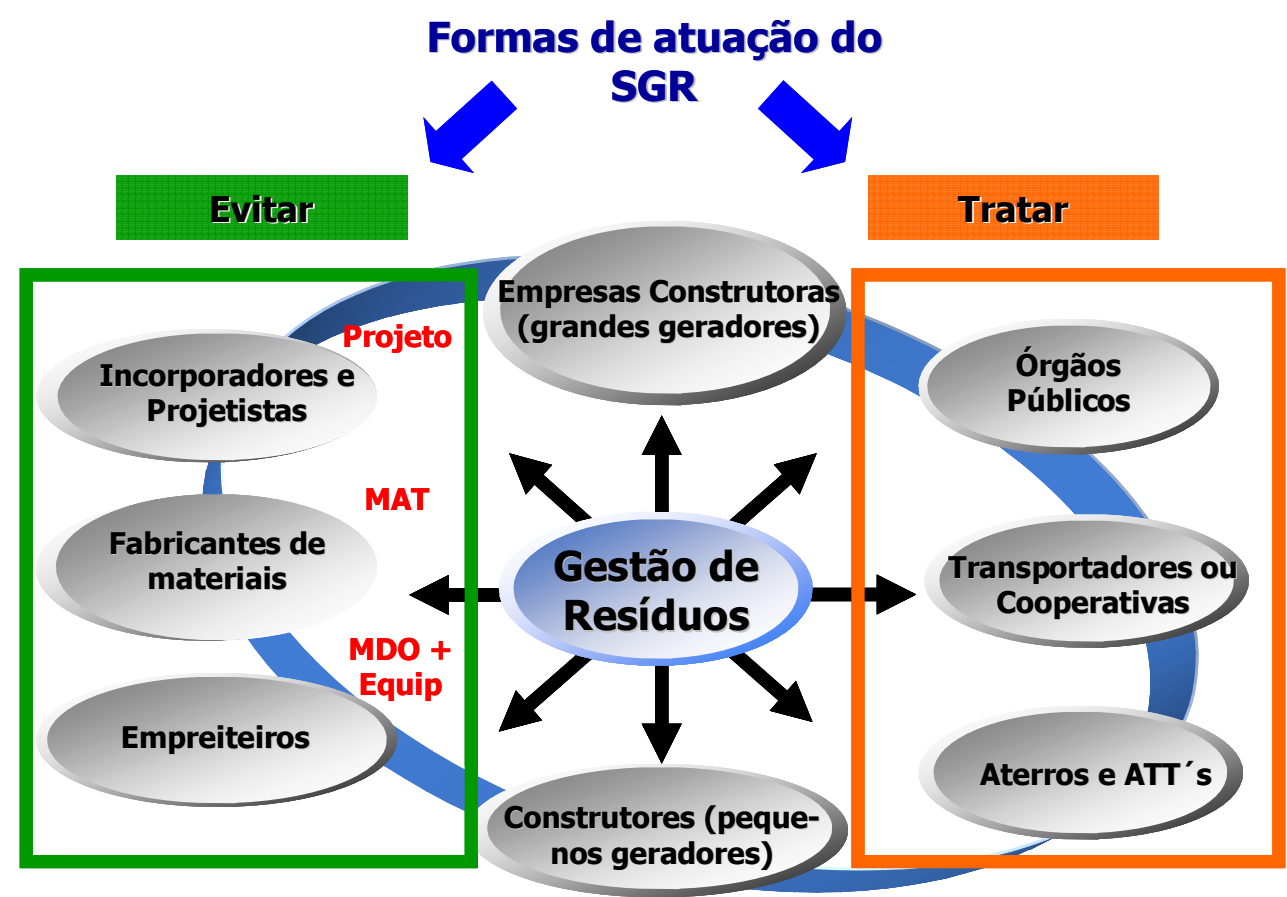

Figura 4.6 - Formas de atuação do Sistema de Gerenciamento de Resíduos para grandes geradores (baseado em OHNUMA; ROZENDO; GONÇALVES, 2005).

Segundo Marcondes e Cardoso (2005), “na etapa denominada de 'processo produtivo', o foco está na gestão das perdas de materiais e na segregação dos resíduos. Todo processo de transformação gera, além de bens e produtos, perdas. São perdas inevitáveis inerentes ao processo, provenientes de um rendimento menor que 1 (um), ou seja, de uma produtividade diferente de 100\%. As perdas de materiais são definidas, segundo Souza et al. (1999) como a 'quantidade de material sobreutilizada em relação às especificações técnicas ou às especificações de projeto, podendo ficar incorporada ao serviço ou transformar-se em resíduo'. Quando as perdas são traduzidas em entulho, elas determinam a maior ou menor quantidade de $R C D$ gerado”. Quando incorporadas, as perdas não contribuem diretamente para a 
geração de RCD. No entanto, são responsáveis pela utilização de recursos naturais em demasia.

A mão-de-obra é o "agente" da perda, aquele que está diretamente ligado ao material/produto. $\mathrm{O}$ treinamento e as competências adquiridas por esta em exercer determinada atividade são determinantes tanto na quantidade de resíduo gerado, quanto na etapa de segregação deste resíduo no canteiro. Assim os empreiteiros e subempreiteiros exercem papel fundamental na prevenção das perdas. Além destes, o uso de equipamentos inadequados ou equipamentos que não tenham recebido a devida manutenção, podem ocasionar perdas significativas.

Após a geração do resíduo em canteiro, os gestores da obra têm duas alternativas para a atividade de segregação. A primeira consiste na atividade de segregação, ou seja, ocorre a identificação, separação e quantificação dos resíduos no canteiro de obras, logo após a sua geração. A segunda alternativa para os gestores é enviar os RCD todos misturados para uma Área de Transbordo e Triagem e delegar a esta área, mediante pagamento, a responsabilidade pela triagem (separação após transporte dos RCD misturados) dos resíduos. Simultaneamente, ou logo após, a atividade de segregação, ocorre a de acondicionamento adequado (MARCONDES; CARDOSO, 2005).

Marcondes e Cardoso (2005) afirmam que "na etapa de reaproveitamento $e$ destinação, ocorre a determinação dos locais adequados para a deposição dos RCD. De acordo com a classe à que pertence, os RCD são destinados à: (1) reutilização, quando não necessitam de beneficiamento para retornar à atividade construtiva; (2) reciclagem, quando necessitam de beneficiamento para serem reaproveitados tanto na atividade construtiva quanto na atividade de outras indústrias que não da ICC; (3) aterros de resíduos. Os resíduos Classe A podem ser reutilizados, ou enviado a áreas de reciclagem para a produção de agregados reciclados, ou, ainda, ser enviados para os aterros e resíduos da construção civil. Os resíduos Classe B podem ser reciclados em outras indústrias ou depositados, já triados, em aterros, onde permanecem aguardando futura reciclagem. Os resíduos Classe C podem ser depositados em aterros onde permanecem segregados aguardando o desenvolvimento de tecnologias que viabilizem técnico e economicamente a sua 
reciclagem. Os resíduos perigosos, de Classe D, são depositados aguardando uma solução específica. Recomenda-se a sua deposição em aterros de resíduos perigosos".

\subsection{Considerações EM Relação À Resolução $\quad$ N. $^{\circ} 307$ Do CONAMA}

A resolução considera que os geradores são os responsáveis pelos RCD e, portanto, pelo adequado manejo e destinação de seus resíduos, instaurando assim o princípio do poluidor-pagador.

No entanto, este é um dos pontos da resolução que pode gerar discussões a cerca de sua interpretação. Inicialmente porque outros agentes participam do processo e possuem atividades e responsabilidades bem delineadas no gerenciamento dos RCD. Segundo, porque o termo "gerador" pode subentender diferentes agentes, como construtoras, incorporadoras, empreendedores e financiadoras, entre outros. Apesar disto, no mercado entende-se que as construtoras sejam consideradas como os geradores por estarem diretamente ligadas ao processo de construção.

Em relação à classificação dos resíduos, faz-se necessário um estudo sobre a equivalência de classificações entre a Resolução n. 307 (CONAMA, 2002) e a NBR 10004 (ABNT, 2004). Ambas usam termos parecidos, como 'resíduos perigosos' mas, por vezes, um resíduo específico da construção civil pode ser classificado em diferentes categorias, de acordo com estas normas.

Outro ponto a ser desenvolvido é sobre qual o máximo teor de contaminante, no caso, por exemplo, de uma fração mineral com teor gesso, que um resíduo pode conter para ser considerado 'limpo', e como medir este teor.

Além da classificação, outra questão a ser esclarecida refere-se às ATT. Segundo a definição da NBR 15112 (ABNT, 2004), a ATT pode receber todos os RCD. Já o Decreto n. ${ }^{\circ} 42.217$ (PMSP/2002) afirma que a ATT “não pode receber cargas de resíduos da construção civil perigosos e não-inertes, enquadrados na Classe I da NBR 10004”. As perguntas que se seguem são: resíduos não-inertes e industriais equivalem às classes C e D (CONAMA, 2002)? Em caso positivo, por que algumas 
ATT recebem resíduos destas classes, como por exemplo, resíduos de gesso e latas de tinta? E se as ATT não receberem estes resíduos, aonde se irá triar, acumular e depositar este material?

Os Aterros de Resíduos de Sólidos da Construção Civil e as Áreas de Reciclagem, segundo as normas técnicas brasileiras - NBR 15113 e 15114 (ABNT, 2004), estão aptos a receberem apenas os resíduos Classe A. Assim, existe uma ausência de área específica para disposição de cada classe de resíduos. Além disso, a Resolução n. ${ }^{\circ}$ 307 (CONAMA, 2002) referencia normas específicas para a destinação dos resíduos classe $\mathrm{C}$ e $\mathrm{D}$, mas estas normas ainda não existem.

A regulamentação e a fiscalização devem ser estabelecidas por cada município em seu Plano de Integrado de Gerenciamento de Resíduos da Construção Civil, sob pena das exigências desta resolução não se consolidarem na prática.

\subsection{CONSIDERAÇões EM RELAÇÃo aO SiSTEMA de GERENCIAMENTO DE REŚ́DUOS Da CONSTRUÇÃo CIVIL EM EMPRESAS CONSTRUTORAS}

O Programa Obra Limpa foi de extrema importância para o início da discussão e implantação dos sistemas de gerenciamento de resíduos para grandes geradores. Contudo, como previa a implantação do sistema em empreendimentos já em fase de execução, não abordava o PGRCC e, portanto, induzia a uma ação reativa em relação ao desenvolvimento dos projetos, à escolha dos materiais e tecnologias de produção, entre outros, ou seja, à etapa de planejamento da produção.

Pinto (2005) aponta como principais aspectos a serem mais bem desenvolvidos pelo programa, os seguintes: divulgação do programa e das ações do setor; envolvimento da alta administração e fornecedores; educação ambiental; indicadores; projetos e especificações.

Destaca-se que o programa tem procurado envolver os fabricantes dos materiais que ainda não dispõem de procedimentos de reciclagem ou reutilização viáveis economicamente, como tinta e gesso, em estudos buscando soluções alternativas de disposição. 
Destaca-se também a questão da informação. Atualmente, a população, incluídos nela pessoas físicas e jurídicas, não tem recebido informação acerca do sistema de gestão de resíduos do município de São Paulo, por exemplo. Principalmente a parcela formada pelas pessoas físicas não tem conhecimento sobre o que é o Ecoponto, como ela funciona, quais são os serviços oferecidos, qual é o custo, entre outros. Igual situação acontece em relação às ATT.

Em relação ao modelo proposto por Marcondes e Cardoso (2005), as principais causas de perdas apresentadas "ressaltam a importância da formulação de um planejamento e da elaboração do sistema de gerenciamento de RCD em conjunto com a liderança da obra. No caso de obras já em andamento, deve-se ainda adequar o canteiro aos procedimentos operacionais do novo sistema de gerenciamento de RCD. Por sua vez, aspectos como as condicionantes da logística do canteiro e treinamento adequado a todos os envolvidos são determinantes para obter sucesso na atividade de segregação”.

"A escassez de reservas de recursos não-renováveis revela a necessidade em se evitar as perdas incorporadas. A redução das perdas incorporadas deve constituirse em motivação para que os projetos e mecanismos de controle de execução de obras sejam cada vez mais precisos e capazes de prever falhas. O objetivo prioritário dos sistemas a serem elaborados deve ser a não geração de resíduos e, secundariamente, a redução, a reutilização, a reciclagem e a destinação final adequados dos resíduos inevitavelmente gerados” (MARCONDES, CARDOSO, 2005).

Marcondes e Cardoso (2005) afirmam que dentre as opções de triagem, a ATT é uma opção cômoda para os grandes geradores, mas que desvirtua o objetivo principal do sistema de gerenciamento de RCD. Isto porque a opção pela ATT é extremamente desfavorável para a reciclagem porque favorece a contaminação do RCD no canteiro. A contaminação, por sua vez, pode inviabilizar muitas aplicações, principalmente a dos agregados reciclados para fins estruturais.

A segregação no canteiro demonstra ser uma alternativa de triagem mais eficaz, pois evita a contaminação dos RCD e proporciona outros benefícios, como a maior organização e limpeza no canteiro de obra. Além disso, algumas empresas 
construtoras que já adotaram um sistema de gestão de resíduos destacam que a análise de custo $\mathrm{X}$ benefício tem demonstrado que a adoção da triagem no canteiro tem menor custo do que a triagem em ATT (MARCONDES; CARDOSO, 2005).

Verifica-se também uma carência de soluções de disposição. Conforme dito anteriormente, os Aterros de Resíduos de Sólidos da Construção Civil e as Áreas de Reciclagem, segundo as normas técnicas brasileiras - NBR 15113 e 15114 (ABNT, 2004), estão aptas a receberem apenas os resíduos Classe A. Assim, a falta de procedimentos e áreas específicos, licenciadas legalmente, para a disposição de resíduos Classe C e D impede a correta destinação destes resíduos e faz todo o processo de gestão no canteiro parecer abstrato, ao questionar qual a razão de separar resíduos no canteiro se não há uma área específica para recebê-lo (MARCONDES; CARDOSO, 2005).

A alternativa seria a disposição destes resíduos classe $\mathrm{C}$ e $\mathrm{D}$ em aterros industriais. No entanto, esta é uma alternativa extremamente onerosa para a construtora. O custo de uma deposição em aterros industriais pode chegar a quatro vezes o custo de uma deposição em aterros de resíduos sólidos urbanos inertes.

Portanto, a participação dos fabricantes dos materiais e componentes que geram resíduos classe $\mathrm{C}$ e D é de vital importância. Estes devem auxiliar na busca e oferecimento de opções de destinação visando o melhor reaproveitamento, ou, em último caso, uma deposição segura e específica. Há ainda que se destacar que para certos resíduos não é possível distinguir os fabricantes, como, por exemplo, os resíduos de gesso de revestimento e de tinta. Nestes casos, a associação de fabricantes deve assumir tal papel.

De acordo com Marcondes e Cardoso (2005), além destes aspectos, a formulação de um modelo de medição próprio ao sistema de gerenciamento de RCD, com indicadores claros, qualitativos e quantitativos, faz-se necessária como forma de avaliar mais precisamente e disseminar claramente os resultados obtidos, e retroalimentar o sistema.

Em relação aos sistemas de gerenciamento de RCD como um todo, a experiência holandesa mostra que o mercado, por ele mesmo, não é capaz de potencializar a adoção destes sistemas (BLUMESCHEIN, 2001). Portanto, acredita-se que somente 
com a atuação dos governos, tanto da municipalidade como do estado, na legislação, regulamentação e determinação das responsabilidades de cada agente envolvido, e proporcionando e estimulando as atividades da cadeia, será possível disseminar e consolidar as iniciativas vigentes. Acredita-se, por outro lado, que para certos produtos a reciclagem já é ou pode se tornar economicamente viável e o mercado vai se encarregar dela, como é o caso do aço (MARCONDES; CARDOSO, 2005).

Do ponto de vista da construtora, o gerenciamento de RCD constitui grande parte do seu sistema logístico reverso. No entanto, o gerenciamento de RCD tem a preocupação voltada para a minimização da geração dos resíduos e sua correta destinação. Já o sistema logístico reverso, vai além, preocupando-se com a reinserção do resíduo no ciclo produtivo.

\subsection{CONSIDERAÇõeS EM RELAÇÃo aO SISTEMA LOGÍSTICO REVERSO de Resíduos da CONSTRuÇão Civil PARa Grandes Geradores.}

Para que o sistema de gerenciamento de resíduos se torne um sistema logístico reverso para grandes geradores (construtoras), ele precisa:

- ser um conjunto de operações organizadas, disciplinadas por acordos, contratos, procedimentos, entre todos os agentes, seja empresas ou órgãos governamentais;

- dispor de recursos humanos capacitados para este fim;

- possuir sistema de informação sobre a composição, quantidade, qualidade, transporte, origens e destinos dos RCD;

- estabelecer formas de revalorização para todas as classes de resíduos, se possível, com viabilidade econômica e ambiental, o que pressupõe a existência de mercado consumidor para os produtos reciclados ou com conteúdo reciclado.

Segundo Marcondes e Cardoso (2005), há duas grandes iniciativas a serem tomadas para desenvolver o sistema logístico reverso para grandes geradores, as quais são interdependentes e isoladamente, provavelmente, não serão eficazes. A primeira é a que se pode chamar de "legislativa", é baseada em "força de lei", em que se acredita 
que a sociedade não está suficientemente apta, no instante atual, a consolidar o sistema logístico reverso e que se trata de assunto emergencial, sobre o qual é necessária uma ação imediata. Por meio desta iniciativa seria possível instaurar formalmente legislações a respeito:

- da co-responsabilidade entre os diversos agentes envolvidos em um empreendimento;

- da responsabilidade de fabricantes sobre o canal reverso (product take-back);

- da proibição da deposição de certos resíduos em aterros;

- de taxação sobre a deposição de certos resíduos em aterros;

- de taxação sobre a compra de determinados produtos que geram resíduos de difícil manejo e destinação e/ou alto impacto ambiental negativo;

- de subsídios para a implantação e operação de centrais de reciclagem;

- de índices mínimos e máximos de conteúdo reciclado em determinados produtos;

- de certificação ambiental de produtos.

No entanto, exige a criação de mecanismos eficientes de fiscalização e o oferecimento de condições para atendimento à legislação.

A segunda iniciativa pode ser chamada de iniciativa "capitalista". Isto porque tem por princípio a crença de que as legislações, por si sós, não conseguem desenvolver as relações necessárias para a consolidação. Para esta opção, há um aspecto extremamente importante: o mercado consumidor de produtos reciclados ou com conteúdo reciclado (MARCONDES; CARDOSO, 2005).

Identifica-se duas formas de criar e desenvolver mercado: (1) incentivar o consumo; e (2) diversificar produtos e aplicações.

O incentivo ao consumo depende de preços competitivos vinculados a ações dirigidas de marketing ambiental. Clientes frequentemente desconfiam da qualidade de produtos reciclados ou com conteúdo reciclado. Segundo John e Agopyan (2000), "esta limitação somente pode ser enfrentada por um política consistente $e$ prolongada de educação ambiental”. O marketing ambiental, pelo uso de selos de certificação ambiental de produtos reciclados, é outra forma de incentivar o consumo destes produtos. 
Um maior consumo pode ser atingido, também, por ações governamentais, tais como a isenção ou diferenciação de taxas e impostos sobre a produção dos materiais e componentes com conteúdo reciclado; e a utilização destes em obras públicas, desde que aplicadas ferramentas de controle de qualidade e de processo que assegurem produtos de qualidade adequada (MARCONDES; CARDOSO, 2005).

Desta forma, incentivando o consumo, haverá maiores chances de se viabilizar negócios, pois haverá volume de demanda, ou seja, escala de produção (MARCONDES; CARDOSO, 2005).

A diversificação de produtos e aplicações dos materiais e componentes com conteúdo reciclado depende, dentre outros fatores, de pesquisa e controle de contaminação. São necessários investimentos, tanto da iniciativa privada quanto da pública, em pesquisa de desenvolvimento tecnológico, isto é, na criação de conhecimento sobre a constituição e o comportamento destes novos produtos reciclados ou com conteúdo reciclado, sobre as possibilidades de seu uso e as técnicas de produção, assim como, sobre a viabilidade técnica e econômica de suas cadeias reversas.

Os itens que seguem mostram como o incentivo ao consumo e a diversificação de aplicações afetam o mercado de cada classe dos RCD.

\section{Mercados para os RCD classe A}

Segundo Angulo et al. (2002) a região metropolitana de São Paulo gera aproximadamente na ordem de $8,5 \times 10^{6}$ t/ano de RCD, dos quais aproximadamente $95 \%$ são fração mineral, potencialmente interessante para a produção de agregados reciclados. De acordo com Zordan (1997) a pavimentação é a forma mais simples de reciclagem da fração mineral do $\mathrm{RCD}$, seja na forma de brita corrida ou ainda em misturas do resíduo com solo, porque é a forma que exige menor utilização de tecnologia, o que implica menor custo do processo e que permite a utilização de todos os componentes minerais do RCD, sem a necessidade de separação de nenhum deles, entre outras vantagens. De acordo com John e Agopyan (2000), no momento a única tecnologia consagrada capaz de consumir os grandes volumes de RCD classe A 
gerados é a pavimentação, que possui praticamente um cliente, as municipalidades.

Angulo et al. (2002) estimam um consumo de pedras britadas para bases de pavimentação na ordem de 4,3 x $10^{6}$ t/ano, na RMSP, montante em tese capaz de consumir cerca da metade do RCD classe A gerado.

Até poucos anos atrás muitos estudos apontavam a necessidade dos órgãos públicos preverem, em seus editais, o uso de agregados reciclados de RCD em obras de pavimentação. Recentemente, em 28/12/2006, “o prefeito de São Paulo assinou o decreto que torna obrigatório o uso de material proveniente da reciclagem de entulho nas obras e serviços de pavimentação de vias públicas na Capital. Os agregados reciclados a serem empregados na pavimentação das vias públicas deverão seguir os critérios estabelecidos pelas diretrizes da Associação Brasileira de Normas Técnicas (ABNT), obedecendo ainda às disposições constantes da Especificação Técnica de Serviços ETS $n^{o}$ 001/2003 - Camadas de reforço do subleito, sub-base e base mista de pavimentação com agregado reciclado de resíduos sólidos na construção civil -, publicada no Diário Oficial da Cidade em março de 2003” (PMSP, 2007).

No entanto, a descontinuidade entre as gestões municipais e a incerteza quanto a pagamentos torna este negócio menos atrativo. Assim, é fundamental o desenvolvimento de mercados alternativos. Com base nas conclusões obtidas por Levy (2002), a utilização de agregados reciclados na produção de componentes de concreto, com uma substituição de $20 \%\left(\mathrm{~m} / \mathrm{m}^{16}\right)$ de agregados, desde que isentos de contaminantes e impurezas, não afeta a durabilidade dos concretos. Esta aplicação poderia consumir um montante um montante de 48,8 x $10^{6}$ t/ano de agregados de RCD reciclados, permitindo, juntamente com o mercado de pavimentação, a reciclagem integral da fração mineral dos RCD. No entanto, o uso dos agregados de RCD reciclados em concretos exige mudanças em procedimentos e em equipamentos nas instalações de reciclagem, na gestão do resíduo, normalização, entre outras (ANGULO et al. ,2002).

\footnotetext{
${ }^{16}$ A relação m/m significa uma relação em massa para massa. Ou seja, da massa total de agregados - 100\% - necessária para fabricar um componente de concreto, $20 \%$, em massa, pode ser substituída por agregado reciclado, sem afetar a durabilidade do componente.
} 
John e Agopyan (2000) afirmam que a introdução de um novo produto no mercado de construção civil é sempre difícil e elencam alguns requisitos para que agregados reciclados ou produtos contendo agregados reciclados sejam aceitos no mercado, dentre eles:

- apresentar vantagens competitivas em relação aos produtos tradicionais, além de preços compatíveis;

- representar um produto confiável perante os clientes, pois existe o temor de que os clientes considerem um produto contendo resíduos como de menor qualidade;

- haver o desenvolvimento de marcas de qualidade ambiental de produto;

- haver a ampla divulgação dos resultados das pesquisas de aplicação de agregados reciclados;

- haver o desenvolvimento de um sistema de controle de qualidade do produto;

- haver estudo de localização das centrais de reciclagem, de forma a minimizar as distâncias de transporte para a captação dos resíduos;

- melhorar o manejo dos RCD quando da sua geração no canteiro de obra, de forma que eles cheguem nas centrais de reciclagem classificados;

- $\quad$ estabelecer uma normalização adequada, de forma a abrir o mercado seja aos agregados, seja aos produtos com eles confeccionados.

Embora estes requisitos tenham sido analisados para os RCD classe A, muitos deles são válidos também para as demais classes de RCD.

\section{Mercados para os RCD classe B}

Os resíduos classe B possuem, em geral, canais reversos já consolidados, mesmo que com alguma informalidade. São, segundo Leite (2003), canais reversos que se desenvolveram, sobretudo, unicamente pela percepção do valor comercial contido em um resíduo, o qual ainda tem por qualidade ter uma fácil utilização, aplicação e reprocessamento, como por exemplo, a cadeia do aço, na qual a economia reversa representa uma fração de cerca de 30 a $40 \%$ da cadeia produtiva direta. 
Os principais agentes da destinação destes resíduos são as cooperativas e empresas de reciclagem. As empresas, em geral, especializam-se em um determinado resíduo, como, por exemplo, as que coletam aparas de papel, conhecidas por 'aparistas'. Já as cooperativas geralmente reciclam mais de um tipo de resíduo. Por vezes estas empresas realizam apenas a triagem, limpeza, classificação e consolidação (em grandes volumes) do resíduo, agregando valor para a compra de uma outra empresa que realizará a reciclagem.

A facilidade em destinar estes resíduos deve-se ao fato dele advir de muitas atividades industriais, não somente da ICC. Assim, embora a ICC gere pouca quantidade desta classe de resíduo, este montante soma-se aos provenientes de outras indústrias e resulta em uma escala suficiente para a operação das empresas de reciclagem.

Porém, a pequena quantia de resíduo classe B gerado na obra pode trazer certa dificuldade, porque para obter melhor eficiência, a coleta destes resíduos deve ser feita quando se juntar uma quantia mínima de resíduos e isto implica em os resíduos classe B ficarem muitos dias armazenados no canteiro.

Exceto por isto, as empresas construtoras não têm tido dificuldades em destinar os resíduos classe B. Por vezes, as empresas de reciclagem os retiram gratuitamente no local da obra. Quando não, as construtoras pagam apenas o transporte até a empresa de reciclagem, não havendo compra nem venda de resíduos.

\section{Mercado para os resíduos classe $C$}

Segundo a Resolução n. 307 do CONAMA (2002), os resíduos classe C não possuem tecnologia de reciclagem economicamente viável e, portanto, não haveria mercado a ser desenvolvido para consumir tais resíduos. No entanto, para uma parcela destes resíduos, os resíduos de chapas de gesso acartonado CGA, o capítulo seguinte irá demonstrar as possibilidades de aproveitamento destes resíduos e suas respectivas viabilidades econômicas. 
Destaca-se ainda que para estabelecer uma cadeia de suprimentos reversa, todas as empresas participantes da cadeia - fornecedores, fabricantes, consumidores, distribuidores, transportadores, recicladores, etc. - precisam ter seus sistemas logísticos reversos e:

- estar alinhados estrategicamente;

- ter interesses não conflitantes;

- remunerar adequadamente suas atividades;

- desenvolver novas aplicações/mercado consumidores. 


\section{5 - Resultados}

A obtenção dos resultados ocorreu de acordo com a metodologia apresentada no item 1.4. Neste capítulo primeiramente apresenta- se os resultados do estudo exploratório, que endossaram a continuidade da pesquisa quando do seu início e forneceram importantes conceitos e referências bibliográficas para o embasamento teórico da dissertação.

A partir do item 5.2 são apresentados os resultados da aplicação do conceito de logística reversa à cadeia de CGA. São caracterizadas as cadeias diretas e os fluxos reversos, assim como a prática existente de gerenciamento de resíduos de CGA em canteiro de obras.

Considerando-se que o processo de reciclagem o mais adequado para o reaproveitamento dos resíduos de CGA, analisa-se as possíveis aplicações dos produtos provenientes dos resíduos de CGA. Para cada possível aplicação são demonstrados o tamanho dos mercados, suas vantagens e restrições.

A análise desta informações permite concluir quais fatores interferem na consolidação dos sistemas logísticos reversos para resíduos de CGA - SLR-CGA e sobre seus mecanismos de ocorrência e atuação. 


\subsection{RESUlTADOS DO ESTUDO EXPLORATóRIO}

As entrevistas com os especialistas indicaram grandes áreas de desenvolvimento da logística reversa. Atualmente os estudos estam mais desenvolvidos na Europa, principalmente na Holanda, nos Países Baixos e na Alemanha. As pesquisas já concluídas referem-se, na sua maioria, a indústria automobilística, de embalagens, gráfica e de vestuário.

Dentre as tendências apontadas pelos especialistas está o desenvolvimento de modelos matemáticos e de cadeias de suprimentos em ciclo fechado (Closed Loops).

A proposta de aplicação do conceito de logística reversa na ICC foi vista pelos especialistas como inovadora e complexa. Apesar disto, todos os consultados incentivaram a pesquisa e demonstraram haver possibilidades de sucesso em sua aplicação.

Além das reflexões, os especialistas também contribuíram com a indicação das principais bibliografias do tema. Sendo assim, prosseguiu-se com a pesquisa nesta área, iniciando-se em seguida a pesquisa bibliográfica 2 .

\subsection{Resultados do Trabalho de Campo: Aplicação do conceito de logística Reversa à Cadeia Produtiva de Chapas DE GESSO ACARTONADO}

Conforme explicitado no item 1.4, a aplicação do conceito de logística reversa foi realizada na cadeia de chapas de gesso acartonado.

Foram realizadas duas reuniões iniciais com os representantes da Associação Drywall. A primeira apresentou-se o projeto. Na segunda, teve-se acesso aos dados iniciais, relativos principalmente à distribuição do consumo no mercado. Foi possível ter acesso somente a dados consolidados das três empresas fabricantes conjuntamente, uma vez que tornar público os dados individuais poderia caracterizar relações comerciais ilegais, como formação de cartel, entre outros inconvenientes.

Procedeu-se então as entrevistas com os fabricantes. As empresas não autorizaram a autora a identificar suas posições individuais obtidas nas entrevistas. 
No entanto, diferentemente do previsto no início da pesquisa, a partir de março de 2006, a Associação Drywall não mais apoiou a presente pesquisa, o que resultou num baixo comprometimento dos distribuidores e instaladores quanto ao retorno dos questionários respondidos. A baixa taxa de retorno do questionário (entre julho e setembro de 2006) pode ser explicada também pelo fato de não ter havido contato pessoal com os mesmos. Devido à baixa taxa de retorno obtida, optou-se por não utilizar as informações dos respondentes, uma vez que estas não possuíam representatividade da amostra. Além deste fator, identificou-se que as informações obtidas destes poucos distribuidores e instaladores eram coerentes, com aquelas obtidas dos fabricantes, construtoras e áreas de triagem e transbordo investigados.

Portanto, o desenho dos fluxos da cadeia de CGA e o estabelecimento das interações entre os agentes que dela participam foram realizados com base nas entrevistas com os demais agentes.

A partir das entrevistas aos fabricantes (perfil comercial) - realizadas em maio e junho de 2006 - foi possível identificar e quantificar os fornecedores de matériasprimas para a produção de CGA, onde estão localizados, as formas de fornecimento e as relações comerciais.

Aplicou-se o questionário de perfil estratégico ao diretor de uma das fábricas, a qual foi escolhida em função de ser a única a apresentar infra-estrutura física de reciclagem (agosto de 2006). Assim, a partir das respostas a este questionário buscou-se identificar a importância de um possível sistema logístico reverso, para o nível de decisões estratégico da empresa.

Em função dos processos de produção de CGA serem semelhantes nos três fabricantes, aplicou-se a somente um deles o questionário de perfil industrial. Nesta entrevista buscou-se coletar informações a cerca do processo de produção, mais especificamente dos requisitos técnicos das matérias-primas e os entraves à utilização de material reciclado (agosto de 2006).

Realizaram-se então as entrevistas com os três tipos de clientes da fábrica de CGA: construtoras, distribuidores e instaladores. Verificou-se o relacionamento entre a fábrica e seus clientes, as diferenças na forma de fornecimento, como as atividades de consumo no canteiro de obras influenciavam a maior ou menor geração de 
resíduos de CGA e como era realizado o manejo destes resíduos dentro do canteiro de obras. Foram inquiridos ainda sobre a disposição da empresa em modificar o manejo ou ser incluído no sistema logístico reverso (do fabricante). As entrevistas com os representantes das quatro construtoras ocorreram em agosto e setembro de 2006.

Para caracterizar o fluxo reverso e seu destino, entrevistou-se representante de uma ATT (julho de 2006), a única até então a receber resíduos à base de gesso.

As consultas à associação de classe ABCP - Associação Brasileira de Cimento Portland (outubro de 2006) e a uma indústria de cimento (outubro de 2006 à fevereiro de 2007) fizeram-se necessárias em virtude das incoerências identificadas entre as informações obtidas na ATT e nas construtoras, relativas à destinação dos resíduos de CGA. Como forma de complementar os possíveis destinos dos resíduos de CGA, realizou-se visita e entrevista também a fábrica de papel 'P' (setembro de 2006).

\subsubsection{Cadeia Direta de CGA}

\subsubsection{Fluxos de matérias-primas}

As matérias-primas necessárias à fabricação das CGA constituem-se do minério de gipsita ${ }^{17}$, do papel cartão, água e aditivos.

Segundo os fabricantes, todo o papel cartão utilizado é importado. Apesar da indústria de papel e celulose brasileira deter tecnologia adequada para produção deste papel cartão, de características bem específicas, sua produção não é viável economicamente devido ao baixo volume de consumo das fábricas de CGA, que incorre em custos de setup muito altos, e consequentemente, baixa competitividade frente ao preço de importação. Além disso, as três empresas pertencem a grupos multinacionais, os quais possuem fábricas deste papel cartão em outros

\footnotetext{
${ }^{17}$ Segundo Linhales (2003 apud CANUT, 2006), os termos "gipsita”, "gipso" $e$ "gesso" são freqüentemente usados como sinônimos. Todavia, a denominação gipsita é reconhecidamente a mais adequada ao mineral em estado natural, enquanto gesso é o termo mais apropriado para designar o produto calcinado.
} 
países. Portanto, o papel cartão utilizado é todo importado, sendo necessários estoques de 60 dias de produção.

De acordo com Marvin (2000), a CGA é formada em 92\% por gesso (sulfato de cálcio dihidratado), $7 \%$ em papel cartão e $1 \%$ de aditivos e impurezas. Em relação aos aditivos, eles são parcela muito pequena na composição da chapa, aproximadamente $2 \%$ em massa. Além disso, estes produtos fazem parte do segredo industrial de cada fabricante, e, portanto, não foi permitida a sua identificação na pesquisa.

No Brasil, os fabricantes de CGA utilizam apenas a gipsita como matéria-prima para a obtenção de gesso (sulfato de cálcio hemihidratado), também chamado de gesso de calcinação de gipsita. No entanto, em outros países, podem ser utilizados o fosfogesso - também chamado de gesso químico, que é um resíduo proveniente principalmente das indústrias de fertilizantes, e os chamados gessos sintéticos, grupo que inclui o dessulfogesso oriundo do processo de dessulfurização de gases de combustão em termelétricas à carvão, o borogesso, o qual possui anidrido bórico $\left(\mathrm{B}_{2} \mathrm{O}_{3}\right)$ em sua composição, além do fluorgesso e do titanogesso (CANUT, 2006). De todos os gessos sintéticos, o fosfogesso é o que apresenta maior produção mundial.

Segundo um dos fabricantes entrevistados, "o fosfogesso possui uma oscilação muito grande no tempo de pega. Devido a isto, não é possível garantir a aderência do cartão à massa de gesso, sendo este o ponto crítico da produção de CGA", sendo esta a razão pela qual ele não é utilizado para este fim no Brasil.

A gipsita é um minério abundante no Brasil, com alto grau de pureza. Dados de 2004 do DNPM - Departamento Nacional de Produção Mineral (LYRA SOBRINHO; AMARAL; DANTAS, 2005), apontam a reserva de gipsita em $1.228 .929 \times 10^{3}$ t. Sua produção, em 2004, foi de $1.472 \times 10^{3}$ t. O estado de Pernambuco destaca-se por deter $89 \%$ da produção nacional de gipsita, ou seja, 1.310,08 x 10 ${ }^{3}$ t. Neste estado, na região da Serra de Araripina situam-se as principais minas em exploração 
- o chamado Pólo Gesseiro de Araripina. Segundo Baltar et al. (2004 apud CAVALCANTI, 2006), o minério de gipsita do Pólo Gesseiro de Araripina é considerado o de melhor qualidade no mundo, apresentando um teor de pureza que varia de $88 \%$ a $98 \%$.

O processo pelo qual a gipsita se transforma em gesso é chamado de calcinação. Segundo Canut (2006), a calcinação é o processo de aquecimento térmico pelo qual a gipsita é desidratada. Este processo ocorre de acordo com as equações:

$\underbrace{\mathrm{CaSO}_{4} \cdot 2 \mathrm{H}_{2} \mathrm{O}}_{\text {gipsita }} \longrightarrow 140^{\circ} \mathrm{C}-160^{\circ} \mathrm{C} \longrightarrow \underbrace{\mathrm{CaSO}_{4} \cdot 0,5 \mathrm{H}_{2} \mathrm{O}+}_{\text {bassanita }} 1,5 \mathrm{H}_{2} \mathrm{O}$ Eq. 1

$\underbrace{\mathrm{CaSO}_{4} \cdot 2 \mathrm{H}_{2} \mathrm{O}}_{\text {gipsita }} \longrightarrow 160^{\circ} \mathrm{C}-250^{\circ} \mathrm{C} \longrightarrow \underbrace{\mathrm{CaSO}_{4} \cdot \varepsilon \mathrm{H}_{2} \mathrm{O}}_{\text {anidrita III }}+2 \mathrm{H}_{2} \mathrm{O} \quad$ Eq. 2

$\underbrace{\mathrm{CaSO}_{4} \cdot 2 \mathrm{H}_{2} \mathrm{O}}_{\text {gipsita }} \longrightarrow 250^{\circ} \mathrm{C}-800^{\circ} \mathrm{C} \longrightarrow \underbrace{\mathrm{CaSO}_{4}}_{\text {anidrita II }}+2 \mathrm{H}_{2} \mathrm{O} \quad$ Eq. 3

$\underbrace{\mathrm{CaSO}_{4} \cdot 2 \mathrm{H}_{2} \mathrm{O}}_{\text {gipsita }} \rightarrow>800^{\circ} \mathrm{C} \longrightarrow \underbrace{\mathrm{CaSO}_{4}}_{\text {anidrita I }}+2 \mathrm{H}_{2} \mathrm{O} \quad$ Eq. 4

A bassanita é o material denominado gesso.

No entanto, nem toda gipsita transforma-se em gesso, pois há aplicações da mesma em seu estado natural. De acordo com o Sumário Mineral 2005 (LYRA SOBRINHO; AMARAL; DANTAS, 2005), além do setor de calcinação, a indústria de cimento e a agroindústria também consomem gipsita, nas proporções indicadas na Figura 5.1. 


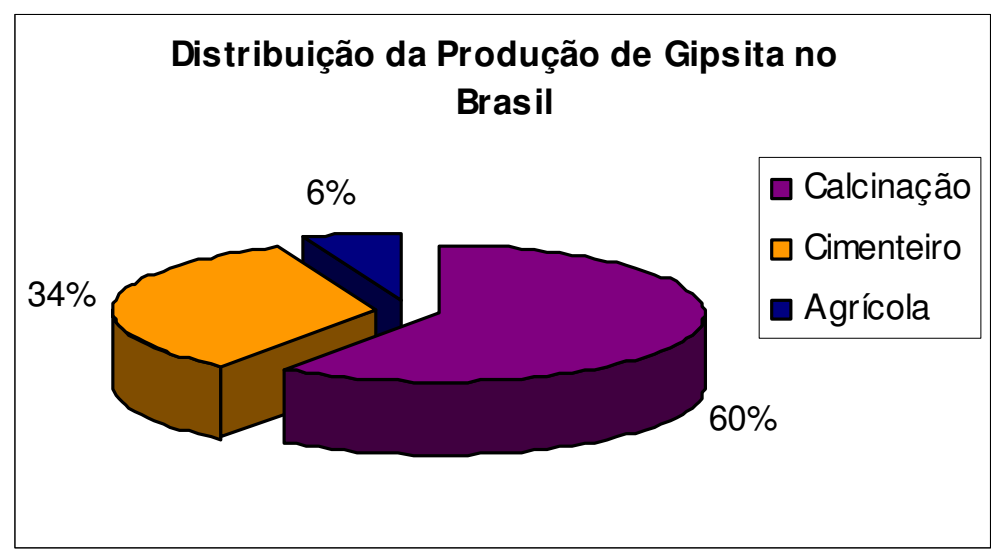

Figura 5.1 - Distribuição da Produção de Gipsita no Brasil (a partir dos dados de LYRA SOBRINHO; AMARAL; DANTAS, 2005).

Assim, 883.000 t de gipsita são destinadas anualmente ao setor de calcinação. O Pólo Gesseiro do Araripe possui 47 minas e 100 calcinadoras que anualmente produzem $531.906 \mathrm{t}$ de gesso, o que corresponde a $84 \%$ da produção nacional de gesso - 640.492 t.

De acordo com os fabricantes, o custo da gipsita é baixo, cerca de $\mathrm{R} \$ 18 / \mathrm{t}$, em função deste minério ser abundante e ser facilmente extraído por meio de técnicas simples de mineração. Segundo os fabricantes, há notícias de condições de trabalho precárias e baixas remunerações dos trabalhadores, tanto na mineração da gipsita quanto na calcinação desta. Durante as entrevistas aos fabricantes, citou-se que o preço baixo da gipsita deve-se às condições precárias de trabalho na extração do minério e à informalidade tributária por parte das empresas mineradoras.

$\mathrm{O}$ preço da gipsita não sofre grandes variações ao longo do ano. $\mathrm{O}$ mesmo não ocorre com o custo de seu transporte até a região Sudeste, onde se situam duas das três fábricas de CGA e onde está o maior mercado de consumo.

O transporte da matéria-prima gipsita, da CGA e dos resíduos de CGA são realizados por meio rodoviário. Os aditivos e o papel cartão importados, depois de entregues nos portos também são transportados 
por meio rodoviário. $\mathrm{O}$ custo de transporte sofre uma sazonalidade durante o ano.

O transporte com origem na região Nordeste e destino para o Sudeste é chamado 'frete de descida'. O que ocorre em sentido contrário, com origem no Sudeste e destino ao Nordeste, é chamado 'frete de subida'.

$\mathrm{O}$ frete de descida geralmente transporta frutas e minérios, dentre outras matérias-primas, para as indústrias localizadas no Sudeste.

Já o frete de subida é comumente de distribuição de produtos manufaturados e ocorre em maior número e volume do que o frete de descida. Assim, muitas vezes, os caminhões que fazem o frete de subida distribuindo produtos industrializados retornam vazios para o Sudeste.

O transporte de gipsita procura então aproveitar este caminhão que retornava vazio para transportar gipsita para as indústrias no Sudeste a um preço mais baixo. $\mathrm{O}$ custo do frete de descida é aproximadamente $50 \%$ do frete de descida.

Ainda assim, devido a gipsita ser um material volumoso, pesado e de baixo valor agregado, o custo de transporte com origem na região de Araripina e entrega na região Sudeste - cerca de $2.300 \mathrm{~km}$ - corresponde de 8 a 12 vezes o custo da matéria-prima.

Atualmente este valor é de aproximadamente $\mathrm{R} \$ 120,00 / \mathrm{t}$. A variação no custo do transporte da gipsita ocorre de acordo com as safras de produtos agrícolas. Quando ocorrem as safras, principalmente as de cebola, frutas (no Vale do São Francisco - PE) e sal (em Natal - RN) no Nordeste e de soja no Centro-Oeste, praticamente não há disponibilidade de frete de descida e o custo de transporte aumenta em até $50 \%$.

\subsubsection{Produção de Chapas de Gesso Acartonado no Brasil}

O processo de produção das chapas de gesso acartonado divide-se em duas grandes etapas. A primeira, denominada calcinação, consiste na transformação do minério de gipsita em gesso, ou seja, do sulfato de 
cálcio dihidratado $\left(\mathrm{CaSO}_{4}+2 \mathrm{H}_{2} \mathrm{O}\right)$ em hemi-hidratado $\left(\mathrm{CaSO}_{4}+1 / 2\right.$ $\mathrm{H}_{2} \mathrm{O}$ ), por meio das etapas de moagem, calcinação e resfriamento controlado (ver Eq. 1).

A segunda etapa, de fabricação da chapa, consiste nas fases de dosagem, endurecimento e secagem. No processo de dosagem o gesso recebe aditivos e água até atingir consistência ideal para ser lançado sob a lâmina de inferior de papel cartão. Em seguida é aplicada a lâmina superior de papel cartão e a chapa passa por um sistema de calandras para garantir a espessura uniforme da chapa. Num processo contínuo, segue na mesa formadora onde acontece o processo de endurecimento. Passa então pela guilhotina para o corte nos comprimentos desejados e segue para o secador. Acontece então a identificação e paletização das chapas.

A Figura 5.2 ilustra simplificadamente o processo de produção das CGA.

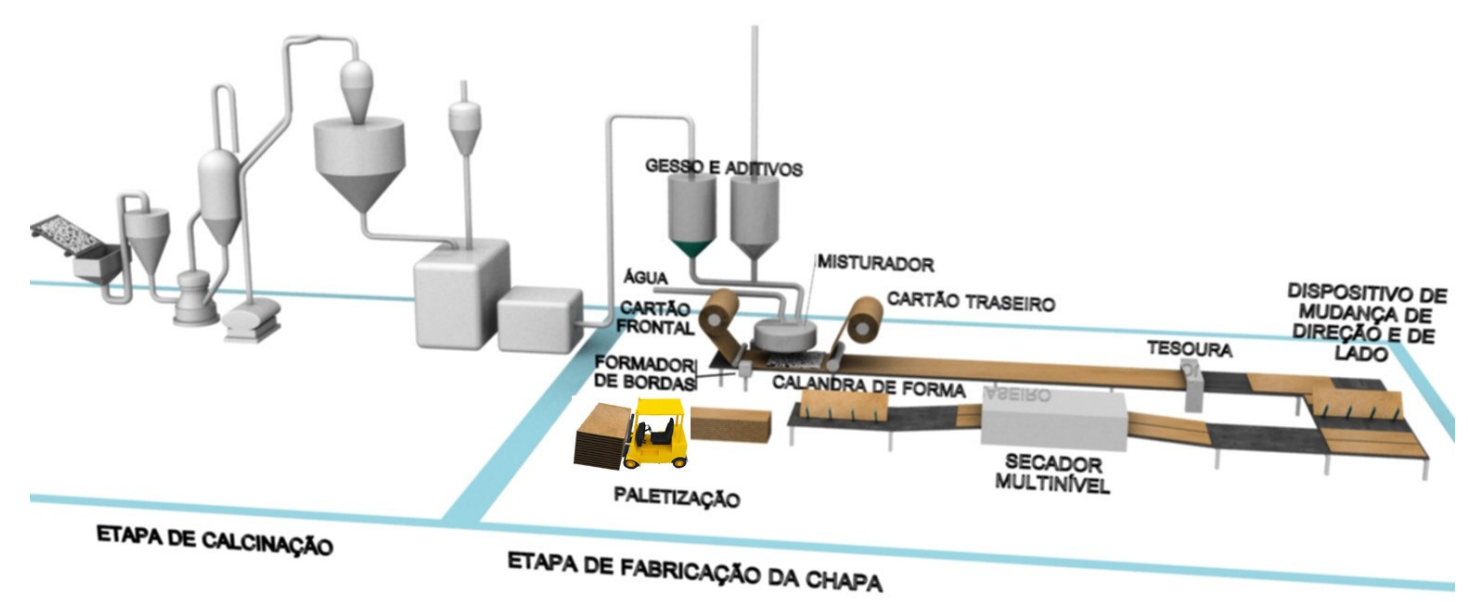

Figura 5.2 - Processo de produção das CGA (autora, 2007).

No processo de produção da CGA, a gipsita que chega ao fabricante possui cerca de $20 \%$ de água livre ${ }^{18}$. Durante a moagem, esta água livre é perdida. Em seguida, ocorre a calcinação, processo em que o sulfato de cálcio dihidratado será transformado em sulfato de cálcio hemi-hidratado.

\footnotetext{
${ }^{18}$ Segundo Metha, Monteiro (1994) a água livre é o volume de água que está livre da influência das forças de atração exercidas pela superfície sólida. Esta água fica contida em vazios grandes, de diâmetro $>50 \mathrm{~nm}(0,05 \mu \mathrm{m})$, e sua remoção não causa graves variações de volume.
} 
Neste processo há a perda de $18 \%$ da água de constituição ${ }^{19}$. Após a calcinação, o pó de gesso é saturado e adicionam-se aditivos, obtendo-se uma pasta de gesso saturada. Esta pasta é lançada sobre o papel cartão na mesa de formação e em seguida, a chapa entra no secador, do qual sai com aproximadamente $16 \%$ de umidade. É então identificada, protegida, embalada e paletizada de acordo com o pedido do cliente.

Há atualmente três empresas multinacionais fabricando Chapas de Gesso Acartonado - CGA no Brasil, a saber: BPB Placo, Lafarge Gypsum e Knauf do Brasil, as quais serão referenciadas daqui em diante como Placo, Lafarge e Knauf, respectivamente.

Juntas, estas empresas produziram 14 milhões de $\mathrm{m}^{2}$ de CGA em 2005. No entanto, a capacidade de produção destas é de aproximadamente 29 milhões de $\mathrm{m}^{2}$, o que revela uma alta ociosidade da produção e, por outro lado, um alto potencial para aumento das vendas.

Durante as entrevistas foram coletadas informações necessárias para quantificar e desenhar os fluxos diretos e reversos, pois estes dados não foram encontrados em bibliografias.

A partir da produção anual de CGA, deduziu-se os consumos de gipsita e papel cartão. Complementaram-se estas informações com as obtidas nas entrevistas a construtoras e a área de transbordo e triagem. Desta forma, deduziu-se por aproximação os valores de perdas em canteiros de obras e o fluxo de resíduos.

Segundo a norma brasileira NBR 14715 (ABNT, 2001) pode haver chapas com espessuras de 9,5, 12,5 ou 15,0 mm. Para efeito dos cálculos realizados, utilizou-se a espessura de CGA mais comum no mercado, ou seja, a de $12,5 \mathrm{~mm}$, a qual possui aproximadamente $8,5 \mathrm{~kg} / \mathrm{m}^{220}$. Desta densidade da CGA, aproximadamente $1 \mathrm{~kg} / \mathrm{m}^{2}$ corresponde ao papel

\footnotetext{
${ }^{19}$ Segundo Metha, Monteiro (1994) a água quimicamente combinada (também conhecida por água de constituição ou água de cristalização) é a água que é parte integrante da estrutura de vários produtos, a qual não é perdida na secagem; é liberada quando os produtos hidratados são decompostos por aquecimento.

${ }^{20}$ Segundo a NBR 14715 (ABNT, 2001), a CGA com 12,0mm de espessura pode ter de 8,0 a $12,0 \pm 0,5 \mathrm{~kg} / \mathrm{m}^{2}$. No entanto, adotou-se a informação dos fabricantes que forneceram densidades entre 8,3 e $8,8 \mathrm{~kg} / \mathrm{m}^{2}$.
} 
cartão. De acordo com as informações dos fabricantes, são necessários cerca de $9 \mathrm{~kg}$ de gipsita para a produção de $1 \mathrm{~m}^{2}$ de CGA.

A partir destas considerações, pode-se concluir que, para a produção nacional de CGA - que em 2005 foi de 14 milhões de $\mathrm{m}^{2}$ - são necessárias 126.000 t de gipsita. Isto significa que dentro dos $60 \%$ de gipsita para calcinação, 14,3\% são destinadas para CGA. Isto é, a indústria de CGA é responsável por 8,6\% do consumo de gipsita no Brasil.

\subsubsection{Mercado de Chapas de Gesso Acartonado no Brasil}

A produção brasileira de chapas de gesso acartonado foi de aproximadamente 14 milhões de metros quadrados $\left(\mathrm{m}^{2}\right)$ em 2005, montante $8 \%$ superior ao ano anterior. De acordo com os dados levantados nas entrevistas aos fabricantes, menos de $1 \%$ da produção de CGA é exportada, ou seja, praticamente toda a produção nacional é consumida pelo mercado interno.

Os fabricantes estimam um crescimento médio de $12 \%$ ao ano para os próximos 3 anos. Não há previsões em longo prazo. Mas, mesmo crescendo $12 \%$ a.a., o consumo de CGA no Brasil ainda é pequeno se comparado com o consumo internacional. Segundo um dos fabricantes, um crescimento razoável em países em desenvolvimento como o Brasil seria da ordem de 30 ou $40 \%$ a.a.

De acordo com Olson (2001), uma residência americana nova consome, em média, $571 \mathrm{~m}^{2}$ de CGA. As estatísticas de consumo da Associação Drywall (2006) encontram-se na Figura 5.3.

O maior consumo de CGA foi observado no Estado de São Paulo, seguido pelos demais estados da região Sudeste e pela região Sul. A região Sudeste também foi responsável pelo maior crescimento no consumo de chapas em 2005, que alcançou 12,5\% (ASSOCIAÇÃO DRYWALL, 2006). 


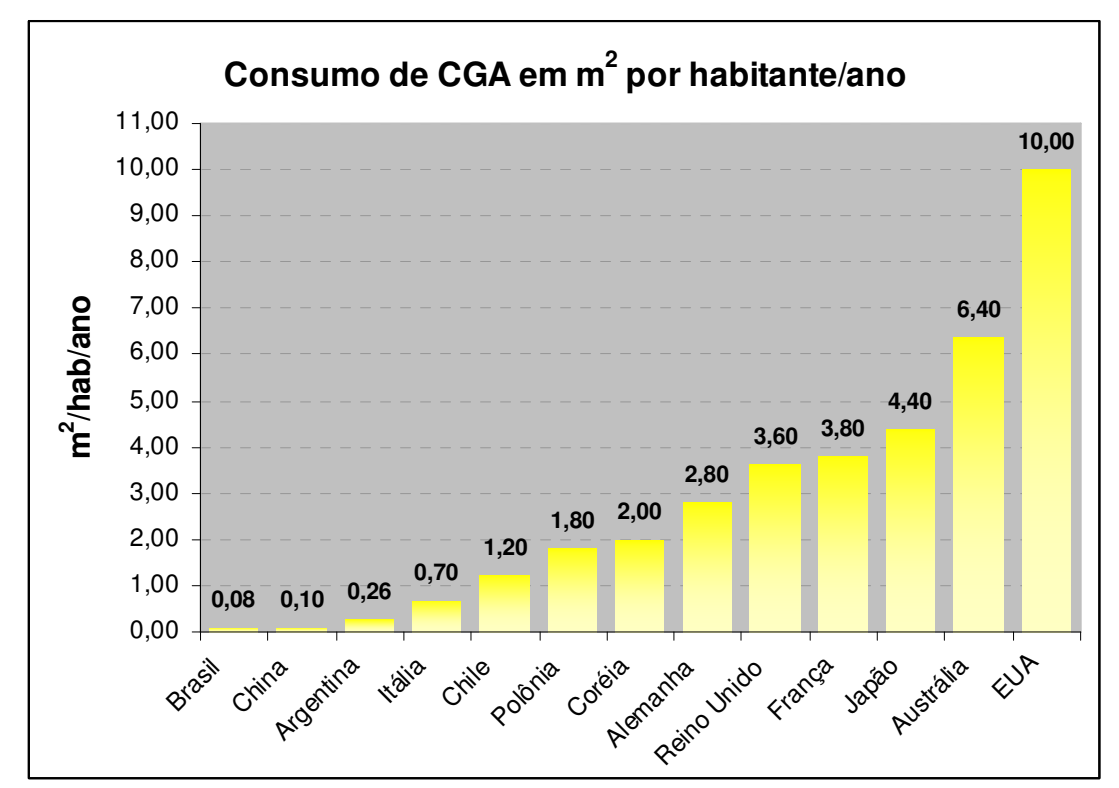

Figura 5.3 - Consumo de CGA em alguns países (ASSOCIAÇÃO DRYWALL, 2006).

A produção foi em $48 \%$ absorvida pelo Estado de São Paulo. Mais especificamente $40 \%$ da produção nacional foi consumida na Região Metropolitana de São Paulo (Figura 5.4). Portanto, devido ao seu expressivo consumo, o presente trabalho se restringi ao estudo somente do mercado da RMSP.

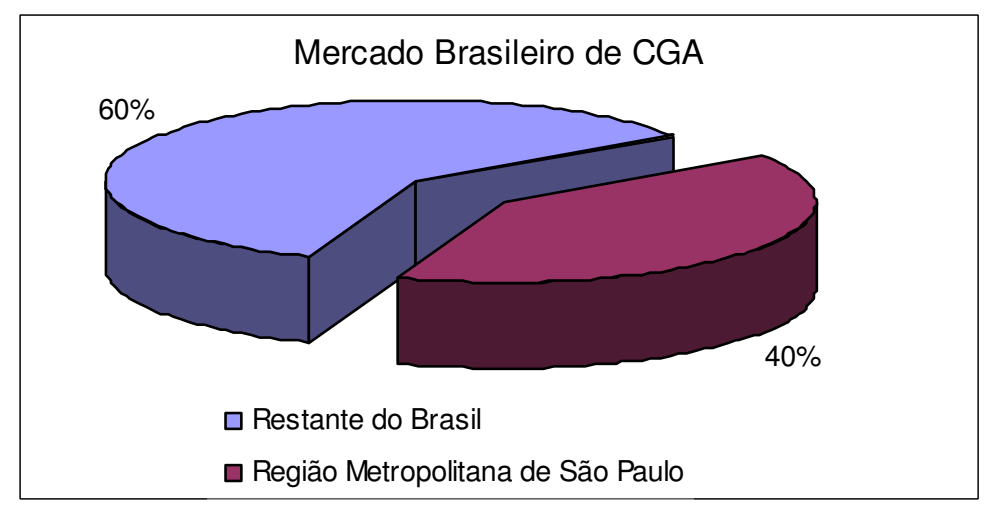

Figura 5.4 - Representação do mercado brasileiro de chapas de gesso acartonado. (ASSOCIAÇÃO DRYWALL, 2005).

O mercado da RMSP é divido em 3 grupos de clientes: construtoras, distribuidores e instaladores, os quais, segundo a Associação Drywall 
(2006), representam 25\%, $35 \%$ e $40 \%$ do mercado da RMSP, respectivamente, conforme Figura 5.5.

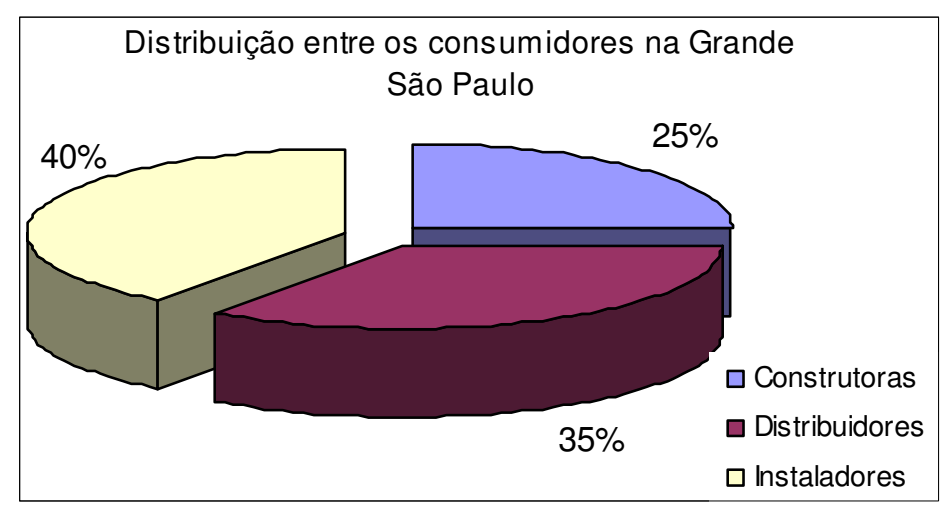

Figura 5.5 - Participação das construtoras, distribuidores e instaladores no mercado de chapas de gesso acartonado da RMSP (ASSOCIAÇÃO DRYWALL, 2005).

Nas entrevistas, as construtoras apontaram como vantagens do fornecimento direto entre o fabricante e elas a solidez financeira destas empresas, a possibilidade de desenvolvimento de processo, o auxílio no projeto de produção de vedações e na escolha de fornecedores de mãode-obra, a garantia de entrega e de sistema certificado, além de um melhor nível de atendimento. Quando há parceria estabelecida, este 'fornecimento direto' tem ainda as vantagens de preço e atendimento diferenciados.

Em comparação aos distribuidores, uma construtora afirmou que eles não conseguem fornecer grandes volumes. Em outra empresa constatou-se que os distribuidores não têm tanto comprometimento com a venda quanto os fabricantes, porque não estão preocupados se irão ou não vender novamente para aquele cliente.

Os distribuidores fornecem tanto para construtoras quanto para instaladores e pequenos geradores. Segundo os fabricantes, para ser distribuidor de CGA a empresa deve:

- $\quad$ ser capitalizada e possuir condição creditícia; 
- ter infra-estrutura adequada, incluindo frota para transporte e local de estoque, de preferência em uma boa localização;

- dispor de mão-de-obra qualificada, incluindo mão-de-obra de carga e descarga, especificador, técnico e engenheiro;

- ter capacidade técnica, gerencial e contábil, possuindo conhecimento do negócio.

A comercialização das CGA pode ser feita pelos instaladores, quando da contratação de empreitada global. No entanto, as construtoras que possuem grande volume de compra, geralmente, realizam a compra diretamente do fabricante de CGA, para evitar uma bitributação sobre o produto. Nestes casos, porém, o gerenciamento do material fica sob responsabilidade do instalador.

A formação de instaladores é realizada por meio de um curso oferecido pelo SENAI - Serviço Nacional de Aprendizagem Industrial, e de cursos oferecidos pelos próprios fabricantes.

Os instaladores de CGA geralmente são escolhidos por meio de indicação dos fabricantes. A partir daí, são qualificados, selecionados e avaliados periodicamente pela construtora. Dentre os critérios para seleção, além do preço, ter tido um bom relacionamento no passado com a construtora é importante.

\subsubsection{Composição Química dos Resíduos de Chapas de Gesso Acartonado}

A composição química dos resíduos de CGA é determinada pela composição química da própria CGA, uma vez que esta não sofre reações químicas após sua utilização no canteiro de obras.

Não existem dados disponíveis sobre a composição da CGA fabricadas no Brasil, pois, segundo os fabricantes, esta composição faz parte do segredo industrial de cada um deles. Sabe-se que dentre as CGA 
nacionais há pequena variação de composição. Segundo John e Cincotto (2003), predominam as parcelas de gesso natural hidratado (gipsita) e papel cartão. No entanto estão presentes também a vermiculita, argilas, amido, potassa, agentes espumantes, dispersantes, hidro-repelentes, entre outros.

Carr e Munn (1997) identificaram, a partir de quatro amostras, a composição típica da CGA norte-americana, conforme a Tabela 5.1.

Tabela 5.1 - Composição química incluindo a presença de metais pesados em gesso acartonado norte-americano (CARR; MUNN, 1997).

\begin{tabular}{|l|l|l|l|}
\hline \multicolumn{1}{|c|}{$\begin{array}{c}\text { Caracterização } \\
\text { Química }\end{array}$} & $\begin{array}{c}\text { Quantidade } \\
(\%)\end{array}$ & \multicolumn{1}{c|}{$\begin{array}{c}\text { Caracterização } \\
\text { Química }\end{array}$} & $\begin{array}{c}\text { Quantidade } \\
(\mathbf{p p m})\end{array}$ \\
\hline Material seco & 96.19 & Sódio & 161.2 \\
\hline Cinzas & 82.89 & Manganês & 114.4 \\
\hline Nitrogênio & 0.15 & Fósforo & 85.5 \\
\hline Enxofre & 17.6 & Boro & 48.1 \\
\hline Cálcio & 23 & Zinco & 40.2 \\
\hline Magnésio & 7.4 & Cromo & 21.7 \\
\hline Potássio & 0.1 & Cobre & 10.3 \\
\hline & & Chumbo & 3.6 \\
\hline & & Mercúrio & 1.2 \\
\hline
\end{tabular}

* Os valores são a média de quatro réplicas de amostras de gesso acartonado. Considerada tradução para português de JOHN; CINCOTTO (2003).

\subsubsection{Geração de Resíduos de Chapas de Gesso Acartonado}

A geração de resíduos de CGA ocorre de duas maneiras: durante a produção, o qual denomina-se aqui por resíduos da produção de CGA; e durante a execução do sistema de vedação em CGA, denominado, no canteiro de obras, resíduos de obra de CGA.

O resíduo da produção de CGA, segundo a Associação Drywall, corresponde de 1 a $3 \%$ da massa de matéria-prima. Durante as três entrevistas foram apurados valores de $2,5 \%, 1 \%$ e $3 \%$. Adotou-se aqui o valor de 2,5\% para os resíduos da produção de CGA, em massa em relação ao total de matérias-primas. Estes resíduos são reciclados por 
meio da reinserção dos mesmos no processo de produção da CGA, posto que possuem composição controlada e perfeitamente conhecida (JOHN; CINCOTTO, 2003).

Já para as perdas em canteiro de obras, medidas em $\mathrm{m}^{2}$, a Associação Drywall, na entrevista, apontou valores entre 3 e 5\% do consumo. No entanto, estes valores estão abaixo daqueles verificados em pesquisas de campo, como por exemplo, a de Rezende (2002) que apurou valores da ordem de 7 a 8\%. Campbell (2003) e CIWMB (2006) afirmam que, nos EUA, estes valores são de 10 a $12 \%$.

De acordo com John e Cincotto (2003) as perdas em canteiro são significativas, devido, principalmente às atividade de corte ${ }^{21}$.

Além da modulação da obra, os índices de perdas variam de acordo com os seguintes fatores:

- elaboração de especificações técnicas detalhadas de forma clara para as compras de materiais, evitando assim erros no processamento de pedidos e/ou na entrega ao canteiro de obras;

- qualificação e seleção de fornecedores, tanto de materiais quanto de mão-de-obra, em função de seu desempenho;

- promoção de parcerias com os fornecedores de materiais e mão-deobra, como forma de estabelecer sinergia entre os agentes e reter profissionais qualificados;

- utilização de projetos para produção com modulação específica para o sistema de vedação em CGA;

- compra de CGA e perfis com dimensões de pé-direito personalizadas, evitando ao máximo o corte em obra;

${ }^{21}$ Teoricamente a atividade de vedação interna em CGA não teria perda incorporada. No entanto, infelizmente, alguns instaladores praticam o ato de colocar os restos de chapa soltos dentro da vedação, ou seja, entre as duas chapas, para esconder a perda/desperdício. 
- inspeção e orientação quanto ao armazenamento e movimentação de materiais no canteiro, evitando que, se feitos de modo inadequado, ocasionem perdas;

- controle de recebimento e estoque de materiais na obra, em qualidade e quantidade (relatórios), auferindo o consumo e inibindo o desperdício de CGA;

- fornecimento de ferramentas e equipamentos adequados, uma vez que a utilização de ferramentas inadequadas de, por exemplo, corte, pode ocasionar perdas também.

De acordo com John e Cincotto (2003), no Brasil a estimativa da indústria é de perdas de $5 \%{ }^{22}\left(\mathrm{em} \mathrm{m}^{2}\right)$ em canteiros de obras.

A análise abrange a Região Metropolitana de São Paulo que representa $40 \%$ do mercado nacional, em volume de vendas, ou seja, 5,6 milhões de $\mathrm{m}^{2}$ de CGA anuais.

Nas empresas construtoras analisadas, encontrou-se valores próximos aos indicados pelos fabricantes, ou seja, entre 4 e 5\%. No entanto, ressalta-se que todas as construtoras analisadas, e que representam $80 \%$ das vendas diretas para construtoras, possuem estreito relacionamento com os fabricantes, estabelecendo relações de parceria. Nestas empresas, os procedimentos implantados, como os para projeto de produção de vedações internas em CGA, compatibilização de projetos, parceria com fornecedores de mão-de-obra (instaladores) treinados, adoção de placas e perfis de tamanhos personalizados e entregas paletizadas, entre outros, possibilita-os a atingir estes índices de perdas.

Todos estes fatores contribuem para perdas menores de material, mas infelizmente, tais práticas não fazem parte da realidade de todas as empresas construtoras e tampouco dos instaladores. A Figura 5.6 ilustra o quadro frequentemente encontrado nestas empresas.

${ }^{22}$ Contato pessoal com Omair Zorzi (Associação Drywall). 
Os instaladores pesquisados apontaram perdas maiores nos canteiros de obra onde trabalham, da ordem de $12 \%$, e distribuidores acreditam que este seja um percentual razoável, uma vez que os levantamentos quantitativos realizados por ambos prevêem este percentual de perda em $\mathrm{m}^{2}$.

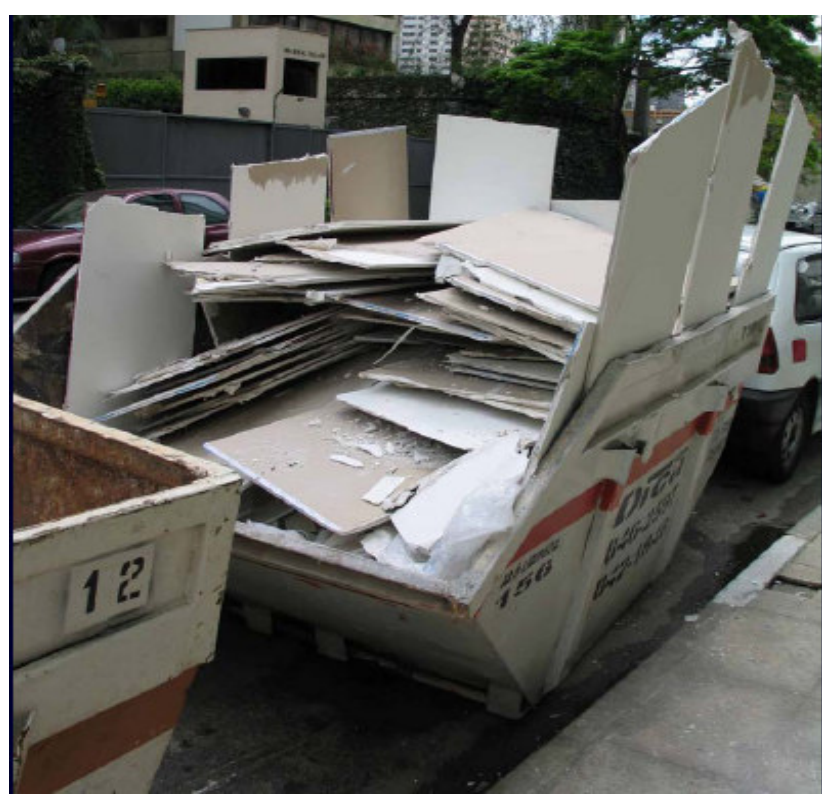

Figura 5.6 - Exemplo de caçamba contendo resíduos de obra de CGA $\left(\right.$ SABATINNI ${ }^{23}$.

Segundo os fabricantes, aproximadamente $50 \%$ dos distribuidores são "puros", ou seja, realizam apenas a comercialização da CGA. Os demais $50 \%$ oferecem também serviços de instalação. Sendo assim, apenas este segundo grupo é responsável pela geração de resíduos de CGA em canteiros de obra e possuem perdas iguais aos dos instaladores 'puros'. Considerou-se, portanto, $12 \%$ de perdas para os instaladores.

Considerando-se a distribuição de vendas apresentada pelos fabricantes, os dados fornecidos pela Associação Drywall, pelos fabricantes, construtoras, distribuidores e instaladores, tem-se a geração de resíduos de CGA na RMSP conforme a tabela Tabela 5.2.

${ }^{23}$ Arquivo pessoal de SABBATINI, F.H. 
Tabela 5.2 - Geração de resíduos de obra de CGA na RMSP no canteiro (autora, 2007).

\begin{tabular}{|c|c|c|c|c|c|c|c|c|}
\hline \multirow[b]{2}{*}{ Consumidor } & \multicolumn{4}{|c|}{$\begin{array}{l}\text { Porcentagem de vendas das empresas de acordo } \\
\text { com os consumidores }\end{array}$} & \multirow{2}{*}{$\begin{array}{c}\text { Volume da } \\
\text { participação na } \\
\text { RMSP } \\
\text { (x10 } \mathrm{m} 2 / \mathrm{ano})\end{array}$} & \multirow[b]{2}{*}{ Perdas } & \multirow{2}{*}{$\begin{array}{l}\text { Quantidade de } \\
\text { Resíduos de } \\
\text { CGA gerado na } \\
\text { RMSP ( } 10^{3} \\
\left.\mathrm{~m}^{2} / \mathrm{ano}\right)\end{array}$} & \multirow{2}{*}{$\begin{array}{l}\text { Quantidade de } \\
\text { Resíduos de } \\
\text { CGA gerado na } \\
\text { RMSP (x10 } \\
\left.\text { m² }^{2} / \mathrm{mês}\right)\end{array}$} \\
\hline & $\begin{array}{c}\text { Fabricante } \\
\text { A }\end{array}$ & $\begin{array}{c}\text { Fabricante } \\
\text { B }\end{array}$ & $\begin{array}{c}\text { Fabricante } \\
\text { C }\end{array}$ & $\begin{array}{c}\text { Média de } \\
\text { Participação }\end{array}$ & & & & \\
\hline Construtora & $30 \%$ & $20 \%$ & $20 \%$ & $23,33 \%$ & 1,31 & $5 \%$ & 65,33 & 5,44 \\
\hline Distribuidor & $50 \%$ & $40 \%$ & $50 \%$ & $46,67 \%$ & $2,61 / 2$ & $12 \%$ & 156,80 & 13,07 \\
\hline Instalador & $20 \%$ & $40 \%$ & $30 \%$ & $30,00 \%$ & 1,68 & $12 \%$ & 201,60 & 16,80 \\
\hline & & & & Total & 2,99 & Total & 423,73 & 35,31 \\
\hline
\end{tabular}

Portanto, a geração de resíduos de CGA na RMSP é de $35.310 \mathrm{~m}^{2}$ por mês. Considerando-se que uma CGA possui $8,5 \mathrm{~kg} / \mathrm{m}^{2}$, tem-se uma quantidade de $300.135 \mathrm{~kg}$ de resíduo de CGA ao mês e, consequentemente, de 3.602 t/ano. Isto significa que o resíduo de obra de CGA representa 0,064\% do fluxo de RCD na RMSP. A Figura 5.7 apresenta a síntese da geração de resíduos de CGA na RMSP.

\section{Fluxo de Resíduos de CGA na Região Metropolitana de São Paulo (RMSP)}

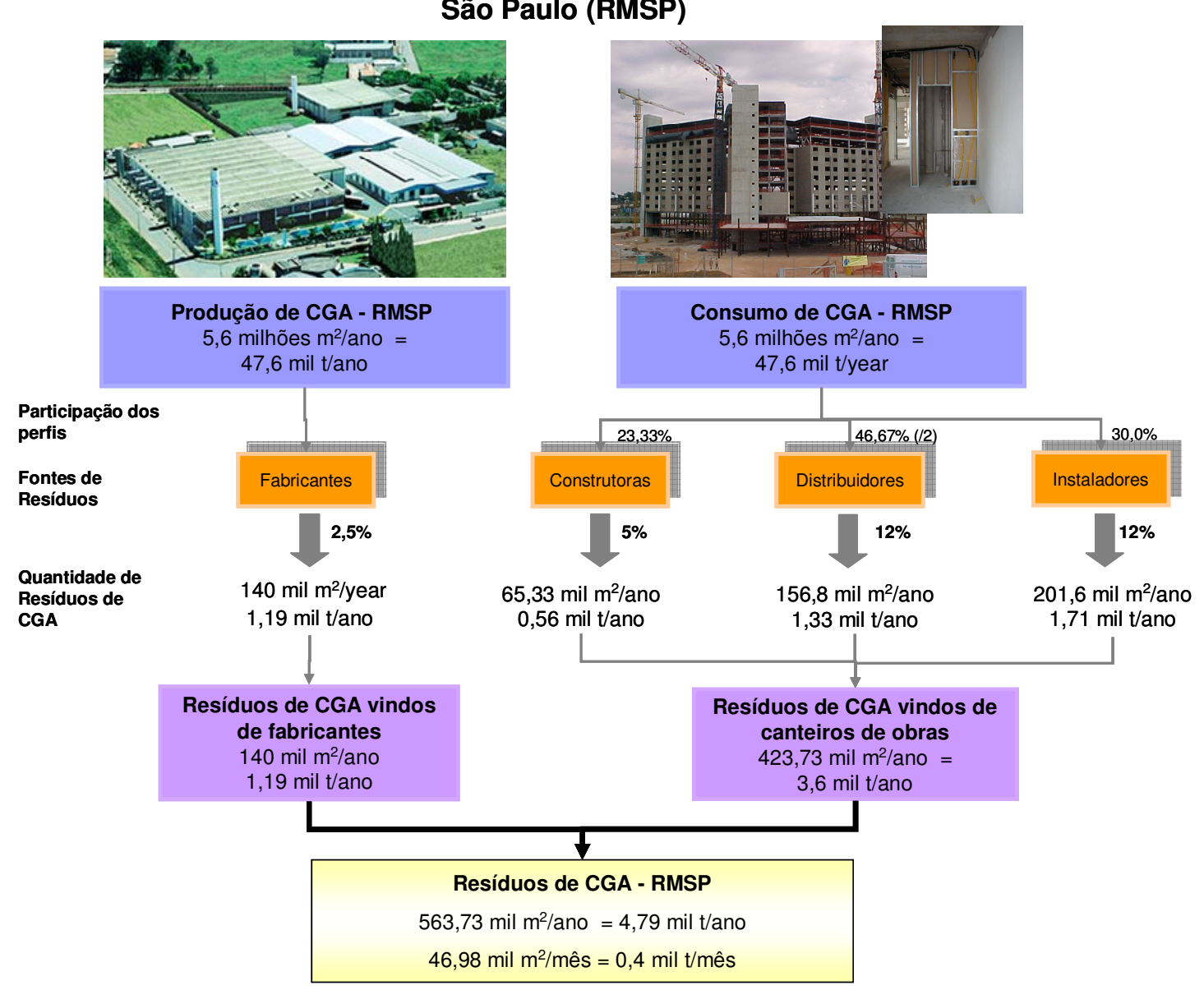

Figura 5.7 - Síntese da geração de resíduos de CGA na RMSP (autora, 2007). 
O resultado obtido para os resíduos de CGA provenientes de canteiros de obras, 3,6 mil t/ano, encontra-se um pouco abaixo da quantidade estimada em John; Silva e Agopyan (2005) que é de 4,8 mil t/ano.

John; Silva e Agopyan (2005) estimaram, a partir de dados do SINDUGESSO e da ABRAGESSO ${ }^{24}$, que os resíduos à base de gesso, na RMSP, totalizam cerca de 120.000 t/ano. Deste montante, 50\% correspondem aos resíduos à base de gesso gerados na fase de construção. A distribuição entre as fontes dos resíduos à base de gesso encontra-se na Figura 5.8.

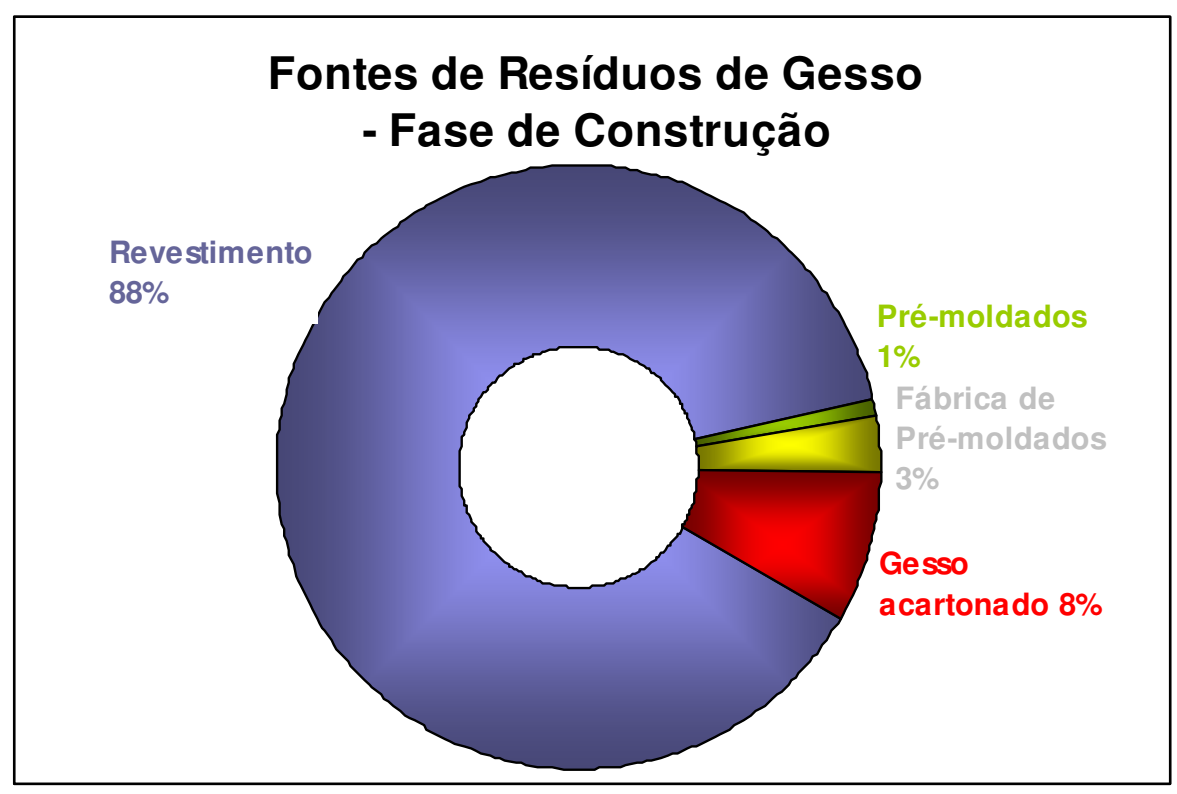

Figura 5.8 - Fontes de resíduos de gesso da fase de construção na RMSP. (JOHN; SILVA; AGOPYAN, 2005 partir de dados do SINDUSGESSO e da ABRAGESSO).

Assim, segundo John, Silva e Agopyan (2005) os resíduos de CGA da fase de construção, na RMSP correspondem a aproximadamente 4,8 mil t/ano.

A diferença entre as estimativas pode ser explicada pelo fato da estimativa aqui realizada não considerar os resíduos provenientes de pequenos geradores. Apesar dos pequenos geradores representarem a

${ }^{24}$ ABRAGESSO é a antiga denominação da Associação Drywall. 
maior parcela do consumo de materiais de construção, e da geração de RCD, a vedação interna em CGA não é uma tecnologia de uso popular. Assim, é razoável considerar que esta diferença de 1,2 mil t/ano na quantidade de resíduo de CGA gerado seja atribuída a este segmento de mercado.

Adota-se aqui a estimativa realizada com base no trabalho de campo, ou seja, a quantia de 3,6 mil t/ano de resíduos de CGA provenientes de canteiros de obras.

\subsubsection{Gerenciamento dos Resíduos à base de Gesso em Canteiros de Obras de Grandes Geradores}

De acordo com a Resolução n. 307 (CONAMA, 2002), os resíduos à base de gesso, independentemente se oriundos de gesso de revestimento, placas pré-moldadas ou chapas de gesso acartonado (CGA), pertencem à classe C, ou seja, "são os resíduos para os quais não foram desenvolvidas tecnologias ou aplicações economicamente viáveis que permitam a sua reciclagem/recuperação”.

\subsection{Triagem das Classes de Resíduos}

O gerenciamento de resíduos à base de gesso envolve, primeiramente, a redução de sua geração, por meio do controle das perdas e de mecanismos de gestão de projetos, suprimentos e produção.

Para os resíduos à base de gesso gerados, pode-se proceder de duas formas: a primeira realizando a triagem na origem, ou seja, no próprio canteiro; a segunda, enviando os RCD misturados para a ATT.

Nos resíduos, o gesso ocorre em forma finamente dispersa e sua origem é principalmente o gesso de revestimento. No entanto, as desagregações de placas pré-moldadas e da massa de gesso das CGA também contribuem para a ocorrência de gesso em pó. O 
gesso em pó é o principal contaminante dos demais RCD e pode inviabilizar o aproveitamento destes.

\section{$\underline{\text { gesso como contaminante dos resíduos classe A }}$}

Os resíduos classe $\mathrm{A}$ quando reciclados dão origem a agregados miúdos e graúdos. Aguiar (2004) estudou a influência de agregados miúdos contaminados por gesso em argamassas de revestimento. De acordo com Aguiar (2004) a contaminação de agregados reciclados para argamassas por baixos teores de gesso de construção, é suficiente para produzir alterações significativas no desempenho mecânico das argamassas e nos seus níveis de sulfatos solúveis.

O estudo de Aguiar (2004) confirmou ser "recomendável um limite máximo de sulfatos solúveis na faixa entre 0,1\% e 0,2\%, sobre a massa de agregados reciclados para argamassas, ou ser adotado o critério da DIN 4226-100 (< 600 mg/L de SO4), compatível com a faixa citada”.

Já para os agregados graúdos reciclados com o objetivo de produzir concretos com cimento Portland, John e Cincotto (2003) afirmam que "a presença de gesso é um limitante importante, posto que a reação entre os aluminatos do cimento e o sulfato do gesso em presença de umidade gera a etringita, composto que ocupa volume muito maior que os reagentes originais, criando tensões expansivas que levam à desagregação das peças de concreto”. Os autores afirmam ainda que a maioria das normas técnicas limita o teor de sulfatos nos agregados a um valor máximo de $1 \%$.

Vrancken e Laethem (2000) observam que o conteúdo de sulfato é o principal critério na valorização do RCD como agregado secundário para concreto. 
Em Flandres - comunidade do norte da Bélgica, segundo Vrancken e Laethem (2000), para produzir agregados reciclados com qualidade certificada e possíveis de serem utilizados em concreto, as unidades de reciclagem fazem um controle de aceitação rigoroso do resíduo que está sendo adquirido. Um dos principais critérios para a aceitação dos resíduos é a ausência de gesso. Cargas de fração mineral de RCD contendo mais do que $1 \%$ de gesso não são aceitas.

\section{$\underline{\text { Triagem realizada pela empresa construtora }}$}

Quando realizada por empresa construtora a triagem dos resíduos à base de gesso é similar às das demais classes. $\mathrm{O}$ acondicionamento geralmente é feito em caçambas metálicas de $4 \mathrm{~m}^{3}$. A quantidade de resíduos que uma caçamba é capaz de acondicionar varia muito em função do material - gesso em pasta ou em chapa - e do índice de vazios, determinado pela forma como o resíduo é disposto dentro da caçamba. Os instaladores e funcionários da obra devem ser orientados a proporcionar o maior aproveitamento possível do volume da caçamba, ou de outro recipiente utilizado.

Durante as entrevistas, algumas das empresas construtoras afirmaram exigir em contrato que o subempreiteiro/instalador se responsabilize pela retirada e destinação dos resíduos provenientes de sua atividade. Este procedimento diminui a preocupação da empresa construtora com a atividade de destinação, mas não resolve o problema da destinação inadequada dos resíduos de CGA. Isto porque a maioria das empresas de instalação possui baixa organização e capacidade gerencial para controlar a quantidade de resíduos e destiná-los corretamente.

No entanto, dentre os fabricantes, uma empresa afirmou ser ideal que "o instalador faça a segregação na obra e retire seu próprio resíduo de CGA para a destinação adequada, no nosso caso a 
ATT. É difícil impor isto para o instalador porque é mais uma atividade que ele terá que gerenciar. O construtor tem uma carga de trabalho a menos, mas o instalador ganha em processo, uma vez que ele irá visualizar a perda e cada vez mais evitá-la”.

Quando a triagem é realizada pela construtora, os resíduos à base de gesso têm três destinações possíveis: uma ATT, que neste caso funciona como uma intermediária entre o gerador e a destinação; um aterro e; uma indústria de cimento. Dentre as empresas construtoras que participaram das entrevistas - as quatro maiores consumidoras diretas dos fabricantes - nenhuma apontou a indústria de cimento como destinação. Apenas uma das construtoras envia seus resíduos para a ATT, enquanto as demais o descartam juntamente com outros tipos de resíduos em aterros.

\section{$\underline{\text { Triagem e destinacão de resíduo à base de gesso realizadas em }}$} $\underline{\text { ATT }}$

Dentre as sete ATT em funcionamento no município de São Paulo (março de 2007) apenas duas recebem resíduos a base de gesso e, por conseqüência, de CGA. Quando da entrevista realizada no trabalho de campo, apenas uma ATT operava recebendo estes resíduos. Portanto, somente os fluxos relativos à esta ATT são contemplados neste estudo.

Em função de sua localização - o bairro do Pari, na cidade de São Paulo - a Maxi Papel Comércio de Aparas e Sucatas Ltda. é conhecida no mercado como ATT do Pari. A ATT do Pari chegou a triar 400 t/mês de resíduos à base de gesso. Em julho de 2006, quando da visita e entrevistas realizadas, a ATT Pari recebia apenas 40 t/mês destes resíduos (Figura 5.9). Nesta época a ATT já estava evitando 'novos clientes com resíduos de gesso' e atendendo apenas as grandes empresas com as quais tinha um compromisso firmado referente a todos os resíduos, independente da classe. 

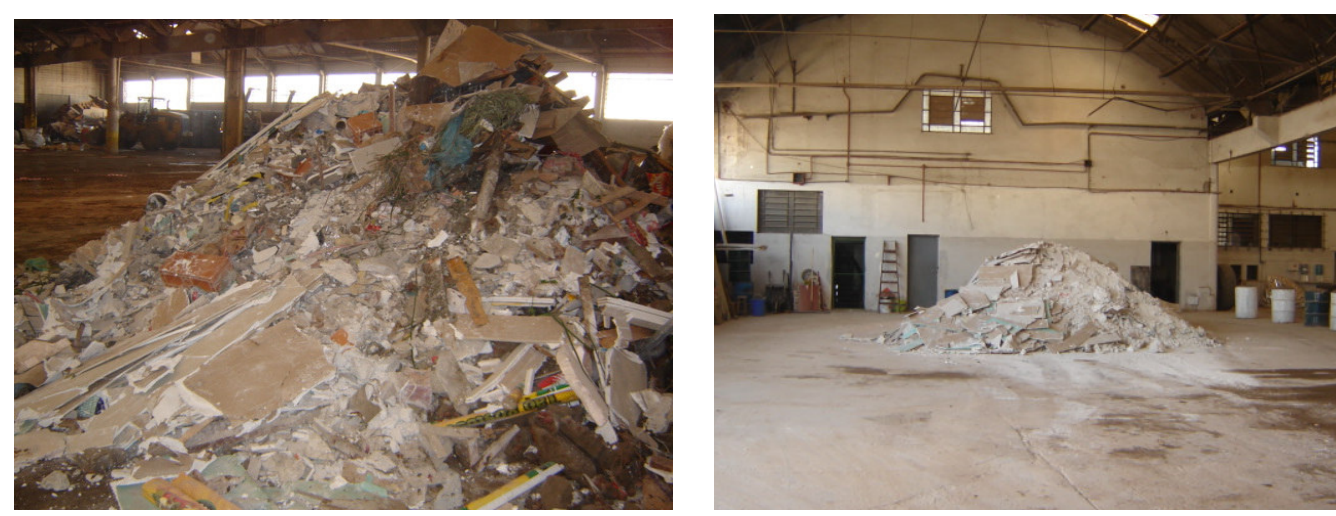

Figura 5.9 - Resíduos de CGA, antes e depois da triagem, na ATT do Pari (autora, 2007).

A ATT é uma empresa que se remunera pela triagem dos resíduos e pela venda de produtos triados que possuam algum valor de mercado remanescente. Isto significa que a ATT não tem interesse em receber resíduos já triados provenientes das obras. Assim, ela cobra mais barato por resíduos misturados e mais caro para resíduos triados, porque para os resíduos triados não é possível aproveitar o valor das demais frações (por exemplo, plásticos, madeira, metal) que seriam vendidas para empresas de reciclagem.

No entanto, no caso específico dos resíduos à base de gesso, tanto em pasta quanto as CGA, a questão se inverte. A ATT cobra então mais caro (cerca de 20\%) por resíduos misturados com gesso, independente da fração de gesso ser predominante na quantidade ou não. Isto porque a presença do gesso contamina as demais partes, e, portanto, impede o aproveitamento do valor das outras frações. No caso dos resíduos à base de gesso seria, portanto, preferível recebê-los já triados.

Segundo o representante da ATT do Pari, a ausência de destinações adequadas para os resíduos à base de gesso triados tem causado o aumento nos preços praticados pela ATT para recebê-los, uma vez que estes se tornam um problema para a empresa. As opções de descarte hoje, para estes resíduos, são o aterro ou as indústrias de 
cimento. Dos cerca de 40t/mês de resíduos à base de gesso que a ATT do Pari recebe atualmente, aproximadamente $30 \%$ correspondem aos resíduos de CGA, ou seja, 12t/mês.

Considerando-se que a geração de resíduos de CGA na RMSP, quantificada no item 5.2.1.5, é de 300 t/mês, 288 t/mês de resíduos de CGA têm sido destinadas aos aterros, seja de forma triada ou misturada às demais classes de RCD.

Os resíduos à base de gesso triados na ATT do Pari foram, durante um período, destinados à uma indústria de cimento. A indústria de cimento aceitava apenas os resíduos à base de gesso que tivessem sido triados pela ATT do Pari.

Estes resíduos eram coletados na ATT do Pari por um distribuidor de cimento. Este distribuidor retirava o cimento na fábrica, localizada no interior do estado de São Paulo, o trazia para a capital e retornava para a fábrica com os resíduos à base de gesso, diminuindo os custos de transporte por meio do aproveitamento do frete de retorno.

No entanto, em determinado momento, a relação entre a ATT e a indústria de cimento não se estabeleceu mais, porque estas empresas tinham interesses divergentes e conflitantes.

A ATT vendia o resíduo para a indústria de cimento a um preço de $\mathrm{R} \$ 10,00 /$ t. Apesar de este preço ser bem abaixo daquele pago por esta indústria pela gipsita, o uso dos resíduos à base de gesso encontrava entraves técnicos na produção de cimento, conforme será explicitado no item 5.2.2.3.2.a. Assim, a indústria de cimento pressionou o preço do resíduo, chegando ao valor de $\mathrm{R} \$ 3,00 /$ t. Este era o mínimo valor de venda da ATT.

Ainda assim, a indústria de cimento não visualizava vantagens em utilizar os resíduos à base de gesso. Assim, a indústria de cimento entendeu que estava apenas prestando o serviço de incineração de 
resíduos à base de gesso e, como tal, deveria cobrar por este serviço.

Sendo assim, a indústria de cimento não mais comprou resíduos à base de gesso e a ATT do Pari começou a evitar o recebimento destes resíduos porque não tinha onde destiná-los, senão para aterros. A opção de deposição destes resíduos em aterro é, portanto, maciçamente utilizada.

Apesar de todas as informações obtidas das construtoras e da ATT do Pari, em consulta a um profissional da $\mathrm{ABCP}$, este informou que a associação foi consultada por alguns de seus membros sobre as possibilidades de se utilizar os resíduos à base de gesso na produção de cimento. No entanto, a ABCP não recomendou o uso em função de não ter desenvolvido ainda qualquer pesquisa que ateste a influência de tais resíduos no processo de produção e no produto cimento.

Segundo o entrevistado, apenas uma indústria de cimento assumiu ter realizados testes com o uso de resíduos à base de gesso em sua produção.

\subsection{Destinação dos Resíduos de CGA}

De acordo com a Resolução n. ${ }^{\circ} 307$ (CONAMA, 2002), os resíduos Classe C “devem ser armazenados, transportados $e$ destinados em conformidade com as normas técnicas específicas”. Em virtude da ausência de tais normas específicas, estes resíduos têm sido manejados sem quaisquer cuidados específicos, tal como as demais classes de resíduos, e depositados em quaisquer tipos de aterros.

A deposição de resíduos à base de gesso em aterro, tanto sanitários quanto de resíduos da construção civil, é amplamente utilizada, ainda que esteja em desacordo com a NBR 15112 (ABNT, 2004). 
A ausência de tecnologias de reciclagem viáveis para o reaproveitamento conjunto dos resíduos a base de gesso determina a sua colocação em áreas de reservação, onde aguardam o desenvolvimento de tal mecanismo para serem aproveitados. $\mathrm{O}$ fato é que a reservação acaba constituindo um aterro específico, o qual deveria ter procedimentos rígidos de controle dos aspectos ambientais, como forma de evitar impactos ambientais negativos provenientes dos RCD à base de gesso.

A ausência destas áreas específicas de reservação - somente para a classe $\mathrm{C}$, induz a deposição deste resíduo em aterros de RCC, aterros sanitários ${ }^{25}$, aterros controlados, ou ainda em lixões, os quais não possuem controles específicos e suficientes para controlar ou mitigar os impactos dos RCD à base de gesso.

Neste cenário, é voz corrente no mercado que muitas empresas construtoras - grandes geradores - têm praticado o ato de “dissolver" os resíduos à base de gesso da obra, misturando-os aos resíduos de outras classes, nas caçambas, ou até mesmo não separando-os. Esta prática condenável é possível porque não há ainda regulamentações que determinem o teor máximo de contaminantes que as outras classes de RCD podem conter para serem aceitos em aterros, nem as formas de como mensurar este teor. A fiscalização também é ineficaz.

Como já visto, isto também causa problemas à fração mineral do RCD, pois, de acordo com John e Cincotto (2003), “a proposta de diluir o gesso na fração mineral complicaria o processo industrial de reciclagem, encarecendo todo processo e, possivelmente, tornando-o economicamente inviável”.

\footnotetext{
${ }^{25}$ Aterro Sanitário: local onde é uma forma de disposição final de resíduos sólidos urbanos no solo, através de confinamento em camadas cobertas com material inerte, geralmente, solo, de acordo com critérios de engenharia e normas operacionais específicas, e de modo a evitar danos ou riscos à saúde pública e à segurança, minimizando os impactos ambientais (NBR 8419, ABNT, 1992).

Aterro Controlado: É como um aterro sanitário, porém, geralmente não dispõe de impermeabilização de base (comprometendo a qualidade das águas subterrâneas), nem sistemas de tratamento de chorume ou de dispersão dos gases gerados. Este método é preferível ao lixão, mas, devido aos problemas ambientais que causa e aos seus custos de operação, a qualidade é inferior ao aterro sanitário (NBR 8849, ABNT, 1985).
} 
A principal conseqüência da deposição de resíduos à base de gesso em aterros é a formação de ácido sulfídrico $\mathrm{H}_{2} \mathrm{~S}$. No entanto, conforme a Tabela 5.1 apresentada, foi identificada também a presença de metais pesados na composição química da CGA. Além destes impactos, a solubilidade do sulfato em água pode provocar problemas no longo prazo, como vazios formados por lixiviação do gesso, e alteração do pH da água e do solo.

Apesar da incineração não ser prática comum no Brasil como destinação de RCD, CIWMB (2006) e Marvin (2000) explicam que a incineração de resíduos à base de gesso não é interessante porque pode produzir o gás tóxico de dióxido de enxofre.

A Figura 5.10 sintetiza como acontece atualmente o gerenciamento dos resíduos à base de gesso em canteiros de obra na RMSP e ilustra o tamanho dos fluxos de resíduos de CGA.

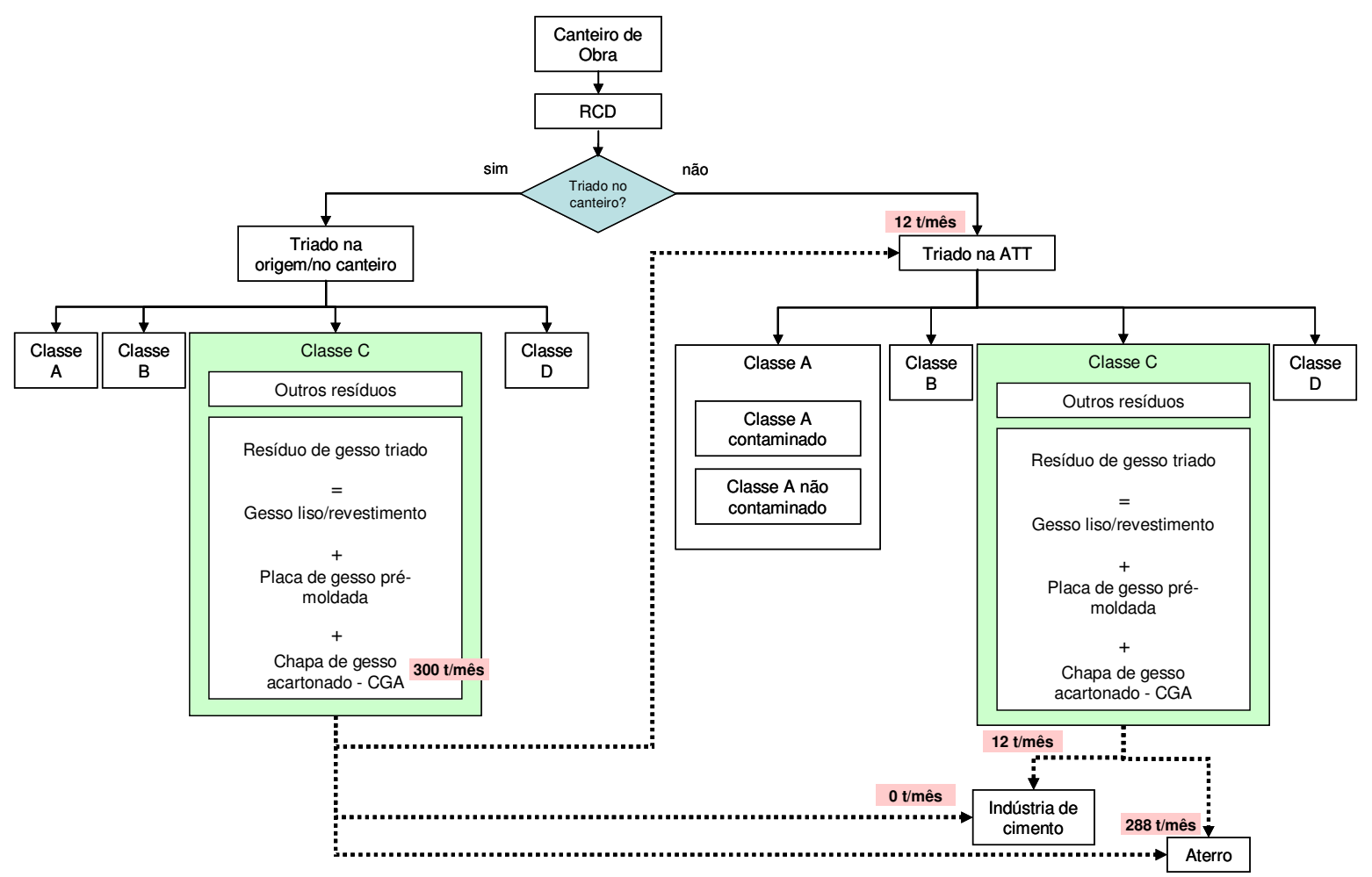

Figura 5.10 - Gerenciamento dos resíduos à base de gesso em canteiros de obra na RMSP e fluxos de resíduos de CGA (autora, 2007). 


\section{Impacto da deposicão de resíduos à base de gesso em aterros}

O impacto da deposição de resíduos de CGA em aterros não se dá em função do papel, que é facilmente biodegradado, mas sim em função do gesso e dos aditivos presentes na massa de gesso das CGA.

O gesso em contato com umidade e condições anaeróbicas, com baixo pH, e sob ação de bactérias redutoras de sulfatos, condições presentes em muitos aterros sanitários e lixões, pode formar gás sulfídrico $\left(\mathrm{H}_{2} \mathrm{~S}\right)$, que possui odor característico de ovo podre, é tóxico e inflamável (CIWMB, 2006).

Além do odor, o $\mathrm{H}_{2} \mathrm{~S}$, em altas concentrações, ou seja, acima de 1.000 ppm causa problemas à saúde humana, podendo levar ao óbito. Este foi o motivo principal de vários aterros nos Estados Unidos terem banido a deposição de RCD à base de gesso (JOHN; CINCOTTO, 2003; MARVIN, 2000; CIWMB, 2006).

A identificação do problema da deposição de resíduos à base de gesso em aterros ocorreu em British Columbia, EUA, no início dos anos 80 (MUSICK, 1992), onde foram encontradas concentrações de gás sulfídrico $\left(\mathrm{H}_{2} \mathrm{~S}\right)$ de até $5.000 \mathrm{ppm}$. Nos EUA os resíduos à base de gesso são majoritariamente $(95 \%)$ de CGA.

Segundo Musick (1992), nesta ocasião identificou-se que a máxima produção de gás ocorre de 6 a 15 anos após a deposição do material. Para este autor, "o banimento forçou os fabricantes $e$ contratantes de drywall a considerarem alternativas de disposição e isto impulsionou o estabelecimento da industria de reciclagem de gesso”.

John e Cincotto (2003) concordam com a determinação da Comunidade Européia (2003), que exige que a deposição do gesso não contaminado em aterros somente é recomendável se realizada 
em células completamente isoladas de resíduos biodegradáveis, ou seja, sem contato com matéria orgânica ou umidade.

No Brasil ainda não existem regras para deposição de resíduos à base de gesso em aterros (JOHN; CINCOTTO, 2003). Acredita-se que a adoção da determinação da Comunidade Européia, apesar de ser uma alternativa possivelmente cara, especialmente em grandes cidades, seja a mais adequada e necessária para evitar impactos ambientais significativos.

Para amenizar a emissão de $\mathrm{H}_{2} \mathrm{~S}$ em aterros existentes, Reinhart e Townsend (2004) estão estudando o efeito de diferentes tipos de solo, ou de materiais baratos, como por exemplo, calcário ou finos de concreto britado, para cobertura destes aterros.

Para evitar os impactos ambientais negativos provocados pela deposição de resíduos à base de gesso em aterros, a melhor alternativa é o estabelecimento do 'negócio' central de reciclagem ou da reciclagem realizada pelo próprio fabricante, como é discutido a seguir.

\subsubsection{Cadeia Reversa de CGA}

\subsubsection{Reciclagem de resíduos à base de gesso}

A presença de diferentes fases de resíduos dentro dos resíduos à base de gesso e a variabilidade de suas proporções (quantidades) nas descargas de resíduos dificultam a identificação e caracterização deste resíduo. Apesar de ser interessante do ponto de vista da escala industrial, a reciclagem conjunta de todos os resíduos à base de gesso é complexa e, até o momento, não se tem conhecimento de como realizá-la.

Separadamente a reciclagem de resíduos de gesso em pasta (revestimento + placas pré-moldadas) e de resíduos de CGA é mais promissora. Para o gesso em pasta, diversos estudos têm sido desenvolvidos, entre eles os de Nita et al. (2004) e Cavalcanti (2006). Portanto, é necessário que haja 
uma triagem dentre os resíduos à base de gesso para separar as fases de gesso em pasta (revestimento + placas pré-moldadas) e de CGA.

\subsubsection{Necessidade de triagem dentre os resíduos à base de gesso}

Atualmente, dentro do canteiro de obras, o gerenciamento dos resíduos à base de gesso é feito conjuntamente, ou seja, não há separação entre suas fontes.

É necessário haver uma segunda triagem dos resíduos de gesso, separando-os entre os provenientes de pastas, como o revestimento liso e as placas pré-moldadas, e os de gesso acartonado. Esta separação se justifica porque não há atualmente tecnologia que permita a reciclagem destas fases conjuntamente. Isto provavelmente deve-se ao fato de que a composição química, as tecnologias de reciclagem existentes, a quantidade, além da forma de comercialização, de consumo e de identificação dos resíduos diferem muito entre estes dois grupos.

Além disso, a triagem dentre os resíduos a base de gesso deveria existir porque ela é fácil de ser realizada, evita a contaminação e possibilita a reciclagem de uma das fases, que são os resíduos de CGA.

Aguiar (2004) observa que na triagem dos resíduos classe $C$ à base de gesso a separação das 'peças' de placas pré-moldadas e de CGA é fácil em função do tamanho destes resíduos e por eles ficarem isolados (no sentido de não-aderidos) dos outros componentes construtivos.

No caso dos resíduos de gesso de revestimento, a identificação do material e a tarefa de separar o gesso do substrato não são viáveis, pois o gesso apresenta elevada aderência a todos os tipos de base mineral (AGUIAR, 2004).

Apesar de não haver, até o momento, tecnologias de reciclagem que permitam o aproveitamento conjunto dos resíduos a base de gesso, alguns estudos desenvolvidos têm mostrado resultados promissores para a reciclagem destas fases em separado. 
Além da fácil triagem e da disponibilidade de tecnologia de reciclagem, os resíduos de CGA possuem como vantagem a fácil identificação de seu fabricante, sendo possível envolvê-lo no gerenciamento do resíduo.

Além de separar os resíduos de CGA das demais fases, a triagem deve retirar os contaminantes possivelmente presentes nestes resíduos. Segundo John e Cincotto (2003) e Tanigutti (1999), os resíduos de CGA podem estar contaminados com metais (pregos, perfis), madeira, massas para o tratamento das juntas, fitas para reforçar os cantos e reparos de fissuras, fitas de papel Kraft, oxidação de suportes e parafusos (TANIGUTI, 1999) e tinta. A ausência de procedimentos adequados de gestão dos resíduos de gesso no canteiro pode introduzir outros contaminantes.

Além da triagem entre as fases é necessário também diferenciar o resíduo de CGA limpo do contaminado. Para tanto, é preciso estabelecer parâmetros para definir o que é resíduo de CGA limpo e o que é contaminado.

As ATT poderiam realizar a segunda etapa de triagem dos resíduos, separando-os em duas frações: gesso liso e pré-moldado, e gesso acartonado, uma vez que já possuem infra-estrutura e certo know-how sobre o manejo de tais resíduos.

Se as ATT assumissem o processo de triagem entre os resíduos à base de gesso, as áreas de reservação, as ATT e as plantas de reciclagem deveriam se localizar o mais próximo possível uma das outras, para minimizar os custos de transporte.

\subsubsection{Canais reversos de resíduos de CGA}

Os resíduos de CGA podem ser aproveitados de acordo com dois canais de distribuição reversos: de reuso e de reciclagem.

Os resíduos de CGA podem fluir em um canal reverso de reuso, sendo utilizados sem necessidade de beneficiamento industrial na indústria de 
cimento. Já nos canais reversos de reciclagem, o resíduo de CGA é reciclado em gesso reciclado e papel cartão fragmentado, os quais possuem seus respectivos mercados consumidores.

\subsection{Reciclagem de resíduos de CGA}

De acordo com John e Cincotto (2003), a experiência internacional atual atesta que é possível reciclar gesso acartonado que contém outros compostos, produzindo aglomerantes (gesso reciclado), desde que sejam removidos contaminantes incorporados no processo de geração de resíduos (HUMMEL, 1997; MARVIN, 2000; CAMPBELL, 2003).

Para serem reciclados os resíduos de CGA devem ser armazenados em local seco, estar livres de materiais isolantes, metais, madeira e plástico. No entanto, papel cartão e fibra de vidro são tolerados no processo de reciclagem (GIPSUM RECYCLING, 2007).

Existem várias tecnologias de reciclagem de resíduos de CGA. Há diversos tipos de equipamentos disponíveis no mercado no exterior. Eles abrangem as opções de capacidade de processamento - de 1 a 10 t/h ou mais - , de introdução de material seco ou molhado, de sistema fixo ou móvel, com ou sem separação magnética, com ou sem separação granulométrica do material reciclado, entre outras. Estes equipamentos de reciclagem possuem alta eficiência. Segundo CIWMB (2006), um equipamento de reciclagem de CGA pode produzir cerca de $93 \%$ de gesso em pó e $7 \%$ de papel fragmentado, em massa.

Empresas especializadas em reciclagem de CGA como a New West Recycling (Canadá), Knauf (Alemanha), Gipsrecycling (Dinamarca) já fazem parte do mercado mundial de gestão e reaproveitamento de resíduos de gesso (JOHN; CINCOTTO, 2003). 


\subsection{Possíveis mercados para a utilização de resíduos de CGA}

O principal mercado para a utilização de gesso reciclado de resíduos de CGA é a fabricação de novas CGA. Além deste, o uso de gesso reciclado de resíduos de CGA encontra oportunidades de uso nos mercados secundários da indústria de cimento e de correção de solos (MARVIN, 2000; CARR; MUNN, 2001; CIWMB, 2006). Outros mercados secundários potenciais existem, mas, por exigirem o desenvolvimento do consumo, não são significantes oportunidades a curto prazo. Eles constituem-se do possível uso de gesso reciclado de resíduo de CGA como:

- aditivo para compostagem (Marvin, 2000; CIWMB, 2006);

- forração para animais (Marvin, 2000; CIWMB, 2006);

- absorvente de oleo (Marvin, 2000; CIWMB, 2006);

- controle de odores em estábulos (CIWMB, 2006);

- $\quad$ secagem de lodo de esgoto (CIWMB, 2006);

- marcação de campos de esporte (CIWMB, 2006).

Dentre as possíveis aplicações analisou-se neste trabalho a destinação dos resíduos de CGA para a indústria de cimento e de produção de CGA; e de gesso reciclado a partir de resíduos de CGA (ilustrado na Figura 5.11), para a indústria de cimento e para a correção de solos.

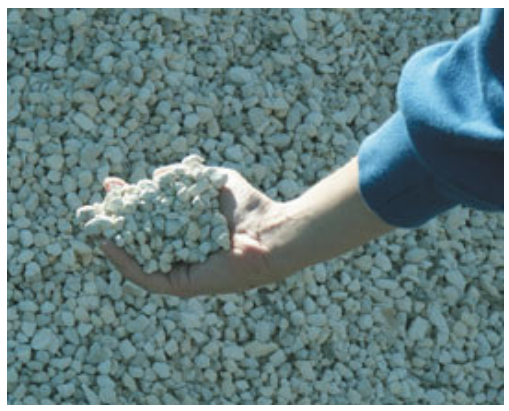

Figura 5.11 - Gesso reciclado a partir de resíduos de CGA (GYSPUM RECYCLING, 2006). 
Estas opções de destinação foram escolhidas porque, segundo os fabricantes, já haviam sido realizadas experiências iniciais com estas aplicações. No entanto, a destinação a outros mercados de reaproveitamento, como por exemplo, e especificamente, o mercado de pré-moldados em gesso liso (principalmente de placas para forro) deve ser estudada com atenção.

\subsubsection{2.a. Alternativa de consumo: Indústria de cimento}

A indústria de cimento pode consumir tanto resíduos de CGA, quanto gesso reciclado ${ }^{26}$ de resíduos de CGA, produto o qual referir-se-á deste ponto em diante do texto como gesso reciclado de rCGA.

A Figura 5.12 ilustra a localização das fábricas de cimento no Brasil, segundo o Sindicato Nacional da Indústria de Cimento SNIC.
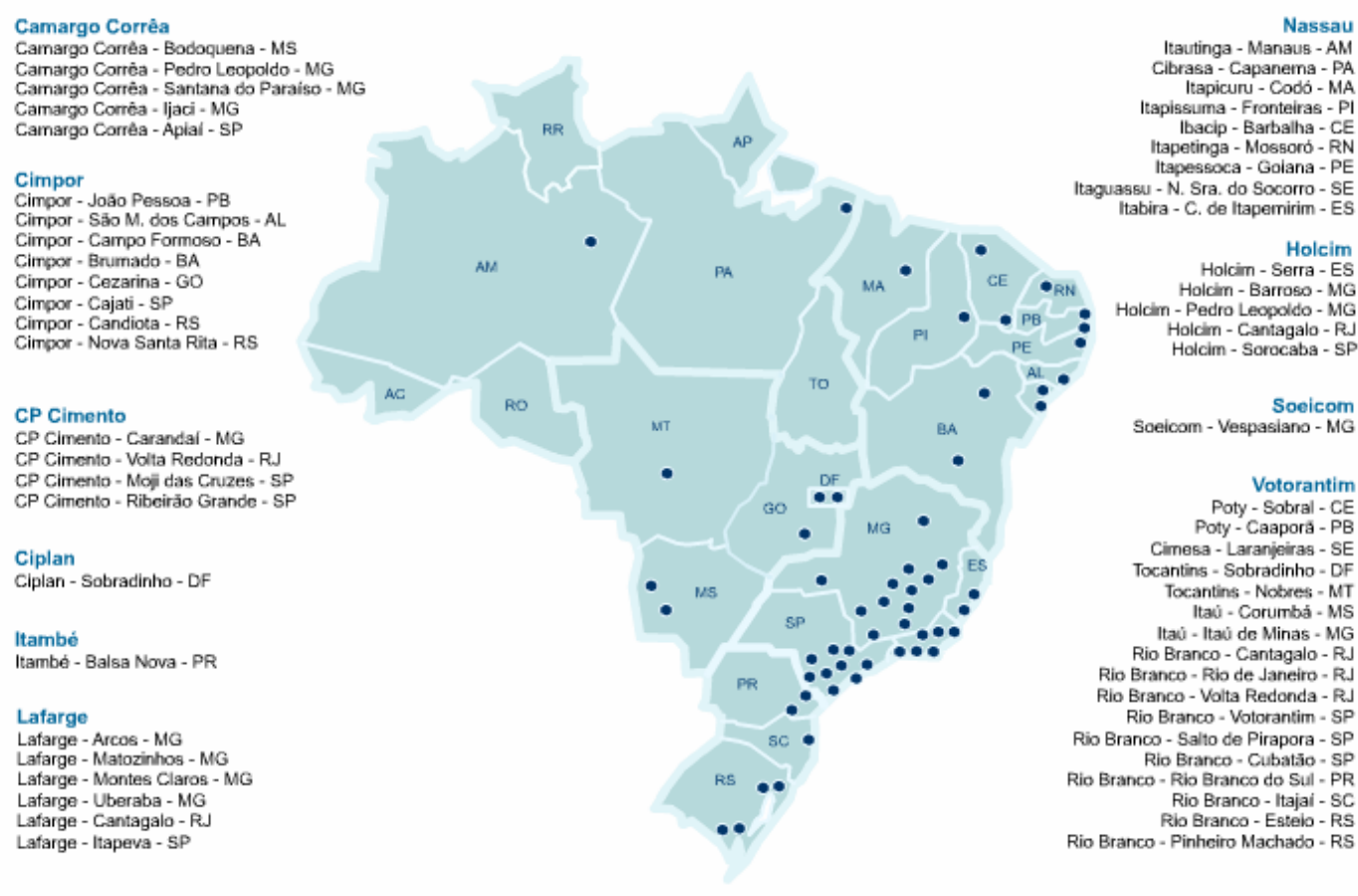

Figura 5.12 - Identificação e localização das fábricas de cimento instaladas no Brasil (SNIC, 2006).

${ }^{26}$ É relevante afirmar que o gesso reciclado trata-se na verdade de gipsita reciclada, uma vez que os resíduos de CGA não sofreram calcinação, apenas separação da 'massa de gesso' do papel cartão, por meio de processos de moagem e peneiramento. 


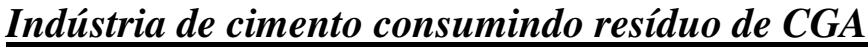

A única alternativa levantada para os resíduos de CGA serem utilizados sem beneficiamento, num CDR de reuso, considerando-se que os 'retalhos' de CGA tiveram um aproveitamento máximo na obra - é o seu consumo na indústria de cimento.

Esta alternativa tem por objetivo o aproveitamento o gesso dihidratado presente na 'massa de gesso' da CGA como adição ao cimento.

A indústria cimenteira é considerada uma das alternativas de destinação dos resíduos de CGA em virtude do alto volume de produção, e de sua composição conter de 2 a 3\% de adição de gesso (gipsita). Pode-se adicionar fosfogesso, gipsita (sulfato de cálcio dihidrato), bassanita (sulfato de cálcio hemidrato - gesso) ou anidrita (sulfato de cálcio anidro) mas, comumente utiliza-se a gipsita.

\section{Mercado:}

De acordo com os dados de 2005 do SNIC, a região Sudeste produziu, em 2005, 17.666.662 $\mathrm{t}$ de cimento e consumiu 17.253.237 t, conforme a Tabela 5.3.

\section{Tabela 5.3 - Produção e consumo de cimento na região} Sudeste, em 2005. (SNIC, 2006).

\begin{tabular}{|c|c|c|}
\hline \multicolumn{3}{|c|}{ REGIÃO SUDESTE } \\
\hline & Produção & Consumo \\
\hline Minas Gerais & 8.786 .375 & 3.930 .124 \\
\hline Espírito Santo & 1.308 .588 & 768.227 \\
\hline Rio de Janeiro & 2.302 .378 & 3.208 .260 \\
\hline São Paulo & 5.268 .281 & 9.346 .626 \\
\hline Total & 17.665 .622 & 17.253.237 \\
\hline
\end{tabular}


Os dados mostram que a produção de cimento em São Paulo é de 5.268.281 t (SNIC, 2006). Aplicando-se a taxa de adição de gesso (gipsita) prevista em 3\%, em massa, tem-se:

$5.268 .281 \times 0,03=158.048$ t/ano.

Isto significa que a indústria cimenteira consome cerca de 158 mil t/ano de gesso (gipsita), no estado de São Paulo.

Tomando-se por base que cada $\mathrm{m}^{2}$ de CGA pesa 7,5 $\mathrm{kg}$ de massa de gesso (gipsita) e $1 \mathrm{~kg}$ de papel cartão, obtêm-se que o papel cartão representa em massa $11,8 \%$ da CGA.

$\%$ papel cartão $=1 \mathrm{~kg} / \mathrm{m}^{2} / 8,5 \mathrm{~kg} / \mathrm{m}^{2}=11,8 \%$ da CGA.

Assim, o mercado potencial da indústria de cimento para os resíduos de CGA, no estado de São Paulo, é 158.048 x 1,118= 176.651 t/ano. Como visto, na RMSP são produzidos 3,6 mil t/ano de resíduos de CGA, valor muitas vezes inferior ao potencial de absorção calculado.

\section{Forma de aproveitamento:}

A utilização de resíduos na fabricação de cimento recebe frequentemente o nome de co-processamento. No entanto, Maringolo (2004) esclarece que o termo co-processamento "expressa a integração de dois processos em um, mais especificamente a utilização da manufatura industrial de um produto a altas temperaturas em fornos, fornalhas ou caldeiras, para destruição de resíduos industriais. No caso particular da indústria de cimento, co-processamento significa a produção de clínquer portland concomitante à queima de resíduos industriais no sistema forno”.

Segundo este autor, a demanda pelo co-processamento em indústrias de cimento deve-se ao fato da incineração "processo de engenharia que emprega a decomposição térmica 
através da oxidação a alta temperatura $\left(900^{\circ}\right.$.C ou maior) para destruir a fração orgânica do resíduo e reduzir o volume” - ser a tecnologia de tratamento que possui "maior capacidade de destruição e controle da maior variedade de resíduos”.

Segundo Maringolo (2004), “a função básica do resíduo no processo de queima do clínquer é complementar ou substituir parte do combustível ou matérias-primas convencionais. Quaisquer resíduos não-perigosos de processos industriais, cujos constituintes principais são os mesmos da farinha para fabricação do clínquer portland (CaO, $\mathrm{SiO} 2, \mathrm{Al} 2 \mathrm{O} 3$ e Fe2O3), podem ser utilizados como substitutos do material natural para correção da composição”.

\section{Restrições:}

Apesar do gesso (gipsita) presente no resíduo de CGA ser fonte de $\mathrm{CaO}$ e $\mathrm{SO}_{3}$, o uso deste resíduo, sem prévio tratamento, em indústrias de cimento apresenta algumas restrições. De fato, o seu co-processamento não é possível, primeiramente porque este resíduo não é fonte de energia atraente para substituir parte do combustível na queima do clínquer.

Segundo porque, conforme John e Cincotto (2003), no processo de fabricação de cimento, a adição de gipsita se dá na etapa de moagem do clínquer (para controle da pega), dentro do moinho de cimento, depois do clínquer já formado, isto é, ele não é adicionado no alto-forno (Figura 5.13).

Em terceiro lugar, porque as temperaturas no forno são de $900^{\circ} \mathrm{C}$ ou mais e a esta temperatura a gipsita (sulfato de cálcio dihidratado) não tem como produto final o gesso (sulfato de cálcio hemihidratado), mas, sim, a anidrita insolúvel (sulfato de cálcio) (CINCOTTO; AGOPYAN; FLORINDO, 1998). 


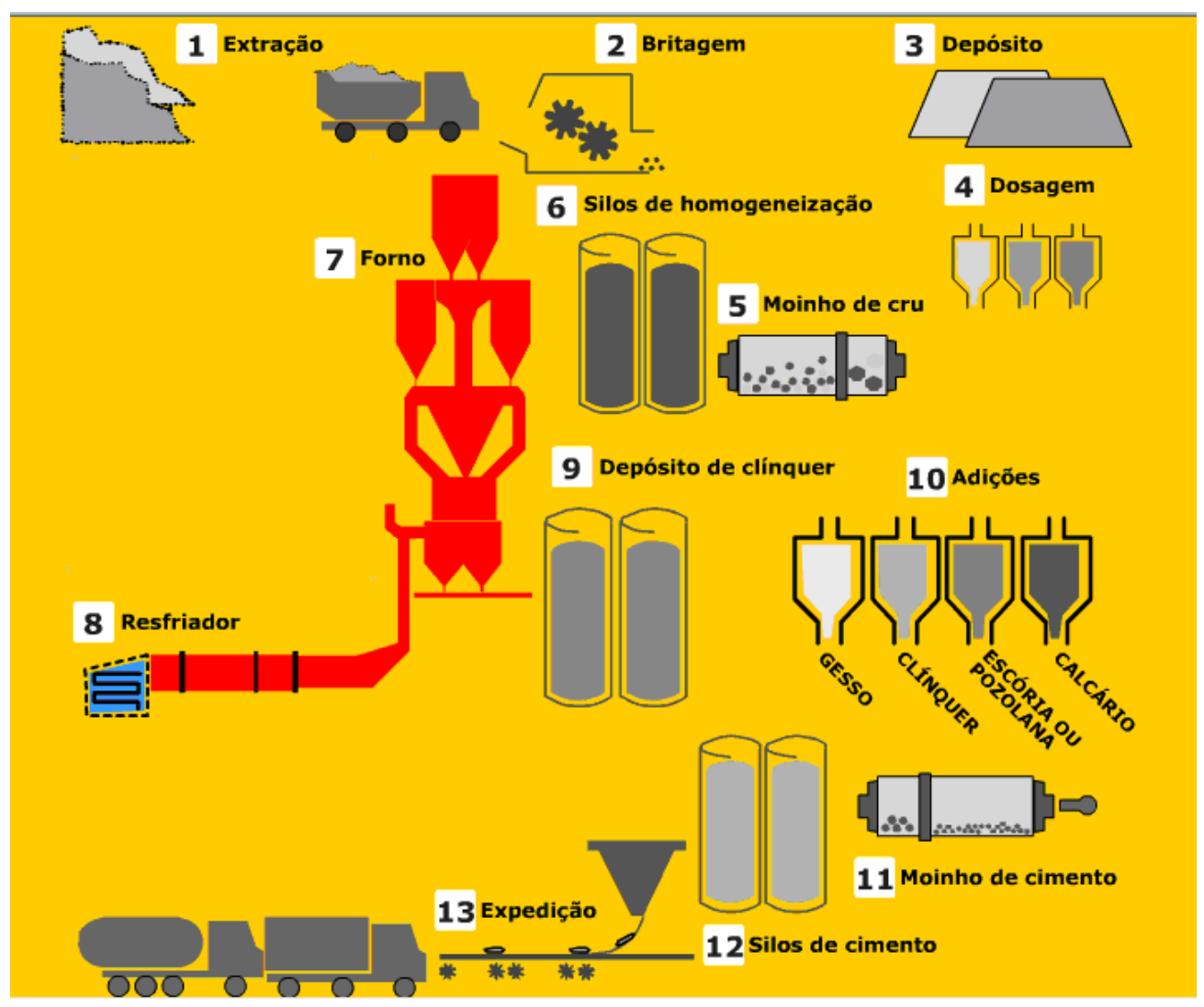

Figura 5.13 - Processo de fabricação de cimento (ABCP, 2006).

Portanto, ainda que se utilizassem os resíduos de CGA em adição à farinha crua no alto-forno, este processo não poderia ser chamado de co-processamento. Esta possibilidade ainda apresentaria as seguintes restrições técnicas:

- necessidade de um processo rígido de triagem dos resíduos na obra ou na ATT, visto que a presença de contaminantes pode causar grandes prejuízos tanto ao maquinário na indústria quanto à composição do produto cimento;

- o fato da composição química destes resíduos ser desconhecida e/ou variável, por causa dos aditivos utilizados durante a fabricação da CGA;

- a necessidade que sua composição seja conhecida e constante para o melhor controle dos elementos e suas proporções 
dentro do alto-forno, durante a formação do clínquer. Segundo Bhatty, Miller e Kosmatka (2004), elementos de enxofre podem estar presentes na produção de cimento na constituição de calcários, calcários argilosos, sedimentos argilosos, gesso e anidrita. Estes autores afirmam que o enxofre é uma substância volátil e seu comportamento no forno é complexo. A presença de enxofre $S$, na forma de sulfatos ou sulfetos é desejável e benéfica, mas o controle da reação de sulfatos e álcalis é complexo e seu desequilíbrio pode ocasionar: a deposição de material no pré-aquecedor, depreciando este equipamento; um alto nível de sulfato e álcalis na zona central do forno, incorrendo no descarte da tubulação secundária de poeira; aumento das emissões de $\mathrm{SO}_{2}$ dos fornos.

Constatou-se que a indústria de cimento estava realizando testes para o uso de resíduos de CGA em meados de 2006. O fabricante que realizou os testes foi contatado por meio de seu gerente de ecologia industrial e meio ambiente - Eng. Paulo Salomão, do Grupo Lafarge, e procedeu-se a coleta de informações por meio de mensagens eletrônicas, no período de outubro de 2006 a fevereiro de 2007.

Segundo o engenheiro (informação pessoal), para a indústria de cimento, "o segundo negócio mais importante, depois da própria fabricação do cimento, é a destruição e destinação de resíduos industriais diversos de forma ecologicamente correta, no processo industrial de fabricação do cimento. A indústria de cimento é o local adequado para destinação de uma enorme gama de resíduos, inclusive perigosos, para os quais não foram encontradas outras oportunidades de reciclagem".

Segundo Salomão (informação pessoal), o grupo de indústrias de cimento em questão possui seis fábricas. Nenhuma delas 
opera atualmente de forma regular com resíduo de CGA. No entanto, já foram realizados testes em duas fábricas. Foram testadas duas formas de resíduos: lotes apenas com resíduos de CGA e lotes com resíduos de gesso de revestimento, de placas pré-moldadas e moldes industriais, todos juntos ${ }^{27}$.

Os testes foram realizados nas fábricas de Itapeva - SP e Arcos - MG por serem as mais próximas da origem do resíduo, que era a ATT do Pari, em São Paulo - SP. Estes testes apontaram que, do ponto de vista de compatibilidade técnica (composição química), o uso dos resíduos de CGA no processo de fabricação de cimento é viável. Os aditivos presentes na massa de gesso da CGA não representaram problemas.

Os resíduos de CGA são adicionados, sem prévio tratamento, no moinho de clínquer. Segundo Salomão (informação pessoal) neste momento do processo de produção há uma medição da quantidade de sulfato existente no clínquer, para se determinar, de acordo com a pureza da adição, sua quantidade na dosagem. Como fontes de sulfatos podem ser adicionados fosfogesso, gesso 'caco', resíduos de CGA ou gipsita.

Apesar de terem sido realizados testes somente nestas duas fábricas, acredita-se que a utilização dos resíduos de CGA não apresente problemas nas demais fábricas, pois a tecnologia de produção é a mesma, havendo mínimas diferenças em relação aos equipamentos de produção.

No entanto, esta experiência identificou algumas dificuldades para a operacionalização de forma regular, do uso dos resíduos de CGA. Do ponto de vista técnico, a qualidade da triagem do resíduo de CGA e a presença do papel cartão restringem o uso destes resíduos. Segundo Paulo, "a presença de contaminação com outros resíduos da construção civil inviabiliza a operação,

${ }^{27}$ Este conjunto de resíduos é geralmente chamado pela indústria de cimento como resíduo de gesso em caco. 
sendo alguns contaminantes críticos, como por exemplo a presença de pedaços de aço. Já o acartonamento constitui uma limitação operacional no processo de produção de cimento. Isto porque o resíduo de CGA é adicionado sem prévio tratamento. Durante a moagem no moinho de clinquer, este papel cartão se desprende da massa de gesso. A umidade das demais matériasprimas que estão no moinho é evaporada e, junto com o papel cartão, forma uma pasta, de aspecto parecido com 'papel machê'. Esta pasta pode obstruir orifícios dos equipamentos $e$ prejudicar o maquinário. Em sistemas de produção de grande volume talvez esta formação não crie problemas. Portanto, a presença de papel cartão dificulta, mas não impede a utilização do resíduo de CGA na indústria de cimento.

Ainda de acordo com Salomão (informação pessoal) "não foi desenvolvida uma solução prática para separar o papel cartão da massa de propriamente dita. O ideal seria esta separação ocorrer antes do envio para a indústria de cimento. Provavelmente, a necessidade desta separação implicará em um custo adicional que deverá ser absorvido pelo gerador, ou incluído na prestação de serviço da cimenteira, caso esta assuma esta etapa de preparação do material”.

Abordando-se os fatores mercadológicos, Salomão (informação pessoal) afirma que não há lote mínimo para envio dos resíduos. No entanto, há a necessidade de uma regularidade no envio das cargas, uma vez que a indústria precisa programar-se em relação ao fornecimento dos resíduos e ter garantia de suprimento. Sem esta regularidade, o uso de resíduos de CGA é inviável para a indústria de cimento. Os lotes mínimos testados foram de $20 \mathrm{~m}^{3}$, transportados em caminhões basculantes.

Segundo Salomão (informação pessoal), estão se instalando no Brasil os primeiros 'blendadores'. Os chamados 'blendadores' 
são empresas que captam resíduos de diversas atividades industriais e, de acordo com uma dosagem, geram um produto interessante para a indústria de cimento. Algumas empresas no Brasil realizam esta atividade hoje mas, comumente, esta é uma atividade terceirizada.

As entrevistas realizadas com a ATT do Pari e com a indústria de cimento, e a visita realizada na $\mathrm{ABCP}$ permitiram concluir que há um impasse (trade-off) na comercialização dos resíduos de CGA.

Sob o ponto de vista da ATT, esta tem que ser adequadamente remunerada pelo serviço de triagem e armazenamento temporário prestado. Além disso, parte da renda da ATT advém da venda dos materiais/produtos recicláveis.

Do outro lado, a indústria de cimento não vê o resíduo de CGA, ainda que triado, como um sub-produto para sua produção. Apesar o uso deste resíduo gerar economia de matéria-prima, esta indústria acredita estar prestando um serviço de incineração para um resíduo não-inerte ou perigoso, e como tal, deve também ser adequadamente remunerada. Esta informação é confirmada por Salomão (informação pessoal), quando afirma que a atividade de incineração de resíduos caracteriza-se por uma prestação de serviço e, como tal, é cobrada dos diversos geradores de resíduos.

Segundo Salomão (informação pessoal), "os atuais operadores de ATT buscam oportunidades para a etapa anterior à destinação, ou seja, de reciclagem numa operação de venda. Como se vê, num primeiro momento, os interesses das ATT e cimenteiras ainda não são congruentes para o tratamento de resíduos da construção civil”. Assim, a indústria de cimento quer ser paga para destruir o resíduo e não pagar pelo resíduo. 
Ainda que fossem utilizados os 'blendadores', a remuneração destas empresas também é um ônus do gerador. Assim, a taxa de deposição paga pelo gerador teria que ser um montante suficiente para remunerar a ATT, remunerar em parte os 'blendadores', pagar os custos de incineração da indústria de cimento e ainda arcar com os custos de transporte envolvidos.

Há ainda um agravante: o volume de resíduos. Segundo Salomão, do ponto de vista prático os volumes evolvidos na operação têm influencia significativa no custo da prestação de serviços de destinação, podendo variar de $\mathrm{R} \$ 20,00 / \mathrm{t}$ para

grandes volumes até $\mathrm{R} \$ 200,00 / \mathrm{t}$ para pequenos volumes. A existência de ATT ainda é incipiente, o que leva nesta etapa a volumes pequenos e, portanto, a um custo de destinação mais elevado.

\section{Indústria de cimento consumindo gesso reciclado de resíduo} $\underline{\text { de } C G A}$

Para o gesso reciclado de resíduo de CGA - rCGA, foram levantadas três aplicações, dentre elas, a utilização pela indústria cimenteira. A aplicação do gesso reciclado de rCGA na indústria de cimento pretende que haja a inserção deste material em substituição à gipsita atualmente utilizada.

Para a venda de gesso reciclado de rCGA considerou-se, inicialmente, como possível mercado, todas as fábricas de cimento localizadas na região Sudeste e no estado do Paraná. No entanto, no levantamento das distâncias entre as fábricas e a RMSP, conforme a Tabela 5.4, foi possível identificar que todas as fábricas (à exceção da localizada em Volta Redonda-RJ) situadas fora do estado de São Paulo distavam da capital mais de $350 \mathrm{~km}$. Esta distância foi considerada pouco atrativa, pois o 
custo do frete teria uma grande influência na formação do preço de venda do gesso reciclado.

Tabela 5.4 - Distância do município de São Paulo até as fábricas de cimento localizadas na região Sudeste e no estado do Paraná (baseado em SNIC, 2006).

\begin{tabular}{|c|c|c|}
\hline Origem & Destino & $\mathbf{K m}$ \\
\hline \multirow{26}{*}{ São Paulo - SP } & Apiaí - SP & 324 \\
\hline & Cajati-SP & 233 \\
\hline & Cubatão - SP & 55 \\
\hline & Itapeva - SP & 320 \\
\hline & Mogi das Cruzes - SP & 58 \\
\hline & Ribeirão Grande - SP & 247 \\
\hline & Salto de Pirapora - SP & 121 \\
\hline & Sorocaba - SP & 87 \\
\hline & Votorantim - SP & 104 \\
\hline & $\overline{A r c o s}-\mathrm{MG}$ & $\overline{500}$ \\
\hline & Barroso - MG & 530 \\
\hline & Carandaí - MG & 531 \\
\hline & Ijaci-MG & 365 \\
\hline & Itaú de Minas - MG & 407 \\
\hline & Matozinhos - MG & 643 \\
\hline & Montes Claros - MG & 996 \\
\hline & Pedro Leopoldo - MG & 630 \\
\hline & Santana do Paraíso - MG & 742 \\
\hline & Vespasiano - MG & 615 \\
\hline & Cantagalo - RJ & $\overline{548}$ \\
\hline & Rio de Janeiro - RJ & 429 \\
\hline & Volta Redonda - RJ & 321 \\
\hline & Balsa Nova - PR & $\overline{443}$ \\
\hline & Rio Branco do Sul - PR & 425 \\
\hline & Cachoeiro de Itapemirim - ES & 770 \\
\hline & Serra - ES & 884 \\
\hline
\end{tabular}

Assim, optou-se por analisar os custos de frete somente para as fábricas localizadas no estado de São Paulo.

Conforme demonstrado no item anterior, a indústria de cimento consome cerca de $158 \mathrm{mil} \mathrm{t/ano} \mathrm{de} \mathrm{gesso} \mathrm{(gipsita),} \mathrm{no} \mathrm{estado} \mathrm{de}$ São Paulo. Portanto, este é o mercado potencial da indústria de cimento para os resíduos de gesso (gipsita) neste estado. 
Assim como os resíduos de CGA, o gesso reciclado de rCGA também encontra algumas restrições ao seu uso. Em relação aos aspectos técnicos, destaca-se a variabilidade de sua composição. Acredita-se que enquanto não houver um controle mínimo de sua composição média o gesso reciclado rCGA não será visto como sub-produto pela indústria do cimento, a qual não estará disposta a comprá-lo, mesmo a um preço menor que o da gipsita natural.

\section{Mercado:}

Conforme demonstrado anteriormente o mercado da indústria de cimento para o gesso reciclado de resíduo de CGA é de 158.048 t/ano.

\section{Restrições de mercado:}

Os fatores restritivos relativos ao mercado que inibem o uso de gesso reciclado de resíduos de CGA em indústrias de cimento são: fornecimento direto, capacidade de estocagem e presença de produto substituto no mercado.

Algumas empresas de cimento possuem, no grupo empresarial à qual pertencem, empresas mineradoras de gipsita, localizadas no Pólo Gesseiro de Araripina. Outras possuem relações de parceria com mineradoras há anos, estabelecidas em contratos de fornecimento de longo prazo. Em ambos os casos as indústrias cimenteiras conseguem ter garantia de fornecimento e confiabilidade de entrega.

Além destas duas vantagens, há a de preço. A gipsita natural é uma matéria-prima barata e abundante, com baixo valor agregado. No entanto, conforme mencionado anteriormente no item 5.2.1.1, o preço do transporte da gipsita varia de acordo com as safras de produtos agrícolas na região Nordeste. 
Assim, as indústrias de cimento aproveitam para comprar grandes quantidades de gipsita durante a entressafra, com um custo de transporte baixo, e a estocam para não sofrer o impacto do aumento do preço do frete durante a safra.

\section{Restrição de mercado: Produto substituto:}

De acordo com Canut (2006) "em algumas fábricas de cimento das regiões sul e sudeste do Brasil, a gipsita natural já é substituída pelo resíduo fosfogesso”.

Segundo a Empresa Brasileira de Pesquisa Agropecuária EMBRAPA (2006), o fosfogesso (também denominado gesso agrícola) é um sub-produto da fabricação de fertilizantes fosfatados. Sua denominação deve-se ao fato deste conter resíduos de fósforo na sua composição $(0,7 \%$ a $\quad 0,9 \%)$ (NUERNBERG; RECH; BASSO, 2005). “As indústrias de fertilizantes, durante o processo de fabricação de superfosfatos, simples e triplo, e fosfatos de amônio, MAP e DAP, usam como matéria prima a rocha fosfática, geralmente a fluorapatita. Esta, ao ser atacada com ácido sulfúrico, na presença de água, forma como subprodutos o sulfato de cálcio, ácido fosfórico e ácido fluorídrico, de acordo com a seguinte equação" (EMBRAPA, 2006):

\section{$\mathrm{Ca}_{10}\left(\mathrm{PO}_{4}\right)_{6} \mathrm{~F}_{2} \mathrm{~S}+10 \mathrm{H}_{2} \mathrm{SO}_{4}+20 \mathrm{H}_{2} \mathrm{O} \longrightarrow 10 \mathrm{CaSO}_{4} \cdot 2 \mathrm{H}_{2} \mathrm{SO}(\mathrm{S})+6 \mathrm{H}_{3} \mathrm{PO}_{4}+2 \mathrm{HF}$}

O esquema da Figura 5.14 ilustra simplificadamente o processo de produção de fertilizantes.

Os dados da eficiência industrial coletados no estudo da EMBRAPA (2006) apontam que, para cada tonelada de $\mathrm{P}_{2} \mathrm{O}_{5}$ obtida, são produzidas 4,5 toneladas de fosfogesso. Essa relação evidencia o grande acúmulo deste material em plantas industriais ligadas ao setor de fertilizantes. 


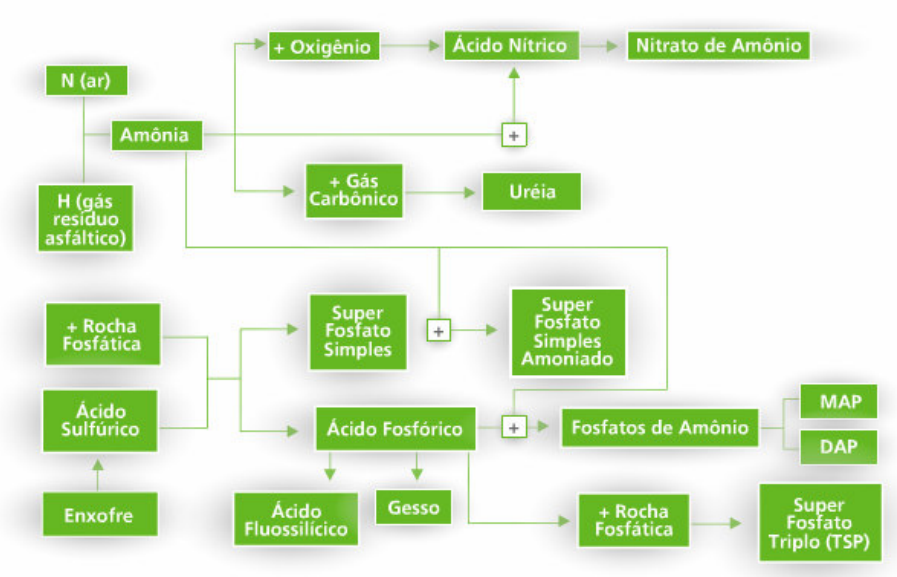

Figura 5.14 - Esquema simplificado de produção de fertilizantes (FOSFÉRTIL, 2006).

Segundo o MCT (2006) "no Brasil, o volume de fosfogesso chega a 6,5 milhões de t/ano, com maior concentração nos estados de São Paulo, Minas Gerais e Goiás”. A destinação de fosfogesso não é um problema somente para o Brasil. "As principais pesquisas em andamento sobre utilização desse material são na agricultura, principalmente para correção de acidez de solo, na cobertura de aterros sanitários, na pavimentação de estradas e como substituto do gesso natural na produção de blocos de cimento para a construção civil” (MCT, 2006). O fosfogesso é um sub-produto abundante e de baixo custo. Segundo Smith $(2006)^{28} " a$ Bélgica, por exemplo, reaproveita $60 \%$ da produção de fosfogesso, e o restante ainda permanece estocado em pilhas ao ar livre".

A estimativa de Aquino (2005) apresentada na Tabela 5.5 (dados de 2004) para a produção nacional está bem abaixo da relatada pelo MCT (2006). No entanto, é possível identificar que

\footnotetext{
${ }^{28}$ Paul Smith - workshop internacional sobre os usos do fosfogesso. O encontro integra a série de eventos da $3^{\text {a }}$ Conferência Internacional de Usuários de Reatores TRIGA (26/08/2006), no Minascentro, em Belo Horizonte - MG.
} 
atualmente o maior consumidor nacional do fosfogesso é a agricultura, seguido pela indústria de cimento.

Tabela 5.5 - Produção e consumo de fosfogesso no Brasil (AQUINO, 2005).

\begin{tabular}{|l|l|}
\hline \multicolumn{2}{|c|}{ Produção e Consumo de Fosfogesso } \\
\hline Produção estimada & 4,5 milhões de t/ano \\
\hline Consumo agrícola & 1,7 milhões de t/ano \\
\hline Consumo na indústria de cimento & 0,7 milhões de t/ano \\
\hline Excedente anual & 2,1 milhões de t/ano \\
\hline
\end{tabular}

Tomando-se por base as proporções apresentadas por Aquino (2005) e a estimativa do MCT (2006), tem-se que o excedente anual seria de aproximadamente 3 milhões de t/ano.

Além do grande volume disponível, o fosfogesso ainda apresenta a vantagem, sobre o gesso reciclado de rCGA, de ser gerado, em sua maioria, na região Sudeste, próximo às indústrias de cimento. Assim, além de possuir um custo baixo do material, possui também um baixo custo de transporte.

\section{Restrições técnicas:}

Segundo Lyra Sobrinho et al. (2001), estudos realizados na França indicam que as dificuldades para a utilização do fosfogesso com gesso para revestimento passam pelo "alto teor de umidade que representa um consumo de energia equivalente ao dobro daquele observado quando se utiliza a gipsita natural; a presença de impurezas (traços de ácido, compostos de flúor, ferro), sob formas complexas, as quais atrapalham a rehidratação e a cristalização do gesso; a granulometria muito 
fina e a coloração variável dos fosfatos, transmitida ao fosfogesso".

Para o seu uso como adição na indústria de cimento, acredita-se que, dentre os aspectos levantados, apenas a presença de impurezas poderia influenciar negativamente esta aplicação.

A radioatividade presente no fosfosgesso pode constituir uma restrição técnica ao seu uso na indústria de cimento. Segundo Canut (2006) "o uso do fosfogesso como material de construção, principalmente em ambientes onde a taxa de ventilação é baixa, pode provocar impactos radiológicos devido à exalação do gás radônio $\left({ }^{222} \mathrm{Rn}\right)$ ser um risco de se obter doenças cancerígenas (RABI; SILVA, 2005 apud CANUT, 2006)”. Segundo esta autora, como as normas brasileiras não estabelecem um limite máximo de exalação deste gás, utiliza-se os limites estabelecidos pela USEPA (Agência de Proteção Ambiental dos Estados Unidos).

No entanto, Canut (2006) ressalta que "o fosfogesso gerado no Brasil, bem como a rocha mãe que dá origem ao resíduo, apresenta baixos níveis de radioatividade natural, abaixo do limite máximo fixado pela USEPA”, não apresentando, portanto, riscos de contaminação para os usuários, manipuladores, etc.

Em relação ao mercado, a expansão do uso de fosfogesso diminuiria a possibilidade de fornecimento de gesso reciclado (rCGA) para as indústrias de cimento.

Além da possibilidade de obter receita da venda de fosfogesso, as empresas de fertilizantes têm interesse na utilização do fosfogesso em outras indústrias como forma de diminuir os custos de deposição deste resíduo. Segundo Freitas (1992) apud Canut (2006), o tratamento do fosfogesso é, geralmente, por via úmida, onde este é enviado como polpa para lagoas de sedimentação, onde decanta e depois de seco formam-se pilhas 
de fosfogesso. A disposição em pilhas exige a disponibilidade de grandes áreas, de um projeto de impermeabilização e um estrutural das pilhas, assim como o monitoramento das pilhas por profissionais especializados (FREITAS, 1992).

Aquino (2005) atenta que há demanda de estudos para desenvolvimento da qualidade do fosfogesso para a indústria de cimento (especificações como de granulometria, umidade, teor de fósforo, acidez e teor de fluor, por exemplo) e para a agricultura (granulometria), aspectos que representam as principais restrições à expansão do uso de fosfogesso atualmente.

Isto significa que tanto na aplicação na indústria de cimento quanto na agricultura, como correção de solos, o gesso reciclado de rCGA possui um produto concorrente competitivo, o qual tem investido em pesquisa para a expansão de seu uso.

De acordo com John e Cincotto (2003) a utilização de gesso reciclado adicionado ao cimento Portland dificilmente será importante porque existem em muitas regiões outras fontes de sulfato de cálcio, como o fosfogesso e o resíduo de gesso industrial, de elevada pureza.

\subsubsection{2.b. Alternativa de consumo: Correção de solos}

De acordo com a EMBRAPA (2006), “os nutrientes [do solo] têm sua disponibilidade determinada por vários fatores, entre eles o valor do pH, medida da concentração (atividade) de íons hidrogênio na solução do solo”.

Os solos ácidos possuem grande quantidade de íons de hidrogênio, apresentam baixa disponibilidade de cálcio $(\mathrm{Ca})$, magnésio $(\mathrm{Mg})$, fósforo $(\mathrm{P})$, nitrogênio $(\mathrm{N})$ e potássio $(\mathrm{K})$, alta 
saturação por alumínio (Al) e alta capacidade de fixação de fósforo (SOUSA, 2005; LOPES; GUILHERME, 1994).

“A acidez do solo limita a produção agrícola em consideráveis áreas no mundo, em decorrência da toxidez causada por Al e Mn e baixa saturação por bases" (COLEMAN; THOMAS, 1967 apud CAIRES et al., 2003). De acordo com Sousa (2005) "as raízes da plantas não se desenvolvem bem em solos ácidos, sobretudo por causa da toxidez de Al e da deficiência de Ca”.

No Brasil, a maioria dos solos sob vegetação do bioma Cerrado "apresenta baixos teores de cálcio associado ou não à toxidez de alumínio não apenas na camada arável, mas principalmente abaixo desta, o que tem limitado o crescimento das raízes $e$ comprometido a produção das lavouras” (SOUSA, 2005).

A solução comumente adotada para superar esse problema na camada arável é a utilização do calcário.

De acordo com os dados de Joly (2002), do Governo do Estado de São Paulo (2006), do IBGE (2004) e da EMBRAPA (2006), tem-se que o bioma cerrado ocupa atualmente menos de $1 \%$ do território do Estado de São Paulo, ou seja, aproximadamente $2.488,08 \mathrm{~km}^{2}$. Desta área, cerca de $70 \%$ é composta por solos ácidos, totalizando $1.741,66 \mathrm{~km}^{2}$. Considerando-se que em média aplica-se duzentas toneladas de fosfogesso por quilômetro quadrado $\left(200 \mathrm{t} / \mathrm{km}^{2}\right)$ estima-se que o mercado potencial para esta aplicação seja de 348.331,2 t/ano no estado de São Paulo.

Segundo a EMBRAPA (2006), “nos solos do Cerrado, a deficiência de cálcio, associada ou não à toxidez de alumínio, não ocorre apenas na camada arável, mas também abaixo dela”.

Korndörfer (2004) explica que "a reação do calcário aumenta a quantidade de $\mathrm{OH}^{-}(>\mathrm{pH}$ ), aumenta a CTC (capacidade de 
troca cationica), aumenta a quantidade de cargas negativas $e$ também aumenta a capacidade do solo em reter bases (K, $\mathrm{Mg}$ e Ca). No entanto, há a liberação de $\mathrm{CO}_{3}^{2-} "$ ".

$$
\begin{gathered}
\mathrm{CaCO}_{3}=\mathrm{Ca}^{2+}+\mathrm{CO}_{3}^{2-} \\
\mathrm{CO}_{3}^{2-}+\mathrm{H}_{2} \mathrm{O}=\mathrm{CO}_{2}+2 \mathrm{OH}^{-}
\end{gathered}
$$

O mesmo autor, comparando o uso do calcário e do gesso, afirma que "no caso do calcário o ânion ou íon acompanhante $\left(\mathrm{CO}_{3}^{-2}\right)$ reage com a água transformando-se em $\mathrm{CO}_{2}$, o qual é perdido (emitido) para a atmosfera. Assim o $\mathrm{Ca}^{2+}$, não tendo um ânion acompanhante irá lixiviar/deslocar menos no perfil (do solo), ficando mais retido na superfície de troca ou adsorvido pelas argilas".

Portanto, a calagem (processo de aplicação de calcário no solo) não corrige a acidez e a deficiência de cálcio da subsuperfície em tempo razoável para evitar que o agricultor corra risco de perda de produtividade devido aos veranicos.

A outra opção para a correção do $\mathrm{pH}$ tem sido a aplicação de gesso. De acordo com EMBRAPA (2006), “o gesso em contato com o solo e com umidade suficiente, sofre inicialmente uma dissolução, segundo a equação:

$$
\mathrm{CaSO}_{4} \cdot 2 \mathrm{H}_{2} \mathrm{OH}_{2} \mathrm{O} \longrightarrow \mathrm{Ca}^{+2}+\mathrm{SO}_{4}{ }^{-2}+\mathrm{CaSO}_{4}{ }^{0}+4 \mathrm{H}_{2} \mathrm{O}
$$

Os íons cálcio deslocam outros cátions como o $\mathrm{Al}, \mathrm{K}, \mathrm{Mg}$ e $\mathrm{H}$, porquanto os íons sulfato formam complexos químicos solúveis neutros como $\mathrm{MgSO}_{4}{ }^{\circ}, \mathrm{K}_{2} \mathrm{SO}_{4}{ }^{\circ}$ como também $\mathrm{AlSO}_{4}{ }^{\circ}$ ". Sendo assim, diferentemente do que ocorre em aterros, os íons de sulfato não formam gás sulfídrico $\left(\mathrm{H}_{2} \mathrm{~S}\right)$ quando utiliza-se o gesso nesta aplicação.

Segundo o CIWMB (2006), o gesso prove aos solos os seguintes benefícios: melhora a penetração da água e a trabalhabilidade em um solo alcalino impermeável; supre o solo com alto 
conteúdo de cálcio; ajuda a neutralizar a acidez do solo; e provê cálcio e enxofre como nutrientes para as plantas.

\section{Restrições:}

\section{Restrição técnica: Presença de componentes químicos:}

Embora não se tenha dados disponíveis sobre a composição química das CGA fabricadas no Brasil, os dados de Carr e Munn (1997) indicam a presença de metais pesados e Boro em CGA norte-americanas. A presença de Boro, em alguns solos, pode retardar ou mesmo impedir o crescimento de determinadas plantas (CARR; MUNN, 2001). Segundo CIWMB (2006), o Boro é adicionado às CGA para conferir a propriedade de retardo ao fogo. Embora muito Boro possa ser tóxico para as plantas, ele é também um nutriente para elas e sua adição pode ser benéfica em solos onde o nível de Boro é baixo, como aqueles derivados de materiais vulcânicos. Ambos os trabalhos (CARR; MUNN, 2001, CIWMB, 2006) afirmam ser necessária uma verificação prévia da influência deste elemento em determinados solos.

\section{Restrição de mercado: Produto concorrente:}

No entanto, uma grande porção dos solos ácidos requer, além de cálcio, fornecimento de enxofre. Nestes casos, a utilização de fosfogesso, também chamado de gesso agrícola, é particularmente interessante. $\mathrm{O}$ fosfogesso também possui como vantagem sobre o gesso a possibilidade de fornecer também fósforo e flúor, benéficos ao solo.

Segundo Vitti e Malavolta (1983 apud EMBRAPA, 2006), a composição média do fosfogesso é: umidade livre 15-17\%; $\mathrm{CaO}$ 
26-28\%; $\mathrm{S} 15-16 \% ; \mathrm{P}_{2} \mathrm{O}_{5} 0,6-0,75 \%, \mathrm{SiO}_{2}$ insolúveis $1,26 \%$; Flouretos $0,63 \%$ e óxidos de $\mathrm{Al}$ e $\mathrm{Fe}$ 0,37\%.

O gesso agrícola mostra-se mais efetivo na redução da toxidez de Al do que o sulfato de cálcio puro por causa da presença de $\mathrm{F}^{-}$,um ânion que forma complexos mais estáveis com $\mathrm{Al}$ do que o $\mathrm{SO}_{4}{ }^{2-}$ (CAMERON; RITCHIE; ROBSON, 1986 apud CAIRES et al., 2003).

Segundo Korndörfer (2004), “o gesso agrícola (fosfogesso), devido a sua alta solubilidade, consegue penetrar mais facilmente no perfil do solo do que o calcário; fornecer Ca em profundidade; reduzir a saturação de Al em sub-superfície; aprofundar o sistema radicular; melhorar a distribuição do sistema radicular; aumentar o peso/volume de raízes; favorecer a absorção de água e nutrientes; e propiciar uma maior tolerância das plantas aos veranicos" (Figura 5.15).

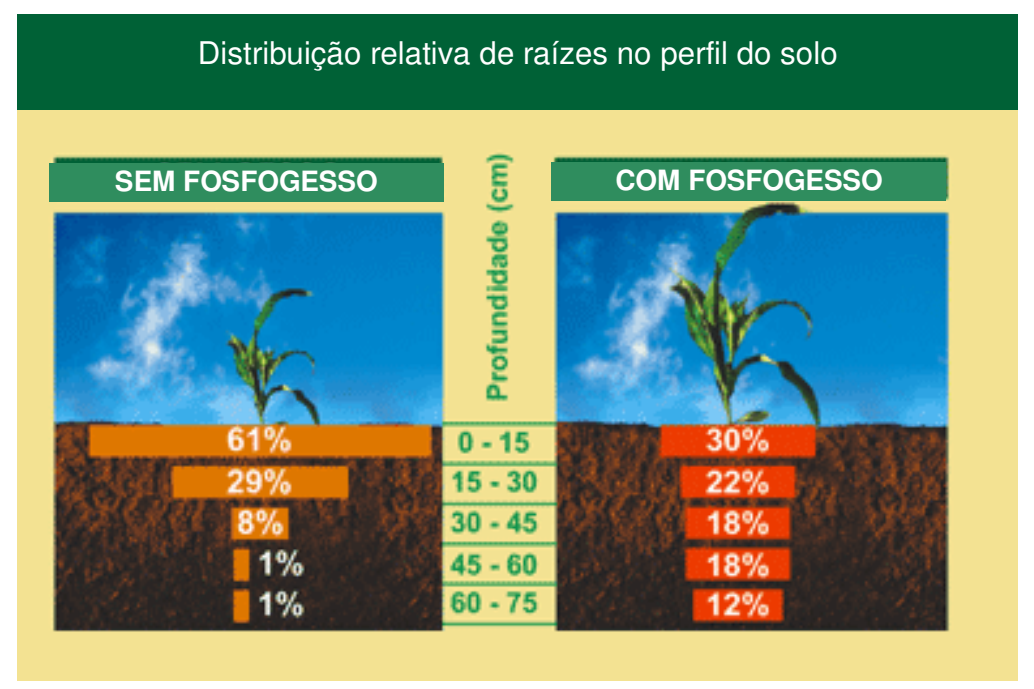

Figura 5.15 - Distribuição relativa de raízes no perfil do solo com e sem o uso de fosfogesso (EMBRAPA, 2006).

Portanto, o desenvolvimento de um mercado para a utilização de gesso reciclado de rCGA como corretivo de solos demonstra-se 
pouco provável em função, principalmente, do fosfogesso possuir vantagens técnicas e preço mais atrativo (menor).

Segundo Marvin (2000), o valor do resíduo de CGA como corretor de solos é menor do que se ele fosse reciclado em uma nova CGA. Além disso, na agricultura moderna um número de fertilizantes de alta qualidade e misturas de calcário estão disponíveis no mercado. Agricultores não estarão dispostos a pagar por um produto, o qual não prove possuir a mesma ou maior capacidade de fertilização e neutralização.

De acordo com Musick (1992), “o uso do gesso e das fibras de papel provenientes da reciclagem de gesso acartonado em compostagem e aditivos para solos, atualmente, não é visto como alternativa potencial devido ao alto $\mathrm{pH}$ destes produtos, à presença de traços de dioxinas e furanos encontrados no papel cartão da placa e devido a contaminantes, como, por exemplo, os pelo menos 12 tipos de aditivos utilizados na fabricação de diferentes chapas, e que incluem sabões, ácido bórico, cola de silicione, sulfato de potássio, fibra de vidro, dispersantes em água e emulsões asfálticas, entre outros, os quais não podem entrar em contato com o solo”, sob pena de poluí-los.

5.2.2.3.2.c. Alternativa de consumo para papel cartão presente nos resíduos de CGA por indústria de papel

Para esta análise foi realizada em setembro de 2006 uma visita técnica a uma empresa de papel localizada na cidade de Londrina (PR), denominada indústria 'P'. A empresa pertence a um grupo multinacional norte-americano com mais de 280 plantas industriais situadas em diversos países.

A planta industrial em questão utiliza como matéria-prima somente aparas de papel, ou seja, resíduos de papel e papelão de 
outras indústrias e consumidores. Estes resíduos apresentam diversas classificações e podem ter como origem o próprio processo industrial ou resíduos de pós-consumo. São utilizados também os resíduos em forma de polpa de celulose, conforme Figura 5.16. As empresas responsáveis pela coleta e classificação dos resíduos de papel e papelão são chamadas de aparistas.
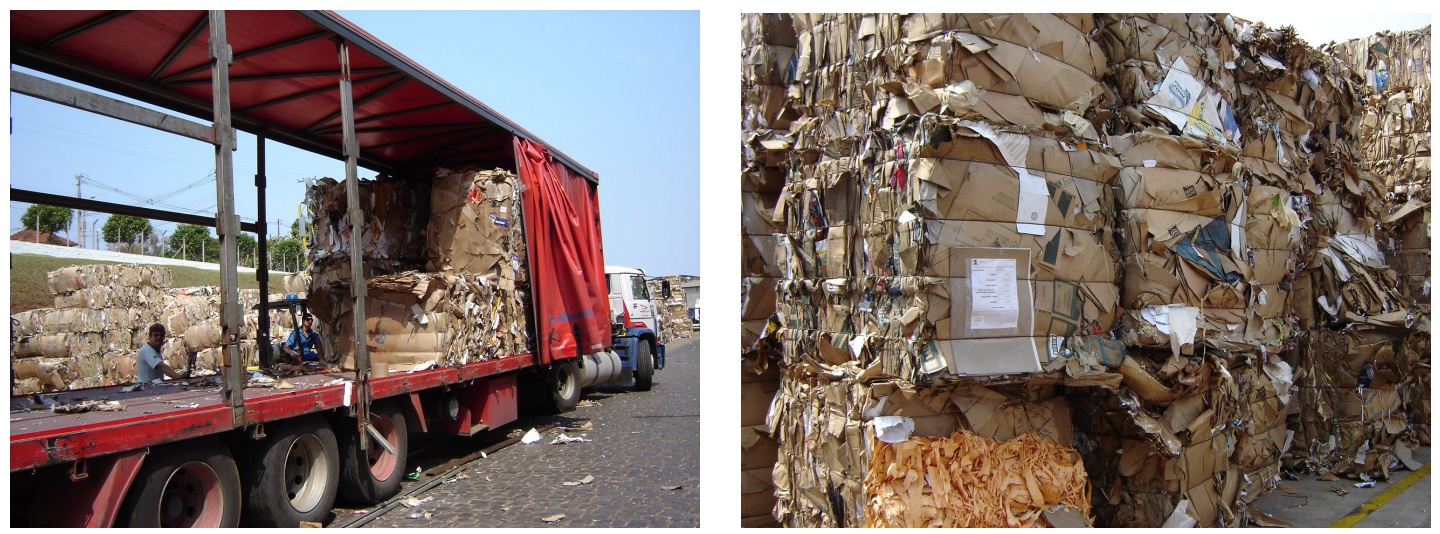

Figura 5.16 - Transporte e identificação de aparas (resíduos) de papel utilizados na fábrica ' $P$ ' (autora, 2007).

Os resíduos de papel e papelão constituídos por fibras longas são mais valorizados pela indústria de papel. Este é o caso do papel cartão que constitui as CGA. Este papel, de fibra longa, poderia ser reaproveitado na indústria de papel, tanto em tamanhos grandes - quando proveniente da separação do papel cartão da massa de gesso na ATT, por processo manual; quanto em pequenas tiras - quando proveniente da central de reciclagem.

No entanto, as restrições ao uso dos resíduos de papel cartão de CGA devem-se ao teor de massa de gesso impregnado no mesmo. A presença de cálcio e óxido de cálcio no processo de produção do papel é prejudicial porque causa um aumento da dureza da água que circula no processo, causando um depósito deste material nos cilindros de aço da máquina e sua conseqüente depreciação, prejudica a colagem, e impregna e 
tampa os poros do feltro da mesa formadora, diminuindo assim sua capacidade de retenção de água (Figura 5.17). Além disso, o processo de produção do papel não é capaz de desagregar polímeros, os quais provavelmente estariam presentes nas CGA (e consequentemente em seus resíduos) na forma de aditivos ou impermeabilizantes.
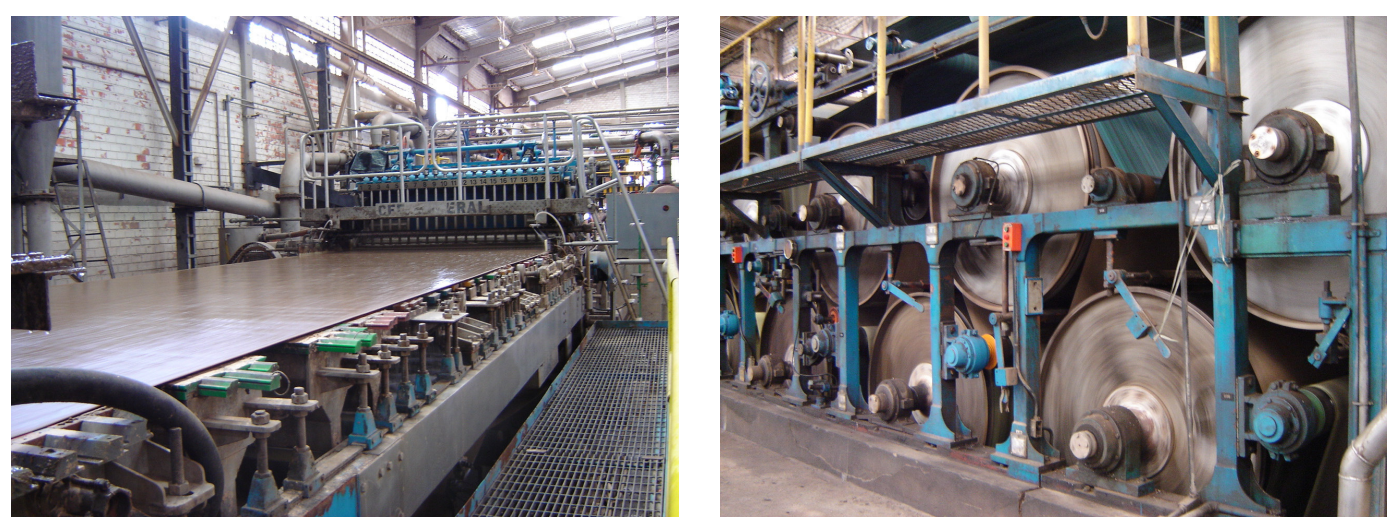

Figura 5.17 - Ilustração da mesa formadora e dos cilindros de secagem e conformação do papel na indústria 'P' (autora, 2007).

\subsection{Fatores Intervenientes na CONSOLIDAÇÃo dos Sistemas Logísticos ReVERSOS DE RECICLAGEM DE RESÍDUOS DE CGA - SLR- R-RCGA.}

Analisa-se neste item como os fatores levantados em 3.3.1 se aplicam especificamente à cadeia de CGA, influenciando sua viabilidade técnica, econômica, ambiental e social.

Primeiramente são apresentados os fatores que interferem no SLR-R-rCGA como um todo, independentemente do produto que será gerado pelo sistema. Os fatores abordam as características e comportamentos dos fluxos, dos CDR e dos agentes envolvidos. A Tabela 5.6 traz uma síntese dos fatores que intervêm na consolidação dos SLR-R-rCGA, os quais são desenvolvidos em seguida.

Já nos itens 5.3.1 e 5.3.2 analisam-se os fatores relacionados especificamente aos $\mathrm{CDR}$, os quais diferem entre si de acordo com o produto que o CDR visa produzir. 
Tabela 5.6 - Síntese dos fatores intervenientes na consolidação de sistemas logísticos reversos de reciclagem de resíduos de chapas de gesso acartonadoSLR-R-rCGA (autora, 2007).

- características regionais de consumo

- existência de tecnologia de reciclagem de rCGA

- dificuldade de identificação e separação dos rCGA das demais frações de gesso

- dificuldade em se distinguir o gesso (gipsita) reciclado do gesso (gipsita) natural

- onerosidade do transporte de coleta dos resíduos

- baixa disponibilidade do resíduo

- incerteza quanto à oferta de resíduos no mercado: existência, quantidade, qualidade e prazo

- preço da matéria-prima original

- necessidade de estoques para proteger a produção

- necessidade de gatekeeping e políticas de devolução

- decisão pela verticalização ou terceirização

- análise das componentes do custo para determinar a viabilidade

- custos das opções de destinação

- impacto ambiental do processo de reciclagem

- ausência de políticas de longo prazo para a gestão dos resíduos

- ausência de informações sobre os resíduos

- existência de interesses conflitantes entre os agentes envolvidos

- interesse dos produtores dos resíduos na reciclagem

- posicionamento e grau de integração dos agentes envolvidos

- Características regionais de consumo. O baixo consumo de CGA em outras regiões do Brasil, provavelmente, não justifica a implantação de centrais de reciclagem. Ainda que se reunisse o volume de resíduos produzidos por algumas regiões próximas, os custos logísticos, principalmente de transporte 
para coleta, tornariam a implantação inviável economicamente. No entanto, este não é o caso da região Sudeste.

- Existência de tecnologia de reciclagem de rCGA. As tecnologia de reciclagem de rCGA existem, mas encontram-se em outros países. Não é possível conhecê-las tecnicamente a fundo porque constituem-se no segredo industrial de cada fornecedor. Apesar de existirem apenas fornecedores estrangeiros, esta tecnologia está disponível para ser importada. Pode-se optar pela aquisição somente de maquinário, como o da Andela Products Inc. (Figura 5.18), ou de sistemas logísticos reversos de reciclagem de rCGa completos, como os oferecidos pela Gypsum Recycling Inc. (ver Anexo A) em oito países, e pela New West Gypsum (HOMEL, 1999). Acredita-se que o volume de rCGA existente na RMSP justifique a importação só da máquina de reciclagem. Em relação à eficiência, é possível a reciclagem de $100 \%$ do material introduzido.

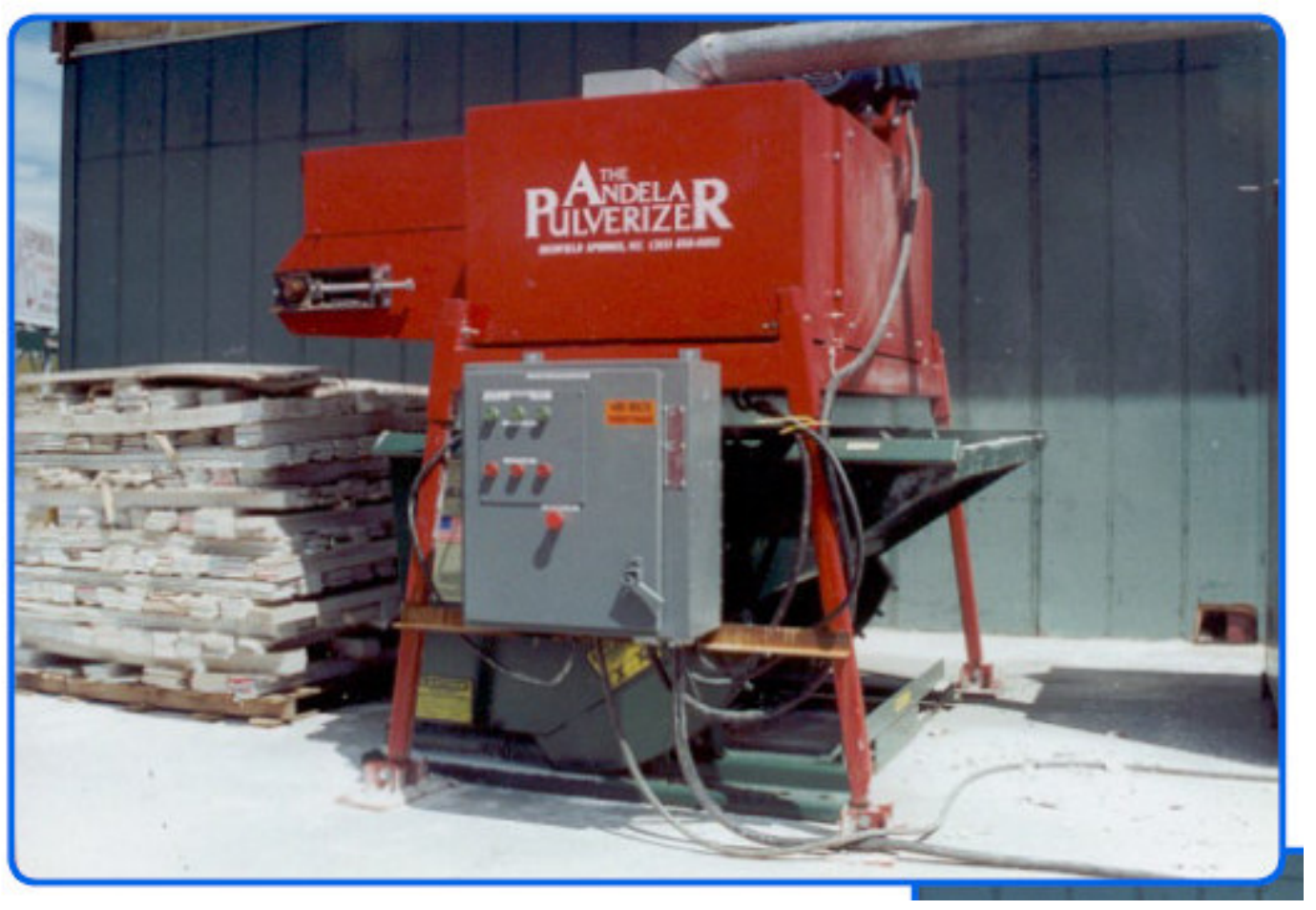

Figura 5.18 - Equipamento de reciclagem de resíduos de CGA (ANDELA, 2006). 
- Não há dificuldade de identificação e separação dos rCGA das demais frações de gesso pois os resíduos de CGA possuem em suas faces o papel cartão, de coloração e textura diferente daquela da massa de gesso. Além disso, encontra-se impresso em suas lâminas de papel cartão a especificação da CGA como fabricante, espessura, dimensão e lote. Não é necessário haver distinção entre as CGA padrão (standard), resistentes à umidade (RU) e resistentes ao fogo $(\mathrm{RF})$ porque a tecnologia de reciclagem não exige esta separação.

- Dificuldade em se distinguir o gesso (gipsita) reciclado do gesso (gipsita) natural. Deve-se estudar mecanismos para distinção entre o gesso (gipsita) reciclado e a gesso (gipsita) natural, visando um melhor controle da adição de material reciclado durante o processo de produção, tanto da CGA quanto do cimento, e do número de vezes em que o material já sofreu reciclagem. Os estudos sobre a reciclabilidade do gesso ainda estão sendo desenvolvidos, não havendo, no momento, conclusões concretas a este respeito.

- Onerosidade do transporte de coleta dos resíduos. Os resíduos de CGA são volumosos, leves se comparados aos resíduos classe $\mathrm{A}$, como solos e argamassas, e possuem baixo valor agregado. Estas características oneram o custo de transporte dos resíduos. O estabelecimento de rotas para coleta dos rCGA que atendam a vários canteiros de obras é possível. No entanto, os resíduos de CGA são gerados durante um curto espaço de tempo no canteiro de obras, cerca de poucos meses. Assim, os pontos de coleta mudam constantemente, de um canteiro de obras para outro. Isto exigiria alterações dinâmicas das rotas de coleta, as quais nem sempre tornar-se-iam eficientes. Deste modo, a opção pelo transporte do resíduo ficar a cargo do gerador é justificada pela imprecisão/inconstância dos pontos de coleta/geração de resíduo/consumo. O acondicionamento dos resíduos de CGA deve procurar aproveitar o máximo volume do recipiente. Os recipientes amplamente utilizados são as caçambas metálicas de $4 \mathrm{~m}^{3}$ para transporte por caminhões poliguindaste. No entanto, pode-se utilizar também bags. 
- Baixa disponibilidade do resíduo. A precisão da estimativa de disponibilidade de resíduo de CGA é fundamental para a determinação da capacidade de processamento da central de reciclagem. Uma estimativa imprecisa pode ocasionar estoque excessivo (se a disponibilidade for maior do que a prevista) ou ociosidade e paradas na produção (se for menor). O consumo de CGA na RMSP, se comparado ao de outros países, tanto os desenvolvidos quanto os em desenvolvimento, é bastante baixo. Por conseqüência, apesar desta relação não ser diretamente proporcional, a quantidade de resíduos de CGA também é pequena. A disponibilidade do resíduo de CGA depende, além da quantidade de resíduos gerada, da acessibilidade a ele. Esta acessibilidade, neste caso, é representada pela abrangência de captação do resíduo, e medida pelo que se denominou taxa de captação. Isto significa que, por exemplo, caso se gere 500 kg de resíduo de CGA em determinado canteiro de obras, mas este resíduo não chegue a central de reciclagem - seja porque o gerador não está comprometido com a correta destinação, seja pelo alto custo de transporte, ou ainda pela possibilidade de outra destinação adequada mais barata - , não se tem acesso a esta quantia do resíduo, significa que não foi possível captá-lo. Para proteger a central de reciclagem de ociosidade ou parada de produção por falta de suprimento (resíduo de CGA) a taxa de captação considerada foi arbitrada em $60 \%$, considerada realista, pois, a central de reciclagem estará em um raio de até $60 \mathrm{~km}$ dos principais pontos de consumo. Esta taxa poderia atingir $100 \%$ desde que a legislação e a fiscalização quanto ao destino dos resíduos de CGA fossem mais rígidas.

- Incerteza quanto à oferta de resíduos no mercado: existência, quantidade, qualidade e prazo. Os resíduos de produção de CGA são reinseridos no processo de produção das CGA por todos os fabricantes devido à sua composição conhecida e constante e ao conhecimento prévio de sua quantidade. Já os resíduos de CGA provenientes do canteiro de obras apresentam impurezas e contaminantes que dificultam a identificação de sua composição. Embora a tecnologia de reciclagem retire as contaminações físicas, como resíduos plásticos e metálicos, e separe o papel cartão da massa de gesso, ela não é capaz de separar contaminantes da massa de gesso. A 
influência destas impurezas tanto nos processos de produção - das CGA e do cimento - quanto nos produtos (CGA com conteúdo reciclado e cimento com gesso reciclado) é desconhecida até o momento. Há um temor de possíveis danos aos equipamentos de produção ou de malefícios à qualidade dos produtos, mas estes não foram comprovados tecnicamente. A segregação dos resíduos de CGA e o controle de sua contaminação durante o acondicionamento, estoque e transporte são primordiais para garantir a qualidade do resíduo de CGA e potencializar a viabilidade dos canais reversos. De acordo com John e Cincotto (2003), “este tipo de medida depende da conscientização das empresas especializadas em gesso, construtores, engenheiros e operários, papel que cabe às organizações setoriais”. Em relação à quantidade, pode-se ter por parâmetro as vendas de CGA. Segundo os fabricantes não há grande variação nas vendas durante o ano. Existe uma pequena concentração de vendas entre junho e dezembro, que representa $60 \%$ das vendas anuais. Além disso, a CGA é utilizada para vedação interna e, portanto, o regime de chuvas não altera o seu consumo no canteiro de obras. No entanto, os índices de produtividade e perda variam enormemente. Poucos levantamentos sobre ambos índices foram realizados até agora. Os já realizados apontam índices de perda médios de CGA de 4\% a $12 \%$, ou seja, uma variação de $300 \%$. Os índices de produtividade e o ritmo de produção da obra determinam a estimativa de prazo, ou seja, em quanto tempo haverá um montante mínimo, por exemplo, uma caçamba de $4 \mathrm{~m}^{3}$ cheia, para coleta e entrega na central de reciclagem.

- Preço da matéria-prima original. Apesar de a gipsita ter um baixo custo, cerca de $\mathrm{R} \$ 18,00 / \mathrm{t}$, o custo do transporte até a região Sudeste é de aproximadamente $\mathrm{R} \$ 120,00 /$ t. Este significativo custo de transporte faz com que os preços da gipsita reciclada tenham possibilidade de ser competitivos nesta região.

- Necessidade de estoques para proteger a produção. Os estoques de resíduos de CGA são vitais para proteger a máquina recicladora de paradas por falta de suprimento. Devem ser suficientes para tal, mas não tão grandes que 
representem custos demasiados. Acredita-se que, devido não existirem outras experiências de reciclagem de CGA ou similares, a determinação do tamanho ideal do estoque se dará por tentativas, após o início de operação da central.

- Necessidade de gatekeeping e políticas de devolução. Conforme já mencionado, as políticas de devolução são elaboradas geralmente pelos fabricantes e definem os requisitos que os produtos devem atender e os procedimentos para a devolução. No caso da RMSP, o retorno dos resíduos de CGA aos fabricantes é inviável para dois deles, pois se localizam muito distantes do local onde o resíduo é gerado. Apenas para o fabricante que se localiza na RMSP é viável o retorno dos resíduos. Assim, há duas opções. Quando a reciclagem é realizada pelo fabricante é ele quem deve estabelecer a política de devolução. Quando realizada por central de reciclagem independente, os três fabricantes devem auxiliá-la no estabelecimento de tal política. A política deve determinar as exigências em relação ao resíduo e ao trâmite comercial, como, por exemplo, índice de contaminação, produtos proibitivos, lote mínimo, prazo máximo entre venda e retorno do resíduo, aceitação de resíduo produzido somente por seus próprios produtos, etc. As exigências em relação ao resíduo são estabelecidas de acordo com a tecnologia de reciclagem empregada. O gatekeeping consiste em um ou mais funcionários treinados para, de acordo com o sistema de inspeção adequado, fazer a seleção entre as cargas de resíduos que atendem ou não à política de devolução. Este processo impede que cargas indevidas sejam aceitas ou até mesmo processadas pela central de reciclagem.

- Decisão pela verticalização ou terceirização ${ }^{29}$ das atividades. No caso das CGA trata-se de uma decisão estratégica do fabricante localizado na RMSP. No entanto, se optar pela terceirização, provavelmente a associação de fabricantes de CGA terá que apoiar tecnicamente a implantação de tal empresa, pois esta irá operacionalizar o reaproveitamento dos resíduos de CGA de todos os três fabricantes.

\footnotetext{
${ }^{29}$ A terceirização das atividades, neste caso, não significa a contratação de uma empresa terceira pelo fabricante, pois ele não é o responsável legal e único pelo resíduo. Significa não verticalizar, deixando a atividade à disposição para a iniciativa privada estabelecer novo negócio, e ainda estimular a sua criação.
} 
- Análise das componentes do custo para determinar a viabilidade. O custo de processamento de reciclagem de resíduos de CGA é potencialmente maior do que o custo para obtenção da matéria-prima original (gipsita natural) principalmente porque envolve os custos de triagem e de equipamentos mais sofisticados. Além disso, os custos de transporte dos rCGA constituem parcela significativa no estudo da viabilidade dos canais reversos de reciclagem de rCGA. No capítulo 6 apresenta-se a análise de viabilidade econômica de possíveis SLR-R-rCGA, na RMSP. Para estas análises a apropriação de custos se deu em função de experiências de reciclagem de RCD classe A. Já as viabilidades ambiental e social foram analisadas somente de forma qualitativa, raciocinando sobre o potencial impacto da reciclagem de CGA, em virtude da dificuldade de valorar os aspectos intangíveis.

- Custos das opções de destinação. Conforme mencionado, o principal destino atual dos resíduos de CGA é o aterro sanitário. Não obstante os problemas técnicos e ambientais de tal prática, já discutidos, observa-se por meio das simulações que a taxação das descargas de resíduos de CGA em aterro é um mecanismo que de grande potencial para viabilizar os canais reversos de CGA (CIWMB, 2006).

- Impacto ambiental do processo de reciclagem. O processo de reciclagem de CGA tem como principais aspectos ambientais a serem considerados o consumo de energia elétrica, a emissão de material particulado (poeira) e a emissão de $\mathrm{CO}_{2}$ devido ao transporte. A maioria dos equipamentos de reciclagem possui dispositivo de captação e armazenamento da poeira gerada durante o processo. No entanto, o manejo do resíduo de CGA e do gesso reciclado também emite poeira e a mitigação de seu impacto deve ser prevista durante a operação. Embora a emissão de $\mathrm{CO}_{2}$ já ocorra no transporte dos resíduos de CGA até as ATT ou aterros, ela pode aumentar em função do aumento da distância percorrida até a central de reciclagem. Além disso, existe também o transporte de distribuição até os clientes. O consumo de energia elétrica da central de reciclagem é pequeno em relação a outras 
indústrias. Apesar destes fatores, um estudo de análise de ciclo de vida de CGA deve atestar tais impressões.

- Ausência de políticas de longo prazo para a gestão dos resíduos. Conforme mencionado anteriormente, a descontinuidade das políticas relativas à gestão de resíduos atrasa o estabelecimento de legislações, regulamentações, procedimentos e normas técnicas vinculados a elas. Para a cadeia da CGA na RMSP são necessários: Plano Integrado de Gerenciamento de Resíduos da Construção Civil dos municípios que compõem a RMSP; regulamentação do Plano Integrado Municipal sobre as penalidades ao seu descumprimento; determinação da implantação de aterros específicos para resíduos classe C; elaboração dos procedimentos de implantação, operação e manutenção de aterros para resíduos classe $\mathrm{C}$; proibição de deposição de resíduos classe $\mathrm{C}$ em aterros sanitários ou de resíduos domiciliares; e estabelecimento de normas que determinem o teor máximo de resíduos classe $\mathrm{C}$ como contaminantes de outras classes de RCD, assim como seu mecanismo de medição deste teor, dentre outras medidas.

- Ausência de informações sobre os resíduos. A ausência de informações e de divulgação de informações sobre a composição, as quantidades e a eficiência do processo de produção das CGA pode acarretar a utilização de informações errôneas e suposições equivocadas em levantamentos indiretos. Além de dificultar o estudo de viabilidade técnica-econômica dos canais reversos de reaproveitamento, impede a livre comercialização dos resíduos de CGA. Como exemplo, o CIWMB (2006) possui um programa de reciclagem disponível 'on-line' em sua página eletrônica ${ }^{30}$ onde é possível realizar a busca de RCD por vários critérios, objetivando a sua comercialização.

- Existência de interesses conflitantes entre os agentes envolvidos no canal reverso de resíduos de CGA, como, por exemplo, a divergência apontada entre a ATT do Pari e a indústria de cimento.

- Interesse dos produtores dos resíduos na reciclagem. Embora algumas construtoras tenham demonstrado firme propósito em estabelecer sistemas de

${ }^{30}$ Construction \& Demolition Debris Recycling Database. Disponível em: http://www.ciwmb.ca.gov/ConDemo/. 
gerenciamento de resíduos e obedecer aos procedimentos impostos pela Resolução n. 307 (CONAMA, 2002), no caso dos resíduos de CGA, estas empresas não dispõem de alternativas para a destinação adequada. Seria necessário haver uma firme disposição dos fabricantes de CGA, os quais conhecem as características dos resíduos e podem ser os principais beneficiados pela reciclagem. Para estimular o estabelecimento dos canais reversos de reciclagem de resíduos de CGA, políticas públicas como a taxação de deposição destes resíduos em aterros e o subsídio fiscal à produção de gesso reciclado poderiam ser formuladas.

- Posicionamento e grau de integração dos agentes envolvidos. A consolidação do SLR-R-rCGA depende da disposição, comprometimento e negociação entre os diversos agentes envolvidos, como forma de estabelecer claramente as responsabilidades de cada um, seu papel na eficiência do todo e relações do tipo 'ganha-ganha', que tragam benefícios mútuos. No caso da cadeia de CGA verifica-se que os agentes contemplados nesta pesquisa possuem grau de integração baixo, havendo pouca comunicação e integração de processos.

\subsubsection{Fatores Intervenientes na Consolidação dos CDR de reciclagem de CGA visando à produção de nova CGA com conteúdo reciclado}

Este item apresenta os fatores particulares relativos à consolidação do CDR-RrCGA visando à produção de CGA com conteúdo reciclado. A Tabela 5.7 apresenta a síntese destes fatores, os quais são desenvolvidos na seqüência.

Tabela 5.7 - Fatores intervenientes na consolidação dos CDR-R-rCGA, visando a produção de nova CGA com conteúdo reciclado (autora, 2007).

- existência de fabricante próximo ao principal centro consumidor

- possibilidade de consumir CGA com conteúdo reciclado para a mesma função da CGA original/tradicional

- impossibilidade de produzir uma CGA com $100 \%$ de conteúdo 
reciclado

- mercado insuficiente ou não-desenvolvido para o produto originado no ciclo reverso

- incerteza quanto à demanda por produtos reciclados ou com conteúdo reciclado: quantidade, qualidade e prazo

- dificuldade de introdução de novas tecnologias

- Existência de fabricante próximo ao principal centro consumidor. Uma das principais dificuldades dos canais de distribuição reversos de pós-consumo é a coleta dos resíduos, devido à dispersão geográfica dos pontos de consumo. No caso dos CDR de Reciclagem de rCGA, existe um fabricante localizado na RMSP, próximo ao 'pólo' de consumo. Esta facilidade é maximizada pelo fato de ser justamente este, dentre os três fabricantes, aquele que já possui uma central de reciclagem vinculada à linha de produção e, portanto, aquele que se demonstrou mais comprometido com a questão ambiental dos resíduos de CGA, tanto de processo quanto de pósconsumo.

- Possibilidade de consumir CGA com conteúdo reciclado para a mesma função da CGA original/tradicional. Esta possibilidade facilita a aceitação do consumidor por este novo produto. Além disso, as exigências do consumidor em relação ao produto já são conhecidas, assim como o padrão de qualidade e custo requeridos pelo mercado.

- Impossibilidade de produzir uma CGA com $100 \%$ de conteúdo reciclado. As experiências internacionais (HOMEL, 1999; GYPSUM RECYCLING, 2006) apontam que as tecnologias de reciclagem atuais permitem valores máximos de $25 \%$ de adição de material reciclado, em massa, em novas CGA.

- Mercado insuficiente ou não-desenvolvido para o produto originado no ciclo reverso - CGA com conteúdo reciclado. Quando o produto originado pelo ciclo reverso é a CGA com conteúdo reciclado, existem duas possibilidades de aplicação. A primeira é ser um novo produto com 
qualidade e desempenho inferiores à CGA tradicional, mas suficientes para outras aplicações, onde as exigências sejam mais brandas. A segunda é concorrer com a CGA tradicional apresentando qualidade e desempenho equivalentes a um preço mais baixo. Na cadeia de CGA há a necessidade de desenvolvimento de mercado para a CGA com conteúdo reciclado. Ambas aplicações precisam desenvolver seus mercados. A possibilidade de certificação ambiental deste produto, juntamente a uma forte campanha de marketing, podem auxiliar na resistência dos consumidores aos produtos com conteúdo reciclado. As ações de marketing devem ainda ressaltar a qualidade e desempenho da CGA com conteúdo reciclado. Este fator é visto como o mais crítico para a viabilidade da cadeia reversa de CGA.

- Incerteza quanto à demanda por produtos reciclados ou com conteúdo reciclado: quantidade, qualidade e prazo. A incerteza quanto à demanda de CGA com conteúdo reciclado é alta, em virtude do mercado consumidor não estar desenvolvido. A qualidade e o prazo de entrega das CGA com conteúdo reciclado devem ser equivalentes à CGA tradicional ou ao produto concorrente.

- Dificuldade de introdução de novas tecnologias. Acredita-se que a CGA com conteúdo reciclado aplicada para o mesmo fim que a CGA tradicional não requeira mudanças em sua tecnologia de uso. Não haverá, portanto, introdução de nova tecnologia para os instaladores e construtoras, mas somente a substituição de um componente por outro similar. Apesar disto, pode haver resistência dos clientes em relação à CGA com conteúdo reciclado se ela for vista como 'produto alternativo'. Isto porque as normas prescritivas impedem que novos produtos, como as CGA com conteúdo reciclado, comprovem seu desempenho. Contudo, as CGA com conteúdo reciclado não devem proporcionar alto impacto sobre a redução de custos do sistema de vedação interna. 


\subsubsection{Fatores Intervenientes para a Consolidação dos CDR de reciclagem de CGA visando à produção de gesso (gipista) reciclado.}

Os fatores intervenientes à consolidação dos CDR-R-rCGA visando a produção de gesso (gipsita) reciclado para a indústria de cimento e a agricultura, são apresentados em síntese na Tabela 5.8 e, em seguida, desenvolvidos no texto.

Tabela 5.8 - Fatores intervenientes na consolidação dos CDR-R-rCGA, visando a produção de gesso (gipsita) reciclado para a indústria de cimento e a agricultura (autora, 2007).

- existência de indústrias de cimento e de solos ácidos em quase todas as regiões do Brasil

- possibilidade do gesso (gipsita) reciclado substituir a gipsita natural

- eficiência da tecnologia de reciclagem

- mercado insuficiente ou não-desenvolvido para o produto originado no ciclo reverso

- incerteza quanto à demanda por produtos reciclados ou com conteúdo reciclado: quantidade, qualidade e prazo

- dificuldade de introdução de novas tecnologias

- Existência de indústrias de cimento e de solos ácidos em quase todas as regiões do Brasil. No caso dos resíduos de CGA, a existência de indústrias de cimento próximas à RMSP significa a presença de mercado consumidor próximo à central de reciclagem, o que proporciona fretes menores e possibilidade de custos mais atrativos. Os solos ácidos do Cerrado não se localizam tão próximo da RMSP quanto as indústrias de cimento, sendo um mercado de mais difícil acesso.

- Possibilidade do gesso (gipsita) reciclado substituir a gipsita natural. A possibilidade do gesso (gipsita) reciclado substituir a gipsita natural sem necessitar de processamentos intermediários, utilizando o mesmo processo de produção facilita a aceitação da indústria de cimento e da agricultura por 
este novo produto. Para tal aceitação o gesso (gipsita) reciclado precisa também atender às exigências de qualidade e possuir custo competitivo.

- Eficiência da tecnologia de reciclagem. A tecnologia de reciclagem permite que $100 \%$ do material introduzido seja reaproveitado. Considerando-se que o papel cartão representa, em massa, aproximadamente $11 \%$ da CGA se obtém no processo $89 \%$ de gipsita reciclada.

- Mercado insuficiente ou não-desenvolvido para o produto originado no ciclo reverso - gesso (gipsita) reciclado. Para o gesso (gipsita) reciclado o mercado da indústria de cimento se mostra mais atrativo em função de seu volume de consumo, da proximidade das indústrias de cimento da RMSP e da possibilidade de se agregar valor ao produto. Já para o mercado de uso agrícola, para solos ácidos, há menores possibilidades de se agregar valor ao produto. Há atualmente três estudos em andamento, segundo o CIWMB (2006) investigando o uso dos resíduos de CGA como corretores de solo (BURGER, 1993; DIXON, [s.n]; KORCAK, 1996). O gesso (gipsita) reciclado pode ter maior valor agregado se tratado como produto, com garantia de composição, de qualidade adequada às exigências, confiabilidade de entrega e certificação ambiental de produto, entre outras ações.

- Incerteza quanto à demanda por produtos reciclados ou com conteúdo reciclado: quantidade, qualidade e prazo. A incerteza quanto à demanda de gesso (gipsita) reciclado para a indústria de cimento e para o uso em agricultura é baixa. Isto porque, no caso do cimento, a produção não sofre muitas variações e o teor de gesso necessário para a produção também não varia. Já na agricultura, prevê-se que o processo de gessagem seja necessário a cada safra, ou seja, na mesma época do ano. Somente a área cultivada pode variar um pouco, o que resultaria numa variação do consumo de gesso reciclado. A qualidade do gesso reciclado deve ser condizente com estas aplicações, assim como a prazo e a confiabilidade de entrega. 
- Dificuldade de introdução de novas tecnologias. O uso de gesso (gipsita) reciclado não altera a tecnologia de produção utilizada na indústria de cimento e na correção da acidez do solo. Desde que o gesso (gipsita) reciclado apresente características e comportamento equivalentes ao da gipsita natural, as indústrias de cimento e os agricultores possuirão baixa resistência à sua substituição.

As análises realizadas demonstraram a diversidade de fatores que interferem nos sistemas logísticos reversos, por estes abordarem assuntos multidisciplinares. Estas análises suportam o estabelecimento de recomendações e linhas de ação apresentadas nas conclusões. 


\section{6 - Análise de Viabilidade Econômica de possiveis Sistemas Logísticos Reversos para Resíduos de Chapas de Gesso Acartonado - CGA}

Este capítulo tem por objetivo demonstrar a análise de viabilidade econômica de possíveis cadeias reversas de CGA. A partir das informações e resultados obtidos no 
capítulo 5, e baseada em um método, realizou-se o levantamento de custos e outros parâmetros para subsidiar as análises.

Procedeu-se a simulação de alguns cenários para a análise de viabilidade econômica de algumas configurações de cadeias reversas. As possibilidades de configuração da cadeia reversa tiveram origem na combinação de cinco variáveis. O item 6.2 demonstra a análise de viabilidade econômica para dez diferentes simulações.

Por fim, com base nas análises de viabilidade econômica, conclui-se sobre os impactos dos custos de deposição no custo da obra, para os grandes geradores; a economia de matéria-prima para o fabricante e a possibilidade de se estabelecer uma cadeia reversa de ciclo fechado para os resíduos de CGA.

\subsection{Método Utilizado Para ANálise de Viabilidade ECONÔMICA}

Os cálculos anteriores e as análises feitas situam claramente a questão da aplicação do conceito de logística reversa na gestão dos resíduos de CGA, na RMSP, e os diversos fatores intervenientes presentes. As análises feitas apontam para duas possíveis iniciativas para alterar a prática atual: a implantação de uma Central de Reciclagem de Resíduos de CGA; ou, a ampliação de uma central de reciclagem pertencente a um dos fabricantes de CGA.

Existem trabalhos publicados internacionalmente que poderiam embasar estudos sobre a viabilidade econômica de centrais de reciclagem (por exemplo, DEKKER; BARROS; SCHOLTEN, 1998; e HSIAO et al., 2002). No entanto, estes trabalhos não foram adotados como modelo pelo fato da análise de viabilidade ser determinada por fatores econômicos e de mercado locais, os quais diferem da realidade brasileira. Dos trabalhos desenvolvidos no Brasil, aquele que mais se aproxima do presente caso é o elaborado por Jadovski e Masuero (2006). Este trabalho apresenta uma metodologia de análise de viabilidade econômica de usinas de reciclagem de RCD, desenvolvido principalmente por meio de entrevistas e visitas às usinas de reciclagem existentes no Brasil, localizadas nos municípios de Belo Horizonte (MG) e São Paulo, Vinhedo, Socorro e Piracicaba (SP). Portanto, este é o trabalho mais 
adequado ao caso da análise de viabilidade de centrais de reciclagem de CGA na RMSP. Sendo assim, adota-se a metodologia proposta por Jadovski e Masuero (2006).

Embora pudessem ser utilizados métodos mais elaborados e detalhados para a análise de viabilidade econômica, não se analisa aqui a metodologia. Nesta pesquisa, ela é empregada como ferramenta para demonstrar como os resultados obtidos no capítulo 5 podem ser utilizados para simulações de cenários.

A partir da metodologia adotada são apresentadas dez análises de viabilidade econômica. Estas análises têm origem na combinação das seguintes variáveis: iniciativa, capacidade, taxa de descarga, receita/economia de matéria-prima e financiamento (Figura 6.1).

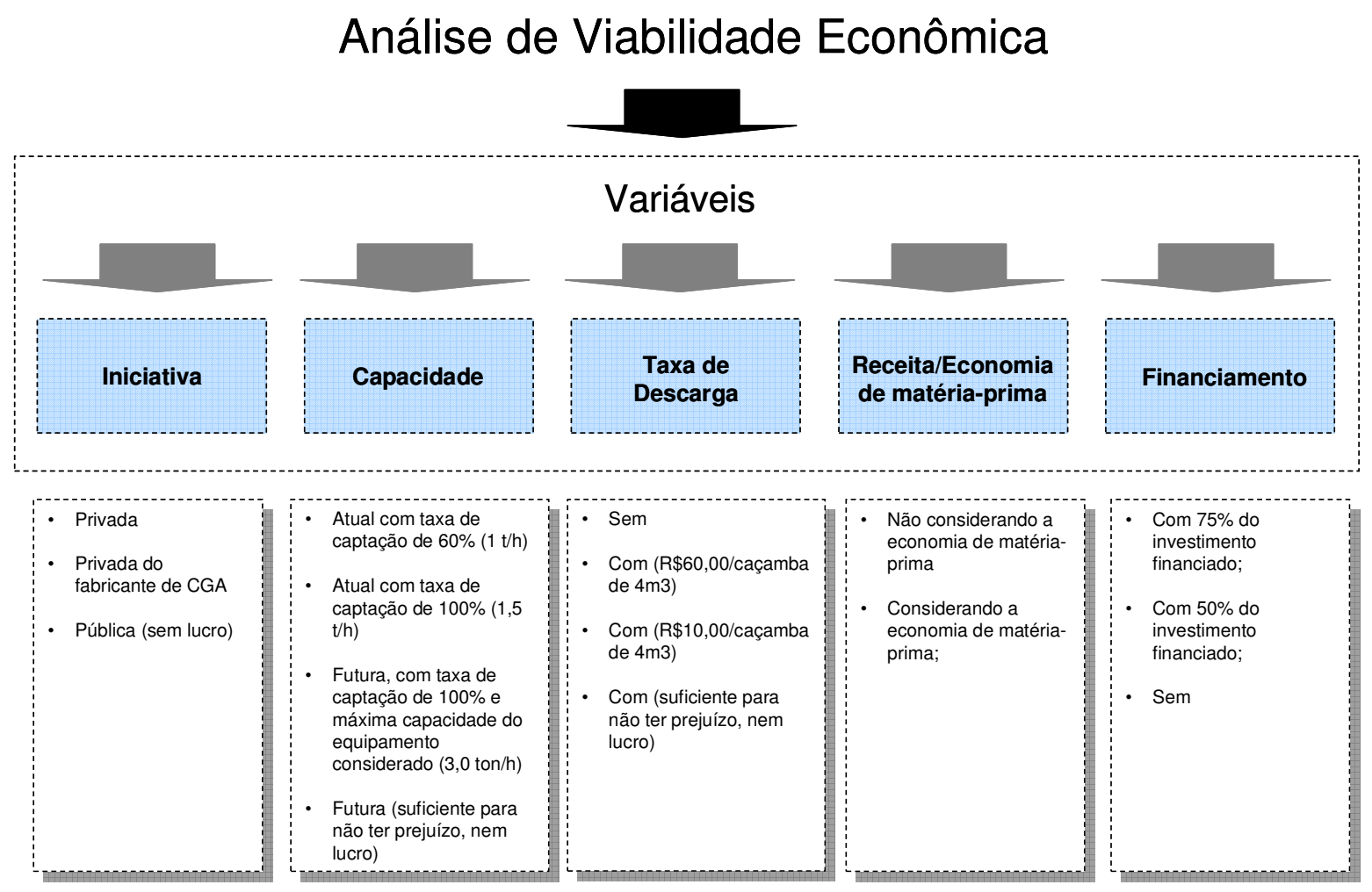

Figura 6.1 - Variáveis consideradas para as análises de viabilidade econômica da implantação de Central de Reciclagem de resíduos de CGA (autora, 2007).

A primeira variável considera as hipóteses de um agente da iniciativa privada investir na abertura de uma central de reciclagem de resíduos de CGA; ou a possibilidade de 
um fabricante localizado no estado de São Paulo, o qual já possui uma máquina recicladora, substituir a tecnologia atual por uma mais moderna; ou a possibilidade de um agente público implantar uma central de reciclagem de resíduos de CGA.

A variável 'Capacidade' diz respeito à capacidade de produção da central. O equipamento considerado pode produzir de 1 a $3 \mathrm{t} / \mathrm{h}$ (capacidade nominal) de gesso reciclado. No entanto, sua produção depende de quanto resíduo de CGA estará disponível para ser processado. Portanto, esta variável está diretamente relacionada com a taxa de captação. A taxa de captação corresponde à relação entre a quantidade de resíduos de CGA que será recebida - disponível para ser processada - e a quantidade total de resíduos de CGA gerados na área considerada (RMSP). Por exemplo, atualmente gera-se na RMSP aproximadamente 1,5 t/h de resíduos de CGA. Se a taxa de captação é de $60 \%$, significa que a central de reciclagem receberá $60 \%$ de 1,5, isto é, terá disponível 0,9 t/h de resíduo de CGA para ser processado. Por conseguinte, a taxa de captação de $100 \%$ corresponde a uma situação em que todo o resíduo de CGA gerado se destina para aquela Central de Reciclagem. A capacidade de 3t/h simula um cenário futuro, onde haverá uma maior geração de resíduos de CGA, devido a um aumento nas vendas de CGA.

A variável 'Taxa de descarga' corresponde à possibilidade da central de reciclagem, ou do fabricante que a possui, cobrar, ou não, uma taxa de deposição sobre os resíduos de CGA. As taxas foram escolhidas em função das outras opções de deposição que o gerador possui. A taxa de $\mathrm{R} \$ 10,00 /$ caçamba de $4 \mathrm{~m}^{3}$ corresponde ao valor praticado atualmente para a deposição de resíduos em aterros públicos. Já a taxa de $\mathrm{R} \$ 60,00 /$ caçamba de $4 \mathrm{~m}^{3}$ equivale a um preço $20 \%$ maior do que o cobrado pela ATT; acredita-se que este seria o máximo valor que os geradores estariam dispostos a pagar por uma adequada deposição. O terceiro item desta variável considera a hipótese da iniciativa pública e, portanto não visa lucro, apenas a taxa necessária para que a central de reciclagem não tenha prejuízo na operação.

Em relação à receita/economia de matéria-prima, as hipóteses são se esta receita será considerada ou não para viabilizar o negócio, principalmente a etapa de implantação. 
Por fim, a última variável contempla as possibilidades de financiamento da etapa de implantação, sendo possível não optar pelo financiamento, financiar 50\%, ou financiar $75 \%$ do investimento.

As análises obedecem às seguintes etapas: 1 - É realizado o balanço de operação da central, comparando os custos e as despesas; 2 - determina-se os custos de implantação e a forma de financiamento (ou a sua ausência); 3 - compara-se os resultados obtidos à expectativa de retorno do investimento.

Os dados obtidos inicialmente no trabalho de campo indicam uma tendência a nãoviabilidade da central, principalmente devido ao baixo consumo de CGA, e consequentemente à pequena produção de resíduos de CGA.

Quando as receitas obtidas não suportam os custos/despesas, ou seja, quando o resultado líquido é negativo, não se prossegue com a análise. Do contrário, parte-se para as demais etapas da análise.

\subsubsection{EXPECTATIVA DE RETORNO DO INVESTIMENTO}

\subsubsection{AVALIAÇÃo DA ATRATIVIDADE Do InVESTIMENTO}

Segundo Lima Júnior (1993), “a comparação entre as duas situações de liquidez é que leva aos indicadores principais da análise de investimentos. Ou seja, do ponto de vista do empreendedor, como será seu interesse em perder poder de compra, imobilizando-se no empreendimento quando investe, para ganhar poder de compra no futuro, em montante maior, quando receber o retorno".

Desta forma, o investidor necessita de indicadores que o permitam avaliar o investimento e decidir sobre a aplicação, ou não, dos mesmos.

Dentre os possíveis indicadores de qualidade de investimentos, optou-se por dois para serem aplicados às análises de viabilidade, a saber:

- Taxa interna de retorno do empreendimento - TIR: "mede a alavancagem de poder de compra oferecida pelo empreendimento ao empreendedor, considerados os fluxos de imobilização (investimento) 
e os de retomada de poder de compra (retorno), no prazo em que se dão os ganhos" (LIMA JÚNIOR, 1993);

- Prazo de recuperação da capacidade de investimento ou "pay-back": "mede o prazo de recuperação da capacidade de investimento do empreendedor, após a ocorrência da sua imobilização no empreendimento" (LIMA JÚNIOR, 1993), ou, “indica para o investidor o grau de imobilização que o empreendimento exige dele” (LIMA JÚNIOR, 1998).

O indicador "pay-back" subdivide-se em quatro tipos relevantes. Dentre eles optou-se por dois tipos: o pay-back seco e o pay-back cop (LIMA JÚNIOR, 1998).

- Pay-back seco (denominado nos resultados somente por "payback"): indica quando o empreendimento devolveu ao investidor uma massa de recursos (LIMA JÚNIOR, 1998);

- Pay-back a custo de oportunidade (pay-back cop): “identifica o tempo que o empreendimento demora para devolver ao empreendedor uma condição de capacidade de investimento equivalente àquela que teria se tivesse aplicado a mesma massa de investimento numa alternativa que arbitra como sendo “isenta” de risco" (LIMA JÚNIOR, 1998).

Estes três indicadores - TIR, pay-back seco e pay-back cop - compõem o critério para a avaliação da atratividade do investimento na central de reciclagem.

Para o cálculo do pay-back cop coletou-se junto ao mercado financeiro o rendimento de aplicações de renda fixa. Adotou-se por base o ranking dos melhores fundos de investimento de renda fixa (VALOR ECONÔMICO, 2006), apresentado na Tabela 6.1. 
Tabela 6.1 - Ranking dos melhores fundos de investimento de renda fixa (VALOR ECONÔMICO, 2006).

\begin{tabular}{|c|c|c|c|c|c|c|}
\hline Fundo & Administrador & $\begin{array}{l}\text { S\&P Star } \\
\text { Ranking }\end{array}$ & $\begin{array}{l}\text { Patrimônio líquido em } \\
29 / 9 / 2006 \text { (em R\$) }\end{array}$ & $\begin{array}{l}\text { Taxa de } \\
\text { adm }(\%)\end{array}$ & $\begin{array}{l}\text { RETORNO - em } \\
\% 12 \text { meses }\end{array}$ & $\begin{array}{l}\text { RETORNO - em } \\
\% 36 \text { meses }\end{array}$ \\
\hline 1 Alfaprev Moderado FI RF Prev. & Alfa & 2 & $67.332 .091,60$ & 1,5 & 16 & 57,4 \\
\hline 2 BB Prev. Público FI Renda Fixa & BB & 1 & $2.603 .779 .232,10-$ & & 13,2 & 54,6 \\
\hline 3 BB Prev. RF 2 FI Renda Fixa & BB & 1 & $557.984 .481,60$ & 0 & 13,4 & 62,2 \\
\hline 4 Bradesco FAPI Fix & Bradesco & 1 & $318.808 .792,30$ & 5 & 10,9 & 41,4 \\
\hline 5 Bradesco FIC RF PGBL Caemi F15 & Bradesco & 4 & $95.005 .889,00-$ & & 15 & 55,2 \\
\hline 6 Bradesco FIC RF PGBL F10 & Bradesco & 4 & $1.064 .058 .432,50$ & 1 & 15,7 & 57,9 \\
\hline 7 Bradesco FIC RF PGBL F15 & Bradesco & 4 & $474.033 .279,70$ & 1,5 & 15 & 55,2 \\
\hline 8 Bradesco FIC RF PGBL Fix Plus & Bradesco & 5 & $1.533 .811 .090,00$ & 0,35 & 16,4 & 60,6 \\
\hline 9 Bradesco FIC RF PGBL Hiperprev & Bradesco & 3 & $49.092 .828,20$ & 2 & 14,4 & 52,7 \\
\hline 10 Bradesco FIC RF Prev. Fácil PGBL Fix & Bradesco & 2 & $4.082 .364 .375,80$ & 3 & 13,3 & 48,8 \\
\hline 11 Bradesco FIC RF VGBL Fix & Bradesco & 3 & $12.377 .602 .955,80$ & 3 & 13,3 & 48,9 \\
\hline 12 Brasilprev Fix Annuity FI Renda Fixa & BB & 1 & $20.428 .598,10$ & & 11,7 & 48 \\
\hline 13 Caixa FIC Previnvest Corporativo RF & CEF & 3 & $85.906 .024,80$ & 1,5 & 15,7 & 56,9 \\
\hline 14 Caixa FIC Previnvest RF & CEF & 2 & $2.657 .514 .335,10$ & 3 & 13,5 & 50 \\
\hline 15 Citi Previdência FI Referenciado DI & Citibank & 4 & $41.440 .620,20$ & 1,7 & 14,7 & 53,8 \\
\hline
\end{tabular}

De acordo com o ranking adotou-se que a aplicação de renda-fixa, de longo prazo e baixo risco, apresentou, em 2006, rentabilidade efetiva de aproximadamente $12 \%$ anuais $^{31}$, e este foi considerado como investimento "isento" de risco.

\subsubsection{ANÁLISE DE RISCO}

Jadovski e Masuero (2006) adotaram uma taxa de risco de $4 \%$ para a análise de viabilidade de uma central de reciclagem de RCD classe A. No entanto, a análise de risco é um procedimento complexo e distinto, específico para cada negócio, não sendo possível adotar um valor sem balizá-lo com algumas possibilidades de cenário. No presente caso, devido à falta de informações, optou-se por analisar a influência de determinados fatores na variação da receita operacional bruta, verificando assim a sensibilidade desta receita perante alguns acontecimentos no cenário macroeconômico. Foram abordados fatores técnicos, econômicos e de mercados. Tendo-se em consideração que:

- Fatores técnicos:

- o negócio denominado Central de Reciclagem de CGA é pioneiro no Brasil;

${ }^{31}$ Da rentabilidade efetiva já estão deduzidos a taxa de administração e a inflação. 
- a tecnologia pressuposta para sua operação não foi nunca anteriormente utilizada no Brasil.

- Fatores de mercado:

- a presença de produtos substitutos/concorrentes com o produto final - gesso (gipsita) reciclado - da central, nas aplicações consideradas;

- o consumo de CGA ainda é baixo no Brasil se comparado aos países desenvolvidos;

- o crescimento do mercado de CGA tem sido lento, a taxas de 10 a $12 \%$ ao ano e a previsão para os próximos 3 anos é de crescimento a estas mesmas taxas; assim, a geração de resíduos de CGA deve crescer a esta mesma proporção; segundo um dos fabricantes entrevistados, "em um país emergente como o Brasil esta taxa de crescimento é considera muito baixa. $O$ normal seria crescer de $30 \%$ a $40 \%$ mas o problema são as condicionantes";

- o crescimento do mercado de CGA depende da continuidade de uma atuação de marketing maciça para mudar a "cultura brasileira";

- o uso de CGA contendo gesso (gipsita) reciclado precisa ter seu desempenho avaliado, para determinar sua aplicação/uso e, consequentemente, que fatia do mercado de vedações verticais poderá atingir;

- a taxa de captação dos resíduos de CGA tende a ser baixa, principalmente se não forem adotadas medidas de mercado ou legislativas que a impulsionem.

- Fatores econômicos:

- a variação do câmbio em relação ao dólar: verifica-se que a cotação do dólar está sofrendo uma tendência a queda e o 
Banco Central tem comprado dólares para manutenção da relação R \$1,00/US\$2,00; no entanto, esta prática não poderá ser mantida por muito tempo, uma vez que as reservas brasileiras de dólares já estão muito $\operatorname{altas}^{32}$; a máquina recicladora é importada e seu custo cotado em dólar; assim, a tendência de queda da cotação do dólar atual poderia gerar uma economia no pagamento desta máquina;

- inflação: um aumento na taxa de inflação teria impacto em um aumento da taxa de juros do financiamento sendo, portanto, negativo para a viabilidade deste investimento.

Os fatores apresentados indicam uma alta taxa de risco, pois pequenas variações, como taxa de captação $10 \%$ mais baixa ou receita operacional bruta 7\% menor, já comprometem em muito a viabilidade econômica deste negócio. Devido a isto se arbitrou uma taxa de risco de $40 \%$ para a abertura da central de reciclagem.

Isto significa que se não for obtido lucro maior ou igual a 52\% a.a. (40\% de taxa de risco $+12 \%$ de rentabilidade do fundo de renda fixa) na análise de viabilidade da central, não é vantajoso investir em sua implantação, sendo mais atrativo aplicar o valor em um investimento/fundo bancário.

\subsubsection{VALOR DE VENDA do GeSSo (GIPSITA) RECICLAdo DE RESÍduO DE CGA}

Com base em Jadovski e Masuero (2006), observa-se que, em operações industriais, o preço de venda de um determinado produto tem que ser, no mínimo, suficiente para remunerar os custos de produção, incluindo os fixos, variáveis, administrativos, etc.; e os custos financeiros, como por

${ }^{32}$ O ESTADO DE SÃO PAULO, 24 fev 2007. 
exemplo, de capital de giro; sendo desejável ainda que este preço de venda proporcione o lucro desejado pelo investidor.

Conforme dito anteriormente, a mudança no fornecimento de uma matéria-prima envolve muitos fatores de risco à produção, tanto técnicos quanto de suprimento. Sendo assim, a diferença de custo entre duas matérias-primas é o principal fator que pode levar a uma predisposição da empresa em alterar seu fornecimento. No presente caso, acredita-se que o valor de venda do gesso (gipsita) reciclado não deva ser superior a $80 \%$ do valor do gesso natural, para que seja atrativo tanto para os fabricantes de CGA quanto para as indústrias de cimento.

No município de São Paulo a gipsita (gesso dihidratado) custa cerca de $\mathrm{R} \$ 138,00 / \mathrm{t}$, sendo que aproximadamente $\mathrm{R} \$ 120,00 / \mathrm{t}$ corresponde ao frete da mina até o comprador e $\mathrm{R} \$ 18,00 / \mathrm{t}$ à matéria-prima. Assim, o preço alvo para o gesso reciclado é de $\mathrm{R} \$ 110,40 / \mathrm{t}$ para modalidade $\mathrm{CIF}^{33}$, ou seja, entregue no comprador.

No entanto, para efeito do cálculo da receita bruta da central de reciclagem é necessário descontar o custo do frete de distribuição. Temse, portanto, que considerar os principais potenciais compradores de gesso (gipsita) reciclado na região Sudeste.

\section{Custo de frete de distribuição de gesso reciclado de rCGA}

O custo de frete de distribuição foi calculado a partir de dados do mercado, coletados em transportadoras, para caminhões tipo truck, com capacidade para 13 t e guincho hidráulico, conforme o lay-out estabelecido no item 6.1.2.

Dentre os compradores em potencial têm-se os fabricantes de CGA e as indústrias de cimento.

\footnotetext{
${ }^{33}$ Sigla em inglês - Cost, Insurance and Freight, que significa que o preço apresentado inclui os custos do produto, do seguro e do frete.
} 
Dentre os fabricantes de CGA, dois localizam-se na região Sudeste. Um no município de Queimados - Rio de Janeiro, a 385km de São Paulo, e outro no município de Mogi das Cruzes, a 58km de São Paulo.

Já a localização das indústrias de cimento foi obtida por meio do SNIC Sindicato Nacional da Indústria de Cimento. A produção de cimento do estado de São Paulo corresponde à soma da produção de nove fábricas localizadas conforme a Tabela 6.2.

Tabela 6.2 - Localização das indústrias de cimento no estado de São Paulo e suas respectivas distâncias até o município de São Paulo (SNIC, 2006).

\begin{tabular}{|l|l|c|}
\hline \multicolumn{1}{|c|}{ Origem } & \multicolumn{1}{|c|}{ Destino } & Km \\
\hline & Apiaí - SP & 324 \\
\hline & Cajati - SP & 233 \\
\hline & Cubatão - SP & 55 \\
\hline Município de São Paulo - SP & Itapeva - SP & 320 \\
\hline & Mogi das Cruzes - SP & 58 \\
\hline & Ribeirão Grande - SP & 247 \\
\hline & Salto de Pirapora - SP & 121 \\
\hline & Sorocaba - SP & 87 \\
\hline & Votorantim - SP & 104
\end{tabular}

É possível verificar que algumas destas fábricas situam-se a uma grande distância da RMSP, influenciando o custo de transporte do gesso reciclado de rCGA. Como forma de estabelecer parâmetros para as análises de viabilidade, levantou-se uma estimativa do custo de distribuição deste gesso, baseando-se nos custos de distribuição de CGA, uma vez que ambos são realizados em caminhões de mesma capacidade.

O custo de distribuição, de acordo as informações dos fabricantes de CGA e com a consulta a duas transportadoras do município de São Paulo, é de aproximadamente $\mathrm{R} \$ 2,20 / \mathrm{km}$. Arbitrou-se que este custo poderia constituir, no máximo, $20 \%$ do custo da carga, conforme demonstrado na Tabela 6.3 . 
Tabela 6.3 - Custo do frete de distribuição de gesso reciclado de rCGA para indústrias de cimento no estado de São Paulo (autora, 2007).

\begin{tabular}{|c|c|c|c|c|c|}
\hline Origem & Destino & $\mathbf{K m}$ & $\begin{array}{l}\text { Custo do frete de distribuição - } \\
\text { caminhão truck aberto - } 13 \mathrm{t} \text { R\$ }\end{array}$ & $\begin{array}{c}\text { Custo do frete por } \\
\text { tonelada } \mathbf{R} \$ / \mathrm{t}\end{array}$ & $\begin{array}{c}\% \text { do frete em relação ao } \\
\text { preço da carga }\end{array}$ \\
\hline \multirow{9}{*}{ São Paulo - SP } & Apiaí - SP & 324 & 712,80 & 54,83 & $49,7 \%$ \\
\hline & Cajati-SP & 233 & 512,60 & 39,43 & $35,7 \%$ \\
\hline & Cubatão - SP & 55 & 121,00 & 9,31 & $8,4 \%$ \\
\hline & Itapeva - SP & 320 & 704,00 & 54,15 & $49,1 \%$ \\
\hline & Mogi das Cruzes - SP & 58 & 127,60 & 9,82 & $8,9 \%$ \\
\hline & Ribeirão Grande - SP & 247 & 543,40 & 41,80 & $37,9 \%$ \\
\hline & Salto de Pirapora - SP & 121 & 266,20 & 20,48 & $18,5 \%$ \\
\hline & Sorocaba - SP & 87 & 191,40 & 14,72 & $13,3 \%$ \\
\hline & Votorantim-SP & 104 & 228,80 & 17,60 & $15,9 \%$ \\
\hline
\end{tabular}

A limitação do custo do frete de distribuição representar no máximo $20 \%$ do preço da carga leva a uma dedução, significa que posso é possível atender clientes, com preço CIF, localizados a no máximo $130 \mathrm{~km}$ de distância da central de reciclagem.

Das nove fábricas no estado, cinco situam-se dentro deste raio de $130 \mathrm{~km}$ da cidade de São Paulo, conforme a Figura 6.2. Estas cinco plantas industriais correspondem a aproximadamente $50 \%$ da produção de cimento no Estado, representando um mercado potencial de 88.325 t/ano.

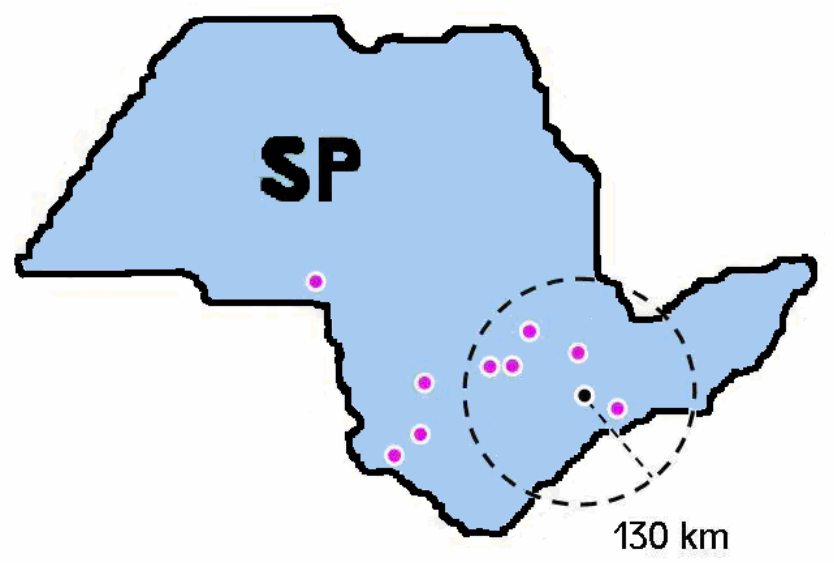

Figura 6.2 - Localização das indústrias de cimento no estado de São Paulo e das situadas num raio de até $130 \mathrm{~km}$ da capital (baseado em SNIC, 2006).

Considerando-se que o frete de distribuição pode variar de 8 a $18 \%$ do preço do produto, adotou-se que o preço do gesso reciclado de CGA CIF irá considerar um custo de distribuição de $18 \%$ do valor do produto, o 
que representa um custo de frete de $\mathrm{R} \$ 19,87 / \mathrm{t}$, tomando por base o preço alvo de $\mathrm{R} \$ 110,40 / \mathrm{t}$, o que permite calcular o preço máximo do produto sem frete de $\mathrm{R} \$ 90,53 /$ t, conforme Figura 6.3 .

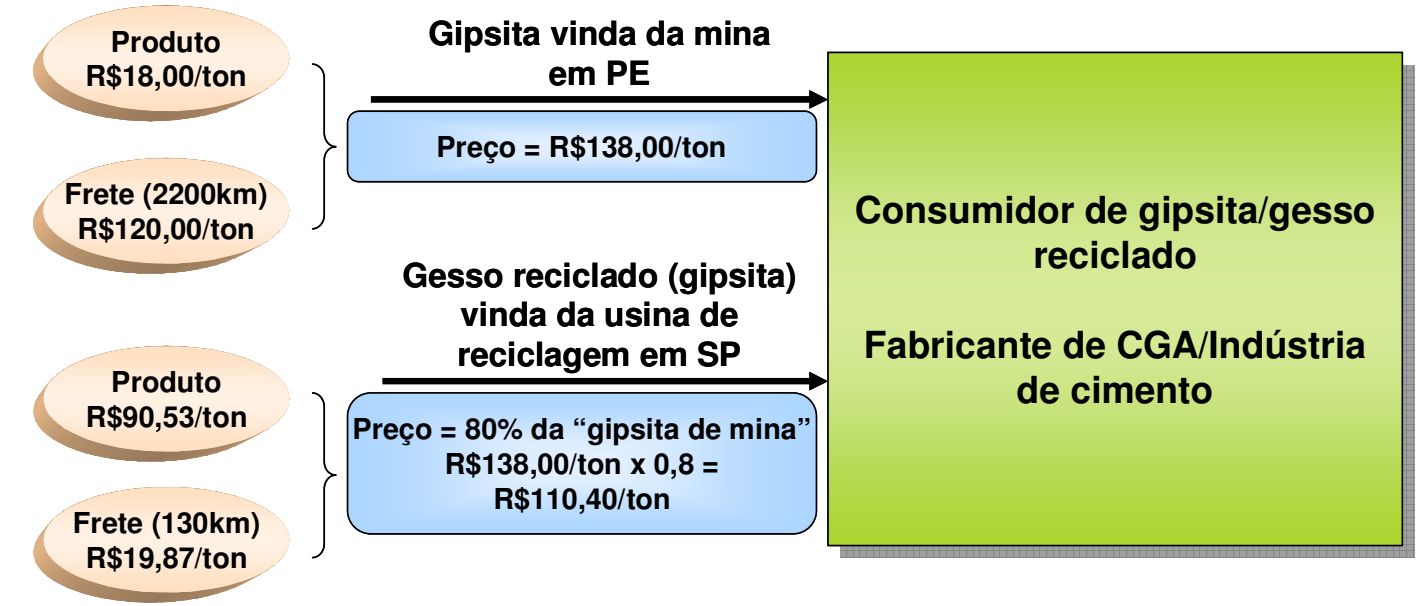

Figura 6.3 - Esquema de formação de custo limite para formação de preço de gesso reciclado de resíduo de CGA, em São Paulo, modalidade CIF até 130km (autora, 2007).

\subsubsection{Custos da Central de Reciclagem}

\subsubsection{CUSTOS DE IMPLANTAÇÃO}

A Figura 6.4 ilustra o layout adotado para a instalação da central de reciclagem de CGA.

Os resíduos de CGA chegam à central em caminhão basculante com caçamba metálica de capacidade de $16 \mathrm{~m}^{3}$. Estes caminhões estacionam no galpão e descarregam na área destinada. O transporte da caçamba até próximo à recicladora é feito através de minicarregadeira. Deposita-se o resíduo no piso e um funcionário realiza a alimentação manual na máquina recicladora.

Os bags cheios de resíduo de papel cartão e do gesso (gipsita) reciclado em grãos são retirados, com a ajuda de um guincho hidráulico manual (equipamento também conhecido por "girafa") para uma área de estoque de produtos acabados. A distribuição do gesso (gipsita) reciclado é 
realizada por meio de caminhão com guindaste hidráulico (tipo “munck"). Transporte interno horizontal e vertical de bags realizado por guincho hidráulico manual.

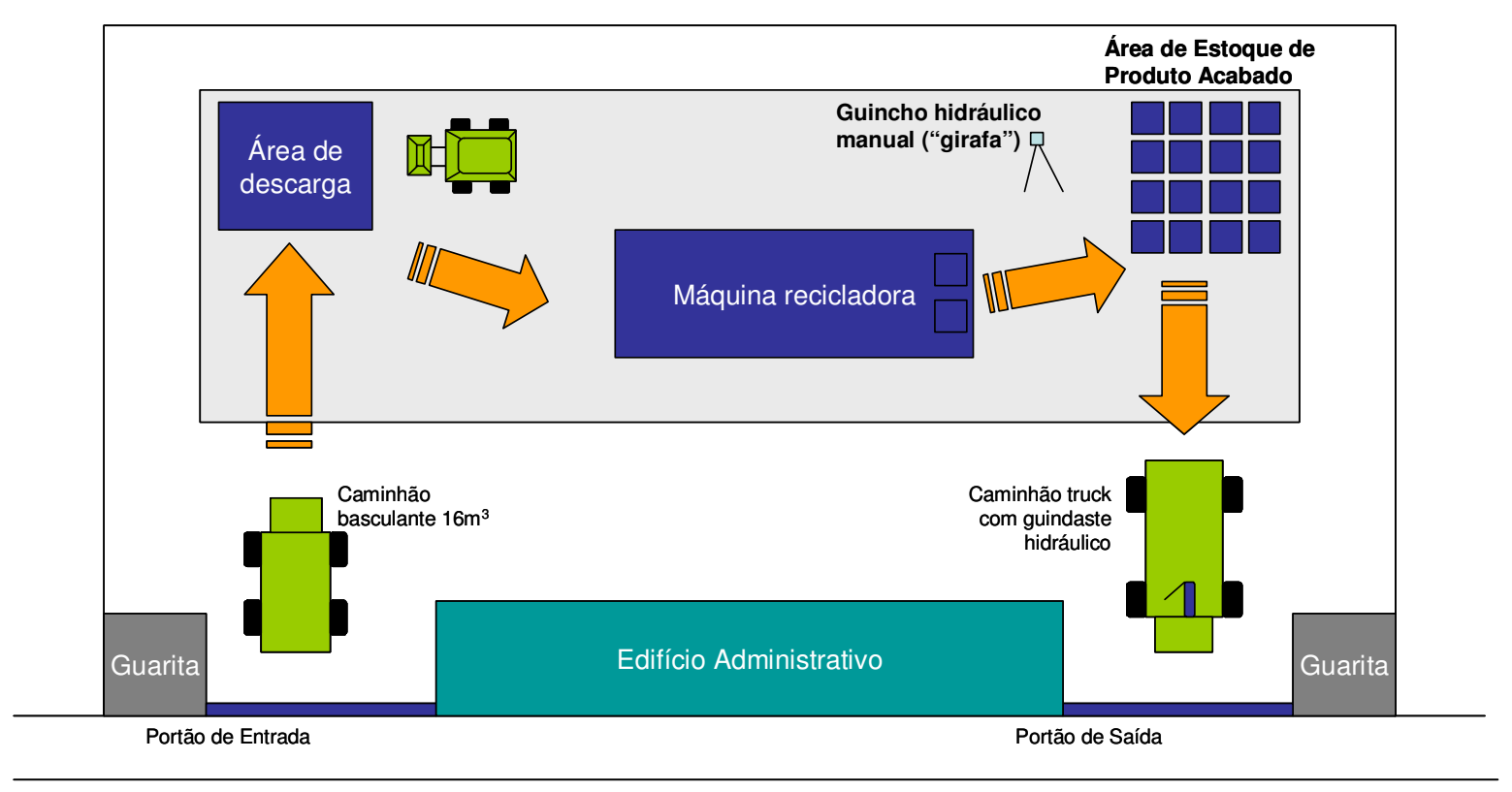

Figura 6.4 - Layout da central de reciclagem de CGA (autora, 2007).

A implantação de uma central de reciclagem de resíduos de CGA tem seu custo constituído pela aquisição e instalação de equipamentos; de máquinas e veículos; do terreno; e das obras civis. Estes custos estão descritos e estimados nos itens que seguem.

\section{Custo de Aquisicão do Terreno}

A área requerida para instalação da central de reciclagem foi arbitrada com base nas características da máquina recicladora e no layout proposto.

O custo unitário do terreno foi obtido no mercado em dezembro de 2006. Obteve-se o valor de $\mathrm{R} \$ 200,00 / \mathrm{m}^{2}$, considerando-se um imóvel na periferia da zona Sul da RMSP de São Paulo. 
Estima-se que seja necessário um terreno de $1.050 \mathrm{~m}^{2}(30 \mathrm{~m} \times 35 \mathrm{~m})$. Assim, tem-se um custo de aquisição do terreno de $\mathrm{R} \$ 210.000,00$.

\section{Custo de Obras Civis}

O custo das obras civis prevê a construção de um edifício de dois pavimentos para administração, de um galpão de $520 \mathrm{~m}^{2}$ (20m x 26m) com piso em concreto, duas guaritas e fechamento lateral em alvenaria em todo o perímetro do terreno.

Para estimar o custo destas obras foi adotado o CUB - Custo unitário básico, no Estado de São Paulo, apurou o SINDUSCON - SP em janeiro de 2007. Para o edifício administrativo e demais construções utilizou-se o CUB da tipologia Comercial Salas 12B, de valor global igual a $\mathrm{R} \$ 611,98 / \mathrm{m}^{2}$. Para o galpão foi adotado o CUB da tipologia Galpão Industrial, que foi de R\$378,64 em janeiro de 2007.

Considerou-se que o galpão têm 20 metros de largura por 26 metros de extensão e o edifício administrativo possui 3 metros de largura por 12 de extensão, em projeção. Aplicando-se os valores do CUB às áreas estimadas das respectivas construções, tem-se que o custo das obras civis totalizou $\mathrm{R} \$ 280.428,07$.

galpão de (20m x 26m) $520 \mathrm{~m}^{2}$

$520 \mathrm{~m}^{2} \times 378,64 \mathrm{R} \$ / \mathrm{m}^{2}=\mathrm{R} \$ 196.892,80$

edifício administrativo $(3 \times 12) \times 2$ pavtos $=72 \mathrm{~m}^{2}$

demais construções $=64,50 \mathrm{~m}^{2}$

$(72+64,50) \mathrm{m}^{2} \times 611,98 \mathrm{R} \$ / \mathrm{m}^{2}=83.535,27$

\section{Custo de Aquisicão de Máquinas, Equipamentos e Veículos Próprios}

Segundo o layout proposto, as máquinas e veículos necessários à central constituem-se de minicarregadeira, máquina recicladora, guincho hidráulico manual e caminhão truck com guindaste hidráulico. 
A minicarregadeira têm custo aproximado de $\mathrm{R} \$ 95.000,00$ e sua descrição encontra-se no anexo A. Já o caminhão tipo truck com guindaste hidráulico custa cerca de $\mathrm{R} \$ 160.000,00$.

A máquina recicladora tem custo aproximado de $\mathrm{R} \$ 252.000,00$ (considerando-se a cotação do dólar de janeiro de 2007 em aproximadamente 1US\$ = R $\$ 2,10$ ). Já o guincho hidráulico manual tem capacidade máxima de duas toneladas e custo de aproximadamente $\mathrm{R} \$ 1.800,00$. Sua descrição encontra-se no anexo A. Todos os equipamentos são novos e os preços foram coletados no mercado em dezembro de 2006.

O custo de aquisição de máquinas e veículos próprios totaliza $\mathrm{R} \$ 508.800,00$.

\subsubsection{CUSTOS DE OPERAÇÃO}

O custo de operação da central de reciclagem de CGA compreende os custos com mão-de-obra própria para operação da central; locação de veículos e máquinas; operação de veículos, máquinas e equipamentos próprios; insumos de produção; despesas administrativas e impostos.

\section{Custo da Mão-de-Obra de Producão}

A equipe de produção é arbitrada em função da capacidade de produção da central de reciclagem, das características da máquina recicladora, do layout estabelecido, e dos salários praticados na indústria da construção civil. Considerou-se uma jornada de trabalho de 44 horas semanais e 22 dias mensais. Para o custo dos encargos sociais foi adotado o percentual publicado pelo SINDUSCON-SP, em janeiro de 2007, que foi de $186,20 \%$, já inclusos os custos com refeições, equipamentos de segurança, vale-transporte e seguro de vida e acidentes.

Considerou-se ainda que a equipe de mão-de-obra necessária para operar a central é composta por um encarregado, um operador para a 
minicarregadeira, um operador da máquina recicladora, um ajudante na saída do gesso reciclado e um motorista para o caminhão truck.

De acordo com CONSTRUÇÃO MERCADO (2006) os salários (base 2006) para as funções similares foram adotados conforme Tabela 6.4.

Tabela 6.4 - Custo de mão-de-obra de operação da central de reciclagem (autora, 2007).

\begin{tabular}{|l|c|c|r|r|r|}
\hline \multicolumn{1}{|c|}{ Equipe } & $\begin{array}{c}\text { Custo } \\
\text { unitário }\end{array}$ & $\begin{array}{c}\text { Jornada } \\
\text { mensal }\end{array}$ & $\begin{array}{c}\text { Salário } \\
(\mathbf{R} \$)\end{array}$ & $\begin{array}{c}\text { Enc. Sociais } \\
(\mathbf{1 8 6 , 2 \%}) \mathbf{R} \$\end{array}$ & Custo total \\
\hline Encarregado & $\mathrm{R} \$ 6,40 / \mathrm{h}$ & $193,6 \mathrm{~h} / \mathrm{mês}$ & 1239,04 & $2.307,09$ & $3.546,13$ \\
\hline $\begin{array}{l}\text { Operador de } \\
\text { Equipamentos - } \\
\text { Minicarregadeira }\end{array}$ & $\mathrm{R} \$ 3,42 / \mathrm{h}$ & $193,6 \mathrm{~h} / \mathrm{mês}$ & 662,11 & $1.232,85$ & $1.894,96$ \\
\hline $\begin{array}{l}\text { Operador de } \\
\text { Equipamentos- Máquina } \\
\text { Recicladora }\end{array}$ & $\mathrm{R} \$ 3,42 / \mathrm{h}$ & $193,6 \mathrm{~h} / \mathrm{mês}$ & 662,11 & $1.232,85$ & $1.894,96$ \\
\hline Auxiliar de produção & $\mathrm{R} \$ 2,84 / \mathrm{h}$ & $193,6 \mathrm{~h} / \mathrm{mês}$ & 549,82 & $1.023,77$ & $1.573,60$ \\
\hline Motorista para caminhão & $\mathrm{R} \$ 4,48 / \mathrm{h}$ & $193,6 \mathrm{~h} / \mathrm{mês}$ & 867,33 & $1.614,96$ & $2.482,29$ \\
\hline
\end{tabular}

Os custos com mão-de-obra própria totalizaram $\mathrm{R} \$ 11.391,94 / \mathrm{mês,} \mathrm{ou}$ seja, R\$136.703,28/ano.

Os custos com segurança estão previstos no item "Despesas Administrativas".

\section{Custo de Operacão de Veículos, Máquinas e Equipamentos Próprios}

Os salários de operadores e motoristas estão previstos no item de mãode-obra da produção.

Considerou-se um consumo de combustível de 4 litros/hora para a minicarregadeira e de 8 litros/km para o caminhão truck com guindaste hidráulico.

Assim a minicarregadeira consome cerca de 9.504 litros de óleo diesel ao ano. Considerando-se o custo do óleo diesel a $\mathrm{R} \$ 1,80$, tem-se um custo de aproximadamente $\mathrm{R} \$ 17.107,20$. 
O custo de operação do caminhão com guindaste hidráulico é dado em função do seu deslocamento e do rendimento do combustível. Seu custo de operação está incluso no item "Custo de frete de distribuição".

\section{Custo dos Insumos de Producão}

De acordo com as especificações do fabricante da máquina recicladora (ANDELA PRODUCTS, 2006) utilizada nesta análise, o único insumo de produção, excetuando-se o próprio resíduo, é a energia elétrica.

Os demais equipamentos e veículos são todos a óleo diesel ou manuais.

Considera-se que o equipamento possui $17 \mathrm{hp}$ de potência e opera 9 horas por dia, 22 dias ao mês.

Segundo a AES ELETROPAULO (2007), a central de reciclagem de CGA enquadra-se na modalidade de tarifas do grupo B, subgrupo B3, por tratar-se de uma unidade industrial que utiliza baixa tensão e rede elétrica trifásica. De acordo com esta modalidade, a tarifa é de R $\$ 0,29335 / \mathrm{kWh}$. Acrescidos os impostos, tem-se o custo de $\mathrm{R} \$ 0,42 / \mathrm{kWh}$, o que totaliza o custo de energia elétrica em $\mathrm{R} \$ 12.653,63 /$ ano.

$17 \mathrm{hp}=12,68 \mathrm{~kW} / \mathrm{h}$

$\mathrm{X}=12,68 \mathrm{~kW} / \mathrm{h} \times 9 \mathrm{~h} \times 22 \mathrm{~d} \times 12 \mathrm{~m}=30.127,68 \mathrm{kWh} / \mathrm{ano}$

$30.127,68 \times 0,42=\mathrm{R} \$ 12.653,63 / \mathrm{ano}$

\subsubsection{Custos de MANUTENÇÃO}

O custo de manutenção de uma central de reciclagem de CGA é composto pelos custos de manutenção das máquinas e equipamentos; de manutenção das obras civis e de depreciação de equipamentos e; de obras civis. 


\section{Custo de Manutencão das Máquinas e Equipamentos}

Devido à falta de informações sobre estes custos, adotou-se o percentual de $1 \% /$ ano do valor de aquisição destes equipamentos. Sendo assim, temse os custos de manutenção conforme a Tabela 6.5.

Tabela 6.5 - Custos de manutenção dos equipamentos previstos para a central de reciclagem (autora, 2007).

\begin{tabular}{|l|l|}
\hline Equipamento/Veículo & $\begin{array}{l}\text { Custo } \\
\text { manutenção }\end{array}$ \\
\hline Mini-carregadeira & $\mathrm{R} \$ 950,00$ \\
\hline Caminhão truck & $\mathrm{R} \$ 1.600,00$ \\
\hline Máquina recicladora & $\mathrm{R} \$ 2.520,00$ \\
\hline Guincho hidráulico (girafa) & $\mathrm{R} \$ 18,00$ \\
\hline Total & $\mathbf{R} \$ \mathbf{5 . 0 8 8 , 0 0}$ \\
\hline
\end{tabular}

\section{Custo de Manutencão das Obras Civis}

O custo de manutenção das obras civis é arbitrado como um percentual do custo de implantação das obras civis (1,0\% anuais), totalizando $\mathrm{R} \$$ 2.804,28/ano.

\section{Custo de Depreciação de Equipamentos e de Obras Civis}

Os custos de depreciação dos equipamentos são calculados de acordo com as informações de prazo de vida útil e de taxa anual de depreciação obtidas na Receita Federal (BRASIL, 1998). Os parâmetro estão descritos na Tabela 6.6 e os custos nas tabelas Tabela 6.7 e Tabela 6.8. 
Tabela 6.6 - Parâmetros para o cálculo dos custos de depreciação dos equipamentos e das obras civis da central de reciclagem, de acordo com a Receita Federal (BRASIL, 1998).

\begin{tabular}{|c|c|c|c|c|}
\hline $\begin{array}{l}\text { Equipamentos da Usina } \\
\text { Recicladora de Gesso } \\
\text { Acartonado }\end{array}$ & $\begin{array}{l}\text { Referência } \\
\text { NCM }\end{array}$ & Bens & $\begin{array}{l}\text { Prazo de vida } \\
\text { útil (anos) }\end{array}$ & $\begin{array}{l}\text { Taxa anual de } \\
\text { depreciação }\end{array}$ \\
\hline Mini-carregadeira & 8429 & $\begin{array}{l}\text { "BULLDOZERS", "ANGLEDOZERS", NIVELADORES, RASPO- } \\
\text { TRANSPORTADORES ("SCRAPERS"), PÁS MECÂNICAS, } \\
\text { ESCAVADORES, CARREGADORAS E PÁS CARREGADORAS, } \\
\text { COMPACTADORES E ROLOS OU CILINDROS COMPRESSORES, } \\
\text { AUTOPROPULSORES }\end{array}$ & 4 & $25 \%$ \\
\hline Guincho hidráulico manual & 8427 & $\begin{array}{l}\text { EMPILHADEIRAS; OUTROS VEÍCULOS PARA MOVIMENTAÇÃO DE } \\
\text { CARGA E SEMELHANTES, EQUIPADOS COM DISPOSITIVOS DE } \\
\text { ELEVAÇÃO }\end{array}$ & 10 & $10 \%$ \\
\hline Máquina recicladora & 8474 & $\begin{array}{l}\text { MÁQUINAS E APARELHOS PARA SELECIONAR, PENEIRAR, } \\
\text { SEPARAR, LAVAR, ESMAGAR, MOER, MISTURAR OU AMASSAR } \\
\text { TERRAS, PEDRAS, MINÉRIOS OU OUTRAS SUBSTÂNCIAS } \\
\text { MINERAIS SÓLIDAS (INCLUÍDOS OS PÓS E PASTAS); } \\
\text { MÁQUINAS PARA AGLOMERAR OU MOLDAR COMBUSTÍVEIS } \\
\text { MINERAIS SÓLIDOS, PASTAS CERÂMICAS, CIMENTO, GESSO OU } \\
\text { OUTRAS MATÉRIAS MINERAIS EM PÓ OU EM PASTA; MÁQUINAS } \\
\text { PARA FAZER MOLDES DE AREIA PARA FUNDIÇÃO }\end{array}$ & 5 & $20 \%$ \\
\hline $\begin{array}{l}\text { Caminhão truck com } \\
\text { guindaste hidráulico }\end{array}$ & 8705 & $\begin{array}{l}\text { VEICULOS AUTOMÓVEIS PARA USOS ESPECIAIS (POR EXEMPLO: } \\
\text { AUTO-SOCORROS, CAMINHÕES-GUINDASTES, VEÍCULOS DE } \\
\text { COMBATE A INCÊNDIOS, CAMINHÕES-BETONEIRAS, VEÍCULOS } \\
\text { PARA VARRER, VEÍCULOS PARA ESPALHAR, VEÍCULOS- } \\
\text { OFICINAS, VEÍCULOS RADIOLÓGICOS), EXCETO OS } \\
\text { CONCEBIDOS PRINCIPALMENTE PARA TRANSPORTE DE } \\
\text { PESSOAS OU DE MERCADORIAS }\end{array}$ & 4 & $25 \%$ \\
\hline Edifício e Galpão & & EDIFICAÇÕES & 25 & $4 \%$ \\
\hline
\end{tabular}

Tabela 6.7 - Custos de depreciação dos equipamentos da central de reciclagem (autora, 2007).

\begin{tabular}{|c|c|c|c|c|c|c|c|}
\hline $\begin{array}{c}\text { Equipamentos da Central } \\
\text { de Reciclagem de Gesso } \\
\text { Acartonado } \\
\end{array}$ & Quantidade & Custo Unitário & Custo Total & Depreciação & Anos & $\begin{array}{l}\text { Taxa de } \\
\text { Depreciação }\end{array}$ & Depreciação/Ano \\
\hline Mini-carregadeira & 1 & $R \$ 95.000,00$ & $R \$ 95.000,00$ & $R \$ 23.750,00$ & 4 & $25,0 \%$ & $R \$ 5.937,50$ \\
\hline Guincho hidráulico manual & 1 & $\mathrm{R} \$ 1.700,00$ & $\mathrm{R} \$ 1.700,00$ & $\mathrm{R} \$ 170,00$ & 10 & $10,0 \%$ & $\mathrm{R} \$ 17,00$ \\
\hline Máquina recicladora & 1 & $R \$ 252.000,00$ & $\mathrm{R} \$ 252.000,00$ & $R \$ 50.400,00$ & 5 & $20,0 \%$ & $R \$ 10.080,00$ \\
\hline $\begin{array}{l}\text { Caminhão truck com } \\
\text { quindaste hidráulico }\end{array}$ & 1 & $R \$ 160.000,00$ & $R \$ 160.000,00$ & $R \$ 40.000,00$ & 4 & $25,0 \%$ & $R \$ 10.000,00$ \\
\hline & \multicolumn{3}{|c|}{ Custo de Depreciação de Equipamentos e Máquinas } & $\mathrm{R} \$ 114.320,00$ & \multicolumn{2}{|c|}{$\begin{array}{r}\text { Custo de Depreciação de } \\
\text { Equipamentos e Máquinas } \\
\text { ao Ano }\end{array}$} & $R \$ 26.034,50$ \\
\hline
\end{tabular}

Tabela 6.8 - Custos de depreciação de obras civis da central de reciclagem (autora, 2007).

\begin{tabular}{|c|c|c|c|c|c|c|c|}
\hline \begin{tabular}{|c|}
$\begin{array}{c}\text { Instalaçōes da Central de } \\
\text { Reciclagem de Gesso } \\
\text { Acartonado }\end{array}$ \\
\end{tabular} & Quantidade & Custo Unitário & Custo Total & Depreciação & Anos & $\begin{array}{c}\text { taxa de } \\
\text { depreciação }\end{array}$ & Depreciação/ano \\
\hline Edifício & 1 & $\mathrm{R} \$ 83.535,27$ & $R \$ 83.535,27$ & $\mathrm{R} \$ 3.341,41$ & 25 & $4,0 \%$ & $R \$ 133,66$ \\
\hline Galpão & 1 & $\mathrm{R} \$ 196.892,80$ & $R \$ 196.892,80$ & $\mathrm{R} \$ 7.875,71$ & 25 & $4,0 \%$ & $R \$ 315,03$ \\
\hline \multicolumn{4}{|c|}{ Custo de Depreciação de Obras Civis } & $\mathrm{R} \$ 11.217,12$ & \multicolumn{2}{|c|}{$\begin{array}{r}\text { Custo de Depreciação de } \\
\text { Obras Civis ao Ano }\end{array}$} & $R \$ 448,68$ \\
\hline
\end{tabular}

Obteve-se um custo total de depreciação de equipamento e obras civis de $\mathrm{R} \$ 26.483,18 / \mathrm{ano}$. 


\subsubsection{CUsto do Frete de Distribuição}

Limitou-se a abrangência do frete de distribuição a $130 \mathrm{~km}$ para que o mesmo não comprometesse mais do que $20 \%$ do custo do gesso reciclado de CGA.

\subsubsection{CUsto DE Despesas AdMINISTRATIVAS}

As despesas administrativas incluem os custos de telefone, vigilância e outros materiais de consumo, como materiais de limpeza, de escritório, etc., além de um funcionário administrativo.

Considerou-se para análise os custos apropriados por Jadovski e Masuero (2006) em centrais de reciclagem de Belo Horizonte, reajustados pela inflação, medida pelo IGP-M entre 2004 - ano do levantamento - e 2006.

Os custos previstos por Jadovski e Masuero (2006) de telefone e de material de consumo somavam $\mathrm{R} \$ 570,00 /$ mês. Considerando-se que o IGP-M (FGV, 2007) entre 2004 e 2006 variou $+10,63 \%$, tem-se um custo de $\mathrm{R} \$ 630,59 / \mathrm{mês}$.

Já o custo de segurança prevê vigilância ininterrupta, ou seja, 24 horas, por dia, 7 dias por semana, representando um custo de $\mathrm{R} \$ 5.419,00 / \mathrm{mês}$, que reajustado pelo IGP-M corresponde a um custo de $\mathrm{R} \$$ 5.995,04/mês.

O funcionário administrativo receberá três salários mínimos. Aplicandose o percentual de Encargos Sociais de 186,20\% (SINDUSCON-SP, 2006), seu custo é de $\mathrm{R} \$ 1.955,10 / \mathrm{mês}$.

Assim, o custo fixo mensal com as despesas administrativas totaliza $\mathrm{R} \$ 8.580,73$.

\subsubsection{CUSTO DE IMPOSTOS}

São considerados os seguintes impostos: PIS/COFINS (9,65\%), ICMS (18\%), imposto de renda (15\%) e contribuição social $(9,00 \%)$. 


\subsubsection{Capacidade de Produção}

Segundo Jadovski e Masuero (2006), pode-se prever que a central sofrerá algumas paradas necessárias para manutenção de equipamentos. Portanto, o valor padrão para a taxa de operação da central de reciclagem de CGA pode ser arbitrada em $90 \%$ de sua capacidade plena. A capacidade plena da central é determinada pela máquina recicladora/sistema de reciclagem, a qual processa de 1 a 3 t/h. Aplicando-se esta taxa tem-se que a capacidade de operação da central de reciclagem é de $0,9 \mathrm{t} / \mathrm{h}$ a $2,7 \mathrm{t} / \mathrm{h}$.

A taxa de captação é uma informação importante para determinar a oferta de resíduos para a central, sendo planejada para que a central não sofra nenhuma parada por falta de suprimento.

Para as centrais/usinas de reciclagem de resíduos classe A, produtoras de agregados, a Prefeitura municipal de Belo Horizonte apurou taxas de captação da ordem de 10\% (SERVIÇO... - SLU/PMBH, 2004 apud JADOVSKI; MASUERO, 2006).

Esta baixa taxa pode ser explicada pelo fato destes resíduos serem facilmente reutilizados, ou seja, utilizados sem a necessidade de beneficiamento industrial, o que "desvia" parte do fluxo destes resíduos classe A para outros locais, que não as centrais de reciclagem.

Soma-se a este fator o fato destes resíduos serem aceitos em aterros de resíduos inertes, enquanto os resíduos de gesso acartonado não (não deveriam ser aceitos devido aos impactos ambientais negativos que causa).

Acredita-se que seria possível obter uma alta taxa de captação de resíduos de gesso acartonado se houvesse legislação obrigando claramente seu destino às centrais de reciclagem.

Para o presente caso, em virtude da falta de locais para deposição destes resíduos e, acreditando-se em uma fiscalização rígida, foi arbitrada uma taxa de captação de 60\%, conforme já discutido. Além disso, a zona sul de São Paulo, região onde se locou a central de reciclagem de resíduos de CGA, concentra 
uma grande parte dos empreendimentos comerciais, os quais representam a maior parte do mercado de CGA dentre as tipologias de edifícios.

No item 5.2.1.5 apurou-se a geração de resíduos de CGA na RMSP em 300,31 t/mês. Sendo a jornada de 198 horas mensais obtém-se uma geração 1,52 t/h, já compatível com a capacidade de operação da central. No entanto, aplica-se a taxa de captação de $60 \%$ e tem-se uma quantidade de $0,91 \mathrm{t} / \mathrm{h}$ que atende a capacidade mínima de operação da central.

\subsubsection{FINANCIAMENTO}

O custo significativo apresentado para a implantação de uma central de reciclagem de CGA justifica a opção pelo financiamento de sua implantação. Dentre os financiamentos disponíveis adota-se aqui o FCP-SAN - Programa de Financiamento a Concessionários Privados de Serviços de Saneamento, na modalidade Resíduos da Construção Civil, oferecido pela Caixa Econômica Federal (CAIXA, 2005).

Este financiamento "destina-se à implementação de ações relativas ao acondicionamento, à coleta e transporte, ao transbordo, à triagem, à reciclagem e à destinação final dos resíduos oriundos de atividades de construção civil, incluindo ações complementares de educação ambiental $e$ participação comunitária”. Dentre os empreendimentos financiáveis consta a Implantação ou ampliação de instalações físicas para reciclagem, sendo financiáveis os seguintes itens:

- estudos e projetos, desde que não de forma isolada;

- obras e serviços;

- aquisição de materiais e equipamentos;

- aquisição de terreno com a finalidade exclusiva de executar a planta industrial;

- obras complementares vinculadas à execução e/ou segurança das obras;

- trabalho social, quando necessário; 
- ações de preservação ambientais necessárias à implantação do empreendimento.

Há a possibilidade de financiamento com recursos do Fundo de Garantia do Tempo de Serviço - FGTS e com recursos do Banco Nacional de Desenvolvimento Econômico e Social - BNDES. No presente caso, optou-se pelo financiamento com recursos do FGTS, pois este exige um percentual de contrapartida menor que aquele oferecido com recursos do BNDES.

Assume-se que o investidor tem disponibilidade para investir $\mathrm{R} \$ 250.000,00$ na implantação da central de reciclagem de CGA e irá financiar o restante da quantia necessária, ou seja, há uma contrapartida de $25,02 \%$ e um financiamento de 74,98\%, conforme Tabela 6.9, exceto para as análises IV, VII e IX, onde o montante e os percentuais de investimento financiado são outros.

Tabela 6.9 - Custos de implantação da central de reciclagem (autora, 2007).

\begin{tabular}{l|r}
\hline \multicolumn{2}{c}{ CUSTOS DE IMPLANTAÇÃO } \\
\hline Custo de Aquisição do Terreno & $\mathrm{R} \$ 210.000,00$ \\
\hline Custo de Obras Civis & $\mathrm{R} \$ 280.428,07$ \\
\hline Custo de Aquisição de Máquinas, Equipamentos e Veículos Próprios & $\mathrm{R} \$ 508.800,00$ \\
\hline \hline \multicolumn{1}{c|}{ Total } & $\mathrm{R} \$ 999.228,07$ \\
\hline \hline Disponibilidade de $\mathrm{R} \$ 250.000,00$ & $25,02 \%$ \\
\hline Financiar $\mathrm{R} \$ 749.228,07$ & $74,98 \%$ \\
\hline
\end{tabular}

O Manual de orientação sobre procedimentos para a solicitação de financiamento do Programa de Financiamento a Concessionários Privados de Serviços de Saneamento, na modalidade Resíduos Sólidos da Construção Civil, da Caixa Econômica (CAIXA, 2005), estabelece as condições de financiamento para a central de reciclagem.

As informações relevantes para a análise foram (CAIXA, 2006):

- o valor da contrapartida mínima é de $25 \%$;

- o período de carência equivale ao prazo previsto para a execução das obras, limitado ao máximo de 24 meses; 
- o prazo total de financiamento, ou seja, a soma dos prazos de carência e de amortização está limitado ao máximo de 240 meses (20 anos);

- os juros são pagos mensalmente, nas fases de carência e de amortização, a taxas nominais de 6,5\% a.a. a 8,0\% a.a., de acordo com a modalidade. Foi considerado juros de $8 \%$ a.a.;

- a taxa de risco é cobrada mensalmente juntamente com os demais encargos do contrato de financiamento, em valor percentual a ser negociado conforme a avaliação de risco de crédito que incidirá sobre o saldo devedor, durante toda a vigência do contrato de financiamento; foi considerada a taxa de risco de crédito de 1,8\%, de acordo com BNDES (2006);

- as prestações são cobradas mensalmente, calculadas pelo Sistema Francês de Amortização - Tabela Price, sendo o saldo devedor atualizado pelo índice e periodicidade aplicados às contas vinculadas do FGTS; as contas vinculadas ao FGTS são remuneradas em 3\%a.a. mais variação da TR do primeiro dia útil de cada mês; como as análises estão sendo feitas em períodos anuais; levantou-se o valor da variação da TR do ano de 2006 e considerou-se sua média, que foi igual a 0,08\%a.a.;

- a remuneração da Caixa é de $2 \%$ a.a. nas fases de carência e de amortização, cobrada mensalmente, junto com as prestações.

As parcelas de composição do financiamento obedecem às regras supracitadas, estabelecidas pelo banco público (CAIXA, 2006), e são apresentadas na Tabela 6.10 .

Tabela 6.10 - Composição do financiamento de $75 \%$ do valor do investimento necessário à implantação da central de reciclagem (autora, 2007).

\begin{tabular}{lr}
\hline & FINANCIAMENTO \\
\hline & \multicolumn{1}{c}{ Ao ano } \\
\hline Taxa de juros & $8,00 \%$ \\
\hline Inflação & $3,40 \%$ \\
\hline Taxa de risco de crédito & $1,80 \%$ \\
\hline Remuneração do banco & $2,00 \%$ \\
\hline Contas Vinculadas ao FGTS & $3,00 \%$ \\
\hline Variação da TR & $0,08 \%$ \\
\hline Taxa de juros final & $11,40 \%$ \\
\hline Valor do financiamento & $\mathrm{R} \$ 749.228,07$ \\
\hline Fator Price & 0,09972 \\
\hline
\end{tabular}




\subsubsection{DEMONSTRATIVO DE RESULTADOS}

Os valores presentes no balanço de operação da central de reciclagem de resíduo de CGA foram obtidos de acordo com as seguintes regras (JADOVSKI; MASUERO, 2006):

- a receita operacional bruta é obtida multiplicando-se a produção de agregado gesso (gipsita) reciclado pelo seu preço de venda;

- são considerados os seguintes impostos: PIS/COFINS (9,65\%), ICMS (18\%), imposto de renda (15\%) e contribuição social $(9,00 \%)$, sendo que o PIS/COFINS e o ICMS incidem sobre a receita operacional bruta e o IR (15\%) e a Contribuição Social (9\%) incidem sobre o Lucro Antes do Imposto de Renda - LAIR;

- a receita operacional líquida é obtida subtraindo-se os impostos sobre a receita da receita operacional bruta;

- o resultado bruto é obtido pela subtração dos custos de produção da receita operacional líquida;

- o resultado antes de juros e imposto de renda é obtido subtraindo as despesas indiretas do resultado bruto;

- os juros de financiamento são calculados conforme descrito em 6.1.4;

- o lucro antes do imposto de renda é obtido subtraindo os juros de financiamento do resultado antes de juros e imposto de renda;

- finalmente, o resultado líquido é obtido subtraindo os impostos e taxas do lucro antes do imposto de renda.

\subsubsection{FLUXO DE CAIXA}

No presente caso, tanto custos como receitas são utilizados em valores constantes no fluxo de caixa.

As tabelas "fluxo de caixa" demonstram as receitas e as despesas, que representam as entradas e saídas de caixa ao longo do horizonte de 
planejamento do empreendimento, que é de 20 anos. São consideradas despesas os custos de implantação no ano zero.

São consideradas receitas o ingresso de financiamento no ano zero o resultado líquido ao longo do horizonte de planejamento. Não foram considerados valores residuais ao final do ano 20 .

Finalmente, as tabelas resultantes das 10 simulações feitas apresentam também os resultados da Taxa Interna de Retorno (TIR) e do Período de Recuperação do Investimento - Pay back, adotados como critérios para avaliar o investimento no empreendimento.

\subsection{Simulações de ANálise de Viabiliddade ECONÔMICA}

A Figura 6.5 ilustra todas as variáveis possíveis das análises e quais serão realizadas, perfazendo-se um total de dez (10) simulações de situações, que foram inicialmente consideradas as mais plausíveis.

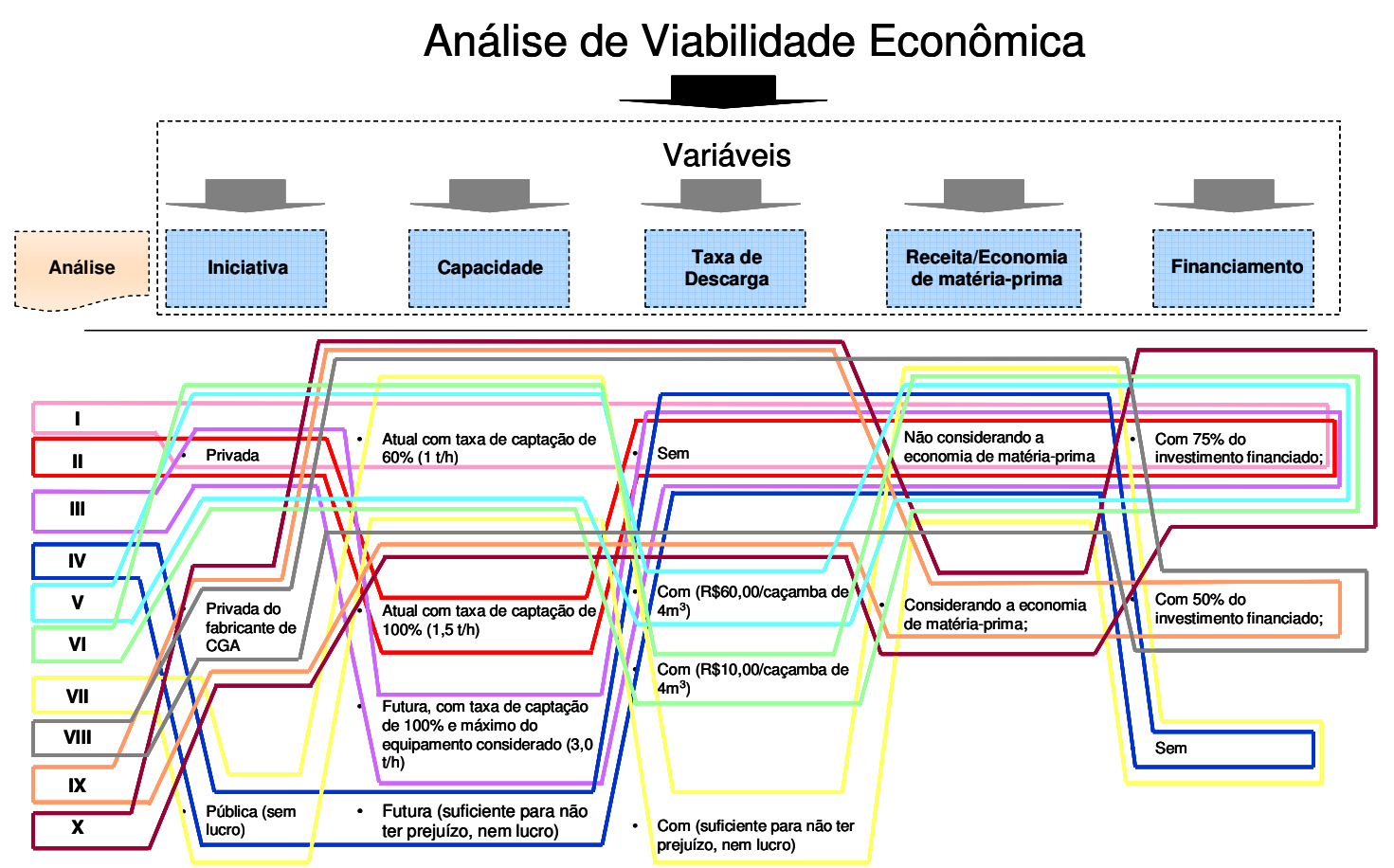

Figura 6.5 - Análises de Viabilidade Econômica e suas respectivas variáveis contempladas (autora, 2007). 


\subsubsection{ANÁliSE DE VIABILIDADE I}

A análise de viabilidade I considera a implantação de uma central de reciclagem na RMSP, por meio da iniciativa privada de um investidor, que não o fabricante de CGA. A central de reciclagem em questão terá a sua disposição 60\% de todo o resíduo de CGA gerado na RMSP (taxa de captação), ou seja, aproximadamente $0,91 \mathrm{t} / \mathrm{h}$, quantia esta condizente com a capacidade de processamento da central, que é de $1,0 \mathrm{t} / \mathrm{h}$.

Adotou-se que não há cobrança de taxa de descarga por parte da central de reciclagem. O ônus do gerador restringe-se somente ao transporte até a central, e a rentabilidade do investidor é determinada por meio da venda de gesso reciclado de rCGA. Como não é fabricante, o investidor não usufrui de nenhuma economia de matéria-prima. Como os custos de implantação da central de reciclagem totalizaram quase um milhão de reais, optou-se pelo financiamento, disponível em um banco público. As variáveis contempladas nesta análise são apresentadas na Figura 6.6.

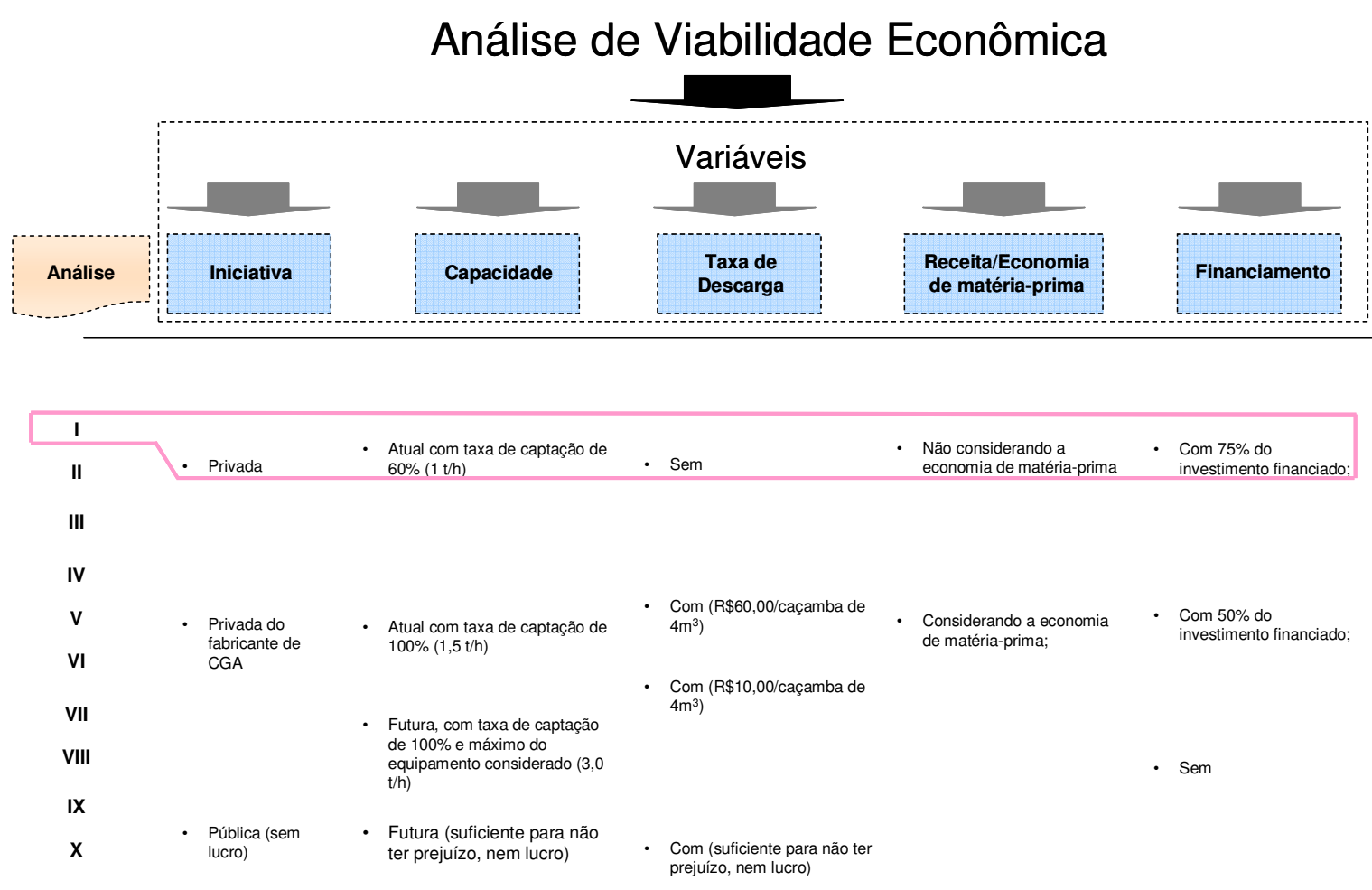

Figura 6.6 - Variáveis contempladas na Análise de Viabilidade Econômica I (autora, 2007). 
Arbitrou-se que o investidor dispõe de $\mathrm{R} \$ 250.000,00$ para o investimento inicial e irá financiar o restante do custo de implantação.

Para determinação da receita operacional bruta utilizou-se a capacidade de produção da central e o preço de venda CIF, o qual absorve os custos de frete de distribuição para clientes distantes até $130 \mathrm{~km}$ da central.

A importância desta análise deve-se ao fato dela ser a que mais se aproximada do cenário atual, conforme o cenário descrito no 5.2.1.6. O balanço de operação da central, para estas variáveis, é apresentado na Tabela 6.11.

Tabela 6.11 - Balanço de operação da Central de Reciclagem segundo as variáveis da Análise de Viabilidade I (autora, 2007).

\begin{tabular}{|c|c|c|}
\hline \multicolumn{3}{|c|}{ Análise I } \\
\hline I'TEM & DESCRIÇÃO & BALANÇO \\
\hline 1 & RECEITA OPERACIONAL BRUTA & $R \$ 262.310,40$ \\
\hline 1.1 & Venda de gesso reciclado de CGA & $\mathrm{R} \$ 262.310,40$ \\
\hline 2 & IMPOSTOS SOBRE A RECEITA & $R \$ 72.528,83$ \\
\hline 2.1 & PIS/COFINS (9,65\%) & $\mathrm{R} \$ 25.312,95$ \\
\hline 2.2 & ICMS (18\%) & $\mathrm{R} \$ 47.215,87$ \\
\hline 3 & RECEITA OPERACIONAL LÍQUIDA & $\mathrm{R} \$ 189.781,57$ \\
\hline 4 & CUSTOS DE PRODUÇÃO & $R \$ 244.802,48$ \\
\hline 4.1 & Custos de Operação & $R \$ 166.464,11$ \\
\hline 4.1 .1 & Custo da Mão-de-Obra de Produção & $\mathrm{R} \$ 136.703,28$ \\
\hline 4.1 .2 & Custo de Operação de Máq., Equip. e Veículos Próprios & $\mathrm{R} \$ 17.107,20$ \\
\hline 4.1 .3 & Custo dos Insumos de Produção & $\mathrm{R} \$ 12.653,63$ \\
\hline 4.2 & Custos de Manutenção & $\mathrm{R} \$ 31.122,50$ \\
\hline 4.2 .1 & Custo de Manutenção de Máq., Equip. e Veículos Próprios & $\mathrm{R} \$ 5.088,00$ \\
\hline 4.2 .2 & Custo de Depreciação de Máq., Equip. e Veículos Próprios & $\mathrm{R} \$ 26.034,50$ \\
\hline 4.3 & Custos de Distribuição & $\mathrm{R} \$ 47.215,87$ \\
\hline 4.3.1 & Custo do frete de distribuição (incluso insumos) & $\mathrm{R} \$ 47.215,87$ \\
\hline 5 & RESULTADO BRUTO & -R\$ 55.020,91 \\
\hline 6 & DESPESAS INDIRETAS & $\mathrm{R} \$ 106.221,72$ \\
\hline 6.1 & Despesas Indiretas de Operação & $R \$ 102.968,76$ \\
\hline 6.1 .1 & Custo da Mão-de-Obra Administrativa & $\mathrm{R} \$ 23.461,20$ \\
\hline 6.1 .2 & Despesas Administrativas (telefone, material de consumo) & $\mathrm{R} \$ 7.567,08$ \\
\hline 6.1 .3 & Vigilância & $\mathrm{R} \$ 71.940,48$ \\
\hline 6.2 & Despesas Indiretas de Manutenção & $\mathrm{R} \$ 3.252,96$ \\
\hline 6.2 .1 & Custo de Manutenção de Obras Civis & $\mathrm{R} \$ 2.804,28$ \\
\hline 6.2 .2 & Custo de Depreciação de Obras Civis & $\mathrm{R} \$ 448,68$ \\
\hline 7 & LAIR (Lucro Antes do Imposto de Renda) & $-R \$ 161.242,63$ \\
\hline 8 & IMPOSTOS E TAXAS & $-R \$ 38.698,23$ \\
\hline 8.1 & Imposto de Renda (15\%) & $-\mathrm{R} \$ 24.186,39$ \\
\hline 8.2 & Contribuição Social (9\%) & $-\mathrm{R} \$ 14.511,84$ \\
\hline 9 & RESULTADO LÍQUIDO & $-R \$ 199.940,86$ \\
\hline
\end{tabular}


Em virtude dos resultados apresentados na Tabela 6.11, conclui-se que os custos de produção são maiores do que a receita operacional líquida, ou seja, não há viabilidade econômica para a operação da central.

\subsubsection{ANÁLISE DE VIABILIDADE II}

Esta segunda análise é similar à primeira, ou seja, a iniciativa de implantação da central de reciclagem continua sendo privada; não há cobrança de taxa de descarga por parte da central; não há economia de matéria-prima e utiliza-se o financiamento de $75 \%$ do capital necessário para a implantação da central.

A única alteração deve-se à capacidade de processamento/produção. Nesta segunda análise pressupõe-se que haja uma rígida fiscalização em relação à deposição destes resíduos, assim como uma severa penalização e que, portanto, a central consegue ter uma taxa de captação de $100 \%$, equivalente a $1,52 \mathrm{t} / \mathrm{h}$ (Figura 6.7).

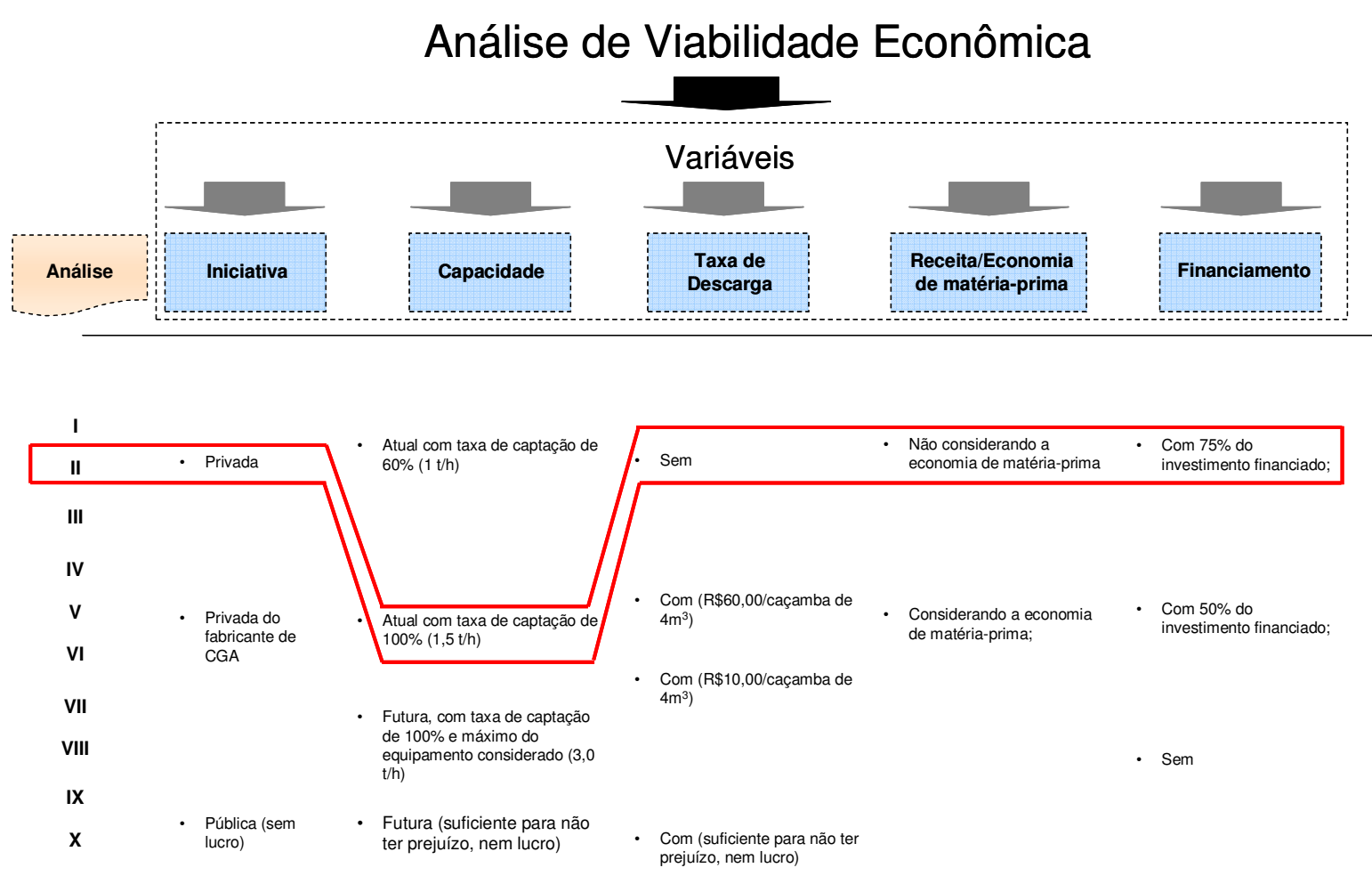

Figura 6.7 - Variáveis contempladas na Análise de Viabilidade Econômica II (autora, 2007). 
Neste cenário, existe apenas uma central de reciclagem na RMSP e, portanto, como forma de atender à legislação em vigor, todos os resíduos de CGA gerados na RMSP seriam enviados a esta central pelos geradores ou pelas ATT. A Tabela 6.12 apresenta os resultados do balanço de operação.

Tabela 6.12 - Balanço de operação da Central de Reciclagem segundo as variáveis da Análise de Viabilidade II (autora, 2007).

\begin{tabular}{|c|c|c|}
\hline \multicolumn{3}{|c|}{ Análise II } \\
\hline ÍTEM & DESCRIÇÃO & BALANÇO \\
\hline 1 & RECEITA OPERACIONAL BRUTA & $\mathrm{R} \$ 322.641,79$ \\
\hline 1.1 & Venda de gesso reciclado de CGA & $\mathrm{R} \$ 322.641,79$ \\
\hline 2 & IMPOSTOS SOBRE A RECEITA & $\mathbf{R} \$ 89.210,46$ \\
\hline 2.1 & PIS/COFINS $(9,65 \%)$ & $\mathrm{R} \$ 31.134,93$ \\
\hline 2.2 & ICMS (18\%) & $\mathrm{R} \$ 58.075,52$ \\
\hline 3 & RECEITA OPERACIONAL LÍQUIDA & $\mathrm{R} \$ 233.431,34$ \\
\hline 4 & CUSTOS DE PRODUÇÃO & $R \$ 268.410,42$ \\
\hline 4.1 & Custos de Operação & $R \$ 166.464,11$ \\
\hline 4.1 .1 & Custo da Mão-de-Obra de Produção & $\mathrm{R} \$ 136.703,28$ \\
\hline 4.1 .2 & Custo de Operação de Máq., Equip. e Veículos Próprios & $\mathrm{R} \$ 17.107,20$ \\
\hline 4.1 .3 & Custo dos Insumos de Produção & $\mathrm{R} \$ 12.653,63$ \\
\hline 4.2 & Custos de Manutenção & $\mathrm{R} \$ 31.122,50$ \\
\hline 4.2 .1 & Custo de Manutenção de Máq., Equip. e Veículos Próprios & $R \$ 5.088,00$ \\
\hline 4.2 .2 & Custo de Depreciação de Máq., Equip. e Veículos Próprios & $\mathrm{R} \$ 26.034,50$ \\
\hline 4.3 & Custos de Distribuição & $\mathrm{R} \$ \mathbf{7 0 . 8 2 3 , 8 1}$ \\
\hline 4.3 .1 & Custo do frete de distribuição (incluso insumos) & $\mathrm{R} \$ 70.823,81$ \\
\hline 5 & RESULTADO BRUTO & $-\mathrm{R} \$ 34.979,08$ \\
\hline 6 & DESPESAS INDIRETAS & $R \$ 106.221,72$ \\
\hline 6.1 & Despesas Indiretas de Operação & $\mathrm{R} \$ 102.968,76$ \\
\hline 6.1 .1 & Custo da Mão-de-Obra Administrativa & $\mathrm{R} \$ 23.461,20$ \\
\hline 6.1 .2 & Despesas Administrativas (telefone, material de consumo) & $\mathrm{R} \$ 7.567,08$ \\
\hline 6.1 .3 & Vigilância & $\mathrm{R} \$ 71.940,48$ \\
\hline 6.2 & Despesas Indiretas de Manutenção & $R \$ 3.252,96$ \\
\hline 6.2 .1 & Custo de Manutenção de Obras Civis & $\mathrm{R} \$ 2.804,28$ \\
\hline 6.2 .2 & Custo de Depreciação de Obras Civis & $\mathrm{R} \$ 448,68$ \\
\hline 7 & LAIR (Lucro Antes do Imposto de Renda) & $-R \$ 141.200,81$ \\
\hline 8 & IMPOSTOS E TAXAS & $-R \$ 33.888,19$ \\
\hline 8.1 & Imposto de Renda (15\%) & $-\mathrm{R} \$ 21.180,12$ \\
\hline 8.2 & Contribuição Social (9\%) & $-\mathrm{R} \$ 12.708,07$ \\
\hline 9 & RESULTADO LÍQUIDO & $-\mathrm{R} \$ 175.089,00$ \\
\hline
\end{tabular}

A alteração da taxa de captação não surtiu muito efeito no balanço de operação, mantendo-se um resultado líquido negativo. Novamente os custos de produção superaram a receita operacional líquida. Isto significa que, ainda que todos os resíduos de CGA gerados na RMSP fossem corretamente destinados a uma central de reciclagem, esta não teria viabilidade econômica (segundo as variáveis consideradas). 


\subsubsection{ANÁLISE DE VIABILIDADE III}

Em virtude dos resultados negativos obtidos nas análises I e II, procurou-se estabelecer a capacidade de produção da central. Esta foi determinada pela capacidade máxima de processamento da máquina recicladora, que é de $3 \mathrm{t} / \mathrm{h}$.

Os fabricantes estimam um crescimento nas vendas de aproximadamente $12 \%$ ao ano, para os próximos três anos. Considerando-se que esta taxa de crescimento permanece pelos próximos anos, a geração de resíduos de CGA atingirá as 3 t/h somente daqui a 6 anos, ou seja, em 2013. Assim, esta análise considera um cenário futuro, em que a iniciativa privada implanta, mediante financiamento (75\%), uma central de reciclagem, a qual possui capacidade de processamento de $3 \mathrm{t} / \mathrm{h}$ - considerando-se uma taxa de captação de $100 \%$ - e não cobra taxa de descarga. A Figura 6.8 ilustra a escolha das variáveis desta análise.

\section{Análise de Viabilidade Econômica}
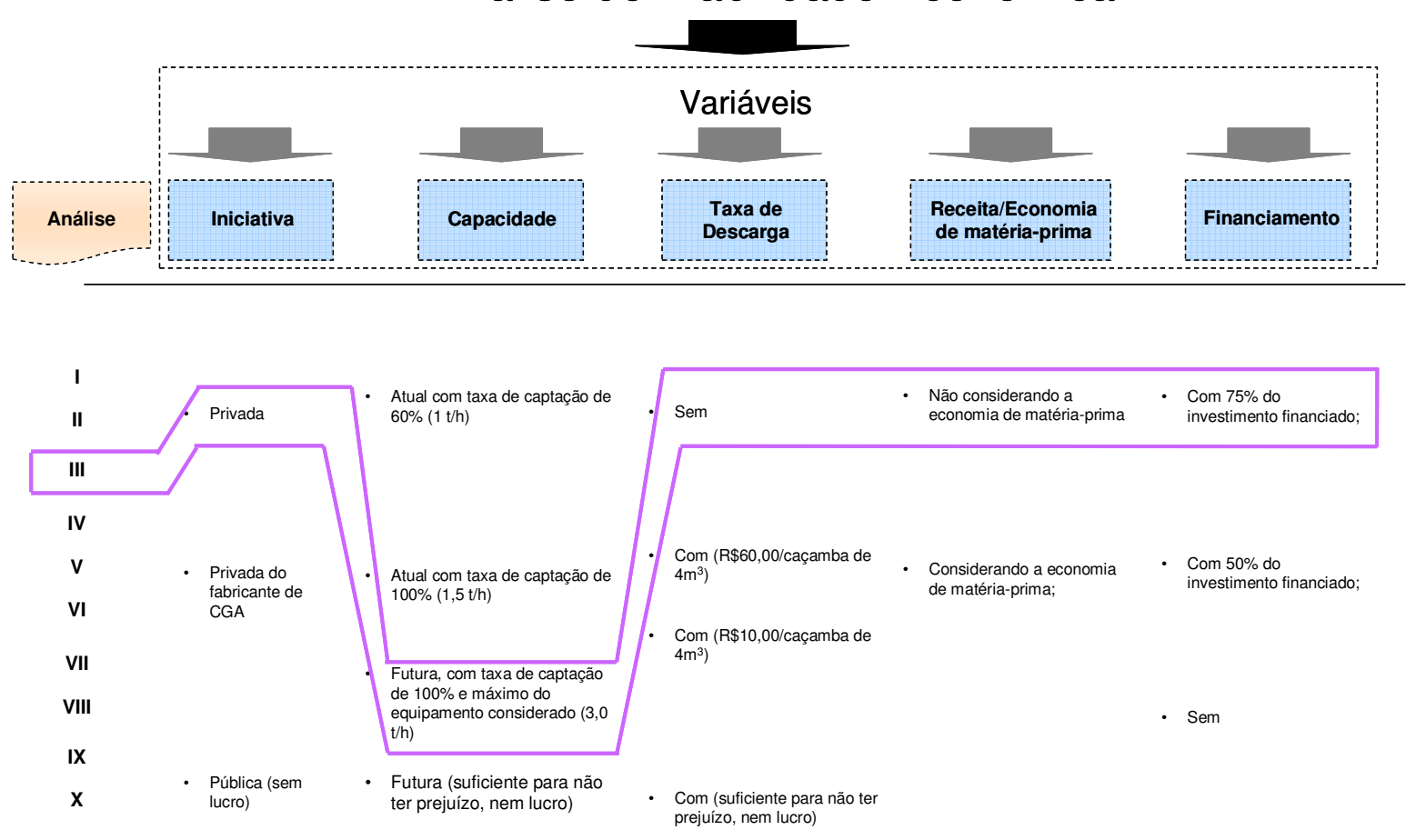

Figura 6.8 - Variáveis contempladas na Análise de Viabilidade Econômica III (autora, 2007). 
A Tabela 6.13 mostra os resultados do balanço de operação, o qual teve resultado líquido positivo, o que significa que a operação da central de reciclagem renderia algum lucro ao investidor.

Tabela 6.13 - Balanço de operação da Central de Reciclagem segundo as variáveis da Análise de Viabilidade III (autora, 2007).

\begin{tabular}{|c|c|c|}
\hline \multicolumn{3}{|c|}{ Análise III } \\
\hline ITEM & DESCRIÇÃO & BALANÇO \\
\hline 1 & RECEITA OPERACIONAL BRUTA & $R \$ 786.931,20$ \\
\hline 1.1 & Venda de gesso reciclado de CGA & $\mathrm{R} \$ 786.931,20$ \\
\hline 2 & IMPOSTOS SOBRE A RECEITA & $R \$ 217.586,48$ \\
\hline 2.1 & PIS/COFINS (9,65\%) & $\mathrm{R} \$ 75.938,86$ \\
\hline 2.2 & ICMS (18\%) & $\mathrm{R} \$ 141.647,62$ \\
\hline 3 & RECEITA OPERACIONAL LÍQUIDA & $\mathrm{R} \$ 569.344,72$ \\
\hline 4 & CUSTOS DE PRODUÇÃO & $\mathrm{R} \$ 339.234,23$ \\
\hline 4.1 & Custos de Operação & $R \$ 166.464,11$ \\
\hline 4.1 .1 & Custo da Mão-de-Obra de Produção & $\mathrm{R} \$ 136.703,28$ \\
\hline 4.1 .2 & Custo de Operação de Máq., Equip. e Veículos Próprios & $\mathrm{R} \$ 17.107,20$ \\
\hline 4.1 .3 & Custo dos Insumos de Produção & $\mathrm{R} \$ 12.653,63$ \\
\hline 4.2 & Custos de Manutenção & $\mathrm{R} \$ \mathbf{3 1 . 1 2 2 , 5 0}$ \\
\hline 4.2 .1 & Custo de Manutenção de Máq., Equip. e Veículos Próprios & $\mathrm{R} \$ 5.088,00$ \\
\hline 4.2 .2 & Custo de Depreciação de Máq., Equip. e Veículos Próprios & $\mathrm{R} \$ 26.034,50$ \\
\hline 4.3 & Custos de Distribuição & $\mathrm{R} \$ 141.647,62$ \\
\hline 4.3 .1 & Custo do frete de distribuição (incluso insumos) & $\mathrm{R} \$ 141.647,62$ \\
\hline 5 & RESULTADO BRUTO & $\mathrm{R} \$ 230.110,50$ \\
\hline 6 & DESPESAS INDIRETAS & $R \$ 106.221,72$ \\
\hline 6.1 & Despesas Indiretas de Operação & $\mathrm{R} \$ 102.968,76$ \\
\hline 6.1 .1 & Custo da Mão-de-Obra Administrativa & $\mathrm{R} \$ 23.461,20$ \\
\hline 6.1 .2 & Despesas Administrativas (telefone, material de consumo) & $\mathrm{R} \$ 7.567,08$ \\
\hline 6.1 .3 & Vigilância & $\mathrm{R} \$ 71.940,48$ \\
\hline 6.2 & Despesas Indiretas de Manutenção & $R \$ 3.252,96$ \\
\hline 6.2 .1 & Custo de Manutenção de Obras Civis & $\mathrm{R} \$ 2.804,28$ \\
\hline 6.2 .2 & Custo de Depreciação de Obras Civis & $\mathrm{R} \$ 448,68$ \\
\hline 7 & LAIR (Lucro Antes do Imposto de Renda) & $\mathrm{R} \$ 123.888,77$ \\
\hline 8 & IMPOSTOS E TAXAS & $\mathrm{R} \$ 29.733,31$ \\
\hline 8.1 & Imposto de Renda (15\%) & $\mathrm{R} \$ 18.583,32$ \\
\hline 8.2 & Contribuição Social (9\%) & $\mathrm{R} \$ 11.149,99$ \\
\hline 9 & RESULTADO LIQQUIDO & $R \$ 94.155,47$ \\
\hline
\end{tabular}

Procede-se então para a etapa de análise do financiamento, uma vez que o resultado líquido obtido para a operação deve também suportar o período de implantação da central de reciclagem, assim como os custos advindos do financiamento. Supõe-se que o investidor tenha disponibilidade imediata de investir $\mathrm{R} \$ 250.000,00$ e que o restante do montante necessário será financiado, conforme as Tabela 6.9 e Tabela 6.10, ilustradas no item 6.1.4. 
Apresenta-se na Tabela 6.14 os resultados do fluxo de caixa da análise em questão.

Tabela 6.14 - Fluxo de caixa da análise de viabilidade econômica III (autora, 2007).

\begin{tabular}{|c|c|c|c|c|}
\hline \multicolumn{5}{|c|}{ Fluxo de caixa - Análise III } \\
\hline Ano & Juros & Parcela & $\begin{array}{l}\text { Resultado } \\
\text { Líquido }\end{array}$ & $\begin{array}{l}\text { Movimentação } \\
\text { Financeira }\end{array}$ \\
\hline 0 & & (250.000,00) & & (250.000,00) \\
\hline 1 & $(85.412,00)$ & & & $(85.412,00)$ \\
\hline 2 & $(85.412,00)$ & & & $(85.412,00)$ \\
\hline 3 & $(85.412,00)$ & $(74.710,42)$ & $94.155,47$ & $(65.966,96)$ \\
\hline 4 & $(85.412,00)$ & $(74.710,42)$ & $94.155,47$ & $(65.966,96)$ \\
\hline 5 & $(85.412,00)$ & $(74.710,42)$ & $94.155,47$ & $(65.966,96)$ \\
\hline 6 & $(85.412,00)$ & $(74.710,42)$ & $94.155,47$ & $(65.966,96)$ \\
\hline 7 & $(85.412,00)$ & $(74.710,42)$ & $94.155,47$ & $(65.966,96)$ \\
\hline 8 & $(85.412,00)$ & $(74.710,42)$ & $94.155,47$ & $(65.966,96)$ \\
\hline 9 & $(85.412,00)$ & $(74.710,42)$ & $94.155,47$ & $(65.966,96)$ \\
\hline 10 & $(85.412,00)$ & $(74.710,42)$ & $94.155,47$ & $(65.966,96)$ \\
\hline 11 & $(85.412,00)$ & $(74.710,42)$ & $94.155,47$ & $(65.966,96)$ \\
\hline 12 & $(85.412,00)$ & $(74.710,42)$ & $94.155,47$ & $(65.966,96)$ \\
\hline 13 & $(85.412,00)$ & $(74.710,42)$ & $94.155,47$ & $(65.966,96)$ \\
\hline 14 & $(85.412,00)$ & $(74.710,42)$ & $94.155,47$ & $(65.966,96)$ \\
\hline 15 & $(85.412,00)$ & $(74.710,42)$ & $94.155,47$ & $(65.966,96)$ \\
\hline 16 & $(85.412,00)$ & $(74.710,42)$ & $94.155,47$ & $(65.966,96)$ \\
\hline 17 & $(85.412,00)$ & $(74.710,42)$ & $94.155,47$ & $(65.966,96)$ \\
\hline 18 & $(85.412,00)$ & $(74.710,42)$ & $94.155,47$ & $(65.966,96)$ \\
\hline 19 & $(85.412,00)$ & $(74.710,42)$ & $94.155,47$ & $(65.966,96)$ \\
\hline \multirow[t]{4}{*}{20} & $(85.412,00)$ & $(74.710,42)$ & $94.155,47$ & $(65.966,96)$ \\
\hline & & \multicolumn{2}{|c|}{ TIR } & -- \\
\hline & & \multicolumn{2}{|c|}{ Pay-back } & --- \\
\hline & & \multicolumn{2}{|c|}{ Pay-back cop } & --- \\
\hline
\end{tabular}

É possível identificar que o resultado líquido suporta apenas o pagamento dos juros, mas não o da parcela do financiamento. Assim, a operação sempre terá prejuízo, não sendo viável economicamente, a menos que o investidor não precise ou não opte pelo financiamento.

\subsubsection{ANÁLISE de ViabILIDADE IV}

A análise de viabilidade IV prevê que a iniciativa pública implante uma central de reciclagem de rCGA, sem necessitar de financiamento, considerando este um investimento "a fundo perdido" em infra-estrutura urbana. Por ser uma iniciativa pública, não visa lucro. Portanto, a receita obtida com a venda do 
gesso reciclado de rCGA precisa ser suficiente para cobrir o custo total da central de reciclagem, ou seja, o balanço de operação deve ter resultado nulo, ou próximo de nulo, sem a cobrança de taxa de descarga (Figura 6.9).
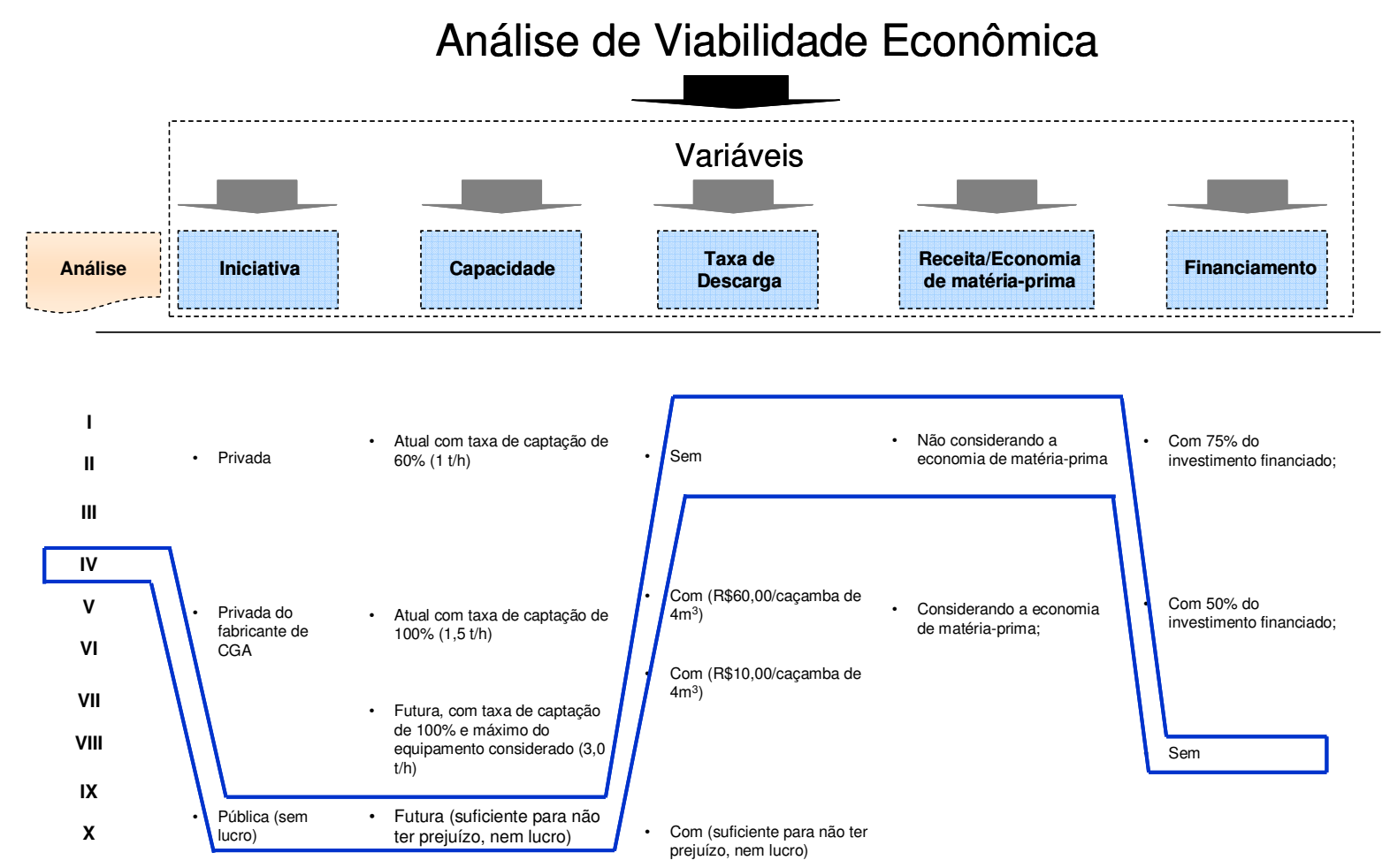

Figura 6.9 - Variáveis contempladas na Análise de Viabilidade Econômica IV (autora, 2007).

Para determinar a receita operacional bruta, fixou-se o preço CIF do gesso reciclado, uma vez que ele determina a atratividade do produto. Portanto, variou-se a capacidade de produção, considerando a taxa de captação de $100 \%$. Para obter um balanço da operação próximo a zero é necessária uma produção de $1,85 \mathrm{t} / \mathrm{h}$.

A Tabela 6.15 demonstra o balanço de operação da análise de viabilidade IV. 
Tabela 6.15 - Balanço de operação da Central de Reciclagem segundo as variáveis da Análise de Viabilidade IV (autora, 2007).

\begin{tabular}{|c|c|c|}
\hline \multicolumn{3}{|c|}{ Análise IV } \\
\hline ITEM & DESCRIÇÃO & BALANÇO \\
\hline 1 & RECEITA OPERACIONAL BRUTA & $R \$ 485.175,98$ \\
\hline 1.1 & Venda de gesso reciclado de CGA & $\mathrm{R} \$ 485.175,98$ \\
\hline 2 & IMPOSTOS SOBRE A RECEITA & $R \$ 134.151,16$ \\
\hline 2.1 & PIS/COFINS $(9,65 \%)$ & $\mathrm{R} \$ 46.819,48$ \\
\hline 2.2 & ICMS (18\%) & $\mathrm{R} \$ 87.331,68$ \\
\hline 3 & RECEITA OPERACIONAL LÍQUIDA & $\mathrm{R} \$ 351.024,82$ \\
\hline 4 & CUSTOS DE PRODUÇÃO & $R \$ 244.802,48$ \\
\hline 4.1 & Custos de Operação & $\mathrm{R} \$ 166.464,11$ \\
\hline 4.1 .1 & Custo da Mão-de-Obra de Produção & $\mathrm{R} \$ 136.703,28$ \\
\hline 4.1 .2 & Custo de Operação de Máq., Equip. e Veículos Próprios & $\mathrm{R} \$ 17.107,20$ \\
\hline 4.1 .3 & Custo dos Insumos de Produção & $\mathrm{R} \$ 12.653,63$ \\
\hline 4.2 & Custos de Manutenção & $\mathrm{R} \$ 31.122,50$ \\
\hline 4.2 .1 & Custo de Manutenção de Máq., Equip. e Veículos Próprios & $\mathrm{R} \$ 5.088,00$ \\
\hline 4.2 .2 & Custo de Depreciação de Máq., Equip. e Veículos Próprios & $\mathrm{R} \$ 26.034,50$ \\
\hline 4.3 & Custos de Distribuição & $\mathrm{R} \$ 47.215,87$ \\
\hline 4.3 .1 & Custo do frete de distribuição (incluso insumos) & $\mathrm{R} \$ 87.331,68$ \\
\hline 5 & RESULTADO BRUTO & $R \$ 106.222,34$ \\
\hline 6 & DESPESAS INDIRETAS & $R \$ 106.221,72$ \\
\hline 6.1 & Despesas Indiretas de Operação & $R \$ 102.968,76$ \\
\hline 6.1 .1 & Custo da Mão-de-Obra Administrativa & $\mathrm{R} \$ 23.461,20$ \\
\hline 6.1 .2 & Despesas Administrativas (telefone, material de consumo) & $\mathrm{R} \$ 7.567,08$ \\
\hline 6.1 .3 & Vigilância & $\mathrm{R} \$ 71.940,48$ \\
\hline 6.2 & Despesas Indiretas de Manutenção & $\mathrm{R} \$ 3.252,96$ \\
\hline 6.2 .1 & Custo de Manutenção de Obras Civis & $\mathrm{R} \$ 2.804,28$ \\
\hline 6.2 .2 & Custo de Depreciação de Obras Civis & $\mathrm{R} \$ 448,68$ \\
\hline 7 & LAIR (Lucro Antes do Imposto de Renda) & $R \$ 0,62$ \\
\hline 8 & IMPOSTOS E TAXAS & $R \$ 0,15$ \\
\hline 8.1 & Imposto de Renda (15\%) & $\mathrm{R} \$ 0,09$ \\
\hline 8.2 & Contribuição Social (9\%) & $\mathrm{R} \$ 0,06$ \\
\hline 9 & RESULTADO LIQQUIDO & $R \$ 0,47$ \\
\hline
\end{tabular}

Se a estimativa de crescimento de vendas dos fabricantes (12\% a.a.) se confirmar, a geração de resíduos de CGA atingirá 1,85 t/h em dois anos. Assim, em 2009 já seria possível a implantação da central pela iniciativa pública, consideradas as demais variáveis.

\subsubsection{ANÁLISE de ViabiLIDAde $\mathbf{V}$}

Em virtude da inviabilidade apresentada pela análise I, a análise IV contempla a possibilidade de cobrança de taxa de descarga pela central de reciclagem. A taxa de descarga é uma prática realizada pelos aterros e ATT. 
De acordo com a entrevista realizada a uma ATT, o preço médio cobrado para a deposição de uma caçamba de $4 \mathrm{~m}^{3}$ com resíduos de gesso de revestimento (liso) ou CGA é de $\mathrm{R} \$ 40,00$.

No entanto, acredita-se que os geradores estariam dispostos a pagar até $20 \%$ a mais por uma correta deposição, se enviassem diretamente para a central de reciclagem. Por esta razão considerou-se para a análise V o custo da taxa de descarga em $\mathrm{R} \$ 60,00$. A Figura 6.10 ilustra a escolha das variáveis da análise de viabilidade $\mathrm{V}$.

Análise de Viabilidade Econômica
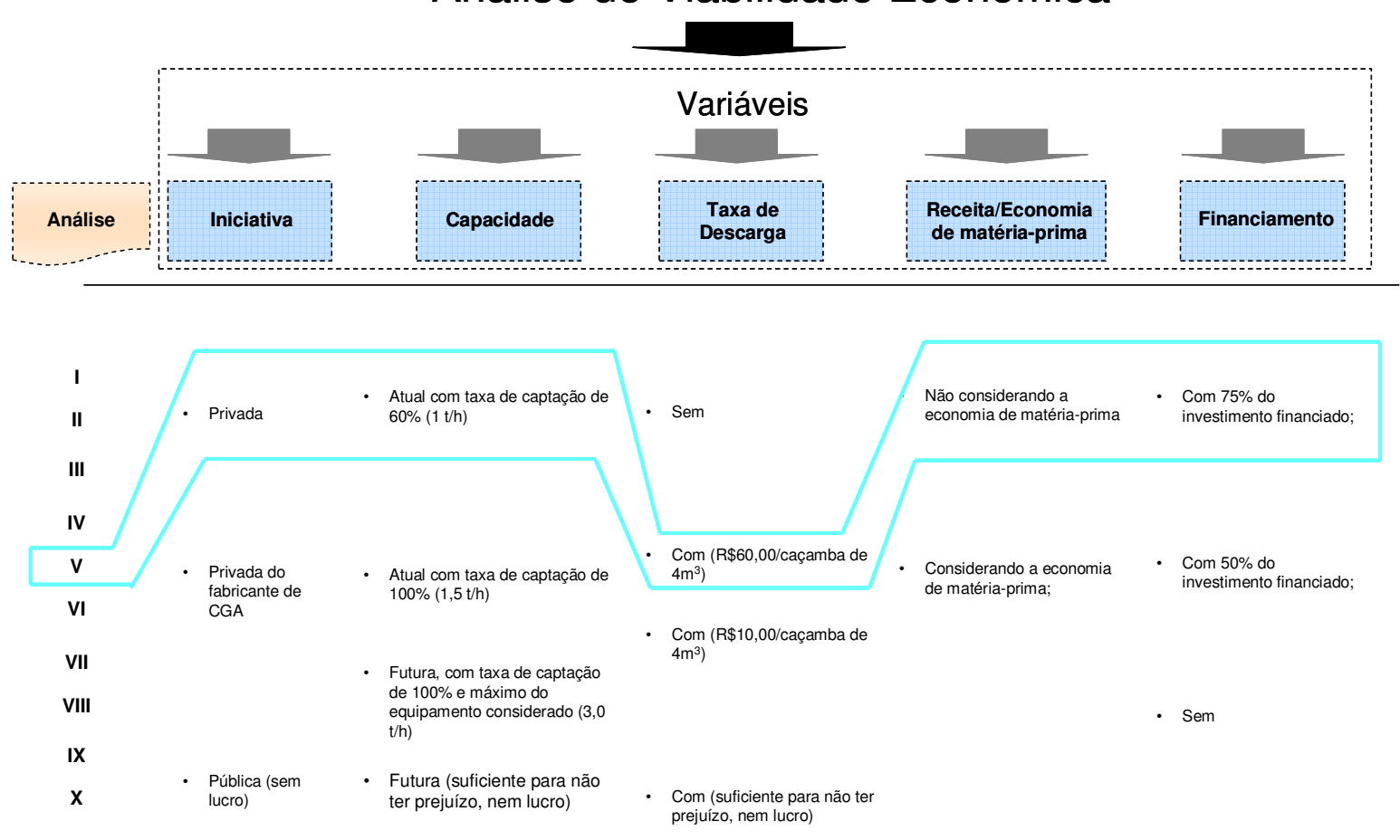

Figura 6.10 - Variáveis contempladas na Análise de Viabilidade Econômica V (autora, 2007).

A taxa de descarga, estipulada em $\mathrm{R} \$ 60,00 /$ caçamba de $4 \mathrm{~m}^{3}$, foi transformada, de forma equivalente em $\mathrm{R} \$ / \mathrm{kg}$, considerando-se que uma caçamba de $4 \mathrm{~m}^{3}$ contém, em média, 200kg de resíduos de CGA. A receita operacional bruta é o resultado da receita obtida com a venda de gesso reciclado de rCGA, somada a receita obtida com a taxa de descarga. A Tabela 6.16 demonstra os resultados do balanço de operação da central de reciclagem para as variáveis escolhidas. 
Tabela 6.16 - Balanço de operação da Central de Reciclagem segundo as variáveis da Análise de Viabilidade V (autora, 2007).

\begin{tabular}{|c|c|c|}
\hline \multicolumn{3}{|c|}{ Análise V } \\
\hline ITEM & DESCRIÇÃO & BALANÇO \\
\hline 1 & RECEITA OPERACIONAL BRUTA & $R \$ 975.110,40$ \\
\hline 1.1 & Venda de gesso reciclado de CGA & $\mathrm{R} \$ 975.110,40$ \\
\hline 2 & IMPOSTOS SOBRE A RECEITA & $R \$ 269.618,03$ \\
\hline 2.1 & PIS/COFINS (9,65\%) & $\mathrm{R} \$ 94.098,15$ \\
\hline 2.2 & ICMS (18\%) & $\mathrm{R} \$ 175.519,87$ \\
\hline 3 & RECEITA OPERACIONAL LÍQUIDA & $\mathrm{R} \$ 705.492,37$ \\
\hline 4 & CUSTOS DE PRODUÇÃO & $R \$ 244.802,48$ \\
\hline 4.1 & Custos de Operação & $\mathrm{R} \$ 166.464,11$ \\
\hline 4.1 .1 & Custo da Mão-de-Obra de Produção & $\mathrm{R} \$ 136.703,28$ \\
\hline 4.1 .2 & Custo de Operação de Máq., Equip. e Veículos Próprios & $\mathrm{R} \$ 17.107,20$ \\
\hline 4.1 .3 & Custo dos Insumos de Produção & $\mathrm{R} \$ 12.653,63$ \\
\hline 4.2 & Custos de Manutenção & R\$ 31.122,50 \\
\hline 4.2 .1 & Custo de Manutenção de Máq., Equip. e Veículos Próprios & $\mathrm{R} \$ 5.088,00$ \\
\hline 4.2 .2 & Custo de Depreciação de Máq., Equip. e Veículos Próprios & $\mathrm{R} \$ 26.034,50$ \\
\hline 4.3 & Custos de Distribuição & R\$ 47.215,87 \\
\hline 4.3 .1 & Custo do frete de distribuição (incluso insumos) & $\mathrm{R} \$ 47.215,87$ \\
\hline 5 & RESULTADO BRUTO & $\mathrm{R} \$ 460.689,89$ \\
\hline 6 & DESPESAS INDIRETAS & $R \$ 106.223,72$ \\
\hline 6.1 & Despesas Indiretas de Operação & $\mathrm{R} \$ 102.968,76$ \\
\hline 6.1 .1 & Custo da Mão-de-Obra Administrativa & $\mathrm{R} \$ 23.461,20$ \\
\hline 6.1 .2 & Despesas Administrativas (telefone, material de consumo) & $\mathrm{R} \$ 7.567,08$ \\
\hline 6.1 .3 & Vigilância & $\mathrm{R} \$ 71.940,48$ \\
\hline 6.2 & Despesas Indiretas de Manutenção & $\mathrm{R} \$ 3.254,96$ \\
\hline 6.2 .1 & Custo de Manutenção de Obras Civis & $\mathrm{R} \$ 2.806,28$ \\
\hline 6.2 .2 & Custo de Depreciação de Obras Civis & $\mathrm{R} \$ 448,68$ \\
\hline 7 & LAIR (Lucro Antes do Imposto de Renda) & $\mathrm{R} \$ 354.466,17$ \\
\hline 8 & IMPOSTOS E TAXAS & $\mathrm{R} \$ 85.071,88$ \\
\hline 8.1 & Imposto de Renda (15\%) & $\mathrm{R} \$ 53.169,93$ \\
\hline 8.2 & Contribuição Social (9\%) & $\mathrm{R} \$ 31.901,96$ \\
\hline 9 & RESULTADO LIQQUIDO & $\mathrm{R} \$ 269.394,29$ \\
\hline
\end{tabular}

O resultado líquido obtido indica que a fase de operação da central de reciclagem é viável economicamente. A próxima etapa consiste em verificar se este resultado será suficiente para suportar os custos de implantação e a rentabilidade pretendida pelo investidor. Os custos de implantação e as parcelas do financiamento foram apresentados nas tabelas Tabela 6.9 e Tabela 6.10 , respectivamente.

Na Tabela 6.17 é apresentado o fluxo de caixa da análise V, composto pelas despesas com juros e parcelas de financiamento, pelo resultado líquido e pela movimentação financeira. 
Tabela 6.17 - Fluxo de caixa da análise de viabilidade econômica V (autora, 2007).

\begin{tabular}{|c|c|c|c|c|}
\hline \multicolumn{5}{|c|}{ Fluxo de caixa - Análise V } \\
\hline Ano & juros & Parcela & $\begin{array}{l}\text { Resultado } \\
\text { Líquido }\end{array}$ & $\begin{array}{c}\text { Movimentação } \\
\text { Financeira }\end{array}$ \\
\hline 0 & & $(250.000,00)$ & & $(250.000,00)$ \\
\hline 1 & $(85.412,00)$ & & & $(85.412,00)$ \\
\hline 2 & $(85.412,00)$ & & & $(85.412,00)$ \\
\hline 3 & $(85.412,00)$ & $(74.710,42)$ & $269.394,29$ & $109.271,86$ \\
\hline 4 & $(85.412,00)$ & $(74.710,42)$ & $269.394,29$ & $109.271,86$ \\
\hline 5 & $(85.412,00)$ & $(74.710,42)$ & $269.394,29$ & $109.271,86$ \\
\hline 6 & $(85.412,00)$ & $(74.710,42)$ & $269.394,29$ & $109.271,86$ \\
\hline 7 & $(85.412,00)$ & $(74.710,42)$ & $269.394,29$ & $109.271,86$ \\
\hline 8 & $(85.412,00)$ & $(74.710,42)$ & $269.394,29$ & $109.271,86$ \\
\hline 9 & $(85.412,00)$ & $(74.710,42)$ & $269.394,29$ & $109.271,86$ \\
\hline 10 & $(85.412,00)$ & $(74.710,42)$ & $269.394,29$ & $109.271,86$ \\
\hline 11 & $(85.412,00)$ & $(74.710,42)$ & $269.394,29$ & $109.271,86$ \\
\hline 12 & $(85.412,00)$ & $(74.710,42)$ & $269.394,29$ & $109.271,86$ \\
\hline 13 & $(85.412,00)$ & $(74.710,42)$ & $269.394,29$ & $109.271,86$ \\
\hline 14 & $(85.412,00)$ & $(74.710,42)$ & $269.394,29$ & $109.271,86$ \\
\hline 15 & $(85.412,00)$ & $(74.710,42)$ & $269.394,29$ & $109.271,86$ \\
\hline 16 & $(85.412,00)$ & $(74.710,42)$ & $269.394,29$ & $109.271,86$ \\
\hline 17 & $(85.412,00)$ & $(74.710,42)$ & $269.394,29$ & $109.271,86$ \\
\hline 18 & $(85.412,00)$ & $(74.710,42)$ & $269.394,29$ & $109.271,86$ \\
\hline 19 & $(85.412,00)$ & $(74.710,42)$ & $269.394,29$ & $109.271,86$ \\
\hline \multirow[t]{4}{*}{20} & $(85.412,00)$ & \multirow{2}{*}{\multicolumn{2}{|c|}{$\frac{(14.710,42)}{\text { TIR }}$}} & $109.271,86$ \\
\hline & & & & $19,28 \%$ \\
\hline & & \multicolumn{2}{|c|}{ Pay-back } & Ano 6 - 2013 \\
\hline & & \multicolumn{2}{|c|}{ Pay-back cop } & Ano 9 - 2016 \\
\hline
\end{tabular}

Em virtude de a movimentação financeira ter sido positiva, calculou-se a TIR, o pay-back e o pay-back cop, tidos como os critérios para a avaliação de atratividade do investimento.

$\mathrm{Na}$ determinação do pay-back calcula-se quando a movimentação financeira acumulada atinge o mesmo valor do montante total investido (disponível no início + financiamento). Já no pay-back cop, a movimentação financeira acumulada é corrigida/atualizada com a rentabilidade efetiva do fundo de renda fixa, de $12 \%$ a.a.

No caso da análise de viabilidade $\mathrm{V}$, o pay-back ocorre no ano 6, que equivale ao ano 2013 se o investimento iniciar em 2007. Já o pay-back cop ocorre no ano 9.

Segundo Lima Júnior (1998), “quanto mais longo o pay-back, maior tempo de maturação apresenta o empreendimento, o que significa menos segurança, na medida em que um certo patamar de qualidade só se verificará mais tarde”. 


\subsubsection{ANÁliSE de VIABILIDADE VI}

Para a análise de viabilidade VI contemplou-se as variáveis apresentadas na Figura 6.11.

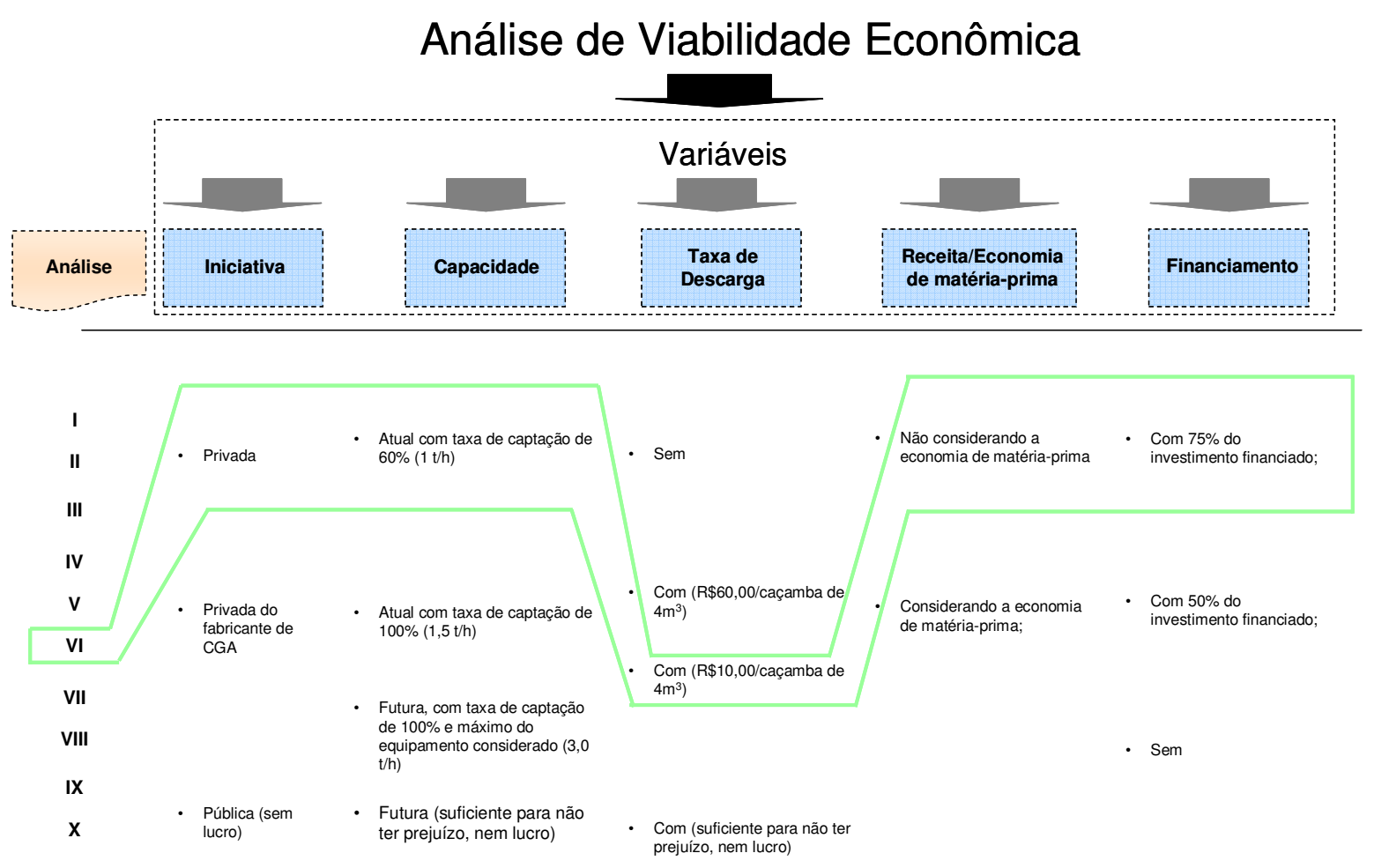

Figura 6.11 - Variáveis contempladas na Análise de Viabilidade Econômica VI (autora, 2007).

A opção por analisar a variável taxa de descarga como o valor de $\mathrm{R} \$ 10,00 /$ caçamba deve-se ao fato deste ser o valor cobrado pelos aterros atualmente. É esta a única mudança feita em relação à análise anterior.

Embora atualmente não devesse ser possível ao gerador enviar os resíduos de CGA para um aterro, pois, como visto no item 4.1.2, os aterros de construção civil recebem resíduos classe A e, em caráter excepcional, apenas para fins de reservação provisória, resíduos de outras classes, esta é uma prática corrente.

Assim, a análise VI pretende verificar se a central de reciclagem de resíduo de CGA poderia ser para o gerador uma alternativa de deposição com custo igual ao do aterro. O balanço de operação desta análise é demonstrado na Tabela 6.18 . 
Tabela 6.18 - Balanço de operação da Central de Reciclagem segundo as variáveis da Análise de Viabilidade VI (autora, 2007).

\begin{tabular}{|c|c|c|}
\hline \multicolumn{3}{|c|}{ Análise VI } \\
\hline ÍTEM & DESCRIÇÃO & BALANÇO \\
\hline 1 & RECEITA OPERACIONAL BRUTA & $\mathrm{R} \$ 381.110,40$ \\
\hline 1.1 & Venda de gesso reciclado de CGA & $\mathrm{R} \$ 381.110,40$ \\
\hline 2 & IMPOSTOS SOBRE A RECEITA & $\mathrm{R} \$ 105.377,03$ \\
\hline 2.1 & PIS/COFINS (9,65\%) & $\mathrm{R} \$ 36.777,15$ \\
\hline 2.2 & ICMS (18\%) & $\mathrm{R} \$ 68.599,87$ \\
\hline 3 & RECEITA OPERACIONAL LÍQUIDA & $\mathrm{R} \$ 275.733,37$ \\
\hline 4 & CUSTOS DE PRODUÇÃO & $R \$ 244.802,48$ \\
\hline 4.1 & Custos de Operação & $\mathrm{R} \$ 166.464,11$ \\
\hline 4.1 .1 & Custo da Mão-de-Obra de Produção & $\mathrm{R} \$ 136.703,28$ \\
\hline 4.1 .2 & Custo de Operação de Máq., Equip. e Veículos Próprios & $\mathrm{R} \$ 17.107,20$ \\
\hline 4.1 .3 & Custo dos Insumos de Produção & $\mathrm{R} \$ 12.653,63$ \\
\hline 4.2 & Custos de Manutenção & $\mathrm{R} \$ 31.122,50$ \\
\hline 4.2 .1 & Custo de Manutenção de Máq., Equip. e Veículos Próprios & $\mathrm{R} \$ 5.088,00$ \\
\hline 4.2 .2 & Custo de Depreciação de Máq., Equip. e Veículos Próprios & $\mathrm{R} \$ 26.034,50$ \\
\hline 4.3 & Custos de Distribuição & $\mathrm{R} \$ 47.215,87$ \\
\hline 4.3 .1 & Custo do frete de distribuição (incluso insumos) & $\mathrm{R} \$ 47.215,87$ \\
\hline 5 & RESULTADO BRUTO & $\mathbf{R} \$ 30.930,89$ \\
\hline 6 & DESPESAS INDIRETAS & $R \$ 106.223,72$ \\
\hline 6.1 & Despesas Indiretas de Operação & $\mathrm{R} \$ 102.968,76$ \\
\hline 6.1 .1 & Custo da Mão-de-Obra Administrativa & $\mathrm{R} \$ 23.461,20$ \\
\hline 6.1 .2 & Despesas Administrativas (telefone, material de consumo) & $\mathrm{R} \$ 7.567,08$ \\
\hline 6.1 .3 & Vigilância & $\mathrm{R} \$ 71.940,48$ \\
\hline 6.2 & Despesas Indiretas de Manutenção & $\mathrm{R} \$ 3.254,96$ \\
\hline 6.2 .1 & Custo de Manutenção de Obras Civis & $\mathrm{R} \$ 2.806,28$ \\
\hline 6.2 .2 & Custo de Depreciação de Obras Civis & $R \$ 448,68$ \\
\hline 7 & LAIR (Lucro Antes do Imposto de Renda) & $-R \$ 75.292,83$ \\
\hline 8 & IMPOSTOS E TAXAS & $-R \$ 18.070,28$ \\
\hline 8.1 & Imposto de Renda (15\%) & $-\mathrm{R} \$ 11.293,92$ \\
\hline 8.2 & Contribuição Social ( $9 \%)$ & $-\mathrm{R} \$ 6.776,35$ \\
\hline 9 & RESULTADO LÍQUIDO & -R\$ 57.222,55 \\
\hline
\end{tabular}

O resultado líquido negativo atesta a inviabilidade das hipóteses de operação contempladas na análise VI. Isto significa que a central de reciclagem não obteria um resultado positivo, se quer para a operação, cobrando a mesma taxa de descarga que um aterro.

\subsubsection{ANÁlise de ViabiLIDADE VII}

Similarmente à analise de viabilidade IV, a análise VII prevê uma iniciativa pública para a implantação da central de reciclagem e, como tal, visa obter apenas receitas que cubram os custos, sem objetivo de lucro. Nesta análise considerou-se a geração atual de resíduos de CGA e uma taxa de captação de 
$60 \%$, condizente com a capacidade de produção de $1 \mathrm{t} / \mathrm{h}$ de gesso reciclado (Figura 6.12).

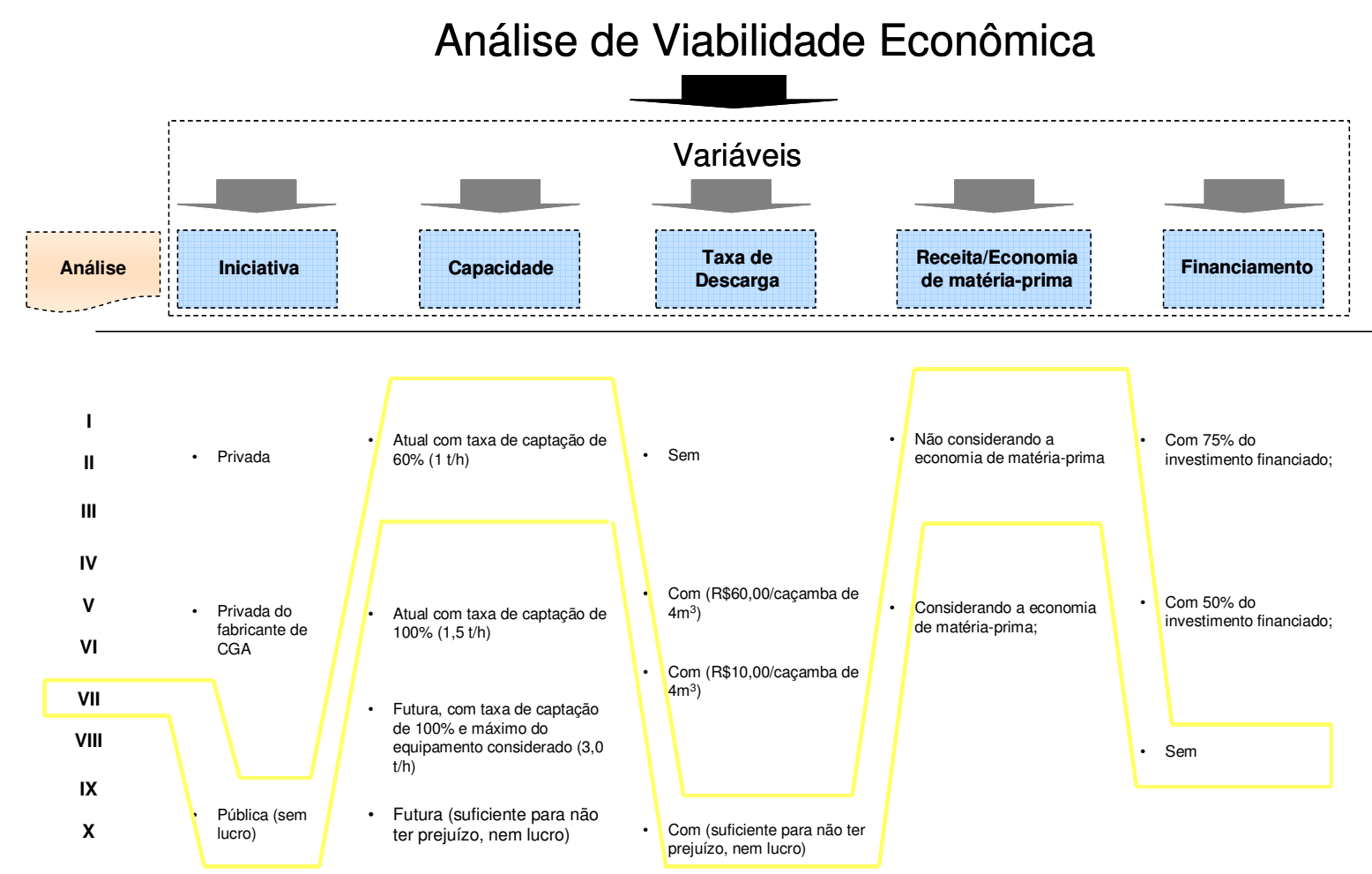

Figura 6.12 - Variáveis contempladas na Análise de Viabilidade Econômica VII (autora, 2007).

Além da receita obtida com a venda do gesso reciclado de rCGA, contabilizase também a taxa de descarga. $O$ valor desta taxa deve ser o necessário para suportar os custos, conforme o balanço de operação, apresentado na Tabela 6.19 .

Para obter o resultado líquido próximo de zero, a taxa de descarga obtida foi de $\mathrm{R} \$ 18,76 /$ caçamba de $4 \mathrm{~m}^{3}$, valor considerado razoável, quase $90 \%$ maior do que o cobrado pelos aterros atualmente $(\mathrm{R} \$ 10,00)$, mas ainda baixo em valores absolutos. 
Tabela 6.19 - Balanço de operação da Central de Reciclagem segundo as variáveis da Análise de Viabilidade VII (autora, 2007).

\begin{tabular}{|c|c|c|}
\hline \multicolumn{3}{|c|}{ Análise VII } \\
\hline ÍTEM & DESCRIÇÃO & BALANÇO \\
\hline 1 & RECEITA OPERACIONAL BRUTA & $R \$ 485.179,20$ \\
\hline 1.1 & Venda de gesso reciclado de CGA & $\mathrm{R} \$ 485.179,20$ \\
\hline 2 & IMPOSTOS SOBRE A RECEITA & $R \$ 134.152,05$ \\
\hline 2.1 & PIS/COFINS (9,65\%) & $\mathrm{R} \$ 46.819,79$ \\
\hline 2.2 & ICMS (18\%) & $\mathrm{R} \$ 87.332,26$ \\
\hline 3 & RECEITA OPERACIONAL LÍQUIDA & $\mathrm{R} \$ 351.027,15$ \\
\hline 4 & CUSTOS DE PRODUÇÃO & $R \$ 244.802,48$ \\
\hline 4.1 & Custos de Operação & $R \$ 166.464,11$ \\
\hline 4.1 .1 & Custo da Mão-de-Obra de Produção & $\mathrm{R} \$ 136.703,28$ \\
\hline 4.1 .2 & Custo de Operação de Máq., Equip. e Veículos Próprios & $\mathrm{R} \$ 17.107,20$ \\
\hline 4.1 .3 & Custo dos Insumos de Produção & $\mathrm{R} \$ 12.653,63$ \\
\hline 4.2 & Custos de Manutenção & $\mathrm{R} \$ 31.122,50$ \\
\hline 4.2 .1 & Custo de Manutenção de Máq., Equip. e Veículos Próprios & $\mathrm{R} \$ 5.088,00$ \\
\hline 4.2 .2 & Custo de Depreciação de Máq., Equip. e Veículos Próprios & $\mathrm{R} \$ 26.034,50$ \\
\hline 4.3 & Custos de Distribuição & R\$ 47.215,87 \\
\hline 4.3 .1 & Custo do frete de distribuição (incluso insumos) & $\mathrm{R} \$ 47.215,87$ \\
\hline 5 & RESULTADO BRUTO & $R \$ 106.224,67$ \\
\hline 6 & DESPESAS INDIRETAS & $R \$ 106.221,72$ \\
\hline 6.1 & Despesas Indiretas de Operação & $\mathrm{R} \$ 102.968,76$ \\
\hline 6.1 .1 & Custo da Mão-de-Obra Administrativa & $\mathrm{R} \$ 23.461,20$ \\
\hline 6.1 .2 & Despesas Administrativas (telefone, material de consumo) & $\mathrm{R} \$ 7.567,08$ \\
\hline 6.1 .3 & Vigilância & $\mathrm{R} \$ 71.940,48$ \\
\hline 6.2 & Despesas Indiretas de Manutenção & $R \$ 3.252,96$ \\
\hline 6.2 .1 & Custo de Manutenção de Obras Civis & $\mathrm{R} \$ 2.804,28$ \\
\hline 6.2 .2 & Custo de Depreciação de Obras Civis & $R \$ 448,68$ \\
\hline 7 & LAIR (Lucro Antes do Imposto de Renda) & $R \$ 2,94$ \\
\hline 8 & IMPOSTOS E TAXAS & $R \$ 0,71$ \\
\hline 8.1 & Imposto de Renda (15\%) & $\mathrm{R} \$ 0,44$ \\
\hline 8.2 & Contribuição Social (9\%) & $\mathrm{R} \$ 0,26$ \\
\hline 9 & RESULTADO LÍQUIDO & $R \$ 2,24$ \\
\hline
\end{tabular}

\subsubsection{ANÁLISE DE VIABILIDAde VIII}

Conforme dito no item 5.2, um dos fabricantes de CGA possui, no início da linha de montagem de sua fábrica, um equipamento para a reciclagem de CGA, o qual permite que seja adicionado até $5 \%$ de resíduo (relação $\mathrm{m} / \mathrm{m}$ ) em uma nova CGA. Nesta análise, prevê-se a iniciativa deste fabricante em substituir o equipamento atual por uma máquina recicladora com tecnologia moderna, a qual permite uma inserção de até $25 \%$ de resíduo (relação $\mathrm{m} / \mathrm{m}$ ). Assim, pressupõe um upgrade no processo de reciclagem existente.

Conforme pode ser visto na Figura 6.13, as demais variáveis contempladas indicam que a capacidade de produção será de 1,0 t/h, não há cobrança de taxa 
de descarga, não é considerada a economia de matéria-prima que a reinserção de resíduos de CGA proporciona.

Apesar de não haver cobrança de taxa de descarga, considera-se que os geradores ou as ATT são os responsáveis por entregar os resíduos de CGA de volta na fábrica de CGA.

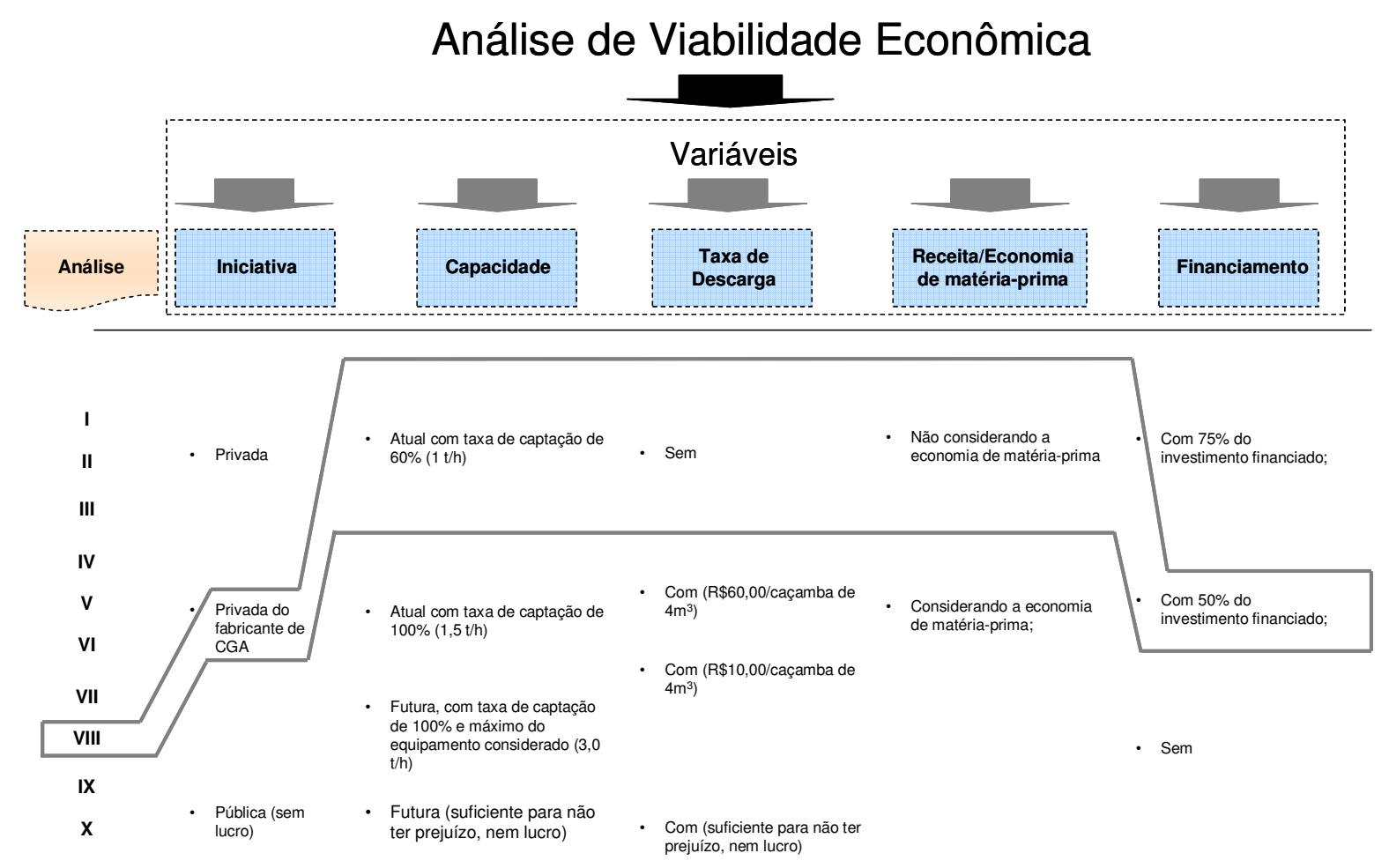

Figura 6.13 - Variáveis contempladas na Análise de Viabilidade Econômica VIII (autora, 2007).

Supondo-se que o investidor tenha disponível imediatamente os mesmos R \$250.000,00 considerados nas análises anteriores, será necessário financiar apenas $50 \%$ do investimento total previsto para o upgrade. Os custos de implantação consideram apenas a máquina recicladora nova, uma vez que as instalações já existem e, pressupõe-se, comportam a nova máquina. Este mesmo raciocínio foi aplicado às despesas indiretas, ou seja, estas despesas já existem no processo de reciclagem atual e não sofrerão influência significativa pela troca do equipamento. 
Os custos de manutenção e depreciação contemplaram somente a máquina de reciclagem, uma vez que os demais equipamentos já existem na fábrica. No entanto, considerou-se seu custo de operação.

Considera-se que a central de reciclagem interna terá seu centro de custo individual, "vendendo" gesso (gipsita) reciclado para a linha de fabricação de CGA.

O custo de frete de distribuição é nulo porque haverá apenas transporte interno à fábrica. Assim, a receita operacional bruta é o produto da capacidade de produção pelo preço $\mathrm{FOB}^{34}$ do gesso reciclado de rCGA. O resultado do balanço de operação da análise VIII é apresentado na Tabela 6.20.

Tabela 6.20 - Balanço de operação da Central de Reciclagem segundo as variáveis da Análise de Viabilidade VIII (autora, 2007).

\begin{tabular}{|c|c|c|}
\hline \multicolumn{3}{|c|}{ Análise VIII } \\
\hline ÍTEM & DESCRIÇÃO & BALANÇO \\
\hline 1 & RECEITA OPERACIONAL BRUTA & $\mathrm{R} \$ 215.094,53$ \\
\hline 1.1 & Venda de gesso reciclado de CGA & $\mathrm{R} \$ 215.094,53$ \\
\hline 2 & IMPOSTOS SOBRE A RECEITA & $\mathrm{R} \$ 59.473,64$ \\
\hline 2.1 & PIS/COFINS $(9,65 \%)$ & $\mathrm{R} \$ 20.756,62$ \\
\hline 2.2 & ICMS (18\%) & $\mathrm{R} \$ 38.717,02$ \\
\hline 3 & RECEITA OPERACIONAL LÍQUIDA & $R \$ 155.620,89$ \\
\hline 4 & CUSTOS DE PRODUÇÃO & $\mathbf{R} \$ 83.983,55$ \\
\hline 4.1 & Custos de Operação & $\mathrm{R} \$ 71.383,55$ \\
\hline 4.1 .1 & Custo da Mão-de-Obra de Produção & $\mathrm{R} \$ 41.622,72$ \\
\hline 4.1 .2 & Custo de Operação de Máq., Equip. e Veículos Próprios & $\mathrm{R} \$ 17.107,20$ \\
\hline 4.1 .3 & Custo dos Insumos de Produção & $\mathrm{R} \$ 12.653,63$ \\
\hline 4.2 & Custos de Manutenção & $\mathrm{R} \$ 12.600,00$ \\
\hline 4.2 .1 & Custo de Manutenção de Máq., Equip. e Veículos Próprios & $\mathrm{R} \$ 2.520,00$ \\
\hline 4.2 .2 & Custo de Depreciação de Máq., Equip. e Veículos Próprios & $\mathrm{R} \$ 10.080,00$ \\
\hline 4.3 & Custos de Distribuição & $\mathbf{R} \$ \mathbf{0 , 0 0}$ \\
\hline 4.3 .1 & Custo do frete de distribuição (incluso insumos) & $\mathrm{R} \$ 0,00$ \\
\hline 5 & RESULTADO BRUTO & $\mathrm{R} \$ 71.637,34$ \\
\hline 6 & DESPESAS INDIRETAS & $\mathbf{R} \$ 0,00$ \\
\hline 6.1 & Despesas Indiretas de Operação & $\mathrm{R} \$ \mathbf{0 , 0 0}$ \\
\hline 6.1 .1 & Custo da Mão-de-Obra Administrativa & $\mathrm{R} \$ 0,00$ \\
\hline 6.1 .2 & Despesas Administrativas (telefone, material de consumo) & $\mathrm{R} \$ 0,00$ \\
\hline 6.1 .3 & Vigilância & $\mathrm{R} \$ 0,00$ \\
\hline 6.2 & Despesas Indiretas de Manutenção & $\mathrm{R} \$ \mathbf{0 , 0 0}$ \\
\hline 6.2 .1 & Custo de Manutenção de Obras Civis & $\mathrm{R} \$ 0,00$ \\
\hline 6.2 .2 & Custo de Depreciação de Obras Civis & $\mathrm{R} \$ 0,00$ \\
\hline 7 & LAIR (Lucro Antes do Imposto de Renda) & $\mathrm{R} \$ 71.637,34$ \\
\hline 8 & IMPOSTOS E TAXAS & $\mathrm{R} \$ 17.192,96$ \\
\hline 8.1 & Imposto de Renda (15\%) & $\mathrm{R} \$ 10.745,60$ \\
\hline 8.2 & Contribuição Social (9\%) & $\mathrm{R} \$ 6.447,36$ \\
\hline 9 & RESULTADO LÍQUIDO & R\$ 54.444,38 \\
\hline
\end{tabular}

${ }^{34}$ Sigla em inglês - Free on Board, que significa que o preço apresentado não inclui os custos do seguro e do frete do produto. 
A Tabela 6.21 apresenta os custos de implantação e o montante financiado.

Tabela 6.21 - Custos de Implantação da central de reciclagem, considerando as variáveis da análise VIII (autora, 2007).

\begin{tabular}{l|c}
\hline \multicolumn{1}{c}{ CUSTOS DE IMPLANTAÇAO } \\
\hline Custo de Aquisição do Terreno & $\mathrm{R} \$ 0,00$ \\
\hline Custo de Obras Civis & $\mathrm{R} \$ 0,00$ \\
\hline Custo de Aquisição de Máquinas, Equipamentos e Veículos Próprios & $\mathrm{R} \$ 508.800,00$ \\
\hline \multicolumn{2}{|c}{ Total } \\
\hline Disponibilidade de $\mathrm{R} \$ 250.000,00$ \\
\hline Financiar $\mathrm{R} \$ 258.800,00$ & $49,14 \%$ \\
\hline
\end{tabular}

As parcelas do financiamento (Tabela 6.22) permanecem inalteradas em relação às outras análises, pois segue as regras da linha de financiamento escolhida.

Tabela 6.22 - Composição do financiamento de $50 \%$ do valor do investimento necessário à atualização (upgrade) da central de reciclagem de um fabricante de CGA (autora, 2007).

\begin{tabular}{lr}
\hline & FINANCIAMENTO \\
\hline & Ao ano \\
\hline Taxa de juros & $8,00 \%$ \\
\hline Inflação & $3,40 \%$ \\
\hline Taxa de risco de crédito & $1,80 \%$ \\
\hline Remuneração do banco & $2,00 \%$ \\
\hline Contas Vinculadas ao FGTS & $3,00 \%$ \\
\hline Variação da TR & $0,08 \%$ \\
\hline Taxa de juros final & $11,40 \%$ \\
\hline Valor do financiamento & $\mathbf{R} 258.800,00$ \\
\hline Fator Price & 0,09972 \\
\hline
\end{tabular}

Mediante as informações do financiamento, elabora-se o fluxo de caixa da análise VIII (Tabela 6.23). 
Tabela 6.23 - Fluxo de caixa da análise de viabilidade econômica VIII (autora, 2007).

\begin{tabular}{|c|c|c|c|c|}
\hline \multicolumn{5}{|c|}{ Fluxo de caixa - Análise VIII } \\
\hline Ano & juros & Parcela & $\begin{array}{l}\text { Resultado } \\
\text { Líquido }\end{array}$ & $\begin{array}{l}\text { Movimentação } \\
\text { Financeira }\end{array}$ \\
\hline 0 & & $(250.000,00)$ & & $\overline{(250.000,00)}$ \\
\hline 1 & $(29.503,20)$ & & & $(29.503,20)$ \\
\hline 2 & $(29.503,20)$ & $(25.806,64)$ & $54.444,38$ & $(865,46)$ \\
\hline 3 & $(29.503,20)$ & $(25.806,64)$ & $54.444,38$ & $(865,46)$ \\
\hline 4 & $(29.503,20)$ & $(25.806,64)$ & $54.444,38$ & $(865,46)$ \\
\hline 5 & $(29.503,20)$ & $(25.806,64)$ & $54.444,38$ & $(865,46)$ \\
\hline 6 & $(29.503,20)$ & $(25.806,64)$ & $54.444,38$ & $(865,46)$ \\
\hline 7 & $(29.503,20)$ & $(25.806,64)$ & $54.444,38$ & $(865,46)$ \\
\hline 8 & $(29.503,20)$ & $(25.806,64)$ & $54.444,38$ & $(865,46)$ \\
\hline 9 & $(29.503,20)$ & $(25.806,64)$ & $54.444,38$ & $(865,46)$ \\
\hline 10 & $(29.503,20)$ & $(25.806,64)$ & $54.444,38$ & $(865,46)$ \\
\hline 11 & $(29.503,20)$ & $(25.806,64)$ & $54.444,38$ & $(865,46)$ \\
\hline 12 & $(29.503,20)$ & $(25.806,64)$ & $54.444,38$ & $(865,46)$ \\
\hline 13 & $(29.503,20)$ & $(25.806,64)$ & $54.444,38$ & $(865,46)$ \\
\hline 14 & $(29.503,20)$ & $(25.806,64)$ & $54.444,38$ & $(865,46)$ \\
\hline 15 & $(29.503,20)$ & $(25.806,64)$ & $54.444,38$ & $(865,46)$ \\
\hline 16 & $(29.503,20)$ & $(25.806,64)$ & $54.444,38$ & $(865,46)$ \\
\hline 17 & $(29.503,20)$ & $(25.806,64)$ & $54.444,38$ & $(865,46)$ \\
\hline 18 & $(29.503,20)$ & $(25.806,64)$ & $54.444,38$ & $(865,46)$ \\
\hline 19 & $(29.503,20)$ & $(25.806,64)$ & $54.444,38$ & $(865,46)$ \\
\hline \multirow[t]{4}{*}{20} & $(29.503,20)$ & $(25.806,64)$ & $54.444,38$ & $(865,46)$ \\
\hline & & & --- \\
\hline & & \multicolumn{2}{|r|}{$\begin{array}{l}\text { TIR } \\
\text { Pay-back }\end{array}$} & --- \\
\hline & & \multicolumn{2}{|r|}{ Pay-back cop } & --- \\
\hline
\end{tabular}

Identifica-se que o resultado líquido obtido no balanço de operação não foi suficiente para suportar as despesas do financiamento, não sendo viável portanto a atualização (upgrade) da central de reciclagem do fabricante sob as condições estabelecidas.

\subsubsection{ANÁLISE DE VIABILIDADE IX}

A análise de viabilidade IX é bastante similar à VIII. Apresenta como diferença o fato de considerar-se aqui a economia proporcionada pela substituição da matéria-prima gipsita pelo gesso reciclado de rCGA. A escolha das variáveis da análise IX está ilustrada na Figura 6.14. 


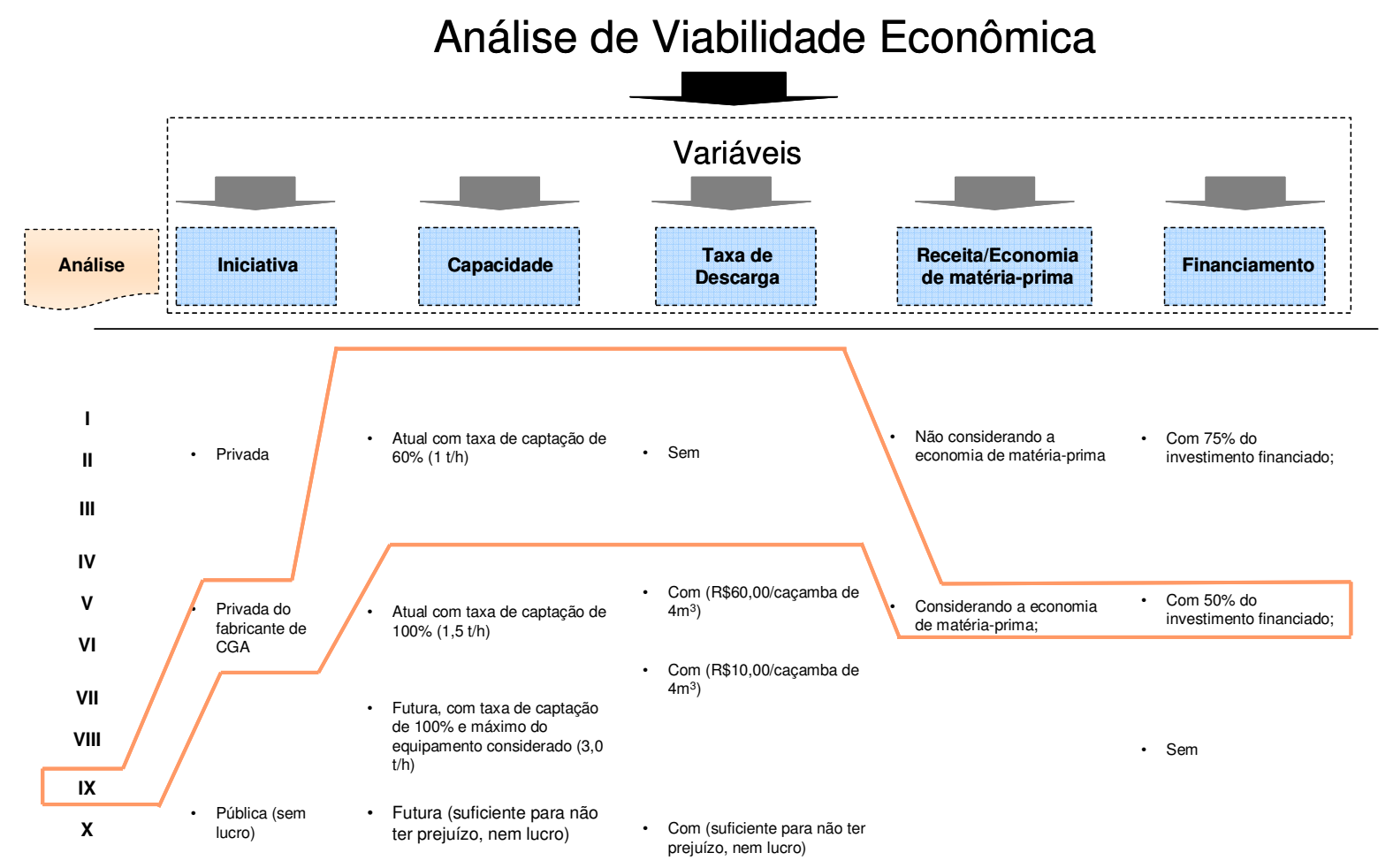

Figura 6.14 - Variáveis contempladas na Análise de Viabilidade Econômica IX (autora, 2007).

Na receita operacional bruta apresentada no balanço de operação (Tabela 6.24), o valor é o resultado da venda de gesso reciclado de rCGA, considerado novamente o preço FOB, pois não há custo de distribuição. As considerações feitas no item anterior sobre as despesas indiretas e os custos de manutenção também são válidas para a análise IX.

O resultado líquido do balanço de operação indica uma viabilidade econômica para a operação da central. Avalia-se então os custos de implantação e financiamento. Os custos de implantação, o montante financiado (50\%) e a composição do financiamento são demonstrados, respectivamente, pelas e Tabela 6.21 e Tabela 6.22, apresentadas anteriormente. 
Tabela 6.24 - Balanço de operação da Central de Reciclagem segundo as variáveis da Análise de Viabilidade IX (autora, 2007).

\begin{tabular}{|c|c|c|}
\hline \multicolumn{3}{|c|}{ Análise IX } \\
\hline ITEM & DESCRIÇÃO & BALANÇO \\
\hline 1 & RECEITA OPERACIONAL BRUTA & $R \$ 215.094,53$ \\
\hline 1.1 & Venda de gesso reciclado de CGA & $\mathrm{R} \$ 215.094,53$ \\
\hline 2 & IMPOSTOS SOBRE A RECEITA & $R \$ 59.473,64$ \\
\hline 2.1 & PIS/COFINS $(9,65 \%)$ & $\mathrm{R} \$ 20.756,62$ \\
\hline 2.2 & ICMS (18\%) & $\mathrm{R} \$ 38.717,02$ \\
\hline 3 & RECEITA OPERACIONAL LÍQUIDA & $R \$ 155.620,89$ \\
\hline 4 & CUSTOS DE PRODUÇÃO & $\mathrm{R} \$ 83.983,55$ \\
\hline 4.1 & Custos de Operação & $R \$ 71.383,55$ \\
\hline 4.1 .1 & Custo da Mão-de-Obra de Produção & $\mathrm{R} \$ 41.622,72$ \\
\hline 4.1 .2 & Custo de Operação de Máq., Equip. e Veículos Próprios & $\mathrm{R} \$ 17.107,20$ \\
\hline 4.1 .3 & Custo dos Insumos de Produção & $\mathrm{R} \$ 12.653,63$ \\
\hline 4.2 & Custos de Manutenção & $R \$ 12.600,00$ \\
\hline 4.2 .1 & Custo de Manutenção de Máq., Equip. e Veículos Próprios & $\mathrm{R} \$ 2.520,00$ \\
\hline 4.2 .2 & Custo de Depreciação de Máq., Equip. e Veículos Próprios & $\mathrm{R} \$ 10.080,00$ \\
\hline 4.3 & Custos de Distribuição & $R \$ 0,00$ \\
\hline 4.3 .1 & Custo do frete de distribuição (incluso insumos) & $\mathrm{R} \$ 0,00$ \\
\hline 5 & RESULTADO BRUTO & $\mathrm{R} \$ 71.637,34$ \\
\hline 6 & DESPESAS INDIRETAS & $R \$ 0,00$ \\
\hline 6.1 & Despesas Indiretas de Operação & $R \$ 0,00$ \\
\hline 6.1 .1 & Custo da Mão-de-Obra Administrativa & $\mathrm{R} \$ 0,00$ \\
\hline 6.1 .2 & Despesas Administrativas (telefone, material de consumo) & $\mathrm{R} \$ 0,00$ \\
\hline 6.1 .3 & Vigilância & $\mathrm{R} \$ 0,00$ \\
\hline 6.2 & Despesas Indiretas de Manutenção & $\mathbf{R} \$ 0,00$ \\
\hline 6.2 .1 & Custo de Manutenção de Obras Civis & $\mathrm{R} \$ 0,00$ \\
\hline 6.2 .2 & Custo de Depreciação de Obras Civis & $\mathrm{R} \$ 0,00$ \\
\hline 7 & LAIR (Lucro Antes do Imposto de Renda) & $\mathbf{R} \$ 71.637,34$ \\
\hline 8 & IMPOSTOS E TAXAS & $\mathrm{R} \$ 17.192,96$ \\
\hline 8.1 & Imposto de Renda (15\%) & $\mathrm{R} \$ 10.745,60$ \\
\hline 8.2 & Contribuição Social (9\%) & $\mathrm{R} \$ 6.447,36$ \\
\hline 9 & RESULTADO LIQQUIDO & $\mathrm{R} \$ 54.444,38$ \\
\hline
\end{tabular}

A Tabela 6.25 apresenta o fluxo de caixa para a análise IX. Diferentemente das outras análises, o financiamento terá um período de carência de um ano. Isto significa que as obras/reformas para a adaptação do novo equipamento de reciclagem na planta industrial do fabricante irão consumir o prazo máximo de um ano, período no qual o equipamento não funcionará e, portanto, não gerará receita.

Nas análises anteriores, devido haver a construção da planta industrial, este período era de dois anos.

A economia proporcionada pela substituição da matéria-prima foi calculada com base no preço da gipsita, entregue na cidade de São Paulo (CIF - SP), que 
é de $\mathrm{R} \$ 138,00 /$ t. Comparando-se, puramente, os preços da gipsita natural e do gesso reciclado de rCGA, ambos CIF-SP, tem-se uma economia de 34,4\%.

Parte desta economia será responsável por viabilizar o fluxo de caixa da atualização (upgrade) da central de reciclagem do fabricante, conforme pode ser visto na Tabela 6.25 .

Tabela 6.25 - Fluxo de caixa da análise de viabilidade econômica IX (autora, 2007).

\begin{tabular}{|c|c|c|c|c|c|c|}
\hline \multicolumn{7}{|c|}{ Fluxo de caixa - Análise IX } \\
\hline Ano & juros & Parcela & $\begin{array}{l}\text { Resultado } \\
\text { Líquido }\end{array}$ & $\begin{array}{c}\text { Economia de matéria- } \\
\text { prima }\end{array}$ & $\begin{array}{l}\text { Resultado Líquido } \\
\text { (considerando } \\
\text { economia) }\end{array}$ & $\begin{array}{l}\text { Movimentação } \\
\text { financeira } \\
\text { (considerando } \\
\text { economia) } \\
\end{array}$ \\
\hline 0 & & $(250.000,00)$ & & & & $(250.000,00)$ \\
\hline 1 & $(29.503,20)$ & & & & & $(29.503,20)$ \\
\hline 2 & $(29.503,20)$ & $(25.806,64)$ & $54.444,38$ & $327.888,00$ & $382.332,38$ & $327.022,54$ \\
\hline 3 & $(29.503,20)$ & $(25.806,64)$ & $54.444,38$ & $327.888,00$ & $382.332,38$ & $327.022,54$ \\
\hline 4 & $(29.503,20)$ & $(25.806,64)$ & $54.444,38$ & $327.888,00$ & $382.332,38$ & $327.022,54$ \\
\hline 5 & $(29.503,20)$ & $(25.806,64)$ & $54.444,38$ & $327.888,00$ & $382.332,38$ & $327.022,54$ \\
\hline 6 & $(29.503,20)$ & $(25.806,64)$ & $54.444,38$ & $327.888,00$ & $382.332,38$ & $327.022,54$ \\
\hline 7 & $(29.503,20)$ & $(25.806,64)$ & $54.444,38$ & $327.888,00$ & $382.332,38$ & $327.022,54$ \\
\hline 8 & $(29.503,20)$ & $(25.806,64)$ & $54.444,38$ & $327.888,00$ & $382.332,38$ & $327.022,54$ \\
\hline 9 & $(29.503,20)$ & $(25.806,64)$ & $54.444,38$ & $327.888,00$ & $382.332,38$ & $327.022,54$ \\
\hline 10 & $(29.503,20)$ & $(25.806,64)$ & $54.444,38$ & $327.888,00$ & $382.332,38$ & $327.022,54$ \\
\hline 11 & $(29.503,20)$ & $(25.806,64)$ & $54.444,38$ & $327.888,00$ & $382.332,38$ & $327.022,54$ \\
\hline 12 & $(29.503,20)$ & $(25.806,64)$ & $54.444,38$ & $327.888,00$ & $382.332,38$ & $327.022,54$ \\
\hline 13 & $(29.503,20)$ & $(25.806,64)$ & $54.444,38$ & $327.888,00$ & $382.332,38$ & $327.022,54$ \\
\hline 14 & $(29.503,20)$ & $(25.806,64)$ & $54.444,38$ & $327.888,00$ & $382.332,38$ & $327.022,54$ \\
\hline 15 & $(29.503,20)$ & $(25.806,64)$ & $54.444,38$ & $327.888,00$ & $382.332,38$ & $327.022,54$ \\
\hline 16 & $(29.503,20)$ & $(25.806,64)$ & $54.444,38$ & $327.888,00$ & $382.332,38$ & $327.022,54$ \\
\hline 17 & $(29.503,20)$ & $(25.806,64)$ & $54.444,38$ & $327.888,00$ & $382.332,38$ & $327.022,54$ \\
\hline 18 & $(29.503,20)$ & $(25.806,64)$ & $54.444,38$ & $327.888,00$ & $382.332,38$ & $327.022,54$ \\
\hline 19 & $(29.503,20)$ & $(25.806,64)$ & $54.444,38$ & $327.888,00$ & $382.332,38$ & $327.022,54$ \\
\hline \multirow[t]{5}{*}{20} & $(29.503,20)$ & $(25.806,64)$ & $54.444,38$ & $327.888,00$ & $382.332,38$ & $327.022,54$ \\
\hline & & & & & TIR & 71,40\% \\
\hline & & & & & TIR (5 anos) & $64,11 \%$ \\
\hline & & & & & Pay-back & Ano $2-2009$ \\
\hline & & & & & Pay-back cop & Ano $3-2010$ \\
\hline
\end{tabular}

O fluxo de caixa indica que há viabilidade na atualização da central de reciclagem do fabricante. Para a avaliação da atratividade deste investimento, calculou-se, além da TIR e dos pay-back e pay-back cop, a TIR no período dos cinco primeiros anos, pois o prazo de depreciação da máquina de reciclagem é, segundo BRASIL (1998), de cinco anos, ou seja, ao final do quinto ano a máquina tem que estar completamente depreciada.

A TIR (5 anos) e o pay-back cop demonstram ser este um investimento bastante atrativo para o fabricante do ponto de vista econômico, sendo mais rentável que as aplicações de renda fixa, mesmo considerando-se sua alta taxa de risco. 


\subsubsection{ANÁlise de Viabilidade $X$}

A análise de viabilidade $\mathrm{X}$ contempla a iniciativa do fabricante pelo 'upgrade' em sua central de reciclagem, considerando a capacidade de $1 \mathrm{t} / \mathrm{h}$ e a economia de matéria-prima. Não há cobrança de taxa. Difere da análise IX em relação ao percentual que será financiado, do montante de investimento necessário (Figura $6.15)$.

\section{Análise de Viabilidade Econômica}

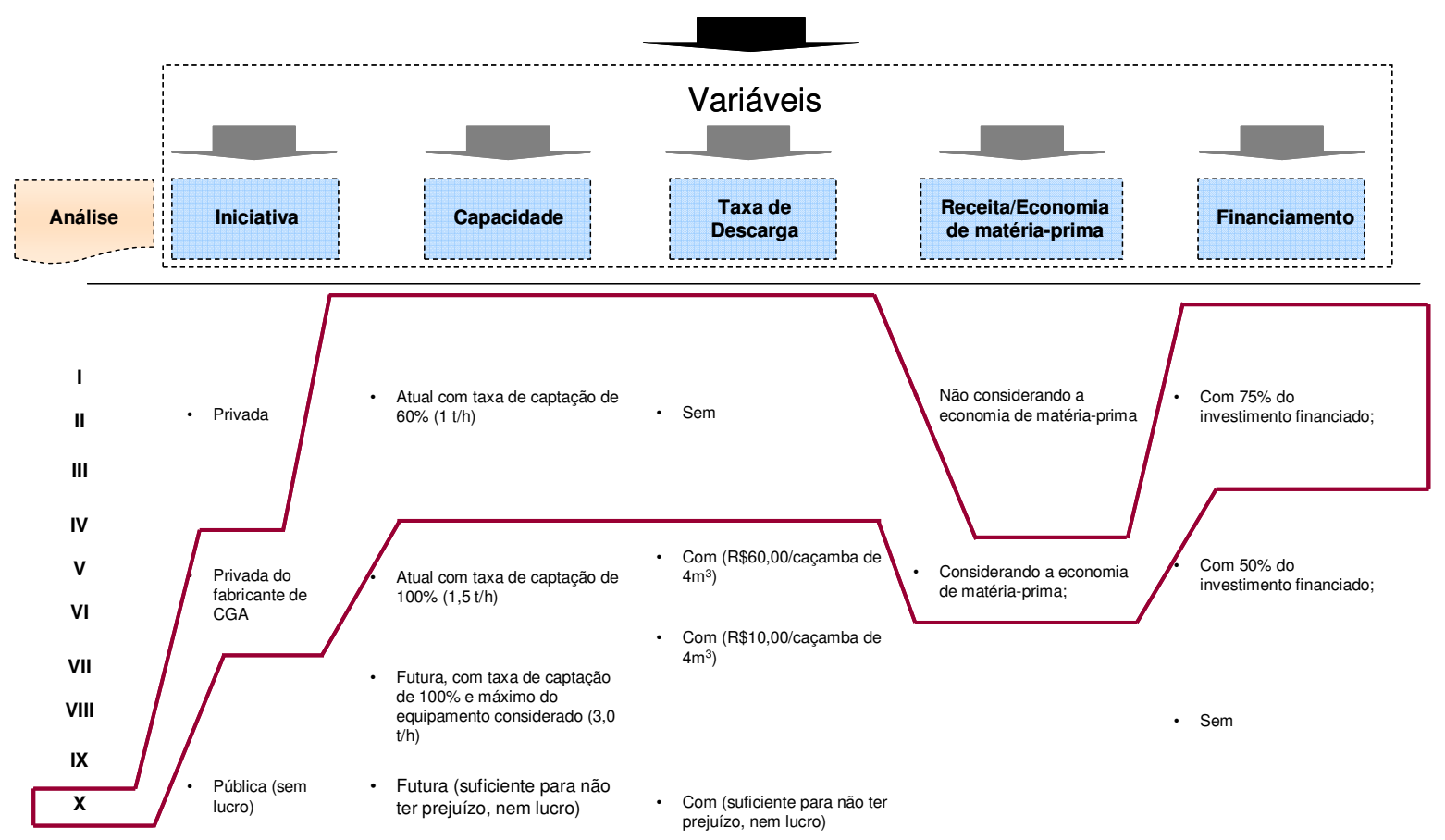

Figura 6.15 - Variáveis contempladas na Análise de Viabilidade Econômica X (autora, 2007).

O balanço da fase de operação da central de reciclagem de resíduos de CGA é apresentado na Tabela 6.26.

Opta-se por avaliar se o financiamento de $74,45 \%$ do valor de investimento não traria maiores vantagens ao investidor, principalmente no fluxo de caixa, visto que o montante de investimento inicial seria quase $50 \%$ menor, e que as aplicações de renda fixa rendem $12 \%$ a.a. enquanto os juros de financiamento são pouco menores que isso, da ordem de 11,4\%a.a. 
Tabela 6.26 - Balanço de operação da Central de Reciclagem segundo as variáveis da Análise de Viabilidade X (autora, 2007).

\begin{tabular}{|c|c|c|}
\hline \multicolumn{3}{|c|}{ Análise $X$} \\
\hline ÍTEM & DESCRIÇÃO & BALANÇO \\
\hline 1 & RECEITA OPERACIONAL BRUTA & $\mathrm{R} \$ 215.094,53$ \\
\hline 1.1 & Venda de gesso reciclado de CGA & $\mathrm{R} \$ 215.094,53$ \\
\hline 2 & IMPOSTOS SOBRE A RECEITA & R\$ 59.473,64 \\
\hline 2.1 & PIS/COFINS $(9,65 \%)$ & $\mathrm{R} \$ 20.756,62$ \\
\hline 2.2 & ICMS (18\%) & $\mathrm{R} \$ 38.717,02$ \\
\hline 3 & RECEITA OPERACIONAL LÍQUIDA & $R \$ 155.620,89$ \\
\hline 4 & CUSTOS DE PRODUÇÃO & $\mathrm{R} \$ 83.983,55$ \\
\hline 4.1 & Custos de Operação & $\mathrm{R} \$ 71.383,55$ \\
\hline 4.1 .1 & Custo da Mão-de-Obra de Produção & $\mathrm{R} \$ 41.622,72$ \\
\hline 4.1 .2 & Custo de Operação de Máq., Equip. e Veículos Próprios & $\mathrm{R} \$ 17.107,20$ \\
\hline 4.1 .3 & Custo dos Insumos de Produção & $\mathrm{R} \$ 12.653,63$ \\
\hline 4.2 & Custos de Manutenção & $\mathrm{R} \$ 12.600,00$ \\
\hline 4.2 .1 & Custo de Manutenção de Máq., Equip. e Veículos Próprios & $\mathrm{R} \$ 2.520,00$ \\
\hline 4.2 .2 & Custo de Depreciação de Máq., Equip. e Veículos Próprios & $\mathrm{R} \$ 10.080,00$ \\
\hline 4.3 & Custos de Distribuição & $R \$ 0,00$ \\
\hline 4.3 .1 & Custo do frete de distribuição (incluso insumos) & $\mathrm{R} \$ 0,00$ \\
\hline 5 & RESULTADO BRUTO & $\mathbf{R} \$ 71.637,34$ \\
\hline 6 & DESPESAS INDIRETAS & $R \$ 0,00$ \\
\hline 6.1 & Despesas Indiretas de Operação & $\mathrm{R} \$ \mathbf{0 , 0 0}$ \\
\hline 6.1 .1 & Custo da Mão-de-Obra Administrativa & $\mathrm{R} \$ 0,00$ \\
\hline 6.1 .2 & Despesas Administrativas (telefone, material de consumo) & $\mathrm{R} \$ 0,00$ \\
\hline 6.1 .3 & Vigilância & $\mathrm{R} \$ 0,00$ \\
\hline 6.2 & Despesas Indiretas de Manutenção & $R \$ 0,00$ \\
\hline 6.2 .1 & Custo de Manutenção de Obras Civis & $\mathrm{R} \$ 0,00$ \\
\hline 6.2 .2 & Custo de Depreciação de Obras Civis & $\mathrm{R} \$ 0,00$ \\
\hline 7 & LAIR (Lucro Antes do Imposto de Renda) & R\$ 71.637,34 \\
\hline 8 & IMPOSTOS E TAXAS & $\mathbf{R} \$ 17.192,96$ \\
\hline 8.1 & Imposto de Renda (15\%) & $\mathrm{R} \$ 10.745,60$ \\
\hline 8.2 & Contribuição Social (9\%) & $\mathrm{R} \$ 6.447,36$ \\
\hline 9 & RESULTADO LÍQUIDO & R\$ 54.444,38 \\
\hline
\end{tabular}

Os custos de implantação e os valores de financiamento encontram-se na tabela

Tabela 6.27.

Tabela 6.27 - Custos de Implantação da central de reciclagem, considerando as variáveis da análise X (autora, 2007).

\begin{tabular}{|c|c|}
\hline \multicolumn{2}{|l|}{ CUSTOS DE IMPLANTAÇACO } \\
\hline Custo de Aquisição do Terreno & $\mathrm{R} \$ 0,00$ \\
\hline Custo de Obras Civis & $\mathrm{R} \$ 0,00$ \\
\hline Custo de Aquisição de Máquinas, Equipamentos e Veículos Próprios & $\mathrm{R} \$ 508.800,00$ \\
\hline $\begin{array}{ll} & \\
& \end{array}$ & $\mathrm{R} \$ 508.800,00$ \\
\hline Disponibilidade de $\mathrm{R} \$ 130.000,00$ & $25,55 \%$ \\
\hline Financiar $\mathrm{R} \$ 378.800,00$ & $74,45 \%$ \\
\hline
\end{tabular}


A Tabela 6.28 apresenta a composição do financiamento.

Tabela 6.28 - Composição do financiamento de $74,45 \%$ do valor do investimento necessário à atualização (upgrade) da central de reciclagem de um fabricante de CGA (autora, 2007).

\begin{tabular}{lr}
\hline & FINANCIAMENTO \\
\hline & \multicolumn{1}{c}{ ano } \\
\hline Taxa de juros & $8,00 \%$ \\
\hline Inflação & $3,40 \%$ \\
\hline Taxa de risco de crédito & $1,80 \%$ \\
\hline Remuneração do banco & $2,00 \%$ \\
\hline Contas Vinculadas ao FGTS & $3,00 \%$ \\
\hline Variação da TR & $0,08 \%$ \\
\hline Taxa de juros final & $11,40 \%$ \\
\hline Valor do financiamento & $\mathrm{R} \$ 378.800,00$ \\
\hline Fator Price & 0,09972 \\
\hline
\end{tabular}

É possível identificar no fluxo de caixa da Tabela 6.29 a contribuição da econômica de matéria-prima para a viabilidade do 'upgrade' desta central de reciclagem.

Tabela 6.29 - Fluxo de caixa da análise de viabilidade econômica X (autora, 2007).

\begin{tabular}{|c|c|c|c|c|c|c|}
\hline Ano & Juros & Parcela & Resultado Líquido & $\begin{array}{l}\text { Economia de } \\
\text { matéria-prima }\end{array}$ & $\begin{array}{l}\text { Resultado Líquido } \\
\text { (considerando } \\
\text { economia) }\end{array}$ & $\begin{array}{l}\text { Movimentação } \\
\text { financeira } \\
\text { (considerando } \\
\text { economia) }\end{array}$ \\
\hline 0 & & $(130.000,00)$ & & & & $(130.000,00)$ \\
\hline 1 & $(43.183,20)$ & & & & & $(43.183,20)$ \\
\hline 2 & $(43.183,20)$ & $(37.772,62)$ & $54.444,38$ & $327.888,00$ & $382.332,38$ & $301.376,56$ \\
\hline 3 & $(43.183,20)$ & $(37.772,62)$ & $54.444,38$ & $327.888,00$ & $382.332,38$ & $301.376,56$ \\
\hline 4 & $(43.183,20)$ & $(37.772,62)$ & $54.444,38$ & $327.888,00$ & $382.332,38$ & $301.376,56$ \\
\hline 5 & $(43.183,20)$ & $(37.772,62)$ & $54.444,38$ & $327.888,00$ & $382.332,38$ & $301.376,56$ \\
\hline 6 & $(43.183,20)$ & $(37.772,62)$ & $54.444,38$ & $327.888,00$ & $382.332,38$ & $301.376,56$ \\
\hline 7 & $(43.183,20)$ & $(37.772,62)$ & $54.444,38$ & $327.888,00$ & $382.332,38$ & $301.376,56$ \\
\hline 8 & $(43.183,20)$ & $(37.772,62)$ & $54.444,38$ & $327.888,00$ & $382.332,38$ & $301.376,56$ \\
\hline 9 & $(43.183,20)$ & $(37.772,62)$ & $54.444,38$ & $327.888,00$ & $382.332,38$ & $301.376,56$ \\
\hline 10 & $(43.183,20)$ & $(37.772,62)$ & $54.444,38$ & $327.888,00$ & $382.332,38$ & $301.376,56$ \\
\hline 11 & $(43.183,20)$ & $(37.772,62)$ & $54.444,38$ & $327.888,00$ & $382.332,38$ & $301.376,56$ \\
\hline 12 & $(43.183,20)$ & $(37.772,62)$ & $54.444,38$ & $327.888,00$ & $382.332,38$ & $301.376,56$ \\
\hline 13 & $(43.183,20)$ & $(37.772,62)$ & $54.444,38$ & $327.888,00$ & $382.332,38$ & $301.376,56$ \\
\hline 14 & $(43.183,20)$ & $(37.772,62)$ & $54.444,38$ & $327.888,00$ & $382.332,38$ & $301.376,56$ \\
\hline 15 & $(43.183,20)$ & $(37.772,62)$ & $54.444,38$ & $327.888,00$ & $382.332,38$ & $301.376,56$ \\
\hline 16 & $(43.183,20)$ & $(37.772,62)$ & $54.444,38$ & $327.888,00$ & $382.332,38$ & $301.376,56$ \\
\hline 17 & $(43.183,20)$ & $(37.772,62)$ & $54.444,38$ & $327.888,00$ & $382.332,38$ & $301.376,56$ \\
\hline 18 & $(43.183,20)$ & $(37.772,62)$ & $54.444,38$ & $327.888,00$ & $382.332,38$ & $301.376,56$ \\
\hline 19 & $(43.183,20)$ & $(37.772,62)$ & $54.444,38$ & $327.888,00$ & $382.332,38$ & $301.376,56$ \\
\hline \multirow[t]{5}{*}{20} & $(43.183,20)$ & $(37.772,62)$ & $54.444,38$ & $327.888,00$ & $382.332,38$ & $301.376,56$ \\
\hline & & & & & TIR & $99,58 \%$ \\
\hline & & & & & TIR (5 anos) & $94,65 \%$ \\
\hline & & & & & Pay-back & Ano 2 - 2009 \\
\hline & & & & & Pay-back cop & Ano $2-2009$ \\
\hline
\end{tabular}


Os resultados de TIR, pay-back e pay-back cop obtidos indicam uma alta atratividade desta alternativa, pois o valor da TIR, nos primeiros cinco anos, é superior a $52 \%$ e o pay-back ocorre logo no segundo ano.

\subsection{CONCLUSÕES SOBRE AS ANÁLISES de VIABILIDADE ECONÔMICA}

Dentre as dez análises realizadas, cinco não apresentaram viabilidade econômica. Dentre as que apresentaram, duas são iniciativas públicas, sem objetivo de lucro, e outras duas são iniciativas privadas dos fabricantes, as quais apresentaram os melhores indicadores, provando que existe viabilidade para a reciclagem ser feita pelo fabricante e de que este pode ser um negócio rentável para a empresa.

$\mathrm{A}$ alternativa $\mathrm{V}$ foi a única da iniciativa privada 'pura' que apresentou viabilidade econômica, ainda que seus indicadores não tenham sido tão atrativos quanto os das análises IX e X, principalmente por causo do pay-back cop mais longo.

Três aspectos apresentados nas análises merecem ser mais explorados. O primeiro trata do impacto dos custos de disposição dos resíduos de CGA nos custos da obra, para os grande geradores. Isto porque, os grandes geradores querem saber quanto terão que pagar para realizar a destinação correta, ou ainda, a melhor dentre as destinações corretas. Além disso, a opção pela destinação à central de reciclagem será tão mais atrativa quanto menor for a diferença de custo entre a alternativa atualmente praticada e a da central.

O segundo aspecto se refere à economia de matéria-prima proporcionada aos fabricantes de CGA, quando das análises IX e X. Este montante ajudou a viabilizar a implantação da central mas, depois de implantada, apresenta-se qual é efetivamente a economia gerada.

Finalmente, o terceiro aspecto analisa as possibilidades existentes para a formação de uma cadeia reversa de ciclo fechado. Segundo Leite (2003) "redes reversas de produtos de pós-consumo em canais de reciclagem (...) tendem a ser planejadas $e$ operacionalizadas como canal reverso fechado, priorizando o domínio completo das operações em todas as fases reversas”. 


\subsubsection{Impacto do Custo de Deposição no Custo da Obra, para GRANDES GERADORES}

É importante ressaltar que dentre todas as análises, a V é a que proporciona maior ônus para o gerador, visto que o mesmo precisa arcar com o transporte do resíduo até a central de reciclagem e com a taxa de descarga de $\mathrm{R} \$ 60,00 /$ caçamba de $4 \mathrm{~m}^{3}$, valor $20 \%$ superior à taxa cobrada pela ATT.

No entanto, o impacto do custo de deposição no custo total da obra é muito pequeno. Tomando-se, por exemplo, uma obra de médio porte, com $5.000 \mathrm{~m}^{2}$ de vedações internas, todas em CGA.

Se o serviço de vedação interna em CGA for realizado por uma construtora, ainda que por mão-de-obra terceirizada, que possui um rígido controle de qualidade do serviço e proporciona ambiente de alta produtividade, entre outros fatores já mencionados no item 5.2.1.5, considera-se $5 \%$ de perda.

Isto resultaria em $250 \mathrm{~m}^{2}$ de resíduo de CGA, o que equivale a aproximadamente $2.125 \mathrm{~kg}$ de resíduos de CGA e corresponde a 11 caçambas de resíduos de CGA durante toda a execução do serviço.

O preço atualmente praticado para a deposição de uma caçamba de resíduos quaisquer da construção civil custa ao gerador cerca de $\mathrm{R} \$ 110,00$, dos quais $\mathrm{R} \$ 40,00$ são pagos à ATT e $\mathrm{R} \$ 70,00$ correspondem ao custo de transporte.

No caso da análise $\mathrm{V}$, que é a mais onerosa ao gerador, o custo de deposição é de $\mathrm{R} \$ 60,00$ e o de transporte permanece inalterado, totalizando portanto um custo de deposição de $\mathrm{R} \$ 130,00 /$ caçamba de $4 \mathrm{~m}^{3}$.

Assim, 11 caçambas de resíduos de CGA representam um custo de disposição total de $\mathrm{R} \$ 1.430,00$, para destinar à central de reciclagem.

Para estimar o impacto do custo de disposição no custo do serviço, coletou-se no mercado (CONSTRUÇÃO MERCADO, 2006), o custo do serviço de execução de vedação interna em CGA. Obteve-se o valor de $\mathrm{R} \$ 62,96 / \mathrm{m}^{2}$ de vedação relativo aos materiais e $\mathrm{R} \$ 17,00 / \mathrm{m}^{2}$ de vedação relativo à mão-deobra. O custo do serviço é então o produto entre o custo da execução da 
vedação interna em CGA, $\mathrm{R} \$ 79,96 / \mathrm{m}^{2}$, e a quantidade do serviço, $5.000 \mathrm{~m}^{2}$, que totaliza $\mathrm{R} \$ 399.800,00$.

Assim, o custo de disposição total (em central de reciclagem), representa 0,36\% do custo total do serviço, sendo este custo diluído em alguns meses da obra (durante a execução das vedações).

Para o mesmo exemplo, comparando-se as duas alternativas de deposição, a saber, a ATT e a central de reciclagem, o envio para a central de reciclagem é aproximadamente $15,3 \%$ mais caro, o que equivale ao montante de $\mathrm{R} \$ 220,00$ em toda a vedação, valor considerado insignificante se comparado ao custo de um empreendimento (Tabela 6.30).

Tabela 6.30 - Impacto do custo de disposição de resíduos de CGA em obras de grandes geradores (autora, 2007).

\begin{tabular}{|c|c|c|c|}
\hline \multicolumn{4}{|c|}{ Dados do serviço de vedação interna em CGA } \\
\hline $\begin{array}{l}\text { Quantidade de serviço de vedação } \\
\text { interna em CGA }\left(\mathrm{m}^{2}\right)\end{array}$ & 5.000 & 5.000 & 5.000 \\
\hline $\begin{array}{l}\text { Custo do serviço de vedação interna em } \\
\mathrm{CGA}\left(\mathrm{R} \$ / \mathrm{m}^{2}\right)\end{array}$ & $\mathrm{R} \$ 79.96$ & $R \$ 79.96$ & $\mathrm{R} \$ 79,96$ \\
\hline $\begin{array}{l}\text { Custo total do serviço de vedação interna } \\
\text { em CGA }\end{array}$ & $\mathrm{R} \$ 399.800,00$ & $\mathrm{R} \$ 399.800,00$ & $\mathrm{R} \$ 399.800,00$ \\
\hline Alternativas de deposição & Aterro & ATT & Central de reciclagem \\
\hline Custo de transporte $(\mathrm{R} \$ /$ caçamba) & $\mathrm{R} \$ 70,00$ & $\mathrm{R} \$ 70,00$ & $\mathrm{R} \$ 70,00$ \\
\hline Custo de deposição (R $\$$ /caçamba) & $\mathrm{R} \$ 10,00$ & $R \$ 40,00$ & $\mathrm{R} \$ 60,00$ \\
\hline Custo de disposição (R\$/caçamba) & $\mathrm{R} \$ 80,00$ & $\mathrm{R} \$ 110,00$ & $\mathrm{R} \$ 130,00$ \\
\hline Quantidade de caçambas & 11 & 11 & 11 \\
\hline Custo total de disposição & $\mathrm{R} \$ 880,00$ & $\mathrm{R} \$ 1.210,00$ & $\mathrm{R} \$ 1.430,00$ \\
\hline $\begin{array}{l}\text { Representativdade do custo de } \\
\text { disposição em relação ao custo do } \\
\text { serviço de vedação interna em CGA (\%) }\end{array}$ & $0,22 \%$ & $0,30 \%$ & $0,36 \%$ \\
\hline $\begin{array}{l}\text { Variação entre as alternativas de } \\
\text { deposição }(R \$)\end{array}$ & , & $\mathrm{R} \$ 330,00$ & $\mathrm{R} \$ 220,00$ \\
\hline $\begin{array}{l}\text { Variação entre as alternativas de } \\
\text { deposição (\%) }\end{array}$ & - & $27,27 \%$ & $15,38 \%$ \\
\hline
\end{tabular}

Padrão: Caçambas de $4 \mathrm{~m}^{3}$

Mesmo que executado por instaladores, onde a perda seria da ordem de $12 \%$, o custo de disposição dos resíduos de CGA na central de reciclagem representaria cerca de $0,85 \%$ do custo total do serviço de vedação interna. 


\subsubsection{ECONOMIA DE MATÉria-Prima PARA O FABricANTE DE CGA}

No item 5.2.1.5 apurou-se que a RMSP gera 4,79 mil t/ano de resíduos de CGA e que a máquina de reciclagem pode produzir desde 1 até $3 \mathrm{t} / \mathrm{h}$ de gesso reciclado. Em virtude da pouca disponibilidade de resíduos de CGA, considerou-se na maioria das análises a capacidade de produção de $1 \mathrm{t} / \mathrm{h}$. Sendo assim, a central de reciclagem é capaz de produzir 2,38 mil t de gesso reciclado/ano, o que equivale a um consumo de 2,66 mil t de resíduos de CGA pela central.

Comparando os fluxos, se a RMSP gera 4,79 mil t/ano de resíduo de CGA e a central só consome 2,66 mil t de resíduos de CGA, não é possível estabelecer o ciclo fechado.

No entanto, é possível estabelecer qual é a taxa de inserção do resíduo de CGA e a taxa de conteúdo reciclado do produto CGA.

A taxa de inserção corresponde a quantidade de matéria-prima que é substituída por matéria-prima reciclada, numa relação de massa/massa. Para este caso, é a quantidade de gesso reciclado de rCGA que substitui a gipsita natural na fabricação de uma nova CGA.

A fábrica localizada da RMSP produz 5,6 milhões de $\mathrm{m}^{2}$ de CGA/ano e, para tanto, consome cerca de 50,4 mil t de gipsita/ano. Consumindo os 2,38 mil t de gesso reciclado/ano, a fábrica terá uma taxa de inserção de $4,71 \%$, considerada baixa em relação à potencial taxa de inserção que a tecnologia da central permite, que é de até $25 \%$. De acordo com a entrevista ao gerente industrial, atualmente a CGA contém $2,5 \%$ de matéria-prima reinserida e a central de reciclagem é capaz de absorver até 250t/mês de rCGA.

A taxa de conteúdo reciclado é a relação, em porcentagem, da quantidade de matéria-prima reciclada utilizada e a unidade comercial do produto. No caso das CGA, é a quantidade de gesso reciclado utilizado na fabricação da CGA e a unidade de uma chapa, podendo ser esta relação em $\mathrm{m}^{2} / \mathrm{m}^{2}$ da unidade ou $\mathrm{kg} / \mathrm{kg}$ da unidade. Assim, considerando-se que:

$1 \mathrm{~m}^{2} \mathrm{CGA}=9 \mathrm{~kg}$ de gipsita 
$X \mathrm{~m}^{2} \mathrm{CGA}=9 \times$ taxa de inserção de gesso reciclado

$\mathrm{X} \mathrm{m} \mathrm{m}^{2} \mathrm{CGA}=9 \times 0,0471$

$\mathrm{X}=0,0471 \mathrm{~m}^{2} \mathrm{CGA}$

$1 \mathrm{CGA}=1,80 \mathrm{~m}^{2}$

Taxa de conteúdo reciclado $=0,0471 \mathrm{~m}^{2} \mathrm{CGA} / 1,80 \mathrm{~m}^{2} / \mathrm{CGA}$

Taxa de conteúdo reciclado $=2,62 \%$

Ou seja, a taxa de conteúdo reciclado existente em uma nova CGA, a qual é fabricação com taxa de inserção de $4,71 \%$, é $2,62 \%$.

Se a fábrica consome 2,38 mil t de gesso reciclado/ano, ela deixa de comprar esta mesma quantidade em gipsita. Portanto, ela deixa de comprar gipsita a $\mathrm{R} \$ 138,00 / \mathrm{t}$ para comprar gesso reciclado à $\mathrm{R} \$ 90,53 / \mathrm{t}$, uma economia de $34,4 \%$.

Mas, no fluxo de caixa, a economia não é de $34,4 \%$ porque parte dela ajuda a financiar a implantação.

A fábrica deixa de comprar 2,38 mil t de gipsita a $\mathrm{R} \$ 138,00$, e, portanto, deixa de desembolsar $\mathrm{R} \$ 327.888,00 /$ ano. Ela paga $\mathrm{R} \$ 90,53 / \mathrm{t}$ de gesso reciclado e consome 2,38 mil t/ano deste produto, totalizando uma despesa de $\mathrm{R} \$ 215.461,4 /$ ano. A diferença entre esta receita e esta despesa é de $\mathrm{R} \$$ 112.426,60/ano, a qual se pode chamar de montante da economia bruta. Parte dela ajuda a pagar o financiamento de implantação.

No fluxo de caixa da análise IX, o financiamento consome $\mathrm{R} \$ 865,46 /$ ano da economia bruta. Portanto, a economia efetiva em matéria-prima é de $\mathrm{R} \$ 111.561,14 / \mathrm{ano}$, ou seja, R\$9.296,76/mês, ou ainda, o equivalente a $\mathrm{R} \$ 0,019 / \mathrm{m}^{2}$ CGA.

Já no fluxo de caixa da análise X, o financiamento consome R \$ 26.511,44/ano. Assim, a economia efetiva é de R \$ 85.915,16/ano, ou seja, R \$7.159,60/mês, ou ainda o equivalente a $\mathrm{R} \$ 0,015 / \mathrm{m}^{2} \mathrm{CGA}$. 


\subsubsection{A Possibiliddade do CiClo FeChado}

No caso brasileiro, da RMSP, a geração de resíduos de CGA totaliza 4,79 mil t/ano, quantia que, se reciclada, geraria 4,23 mil t de gesso reciclado/ano.

Para analisar a possibilidade de uma cadeia reversa de ciclo fechado, é necessário verificar:

1 - a central de reciclagem tem capacidade para processar 4,79 mil t/ano de resíduos de CGA;

2 - existe demanda da produção de CGA para o consumo de 4,23 mil t/ano de gesso reciclado e, para tal consumo, qual a taxa de inserção necessária;

3 - até quando a central de reciclagem conseguirá manter o ciclo fechado.

A central de reciclagem tem capacidade de produção de 1 a $3 \mathrm{t} / \mathrm{h}$. Para processar 4,79 mil t/ano teria que operar com 1,78 t/h. Portanto, a central tem capacidade de processar todo o resíduo de CGA gerado na RMSP.

O fabricante que está localizado na RMSP consome 50,4 mil t/ano de gipsita. Portanto, tem condições de absorver toda a produção da central de reciclagem, que é de 4,23 mil t/ano de gesso reciclado. A utilização de todo o gesso reciclado produzido proporciona uma taxa de inserção de apenas $8,39 \%(\mathrm{~m} / \mathrm{m})$ e uma taxa de conteúdo reciclado de $4,66 \%$.

A taxa de inserção obtida encontra-se bem abaixo das encontradas na bibliografia. Segundo o fabricante da máquina de reciclagem (ANDELA, 2006) e as bibliografias consultadas, há experiências internacionais que atestam a substituição de até $25 \%$ de gesso reciclado em uma nova CGA (CAMPBELL, 2003).

Isto é, a inserção de 8,39\% de gesso reciclado na produção de uma nova CGA já é suficiente para consumir todo o resíduo de CGA gerado na RMSP, de forma a configurar um canal de distribuição reverso, de pós-consumo, de ciclo fechado, com processo de reaproveitamento de reciclagem.

Para determinar até quando a central de reciclagem conseguirá manter o ciclo fechado, considerou a taxa máxima de inserção de $25 \%$, ou seja, do montante 
de gipsita necessário (50,4 mil t/ano), 25\% será substituído por gesso reciclado, obtendo-se uma demanda por gesso reciclado de 12,6 mil t/ano.

Para a produção de 12,6 mil t/ano de gesso reciclado serão necessários 14,1 mil t de resíduo de CGA. Se hoje a RMSP gera 4,79 mil t/ano, então a quantidade de resíduos de CGA pode crescer até 2,9 vezes que o ciclo continuará fechado. No entanto, a atual central de reciclagem só conseguirá absorver todo o fluxo de resíduos se o equipamento de reciclagem aumentar sua capacidade de produção para $6 \mathrm{t} / \mathrm{h}$.

Considerando-se que o crescimento da quantidade de resíduos de CGA é proporcional ao crescimento das vendas de CGA, previsto em $12 \%$ a.a. ${ }^{35}$, o consumo de CGA e a geração aumentam a esta taxa anual. Considerando-se o consumo atual de CGA na RMSP de 5,6 milhões de $\mathrm{m}^{2}$ de CGA e a população de 17,879 milhões de habitantes, tem-se um consumo de $0,313 \mathrm{~m}^{2} / \mathrm{hab} / \mathrm{ano}$. Já a geração do resíduo, levantada no item 5.2 .1 .5 , é de $563,73 \mathrm{mil} \mathrm{m}^{2} /$ ano. A capacidade máxima de absorver os resíduos de CGA, determinada pela máxima inserção de $25 \%$, é obtida pela divisão da demanda por gesso reciclado - 14,1 mil t/ano, pela população da RMSP.

Assim, considerando o ano de 2007 como o ano zero e os dados citados, compõe-se a Tabela 6.31 .

Tabela 6.31 - Consumo de CGA, geração e capacidade de absorção de resíduos de CGA, na RMSP (autora, 2007).

\begin{tabular}{|c|c|c|c|c|c|c|}
\hline & \multicolumn{6}{|c|}{ Dados da RMSP - Chapas de Gesso Acartonado - CGA } \\
\hline Ano & \multicolumn{2}{|c|}{ Consumo } & \multicolumn{2}{|c|}{ Geração de resíduo } & \multicolumn{2}{|c|}{$\begin{array}{l}\text { Capacidade máxima da central em } \\
\text { absorver resíduos }-25 \%\end{array}$} \\
\hline $\begin{array}{c}\text { (Referência: } \\
\text { Ano } 0=2007 \text { ) }\end{array}$ & em $\mathrm{m} 2 / \mathrm{hab} / \mathrm{ano}$ & em kg/hab/ano & em m2/hab/ano & em kg/hab/ano & em m2/hab/ano & em kg/hab/ano \\
\hline 0 & 0,313 & 2,662 & 0,032 & 0,268 & 0,093 & 0,788 \\
\hline 1 & 0,351 & 2,982 & 0,035 & 0,300 & 0,093 & 0,788 \\
\hline 2 & 0,393 & 3,340 & 0,040 & 0,336 & 0,093 & 0,788 \\
\hline 3 & 0,440 & 3,740 & 0,044 & 0,377 & 0,093 & 0,788 \\
\hline 4 & 0,493 & 4,189 & 0,050 & 0,422 & 0,093 & 0,788 \\
\hline 5 & 0,552 & 4,692 & 0,056 & 0,472 & 0,093 & 0,788 \\
\hline 6 & 0,618 & 5,255 & 0,062 & 0,529 & 0,093 & 0,788 \\
\hline 7 & 0,692 & 5,886 & 0,070 & 0,592 & 0,093 & 0,788 \\
\hline 8 & 0,776 & 6,592 & 0,078 & 0,664 & 0,093 & 0,788 \\
\hline 9 & 0,869 & 7,383 & 0,087 & 0,743 & 0,093 & 0,788 \\
\hline 10 & 0,973 & 8,269 & 0,098 & 0,832 & 0,093 & 0,788 \\
\hline
\end{tabular}

${ }^{35}$ Os fabricantes estimam um crescimento de vendas de $12 \%$ a.a., para os próximos 3 anos. Não há estimativas de longo prazo. No entanto, para efeito deste raciocínio, considerou-se que este índice de crescimento permanece o mesmo para os próximos 10 anos. 
Pela comparação dos dados mostrados na Tabela 6.31, é possível concluir que a central de reciclagem será suficiente para manter o ciclo fechado por mais 9 anos (2016), momento em que o consumo de CGA na RMSP estará em 0,869 $\mathrm{m}^{2} / \mathrm{hab} / \mathrm{ano}$, índice de consumo próximo à países como Itália $\left(0,7 \mathrm{~m}^{2} / \mathrm{hab} / \mathrm{ano}\right)$ e Chile $\left(1,2 \mathrm{~m}^{2} / \mathrm{hab} / \mathrm{ano}\right)$ (ver Figura 5.3).

No entanto, a capacidade de processamento de resíduo da central de reciclagem - determinada pela máxima capacidade do equipamento de reciclagem que é de $3 \mathrm{t} / \mathrm{h}$ - é de 0,4 kg/hab/ano. Assim, a central de reciclagem teria que adquirir mais um equipamento, ou trocá-lo para um de capacidade de processamento de $6 \mathrm{t} / \mathrm{h}$, em 2010, para continuar a absorver resíduos de CGA objetivando $25 \%$ de taxa de inserção. A figura ilustra o ciclo fechado da cadeia de CGA.

As principais barreiras encontradas para fechar o ciclo dos canais reversos de CGA são a ausência de legislações que contemplem a co-responsabilidade do fabricante de CGA e o baixo preço cobrado pelos aterros para a deposição de quaisquer resíduos, inclusive os de CGA.

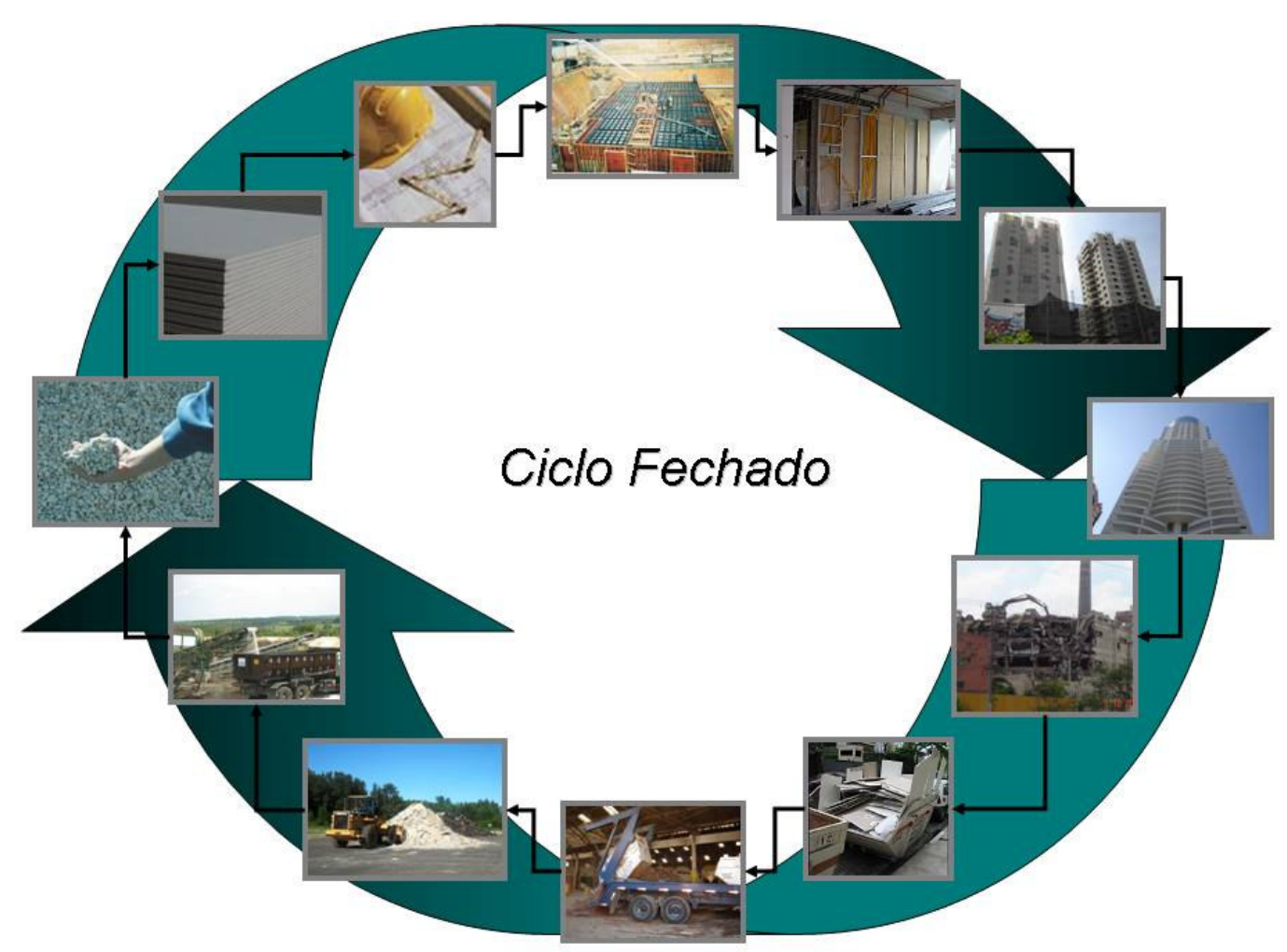

Figura 6.16 - Ciclo fechado da cadeia produtiva de CGA (autora, 2007). 


\section{7 - Conclusões}

A implantação da logística reversa revela-se como uma grande oportunidade de se desenvolver a sistematização dos fluxos de resíduos, bens e produtos descartados seja pelo fim de sua vida útil, seja por obsolescência tecnológica ou outro motivo - e o seu reaproveitamento, dentro ou fora da cadeia produtiva que o originou, contribuindo para o respeito ambiental, por meio da redução do uso de recursos naturais, e conseqüente economia das reservas minerais, assim como da mitigação de outros impactos ambientais.

Acredita-se que a exigência quanto a novos requisitos logísticos, dentre eles os de logística reversa, por parte dos clientes, sejam eles consumidores finais ou empresas, irá atingir todas as cadeias produtivas, dentre elas a da Construção Civil. Apesar do interesse ainda incipiente identificado na ICC, evidentemente, cada indústria ou cadeia produtiva será solicitada a seu tempo e numa velocidade específica.

No entanto, ao se prever esta nova necessidade, a cadeia produtiva deve antecipar-se a estas novas exigências e iniciar a estruturação dos sistemas logísticos reversos desde agora, visto que a estruturação e consolidação destes sistemas demandam prazos extensos, devido a sua complexidade. Desta forma, faz-se necessária uma abordagem sistêmica dos fatores que influenciam estes fluxos, identificando-se os obstáculos e dificuldades a serem transpostos para a consecução de um sistema logístico reverso aplicado às obras civis. 
A revisão bibliográfica permitiu concluir que o conceito de logística reversa pode ser aplicado à cadeia produtiva da construção civil, desde que respeitadas as características específicas desta indústria. A operacionalização desta aplicação ocorre por meio do estabelecimento de sistemas logísticos reversos - SLR.

A motivação para o estabelecimento de um SLR pode advir de uma oportunidade de negócio lucrativa, como, por exemplo, o reaproveitamento de aço, da escassez de matéria-prima, como, por exemplo, o caso das madeiras e dos agregados naturais, da pressão exercida por clientes com alto poder de compra, ou por força de legislações. O SLR pode ainda configurar-se como um novo negócio (por exemplo, o reaproveitamento de resíduos de tintas) ou aprimorar um processo de aproveitamento de resíduos já existente (por exemplo, a produção de agregados reciclados).

Em termos de abrangência, pode ser focado em um produto de pós-venda, como as embalagens, ou em um produto de pós-consumo, que denominou-se resíduo. Pode abordar um resíduo que tenha como origem atividades industriais diversas, ou ser focado em uma atividade industrial e tratar de todos os resíduos produzidos por ela. O SLR pode ainda conter apenas um tipo de canal reverso ou diversos, como, por exemplo, canal reverso de reuso e de reciclagem para um mesmo tipo de RCD.

A iniciativa em estabelecer um SLR pode ser desempenhada por uma empresa isoladamente, por exemplo, uma construtora, uma demolidora ou um fabricante de componentes, ou por uma entidade setorial ou associação de classe de um determinado agente da cadeia. No entanto, sua consolidação depende de esforços e da cooperação entre todos os agentes envolvidos.

A revisão bibliográfica apresentada nos capítulos 2 permitiu visualizar como as características específicas da ICC influenciam a aplicação do conceito de logística reversa. Na ICC, apesar dos insumos utilizados possuírem um ciclo de vida útil extenso (são bens duráveis), se comparados com outros produtos, a tendência na utilização de reuso (por exemplo, o retrofit), reciclagem ou reforma tem demonstrado a preocupação em se evitar tanto a produção de entulho por demolição, quanto a economia de recursos naturais para a fabricação de novos insumos, como forma de contribuir para a construção mais sustentável. Assim, conclui-se que a função dos sistemas logísticos reversos na ICC é estabelecer canais de reaproveitamento dos 
produtos e RCD, integrando os agentes envolvidos em torno da questão da responsabilidade por todo o ciclo de vida do produto.

Dentre as características da ICC, a alta informalidade na ICC dificulta as previsões e o gerenciamento dos RCD, principalmente em relação ao controle das deposições ilegais e das destinações incorretas. Já a extensão territorial do Brasil, e mesmo do estado de São Paulo, associada à sofrível infra-estrutura de transporte rodoviário, acarreta custos de distribuição e coleta expressivos para os SLR, dificultando a viabilidade dos CDR. Comumente as indústrias estão longe dos pontos de consumo e vice e versa.

No âmbito social, o baixo grau de capacitação da mão-de-obra e do nível técnicogerencial nas empresas construtoras é outra característica da ICC que pode contribuir para uma significativa geração de RCD.

As empresas dispostas a estabelecer um SLR precisam capacitar seus trabalhadores, para que estes sejam capazes de absorver processos mais complexos e sistêmicos, como os que são necessários para a maior eficiência dos sistemas logísticos reversos. Além disso, a abertura de novos negócios inseridos no sistema de logística reversa, como a coleta seletiva, a reciclagem de várias frações e o gerenciamento do transporte de RCD, pode impulsionar a geração de novos postos de trabalho. Os agentes envolvidos podem ainda contribuir para estruturar as atividades de logística reversa já existentes em sistemas formais, mais organizados e eficientes.

Ainda em relação à questão social, impõe-se às cadeias reversas da ICC o desafio social de inclusão de catadores, também conhecidos por carroceiros e carrinheiros. Vislumbra-se como alternativa a organização destes em cooperativas de reciclagem e postos de acumulação e adensamento de resíduos.

No capítulo 3, o estudo da cadeia direta forneceu elementos importantes, como localização de plantas industriais e nível de integração das relações comerciais, para a compreensão da dinâmica dos canais de distribuição diretos (CDD) e sua relação com os canais de distribuição reversos (CDR). Foi possível concluir acerca dos fatores técnicos, econômicos, mercadológicos, ambientais e sociais que podem influenciar na operacionalização de canais de distribuição reversos de pós-consumo de RCD. 
Por outro lado, demonstrou-se como as atividades de logística reversa podem subsidiar a decisão de atitudes e como seu estabelecimento pode beneficiar todas as dimensões do desenvolvimento sustentável na ICC.

Com base no capítulo 4 constatou-se que o gerenciamento de RCD dentro do canteiro de obras é determinante da quantidade e qualidade do RCD gerado. Se os processos de triagem ocorrem na fonte, evitando-se a contaminação, maiores são as chances de reaproveitamento dos RCD.

Para os RCD classe A e B, os quais já possuem mercado consumidor, os SLR auxiliam no planejamento e controle das atividades, a custos possíveis e nos prazos requeridos. Para os RCD classe $\mathrm{C}$ foi comprovada a importância da participação dos fabricantes na implantação de um SLR para cada resíduo, e a necessidade de legislações complementares às já existentes.

O gerenciamento de RCD classe C para os quais é possível identificar o fabricante, como no caso da CGA, é diferente daqueles onde não é possível, como gesso de revestimento e tintas. Para os RCD ‘identificáveis’ é possível obter informações, pois sabe-se a origem. Para os RCD para os quais não é possível a identificação, a reciclagem tem que ser uma iniciativa conjunta dos fabricantes, geralmente representados por associações setoriais.

Dentre os mecanismos utilizados em outros países para motivar o estabelecimento dos SLR destacam-se a cobrança de altas taxas de deposição em aterros e a responsabilização do fabricante do produto pelo resíduo gerado por este. Acredita-se que, a médio prazo, a ausência de opções de adequada destinação de um RCD provocará a perda de competitividade do produto que o gerou.

No Brasil, a política do take-back é aplicada a alguns resíduos, como os provenientes de pilhas e baterias e de pneus. A aplicação desta política para os RCD, sem distinção de suas frações, não é interessante, pois o custo logístico de retornar o resíduo ao fabricante do produto é, por muitas vezes, alto e inviabiliza economicamente o seu reaproveitamento.

Assim, para determinadas frações do RCD, como, por exemplo, a fração mineral, em que as tecnologias de reciclagem estão disponíveis e os canais reversos começam a 
se consolidar, a política de take-back não seria interessante, além de difícil aplicação. No entanto, para as frações de RCD que não possuem soluções de destinação consolidadas, como é o caso da CGA, esta aplicação é uma oportunidade de envolver e comprometer os fabricantes a desenvolver opções adequadas de destinação.

Isto porque, na ICC as empresas fornecedoras, as quais atuam como indústria e, portanto, estão expostos a menos variáveis, incertezas e imprevistos do que a empresa construtora. Assim, o desenvolvimento da logística reversa tem maiores possibilidades de sucesso quando função destas empresas, as quais podem assumir o papel de propulsoras da implantação dos SLR na ICC.

Acredita-se que o desenvolvimento e criação dos canais reversos podem ser melhor desempenhadas pelas empresas fornecedoras através da aplicação do conceito de EPR (Extended Product Responsibility - Responsabilidade Extendida do Produto), segundo o qual "a cadeia industrial produtora ou o próprio produtor, que de certa maneira agridem o meio ambiente, devem se responsabilizar pelo seu produto até a decisão correta do seu destino após seu uso original” (LEITE, 2003), ou seja, a responsabilidade sobre o produto não termina com a venda.

O estudo de SLR para os RCD da ICC deve contemplar as seguintes atividades:

- escolha do resíduo, ou fração de resíduo;

- levantamento das características do resíduo:

- caracterização física;

- caracterização química;

- caracterização da microestrutura;

- comportamento das propriedades mecânicas;

- durabilidade;

- quantidade.

- identificação e análise do interesse dos fabricantes do produto que dá origem ao resíduos e dos demais agentes envolvidos;

- identificação da possibilidade e grau de acesso às informações;

- levantamento dos fornecedores primários e secundários da cadeia direta;

- mapeamento das unidades fabris e de estoque dos fabricantes do produto;

- identificação e análise do processo industrial de fabricação; 
- levantamento das formas de distribuição e consumo do produto;

- levantamento dos perfis dos clientes;

- mapeamento dos principais pontos de consumo;

- identificação das formas de geração de resíduos;

- identificação do manejo do resíduo após sua geração;

- levantamento da existência de tecnologias de reaproveitamento, sua disponibilidade e características;

- levantamento de possíveis plantas de reaproveitamento já existentes e de sua forma de operação;

- levantamento da necessidade de coleta e transporte do resíduo;

- levantamento dos aspectos e possíveis impactos ambientais gerados pelo resíduo;

- levantamento dos custos de reaproveitamento do resíduo, incluindo os de processamento, logísticos e ambientais;

- levantamento das demandas das tecnologias de reaproveitamento disponíveis;

- levantamento da existência de tecnologias de deposição específicas;

- levantamento dos possíveis e potenciais mercados para o produto reciclado;

- caracterização do produto reciclado;

- avaliação de desempenho e durabilidade do produto reciclado;

- identificação da existência de valor de mercado para os produtos reciclados;

- identificação das restrições ao uso do produto reciclado, incluindo os produtos a análise dos produtos concorrentes;

- estudo da localização das plantas de triagem e de reaproveitamento; e

- análise de viabilidade econômica e sócio-ambiental dos canais reversos.

A partir destas atividades, foram elaborados os questionários do trabalho de campo. O capítulo 5 mostrou os resultados da aplicação do sistema logístico reverso à cadeia de CGA e simulou possíveis configurações dos canais reversos para analisar suas respectivas viabilidades econômicas. 
Em relação à cadeia de CGA, conclui-se que o correto gerenciamento dos resíduos de CGA dentro do canteiro, sendo a triagem realizada preferencialmente na origem, é fator técnico determinante para a reciclagem das fases dos resíduos à base de gesso.

No caso da cadeia direta de CGA verificou-se que a relação entre os fornecedores de insumos e os fabricantes de CGA apresenta certa estabilidade, apesar do extenso lead-time para o suprimento de papel cartão.

A relação entre o fabricante e o distribuidor e o instalador é calcada em relação comercial, suporte técnico e treinamentos. Mas, a integração entre os processos, principalmente os de comunicação e informação, é pequena.

A possibilidade de retorno dos resíduos de CGA por meio do canal de distribuição direta, ou seja, a entrega do resíduo do gerador ou instalador para o distribuidor e deste para o fabricante é uma alternativa descartada. Identificou-se no trabalho de campo que os distribuidores de CGA não possuem, em geral, infra-estrutura física suficiente para receber e armazenar resíduos de CGA. Além disto, salvo algumas exceções, estes agentes possuem baixa capacitação gerencial e não estão propícios a assumir as atividades de coleta e armazenamento de resíduos de CGA, a menos que fosse sobre forte imposição dos fabricantes e com muitas restrições.

Dentre os processos de reaproveitamento, a reciclagem foi o que possibilitou a obtenção de um produto reciclado com maiores aplicações.

A inviabilidade econômica de um CDR de reciclagem de CGA é, muitas vezes, um problema de logística resultante, principalmente, dos altos custos de coleta e transporte advindos da existência de muitos pontos de consumo e poucos pontos de aproveitamento de resíduos. Conforme John e Agopyan (2000) "é necessário que centrais de reciclagem estejam localizadas em zonas urbanas, o mais próximo possível do local de geração do resíduo para encurtar as distâncias de transporte, que é um aspecto crítico para a captação dos resíduos".

O objetivo principal da central de reciclagem, independente de ser uma iniciativa privada ou pública em São Paulo, ou privada pelo fabricante da RMSP, é diminuir as distâncias entre o produto e seus possíveis compradores. Por conseqüência, isto diminui os impactos ambientais e econômicos advindos deste transporte. 
Para os casos das iniciativas privadas de estabelecer centrais de reciclagem de resíduos de CGA, acredita-se que a operação conjunta ${ }^{36}$, com uma instalação de reciclagem de gesso "comum", ou seja, gesso de revestimento e de placas prémoldadas, tornaria o negócio ‘central de reciclagem' mais atrativo, devido ao maior volume de resíduos disponível - que significa também um baixo risco de falta de suprimento -, e a existência de mais mercados consumidores para o produto gesso em pó reciclado.

No entanto, seria necessário estudar a composição química do gesso (gipsita) granular produzido a partir de resíduos de gesso de revestimento e de placas prémoldadas, e do produzido a partir de resíduos de CGA, uma vez que os aditivos presentes nas CGA podem alterar sua composição. Em caso positivo, seria importante desenvolver mecanismos para a distinção entre os dois produtos. Uma das opções para tanto é o tingimento de um dos produtos.

Analisando-se as opções de iniciativas de fabricantes para estabelecer centrais de reciclagem conjuntas com o processo de produção de CGA, sabe-se que a utilização de uma nova tecnologia exige esforços técnicos e econômicos, principalmente em testes para ajustes da situação anterior com a nova.

No entanto, estes esforços podem ser devidamente recompensados pelas possibilidades de economia de matéria-prima - como demonstrado nas análises de viabilidade econômica -, parceria com grandes geradores, atuação responsável em relação ao meio ambiente e diferencial de imagem no mercado.

As simulações de análise de viabilidade econômica provaram que, atualmente, há condições para a viabilidade econômica da reciclagem de resíduos de CGA.

O modelo mais adequado é o que estabelecesse uma co-responsabilidade, inclusive em passivos ambientais, entre o fabricante e a construtora. $\mathrm{O}$ fabricante deve desenvolver, juntamente com os órgãos de pesquisa, opções adequadas de destinação e a construtora deve assegurar que o fluxo de resíduos será corretamente destinado aos locais adequados. Este é o caso da cadeia de CGA. Embora se tenha a impressão de que, para os fabricantes e muitos construtores, a questão da destinação de gesso

\footnotetext{
36 'Operação conjunta', neste caso, significa a operação de dois equipamentos de reciclagem distintos compartilhando a mesma infra-estrutura.
} 
esteja resolvida se o resíduo de CGA for destinado às indústrias de cimento, esta não é a conclusão a que chega esta pesquisa.

A consolidação do sistema logístico reverso para a cadeia de CGA exige o desenvolvimento de muitos mecanismos. No caso da cadeia de CGA, cada agente pode atuar em seu âmbito para estabelecer estes mecanismos.

Os órgãos governamentais necessitam estabelecer as legislações, que definam:

- as responsabilidades e co-responsabilidades de cada agente sobre o gerenciamento dos RCD;

- $\quad$ as formas de fiscalização e penalização de seu cumprimento;

- a proibição da deposição de certos resíduos em aterros, em especial daqueles à base de gesso;

- taxação sobre a deposição de certos resíduos em aterros;

- taxação sobre a compra de determinados produtos que geram resíduos de difícil manejo e destinação e/ou alto impacto ambiental negativo;

- $\quad$ subsídios para a implantação e operação de centrais de reciclagem;

- índices mínimos e máximos de conteúdo reciclado em determinados produtos;

- a certificação ambiental de produtos.

As entidades de classe devem organizar seus afiliados auxiliando na divulgação de estudos e na conscientização da responsabilidade ambiental e da construção sustentável. A academia precisa desenvolver conhecimento sobre, principalmente, as restrições técnicas e novas aplicações dos RCD, em especial dos resíduos de CGA.

Os consumidores de produtos reciclados devem também auxiliar no estabelecimento claro e objetivo das especificações de qualidade e desempenho mínimas necessárias aos seus respectivos consumos.

Apesar da crescente preocupação das empresas da ICC em relação à sustentabilidade ambiental, poucas iniciativas têm sido tomadas. Esta constatação se confirma no caso 
dos fabricantes de CGA que apresentaram um baixo comprometimento com relação às soluções de destinação dos resíduos provenientes das obras.

Verifica-se que os fabricantes devem estimular e dar suporte às pesquisas, e assumirem papel mais ativo na busca de soluções de disposição e assumirem a reciclagem de CGA num processo vertical. Esta posição poderia lhes proporcionar um diferencial no relacionamento com os clientes, em específico as construtoras, com papel mais ativo na busca de soluções adequadas de destinação, uma vez que são os fabricantes que detêm maior conhecimento sobre o produto CGA. Os fabricantes devem ainda:

- formalizar a composição do resíduo de CGA;

- estabelecer programas com objetivos e prazos bem definidos para o desenvolvimento de opções de destinações;

- elaborar análise de ciclo de vida das CGA e do sistema de vedação interna em CGA;

- procurar investigar as soluções encontradas por outras empresas no exterior para os resíduos de CGA, e sua aplicabilidade no Brasil.

As construtoras, distribuidores, instaladores e ATT devem colaborar realizando os processos de triagem e acondicionamento com rigor e contratando apenas transportadores idôneos. Elas podem ainda, por meio de seu poder de compra, pressionar os fornecedores de CGA para a busca de soluções de destinação.

Os transportadores, por sua vez, devem cumprir as exigências de transporte e destinação previstas nas legislações, sendo inclusive, agentes de mudança do comportamento dos geradores. Por fim, todos precisam que estabelecer sistema de informação e comunicação eficazes entre si.

A Figura 7.1 ilustra os fluxos do sistema logístico reverso de resíduos de CGA considerado ideal. A estruturação deste SLR ocorreu por meio da identificação, quantificação, organização e consolidação dos fluxos reversos, físicos e de informação, das atividades necessárias - coleta, armazenamento, transporte, classificação, etc. - e dos agentes envolvidos, considerando-se os aspectos técnicos, ambientais, sociais e econômicos da RMSP. 


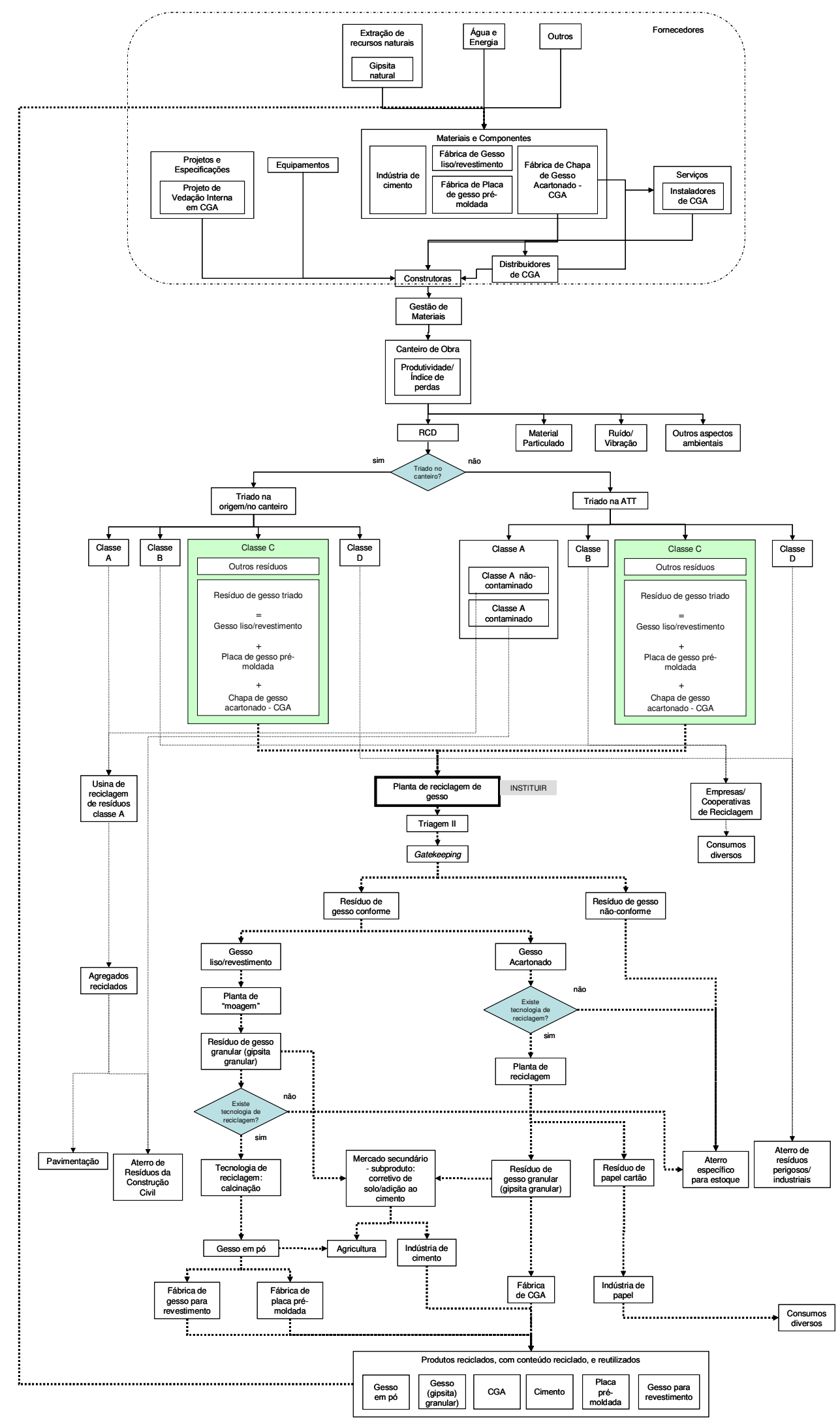

Figura 7.1 - Fluxos do Sistema Logístico Reverso de resíduos de Chapas de Gesso Acartonado, considerado ideal (autora, 2007). 
O estabelecimento de cadeias de suprimentos reversas está condicionado a uma forte cooperação entre os agentes, os quais devem estar alinhados estrategicamente e ter uma visão conjunta e holística do ambiente em que estão inseridos, e censo de responsabilidade sobre toda vida útil do produto. Segundo Leite (2003), quando atingem o supply chain management "as empresas possuem uma visão sistêmica interna e externalizam essa estratégia para sua rede de operações, formando redes de organizações constituídas pelos diversos elos anteriores e posteriores a elas na cadeia industrial, com o intuito de otimizar as operações e os fluxos logísticos desse novo sistema, as chamadas cadeias de suprimento. Apresentam um ambiente empresarial de alta flexibilidade, qualidade total e elevado nível de relacionamento com seus clientes e fornecedores, por meio de alianças e parcerias estratégicas de várias naturezas, que permitem interações, compartilhamento de informações e acréscimo de valor nos serviços prestados, melhorando a operação dos clientes e mantendo-os por mais tempo". A Figura 7.2 ilustra a cadeia de suprimentos reversa de resíduos de CGA.

Em relação à cadeia de CGA especificamente, apesar de ser possível o estabelecimento de canais reversos de reciclagem de rCGA em ciclo aberto, considerando-se as restrições apresentadas, concluiu-se que a forma mais promissora e atrativa de seu reaproveitamento é através de canais reversos de reciclagem de ciclo fechado.

Constata-se ainda que a consolidação da logística reversa é um processo progressivo e interdependente entre as empresas fornecedoras e as construtoras. Esforços de um único lado (agente) ou esforços dispersos tendem a gerar resultados medíocres e por consequiência a não-propagação de seus princípios.

Propõem-se como estudos futuros:

- a elaboração de mecanismos de controle de pureza para os gessos em pó reciclados;

- a determinação da reciclabilidade dos gessos em pó, ou seja, quantas vezes é possível realizar o ciclo de desidratação e hidratação da gipsita e que influência isto exerce sobre as propriedades do material (NITTA et al., 2004), do produto e sobre o desempenho da vedação e do revestimento; 


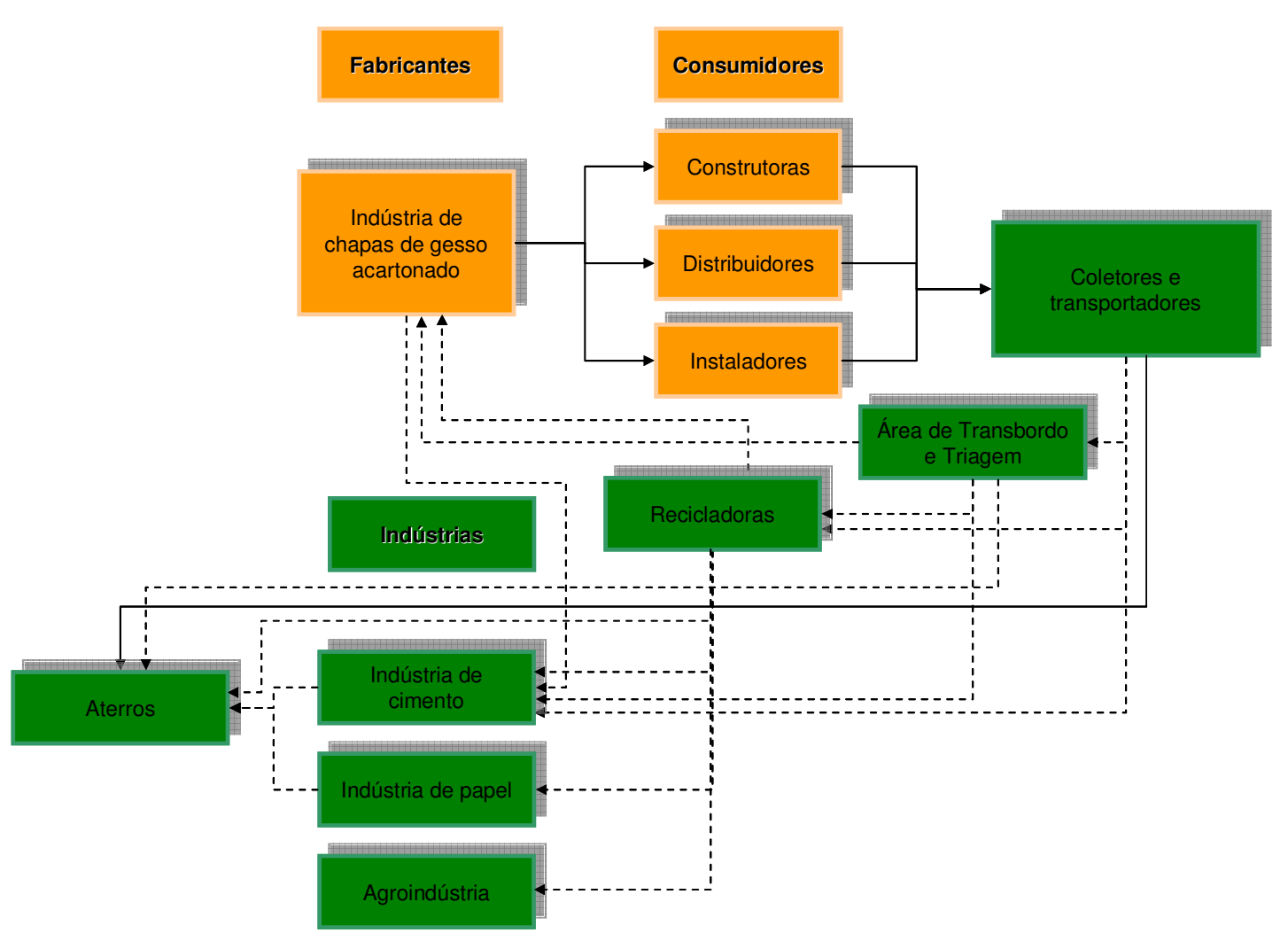

Legenda

Grupo de agentes 'diretos'

Agentes 'diretos'

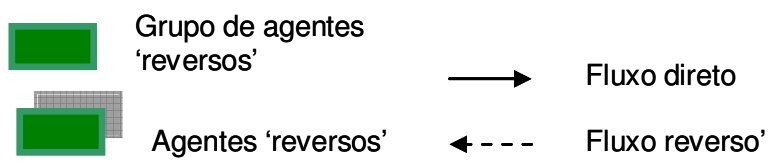

Agentes 'reversos' $\quad$ - - - F Fluxo reverso'

Figura 7.2 - Cadeia de suprimentos reversa de resíduos de CGA (autora, 2007).

- a elaboração de mecanismos de identificação para os gessos em pó reciclados e os produtos dele provenientes, de forma a classificá-los quanto à reciclabilidade;

- o desenvolvimento de projetos e especificações técnicas que estabeleçam a mais correta e adequada forma de armazenamento e deposição dos resíduos de gesso, incluindo-se os de gesso de revestimento, de placas pré-moldadas, de CGA e de moldes industriais, levando em consideração principalmente os aspectos ambientais de tal atividade;

- o estudo aprofundado e específico da utilização de resíduos de CGA (e dos demais gessos) em indústrias de cimento, estabelecendo quais parâmetros 
técnicos estes resíduos devem apresentar para serem aproveitados sem prejuízos à produção de cimento e ao produto cimento;

- o estabelecimento de parâmetros para certificar a contaminação de resíduos de todas as classes mas, especificamente, mais urgentemente, do teor admissível de contaminação por gesso em resíduos classe A, e de como medir tal teor;

- com base na metodologia de John (2000) ampliar o estudo das etapas de ‘custos associados aos resíduos' e de ‘caracterização do resíduo'; e desenvolver as etapas de 'desenvolvimento do produto', 'avaliação do produto', 'análise de desempenho ambiental', 'viabilidade econômica' e 'transferência de tecnologia';

- elaboração de modelo dinâmico para o estudo do roteamento de transporte de coleta de resíduos;

- análise de ciclo de vida do processo construtivo de vedação interna com chapas de gesso acartonado;

- elaboração de sistemas de informação e comunicação empresarial para comercialização de resíduos;

- estabelecimento de método para catalogação nacional de RCD, com suas respectivas especificações para processos de reaproveitamento;

- elaboração de método de planejamento e controle da produção para ambientes de produção com alto grau de incerteza de suprimento;

- elaboração de ferramentas informatizadas para integração das atividades de orçamento, suprimentos e produção em obra, objetivando o controle de custo, consumo, quantidade e prazo de transporte dos resíduos;

- estabelecimento de rede de comunicação eficiente entre gerador, transportador, reciclador e consumidor;

- estudos de prospecção de novos mercados e aplicações para os RCD;

- metodologia para estudo das cadeias reversas da Construção Civil.

Agradece-se a Coordenadoria de Aperfeiçoamento de Pessoal do Ensino Superior CAPES pelo suporte a esta dissertação por meio de concessão de bolsa de estudos à autora. 


\section{8 - Referências}

AES ELETROPAULO. Apresenta informações sobre a concessionária de serviços de energia elétrica, entre elas as referentes às tarifas. Disponível em: $<\mathrm{http} / / / \mathrm{www}$.eletropaulo.com.br/portal/page.cfm?conteudo_id=688>. Acesso em: 7 jan. 2007.

AGUIAR, G. Estudo de argamassas com agregados reciclados contaminados por gesso de construção. São Paulo. 2004. 282 f. Dissertação (Mestrado) - Escola Politécnica, Universidade de São Paulo, São Paulo, 2004.

ANDELA PRODUCTS LTD. A/S. Apresenta informações sobre os sistemas de reciclagem comercializados pela empresa. Disponível em: <http://www.andelaproducts.com>. Acesso em: 13 out. 2006.

ANGULO, S. C. et al . Desenvolvimento de novos mercados para a reciclagem massiva de RCD. In: SEMINÁRIO DE DESENVOLVIMENTO SUSTENTÁVEL E A RECICLAGEM NA CONSTRUÇÃO CIVIL, 5., 2002, São Paulo. Anais... São Paulo: IBRACON CT-206/IPEN, 2002. p. 293-308.

AQUINO, P. E. A produção de ácido fosfórico e a geração de fosfogesso. In: DESAFIOS TECNOLÓGICOS PARA O REAPROVEITAMENTO DO FOSFOGESSO, 1., 2005, Belo Horizonte. Anais eletrônicos... Belo Horizonte: UFMG, 2005. Disponível em: <http:/www.fosfogesso.eng.ufmg.br>. Acesso em: 21 jan. 2006.

ASSOCIAÇÃO BRASILEIRA DE NORMAS TÉCNICAS. NBR 8849: apresentação de projetos de aterros controlados de resíduos sólidos urbanos. Rio de Janeiro, 1985.9 p.

NBR 8419: apresentação de projetos de aterros sanitários de resíduos sólidos urbanos. Rio de Janeiro, 1992.7 p. 
$5 \mathrm{p}$.

NBR 14715: chapas de gesso acartonado - requisitos. Rio de Janeiro, 2001.

NBR 15112: resíduos da construção civil e resíduos volumosos - áreas de transbordo e triagem - diretrizes para projeto, implantação e operação. Rio de Janeiro, 2004. 7 p.

NBR 10004: resíduos sólidos - classificação. Rio de Janeiro, 2004. 71 p.

NBR 15114: resíduos sólidos da construção civil - áreas de reciclagem diretrizes para projeto, implantação e operação. Rio de Janeiro, 2004. 7 p.

NBR 15113: resíduos sólidos da construção civil e resíduos inertes - aterros - diretrizes para projeto, implantação e operação. Rio de Janeiro, 2004. 12 p.

NBR ISO 14001: sistemas de gestão ambiental - requisitos com orientações para uso. Rio de Janeiro, 2004. 27 p.

ASSOCIAÇÃO BRASILEIRA DOS FABRICANTES DE CHAPAS PARA DRYWALL (ASSOCIAÇÃO DRYWALL). Apresenta informações sobre o sistema de vedação vertical em chapas de gesso acartonado. São Paulo. Disponível em: $<$ http://www.drywall.org.br>. Acesso em: 25 jan. 2007.

BALLOU, R. H. Logística empresarial: transporte, administração de materiais e distribuição física. São Paulo: Atlas, 1993. 388 p.

BALTAR, C. A .M.; BASTOS, F .F.; BORGES, L. E. P. Variedades mineralógicas e processos utilizados na produção dos diferentes tipos de gesso. In: ENCONTRO NACIONAL DE TRATAMENTO DE MINÉRIOS E METALURGIA EXTRATIVA, 2004, Florianópolis. Anais... Florianópolis: [s.n.], 2004. p. 329.

BANCO NACIONAL DE DESENVOLVIMENTO ECONÔMICO E SOCIAL. Apresenta informações sobre o banco e as linhas de financiamento para o setor industrial. Disponível em: <http://www.bndes.br>. Acesso em: 10 nov. 2006.

BHATTY, J. I; MILLER, F. M.; KOSMATKA, S. H. (Ed.). Sulfur. In: INNOVATIONS in Portland Cement Manufacturing. Illinois: Portland Cement Association, 2004. p. 430-433.

BLUMENSCHEIN, R. N. Gerenciamento de resíduos sólidos oriundos da indústria da construção civil. In: ENCONTRO ECO-ECO - ECONOMIA ECOLÓGICA: TEORIA, METODOLOGIA E ANÁliSE DE CASOS, 5., 2001, Belém. Anais... Belém: [s.n.], 2001.17 p.

BRASIL. Ministério da Fazenda. Secretaria da Receita Federal. Instrução Normativa SRF n. ${ }^{\circ} 162$ de 31 de dez. de 1998. Fixa prazo de vida útil e taxa de depreciação dos bens que relaciona. Diário Oficial da União, Brasília, DF, 07 jan. 1999). Disponível em:

<http://www.receita.fazenda.gov.br/legislacao/ins/ant2001/1998/in16298ane1.htm>. Acesso em: 12 fev. 2007. 
. Ministério do Desenvolvimento, Indústria e Comércio Exterior. Secretaria do Desenvolvimento da Produção. Fórum de competitividade: diálogo para o desenvolvimento. [S.1.:s.n.], 2004. 15 p. (Cadeia Produtiva da Indústria da Construção Civil: Perfil - Relatório).

Ministério do Desenvolvimento, Indústria e Comércio Exterior. Secretaria do Desenvolvimento da Produção. Fórum de competitividade: diálogo para o desenvolvimento. [S.1.:s.n.], 2000. 22 p.(Documento Básico - Relatório).

BRITO FILHO, J. A. Cidades versus entulhos. In: SEMINÁRIO DE DESENVOLVIMENTO SUSTENTÁVEL A RECICLAGEM NA CONSTRUÇÃO CIVIL, 2., 1999, São Paulo. Anais... São Paulo, SP, 1999. p. 56-67.

BURGER, M. Potential of pulverized construction drywall waste as a soil amendment. 1993. Thesis (M. S.) - University of New York, New York, 1993.

BUSINESS COUNCIL FOR SUSTAINABLE DEVELOPMENT - GULF OF MEXICO (BSC-GM). By-product synergy: a strategy for sustainable development. Austin: WBSC-GM, 1997. 36p.

CAÍRES, E. F. et al. Alterações químicas do solo e resposta da soja ao calcário e gesso aplicados na implantação do sistema plantio direto. Revista Brasileira de Ciência do Solo. Viçosa, Seção IV, v.27 n.2, mar./abr. 2003.

CAIXA ECONÔMICA FEDERAL. Apresenta informações sobre os serviços oferecidos pela instituição, entre eles o financiamento de empreendimentos. (Programa de Financiamento a Concessionários Privados de Serviços de Saneamento - FCP-SAN). Disponível em: $<$ https://webp.caixa.gov.br/urbanizacao/Publicacao/Texto/programa/fcp_san.asp $>$. Acesso em: 10 dez. 2006.

Manejo e gestão de resíduos da construção civil - Manual de orientação: procedimentos para a solicitação de financiamento. PINTO, T.P.; GONZÁLES, J.L.R. (Coords.). Brasília: Ministério das Cidades/Ministério do Meio Ambiente/ Caixa Econômica Federal. 2005. 68 p.

CALDAS, C. H. S.; SOIBELMAN, L. Avaliação da logística de informação em processos inter-organizacionais na Construção Civil. In: SIMPÓSIO BRASILEIRO DE GESTÃO DA QUALIDADE E ORGANIZAÇÃO DO TRABALHO NO AMBIENTE CONSTRUÍDO, 2., 2001, Fortaleza, CE, 2001. Anais... Porto Alegre, RS, $2001.11 \mathrm{p}$

CALIFÓRNIA INTEGRATED WASTE MANAGEMENT BOARD (CIWMB). Drywall recycling. Apresenta informações sobre o gerenciamento de resíduos, incluindo os de chapas de gesso acartonado, no estado norte-americano da Califórnia. Disponível em: <http://www.ciwmb.ca.gov/ConDemo/Wallboard/. Acesso em: 19 jun. 2006. 
CAMERON, R. S.; RITCHIE, G. S. P.; ROBSON, A. D. Relative toxicities of inorganic aluminum complexes to barley. Soil Science Society of America Journal, Stanford, v.50, p.1231-1236, 1986.

CAMPBELL, S. Lead by example. Walls\&Ceilings Maganize. Michigan. [s.n.]. march 2003. Disponível em: $<$ http://www.wconline.com/CDA/Archive/6f999d146a768010VgnVCM100000f932a 8c0___ Acesso em: 03 ago. 2006.

CANUT, M. M. C. Estudo da viabilidade do uso do resíduo fosfogesso como material de construção. Belo Horizonte. 2006. 154 f. Dissertação (Mestrado) Escola de Engenharia, Universidade Federal de Minas Gerais, Belo Horizonte, 2006.

CARDOSO, F. F. Importância dos estudos de preparação e da logística na organização dos sistemas de produção de edifícios: alguns aprendizados a partir da experiência francesa. In: SEMINÁRIO INTERNACIONAL SOBRE LEAN CONSTRUCTION: A CONSTRUÇÃO SEM PERDAS, 1., 1996, São Paulo. Anais... São Paulo: Idort, 1996. p. 01-24.

CARR, J.; MUNN, D. A. Agricultural disposal method of construction site gypsum wallboard waste. The Journal of Construction Education, v.6, n.1, abr. 2001.

CARTER, C. R.; ELLRAM, L. M. Reverse logistics: a review of the literature and framework for future investigation. Journal of Business Logistics, v.19, n.1, 1998. p.85-102, 1998.

CAVALCANTI, L. B. Determinação de condições operacionais adequadas na desidratação do minério de gipsita para obtenção de um gesso beta reciclável. 2006. 67 f. Dissertação (Mestrado) - Universidade Católica de Pernambuco, Recife, 2006.

CHRISTOPHER, M. Logística e gerenciamento da cadeia de suprimentos estratégias para redução de custos e melhoria dos serviços. São Paulo: Pioneira, 1997.

CINCOTTO, M. A ; AGOPYAN, V ; FLORINDO, M. C. O gesso como material de construção - composição química ( $1^{\mathrm{a}}$ parte). In: INSTITUTO DE PESQUISAS TECNOLÓGICAS. Tecnologia de edificações. São Paulo: Instituto de Pesquisas Tecnológicas/Divisão de Edificações. 1998. p.53-56.

COLEMAN, N. T.; THOMAS, G. W. The basic chemistry of soil acidity. In: PEARSON, R.W.; ADAMS, F. (Ed.). Soil acidity and liming. Madison: American Society of Agronomy, 1967. p.1-41.

COMISSÃO EUROPÉIA. Apresenta informações sobre os objetivos, ações e legislações comuns aos estados-membros da União Européia, inclusive em relação ao desenvolvimento sustentável, incluindo o documento, Council Decision of 19 December 2002 establishing criteria and procedures for the acceptance of waste at landfills pursuant to Article 16 of and Annex II to Directive 1999/31/EC 
(2003/33/EC). Disponível em: http://ec.europa.eu/index_pt.htm\# ou <http://europa.eu.int/comm/sustainable/pages/idea_en.htm>. Acesso em: 7 abr. 2005.

CONSELHO NACIONAL DO MEIO AMBIENTE. São Paulo. Apresenta informações sobre as legislações brasileiras acerca do meio ambiente. Resolução n. ${ }^{\circ}$ 307 de 2002. Disponível em: < http://www.mma.gov.br/port/conama/>. Acesso em: 20 maio 2004.

CONSTRUÇÃO MERCADO. São Paulo: PINI, n. 64. nov. 2006.

COUNCIL OF SUPPLY CHAIN MANAGEMENT PROFESSIONALS. Apresenta conceitos e informações sobre logística e cadeia de suprimentos. Consiste em uma associação de profissionais destas áreas. Disponível em: <http://www.cscmp.org>. Acesso em: 22 fev. 2004.

CRUZ, A. L. G.da Método para o estudo do comportamento do fluxo material em processos construtivos, em obras de edificações, na indústria da Construção Civil: uma abordagem logística. 2002. 401 f. Tese (Doutorado) - Universidade Federal de Santa Catarina, Florianópolis, SC, 2002.

DEGANI, C. M. Sistemas de gestão ambiental em empresas construtoras. 2003. 223 f. Dissertação (Mestrado) - Escola Politécnica, Universidade de São Paulo, São Paulo, 2003.

DEKKER, R.; BARROS, A. I.; SCHOLTEN, V. A two-level network for recycling sand: a case study. European Journal of Operational Research. v.110, n. 2, p.199214, jul. 1998.

DIXON, R. C., Suitability of Ground Gypsum Board as a Source of Agricultural Gypsum for Application to Croplands. Certified Professional Agronomist, Stockton, California.

EMPRESA BRASILEIRA DE PESQUISA AGROPECUÁRIA. Apresenta informações sobre pesquisas do setor agrícola. Disponível em: $<$ http://www.cnpms.embrapa.br/publicacoes/sorgo/acalagem.htm>. Acesso em: 17 nov. 2006.

ESTEBAN, F. F. S. Autogestão e a atuação do setor privado, propostas e viabilidade para o setor. Palestra proferida em nome da ABRAMAT ASSOCIAÇÃO BRASILEIRA DA INDÚSTRIA DE MATERIAIS DE CONSTRUÇÃO, no Seminário de Habitação, Saneamento e Desenvolvimento Urbano no Brasil - políticas, recursos, tecnologias e oportunidades de negócios. São Paulo, 2004. Disponível em: <http://www.cte.com.br/fehab>. Acesso em: 04 out 2004. 17p.

FLEISCHMANN, M. Quantitative models for reverse logistics. Berlin, Springer, 2001. (Lecture Notes in Economics and Mathematical Systems, 501). 
FORUM FOR THE FUTURE. Instituição do Reino Unido que assessora organizações na prática do desenvolvimento sustentável. Apresenta informações e estudos sobre desenvolvimento sustentável. Disponível em: <http://www.forumforthefuture.org.uk/aboutus/sustdevoutlined_page805.aspx>. Acesso em: 5 abr. 2005.

FREIRE, G.; FERNANDES, A. Compra de dólar pelo BC é recorde. O Estado de São Paulo, 24 de fev. 2007. Caderno Economia. p.B1 e B4.

FREITAS, J. B. A disposição do fosfogesso e seus impactos ambientais. In: SEMINÁRIO SOBRE O USO DO GESSO NA AGRICULTURA, 2., 1992, Uberaba. Anais... Uberaba: IBRAFOS, 1992. p.325-339.

FUNDAÇÃO JOÃO PINHEIRO. Centro de Estatística e Informações. Déficit habitacional no Brasil. Belo Horizonte: Fundação João Pinheiro, 2004. 108 p. (Projeto PNUD-BRA-00/019 - Habitar Brasil - BID).

GARCIA, F. et al. Construção formal $\mathbf{x}$ informal: produtividade e carga tributária. São Paulo. GV Consult/SINDUSCON-SP, 2004. 9 f. (Relatório de pesquisa).

GIMENES, M. Análise dos custos de gerenciamento de resíduos em canteiros de obras. 2007. Monografia (MBA em Tecnologia e Gestão da Produção de Edifícios) - Escola Politécnica, Universidade de São Paulo, Programa de Educação Continuada em Engenharia. São Paulo, 2007.

GIPSUM RECYCLING INTERNATIONAL A/S. Apresenta informações sobre reciclagem de chapas de gesso acartonado e serviços correlatos prestados pela empresa e suas sete filiais em diversos países. Disponível em: <http://www.gipsrecycling.biz>. Acesso em: 16 jan. 2007.

GONDIM, I. A. et al. Análise da economia nacional e a participação da indústria da construção civil. In: CONFERÊNCIA LATINO-AMERICANA DE CONSTRUÇÃO SUSTENTÁVEL, 1; ENCONTRO NACIONAL DE TECNOLOGIA DO AMBIENTE CONSTRUídO, 10., 2004, São Paulo. Anais... São Paulo: ANTAC, 2004. 1 CD-ROM.

HARTLÉN, J. Environmental consequences using residues. In: INTERNATIONAL SYMPOSIUM ON BULK 'INERT' WASTE. Leeds: U. Leeds. p.21-11. set. 1995. (pre-prints of the papers).

HOMEL, G. New West Gypsum takes drywall full circle. Small Business Canada Magazine (a partir de 2002, Enterprise Magazine). Ontario: [s.n.]. p. 18., jun. 1999.

HSIAO, T. Y. et al. Modeling materials flow of waste concrete from construction and demolition wastes in Taiwan. Resources Policy: The International Journal of Minerals Policy and Economics. v.28, n. 1-2, p.39-47, 2002.

HUMMEL, H. U. Recycling von Gipsplatten. Beitrag zum Darmstädter MassivbauSeminar 1997, Band 18, Oktober 1997. Disponível em: <http://www.b- 
im.de/public/AddFrame.asp?url_left=/Doku_Inhalt.htm\&url_main=/Public/BVGips/ damasemhummel.htm>. Acesso em: 9 jan. 2007.

$\begin{array}{lccccr}\text { INSTITUTO } & \text { BRASILEIRO } & \text { DE } & \text { GEOGRAFIA } & \text { E } & \text { ESTATÍSTICA. Biomas } \\ \text { continentais } & \text { do } & \text { Brasil. } & 2004 . & \text { Disponível } & \text { em: } \\ \text { <http://www.ibge.gov.br/home/presidencia/noticias/21052004biomashtml.shtm>. } \\ \text { Acesso em: } 13 \text { jan. } 2007 .\end{array}$

São Paulo. Apresenta informações e dados estatísticos sobre as atividades econômicas e a população no Brasil. Diretoria de Pesquisas, Departamento de População e Indicadores Sociais, Censo Demográfico 2000 - Características gerais da população. 2000. Disponível em: <http://www.censo.gov.br/>. Acesso em: 20 maio 2005.

INTERNATIONAL COUNCIL FOR RESEARCH AND INNOVATION IN BUILDING AND CONSTRUCTION. Agenda 21 on sustainable construction. Rotterdam: CIB, 1999. (CIB Report Publication 237)

INTERNATIONAL COUNCIL FOR RESEARCH AND INNOVATION IN BUILDING AND CONSTRUCTION. Agenda 21 para a construção sustentável. Tradução do relatório CIB - Publicação 237. Tradução de GONÇALVES, I.; WHITAKER, T./ WEINSTOCK, G.; WEINSTOCK, D.M. (Ed.). São Paulo: [s.n.], 2000.

JADOVSKI, I; MASUERO, A. B. Metodologia de análise de viabilidade econômica de usinas de reciclagem de resíduos de construção e demolição. In: SEMINÁRIO DESENVOLVIMENTO SUSTENTÁVEL E A RECICLAGEM NA CONSTRUÇÃO CIVIL, 6., 2006, São Paulo. Anais... São Paulo: IBRACON/CTMAB MEIO AMBIENTE, 2006.

JOHN, V. M.; SILVA, V. G.; AGOPYAN, V. Agenda 21: uma proposta de discussão para o construbusiness brasileiro. In: ENCONTRO NACIONAL SOBRE EDIFICAÇÕES E COMUNIDADES SUSTENTÁVEIS, 2.; ENCONTRO LATINO AMERICANO SOBRE EDIFICAÇÕES E COMUNIDADES SUSTENTÁVEIS, 1. 2001, Canela. Anais... Porto Alegre: ANTAC, 2001. p. 91-98.

JOHN, V. M. Construção sustentável. Aula ministrada em mar. 2004 na disciplina PCC 5100 - Sustentabilidade no ambiente construído. São Paulo, Escola Politécnica da Universidade de São Paulo, 16 mar. 2004. Texto técnico. Disponível em: $<$ http://www.reciclagem.pcc.usp.br>. Acesso em: 12 abr. 2005.

JOHN, V. M. Reciclagem de resíduos na construção civil: contribuição à metodologia de pesquisa e desenvolvimento. 2000. 102 f Tese (Livre Docência) Escola Politécnica, Universidade de São Paulo, São Paulo, 2000.

JOHN, V. M.; AGOPYAN, V. Reciclagem de resíduos da construção. In: SEMINÁRIO DE RESÍDUOS SÓLIDOS DOMICILIARES CETESB., 2000, São Paulo, Anais... São Paulo: CETESB, 2000. 
JOHN, V. M.; CINCOTTO, M. A. Alternativas da gestão de resíduos de gesso. Contribuição apresentada a discussão da reformulação da Resolução CONAMA 307, relativa a gestão do gesso. jul. 2003. Disponível em: < http://www.reciclagem.pcc.usp.br/artigos1.htm>. Acesso em: 20 mar. 2005.

JOHN, V. M.; SILVA, V. S.; AGOPYAN, A. Reciclagem de gesso. In: SEMINÁRIO AVANÇOS E DESAFIOS NA GESTÃO E RECICLAGEM DE RCD, 2005, São Paulo. Anais... São Paulo: EPUSP, 2005. (Palestra proferida por JOHN, V. M.).

JOHN, V. M.; ZORDAN, S. E. Research \& development methodology for recycling residues as building materials: a proposal. In: INTERNATIONAL CONFERENCE ON THE ENVIRONMENTAL AND TECHNICAL IMPLICATIONS OF CONSTRUCTION WITH ALTERNATIVE MATERIALS (WASCON), 4., 2000, Leeds: Pergamon, 2000. v. 1., p. 513-524.

JOLY, C. A. (Coord.), Biodiversidade do Estado de São Paulo. São Paulo: FAPESP, 2002. Disponível em:<http://www.biota.org.br/expobio/Biota.pdf $>$. Acesso em: 04 nov. 2006.

KOPICKI, R. J. et al. Reuse and recycling reverse logistics opportunities. Illinois: Council of Logistics Management, 1993.

KORCAK, R. Scrap construction gypsum utilization. Plant Sciences Institute, USDA-Agricultural Research Service, Maryland, July 1996.

KORNDÖRFER, G. H. Gesso agrícola. Instituto de Ciências Agrárias, Universidade Federal de Uberlândia. Apostila da disciplina Adubos e Adubações, do curso de pósgraduação em Agronomia. 2004. Disponível em: <http://www.dpv24. iciag.ufu.br/new/dpv24/Apostilas/Transp.-\%20S+GESSO\%2010.pdf>. Acesso em: 17 dez. 2006.

KOTLER, P. Administração de marketing. 10. ed. São Paulo: Atlas, 2000. 764 p.

KRAEMER, M. E. P. Contabilidade Ambiental: Relatório para um Futuro Sustentável, Responsável e Transparente. Texto técnico. Disponível em: $<$ http://www.ambientebrasil.com.br/composer.php3?base=./gestao/index.html\&conte

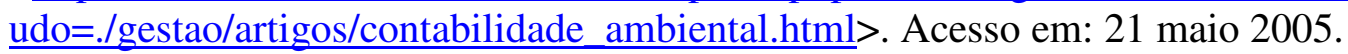

LEITE, P. R. Logística reversa: meio ambiente e competitividade. São Paulo: Prentice Hall, 2003.

LEVY, S. M. Contribuição ao estudo da durebilidade de concretos produzidos com resíduos de concreto e alvenaria. 2002. 194 f. Tese (Doutorado) - Escola Politécnica, Universidade de São Paulo, São Paulo, 2002.

LINHALES, F. Caracterização do gesso. Belo Horizonte. Escola de Engenharia de Minas e Metalúrgica, Universidade Federal de Minas Gerais. 2003. 22p. (Trabalho de curso de pós graduação). 
LOPES, A. S.; GUILHERME, L. R. G. Solos sob cerrado: manejo da fertilidade para a produção agropecuária. $2^{\text {a }}$.ed. São Paulo: Associação Nacional para Difusão de Adubos e Corretivos Agrícolas, 1994. 62 p. (Boletim técnico 5).

LYRA SOBRINHO, A. C. P. et al. Gipsita. In: SOUZA, A.E.; OLIVEIRA, M.L. (Coords.) Balanço mineral 2001. Brasília: Departamento Nacional de Produção Mineral. 2001. Disponível em: < http://www.dnpm.gov.br/>. Acesso em: 6 jun. 2006.

LYRA SOBRINHO, A. C. P.; AMARAL, A. J. R.; DANTAS, J. O. C. Gipsita. In: SOUZA, A. E.; OLIVEIRA, M. L. (Coord.) Sumário mineral 2005. Brasília: Departamento Nacional de Produção Mineral, 2005. v.25. Disponível em: < http://www.dnpm.gov.br/conteudo.asp?IDSecao=68\&IDPagina=64>. Acesso em 4 ago. 2006.

MACKOY, R.; CALATONE, R.; DRÖGE, C. Environmental marketing: bridging the divide between the consumption culture and environmentalism. In: POLONSKY, M. J. et al. (Ed.) Environmental marketing: strategies practice, theory and research. Nova York: Haworth Press, 1995.

MARCONDES, F. C. S.; CARDOSO, F. F. Gerenciamento de resíduos de construção e demolição: a experiência de construtoras paulistas. In: SIMPÓSIO BRASILEIRO DE GESTÃO E ECONOMIA DA CONSTRUÇÃO, 4.; ENCONTRO LATINO-AMERICANO DE GESTÃO E ECONOMIA DA CONSTRUÇÃO, 1. 2005, Porto Alegre. Anais... Porto Alegre: ANTAC, 2005. 1 CD-ROM.

MARCONDES, F. C. S.; CARDOSO, F. F. Proposta de método para planejamento operacional do sistema de gerenciamento de resíduos de construção e demolição para grandes geradores. In: ENCONTRO NACIONAL DE TECNOLOGIA DO AMBIENTE CONSTRUÍDO, 10., 2006, Florianópolis. Anais... Florianópolis: ANTAC, 2006. 1 CD-ROM.

MARINGOLO, V. Clínquer co-processado: produto de tecnologia integrada para sustentabilidade e competitividade da indústria de cimento. 2001. 163 f. Tese (Doutorado) - Instituto de Geociências, Universidade de São Paulo, São Paulo, 2001.

MARVIN, E. Gypsum wallboard recycling and reuse opportunities in the state of vermont. Vermont: Vermont Agency of Natural Resources, 2000.

MELLO, R. B. O estudo da mudança estratégica organizacional em pequenas empresas de construção: um estudo de caso em Florianópolis. 1997. Dissertação (Mestrado) - Engenharia de Produção e Sistemas, Universidade Federal de Santa Catarina, Florianópolis, 1997.

METHA, K; MONTEIRO, J. M. Concreto: estrutura, propriedades e materiais. São Paulo: Pini, 1994. 573 p.

MINISTÉRIO DA CIÊNCIA E TECNOLOGIA. Centro de Desenvolvimento da Tecnologia Nuclear. Apresenta notícias sobre os eventos apoiados pelo ministério, incluindo o workshop internacional sobre os usos do fosfogesso, que aconteceu em 
21 de ago. 2006, em Belo Horizonte. Disponível em: <http://agenciact.mct.gov.br/index.php/content/view/41022.html>. Acesso em: 13 out. 2006.

MUSICK, M. Recycling gypsum from C\&D debris. Industrial Waste Recovery. Biocycle, Mar. 1992. p.34-36.

MYERS, N. Sustainable Consumption: The Meta-Problem. In: HEAP, B.; KENT, J. (eds.) Towards Sustainable Consumption: A European Perspective. Londres: The Royal Society, 2000. 157p.

NITTA, C. et al. Estudo da reciclagem do gesso de construção. In: ENCONTRO NACIONAL DE TECNOLOGIA DO AMBIENTE CONSTRUÍDO, 10; CONFERÊNCIA LATINO-AMERICANA DE CONSTRUÇÃO SUSTENTÁVEL, 1., 2004, São Paulo. Anais... São Paulo: ANTAC, 2004. 1 CD-ROM.

NUERNBERG, N. J.; RECH, T. D.; BASSO, C. Uso do gesso agrícola. BOLETIM TÉCNICO n. 122. Empresa de Pesquisa Agropecuária e Extensão Rural de Santa Catarina S.A. Santa Catarina:EPAGRI, 2005.

OHNUMA, D.; ROZENDO, S. L.; GONÇALVES, G. O. Projeto de Gerenciamento de Resíduos da Construção Civil. São Paulo: Centro Tecnológico de Edificações - CTE, 2005. Apostila de curso.

OLSON, D. W. Gypsum. In: U. S. DEPARTMENT OF THE INTERIOR - U. S. GEOLOGICAL SURVEY. U. S. Geological Survey Minerals Yearbook. 2001. Washington. 2001. p35.1 e 35.2. Disponível em: $<$ http://minerals.usgs.gov/minerals/pubs/commodity/gypsum/gypsmyb01.pdf>. Acesso em: 27 out. 2006.

PARKIN, S. et al. Sustainable development: understanding the concept and practical challenge. Engineering sustainability. Institution of Civil Engineers. Vol.156, ES1, p.19-26. mar. 2003.

PINTO, T. P. Metodologia para gestão diferenciada de resíduos sólidos da construção urbana. 1999. 189 f. Tese (Doutorado) - Escola Politécnica, Universidade de São Paulo, São Paulo, 1999.

Gestão ambiental de resíduos da construção civil: a experiência do SINDUSCON-SP. São Paulo, Obra Limpa: I\&T: SINDUSCON-SP, 2005. 48p.

PREFEITURA DO MUNICÍPIO DE SÃO PAULO. São Paulo. Apresenta informações e dados estatísticos sobre o município. Disponível em: $<$ http://www6.prefeitura.sp.gov.br/secretarias/planejamento/sp_em_numeros/0001/p ortal/secretarias/planejamento/sp_em_numeros/0003>. Acesso em: 20 dez. 2006.

Disponível

Apresenta informações sobre a secretaria municipal de serviços. São Paulo. em: 
$<$ http://portal.prefeitura.sp.gov.br/secretarias/servicoseobras/limpurb/>. Acesso em: 23 out. $2006 \mathrm{c}$.

Apresenta as principais notícias sobre o município. São Paulo. Disponível

em:

$<$ http://www.prefeitura.sp.gov.br/portal/a_cidade/noticias/index.php?p=6061http://po rtal.prefeitura.sp.gov.br/secretarias/servicoseobras/limpurb/>. Acesso em: 23 out. $2006 b$.

Apresenta informações e legislações municipais. São Paulo. Disponível em: <http://www3.prefeitura.sp.gov.br/cadlem/secretarias/negocios_juridicos/cadlem/inte gra.asp?alt=04112005D\%20465940000> e <http://www3.prefeitura.sp.gov.br/ cadlem/secretarias/negocios_juridicos/cadlem/integra.asp?alt=04112005D\%2046594 0000>. Acesso em: 23 out. 2006 d.

Apresenta as principais notícias sobre o município. São Paulo. Disponível em: <http://www.prefeitura.sp.gov.br/portal/a_cidade/noticias/index.php?p=14065>. Acesso em: 3 jan. 2007.

PRINCEN, T.; MANIATES, M.; CONCA, K. Confronting consumption. Cambridge: MIT Press, 2002. 392 pp.

RABI, J. A.; SILVA, N. C.da. Radon exalation from phosphogypsum building boards: symmetry constraints, impermeable boundary conditions and numerical simulation of a test case. Journal of Environmetnal Radioactivy, p.1 -12, 2005.

RAVI, V.; SHANKAR, R. Analysis of interactions among the barriers of reverse logistics. Technological Forecasting and Social Change. v.72, issue 8. p.10111029. out. 2005.

REINHART, D. R.; TOWNSEND, T. G. Control of odors from construction and demolition debris landfills. University of Central Florida. Relatório de pesquisa. Dez 2003 - Feb. 2004.

RESENDE, F. Produtividade na execução de forros e divisórias de gesso acartonado. São Paulo. Escola Politécnica da Universidade de São Paulo. 2002. 42 f. (Trabalho de curso de pós-graduação).

REVERSE LOGISTICS EXECUTIVE COUNCIL. Apresenta informações sobre processos de logística reversa, estudos, projetos e melhores práticas. Disponível em: $<$ http://www.rlec.org/>. Acesso em: 17 mar. 2005.

ROCHA LIMA JÚNIOR, J. Análise de investimentos: princípios e técnicas para empreendimentos do setor da construção civil. São Paulo: EPUSP, 1993. 50p. (Texto Técnico. Escola Politécnica da USP, Departamento de Engenharia de Construção Civil, TT/PCC/06).

ROCHA LIMA JÚNIOR, J. Formação da taxa de retorno em empreendimentos de base imobiliária. São Paulo: EPUSP, 1998. 33p. (Boletim Técnico. Escola 
Politécnica da USP, Departamento de Engenharia de Construção Civil, $\mathrm{BT} / \mathrm{PCC} / 218)$.

ROGERS, D. S; TIBBEN-LEMBKE, R. S. Going backwards: reverse logistics trends and practices. Pittsburgh, Pennsylvania: RLEC Press, 1999.

SABBATINI, F. H. Desenvolvimento de métodos, processos e sistemas construtivos: formulação e aplicação de uma metodologia. 1989. $321 \mathrm{f}$. Tese (Doutorado) - Escola Politécnica, Universidade de São Paulo, São Paulo, 1989.

SANTANA, C. Prefeitura quer ampliar reciclagem de entulho. Diário Comércio, Indústria \& Serviços (DCI). São Paulo, 20 dez. 2006. Disponível em: $<$ http://www.sindusconsp.com.br>. Acesso em: 10 jan. 2007.

SCHILLER, S. et al. Sustainable building: implementation in the latin america context. In: CONFERENCE ON PASSIVE AND LOW ENERGY ARCHITECTURE, 20., 2003. Anais... Santiago, Chile: [s.n.]. 2003.

SCHNEIDER, D. M. Deposições irregulares de resíduos da construção civil na cidade de São Paulo. 2003. 130 f. Dissertação (Mestrado) - Faculdade de Saúde Pública, Universidade de São Paulo, São Paulo, 2004.

SEMINÁRIO DA INDÚSTRIA BRASILEIRA DA CONSTRUÇÃO CONSTRUBUSINESS, 6.; São Paulo, 2005. Anais... [S.1.] [s.n.].

SILVA, F. B. Conceitos e diretrizes para gestão da logística no processo de produção de edifícios. 2000. 206p. Dissertação (Mestrado) - Escola Politécnica, Universidade de São Paulo. São Paulo, 2000.

SILVA, F. B. da; CARDOSO, F. F. Ferramentas e diretrizes para a gestão da logística no processo de produção de edifícios. Boletim técnico, BT/PCC/263, São Paulo, Escola Politécnica, Universidade de São Paulo, 2000.

Os sistemas de gestão da qualidade e a logística na construção de edifícios In: WORKSHOP: TENDÊNCIAS RELATIVAS À GESTÃO DA QUALIDADE NA CONSTRUÇÃO DE EDIFÍCIOS, 1997, São Paulo. Anais... São Paulo: [s.l.], 1997. p. $25-27$.

SINDICATO DA INDÚSTRIA DA CONSTRUÇÃO CIVIL DO ESTADO DE SÃO PAULO - COMITÊ DE MEIO AMBIENTE, SEGURANÇA E PRODUTIVIDADE. São Paulo. Apresenta informações sobre o sindicato e suas ações na área de meio ambiente, segurança e produtividade. Disponível em: <http://www.sindusconsp.com.br>. Acesso em: 19 fev. 2007.

SINDICATO NACIONAL DA INDÚSTRIA DE CIMENTO. Apresenta informações sobre a indústria brasileira de cimento. Disponível em <http://wwww.snic.com.br>. Acesso em: 13 ago. 2006.

SJÖSTRÖM, C. Service life of the building. In: Applications of the performance concept in building. Proceedings... CIB: Tel Aviv, 1996. v.2, p. 6-11. 
SLAYEN, S. (Ed.) Advancing sustainable development in canada: Policy issues and research needs. Otawa: Policy Research Initiative/ International Institute for Sustainable Development, 2003. 78 p.

SMITH, P. Usos do fosfogesso. Belo Horizonte. Minascentro, 26 ago. 2006. /Palestra proferida por ocasião da $3^{\mathrm{a}}$. Conferência Internacional de Usuários de Reatores TRIGA, Belo Horizonte, 2006. Disponível em:<http://agenciact.mct.gov.br/index.php/content/view/41022.html>. Acesso em: 14 jan. 2007. (*)

SOUSA, D. M. G.; LOBATO, E.; REIN, T. A. Uso de gesso agrícola nos solos do Cerrado. Planaltina: EMBRAPA Cerrados. Circular Técnica n. ${ }^{\circ}$ 32. 2005.

SOUZA, U. E. L. et al. Desperdício de materiais nos canteiros de obras: a quebra do mito. In: SIMPÓSIO NACIONAL - DESPERDÍCIO DE MATERIAIS NOS CANTEIROS DE OBRAS: A QUEBRA DO MITO. 1999, São Paulo. Anais... São Paulo (PCC/EPUSP), 1999. 48 p.

STEVEN, M. Networks in reverse logistics. In: DYCKHOFF, H.; LACKES, R.; REESE, J. (eds.) Supply chain management and reverse logistics. Berlim; Nova York: Springer. 2004. 426 p.

STOCK, J. R. Development and implementation of reverse logistics programs. Oak Brook, Illions: Council of Logistics Management, 1998.

STOCK, J. R. Reverse Logistics in the Supply Chain. In: Briefing: Global Purchasing and Supply Chain Strategies - Transport \& Logistics. INTERNATIONAL FEDERATION OF PURCHASING AND MATERIALS MANAGEMENT WORLD CONGRESS, $12^{\circ}$., 2001, Sun City, África do Sul, 2001. p. 44-47.

TANIGUTI, E. K. Método construtivo de vedação vertical interna de chapas de gesso acartonado. 1999, 293 f. Dissertação (Mestrado) - Escola Politécnica, Universidade de São Paulo, São Paulo, 1999.

THE EUROPEAN WORKING GROUP IN REVERSE LOGISTICS (REVLOG). Apresenta informações e análises sobre pontos-chave da Logística Reversa e seus impactos em diversas indústrias e na sociedade. Disponível em:<http://www.fbk.eur.nl/OZ/REVLOG/welcome.html>. Acesso em: 17 mar. 2005.

VALOR ECONÔMICO. Apresenta informações sobre economia, incluindo ranking de rentabilidade de fundos de investimento. Vinculação nacional. Disponível em: $<$ http://www.valoronline.com.br/Especiais/2006/ValorInveste13/RankingPrevidencia .aspx>. Acesso em: 9 jan. 2007.

VITTI, G. C.; MALAVOLTA, E. Fosfogesso - Uso agrícola. In: MALAVOLTA, E. (Org.). SEMINÁRIO SOBRE CORRETIVOS AGRÍCOLAS, Piracicaba, 1985. Anais... Campinas: Fundação Cargill, 1985. p. 159-201. 
VRANCKEN, K. C.; LAETHEM, B. Recycling options for gypsum from construction and demolition waste. In: INTERNATIONAL CONFERENCE ON THE ENVIRONMENTAL AND TECHNICAL IMPLICATIONS OF CONSTRUCTION WITH ALTERNATIVE MATERIALS, 4., Leeds, 2000. Leeds: Pergamon, 2000. v. 1. p. 325-331.

WORLD COMMISSION ON ENVIRONMENTAL INITIATIVES. Our Commom Future. United Nations Brundtland Comission. 1987 (Relatório Brundtland).

YIN, R. K. Estudo de caso: planejamento e métodos. $3^{\text {a }}$.ed. São Paulo: Editora Bookman, 2005. 212 p.

ZAIDAN, E. M. Construção: características, desempenho recente e perspectivas. São Paulo. GVConsult/ SINDUSCON-SP. 2005. Disponível em: $<$ http://www.sindusconsp.com.br/especiais/Construcao_caracteristicas_desempenho_ recente_e_perspectivas/Apresentacao_jul2005.ppt>. Acesso em: 05 abr. 2006.

ZEGARRA, S. L. V. Diretrizes para a elaboração de um modelo de gestão dos fluxos de informações como suporte à logística em empresas construtoras de edifícios. 2000. 225 f. Dissertação (Mestrado) - Escola Politécnica, Universidade de São Paulo, São Paulo, 2000.

ZORDAN, S. E. A utilização do entulho como agregado na confecção do concreto. 1997. 156 f. Dissertação (Mestrado) - Faculdade de Engenharia Civil, Universidade Estadual de Campinas, Campinas, 1997. 
Apêndice A: Questionário de entrevista semi-estruturado, aplicado a especialistas, para realização do Estudo Exploratório.

\author{
ESCOLA POLITÉCNICA DA UNIVERSIDADE DE SÃO PAULO \\ Departamento de Engenharia de Construção Civil \\ Sub-Área de Concentração: Construção Civil e Urbana
}

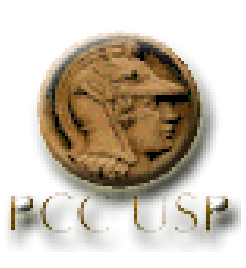

\title{
Questionário de Entrevista
}

\section{Grupo: Especialistas}

\section{LEIA COM ATENCÃO AS INFORMACÕES ABAIXO}

O Entrevistado tem a liberdade de, a qualquer momento, interromper a entrevista ou mesmo recusar-se a responder as perguntas que considerar necessárias.

A duração das entrevistas é, em média, de uma hora.

Para sua comodidade, não há a necessidade de anotar as respostas nestas folhas, todas as informações são documentadas pelo próprio pesquisador.

Salienta-se que esta pesquisa está relacionada ao curso de pósgraduação em Engenharia Civil da Escola Politécnica da Universidade de São Paulo. Esta entrevista está inserida no estudo exploratório que irá subsidiar a dissertação de mestrado intitulada "Contribuição para a Aplicação do Conceito de Logística Reversa na Cadeia Produtiva da Construção Civil: O Exemplo da Cadeia de Chapas de Gesso Acartonado", sob orientação do Prof. Dr. Francisco Ferreira Cardoso e de autoria de Fábia Cristina Segatto Marcondes.

Os dados e informações obtidos nesta pesquisa não serão divulgados caso seja a determinação do entrevistado. O produto principal desta pesquisa, na sua forma documental final, será disponibilizado ao entrevistado após a finalização da pesquisa.

ENTREVISTADO: FONE:

ENFEREÇO: CIDADE: CEP: E-mail:

DATA E LOCAL DA ENTREVISTA: 


\section{Questionário:}

1. Quando e como o Sr.(a) teve contato com o tema Logística Reversa?

2. Quais pesquisas o Sr.(a) desenvolveu ou está desenvolvendo atualmente nesta área?

3. Quais assuntos, dentro da área de Logística Reversa, estão sendo mais estudados atualmente?

4. Quais os setores industriais em que o Sr.(a) tem conhecimento da aplicação deste conceito?

5. Que ferramentas o Sr.(a) conhece/utiliza?

6. Quais são os principais grupos de pesquisa no mundo?

7. Como o Sr.(a) acha que ela irá se desenvolver no Brasil?

8. Como o Sr.(a) vê a aplicação deste conceito na Construção Civil?

9. Quais bibliografias o Sr.(a) indicaria?

\section{Observações:}


Apêndice B: Questionário de entrevista semi-estruturado, aplicado a fabricantes de CGA, no perfil Estratégico.

\author{
ESCOLA POLITÉCNICA DA UNIVERSIDADE DE SÃO PAULO \\ Departamento de Engenharia de Construção Civil \\ Sub-Área de Concentração: Construção Civil e Urbana
}

\title{
Questionário de Entrevista
}

\section{Grupo: Fabricantes de CGA Estratégico - Tipo A}

\section{LEIA COM ATENCÃO AS INFORMACÕES ABAIXO}

O Entrevistado tem a liberdade de, a qualquer momento, interromper a entrevista ou mesmo recusar-se a responder as perguntas que considerar não pertinentes.

A duração das entrevistas é, em média, de uma hora.

Para sua comodidade, não há a necessidade de assinalar as respostas nestas folhas, todas as informações são documentadas pelo próprio pesquisador.

Salienta-se que esta pesquisa está relacionada ao curso de pósgraduação em Engenharia Civil - Área de Engenharia de Construção Civil e Urbana da Escola Politécnica da Universidade de São Paulo. Esta entrevista está inserida no trabalho de campo que irá subsidiar a dissertação de mestrado intitulada "Contribuição para a Aplicação do Conceito de Logística Reversa na Cadeia Produtiva da Construção Civil: O Exemplo da Cadeia de Chapas de Gesso Acartonado", de Fábia Cristina Segatto Marcondes, sob orientação do Prof. Dr. Francisco Ferreira Cardoso.

Os dados e informações obtidos nesta pesquisa, bem como o nome da empresa pesquisada, não serão divulgados caso seja esta a determinação da empresa. O produto principal desta pesquisa, na sua forma documental final, será disponibilizado à empresa após a sua finalização.

\section{ENTREVISTADO:}

EMPRESA: FONE:

$\begin{array}{ll}\text { ENTREVISTADO: } & \text { CARGO: } \\ \text { ENFEREÇO: } & \text { CIDADE: }\end{array}$

CEP: E-MAIL: 


\section{Caracterização Geral da Placo do Brasil}

CG1. Qual foi o faturamento anual da Placo, decorrente da comercialização de CGA, nos últimos 3 anos?

CG2.Qual o market share da CGA no total do faturamento da empresa?

CG3. Qual é o volume de produção anual de CGA da Placo nos três últimos anos?

CG4. Qual o tamanho total da empresa em números de empregados?
menos de $50 \square 51-100$
$\square 101-250$
$\square 251-500$
$\square$ mais de 500

\section{Preocupação da Empresa com Sustentabilidade}

SS1. A sustentabilidade, consideradas as dimensões ambiental e social, é vista pela sua empresa como diferencial competitivo?

SS2. Existem projetos na área de sustentabilidade? Quais são?

SS3. A Placo procura boas práticas de sustentabilidade em outras empresas do grupo? Quais são?

\section{Caracterização do mercado de CGA.}

ECM1. Há perspectiva de crescimento do mercado brasileiro da CGA a curto prazo (3 próximos anos)? De quantos \%?

ECM2. E a médio prazo (próximos 5 anos)? De quantos \%?

ECM3. Quais fatores externos influenciam negativamente o negócio dos fabricantes de CGA?

Ambiente econômico nacional:

$\square$ Situação econômica do país

$\square$ Carga tributária elevada

$\square$ Legislação deficiente

Falta de infra-estrutura pública

Política industrial pública

$\square$ Qualidade da mão-de-obra da fábrica

Altos custos de implantação de inovações na fábrica 
$\square$ Ausência ou escassez de financiamentos industriais

Setor da Construção Civil

$\square$ Baixo grau de integração da cadeia produtiva da ICC - elevada integração.

$\square$ Exigências dos órgãos de financiamento de imóveis

Falta / descontinuidade de obras $\square$ Ausência de normalização do produto

$\square$ Qualidade dos distribuidores $\quad \square$ Restrição dos clientes finais quanto à CGA

$\square$ Qualidade dos instaladores $\quad \square$ Qualidade dos projetistas

Outros:

CM4. Que ações julga necessárias para a expansão do mercado de CGA e quais delas estão conduzidas atualmente pela Placo? Qual o papel da Associação Drywall?

CM5. Qual a meta de participação do sistema em CGA no mercado de sistemas de vedação interna (todos os fabricantes juntos, $\mathrm{em}^{2}$ )?

CM5. A chapa de gesso acartonado produzida no Brasil é mais barata do que a produzida no exterior? Quanto? Por que? É viável importar?

\section{Logística Direta}

\section{Gestão de materiais:}

CLGM7. Em relação aos fornecedores, questiona-se:

ESCALA para "Prazo de entrega": Suficiente - Insuficiente (1 ou 2)

ESCALA para "Nível de qualidade": Péssimo - Ruim - Razoável - Bom - Excelente (1 a 5)

ESCALA para "Nível de poder de negociação": Baixo - Médio - Elevado (1 a 3)

ESCALA para "Critério (política)": Custo $=1$; Confiabilidade de abastecimento $=2$; Aliança/Parcerias $=3$

ESCALA para "Grau do uso de TI na comunicação empresa/fornecedor" : Baixo - Médio Elevado (1 a 3) 


\begin{tabular}{|c|c|c|c|c|c|c|c|c|c|c|c|c|c|c|c|}
\hline 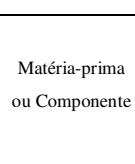 & $\begin{array}{c}\text { Cintrio } \\
\text { (Pollicas) }\end{array}$ & 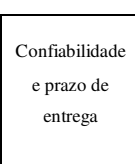 & $\begin{array}{l}\text { Nivel de } \\
\text { qualidade }\end{array}$ & 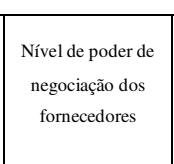 & 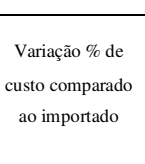 & 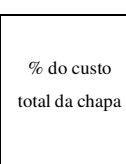 & 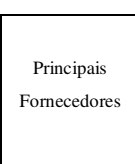 & Localiarasio & 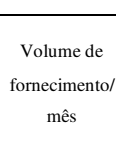 & 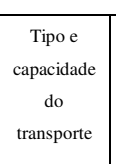 & \begin{tabular}{|c} 
Grau de \\
Compartihame \\
nto/ uso de TC
\end{tabular} & 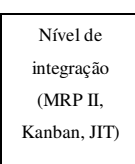 & 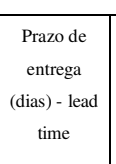 & 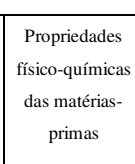 & 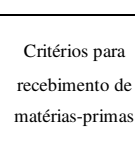 \\
\hline \multicolumn{16}{|l|}{ Gipsita } \\
\hline & & & & & & & & & & & & & & & \\
\hline & & & & & & & & & & & & & & & \\
\hline \multicolumn{16}{|l|}{$\begin{array}{l}\text { Cartiáo } \\
\end{array}$} \\
\hline & & & & & & & & & & & & & & & \\
\hline & & & & & & & & & & & & & & & \\
\hline \multicolumn{16}{|l|}{ Aditivos } \\
\hline & & & & & & & & & & & & & & & \\
\hline & & & & & & & & & & & & & & & \\
\hline \multicolumn{16}{|l|}{ Peffis } \\
\hline & & & & & & & & & & & & & & & \\
\hline & & & & & & & & & & & & & & & \\
\hline \multicolumn{16}{|l|}{$\begin{array}{l}\text { Paraflusos } \\
\end{array}$} \\
\hline & & & & & & & & & & & & & & & \\
\hline & & & & & & & & & & & & & & & \\
\hline \multicolumn{16}{|l|}{$\begin{array}{l}\text { Massapara } \\
\text { jomas }\end{array}$} \\
\hline & & & & & & & & & & & & & & & \\
\hline & & & & & & & & & & & & & & & \\
\hline Ouro: & & & & & & & & & & & & & & & \\
\hline
\end{tabular}




\section{Distribuição física:}

ELD2. Qual a política para escolha dos transportadores de CGA? Existem alianças estratégicas?

ELD3. Quais ações são desenvolvidas pela empresa para minimizar o impacto do custo do frete de distribuição no custo final do sistema de CGA?

ELD5. Qual a política para escolha dos distribuidores de CGA? Existem alianças estratégicas? Que critérios a empresa distribuidora deve atender?

ELD6. Qual a política para escolha dos instaladores de CGA? Existem alianças estratégicas? Que critérios a empresa instaladora deve atender?

\section{Logística Reversa}

Definição: Gerenciamento do retorno de bens devolvidos ou resíduos ao ciclo produtivo. Por exemplo, o gerenciamento do aproveitamento de resíduos de construção na fabricação de agregados reciclados.

ELR1. Quais são os fatores de estímulo para aplicação da logística reversa na sua empresa?

$\square$ Conquista e ampliação do mercado $\square$ Possibilidade de elevação dos preços

$\square$ Melhoria do nível de serviço $\quad \square$ Melhoria da imagem corporativa

$\square$ Diminuição dos custos $\square$ Atendimento da legislação

$\square$ Não vejo estímulos

$\square$ Outros:

ELR4. Qual foi o montante de investimento necessário para implantar a Central de Reciclagem? Qual a previsão de pay back deste investimento?

ELR5. Isto tem trazido vantagem competitiva para a empresa? De que maneira (fidelização, preferência na compra, redução de custos, imagem corporativa, etc)?

CLR17. Acredita que a médio prazo (5 anos) poderá se tornar um operador logístico reverso para outras empresas fabricantes de CGA? 


\section{Boas Práticas no Exterior}

EBP1. Quais são as exigências dos outros países onde a empresa atua quanto à questão da destinação dos resíduos do sistema de CGA?

EBP2. Como isto ocorre nas outras filiais do exterior?

\section{Observações:}


APÊNDICE C: Questionário de entrevista semi-estruturado, aplicado a fabricantes de CGA, no perfil Comercial.

\author{
ESCOLA POLITÉCNICA DA UNIVERSIDADE DE SÃO PAULO \\ Departamento de Engenharia de Construção Civil \\ Sub-Área de Concentração: Construção Civil e Urbana
}

\title{
Questionário de Entrevista
}

\section{Grupo: Fabricantes de CGA Comercial - Tipo B}

\section{LEIA COM ATENCÃO AS INFORMACÕES ABAIXO}

O Entrevistado tem a liberdade de, a qualquer momento, interromper a entrevista ou mesmo recusar-se a responder as perguntas que considerar não pertinentes.

A duração das entrevistas é, em média, de uma hora.

Para sua comodidade, não há a necessidade de assinalar as respostas nestas folhas, todas as informações são documentadas pelo próprio pesquisador.

Salienta-se que esta pesquisa está relacionada ao curso de pósgraduação em Engenharia Civil - Área de Engenharia de Construção Civil e Urbana da Escola Politécnica da Universidade de São Paulo. Esta entrevista está inserida no trabalho de campo que irá subsidiar a dissertação de mestrado intitulada "Contribuição para a Aplicação do Conceito de Logística Reversa na Cadeia Produtiva da Construção Civil: O Exemplo da Cadeia de Chapas de Gesso Acartonado", de Fábia Cristina Segatto Marcondes, sob orientação do Prof. Dr. Francisco Ferreira Cardoso.

Os dados e informações obtidos nesta pesquisa, bem como o nome da empresa pesquisada, não serão divulgados caso seja esta a determinação da empresa. O produto principal desta pesquisa, na sua forma documental final, será disponibilizado à empresa após a sua finalização.

\section{ENTREVISTADO:}

EMPRESA: FONE:

ENTREVISTADO: CARGO:

ENFEREÇO: CIDADE:

CEP: E-MAIL:

DATA E LOCAL DA ENTREVISTA: 


\section{Caracterização Geral da Placo do Brasil}

CG1. Qual foi o faturamento anual da Placo, decorrente da comercialização de CGA, nos últimos 3 anos?

CG2.Qual o market share da CGA no total do faturamento da empresa?

CG3. Qual é o volume de produção anual de CGA da Placo nos três últimos anos?

CG4. Qual o tamanho total da empresa em números de empregados?
menos de $50 \square 51-100$
$101-250$
$\square 251-500$
mais de 500

TCG10. Qual o número atual de obras concluídas ( $\mathrm{m}^{2}$ instalados) com o uso do sistema de CGA?

\section{Preocupação da Empresa com Sustentabilidade}

SS1. A sustentabilidade, consideradas as dimensões ambiental e social, é vista pela sua empresa como diferencial competitivo?

SS2. Existem projetos na área de sustentabilidade? Quais são?

SS3. A Placo procura boas práticas de sustentabilidade em outras empresas do grupo? Quais são?

SS7. Qual é a vida útil do sistema em CGA?

\section{Caracterização do mercado de CGA.}

ECM4. Que ações julga necessárias para a expansão do mercado de CGA e quais delas estão conduzidas atualmente pela Placo? Qual o papel da Associação Drywall?

CM5. Qual a meta de participação do sistema em CGA no mercado de sistemas de vedação interna (todos os fabricantes juntos, $\mathrm{em}^{2}$ )?

CR7. Qual a participação dos seguintes perfis de clientes no volume de vendas da empresa:

Construtora: $\% \quad$ Distribuidor: $\%$

Instalador: $\%$

CR8. Quais os principais mercados regionais atendidos pela empresa?

LDF2. Existem microregiões em que o consumo se concentra? Quais são? O que determina esta concentração? 
CR10. Há controle da abrangência geográfica de cada revendedor/instalador?

CR11. Existe programa de assistência técnica pós-venda? Descreva-o resumidamente.

TM4. São realizadas avaliações de pós-venda? Quais os principais resultados?

CR9. Existem diferenças para venda a distribuidores / revendedores e para as construtoras (consumidores finais) (por exemplo, lote mínimo)?

CM5. A chapa de gesso acartonado produzida no Brasil é mais barata do que a produzida no exterior? Quanto? Por que? É viável importar?

\section{Logística Direta}

Gestão de materiais:

CLGM7. Em relação aos fornecedores, questiona-se:

ESCALA para "Prazo de entrega": Suficiente - Insuficiente (1 ou 2)

ESCALA para "Nível de qualidade”: Péssimo - Ruim - Razoável - Bom - Excelente (1 a 5)

ESCALA para "Nível de poder de negociação": Baixo - Médio - Elevado (1 a 3)

ESCALA para "Critério (política)": Custo $=1$; Confiabilidade de abastecimento $=2$; Aliança/Parcerias $=3$

ESCALA para "Grau do uso de TI na comunicação empresa/fornecedor" : Baixo - Médio Elevado (1 a 3) 


\begin{tabular}{|c|c|c|c|c|c|c|c|c|c|c|c|c|c|c|c|}
\hline $\begin{array}{c}\text { Matciatprima } \\
\text { oun Componene }\end{array}$ & $\begin{array}{l}\text { Cititrio } \\
\text { (Pollitica) }\end{array}$ & $\begin{array}{c}\text { Confibilidade } \\
\text { eprax ode } \\
\text { entrege }\end{array}$ & $\begin{array}{l}\text { Nivel de } \\
\text { qualidede }\end{array}$ & 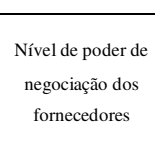 & 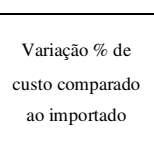 & 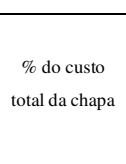 & $\begin{array}{c}\text { Pininipais } \\
\text { Fomecedorors }\end{array}$ & Localiasasio & $\begin{array}{c}\text { Volume de } \\
\text { formecimeno/ } \\
\text { mess }\end{array}$ & 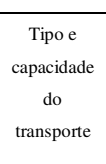 & 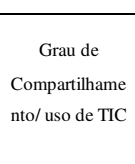 & 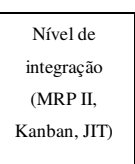 & 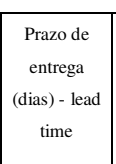 & 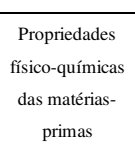 & 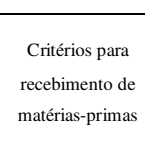 \\
\hline \multicolumn{16}{|l|}{ Gipsita } \\
\hline & & & & & & & & & & & & & & & \\
\hline & & & & & & & & & & & & & & & \\
\hline \multicolumn{16}{|l|}{$\begin{array}{l}\text { Carắo } \\
\end{array}$} \\
\hline & & & & & & & & & & & & & & & \\
\hline & & & & & & & & & & & & & & & \\
\hline \multicolumn{16}{|l|}{ Adivivos } \\
\hline & & & & & & & & & & & & & & & \\
\hline & & & & & & & & & & & & & & & \\
\hline \multicolumn{16}{|l|}{\begin{tabular}{|l|l} 
Perfis \\
\end{tabular}} \\
\hline & & & & & & & & & & & & & & & \\
\hline & & & & & & & & & & & & & & & \\
\hline \multicolumn{16}{|l|}{ Panafitos } \\
\hline & & & & & & & & & & & & & & & \\
\hline & & & & & & & & & & & & & & & \\
\hline \multicolumn{16}{|l|}{\begin{tabular}{|l|} 
Massa para \\
jumas
\end{tabular}} \\
\hline & & & & & & & & & & & & & & & \\
\hline & & & & & & & & & & & & & & & \\
\hline Outro: & & & & & & & & & & & & & & & \\
\hline
\end{tabular}


CLGM12. Como incide o custo do frete das matérias-primas no custo final do sistema de CGA?

TLGM4. Qual é o procedimento adotado quando um produto entregue na obra não atende às especificações de compra?

Logística interna à fábrica (questões relacionadas apenas à reciclagem):

LIF2. Qual é o destino dado a uma CGA danificada no estoque ou transporte?

\section{Distribuição física:}

ELD2. Qual a política para escolha dos transportadores de CGA? Existem alianças estratégicas?

CLDF2. Quais os tipos de transporte utilizados, e suas respectivas capacidades, para a distribuição da CGA?

CLDF3. O custo do frete de distribuição representa que porcentagem do custo final do sistema de CGA? Que outros fatores interferem neste custo?

ELD3. Quais ações são desenvolvidas pela empresa para minimizar o impacto do custo do frete de distribuição no custo final do sistema de CGA?

ELD5. Qual a política para escolha dos distribuidores de CGA? Existem alianças estratégicas? Que critérios a empresa distribuidora deve atender?

ELD6. Qual a política para escolha dos instaladores de CGA? Existem alianças estratégicas? Que critérios a empresa instaladora deve atender?

\section{Logística Reversa}

Definição: Gerenciamento do retorno de bens devolvidos ou resíduos ao ciclo produtivo. Por exemplo, o gerenciamento do aproveitamento de resíduos de construção na fabricação de agregados reciclados.

ELR4. Qual foi o montante de investimento necessário para implantar a Central de Reciclagem? Qual a previsão de pay back deste investimento?

ELR5. Isto tem trazido vantagem competitiva para a empresa? De que maneira (fidelização, preferência na compra, redução de custos, imagem corporativa, etc)? 
CLR17. Acredita que a médio prazo (5 anos) poderá se tornar um operador logístico reverso para outras empresas fabricantes de CGA?

\section{Boas Práticas no Exterior}

EBP1. Quais são as exigências dos outros países onde a empresa atua quanto à questão da destinação dos resíduos do sistema de CGA?

EBP2. Como isto ocorre nas outras filiais do exterior?

\section{Observações:}


Apêndice D: Questionário de entrevista semi-estruturado, aplicado a fabricantes de CGA, no perfil Industrial.

\section{ESCOLA POLITÉCNICA DA UNIVERSIDADE DE SÃO PAULO

\section{Questionário de Entrevista}

\section{Grupo: Fabricantes de CGA Industrial - Tipo C}

\section{LEIA COM ATENCCÃO AS INFORMACÕ̃ES ABAIXO}

O Entrevistado tem a liberdade de, a qualquer momento, interromper a entrevista ou mesmo recusar-se a responder as perguntas que considerar não pertinentes.

A duração das entrevistas é, em média, de uma hora.

Para sua comodidade, não há a necessidade de assinalar as respostas nestas folhas, todas as informações são documentadas pelo próprio pesquisador.

Salienta-se que esta pesquisa está relacionada ao curso de pósgraduação em Engenharia Civil - Área de Engenharia de Construção Civil e Urbana da Escola Politécnica da Universidade de São Paulo. Esta entrevista está inserida no trabalho de campo que irá subsidiar a dissertação de mestrado intitulada "Contribuição para a Aplicação do Conceito de Logística Reversa na Cadeia Produtiva da Construção Civil: O Exemplo da Cadeia de Chapas de Gesso Acartonado", de Fábia Cristina Segatto Marcondes, sob orientação do Prof. Dr. Francisco Ferreira Cardoso.

Os dados e informações obtidos nesta pesquisa, bem como o nome da empresa pesquisada, não serão divulgados caso seja esta a determinação da empresa. O produto principal desta pesquisa, na sua forma documental final, será disponibilizado à empresa após a sua finalização.

\section{ENTREVISTADO:}

EMPRESA: FONE:

ENTREVISTADO: CARGO:

ENFEREÇO: CIDADE:

CEP: E-MAIL:

DATA E LOCAL DA ENTREVISTA: 


\section{Caracterização Geral da Placo do Brasil}

CG3. Qual é o volume de produção anual de CGA da Placo nos três últimos anos?

\section{Preocupação da Empresa com Sustentabilidade}

SS1. A sustentabilidade, consideradas as dimensões ambiental e social, é vista pela sua empresa como diferencial competitivo?

SS2. Existem projetos na área de sustentabilidade? Quais são?

SS4. Quais os impactos ambientais causados na própria empresa pela fabricação do produto? (Em relação à eficiência energética, à eficiência no uso de água, qualidade do ar e resíduos gerados, entre outros).

SS5. E na obra?

SS6. Que ações são desenvolvidas para minimizá-los?

\section{Caracterização do mercado de CGA.}

CR11. Existe programa de assistência técnica pós-venda? Descreva-o resumidamente.

TM4. São realizadas avaliações de pós-venda? Quais os principais resultados?

CR9. Existem diferenças para venda a distribuidores / revendedores e para as construtoras (consumidores finais) (por exemplo, lote mínimo)?

\section{Logística Direta}

\section{Gestão de materiais:}

CLIF1. Quais ferramentas são utilizadas para controle de estoques, internos e no final da produção?

CLGM7. Em relação aos fornecedores, questiona-se:

ESCALA para "Prazo de entrega": Suficiente - Insuficiente (1 ou 2)

ESCALA para "Nível de qualidade": Péssimo - Ruim - Razoável - Bom - Excelente (1 a 5)

ESCALA para "Nível de poder de negociação": Baixo - Médio - Elevado (1 a 3 )

ESCALA para "Critério (política)": Custo $=1$; Confiabilidade de abastecimento $=2$; Aliança/Parcerias = 3

ESCALA para "Grau do uso de TI na comunicação empresa/fornecedor” : Baixo - Médio Elevado (1 a 3) 


\begin{tabular}{|c|c|c|c|c|c|c|c|c|c|c|c|c|c|c|c|}
\hline 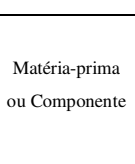 & 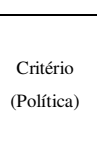 & $\begin{array}{c}\text { Confibilidade } \\
\text { ceprax de } \\
\text { entrega }\end{array}$ & 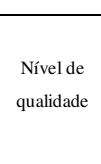 & $\begin{array}{l}\text { Nivelde poder de } \\
\text { negogianacios } \\
\text { fomecedoroses }\end{array}$ & 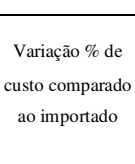 & $\begin{array}{l}\text { \%odoc custo } \\
\text { total da chapa }\end{array}$ & $\begin{array}{c}\text { Prinicipis } \\
\text { Fomecedores }\end{array}$ & Localianasio & $\begin{array}{c}\text { Volume de } \\
\text { tomecimentol } \\
\text { mess }\end{array}$ & $\begin{array}{c}\begin{array}{c}\text { Tipoo } \\
\text { capaciadade } \\
\text { do } \\
\text { transporte }\end{array} \\
\end{array}$ & 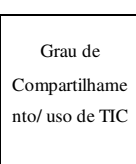 & 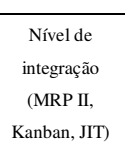 & 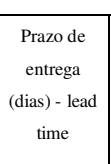 & 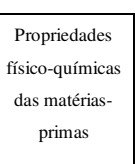 & 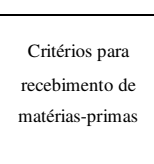 \\
\hline \multicolumn{16}{|l|}{ Gipsita } \\
\hline & & & & & & & & & & & & & & & \\
\hline & & & & & & & & & & & & & & & \\
\hline \multicolumn{16}{|l|}{ Caratáo } \\
\hline & & & & & & & & & & & & & & & \\
\hline & & & & & & & & & & & & & & & \\
\hline \multicolumn{16}{|l|}{ Aditivos } \\
\hline & & & & & & & & & & & & & & & \\
\hline & & & & & & & & & & & & & & & \\
\hline \multicolumn{16}{|l|}{ Perfis } \\
\hline & & & & & & & & & & & & & & & \\
\hline & & & & & & & & & & & & & & & \\
\hline \multicolumn{16}{|l|}{ Pataflusos } \\
\hline & & & & & & & & & & & & & & & \\
\hline & & & & & & & & & & & & & & & \\
\hline \multicolumn{16}{|l|}{$\begin{array}{l}\text { Massaparata } \\
\text { jumas }\end{array}$} \\
\hline & & & & & & & & & & & & & & & \\
\hline & & & & & & & & & & & & & & & \\
\hline Outro: & & & & & & & & & & & & & & & \\
\hline
\end{tabular}


TLGM4. Qual é o procedimento adotado quando um produto entregue na obra não atende às especificações de compra?

Logística interna à fábrica (questões relacionadas apenas à reciclagem):

CLIF1. Quais ferramentas são utilizadas para controle de estoques, internos e no final da produção?

CLIF2. Quais os resíduos gerados durante a produção? Em que \% (em relação aos volumes de entrada)? Que tratamento eles recebem?

LIF2. Qual é o destino dado a uma CGA danificada no estoque ou transporte?

\section{Distribuição física:}

ELD2. Qual a política para escolha dos transportadores de CGA? Existem alianças estratégicas?

CLDF2. Quais os tipos de transporte utilizados, e suas respectivas capacidades, para a distribuição da CGA?

\section{Logística Reversa}

Definição: Gerenciamento do retorno de bens devolvidos ou resíduos ao ciclo produtivo. Por exemplo, o gerenciamento do aproveitamento de resíduos de construção na fabricação de agregados reciclados.

ELR6. Qual é a tecnologia empregada na reciclagem? Ela já havia sido previamente testada? Quais os resultados alcançados?

ELR7. Qual quantidade de resíduo a Central de Reciclagem é capaz de absorver?

ELR8. Qual a capacidade de produção diária de gesso da Central de Reciclagem? Que \% desta é absorvida na produção de CGA novas? 
ELR9. Quais as fontes dos resíduos usados na Central de Reciclagem (a própria empresa, construtoras, distribuidores, instaladores) e a participação \% de cada uma? Aceitam resíduos somente oriundos de CGA produzidas pela empresa?

ELR10. Para o resíduo coletado (Construtora, Distribuidor, Instalador) como é feita a coleta em cada caso? Por quem é feita? Há imposições para a coleta?

ELR11. Qual \% dos resíduos é coletada pela própria empresa e qual é entregue por terceiros?

ELR12. Quais os parâmetros para aceitação dos resíduos advindos da própria produção?

ELR13. Quais os parâmetros para aceitação dos resíduos advindos da obra? visual

CLR17. Acredita que a médio prazo (5 anos) poderá se tornar um operador logístico reverso para outras empresas fabricantes de CGA?

\section{Boas Práticas no Exterior}

EBP1. Quais são as exigências dos outros países onde a empresa atua quanto à questão da destinação dos resíduos do sistema de CGA?

EBP2. Como isto ocorre nas outras filiais do exterior?

$$
\text { Observações: }
$$


Apêndice E: Questionário de entrevista semi-estruturado, aplicado a construtoras.

ESCOLA POLITÉCNICA DA UNIVERSIDADE DE SÃO PAULO

Departamento de Engenharia de Construção Civil

Sub-Área de Concentração: Construção Civil e Urbana

\section{Questionário de Entrevista}

\section{Grupo: Construtoras - Tipo D}

\section{LEIA COM ATENCÃO AS INFORMACÕES ABAIXO}

O Entrevistado tem a liberdade de, a qualquer momento, interromper a entrevista ou mesmo recusar-se a responder às perguntas que considerar não pertinentes.

A duração das entrevistas é, em média, de uma hora.

Para sua comodidade, não há a necessidade de assinalar as respostas nestas folhas, todas as informações são documentadas pelo próprio pesquisador.

Salienta-se que esta pesquisa está relacionada ao curso de pósgraduação em Engenharia Civil - Área de Engenharia de Construção Civil e Urbana da Escola Politécnica da Universidade de São Paulo. Esta entrevista está inserida no trabalho de campo que irá subsidiar a dissertação de mestrado intitulada "Contribuição para a Aplicação do Conceito de Logística Reversa na Cadeia Produtiva da Construção Civil: O Exemplo da Cadeia de Chapas de Gesso Acartonado", de Fábia Cristina Segatto Marcondes, sob orientação do Prof. Dr. Francisco Ferreira Cardoso.

Os dados e informações obtidos nesta pesquisa, bem como o nome da empresa pesquisada, não serão divulgados caso seja esta a determinação da empresa. O produto principal desta pesquisa, na sua forma documental final, será disponibilizado à empresa após a sua finalização.

\section{ENTREVISTADO:}

EMPRESA: FONE:

ENTREVISTADO: CARGO:

ENFEREÇO: CIDADE:

CEP: E-MAIL:

DATA E LOCAL DA ENTREVISTA: 


\section{Caracterização Geral da empresa Construtora}

TCG1. De quanto é aproximadamente o faturamento anual?

TCG2. Distribuição percentual do faturamento anual, segundo o tipo de construção
a) construção térrea (casa)
$\%$
d) obras públicas $\%$
b) construção predial (apartamento) $\%$
e) outras obras $\%$
c) construção industrial/ comercial $\%$

TCG3. Quais as formas de comercialização de seus serviços (empreitada global, gerenciamento, administração, etc)?

TCG4. Qual o tamanho total da empresa em números de empregados?

$\square$ menos de $50 \square$ 51-100 $\square$ 101-250 $\square$ 251-500 $\square$ mais de 500

TCG5. Quais os três fatores mais importantes para melhorar a lucratividade de sua empresa? Assinalar apenas três por ordem de importância, numerando-os, sendo que o número 1 significa o mais importante:

$\square$ Qualidade de recebimento de materiais dos fornecedores

$\square$ Tempo de construção do imóvel

$\square$ Custo de mão-de-obra por unidade construída

$\square$ Custo de materiais por unidade construída

$\square$ Despesas gerais administrativas

$\square$ Qualidade final do imóvel construído

$\square$ Pontualidade final do imóvel construído

$\square$ Volume dos estoques de materiais de construção

$\square$ Volume dos imóveis construídos/ em construção e não vendidos

$\square$ Possibilidade/Facilidade de integração de sistemas

$\square$ Existência de modulação e projeto para produção

$\square$ Facilidade de montagem

$\square$ Redução de acidentes de trabalho/ $\mathrm{n}^{\circ}$ de dias de afastamento do trabalho 
TCG6. Quais sistemas de gestão utilizam (qualidade, saúde e segurança ocupacional, ambiental, responsabilidade social)? Estão integrados? São certificados?

TCG7. Em sua opinião, quais os fatores restritivos ao desenvolvimento mercadológico de sua empresa (assinale com $\mathbf{X}$ )? E das CGA em particular (sublinhe)?

Ambiente econômico nacional:

$\square$ Situação econômica do país

$\square$ Legislação deficiente $\square$ Carga tributária elevada

Falta de infra-estrutura pública

Setor da Construção Civil

Altos custos de implantação de inovações

Ausência ou escassez de financiamentos imobiliários para construtoras

Ausência ou escassez de financiamentos imobiliários para clientes finais

Baixo grau de integração da cadeia produtiva da ICC

$\square$ Exigências dos órgãos de financiamento de imóveis

$\square$ Falta / descontinuidade de obras

$\square$ Qualidade dos distribuidores

Qualidade da mão-de-obra

Outros:

TCG8. Quantas obras estão em execução atualmente? Destas, quantas utilizam o sistema de CGA? Quantos m2 estão previstos de CGA/obra, aproximadamente?

TCG9. Qual a composição de custos do sistema de CGA? Qual a principal vantagem deste sistema? Qual a diferença de custo para outros sistemas de vedação?

\section{Preocupação da Empresa com Sustentabilidade}

SS1. A sustentabilidade, consideradas as dimensões ambiental e social, é vista pela sua empresa como diferencial competitivo?

SS2. Existem projetos na área de sustentabilidade? Quais são? 
SS3. Quais os impactos ambientais gerados pela obra? (Em relação à eficiência energética, à eficiência no uso de água, qualidade do ar e resíduos gerados, entre outros).

SS4. Que ações são desenvolvidas para minimizá-los?

\section{Caracterização do mercado de CGA.}

ECR1. A empresa adquiri o sistema de CGA:
Direto do fabricante: $\%$
Distribuidor: $\%$.

ECR2. Quem realiza a compra:

Construtora: $\%$,

Instalador: $\%$.

ECR3. Sua empresa já precisou acionar a assistência técnica do fabricante de CGA? Foi satisfatoriamente atendida?

ECR4. São realizadas avaliações de pós-ocupação em relação ao sistema de CGA? Quais os principais resultados obtidos nestas avaliações?

\section{Política do Setor de Suprimentos da Construtora}

TSF1. Em qual departamento estão alocadas as atividades de logística e suprimentos?

TSF2. As cotações e as compras são centralizadas ou cada obra negocia seus contratos? No caso das CGA, os levantamentos quantitativos são realizados pelas empresas ou pelos instaladores?

TSF3. Qual sistema de informação (software) é utilizado para gerenciar o processo de suprimentos?

TSF4. Como acontece a comunicação entre os fornecedores de materiais e a empresa (ou diretamente a obra)? (grau de formalidade, uso de protocolo, TI, intranet).

TSF5. Na aquisição consideram-se os aspectos de sustentabilidade?

TSF6. A empresa adota alguns destes procedimentos?

$\square$ Detalha de forma clara as especificações técnicas para as compras de materiais

Compra os materiais considerando a necessidade das outras obras 
Controla o recebimento de materiais na obra, em qualidade e quantidade (relatórios)

Inspeciona e orienta o armazenamento e movimentação de materiais no canteiro

Qualifica e seleciona os fornecedores em função de seu desempenho (documentando)

$\square$ Promove parcerias com os fornecedores de materiais

Quais? Por que?

$\square$ Promove parcerias com os fornecedores de mão-de-obra

Quais? Por que?

$\square$ Monitora freqüentemente o estoque de materiais (relatórios)

TSF7. Quais os fatores efetivamente considerados na decisão de compra?

$\square$ Qualidade especificada no projeto

$\square$ Pontualidade de entrega

$\square$ Relacionamento do passado

$\square$ Desenvolvimento conjunto de produto e processo

$\square$ Integração de informações

TSF8. Como é feita a avaliação de fornecedores?

TSF9. Qual a vantagem em negociar diretamente com os fabricantes de CGA?

\section{Logística Direta}

\section{Gestão de materiais:}

TLGM1. Em relação aos fornecedores, questiona-se:

Qual é o critério utilizado para a escolha do fornecedor?

Em relação à confiabilidade de entrega, o fornecedor?

E o nível de qualidade?

E o nível de poder de negociação? 
Quais são as condições do prazo de entrega dos fabricantes de CGA?

ESCALA para "Critério (política)": Custo $=1$; Confiabilidade de abastecimento $=2$; Aliança/Parcerias $=3$

ESCALA para "Confiabilidade de entrega": Atende - Não atende (1 ou 2)

ESCALA para "Nível de qualidade": Péssimo - Ruim - Razoável - Bom - Excelente (1 a 5)

ESCALA para "Nível de poder de negociação": Baixo - Médio - Elevado (1 a 3)

ESCALA para "Prazo de entrega": Suficiente - Insuficiente (1 ou 2)

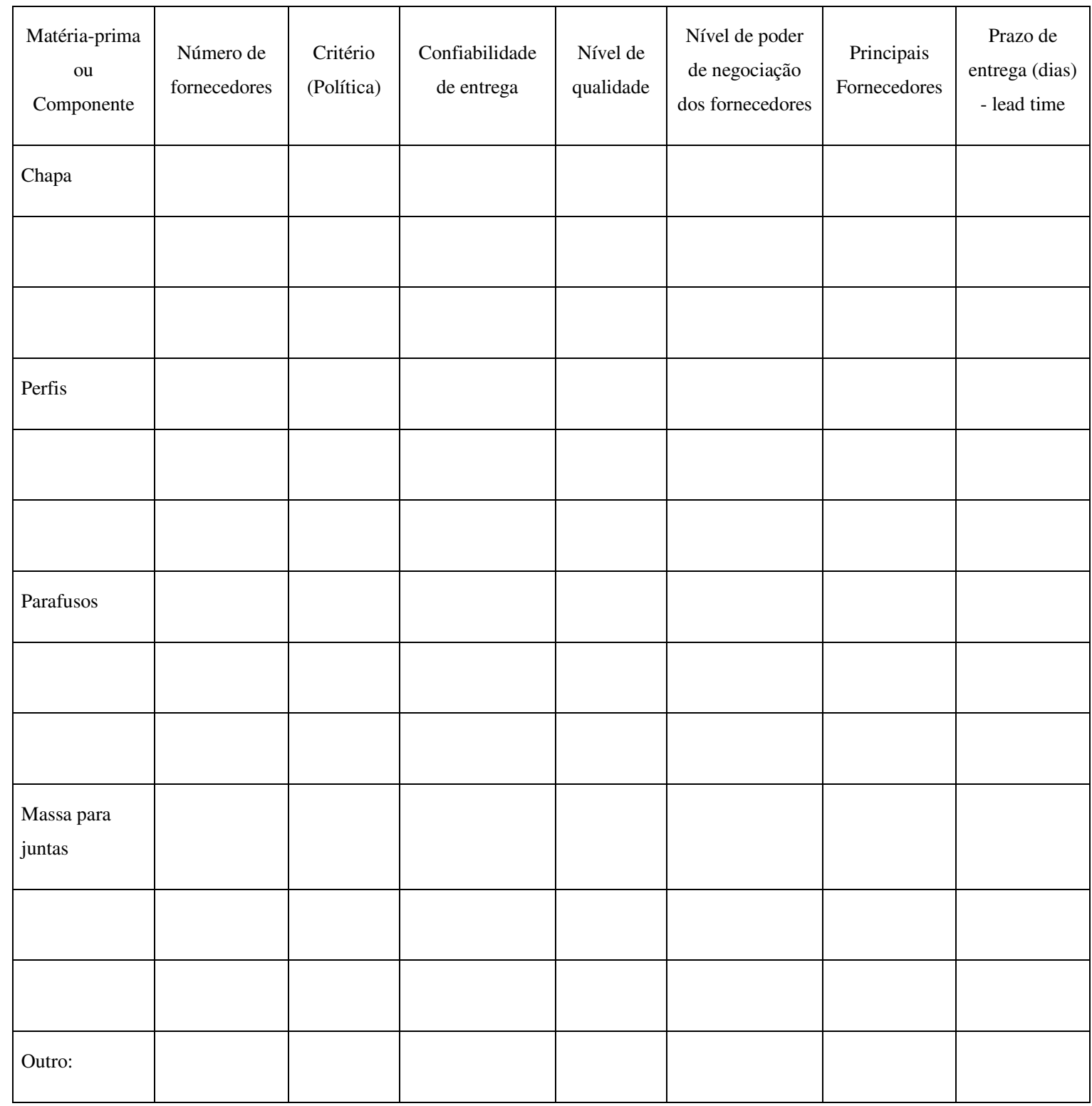


TLGM2. Quais são os critérios de recebimento das CGA no canteiro? Qual seu índice de conformidade?

TLGM3. Qual é o procedimento adotado quando um produto entregue na obra não atende às especificações de compra?

TLGM4. Há dificuldade em encontrar projetistas familiarizados com o sistema de CGA? Eles projetam modularmente a vedação em CGA, de forma a integrá-la com outros sistemas?

TLGM5. Como são transportados os componentes até as obras?

TLGM6. Quais são os prazos de entrega das distribuidoras? E dos fabricantes?

TLGM7. Qual a política para escolha dos distribuidores de CGA? Existem alianças estratégicas? Que critérios a empresa deve atender?

TLGM8. Qual a política para escolha dos instaladores de CGA? Existem alianças estratégicas? Que critérios a empresa deve atender?

\section{Logística do canteiro de obras:}

TLCO1. Indicar as ferramentas adotadas pela empresa relativas ao planejamento da produção:

Adoção de Projeto para Produção de Vedações Internas em CGA

$\square$ Organização do trabalho (escolha em quantidade e qualidade do pessoal, ordenação do trabalho, acompanhamento da evolução do método construtivo).

Procedimentos de execução baseados em: redução de tempos mortos, racionalização em canteiro, ordenação de execução das atividades.

Procedimentos de execução baseados em: prevenção de acidentes de trabalho, escolha de materiais adequados, controle de qualidade.

Estudo do sistema construtivo (verificação da compatibilização dos projetos, detalhamentos, memoriais e especificações).

$\square$ Definição de tarefas prioritárias, atividades que podem ser executadas em paralelo, estabelecendo uma relação de dependência e determinação de datas de início e término das atividades. 
Organização das atividades (eventos) ao longo do tempo: cronogramas de barras, Pert-CPM, outros.

Sistemas de controle de custos, de tempos, de recursos, de qualidade que fornecem os padrões para o estabelecimento dos índices de produtividade.

Sistemas de informações com o registro da história tecnológica das obras que auxiliam na apropriação de índices ou medidas. Coleta de dados.

TLCO2. A empresa projeta o layout do canteiro antes do início da obra?
$\square$ não
$\square$ às vezes
$\square$ sempre

TLCO3. Quais fatores são considerados na elaboração do layout do canteiro de obras?

TLCO4. Quais ferramentas são utilizadas para controle de estoques?

TLCO5. Qual o grau de uso de TI- tecnologia de informação, na comunicação do canteiro de obras com os fornecedores? [1] [2] [3]

ESCALA: Baixo - Médio - Elevado (1 a 3)

TLCO6. Qual é o destino dado a uma CGA danificada no estoque ou transporte?

\section{Perdas e Gerenciamento de Resíduos}

TPR1. Na sua opinião o desperdício de CGA ocorre por (mais de uma opção possível):

$\square$ Erros ou falhas de detalhamento de projeto

$\square$ Retrabalho provocado por despreparo da mão-de-obra

$\square$ Canteiro de obras organizado de forma inadequada

$\square$ Deficiência no método de transporte fornecedor-obra

$\square$ Deficiência no manuseio e estocagem de materiais na obra

Quebras e perdas devido à má qualidade dos materiais

TPR2. Qual é o índice de perda médio (volume de resíduo gerado) de CGA em seus empreendimentos?

TPR3. Qual é o procedimento adotado quando sobram CGA na obra?

TPR4. Existe programa de gerenciamento de resíduos (Resolução CONAMA 307)? 
TLR5. Qual foi o montante de investimento necessário para implantar o Gerenciamento de Resíduos? Qual a previsão de pay back deste investimento?

TLR6. Adotar o sistema de gerenciamento de resíduos tem trazido vantagem competitiva para a empresa? De que maneira (fidelização, preferência na compra, redução de custos de deposição, imagem corporativa, etc)?

TPR7. Quais os resíduos gerados durante a execução do sistema de CGA?

TPR8. Como é realizada a quantificação dos resíduos de CGA no sistema de gestão de resíduos (Resolução CONAMA 307)?

TLR9. Quais as diretrizes específicas para o manejo dos resíduos de CGA?

TLR10. Qual o destino dado aos resíduos de CGA gerados no canteiro?

TPR11. Quais os modais de transporte utilizados, e suas respectivas capacidades, para a deposição de resíduos de CGA?

TPR12. Qual o custo de deposição atual (caçamba de resíduos de CGA)?

TPR13. A empresa está orientando seus fornecedores quanto à correta segregação e destinação de resíduos de CGA?

TPR14. Quem é responsável pela limpeza e retirada dos resíduos de CGA da obra?

\section{Logística Reversa}

Definição: Gerenciamento do retorno de bens devolvidos ou resíduos ao ciclo produtivo. Por exemplo, o gerenciamento do aproveitamento de resíduos de construção na fabricação de agregados reciclados.

LR1. A empresa possui relações comerciais com empresas de reciclagem?

LR2. Qual o destino atualmente dado aos resíduos de CGA gerados pelos Distribuidores, Instaladores e Construtoras?

Observações: 
Apêndice F: Questionário de entrevista semi-estruturado, aplicado a distribuidores.

ESCOLA POLITÉCNICA DA UNIVERSIDADE DE SÃO PAULO

Departamento de Engenharia de Construção Civil

Sub-Área de Concentração: Construção Civil e Urbana

\section{Questionário}

\section{Grupo: Distribuidores de CGA - Chapa de Gesso Acartonado - Tipo E}

\section{LEIA COM ATENCÃO AS INFORMAC̄̃̃ES ABAIXO}

O Respondente tem a liberdade de recusar-se a responder as perguntas que considerar não pertinentes.

Esta pesquisa está relacionada ao curso de pós-graduação em Engenharia Civil - Área de Engenharia de Construção Civil e Urbana da Escola Politécnica da Universidade de São Paulo. Este questionário está inserido no trabalho de campo que irá subsidiar a dissertação de mestrado intitulada "Contribuição para a Aplicação do Conceito de Logística Reversa na Cadeia Produtiva da Construção Civil: O Exemplo da Cadeia de Placas de Gesso Acartonado", de Fábia Cristina Segatto Marcondes, sob orientação do Prof. Dr. Francisco Ferreira Cardoso.

Os dados e informações obtidos nesta pesquisa, bem como o nome da empresa pesquisada, não serão divulgados caso seja esta a determinação da empresa. O produto principal desta pesquisa, na sua forma documental final, será disponibilizado à empresa após a sua finalização.

DADOS:

EMPRESA: FONE:

RESPONDENTE: CARGO:

ENFEREÇO: CIDADE:

CEP: E-MAIL: DATA: 


\section{Caracterização Geral da empresa}

CG1.Qual a participação da CGA - Chapa de Gesso Acartonado, no total do faturamento da empresa?

$\square$ menor que $20 \% \quad \square 21-40 \% \quad \square$ 41-60\% $\square$ 61-80\% $\square$ maior que $80 \%$

CG2. Quantas lojas possuem no Brasil? Onde elas estão localizadas? Qual é o volume de vendas de Chapas de Gesso Acartonado (em m2/mês/loja)?

CG3. Qual o tamanho total da empresa em números de empregados próprios?
$\square$ menos de $50 \square 51-100$
$101-250$
$\square 251-500$
$\square$ mais de 500

CG4. Quantos instaladores possui?

$\square$ nenhum, é somente Distribuidor

$\square$ menos de $5 \square$ 6-10 $\square$ 11-25 $\square$ 26-50 $\square$ mais de 50

\section{Caracterização do mercado de CGA.}

ECM1. Quais fatores externos influenciam negativamente o negócio dos distribuidores de CGA?

$\square$ Situação econômica do país

Carga tributária elevada

Baixo grau de integração da cadeia produtiva da ICC

$\square$ Falta / descontinuidade de obras

Ausência de normalização do produto

Restrição dos clientes finais quanto à CGA

$\square$ Qualidade dos instaladores

Qualidade dos projetistas

Outros:

ECM2. Qual a participação dos seguintes perfis de clientes no volume de vendas da empresa:

Construtora: $\%$ Cliente final: $\%$

Instalador: $\%$

ECM3. Há diferenças para vendas a construtoras e a consumidores finais? Quais são? 


\section{Logística}

\section{Gestão de materiais:}

LGM1. Qual o volume de CGA adquirido mensalmente? Há lote mínimo para aquisição/pedidos?

LGM2. Quais são os critérios de recebimento dos componentes/sistema em sua loja?

LGM3. Quantos fornecedores possui dos seguintes componentes: Quem são os fornecedores? Onde eles estão localizados? Qual é o prazo de entrega de cada componente?

\begin{tabular}{|l|c|c|c|c|}
\hline Componente & $\begin{array}{c}\text { Número de } \\
\text { fornecedores }\end{array}$ & $\begin{array}{c}\text { Nome dos } \\
\text { fornecedores }\end{array}$ & $\begin{array}{c}\text { Localização } \\
\text { (Cidade/Estado) }\end{array}$ & $\begin{array}{c}\text { Prazo de } \\
\text { entrega (dias) }\end{array}$ \\
\hline Ghapa & & & & \\
\hline Perfis & & & & \\
\hline Parafusos & & & & \\
\hline Massa $\mathrm{p}$ juntas & & & & \\
\hline
\end{tabular}

\section{Logística interna à loja:}

LIF1. Quais ferramentas são utilizadas para controle de estoques?

LIF2. O que acontece quando um produto é danificado no estoque ou transporte?

\section{Distribuição física:}

LDF1. Em geral, recebem componentes advindos diretamente da fábrica ou de Centros de Distribuição?

LDF2. Qual a política para escolha dos fornecedores de CGA? Existem alianças estratégicas?

LDF3. Qual a política para escolha dos transportadores de CGA? Existem alianças estratégicas?

LDF4. Quais os tipos de transporte utilizados, e suas respectivas capacidades, para a entrega da CGA ao cliente?

LDF5. Qual a política para escolha dos instaladores de CGA? Que critérios ele deve atender?

LDF6. Como incide o custo do frete de distribuição no custo final do sistema de CGA? 


\section{Logística Reversa}

Definição: Gerenciamento do retorno de bens devolvidos ou resíduos ao ciclo produtivo. Por exemplo, o gerenciamento do aproveitamento de resíduos de construção na fabricação de agregados reciclados.

ELR1. Se sua empresa recebesse o resíduo da obra e o encaminhasse de volta para a fábrica de chapa de gesso acartonado, você conseguiria:

$\square$ Conquistar e ampliar seu mercado

Melhorar o nível de serviço

Ter a preferência de compra de construtoras

Não mudaria em nada a situação atual
Elevar os preços

Melhorar a imagem corporativa

Diminuir os custos

Outros:

ELR2. A empresa está sendo orientada pelos seus fornecedores quanto à correta segregação e destinação de resíduos de CGA? Possui local para recebimento e armazenagem de devoluções/resíduos das obras?

ELR3. Qual volume de resíduo a loja seria capaz de receber?

ELR4. O distribuidor aceita ou aceitaria resíduos somente de seus próprios clientes?

ELR5. Dispor-se-ia a fazer a coleta remunerada? De quaisquer clientes?

ELR6. Qual o destino atualmente dado aos resíduos de CGA gerados pelos Distribuidores e Instaladores?

ELR7. Acredita que a longo prazo (10 anos) sua empresa poderá se tornar um operador logístico reverso (empresa que realiza a coleta, transporte, triagem e venda de resíduos de CGA das obras) para empresas fabricantes de CGA?

Observações: 
Apêndice G: Questionário de entrevista semi-estruturado, aplicado a instaladores.

ESCOLA POLITÉCNICA DA UNIVERSIDADE DE SÃO PAULO

\section{Questionário de Entrevista}

\section{Grupo: Instaladores de CGA - Chapa de Gesso Acartonado - Tipo F}

\section{LEIA COM ATENCÃO AS INFORMACÕES ABAIXO}

O Respondente tem a liberdade de recusar-se a responder as perguntas que considerar não pertinentes.

Esta pesquisa está relacionada ao curso de pós-graduação em Engenharia Civil - Área de Engenharia de Construção Civil e Urbana da Escola Politécnica da Universidade de São Paulo. Este questionário está inserido no trabalho de campo que irá subsidiar a dissertação de mestrado intitulada "Contribuição para a Aplicação do Conceito de Logística Reversa na Cadeia Produtiva da Construção Civil: O Exemplo da Cadeia de Placas de Gesso Acartonado", de Fábia Cristina Segatto Marcondes, sob orientação do Prof. Dr. Francisco Ferreira Cardoso.

Os dados e informações obtidos nesta pesquisa, bem como o nome da empresa pesquisada, não serão divulgados caso seja esta a determinação da empresa. O produto principal desta pesquisa, na sua forma documental final, será disponibilizado à empresa após a sua finalização.

DADOS:

EMPRESA: FONE:

RESPONDENTE: CARGO: ENFEREÇO: CIDADE: CEP: E-MAIL: DATA: 


\section{Caracterização Geral da empresa}

CG1. Quais são os serviços prestados pela empresa? Qual o volume de produção mensal (aproximadamente em m2 instalados de CGA - Chapa de Gesso Acartonado/mês)?

CG2. Qual o tamanho total da empresa em números de empregados próprios?

$\square$ menos de $5 \quad \square$ 6-10 $\square$ 11-25 $\quad \square$ 26-50 $\square$ mais de 50

\section{Caracterização quanto às relações comerciais.}

ECM1. Quais fatores externos influenciam negativamente o negócio dos instaladores de CGA?
Situação econômica do país
Carga tributária elevada

Baixo grau de integração da cadeia produtiva da ICC

$\square$ Falta / descontinuidade de obras

Ausência de normalização do produto

$\square$ Restrição dos clientes finais quanto à CGA

$\square$ Qualidade dos instaladores

Qualidade dos projetistas

$\square$ Outros:

ECM2. Qual a participação dos seguintes perfis de clientes no volume de vendas da empresa:

Construtora: $\%$, Cliente final: \%, Indicação distribuidor: $\%$

ECM3. Quais as formas de contratação de seus serviços?

$\square$ somente mão-de-obra

$\square$ material e mão-de-obra ambos

ECM4. Quais requisitos o profissional deve atender para ser instalador de CGA?

ECM5. Há muita concorrência entre instaladores? Quem são os principais?

ECM6. Qual o número atual de obras em andamento que sua empresa está realizando?

\section{Logística}

\section{Gestão de materiais:}

LGM1. Quem são os principais distribuidores do sistema em CGA instalado pela empresa? 
LGM2. Como são transportados os componentes até as obras?

LGM3. Quais são os prazos de entrega para:

Chapas de Gesso Acartonado dias

Massa para Juntas dias

Perfis dias

Parafusos dias

LGM4. Quais são os critérios de recebimento das CGAs?

LGM5. Como são emitidos os pedidos de compra? Quem é responsável pelo levantamento quantitativo dos materiais?

LGM6. A partir de que volume sua empresa consegue comprar diretamente da fábrica?

Distribuição física:

LDF1. Qual a política para escolha dos fornecedores? Existem alianças estratégicas?

\section{Logística Reversa}

Definição: Gerenciamento do retorno de bens devolvidos ou resíduos ao ciclo produtivo. Por exemplo, o gerenciamento do aproveitamento de resíduos de construção na fabricação de agregados reciclados.

LR1. Na sua opinião, quais são os fatores que promovem perdas no processo de instalação do sistema de CGA?

$\square$ Transporte inadequado

Ausência de modulação da vedação

$\square$ Uso de ferramentas inadequadas
Ausência de projeto de produção

Falta de qualificação da mão-de-obra

$\square$ Outros:

LR2. As obras possuem programa de gerenciamento de resíduos?

LR3. Os instaladores recebem orientação sobre a correta segregação dos resíduos de CGA?

LR4. Atualmente, onde são colocados os resíduos de CGA? 
LR5. Quem é responsável pela limpeza e retirada dos resíduos na obra?

Observações: 
Apêndice H: Questionário de entrevista semi-estruturado, aplicado a ATT.

ESCOLA POLITÉCNICA DA UNIVERSIDADE DE SÃO PAULO

Departamento de Engenharia de Construção Civil

Sub-Área de Concentração: Construção Civil e Urbana

\section{Questionário de Entrevista}

\section{Grupo: Áreas de Transbordo e Triagem - Tipo G}

\section{LEIA COM ATENCÃO AS INFORMACÕES ABAIXO}

O Entrevistado tem a liberdade de, a qualquer momento, interromper a entrevista ou mesmo recusar-se a responder as perguntas que considerar necessárias.

A duração das entrevistas é, em média, de uma hora.

Para sua comodidade, não há a necessidade de anotar as respostas nestas folhas, todas as informações são documentadas pelo próprio pesquisador.

Salienta-se que esta pesquisa está relacionada ao curso de pósgraduação em Engenharia Civil - Área de Engenharia de Construção Civil e Urbana da Escola Politécnica da Universidade de São Paulo. Esta entrevista está inserida no trabalho de campo que irá subsidiar a dissertação de mestrado intitulada "Contribuição para a Aplicação do Conceito de Logística Reversa na Cadeia Produtiva da Construção Civil: O Exemplo da Cadeia de Chapas de Gesso Acartonado", sob orientação do Prof. Dr. Francisco Ferreira Cardoso e de autoria de Fábia Cristina Segatto Marcondes.

Os dados e informações obtidos nesta pesquisa, bem como o nome da empresa pesquisada, não serão divulgados caso seja esta a determinação da empresa. O produto principal desta pesquisa, na sua forma documental final, será disponibilizado à empresa após a sua finalização.

\section{ENTREVISTADO:}

EMPRESA: FONE:

ENTREVISTADO: CARGO:

ENFEREÇO: CIDADE:

CEP: E-MAIL:

DATA E LOCAL DA ENTREVISTA: 


\section{Questionário:}

1. Quais classes de resíduo a ATT está licenciada para receber?

2. Quais foram as exigências técnicas para receber resíduos de gesso? Que orientou/decidiu que condições a ATT deveria atender para tal?

3. Qual o volume médio de resíduos de revestimento e de gesso acartonado recebem, por mês, atualmente?

4. Quais são as exigências mínimas em relação à carga de uma caçamba de resíduos de CGA? O que acontece se ela não atende a estas exigências?

5. Quanto custa para depositar o resíduo do gesso de revestimento em aterros? E resíduo de CGA?

6. Quais são os principais compradores de resíduo de gesso? E de gesso acartonado?

7. Quando se paga pelo resíduo de gesso? Estão inclusos frete e impostos?

8. Quais os custos de implantação e manutenção desta ATT?

9. Qual o horizonte de operação?

10. A ATT tem recebido o apoio dos órgãos públicos?

11. Quais técnicas e/ou ferramentas utiliza para a triagem?

12. Como acontece a solicitação de deposição e quais controle realiza em relação às cargas?

13. A ATT exige o CTR de todas as cargas?

14. A ATT tem interesse em receber um volume maior de resíduo de CGA?

\begin{tabular}{|l|}
\hline Observações: \\
\hline \\
\hline \\
\hline
\end{tabular}


Apêndice I: Questionário aplicado a indústria de cimento.

ESCOLA POLITÉCNICA DA UNIVERSIDADE DE SÃO PAULO

Departamento de Engenharia de Construção Civil

Sub-Área de Concentração: Construção Civil e Urbana

\section{Questionário de Entrevista}

\section{Grupo: Indústria de Cimento - Tipo H}

\section{LEIA COM ATENCCÃO AS INFORMACÕ̃ES ABAIXO}

O Entrevistado tem a liberdade de, a qualquer momento, interromper a entrevista ou mesmo recusar-se a responder as perguntas que considerar necessárias.

A duração das entrevistas é, em média, de uma hora.

Para sua comodidade, não há a necessidade de anotar as respostas nestas folhas, todas as informações são documentadas pelo próprio pesquisador.

Salienta-se que esta pesquisa está relacionada ao curso de pósgraduação em Engenharia Civil - Área de Engenharia de Construção Civil e Urbana da Escola Politécnica da Universidade de São Paulo. Esta entrevista está inserida no trabalho de campo que irá subsidiar a dissertação de mestrado intitulada "Contribuição para a Aplicação do Conceito de Logística Reversa na Cadeia Produtiva da Construção Civil: O Exemplo da Cadeia de Chapas de Gesso Acartonado", sob orientação do Prof. Dr. Francisco Ferreira Cardoso e de autoria de Fábia Cristina Segatto Marcondes.

Os dados e informações obtidos nesta pesquisa, bem como o nome da empresa pesquisada, não serão divulgados caso seja esta a determinação da empresa. O produto principal desta pesquisa, na sua forma documental final, será disponibilizado à empresa após a sua finalização.

\section{ENTREVISTADO:}

EMPRESA: FONE:

ENTREVISTADO: CARGO:

ENFEREÇO: CIDADE:

CEP: E-MAIL

DATA E LOCAL DA ENTREVISTA: 


\section{Questionário:}

1. Quantas fábricas possuem no Brasil? Onde estão localizadas?

2. É possível utilizar de CGA na fabricação de cimento?

3. As fábricas utilizam resíduos de CGA na fabricação de cimento?

4. Qual é o consumo mensal de gesso para a produção de cimento?

5. Quais as exigências técnicas para receber resíduos de CGA

6. Quais as dificuldades para utilizar sistematicamente resíduos de CGA na fabricação de cimento?

7. Por que as indústrias de cimento não utilizam os resíduos de CGA como matéria-prima atualmente?

8. Quanto custa para destinar o resíduo de CGA à indústria de cimento?

9. Quais fábricas fizeram o teste

10. Todas as fábricas possuem o mesmo maquinário?

11. Consome-se gesso ou gipsita? Isto é, compra-se gipsita e a calcina no forno, juntamente com a farinha que se tornará clínquer, ou, compra-se gesso e ele entra direto como adição no clínquer?

12. Os aditivos utilizados na fabricação da chapa de gesso acartonado não comprometem sua composição química, inviabilizando o seu uso?

13. Os resíduos de gesso acartonado são colocados diretamente nos fornos, junto com a farinha de clínquer? E o papel-cartão, é incinerado junto? Os resíduos - cinzas - da incineração do papel-cartão não afetam a composição do clínquer?

14. A presença de enxofre (S), constituinte do gesso (CaSO4), em altos teores, no forno, não é prejudicial ao processo de formação do clínquer?

15. Sobre os volumes evolvidos na operação, qual volume é o parâmetro para se determinar pequenos e grandes volumes? Há lote mínimo? Há necessidade de regularidade no envio das cargas?

16. Que materiais são considerados contaminantes além do aço? Argamassa?Tinta? Gesso liso?

17. O co-processamento de resíduos de gesso acartonado gera economia de matéria-prima para a indústria de cimento? Se sim, em que porcentagem do volume? 
Apêndice J: Questionário aplicado a indústria de papel 'P'.

ESCOLA POLITÉCNICA DA UNIVERSIDADE DE SÃO PAULO

Departamento de Engenharia de Construção Civil

Sub-Área de Concentração: Construção Civil e Urbana

\section{Questionário de Entrevista}

\section{Grupo: Indústria de papel - Tipo I}

\section{LEIA COM ATENCCÃO AS INFORMACÕ̃ES ABAIXO}

O Entrevistado tem a liberdade de, a qualquer momento, interromper a entrevista ou mesmo recusar-se a responder as perguntas que considerar necessárias.

A duração das entrevistas é, em média, de uma hora.

Para sua comodidade, não há a necessidade de anotar as respostas nestas folhas, todas as informações são documentadas pelo próprio pesquisador.

Salienta-se que esta pesquisa está relacionada ao curso de pósgraduação em Engenharia Civil da Escola Politécnica da Universidade de São Paulo. Esta entrevista está inserida no estudo exploratório que irá subsidiar a dissertação de mestrado intitulada "Contribuição para a Aplicação do Conceito de Logística Reversa na Cadeia Produtiva da Construção Civil: O Exemplo da Cadeia de Chapas de Gesso Acartonado", sob orientação do Prof. Dr. Francisco Ferreira Cardoso e de autoria de Fábia Cristina Segatto Marcondes.

Os dados e informações obtidos nesta pesquisa não serão divulgados caso seja a determinação do entrevistado. O produto principal desta pesquisa, na sua forma documental final, será disponibilizado ao entrevistado após a finalização da pesquisa.

ENTREVISTADO: FONE:

ENFEREÇO: CIDADE: CEP: E-mail:

DATA E LOCAL DA ENTREVISTA: 


\section{Questionário:}

1. Qual a aplicação do papel fabricado por esta indústria?

2. Que tipos de aparas podem ser consumidas para a fabricação deste papel?

3. Descreva simplificadamente o processo de fabricação.

4. Quais as especificações das aparas e suas diferenças?

5. Como é realizado o controle de qualidade e a aceitação das aparas?

6. Quais as restrições ao uso de aparas de papel cartão de chapas de gesso acartonado?

7. Que materiais/substâncias podem ser considerados contaminantes das aparas de papel?

8. Onde estão localizados os fornecedores de aparas?

9. Por que utilizar $100 \%$ de aparas como matéria-prima?

10. De que forma as aparas chegam à indústria? (transporte, lote, volume, etc.)

\section{Observações:}




\section{Anexo A: Exemplos de equipamentos considerados para levantamento dos custos da Central de Reciclagem}

1 - Guincho Hidráulico manual com prolongador

\begin{tabular}{|l|l|}
\hline \multicolumn{1}{|c|}{ Descrição } \\
\cline { 2 - 3 } & Capacidade: 2 toneladas c/ prolongador \\
\hline Peso $178 \mathrm{Kg}$ \\
\hline Comprimento: $1980 \mathrm{~mm}$ \\
\hline Largura: $1100 \mathrm{~mm}$ \\
\hline Altura: $1795 \mathrm{~mm}$ \\
\hline $\begin{array}{l}\text { Quatro rodas de ferro fundido, sendo duas fixas } \\
\text { de } 6 \text { "x45mm, e duas giratórias de } 6 \text { "x45mm }\end{array}$ \\
\hline Acionamento em 2 velocidades. \\
\hline Possui prolongador. \\
\hline Comprimento do braço recolhido: $1600 \mathrm{~mm}$ \\
\hline \begin{tabular}{l} 
Comprimento do braço extendido: $2106 \mathrm{~mm}$ \\
\hline Curso do pistão: $304 \mathrm{~mm}$
\end{tabular} \\
\hline $\begin{array}{l}\text { Distância do solo com o braço aberto } \\
\text { (mínimo/máximo): } 620 / 2900 \mathrm{~mm}\end{array}$ \\
\hline $\begin{array}{l}\text { Distância do solo com o braço recolhido } \\
\text { (mínimo/máximo): } 910 / 2580 \mathrm{~mm}\end{array}$ \\
\hline
\end{tabular}

2 - Minicarregadeira:

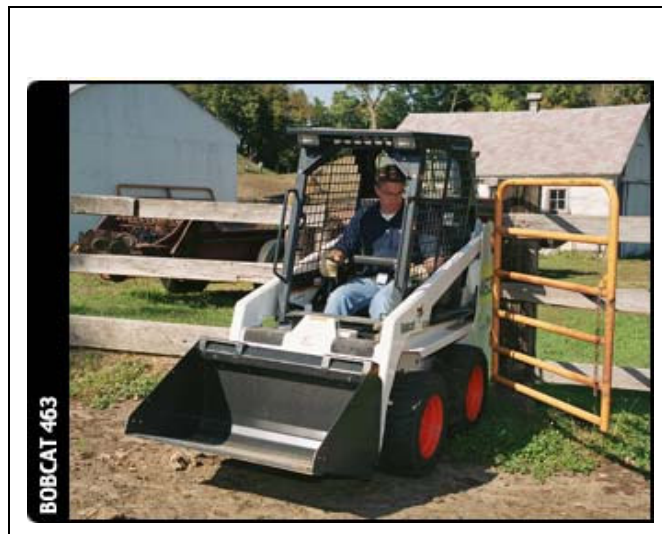

\begin{tabular}{|l|l|}
\hline \multicolumn{2}{|c|}{ Descrição } \\
\hline $\begin{array}{l}\text { Capacidade nominal de } \\
\text { Operação }\end{array}$ & $318 \mathrm{~kg}(700 \mathrm{lb})$ \\
\hline $\begin{array}{l}\text { Capacidade nominal de } \\
\text { Operação com contrapeso }\end{array}$ & $637 \mathrm{~kg}(1405 \mathrm{lb})$ \\
\hline $\begin{array}{l}\text { Capacidade da bomba } \\
\text { hidráulica }\end{array}$ & $37,11 / \mathrm{min}(9,8 \mathrm{gpm})$ \\
\hline Velocidade de deslocamento & $10,5 \mathrm{~km} / \mathrm{h}(6,5 \mathrm{~m} / \mathrm{h})$ \\
\hline Comprimento com caçamba & $\begin{array}{l}2553 \mathrm{~mm} \\
(100,5 \mathrm{pol})\end{array}$ \\
\hline Largura & $914 \mathrm{~mm}(36 \mathrm{pol})$ \\
\hline Altura & $1814 \mathrm{~mm}(71,4 \mathrm{pol})$ \\
\hline Altura até o pino da caçamba & $2399 \mathrm{~mm}(94,5 \mathrm{pol})$ \\
\hline \multicolumn{2}{|c|}{ Direção e tração } \\
\hline $\begin{array}{l}\text { Velocidade de deslocamento e direção controlados } \\
\text { por duas alavancas manuais. }\end{array}$ \\
\hline
\end{tabular}




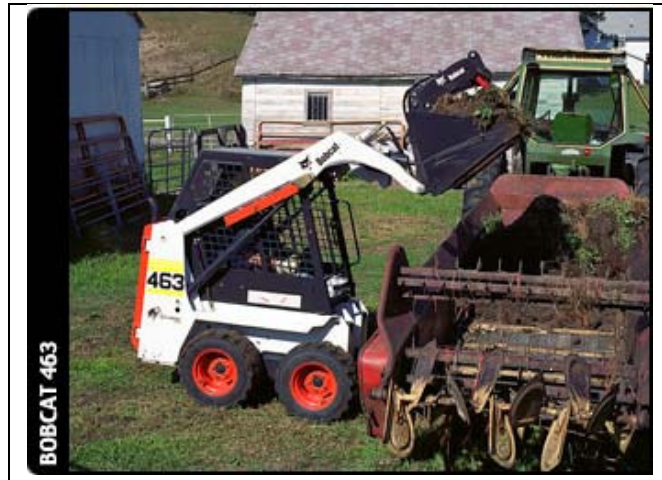

Elevação do braço e descarga da caçamba controlados por dois pedais ou controles manuais opcionais

Transmissão Hidrostática, Tração nas 4 rodas.

\section{3 - Caminhão tipo truck com guincho hidráulico}

\begin{tabular}{|l|l|}
\hline \multicolumn{1}{|c|}{} & \multicolumn{1}{|c|}{ Descrição } \\
\cline { 2 - 2 } & Capacidade: 13 toneladas \\
\cline { 2 - 2 } & Comprimento da carroceria: $7000 \mathrm{~mm}$ \\
\cline { 2 - 2 } & Largura da carroceria: $2400 \mathrm{~mm}$ \\
\cline { 2 - 2 } & Possui guincho hidráulico tipo munck. \\
\hline
\end{tabular}

\section{4 - Equipamento de reciclagem de CGA}




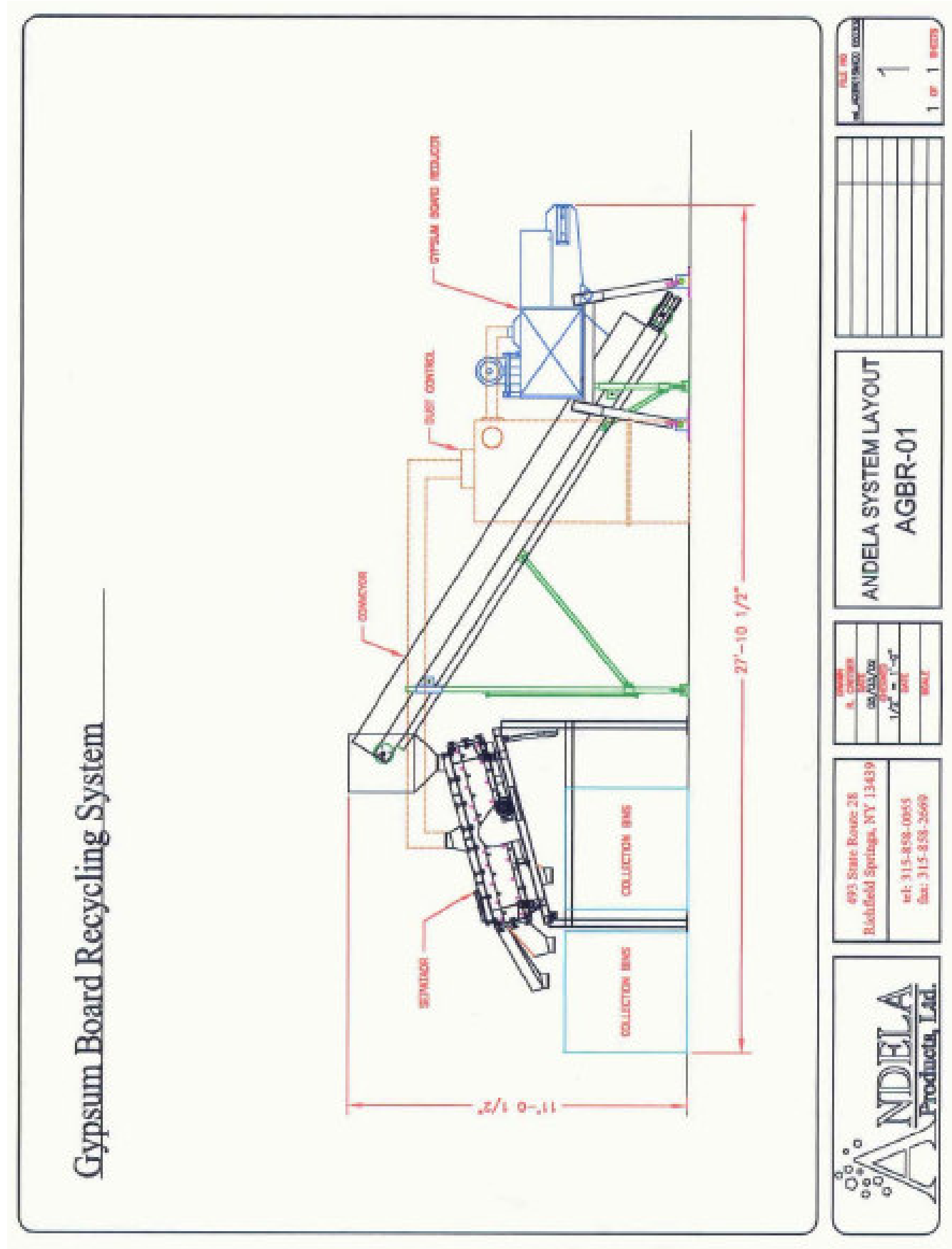




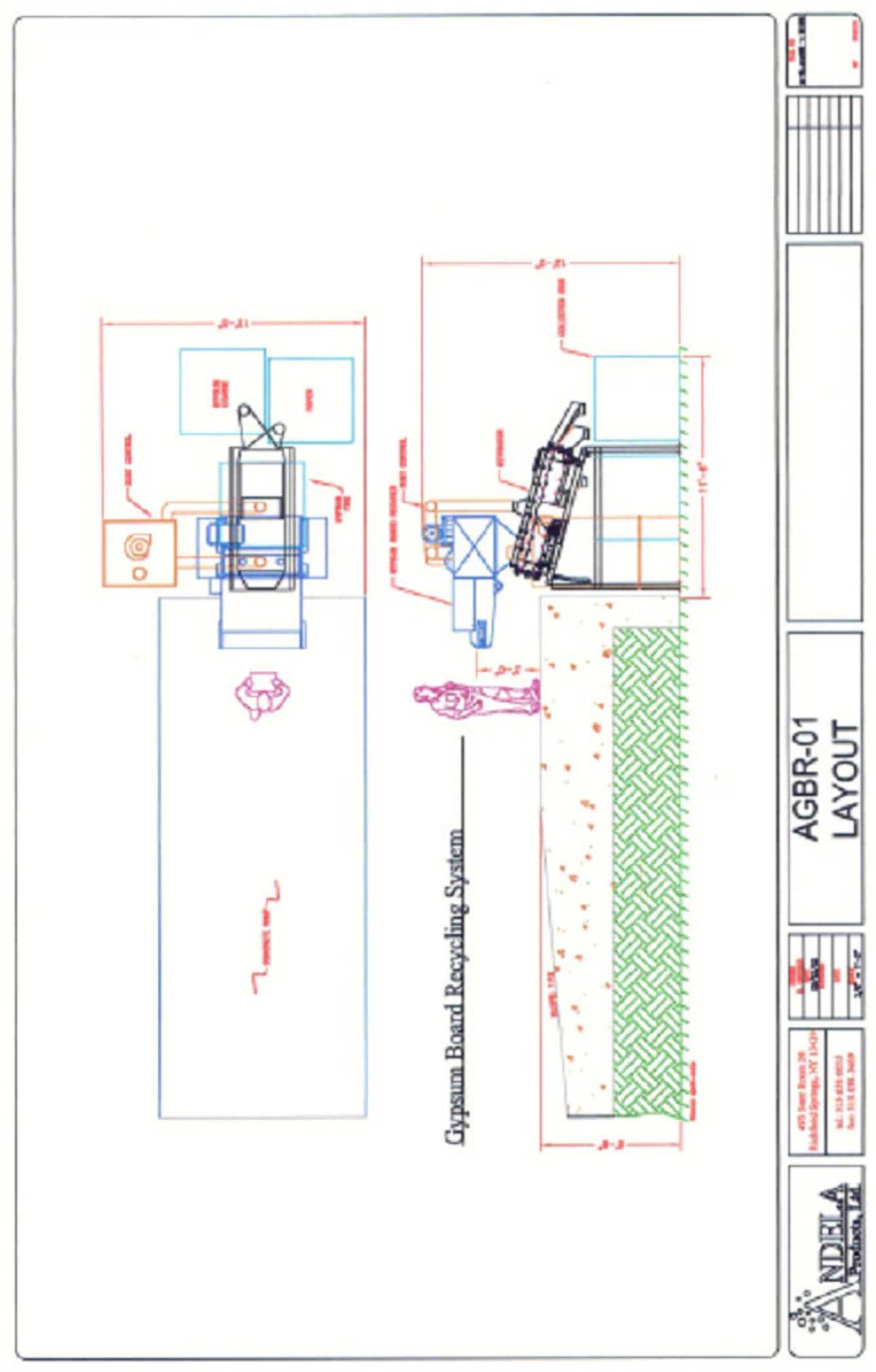


5 - Sistema de reciclagem de CGA

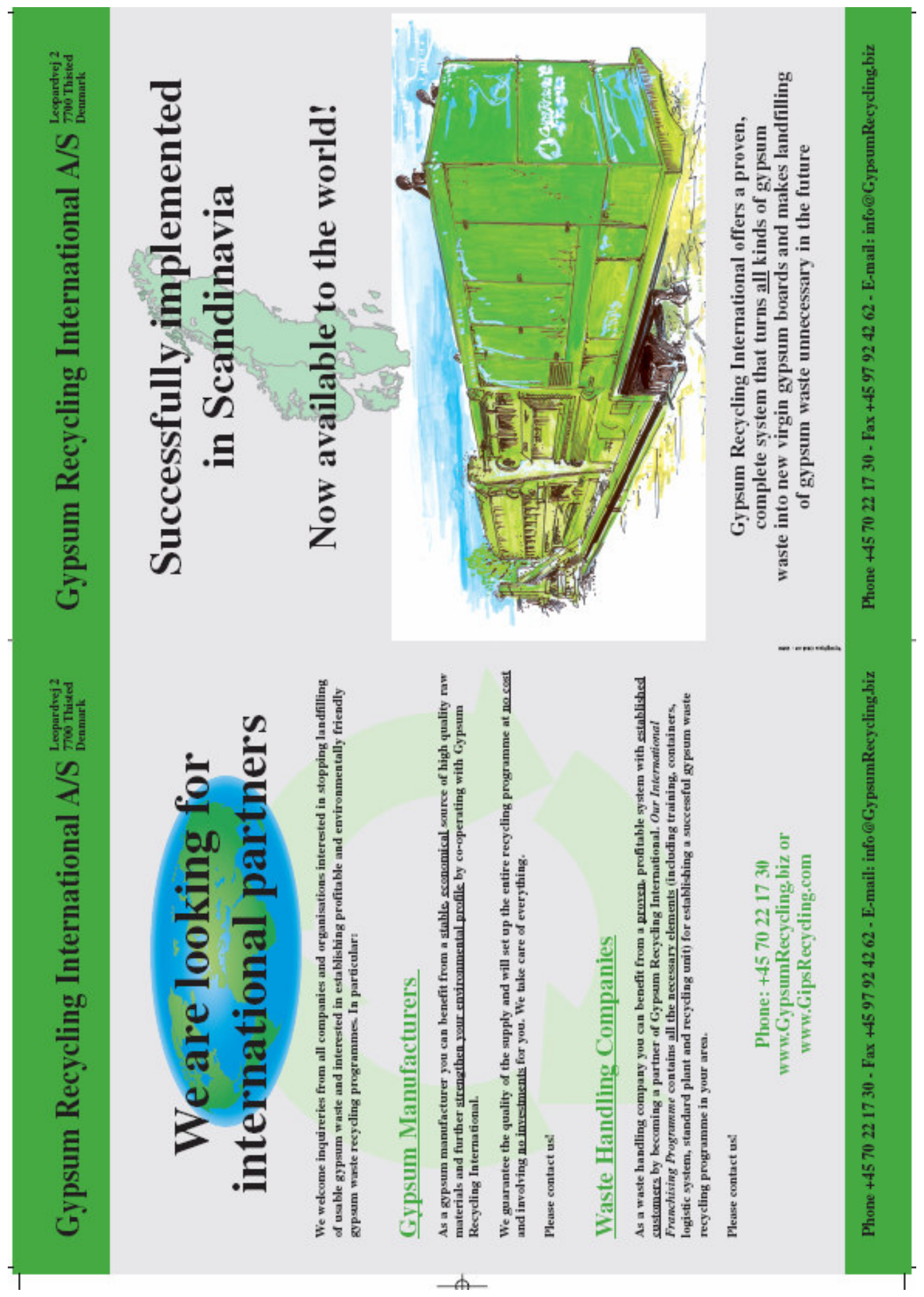




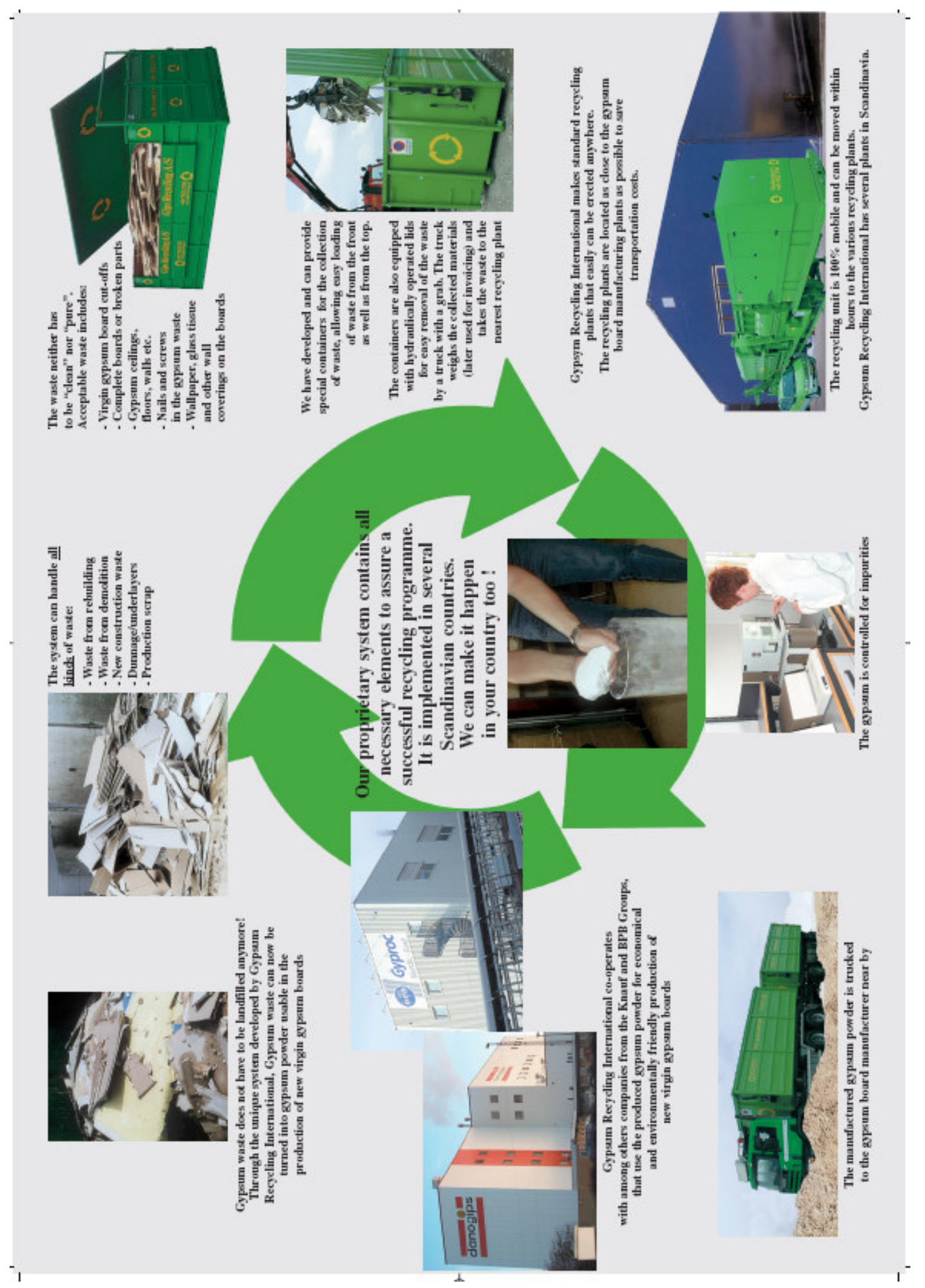




\section{Anexo B - Resolução n. 307 do CONAMA}

\section{RESOLUÇÃO No 307, DE 5 DE JULHO DE 2002.}

Estabelece diretrizes, critérios e procedimentos para a gestão dos resíduos da construção civil.

O CONSELHO NACIONAL DO MEIO AMBIENTE-CONAMA, no uso das competências que lhe foram conferidas pela Lei ${ }^{\circ}$ 6.938, de 31 de agosto de 1981, regulamentada pelo Decreto $\mathrm{n}^{\circ} 99.274$, de 6 de julho de 1990, e tendo em vista o disposto em seu Regimento Interno, Anexo à Portaria no 326, de 15 de dezembro de 1994, e;

Considerando a política urbana de pleno desenvolvimento da função social da cidade e da propriedade urbana, conforme disposto na Lei $\mathrm{n}^{\circ} 10.257$, de 10 de julho de 2001;

Considerando a necessidade de implementação de diretrizes para a efetiva redução dos impactos ambientais gerados pelos resíduos oriundos da construção civil;

Considerando que a disposição de resíduos da construção civil em locais inadequados contribui para a degradação da qualidade ambiental;

Considerando que os resíduos da construção civil representam um significativo percentual dos resíduos sólidos produzidos nas áreas urbanas;

Considerando que os geradores de resíduos da construção civil devem ser responsáveis pelos resíduos das atividades de construção, reforma, reparos e demolições de estruturas e estradas, bem como por aqueles resultantes da remoção de vegetação e escavação de solos;

Considerando a viabilidade técnica e econômica de produção e uso de materiais provenientes da reciclagem de resíduos da construção civil; e

Considerando que a gestão integrada de resíduos da construção civil deverá proporcionar benefícios de ordem social, econômica e ambiental, resolve:

Art. $1^{\circ}$ Estabelecer diretrizes, critérios e procedimentos para a gestão dos resíduos da construção civil, disciplinando as ações necessárias de forma a minimizar os impactos ambientais.

Art. $2^{\circ}$ Para efeito desta Resolução, são adotadas as seguintes definições:

I - Resíduos da construção civil: são os provenientes de construções, reformas, reparos e demolições de obras de construção civil, e os resultantes da preparação e da escavação de terrenos, tais como: tijolos, blocos cerâmicos, concreto em geral, solos, rochas, metais, resinas, colas, tintas, madeiras e compensados, forros, argamassa, gesso, telhas, pavimento asfáltico, vidros, plásticos, tubulações, fiação elétrica etc., comumente chamados de entulhos de obras, caliça ou metralha;

II - Geradores: são pessoas, físicas ou jurídicas, públicas ou privadas, responsáveis por atividades ou empreendimentos que gerem os resíduos definidos nesta Resolução;

III - Transportadores: são as pessoas, físicas ou jurídicas, encarregadas da coleta e do transporte dos resíduos entre as fontes geradoras e as áreas de destinação; 
IV - Agregado reciclado: é o material granular proveniente do beneficiamento de resíduos de construção que apresentem características técnicas para a aplicação em obras de edificação, de infra-estrutura, em aterros sanitários ou outras obras de engenharia;

V - Gerenciamento de resíduos: é o sistema de gestão que visa reduzir, reutilizar ou reciclar resíduos, incluindo planejamento, responsabilidades, práticas, procedimentos e recursos para desenvolver e implementar as ações necessárias ao cumprimento das etapas previstas em programas e planos;

VI - Reutilização: é o processo de reaplicação de um resíduo, sem transformação do mesmo;

VII - Reciclagem: é o processo de reaproveitamento de um resíduo, após ter sido submetido à transformação;

VIII - Beneficiamento: é o ato de submeter um resíduo à operações e/ou processos que tenham por objetivo dotá-los de condições que permitam que sejam utilizados como matéria-prima ou produto;

IX - Aterro de resíduos da construção civil: é a área onde serão empregadas técnicas de disposição de resíduos da construção civil Classe "A" no solo, visando a reservação de materiais segregados de forma a possibilitar seu uso futuro e/ou futura utilização da área, utilizando princípios de engenharia para confiná-los ao menor volume possível, sem causar danos à saúde pública e ao meio ambiente;

$\mathrm{X}$ - Áreas de destinação de resíduos: são áreas destinadas ao beneficiamento ou à disposição final de resíduos.

Art. $3^{\circ}$ Os resíduos da construção civil deverão ser classificados, para efeito desta Resolução, da seguinte forma:

I - Classe A - são os resíduos reutilizáveis ou recicláveis como agregados, tais como:

a) de construção, demolição, reformas e reparos de pavimentação e de outras obras de infra-estrutura, inclusive solos provenientes de terraplanagem;

b) de construção, demolição, reformas e reparos de edificações: componentes cerâmicos (tijolos, blocos, telhas, placas de revestimento etc.), argamassa e concreto; c) de processo de fabricação e/ou demolição de peças pré-moldadas em concreto (blocos, tubos, meios-fios etc.) produzidas nos canteiros de obras;

II - Classe B - são os resíduos recicláveis para outras destinações, tais como: plásticos, papel/papelão, metais, vidros, madeiras e outros;

III - Classe C - são os resíduos para os quais não foram desenvolvidas tecnologias ou aplicações economicamente viáveis que permitam a sua reciclagem/recuperação, tais como os produtos oriundos do gesso;

IV - Classe D - são os resíduos perigosos oriundos do processo de construção, tais como: tintas, solventes, óleos e outros, ou aqueles contaminados oriundos de demolições, reformas e reparos de clínicas radiológicas, instalações industriais e outros.

Art. $4^{\circ}$ Os geradores deverão ter como objetivo prioritário a não geração de resíduos e, secundariamente, a redução, a reutilização, a reciclagem e a destinação final.

$\S 1^{\circ}$ Os resíduos da construção civil não poderão ser dispostos em aterros de resíduos domiciliares, em áreas de "bota fora", em encostas, corpos d’água, lotes vagos e em áreas protegidas por Lei, obedecidos os prazos definidos no art. 13 desta Resolução. 
$\S 2^{\circ}$ Os resíduos deverão ser destinados de acordo com o disposto no art. 10 desta Resolução.

Art. $5^{\circ}$ É instrumento para a implementação da gestão dos resíduos da construção civil o Plano Integrado de Gerenciamento de Resíduos da Construção Civil, a ser elaborado pelos Municípios e pelo Distrito Federal, o qual deverá incorporar:

I - Programa Municipal de Gerenciamento de Resíduos da Construção Civil; e

II - Projetos de Gerenciamento de Resíduos da Construção Civil.

Art $6^{\circ}$ Deverão constar do Plano Integrado de Gerenciamento de Resíduos da Construção Civil:

I - as diretrizes técnicas e procedimentos para o Programa Municipal de Gerenciamento de Resíduos da Construção Civil e para os Projetos de Gerenciamento de Resíduos da Construção Civil a serem elaborados pelos grandes geradores, possibilitando o exercício das responsabilidades de todos os geradores.

II - o cadastramento de áreas, públicas ou privadas, aptas para recebimento, triagem e armazenamento temporário de pequenos volumes, em conformidade com o porte da área urbana municipal, possibilitando a destinação posterior dos resíduos oriundos de pequenos geradores às áreas de beneficiamento;

III - o estabelecimento de processos de licenciamento para as áreas de beneficiamento e de disposição final de resíduos;

IV - a proibição da disposição dos resíduos de construção em áreas não licenciadas;

V - o incentivo à reinserção dos resíduos reutilizáveis ou reciclados no ciclo produtivo;

VI - a definição de critérios para o cadastramento de transportadores;

VII - as ações de orientação, de fiscalização e de controle dos agentes envolvidos;

VIII - as ações educativas visando reduzir a geração de resíduos e possibilitar a sua segregação.

Art $7^{\circ} \mathrm{O}$ Programa Municipal de Gerenciamento de Resíduos da Construção Civil será elaborado, implementado e coordenado pelos municípios e pelo Distrito Federal, e deverá estabelecer diretrizes técnicas e procedimentos para o exercício das responsabilidades dos pequenos geradores, em conformidade com os critérios técnicos do sistema de limpeza urbana local.

Art. $8^{\circ}$ Os Projetos de Gerenciamento de Resíduos da Construção Civil serão elaborados e implementados pelos geradores não enquadrados no artigo anterior e terão como objetivo estabelecer os procedimentos necessários para o manejo e destinação ambientalmente adequados dos resíduos.

$\S 1^{\circ}$ O Projeto de Gerenciamento de Resíduos da Construção Civil, de empreendimentos e atividades não enquadrados na legislação como objeto de licenciamento ambiental, deverá ser apresentado juntamente com o projeto do empreendimento para análise pelo órgão competente do poder público municipal, em conformidade com o Programa Municipal de Gerenciamento de Resíduos da Construção Civil.

$\S 2^{\circ} \mathrm{O}$ Projeto de Gerenciamento de Resíduos da Construção Civil de atividades e empreendimentos sujeitos ao licenciamento ambiental, deverá ser analisado dentro do processo de licenciamento, junto ao órgão ambiental competente. 
Art. $9^{\circ}$ Os Projetos de Gerenciamento de Resíduos da Construção Civil deverão contemplar as seguintes etapas:

I - caracterização: nesta etapa o gerador deverá identificar e quantificar os resíduos;

II - triagem: deverá ser realizada, preferencialmente, pelo gerador na origem, ou ser realizada nas áreas de destinação licenciadas para essa finalidade, respeitadas as classes de resíduos estabelecidas no art. $3^{\circ}$ desta Resolução;

III - acondicionamento: o gerador deve garantir o confinamento dos resíduos após a geração até a etapa de transporte, assegurando em todos os casos em que seja possível, as condições de reutilização e de reciclagem;

IV - transporte: deverá ser realizado em conformidade com as etapas anteriores e de acordo com as normas técnicas vigentes para o transporte de resíduos;

V - destinação: deverá ser prevista de acordo com o estabelecido nesta Resolução.

Art. 10. Os resíduos da construção civil deverão ser destinados das seguintes formas: I - Classe A: deverão ser reutilizados ou reciclados na forma de agregados, ou encaminhados a áreas de aterro de resíduos da construção civil, sendo dispostos de modo a permitir a sua utilização ou reciclagem futura;

II - Classe B: deverão ser reutilizados, reciclados ou encaminhados a áreas de armazenamento temporário, sendo dispostos de modo a permitir a sua utilização ou reciclagem futura;

III - Classe C: deverão ser armazenados, transportados e destinados em conformidade com as normas técnicas especificas.

IV - Classe D: deverão ser armazenados, transportados, reutilizados e destinados em conformidade com as normas técnicas especificas.

Art. 11. Fica estabelecido o prazo máximo de doze meses para que os municípios e o Distrito Federal elaborem seus Planos Integrados de Gerenciamento de Resíduos de Construção Civil, contemplando os Programas Municipais de Gerenciamento de Resíduos de Construção Civil oriundos de geradores de pequenos volumes, e o prazo máximo de dezoito meses para sua implementação.

Art. 12. Fica estabelecido o prazo máximo de vinte e quatro meses para que os geradores, não enquadrados no art. $7^{\circ}$, incluam os Projetos de Gerenciamento de Resíduos da Construção Civil nos projetos de obras a serem submetidos à aprovação ou ao licenciamento dos órgãos competentes, conforme $\S \S 1^{\circ}$ e $2^{\circ}$ do art. $8^{\circ}$.

Art. 13. No prazo máximo de dezoito meses os Municípios e o Distrito Federal deverão cessar a disposição de resíduos de construção civil em aterros de resíduos domiciliares e em áreas de "bota fora".

Art. 14. Esta Resolução entra em vigor em 2 de janeiro de 2003.

\author{
JOSÉ CARLOS CARVALHO \\ Presidente do Conselho
}

Publicada DOU 17/07/2002 


\section{Anexo C - Decreto n. ${ }^{\circ}$ 42.217, da Prefeitura do Município de São Paulo.}

DECRETO No 42.217, DE 24 DE JULHO DE 2002.

Publicado no D.O. de 25 de julho de 2002.

Regulamenta a Lei $n^{\circ} 10.315$, de 30 de abril de 1987, no que se refere ao uso de áreas destinadas ao transbordo e triagem de resíduos de construção civil e resíduos volumosos, na forma que especifica, e dá outras providências.

MARTA SUPLICY, Prefeita do Município de São Paulo, no uso das atribuições que lhe são conferidas por lei, e

CONSIDERANDO que, nos termos do artigo $7^{\circ}$ da Lei Orgânica do Município de São Paulo, é dever do Poder Público Municipal assegurar a todos os munícipes meio ambiente humanizado, sadio e ecologicamente equilibrado;

CONSIDERANDO que a regulamentação do uso de áreas para transbordo e triagem dos resíduos de construção civil e resíduos volumosos permitirá resguardar a qualidade de vida e as condições ambientais de áreas contíguas aos empreendimentos;

CONSIDERANDO os benefícios ao meio ambiente, pela utilização dos resíduos de construção civil reciclados, economizando matéria-prima virgem não-renovável;

CONSIDERANDO que o descarte irregular de resíduos de construção civil e resíduos volumosos em vias e áreas públicas, corpos d'água e outros será significativamente reduzido com a criação de maior número de áreas para o transbordo e triagem daqueles resíduos;

CONSIDERANDO que a criação de maior número de áreas para o recebimento dos resíduos de construção civil e resíduos volumosos possibilitará significativa redução das distâncias para o seu transporte;

CONSIDERANDO, finalmente, a economia de recursos municipais, com a redução de pontos de descarte irregulares de entulho em vias e áreas públicas, bem como a redução das distâncias do transporte daqueles resíduos e a otimização operacional dos equipamentos de coleta e transporte a cargo do Município;

\section{DECRETA:}

Art. $1^{\circ}$ - O uso de áreas destinadas ao transbordo e triagem de resíduos de construção civil e resíduos volumosos, aos quais se refere à Lei $\mathrm{n}^{\circ} 10.315$, de 30 de abril de 1987, fica regulamentado de acordo com as normas constantes deste decreto.

Art. $2^{\circ}$ - Para os efeitos deste decreto, consideram-se 
I - resíduos de construção civil - os materiais residuais oriundos de construções, reformas, reparos, restaurações e demolições de obras de construção civil, bem como os resultantes da preparação e escavação de terrenos, tais como tijolos, blocos cerâmicos, concreto em geral, solo, rocha, madeira, forros, argamassa, gesso, telhas, pavimento asfáltico, vidros, plásticos, tubulações, fiação elétrica, metais, todos comumente denominados de entulho de obras;

II - resíduos volumosos - os resíduos não provenientes de processos industriais, constituídos basicamente por material volumoso não removido pela coleta pública municipal rotineira, como móveis e equipamentos domésticos inutilizados, grandes embalagens e peças de madeira, podas e assemelhados;

III - Pontos de Entrega (Pequenos Volumes) - os equipamentos públicos destinados ao recebimento de resíduos da construção civil e resíduos volumosos limitados a 1 (um) metro cúbico, gerados e entregues pelos munícipes ou por pequenos coletores diretamente contratados pelos geradores, e que deverão ser usados para a triagem de resíduos recebidos, posterior coleta diferenciada e remoção, para adequada disposição;

IV - Áreas de Transbordo e Triagem de Resíduos da Construção Civil - ATT - os estabelecimentos privados destinados ao recebimento de resíduos da construção civil e resíduos volumosos gerados e coletados por agentes privados, e que deverão ser usadas para a triagem dos resíduos recebidos, eventual transformação e posterior remoção para adequada disposição;

V - Aterros de Resíduos da Construção Civil - as áreas para disposição de resíduos minerais no solo, utilizando princípios de engenharia para confiná-los ao menor volume possível, com o máximo de compactação permissível, sem causar danos à saúde pública e ao meio ambiente, visando à reservação de minerais segregados, de forma a possibilitar seu uso futuro ou da área.

Art. $3^{\circ}$ - Os Pontos de Entrega ocuparão áreas públicas ou viabilizadas pela administração pública, preferencialmente aquelas já degradadas por descarte irregular de entulho, e serão implantados pela Administração, segundo diretrizes estabelecidas pela Secretaria de Serviços e Obras, observada a legislação de uso e ocupação do solo e de acordo com adequado planejamento e sustentabilidade técnica, ambiental e econômica.

Parágrafo único - A reutilização das áreas, nos casos de mudança de uso, dependerá de projetos de recuperação ambiental, devidamente analisados e aprovados pelo Departamento de Controle da Qualidade Ambiental - DECONT, da Secretaria Municipal do Meio Ambiente.

Art. $4^{\circ}$ - O Departamento de Limpeza Urbana - LIMPURB, da Secretaria de Serviços e Obras, será responsável pela operação adequada dos Pontos de Entrega. 
Art. $5^{\circ}$ - Os Pontos de Entrega,sem comprometimento de suas funções, poderão ser utilizados de forma compartilhada por grupos locais que desenvolvam ações de coleta seletiva de resíduos sólidos recicláveis, de origem domiciliar.

Art. $6^{\circ}$ - Para a implantação dos Pontos de Entrega deverão ser previstas as seguintes condições:

I - isolamento;

II - recepção diferenciada;

III - identificação da área e dos resíduos a serem recebidos.

Art. $7^{\circ}$ - O isolamento do Ponto de Entrega dar-se-á mediante:

I - cercamento da área em operação, na totalidade de seu perímetro, definido de modo a impedir o acesso de animais e pessoas estranhas à atividade;

II - portão para o controle de acesso ao local;

III - cerca viva arbustiva ou arbórea ao redor da instalação, quando os aspectos relativos à vizinhança, ventos dominantes e estética o exigirem.

Art. $8^{\circ}$ - Para a recepção diferenciada de resíduos, o equipamento deverá dispor de áreas específicas, fisicamente diferenciadas, que possibilitem a disposição, em separado, de resíduos de características e densidades diversas.

Art. $9^{\circ}$ - O Ponto de Entrega deverá ser sinalizado com placa de identificação visível, junto à sua entrada, na qual deverá constar, também, os tipos de resíduos recebidos.

Art. 10 - O Departamento de Limpeza Urbana - LIMPURB, da Secretaria de Serviços e Obras, elaborará relatórios mensais, contendo:

I - quantidade de resíduos recebidos mensalmente em cada um dos Pontos de Entrega;

II - quantidade e destino dos diversos tipos de resíduos triados.

Art. 11 - A operação dos Pontos de Entrega deverá obedecer às seguintes condições gerais:

I - a unidade receberá apenas resíduos da construção civil, resíduos volumosos e resíduos domiciliares secos e recicláveis;

II - não será permitido o recebimento de cargas de resíduos de construção civil constituídas predominantemente por resíduos da construção civil perigosos e nãoinertes (tintas, solventes, óleos, resíduos provenientes de instalações industriais e outros), enquadrados como Classe I da NBR 10.004; 
III - os resíduos que forem descarregados deverão ser integralmente triados, evitando-se o acúmulo de material não triado;

IV - os resíduos deverão ser classificados pela sua origem e características físicoquímicas, sendo subclassificados, quando possível, e acondicionados separadamente em locais adequados;

$\mathrm{V}$ - o acondicionamento dos materiais descarregados ou armazenados temporariamente deverá ser efetuado de modo a impedir o acúmulo de água;

VI - os rejeitos que eventualmente estejam na massa de resíduos recebidos deverão ter destino adequado;

VII - a remoção de resíduos do Ponto de Entrega deverá estar acompanhada pelo respectivo Controle de Transporte de Resíduos, emitido em 3 (três) vias, de acordo com o modelo constante do Anexo "A" integrante deste decreto.

Art. 12 - Os resíduos da construção civil de origem mineral (concreto, argamassas, produtos cerâmicos e outros) removidos dos Pontos de Entrega, excluídos os produtos à base de gesso e amianto, deverão ser reutilizados, reciclados na forma de agregados ou encaminhados a Aterros de Resíduos da Construção Civil, para reservação segregada ou constituição de espaços para futura utilização.

Parágrafo único - Os demais tipos de resíduos da construção civil e os resíduos volumosos deverão ser encaminhados à reutilização, reciclagem, armazenagem ou a aterros adequados, obedecidas as normas técnicas específicas.

Art. 13 - As Áreas de Transbordo e Triagem de Resíduos de Construção Civil - ATT serão implantadas e operadas por particulares interessados, observando-se a legislação municipal de uso e ocupação do solo, bem assim a legislação federal e estadual de controle da poluição ambiental, quando for o caso.

Art. 14 - Os empreendedores interessados na implantação de Área de Transbordo e Triagem de Resíduos da Construção Civil - ATT deverão consultar a Secretaria Municipal de Planejamento Urbano - SEMPLA quanto às diretrizes urbanísticas relativas ao empreendimento e apresentar seu projeto à Administração Regional correspondente à sua área de implantação, que, após análise e manifestação do Departamento de Aprovação das Edificações - APROV, da Secretaria da Habitação e Desenvolvimento Urbano - SEHAB, expedirá a respectiva licença de funcionamento.

Parágrafo único - As Administrações Regionais da Secretaria de Implementação das Subprefeituras - SIS deverão comunicar ao Departamento de Limpeza Urbana LIMPURB, da Secretaria de Serviços e Obras - SSO, a emissão da licença de funcionamento das Áreas de Transbordo e Triagem de Resíduos da Construção Civil - ATT. 
Art. 15 - O projeto de implantação da Área de Transbordo e Triagem de Resíduos da Construção Civil - ATT deverá contemplar os seguintes elementos:

I - memorial descritivo;

II - planta baixa do empreendimento;

III - relatório fotográfico da área;

IV - informações cadastrais da área (inscrição imobiliária);

V - cópia da matrícula do imóvel no Cartório de Registro de Imóveis;

VI - informações cadastrais do empreendedor e do operador da unidade;

VII - anotação de responsabilidade técnica no Conselho Regional de Engenharia, Arquitetura e Agronomia - CREA, do profissional autor do projeto;

VIII - anexos.

Art. 16 - O projeto de implantação da Área de Transbordo e Triagem de Resíduos da Construção Civil - ATT deverá ser de responsabilidade e subscrito por profissional habilitado pelo Conselho Regional de Engenharia, Arquitetura e Agronomia - CREA, o qual firmará todos os documentos que o compõem, indicando, em cada um deles, o número de seu registro naquele Conselho.

Art. 17 - O memorial descritivo deverá conter, obrigatoriamente:

I - informações sobre o local destinado à Área de Transbordo e Triagem de Resíduos da Construção Civil - ATT, para avaliação da adequabilidade da atividade quanto à topografia, acessos e vizinhança;

II - justificativa da Área de Transbordo e Triagem de Resíduos da Construção Civil ATT;

III - descrição da implantação da Área de Transbordo e Triagem de Resíduos da Construção Civil - ATT;

IV - descrição da operação da Área de Transbordo e Triagem de Resíduos da Construção Civil - ATT;

$\mathrm{V}$ - equipamentos utilizados no empreendimento;

VI - equipamentos de segurança;

VII - equipamentos de controle de poluição ambiental;

VIII - medidas mitigadoras.

Art. 18 - A planta baixa do empreendimento deverá conter os seguintes dados:

I - dimensões;

II - confrontantes;

III - dispositivos de drenagem superficial;

IV - acessos; 
$\mathrm{V}$ - edificações;

VI - local de recebimento e triagem;

VII - local de armazenamento temporário;

VIII - locação dos equipamentos utilizados;

IX - local de eventual transformação dos materiais segregados;

$\mathrm{X}$ - indicação do posicionamento das fotos do relatório fotográfico.

Art. 19 - O relatório fotográfico deverá visualizar a área do empreendimento, apresentando os principais aspectos do meio físico, antrópico e biótico, bem como sua testada e acessos.

Art. 20 - As informações cadastrais consistirão em:

I - inscrição imobiliária (cadastro fiscal do Departamento de Rendas Imobiliárias RI, da Secretaria de Finanças e Desenvolvimento Econômico - SF, para fins de Imposto Predial e Territorial Urbano - IPTU) ou registro da área no Instituto Nacional de Colonização e Reforma Agrária - INCRA, se for o caso de imóvel rural; II - documento de posse ou autorização do proprietário para implantação do empreendimento;

III - qualificação da entidade ou do empreendedor responsável pela Área de Transbordo e Triagem de Resíduos da Construção Civil - ATT.

Art. 21 - Para a implantação da Área de Transbordo e Triagem de Resíduos da Construção Civil - ATT, deverão ser previstas as seguintes condições:

I - isolamento da área;

II - identificação da área e resíduos a serem recebidos;

III - equipamentos de segurança.

Art. 22 - O isolamento da Área de Transbordo e Triagem de Resíduos da Construção Civil - ATT será verificado mediante:

I - cercamento da área em operação, na totalidade de seu perímetro definido, de modo a impedir o acesso de animais e pessoas estranhas à atividade;

II - portão para o controle de acesso ao local;

III - cerca viva arbustiva ou arbórea ao redor da instalação, quando os aspectos relativos à vizinhança, ventos dominantes e estética o exigirem.

Art. 23 - A Área de Transbordo e Triagem de Resíduos da Construção Civil - ATT deverá ser sinalizada com placa de identificação visível, junto à sua entrada, na qual deverá constar, também, as atividades desenvolvidas e os números do processo 
administrativo da aprovação do empreendimento, do alvará e da licença de funcionamento.

Art. 24 - A Área de Transbordo e Triagem de Resíduos da Construção Civil - ATT deverá contar com, no mínimo, os seguintes equipamentos de segurança:

I - equipamentos de proteção individual;

II - equipamentos de proteção contra descargas atmosféricas;

III - equipamentos de combate a incêndio;

IV - iluminação e força para permitir ação de emergência em qualquer período.

Art. 25 - O empreendedor será responsável pela operação adequada da Área de Transbordo e Triagem de Resíduos da Construção Civil - ATT, ficando sujeito às sanções legais, quando em desacordo.

Art. 26 - Os resíduos recebidos nas Áreas de Transbordo e Triagem de Resíduos da Construção Civil - ATT deverão ser controlados quanto à procedência, quantidade e qualidade, conforme o Controle de Transporte de Resíduos a que se refere o Anexo "B" integrante deste decreto.

Art. 27 - O responsável pela Área de Transbordo e Triagem de Resíduos da Construção Civil - ATT deverá apresentar ao Departamento de Limpeza Urbana LIMPURB, da Secretaria de Serviços e Obras, relatórios mensais, contendo:

I - quantidade de resíduos recebidos mensalmente;

II - quantidade e destino dos diversos tipos de resíduos triados, com os respectivos comprovantes;

III - relação de transportadores usuários no mês vigente.

Art. 28 - A operação da Área de Transbordo e Triagem de Resíduos da Construção Civil - ATT deverá obedecer às seguintes condições gerais:

I - a unidade receberá apenas resíduos de construção civil e resíduos volumosos;

II - não será permitido o recebimento de cargas de resíduos de construção civil constituídas predominantemente por resíduos da construção civil perigosos e nãoinertes (tintas, solventes, óleos, resíduos provenientes de instalações industriais e outros), enquadrados na Classe I da NBR 10.004;

III - só serão aceitas descargas e expedições de veículos com a devida cobertura dos resíduos neles acondicionados;

IV - os resíduos descarregados na Área de Transbordo e Triagem de Resíduos da Construção Civil - ATT estarão acompanhados do respectivo Controle de Transporte de Resíduos; 
V - a emissão do Controle de Transporte de Resíduos será de responsabilidade do transportador;

VI - os resíduos que forem descarregados deverão ser integralmente triados, evitando-se o acúmulo de material não triado;

VII - os resíduos deverão ser classificados pela sua origem e características físicoquímicas, sendo subclassificados, quando possível, e acondicionados em locais adequados;

VIII - o acondicionamento dos materiais descarregados ou armazenados temporariamente deverá impedir o acúmulo de água;

IX - os rejeitos que eventualmente estejam na massa de resíduos recebidos deverá ter destino adequado;

X - a remoção de resíduos da Área de Transbordo e Triagem de Resíduos da Construção Civil - ATT deverá estar acompanhada pelo respectivo Controle de Transporte de Resíduos, emitido em 3 (três) vias.

Art. 29 - Os resíduos da construção civil de origem mineral (concreto, argamassas, produtos cerâmicos e outros), excluídos os produtos à base de gesso e amianto, deverão ser reutilizados, reciclados na forma de agregados ou encaminhados aos Aterros de Resíduos da Construção Civil, para reservação segregada ou constituição de espaços para futura utilização.

Parágrafo único - Os demais tipos de resíduos da construção civil deverão ser encaminhados à reutilização, reciclagem, armazenagem ou a aterros adequados, obedecidas as normas técnicas específicas.

Art. 30 - Os resíduos volumosos deverão ser encaminhados à reutilização, reciclagem ou aos aterros adequados.

Art. 31 - A transformação dos materiais triados somente poderá ser realizada na própria Área de Transbordo e Triagem de Resíduos da Construção Civil - ATT se a área possuir licenciamento específico para essa atividade, a critério do órgão ambiental municipal.

Art. 32 - Deverá ser garantida a existência de sistema de controle de poeira, ativo, tanto nas descargas quanto no manejo e nas zonas de acumulação de resíduos.

Art. 33 - Deverão ser utilizados dispositivos de contenção de ruídos em veículos e equipamentos presentes na Área de Transbordo e Triagem de Resíduos da Construção Civil - ATT. 
Art. 34 - Os resíduos de construção civil oriundos de eventos de grande porte (demolições, calamidades, escavações e outros) poderão ser encaminhados diretamente para Aterros de Resíduos da Construção Civil, visando sua reutilização, reciclagem ou reservação segregada, após consulta ao órgão ambiental responsável.

Parágrafo único - Solos de escavação poderão ser encaminhados diretamente para a cobertura de Aterros Sanitários.

Art. 35 - A limpeza das vias nos acessos e no entorno da Área de Transbordo e Triagem de Resíduos da Construção Civil - ATT, será responsabilidade do empreendedor, devendo tal obrigação constar do respectivo projeto, sujeitando-se ele, quando em desacordo, às sanções legais aplicáveis na espécie.

Art. 36 - Deverá ser implantado revestimento primário nas áreas de operação e estocagem da Área de Transbordo e Triagem de Resíduos da Construção Civil ATT, de maneira a permitir sua utilização sob quaisquer condições climáticas.

Art. 37 - As despesas com a execução deste decreto correrão por conta de dotações orçamentárias próprias, suplementadas se necessário.

Art. 38 - Este decreto entrará em vigor na data de sua publicação, revogadas as disposições em contrário.

PREFEITURA DO MUNICÍPIO DE SÃO PAULO, aos 24 de julho de 2002, $449^{\circ}$ da fundação de São Paulo.

MARTA SUPLICY, PREFEITA

ILZA REGINA DEFILIPPI DIAS, Respondendo pelo Cargo de Secretária dos Negócios Jurídicos

JOÃO SAYAD, Secretário de Finanças e Desenvolvimento Econômico

JORGE FONTES HEREDA, Secretário de Serviços e Obras

JILMAR AUGUSTINHO TATTO, Secretário de Implementação das Subprefeituras

LUIZ PAULO TEIXEIRA FERREIRA, Secretário da Habitação e Desenvolvimento

Urbano

JORGE WILHEIM, Secretário Municipal do Planejamento Urbano

Publicado na Secretaria do Governo Municipal, em 24 de julho de 2002.

UBIRATAN DE PAULA SANTOS, Respondendo pelo de Cargo de Secretário do Governo Municipal. 


\section{Anexo D - Resolução n. 41 da Secretaria do Meio Ambiente do Estado de São Paulo.}

\section{RESOLUÇÃO SMA Nº 41, DE 17 DE OUTRUBRO DE 2002.}

Dispõe sobre procedimentos para o licenciamento ambiental de aterros de resíduos inertes e da construção civil no Estado de São Paulo.

O Secretário do Meio Ambiente:

Considerando que a indústria da construção civil gera grande quantidade de resíduos, que, se dispostos em locais inadequados, contribuem para a degradação da qualidade ambiental;

Considerando que os resíduos da construção civil representam um significativo percentual dos resíduos sólidos produzidos nas áreas urbanas;

Considerando que as cavas de mineração resultantes da atividade mineraria constituem degradação ambiental, além de sério risco à saúde da população, por facilitar a proliferação de vetores de doenças e provocar freqüentes casos de morte por afogamento;

Considerando que as cavas de mineração inundadas, enquanto não tiverem uma destinação definida, não podem ser consideradas como lagoas, lagos ou reservatórios artificiais, como definido no Código Florestal;

Considerando, ainda, a necessidade de disciplinar o gerenciamento dos resíduos da construção civil e resíduos inertes em geral, por meio da adoção de soluções tecnicamente corretas e de ferramentas institucionais que privilegiem a ação preventiva;

Considerando que o Estado tem o dever de providenciar a preservação, recuperação e a melhoria do meio ambiente, nos termos do disposto no artigo 191 da Constituição do Estado;

Resolve:

Art. $1^{\circ}$ - A disposição final de resíduos da construção civil classificados como classe A, pela Resolução CONAMA 307, de 05/07/2002 e de resíduos inertes classificados como classe III, pela NBR - 10.004 - Classificação de Resíduos, da ABNT, no Estado de São Paulo, fica sujeita ao licenciamento ambiental quanto à localização, à instalação e à operação, no âmbito dos órgãos da Secretaria do Meio Ambiente SMA.

Art $2^{\circ}$ - A disposição final dos resíduos mencionados no artigo $1^{\circ}$ deverá ser feita em aterros que atendam às normas e exigências estabelecidas pelos órgãos ambientais competentes, a saber: DAIA - Departamento de Avaliação de Impacto Ambiental, DUSM - Departamento de Uso do Solo Metropolitano, DEPRN - Departamento Estadual de Proteção de Recursos Naturais e CETESB - Companhia de Tecnologia de Saneamento Ambiental.

Art. $3^{\circ}$ - O licenciamento dos aterros mencionados no Artigo 2o fica sujeito à manifestação do DUSM, quando localizados em Área de Proteção aos Mananciais APM, e do DEPRN, quando houver intervenção em Área de Preservação Permanente - APP ou supressão de vegetação nativa. 
Art. $4^{\circ}$ - Os aterros mencionados no artigo $2^{\circ}$, cuja capacidade total não exceda $100.000 \mathrm{~m} 3$ e que recebam uma quantidade de resíduos igual ou inferior a $150 \mathrm{~m} 3$ por dia, serão dispensados de licenciamento ambiental prévio, no âmbito da SMA/DAIA, procedendo-se o licenciamento ambiental no âmbito da CETESB.

Parágrafo Único - Ficam condicionados à manifestação do Departamento de Avaliação de Impacto Ambiental - DAIA, da SMA, sobre a necessidade de licenciamento ambiental prévio por aquele departamento, independentemente das demais características, os aterros cuja localização se enquadre em uma ou mais situações relacionadas a seguir:

I. Unidades de Conservação definidas pela Lei Federal 9.985/00, Capítulo III, e áreas limítrofes às mesmas;

II. Áreas e monumentos tombados pelo CONDEPHAAT;

III. Áreas com cobertura vegetal primária ou secundária em estágio médio ou avançado de regeneração.

Art. $5^{\circ}$ - Os aterros mencionados no artigo $2^{\circ}$, cuja capacidade total seja inferior ou igual a $100.000 \mathrm{~m} 3$ e que recebam uma quantidade de resíduos superior a $150 \mathrm{~m} 3$ por dia e inferior ou igual a $300 \mathrm{~m} 3$ por dia, dependerão de consulta, a ser encaminhada pela agência ambiental da CETESB, ao Departamento de Avaliação de Impacto Ambiental - DAIA da SMA para manifestação acerca da necessidade de licenciamento ambiental prévio por aquele departamento.

Art. $6^{\circ}$ - Os aterros mencionados no artigo $2^{\circ}$, cuja capacidade total seja superior a $100.000 \mathrm{~m} 3$ ou que recebam uma quantidade de resíduos superior a $300 \mathrm{~m} 3$ por dia dependerão do licenciamento ambiental prévio da SMA/DAIA, nos termos da Resolução SMA nº 42, de 29 de dezembro de 1994, mediante a apresentação de RAP na agência ambiental da CETESB.

Art. $7^{\circ}$ - Os aterros para a disposição dos resíduos mencionados no artigo $1^{\circ}$ que, simultaneamente, ocupem área igual ou inferior a $1.000 \mathrm{~m} 2$, volume total igual ou inferior a $1.000 \mathrm{~m} 3$ e tenha como finalidade imediata a regularização de terrenos para fins de edificação ficam dispensados do licenciamento ambiental, porém, sujeitos à manifestação do DEPRN, e do DUSM quando localizado em APM.

Art. $8^{\circ} \mathrm{O}$ licenciamento ambiental de empreendimentos que se localizem na Região Metropolitana de São Paulo, será regido pela Resolução SMA 35/96, que instituiu o regime de Balcão Único.

Art. $9^{\circ}$ - Os aterros mencionados no artigo $2^{\circ}$ que serão implantados em cavas exauridas de mineração terão o licenciamento ambiental vinculado à prévia aprovação de um PRAD - Plano de Recuperação de Área Degradada ou do RCA/PCA - Relatório de Controle Ambiental e Plano de Controle Ambiental, ou documento equivalente.

Art. 10 - Os aterros mencionados no artigo $2^{\circ}$ em operação na data de publicação desta Resolução deverão solicitar junto à CETESB a respectiva licença de funcionamento, em um prazo máximo de 180 (cento e oitenta dias), contados a partir da data de publicação desta Resolução. 
Art. 11 - Caberá ao DUSM, ao DEPRN e à CETESB, no âmbito de suas competências, a fiscalização para a correta aplicação desta Resolução.

Art. 12 - Esta resolução entrará em vigor na data de sua publicação, ficando revogada a Resolução n. 34, de 06.05.96, publicada no D.O. de 07.05.96.

FONTE D.O.E DATA PUB. 23/10/02

SEÇÃO I VOLUME 112

PÁGINA 40 NÚMERO 203 


\section{Anexo E - Lei n. ${ }^{\circ}$ 13.298 da Prefeitura do Município de São Paulo}

\section{LEI n. 13.298, DE 16 DE JANEIRO DE 2002.}

Publicado D.O. de 16-01-2002

Dispõe sobre as responsabilidades e condições de remoção de entulho, terra e materiais de construção.

MARTA SUPLICY, Prefeita do Município de São Paulo, usando das atribuições que lhe são conferidas por lei, faz saber que a Câmara Municipal, em sessão de 23 de dezembro de 2001, decretou e eu promulgo a seguinte lei:

Art. $1^{\circ}$ Os proprietários, possuidores, incorporadores e construtores de imóveis, geradores de resíduos da construção civil responderão com as empresas prestadoras de serviços de remoção, transporte e destinação final desses materiais inertes, quanto dão cumprimento dos dispositivos aplicáveis da Lei 10.315, de 30 de abril de 1987 a eles aplicáveis.

$\S 1^{\circ}$ - As partes responderão pelas respectivas atividades que, por contrato, sejam cominadas a cada uma, dentro dos correspondentes limites de responsabilidade quanto à qualidade do material a ser removido, ao cumprimento das exigências de transporte e segurança de trânsito e à destinação final dos resíduos.

$\S 2^{\circ}$ - Na ausência de contrato, as partes responderão solidariamente pela destinação final dos resíduos.

Art. $2^{\circ} \mathrm{A}$ empresa ou prestador de serviço contratado para a remoção não abrangida pela coleta regular, devem comunicar previamente à Municipalidade, quanto à remoção e a destinação dos resíduos de que trata o artigo $1^{\circ}$ desta lei.

Parágrafo único - A empresa ou prestador de serviços contratado deverá fornecer ao gerador dos resíduos comprovante declarando a sua correta destinação.

Art. $3^{\circ}$ As despesas para a execução desta lei correrão por conta de dotações orçamentárias próprias, suplementadas se necessário.

Art. $4^{\circ}$ Esta lei entrará em vigor na data de sua publicação, revogadas as disposições em contrário.

\section{MARTA SUPLICY, PREFEITA}

ILZA REGINA DEFILIPPI DIAS, Respondendo pelo Cargo de Secretária dos Negócios Jurídicos

JOÃO SAYAD, Secretário de Finanças e Desenvolvimento Econômico JORGE FONTES HEREDA, Secretário de Serviços e Obras

JILMAR AUGUSTINHO TATTO, Secretário de Implementação das Subprefeituras Publicado na Secretaria do Governo Municipal, em 16 de janeiro de 2002. 
UBIRATAN DE PAULA SANTOS, Respondendo pelo de Cargo de Secretário do Governo Municipal. 


\section{Anexo F - Decreto n. 46.594 da Prefeitura do Município de São Paulo}

\section{DECRETO No 46.594, DE 3 DE NOVEMBRO DE 2005}

Regulamenta a coleta, o transporte, o tratamento e a disposição final de resíduos inertes, de que trata a Lei $\mathrm{n}^{\circ}$ 13.478, de 30 de dezembro de 2002, com as alterações subseqüentes.

JOSÉ SERRA, Prefeito do Município de São Paulo, no uso das atribuições que lhe são conferidas por lei,

D E C R E T A:

Capítulo I

Dos Grandes Geradores

Art. $1^{\circ}$. Os proprietários, possuidores ou titulares de estabelecimentos públicos, institucionais, de prestação de serviços, comerciais e industriais, dentre outros, geradores de resíduos sólidos inertes, tais como entulhos, terra e materiais de construção, com massa superior a 50 (cinqüenta) quilogramas diários, de produção contínua e não sujeita a prazo, ficam obrigados a proceder ao seu cadastramento na Autoridade Municipal de Limpeza Urbana - AMLURB, nos termos do artigo 140 da Lei $\mathrm{n}^{\circ}$ 13.478, de 30 de dezembro de 2002, e deste decreto, conforme modelo constante do Anexo I integrante deste decreto.

Parágrafo único. Para o cadastramento de que trata o "caput" deste artigo, deverá ser apresentada cópia dos seguintes documentos:

I - comprovante de inscrição no Cadastro Nacional da Pessoa Jurídica - CNPJ ou equivalente;

II - comprovante de inscrição no cadastro imobiliário do Município de São Paulo, referente à unidade em que está localizado o grande gerador;

III - extrato de contrato firmado com empresa autorizatária para a prestação em regime privado dos serviços de coleta, transporte, tratamento e disposição final de seus resíduos inertes, que deverá conter nome do responsável pelo contrato, nome da autorizatária, prazo de vigência, quantidade de resíduos, frequiência e horário de coleta, locais coletados e de disposição final, sem prejuízo de outras informações pertinentes que poderão ser solicitadas pela Autoridade Municipal de Limpeza Urbana - AMLURB, inclusive, sempre que exigido, o inteiro teor do instrumento contratual;

IV - declaração indicando as características e a quantidade média diária de resíduos inertes produzidos pelo grande gerador, considerando-se a Unidade Imobiliária Fiscal onde se localiza.

Art. $2^{\circ}$. O cadastramento terá validade de 3 (três) anos, podendo ser renovado, por iguais períodos.

Parágrafo único. Havendo alteração na quantidade de resíduos sólidos produzidos, o grande gerador deverá atualizar seu cadastro na Autoridade Municipal de Limpeza Urbana - AMLURB, no prazo de 30 (trinta) dias, contados da data da alteração. 
Art. $3^{\circ}$. Os grandes geradores deverão manter em seu poder, durante 5 (cinco) anos, registros e comprovantes de cada coleta feita, da quantidade coletada e da disposição dada aos resíduos.

\section{Capítulo II}

Dos Autorizatários

Art. $4^{\circ}$. Para a obtenção, por pessoa jurídica, da autorização de que trata o artigo 123 da Lei $n^{\circ} 13.478$, de 2002, para a prestação dos serviços de limpeza urbana no regime privado, referentes a coleta, transporte, tratamento e disposição final dos resíduos sólidos inertes previstos no inciso II do artigo 119 da mesma lei, a empresa deverá cadastrar-se na Autoridade Municipal de Limpeza Urbana - AMLURB, apresentando documentação relativa a:

I - capacidade jurídica;

II - idoneidade financeira;

III - regularidade fiscal;

IV - capacidade técnica;

$\mathrm{V}$ - relação de equipamentos;

VI - declaração de disposição final.

$\S 1^{\circ}$. Somente serão cadastradas as empresas que possuam sede ou filial no Município de São Paulo.

$\S 2^{\circ}$. O cadastramento é individual e deverá ser atualizado anualmente, não sendo admitidas associações ou consórcios de autorizatários.

$\S 3^{\circ}$. Os prestadores dos serviços a que se refere o "caput" deste artigo deverão requerer seu cadastramento à Autoridade Municipal de Limpeza Urbana - AMLURB, conforme modelo constante do Anexo II integrante deste decreto.

$\S 4^{\circ}$. A autorização para a prestação dos serviços de limpeza urbana no regime privado é intransferível.

Art. $5^{\circ}$. A documentação relativa à capacidade jurídica consiste na apresentação de: I - comprovante de inscrição no Cadastro Nacional da Pessoa Jurídica - CNPJ ou equivalente;

II - cédula de identidade do(s) sócio(s) ou diretor(es) representante(s) das sociedades simples ou empresárias, e das sociedades anônimas, respectivamente, observado o disposto no correspondente contrato ou estatuto social;

III - registro perante a Junta Comercial, no caso de firma individual;

IV - ato constitutivo, estatuto social ou contrato social em vigor e respectivas alterações subseqüentes, devidamente registrados, em se tratando de sociedades empresárias;

V - inscrição do contrato social no Cartório de Registro Civil de Pessoas Jurídicas, no caso de sociedades simples;

VI - arquivamento, na Junta Comercial, da publicação oficial das atas de assembléias gerais que tenham aprovado ou alterado os estatutos em vigor, no caso de sociedades por ações, bem como da ata da assembléia que elegeu a última diretoria em exercício; 
VII - decreto de autorização, em se tratando de empresa ou sociedade estrangeira em funcionamento no país.

Art. $6^{\circ}$. A documentação relativa à idoneidade financeira consiste na apresentação de:

I - balanço patrimonial e demonstrações contábeis do último exercício social, exigíveis na forma da lei, que comprovem a boa situação financeira da empresa;

II - certidão negativa de concordata ou falência, no caso de sociedades comerciais, ou certidões dos Distribuidores Forenses Cíveis, no caso das demais sociedades, da sede da empresa, datadas de até 60 (sessenta) dias anteriores ao pedido de inscrição.

Art. $7^{\circ}$. A documentação relativa à regularidade fiscal consiste na apresentação de:

I - comprovante de inscrição no Cadastro de Contribuintes Mobiliários - CCM do Município de São Paulo;

II - Certidão Negativa de Débito - CND referente ao Instituto Nacional do Seguro Social - INSS e ao Fundo de Garantia por Tempo de Serviço - FGTS, comprovando a situação de regularidade no cumprimento dos encargos sociais instituídos por lei;

III - certidões negativas de tributos mobiliários e imobiliários, expedidas pela Secretaria Municipal de Finanças - SF, comprovando a situação de regularidade fiscal perante a Fazenda do Município de São Paulo;

IV - Certidão Negativa de Débito expedida pela Autoridade Municipal de Limpeza Urbana - AMLURB, no caso de renovação do cadastramento.

Art. $8^{\circ}$. A documentação relativa à comprovação da capacidade técnica consiste na apresentação de:

I - declaração identificando o responsável técnico, devidamente registrado no Conselho Regional de Engenharia, Arquitetura e Agronomia - CREA, para o acompanhamento dos serviços executados pelo autorizatário juntamente com a correspondente Anotação de Responsabilidade Técnica - ART;

II - declaração devidamente assinada pelo representante legal da empresa, em papel timbrado, relacionando os equipamentos e automotores que possui para a execução dos serviços, indicando marca, tipo, placas, capacidade de carga, dimensões, tara em quilos, ano de fabricação e número da licença no Departamento Estadual de Trânsito - DETRAN;

III - cópia do Certificado de Registro e Licenciamento do Veículo em nome da empresa ou de um de seus sócios, no caso de sociedade simples, empresária ou por ações e, no caso do veículo estar registrado em nome de terceiros, além do Certificado de Registro e Licenciamento do Veículo, cópia do correspondente contrato de locação ou "leasing" vinculando-o ao autorizatário;

IV - cópia autenticada do Comprovante de Segurança Veicular, Veículo e Equipamento em condições operacionais para execução da atividade, expedido por organismos de inspeção credenciados pelo Instituto Nacional de Metrologia, Normatização e Qualidade Industrial - INMETRO; 
V - declaração identificando o local de guarda de veículos e equipamentos (caçambas e outros), assim equiparado aos locais em que é possível a atividade de garagem de veículos;

VI - ato de registro ou autorização para funcionamento, expedido pelo órgão federal, estadual e municipal competente, para a sede e/ou filial da empresa, enquanto estabelecida no Município de São Paulo, quando a atividade assim o exigir.

Art. $9^{\circ}$. Os documentos necessários ao cadastramento de que tratam os artigos $4^{\circ}$ a $8^{\circ}$ deste decreto poderão ser apresentados em original, cópia autenticada ou publicação em órgão da imprensa oficial, quando for o caso; aqueles expedidos pela própria empresa deverão ser subscritos pelo respectivo representante legal.

$\S 1^{\circ}$. A documentação mencionada nos artigos $4^{\circ}$ a $8^{\circ}$ deste decreto deverá ser apresentada na ordem por eles estabelecida, acompanhada de pedido regularmente preenchido, conforme modelo constante de seu Anexo II.

$\S 2^{\circ}$. Todos os documentos deverão estar com prazo de validade em vigor na data do protocolamento do pedido de cadastramento.

Art. 10. São obrigações dos autorizatários dedicados a coleta, transporte, tratamento e/ou disposição final de resíduos sólidos inertes de que trata este decreto:

I - identificar, conforme modelo constante do Anexo III integrante deste decreto, todos os locais utilizados para tratamento e/ou disposição final dos resíduos, dentro do Município ou fora dele, os quais deverão ser licenciados pelos órgãos competentes;

II - fornecer todos os dados necessários ao controle e à fiscalização de sua atividade pela Autoridade Municipal de Limpeza Urbana - AMLURB, na forma por ela estabelecida;

III - apresentar à Autoridade Municipal de Limpeza Urbana - AMLURB relação nominal dos veículos e equipamentos utilizados para a prestação dos serviços e cópia dos correspondentes Certificados de Registro e Licenciamento de Veículo ou equivalentes;

IV - responsabilizar-se pela constante atualização dos dados fornecidos à Autoridade Municipal de Limpeza Urbana - AMLURB;

$\mathrm{V}$ - manter em seu poder, durante 5 (cinco) anos, registros e comprovantes de tratamento e/ou disposição final dada aos resíduos inertes coletados;

VI - fornecer aos geradores usuários dos serviços de coleta em regime privado, em até 15 (quinze) dias após a data da descarga, cópia (segunda via) dos comprovantes de cada coleta e destinação final realizada;

VII - utilizar, na execução dos serviços autorizados, apenas os veículos e equipamentos cadastrados na Autoridade Municipal de Limpeza Urbana AMLURB, colocando-os à disposição da fiscalização sempre que requisitados para vistoria;

VIII - manter a identificação dos veículos autorizados, conforme modelo constante do Anexo IV integrante deste decreto. 
Art. 11. A autorização para prestação dos serviços de que trata este decreto vigorará a partir da respectiva publicação no Diário Oficial da Cidade de São Paulo - D.O.C. e terá prazo de validade indeterminado, extinguindo-se somente por cassação, caducidade, decaimento, renúncia ou anulação, nos termos dos artigos 132 a 138 da Lei $n^{\circ} 13.478$, de 2002.

Art. 12. A extinção da autorização será declarada pela Autoridade Municipal de Limpeza Urbana - AMLURB, mediante ato administrativo e dependerá de procedimento prévio, garantido o contraditório e a ampla defesa.

$\S 1^{\circ}$. No curso do procedimento, a Autoridade Municipal de Limpeza Urbana AMLURB poderá tomar as medidas cautelares que considerar adequadas para preservar o interesse público envolvido, notadamente a saúde pública e o meio ambiente, inclusive suspender liminarmente as atividades dos autorizatários.

$\S 2^{\circ}$. Em qualquer hipótese, a extinção da autorização não elide a responsabilidade do autorizatário ou de seus controladores em relação aos compromissos assumidos com a Autoridade Municipal de Limpeza Urbana - AMLURB, munícipes-usuários, outros operadores e terceiros.

Art. 13. Os resíduos sólidos inertes coletados e transportados pelos autorizatários somente poderão ser destinados aos locais devidamente licenciados pelos órgãos competentes, atendidas as normas técnicas específicas e a legislação ambiental vigente.

Parágrafo único. São proibidos o armazenamento e o transporte de materiais orgânicos, perigosos e nocivos à saúde por meio de caçambas.

Art. 14. A coleta e o transporte dos resíduos de que trata este decreto serão efetuados em equipamentos compatíveis com a natureza dos serviços a serem prestados, observadas as normas técnicas vigentes, de forma a não provocar derramamentos na via pública e poluição local, devendo trafegar com carga rasa, limitada à borda da caçamba, sem qualquer coroamento, e ter seu equipamento de rodagem limpo antes de atingir a via pública.

$\S 1^{\circ}$. As caçambas estacionárias deverão obedecer as especificações e requisitos a seguir fixados:

I - possuir dimensões externas máximas de $2,80 \mathrm{~m}$ (dois metros e oitenta centímetros) por $1,80 \mathrm{~m}$ (um metro e oitenta centímetros) e altura de $1,40 \mathrm{~m}$ (um metro e quarenta centímetros);

II - ser dotadas de tampa ou outro dispositivo de cobertura adequado, de modo a impedir a queda de materiais durante o período de transporte e restringir o conteúdo da caçamba ao volume máximo de sua capacidade, limitado à sua altura e largura;

III - o armazenamento e o transporte dos resíduos inertes não poderão exceder o nível superior das caçambas nem suas laterais, particularmente quanto a ferragens e elementos pontiagudos;

IV - possuir identificação, conforme especificado no Anexo V deste decreto, com nome da empresa prestadora dos serviços, número(s) do(s) telefone(s) disponível(is) para emergências durante 24 (vinte e quatro) horas por dia e telefone da Central de 
Atendimento da Prefeitura Municipal de São Paulo - 156, bem como número de ordem que as individualize e diferencie de qualquer outra caçamba da mesma firma. $\S 2^{\circ}$. É proibida qualquer inscrição, propaganda ou publicidade nas caçambas, além da especificada neste decreto e em seu Anexo V.

$\S 3^{\circ}$. A Autoridade Municipal de Limpeza Urbana - AMLURB poderá vistoriar as caçambas do interessado para verificar as especificações e requisitos constantes deste decreto, sob as penas da lei.

Art. 15. As caçambas estacionárias, além de atenderem ao disposto no artigo 14 deverão estar devidamente sinalizadas por meio de pintura retrorreflexiva, de modo a permitir sua rápida visualização diurna e noturna a, pelo menos, 40 (quarenta) metros de distância, nos termos da Lei $\mathrm{n}^{\circ}$ 13.847, de 18 de junho de 2004, na forma constante do Anexo V deste decreto.

Parágrafo único. Por pintura retrorreflexiva compreende-se também a afixação de película refletiva que permita, nas caçambas, o mesmo efeito de visualização descrito no "caput" deste artigo.

Art. 16. Aos serviços de coleta e remoção de que trata o presente decreto aplicam-se, no que forem cabíveis, as disposições previstas na Lei $\mathrm{n}^{\circ} 13.478$, de 2002 , com as respectivas alterações subseqüentes, e nos decretos relativos aos preços de serviços prestados por unidades da Prefeitura.

Art. 17. É expressamente proibida a permanência das caçambas na via pública quando não estiverem sendo utilizadas para a coleta de entulho.

Art. 18. O período de permanência máximo de cada caçamba em vias públicas é de 72 (setenta e duas) horas corridas, compreendendo o tempo de colocação e retirada, exceção feita aos locais onde funcione estacionamento rotativo pago, caso em que o Departamento de Operação do Sistema Viário - DSV poderá fornecer autorização por prazo maior, nunca superior a 5 (cinco) dias no total, para atender a necessidades locais.

Art. 19. Em qualquer circunstância, na via pública, as caçambas manterão preservada a passagem dos veículos e de pedestres, em condições de segurança.

Art. 20. A colocação de caçambas para coleta de resíduos inertes no leito carroçável da via somente será permitida quando não for possível sua colocação nos recuos frontal ou lateral da testada do imóvel do contratante dos serviços, obedecendo, nessa hipótese, a seguinte condição: longitudinalmente, e paralela ao alinhamento das guias correspondentes à testada do imóvel do contratante do serviço, com o lado menos pontiagudo e de maior visibilidade voltado para a aproximação dos veículos que circulam pela via junto à caçamba, e afastada $0,30 \mathrm{~m}$ (trinta centímetros) do meio-fio, de modo a preservar a drenagem de águas pluviais, sendo o afastamento máximo do meio-fio limitado a $0,50 \mathrm{~m}$ (cinqüenta centímetros). 
Art. 21. Nos locais onde é regulamentado o estacionamento rotativo pago pelo sistema de Zona Azul, previsto nas Leis $\mathrm{n}^{\circ} 6.895$, de 25 de maio de 1966, e $\mathrm{n}^{\circ}$ 12.523, de 28 de novembro de 1997, regulamentada pelo Decreto $\mathrm{n}^{\circ} 37.292$, de 27 de janeiro de 1998, alterado pelo Decreto $\mathrm{n}^{\circ}$ 37.540, de 27 de julho de 1998, os prestadores de serviços de coleta e remoção de resíduos inertes que utilizarem caçambas estacionárias deverão requerer autorização ao Departamento de Operação do Sistema Viário - DSV, sempre que pretenderem a colocação desses equipamentos nas referidas vagas.

Parágrafo único. O deferimento do pedido estará sempre condicionado ao limite de $20 \%$ (vinte por cento) do número de vagas por quadra, para a ocupação simultânea por caçamba de coleta e remoção de resíduos inertes, ou a uma única caçamba, na hipótese de haver 10 (dez) vagas ou menos na quadra.

Art. 22. O requerimento de autorização mencionado no artigo 21 , endereçado ao Diretor do Departamento de Operação do Sistema Viário - DSV, será protocolado no mínimo 5 (cinco) dias úteis antes do início do período pretendido e instruído com cópia do Ato de Autorização do prestador de serviço expedido pela Autoridade Municipal de Limpeza Urbana - AMLURB, além de conter a especificação do endereço onde a caçamba será colocada, a indicação do número de vagas a serem ocupadas e do tempo de permanência pleiteado.

Art. 23. Atendidos os requisitos mencionados no artigo 22, o requerente receberá guia bancária para o pagamento do preço público relativo ao tempo permitido para que a caçamba permaneça estacionária, nos termos previstos neste artigo e no artigo 16 deste decreto.

$\S 1^{\circ}$. Fica estabelecido que o preço público por vaga efetivamente ocupada pela caçamba, por dia, é igual ao preço do total de horas diárias cobradas por vaga, em estacionamento rotativo pago pelo sistema de Zona Azul.

$\S 2^{\circ}$. Na hipótese de a caçamba ocupar apenas parcialmente vaga de estacionamento rotativo pago, de modo a não comprometer o seu uso, ficará a critério da autoridade o deferimento do pedido de autorização com dispensa do pagamento do preço público estipulado no $\S 1^{\circ}$ deste artigo.

Art. 24. Comprovado o pagamento do preço público, o requerente receberá a autorização pleiteada.

Art. 25. É proibida, sob pena de multa, remoção e apreensão, a colocação de caçambas para coleta de resíduos inertes no leito carroçável das vias, nas seguintes situações:

I - em pistas com largura inferior a 5,80 m (cinco metros e oitenta centímetros) de guia a guia;

II - em um dos lados, nas pistas com até $8,00 \mathrm{~m}$ (oito metros) de largura e sentido único de circulação, hipótese em que, a cada quadra, a colocação da segunda caçamba deverá seguir o lado onde a primeira foi colocada; 
III - em um dos lados, nas pistas com até 10,80 m (dez metros e oitenta centímetros) de largura e sentido duplo de circulação; nesses casos, a cada quadra, a colocação da segunda caçamba deverá seguir o lado onde a primeira foi colocada;

IV - nas esquinas e a menos de 10,00 $\mathrm{m}$ (dez metros) do bordo do alinhamento da via transversal;

V - nos locais onde o estacionamento e/ou a parada de veículos forem proibidos pelas regras gerais de estacionamento e parada estabelecidas pelo Código de Trânsito Brasileiro - CTB, instituído pela Lei Federal n ${ }^{\circ}$ 9.503, de 23 de setembro de 1997, alterada pela Lei Federal no 10.517, de 11 de julho de 2002;

VI - nos locais onde o estacionamento e/ou a parada de veículos sofrerem restrições ou proibições estabelecidas por sinalização vertical de regulamentação;

VII - nos locais onde existir regulamentação de estacionamentos especiais (táxis, caminhões, pontos e terminais de ônibus, farmácias, deficientes físicos e outros);

VIII - nas vias e logradouros onde ocorrerem feiras livres, ruas de lazer ou eventos autorizados, nos dias de sua realização;

IX - nos locais onde houver faixas de pedestres, linhas de retenção, sinalização horizontal de canalização (zebrado ou sargento);

$\mathrm{X}$ - no interior de qualquer espaço viário delimitado por prismas de concreto ou tachões, ou, ainda, sobre pintura zebrada;

XI - sobre poços de visita ou impedindo acesso a equipamentos públicos (caixas de correio, hidrantes, telefones públicos e outros);

XII - nos trechos de pistas em curvas (horizontal ou vertical) onde a caçamba não seja visível a, pelo menos, 40,00m (quarenta metros) para os condutores de veículos que se aproximem;

XIII - em locais sem incidência direta de luz artificial (iluminação pública ou dispositivos luminosos próprios) que garanta a identificação visual da caçamba a, pelo menos, 40,00m (quarenta metros), tanto em dias de chuva como no período noturno;

XIV - quando não estiver em bom estado de conservação a pintura retrorreflexiva da caçamba e legível sua identificação, conforme especificado no Anexo V deste decreto.

Art. 26. Para colocação, retirada e transporte de caçambas, a empresa prestadora de serviços utilizará caminhão dotado de equipamento guindaste, cabendo a seu condutor a observância das regras do Código de Trânsito Brasileiro - CTB, bem como das normas locais de circulação e estacionamento e demais disposições legais vigentes.

Art. 27. É proibido o depósito de entulho, terra e resíduos de qualquer natureza, de massa superior a 50 (cinqüenta) quilogramas, em vias, passeios, canteiros, jardins, áreas e logradouros públicos, conforme disposto no artigo 161 da Lei $n^{\circ} 13.478$, de 2002.

Parágrafo único. O disposto neste artigo aplica-se também aos veículos abandonados em vias públicas, por mais de 5 (cinco) dias consecutivos, bem como aos materiais de construção depositados em vias públicas por mais de 2 (dois) dias consecutivos. 
Art. 28. Os veículos e equipamentos que transportarem os resíduos referidos no artigo 27 e os depositarem nos locais citados, ou em local diverso do autorizado pela Administração Municipal, serão multados, apreendidos e removidos para os depósitos da Prefeitura, dependendo a sua liberação do pagamento das despesas de remoção e das multas correspondentes, além do competente cadastramento para obtenção de autorização ao exercício da atividade, na conformidade do disposto neste decreto.

Parágrafo único. O infrator, após a liberação do veículo e/ou equipamentos, nos termos do "caput" deste artigo, se carregado por ocasião da apreensão, deverá comprovar perante a Autoridade Municipal de Limpeza Urbana - AMLURB a correta disposição final dos resíduos que transportava no prazo de 24 (vinte e quatro horas) horas, sob as penas da lei.

Art. 29. A inobservância às normas previstas neste decreto sujeitará, ainda, a empresa prestadora de serviços às medidas administrativas e penalidades previstas no Código de Trânsito Brasileiro - CTB, especialmente em seu artigo 245, que determina a remoção das caçambas e a aplicação de multa à pessoa física ou jurídica responsável, inclusive nos casos de utilização de vaga de estacionamento rotativo sem a autorização do órgão competente.

Art. 30. Os agentes do Departamento de Operação do Sistema Viário - DSV ou da Autoridade Municipal de Limpeza Urbana - AMLURB, atendendo ao interesse público, poderão determinar, a qualquer tempo, ao prestador de serviços que, em caráter de urgência, às próprias expensas, retire a caçamba do local, ainda que regularmente colocada, ou caso se trate de utilização de vaga de estacionamento rotativo pago, mesmo que não esgotado o prazo autorizado.

Art. 31. Os casos especiais serão analisados pelo Departamento de Operações do Sistema Viário - DSV que, após parecer técnico, poderá conceder ou não autorizações específicas para colocação de caçambas regularmente cadastradas em locais e situações não enquadradas nas normas deste decreto.

Art. 32. Constituem motivos para a suspensão do Cadastro de Autorizatário:

I - o desatendimento a quaisquer das obrigações contidas no artigo 14 deste decreto;

II - a realização do tratamento e/ou a disposição final dos resíduos sólidos inertes em estabelecimentos sem licenciamento ambiental;

III - o descumprimento das normas técnicas estabelecidas pela ABNT;

IV - a avaliação que demonstre desempenho insuficiente da empresa na prestação dos serviços;

V - a prática de atos ilícitos;

VI - a suspensão da participação em licitação e o impedimento de contratar com a Administração Pública;

VII - a falência ou a dissolução da empresa;

VIII - a declaração de inidoneidade da empresa; 
IX - o descumprimento à legislação de controle de poluição ambiental.

Parágrafo único. Na hipótese prevista no inciso VI do "caput" deste artigo, o prazo de suspensão do Cadastro de Autorizatário será equivalente ao da penalidade aplicada pela Administração Pública.

\section{Capítulo III}

\section{Da Fiscalização}

Art. 33. A Autoridade Municipal de Limpeza Urbana - AMLURB definirá a forma, condições e procedimentos necessários à fiscalização da geração, acondicionamento, armazenamento, coleta, transporte, tratamento e/ou disposição final dos resíduos sólidos inertes oriundos dos serviços de limpeza urbana em regime privado tratados neste decreto.

Art. 34. Na hipótese de descumprimento das disposições previstas na Lei $\mathrm{n}^{\mathbf{0}} 13.478$, de 2002, e neste decreto, ou de execução inadequada da prestação dos serviços, a Autoridade Municipal de Limpeza Urbana - AMLURB poderá cassar a autorização, nos termos dos artigos 11 e 12 deste decreto, sem prejuízo da aplicação das penalidades previstas na mencionada lei.

Art. 35. Caberá à Autoridade Municipal de Limpeza Urbana - AMLURB fiscalizar o cumprimento das normas estabelecidas neste decreto, devendo, para tanto, inspecionar os veículos, equipamentos e outros dispositivos utilizados na prestação dos serviços em regime privado, além de realizar inspeções periódicas nas áreas internas dos grandes geradores e dos autorizatários, podendo deles solicitar a apresentação de laudos técnicos emitidos por entidades competentes e idôneas, quando necessário.

$\S 1^{\circ}$. A Autoridade Municipal de Limpeza Urbana - AMLURB poderá articular-se com outros órgãos municipais para a fiscalização prevista neste decreto.

$\S 2^{\circ}$. As Subprefeituras comunicarão à Autoridade Municipal de Limpeza Urbana AMLURB, para as devidas providências, eventuais irregularidades ou infrações ao disposto neste decreto, detectadas durante a fiscalização exercida no âmbito de suas competências.

\section{Capítulo IV}

\section{Dos Recursos}

Art. 36. Das decisões proferidas pela Autoridade Municipal de Limpeza Urbana AMLURB, previstas neste decreto, caberá recurso ao Secretário Municipal de Serviços, no prazo de 5 (cinco) dias úteis, contados da publicação do respectivo ato no Diário Oficial da Cidade de São Paulo - D.O.C.

\section{Capítulo V}

Das Disposições Finais

Art. 37. Os proprietários, possuidores ou titulares de estabelecimentos grandes geradores de resíduos inertes, bem como as empresas ou prestadores de serviços de 
coleta, transporte, tratamento e/ou disposição final de resíduos sólidos inertes serão solidariamente responsáveis pelo cumprimento dos dispositivos estatuídos na Lei $\mathrm{n}^{\circ}$ 13.478, de 2002, com as alterações subseqüentes, a eles aplicáveis, e também por quaisquer danos que vierem a causar a bens públicos e particulares na execução dos serviços de limpeza urbana prestados em regime privado, não cabendo à Autoridade Municipal de Limpeza Urbana - AMLURB qualquer tipo de responsabilidade.

Art. 38. Os pedidos de cadastramento de que trata este decreto deverão ser submetidos à Autoridade Municipal de Limpeza Urbana - AMLURB que, em caso de deferimento, expedirá o respectivo certificado contendo a data de validade, o nome da empresa cadastrada, o número de sua inscrição no Cadastro Nacional da Pessoa Jurídica - CNPJ, o seu endereço e a atividade autorizada.

Parágrafo único. A validade do cadastramento fica condicionada à publicação do correspondente ato de deferimento no Diário Oficial da Cidade de São Paulo D.O.C.

Art. 39. Os grandes geradores e as empresas prestadoras dos serviços a que se refere este decreto terão o prazo de 30 (trinta) dias, contados da data de sua publicação, para se adequarem às suas disposições, sob pena de incorrerem nas penalidades nele previstas, bem como na Lei $\mathrm{n}^{\circ} 13.478$, de 2002.

$\S 1^{\circ}$. Excetuam-se do estabelecido no "caput" deste artigo as disposições constantes dos incisos II a VII do artigo $5^{\circ}$, do artigo $6^{\circ}$, dos incisos II a IV do artigo $7^{\circ}$, e dos incisos I e VI do artigo $8^{\circ}$, todos deste decreto, cujo prazo de adequação será de 1 (um) ano, contado da data de sua publicação.

$\S 2^{\circ}$. A obtenção, por pessoa física, da autorização de que trata o artigo 123 da Lei ${ }^{\circ}$ 13.478 , de 2002, para a prestação dos serviços de limpeza urbana no regime privado, referentes a coleta, transporte, tratamento e disposição final dos resíduos sólidos inertes, exclusivamente por veículo basculante, será disciplinada oportunamente por decreto específico.

Art. 40. Para cumprimento das obrigações previstas no $\S 1^{\circ}$ do artigo 14 deste decreto, a Autoridade Municipal de Limpeza Urbana - AMLURB poderá enviar planilha-padrão aos autorizatários.

Art. 41. A Autoridade Municipal de Limpeza Urbana - AMLURB disponibilizará, em sítio da rede mundial de computadores (Internet) da Prefeitura, a relação de autorizatários cadastrados na autarquia.

Art. 42. Enquanto não instalada a Autoridade Municipal de Limpeza Urbana AMLURB, atribuições a ela conferida por este decreto serão exercidas pelo Departamento de Limpeza Urbana - LIMPURB, da Secretaria Municipal de Serviços - SES.

Art. 43. As despesas com a execução deste decreto correrão por conta das dotações orçamentárias próprias, suplementadas se necessário. 
Art. 44. Este decreto entrará em vigor na data de sua publicação.

PREFEITURA DO MUNICÍPIO DE SÃO PAULO, aos 3 de novembro de 2005, $452^{\circ}$ da fundação de São Paulo.

JOSÉ SERRA, PREFEITO

ANGELO ANDREA MATARAZZO, Secretário Municipal de Serviços Publicado na Secretaria do Governo Municipal, em 3 de novembro de 2005.

ALOYSIO NUNES FERREIRA FILHO, Secretário do Governo Municipal

Obs.: Quadros anexo vide DOC dia 04 de novembro de 2005 - páginas 4, 5 e 6.

DECRETO No 46.594, DE 5 DE NOVEMBRO DE 2.005

REPUBLICAÇÃO

Republicação dos Anexos I, II, III, IV e V do Decreto n. ${ }^{\circ}$ 46.594, de 03 de novembro de 2005, por terem saído com incorreções no D.O.C. de 04/11/2005. II 
Anexo G - Levantamento de ATTs com licença de funcionamento na Prefeitura do Município de São Paulo, em 15 de janeiro de 2007.

ATT em fucionamento: (com licença de funcionamento)

- BASE AMBIENTAL RECICLADORA LTDA - ME.

Rua Alvorada D'Oeste n'20 - Jaçanã

Telefone: (11) 6241.7217

- MAXXIPAPPEL COM. APARAS E SUCATAS LTDA.

Rua Joaquim Carlos n 870 - Pari

Telfone: (11) 6618.1384

ATT com licença provisória: (com licença provisória, a título precário)

- PORTO DE AREIA DE SETE PRAIAS LTDA.

Rua. Josephina Gianini Elias, n499 (SP-AD)

Telefone: 5674-0833

- MARIA PATRÍCIA ADINOLFI-ME (MORELIX).

Rua Clodomiro de Oliveria s $/ \mathrm{n}^{\circ}$ - (SP-CL)

Telefone: 5844.9130

- NOVA SAT LOCAÇÕES E TRASPORTES LTDA. (ATT-TUIUIÚ).

Rua Cajurú no 74 - (SP-MO)

Telefone: 6698.7007

- PePeC AMBIENTAL COM. E SERV. LTDA.

Avenida Aricanduva no 1809 - (SP-PE)

Telefone: 6192.7922

- PePeC AMBIENTAL COM. E SERV. LTDA.

Rua Inácio Monteiro s/n ${ }^{\circ}$ - (SP-CT)

Telefone: 6192.7922 


\section{Anexo H - Condições financeiras e operacionais de financiamento da fonte FGTS (CAIXA, 2005).}

As condições a seguir anunciadas estão sujeitas a alterações decorrentes de mudanças na legislação do FGTS

- Limite máximo de financiamento:

- Setor Público: 85\% do valor do investimento;

- Setor Privado: $75 \%$ do valor do investimento;

- Contrapartida mínima:

- Setor Público: $15 \%$ do valor do investimento;

- Setor Privado: $25 \%$ do valor do investimento;

- O valor da contrapartida mínima deve ser integralizado simultaneamente ou antecipadamente ao desembolso CAIXA/FGTS.

- O período de carência equivale ao prazo previsto para a execução das obras, acrescido de até dois meses, limitado ao máximo de 24 meses, contatos a partir do primeiro desembolso previsto em contrato.

- O prazo de amortização é definido pela capacidade de pagamento do projeto, contado a partir do mês subseqüente ao término da carência.

- O prazo total de financiamento, ou seja, a soma dos prazos de carência e de amortização está limitado ao máximo de 240 meses conforme modalidade.

- Os juros são pagos mensalmente, na data estabelecida em contrato, nas fases de carência e de amortização, a taxas nominais de 6,5\% a.a. a 8,0\% a.a., de acordo com a modalidade.

- Os desembolsos são efetuados com periodicidade não inferior a um mês, de acordo com a execução do empreendimento, comprovada pela Caixa.

- A taxa de risco é cobrada mensalmente juntamente com os demais encargos do contrato de financiamento, em valor percentual a ser negociado conforme a avaliação de risco de crédito, que incidirá sobre o saldo devedor, durante toda a vigência do contrato de financiamento.

- As prestações são cobradas mensalmente, calculadas pelo Sistema Francês de Amortização - Tabela Price, sendo o saldo devedor atualizado pelo índice e periodicidade aplicados às contas vinculadas do FGTS.

- A remuneração da Caixa é de $2 \%$ a.a. nas fases de carência e de amortização, cobrada mensalmente, junto com as prestações.

- As garantias são definidas de acordo com cada projeto, sendo a garantia principal a receita tarifária.

- Encargos da operação de crédito: cobrados nas fases de carência e amortização, constituídos de:

- Taxa nominal de juros da modalidade: $8 \%$ a.a., cobrada mensalmente, na data estabelecida em contrato;

- Remuneração da CAIXA: de 2\% a.a., calculados sobre o saldo devedor da operação contratada, cobrada mensalmente e junto com as prestações mensais;

- Taxa de risco de crédito do proponente: definida conforme conceito de risco de crédito emitido para cada operação, incidente sobre o saldo devedor do contrato e cobrada juntamente com as prestações mensais; 
- Prazos da operação de crédito:

- Prazo máximo para início de utilização do recurso contratado: corresponde a 12 (doze) meses, contados a partir da data de assinatura do instrumento contratual para a realização do primeiro desembolso. Caso o $1^{\circ}$ desembolso não ocorra dentro do prazo estabelecido no instrumento contratual, a critério do Agente Operador e do Gestor da Aplicação, ele pode vir a ser prorrogado por uma única vez por, no máximo, igual período, ou seja, por até mais 12 (doze) meses;

- Prazo de desembolso: correspondente ao prazo de execução do empreendimento, 25 limitado até 24 (vinte e quatro) meses, conforme cronograma de desembolso apresentado no instrumento contratual;

- Prazo de carência: equiivale ao prazo previsto para a execução das obras, acrescido de até 02 (dois) meses, limitado ao prazo máximo de 24 (vinte e quatro) meses. Contado a partir do mês previsto para o $1^{\circ}$ desembolso, conforme cronograma apresentado no instrumento contratual;

- Prorrogação do prazo de carência: limitado à metade do prazo de carência originalmente contratado e conseqüente redução do prazo de amortização em igual período;

- Prazo de amortização: corresponde ao prazo máximo de 180 (cento e oitenta) meses, a ser definido conforme análise do fluxo de caixa do projeto;

- Desembolso de recursos: efetuado com periodicidade não inferior a um mês, de acordo com o cronograma previsto no contrato de financiamento e mediante a execução do empreendimento comprovada pela CAIXA;

- Prestações: cobradas mensalmente, nas fases de carência e de amortização, calculadas pelo Sistema Francês de Amortização (Tabela Price), sempre na data eleita, conforme estabelecido no instrumento contratual;

- Saldo devedor: atualizado pelo índice e periodicidade aplicados às contas vinculadas do FGTS ou índice que vier a substituí-lo e realizado no primeiro dia de cada mês;

- Índice de atualização do saldo devedor: Taxa Referencial (TR), índice atualmente praticado para as contas do FGTS;

- Garantias:

- Setor público: Cotas do Fundo de Participações do Estado (FPE), cotas do Fundo de Participações do Município (FPM), Imposto sobre Circulação de Mercadorias e Serviços (ICMS), vinculação de receitas e outras que venham a ser aprovadas pela CAIXA;

- Setor privado: vinculação de receitas, fianças, aval dos sócios e outras que venham a ser aprovadas pela CAIXA. 